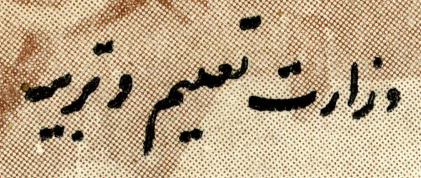

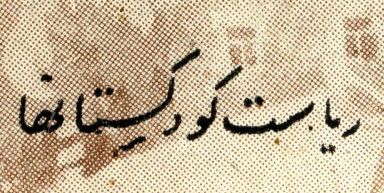

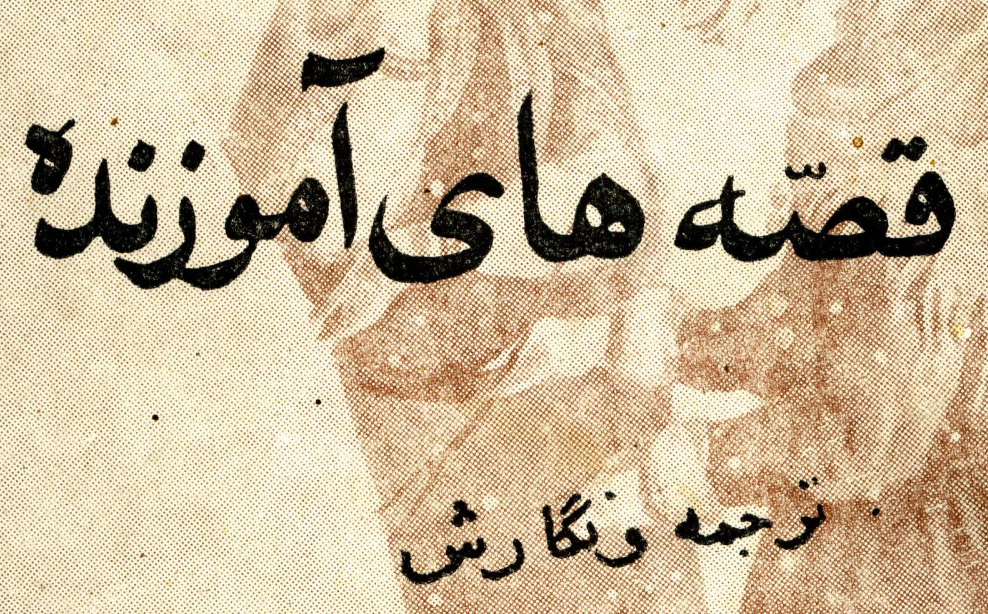

$$
\text { " }
$$


نـام اثر :قصه هاى آموزنده

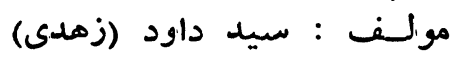

نشر كرده اى :رياست كودكستانها

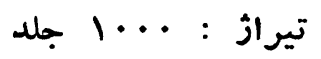

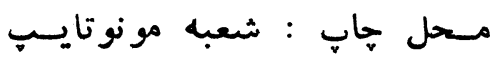

$$
\text { مطابع دولتى : محس I }
$$



فهرست مندر جاتّ

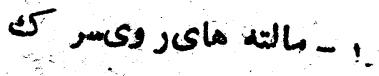

$$
\text { - د ريان }
$$

م- - عفر يتجهيل نيستى

- - مكك مسال عجينب

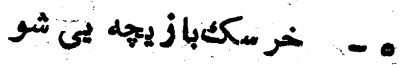

$\therefore$

$$
\begin{aligned}
& 7= \\
& \text { - - }
\end{aligned}
$$

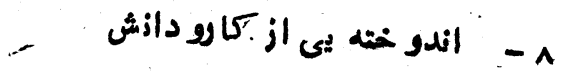

$$
\begin{aligned}
& \text { - - هـمسار } \\
& \text { - } 1 . \\
& \text { - } \\
& \text { - Ir } \\
& , L r-i r
\end{aligned}
$$

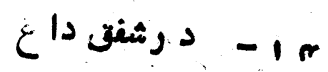

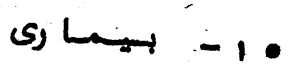


17 - انسان انساندومت

C - IV

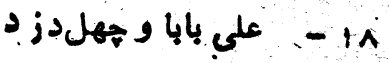

19 - تيسيوستهر مان

- ه

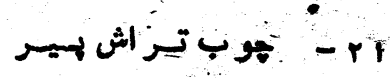

r - r - مواكر وخلنتكاو انشل

rr

rir 


\section{مقلذ مه}

\section{خو انثدهار جمند !}

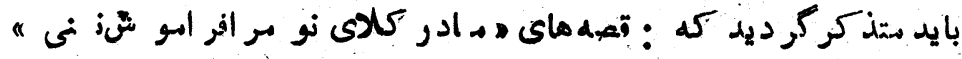

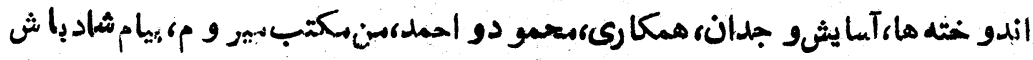

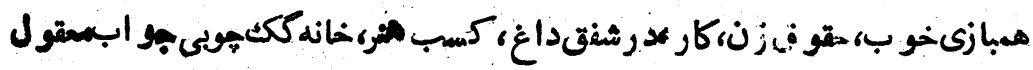

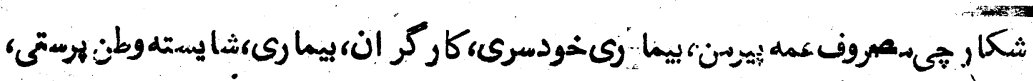

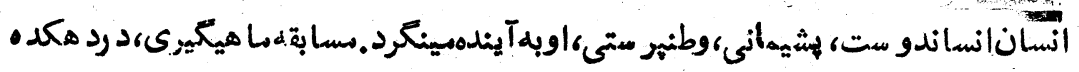

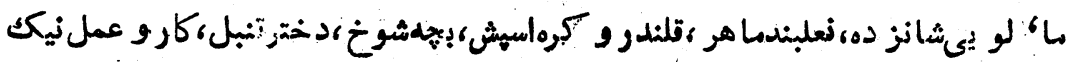
نو شثدو قصه علىباباو جهل دزدو زشتو نفرت|نكيز ازكتمابقصه (اشال تميلسي" قصه

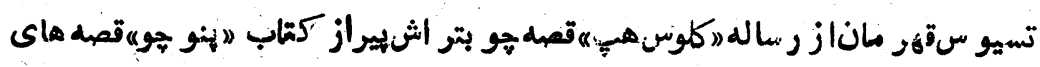
خيالشال ز يباو سوداكر وخدم:كار انشاز مجلمميشاقصهمسافرت هاىكليور ازكتاب

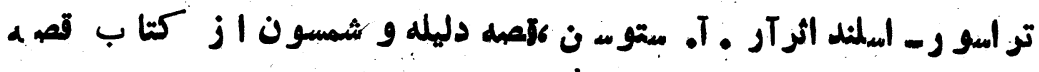
شمسون و دليله اثر كانل كيلانى، تر جمدو نكارشكر ديلهواست.

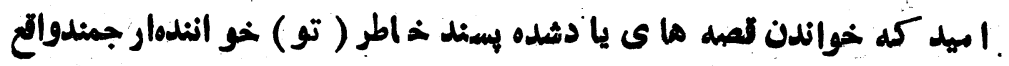
كو ددو ر امسبزو ير كل حقيقتوسعادت ر اجلو ديدهانتر و شنكر داند! ! ! 


\section{· مالتهاىروىسرك}

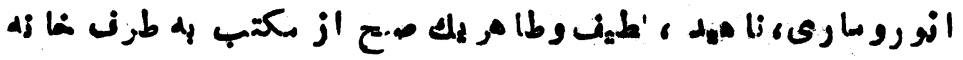

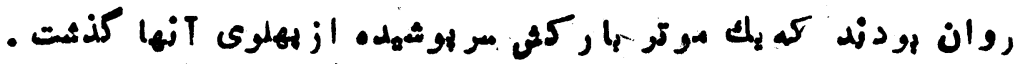

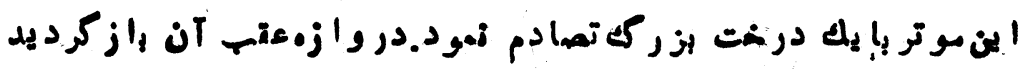

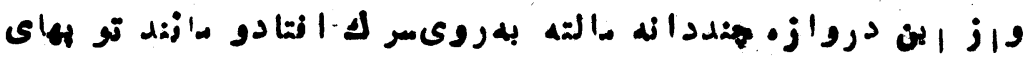

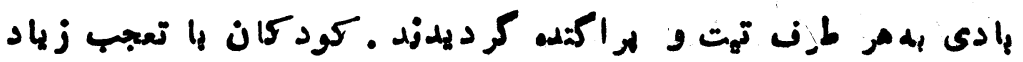

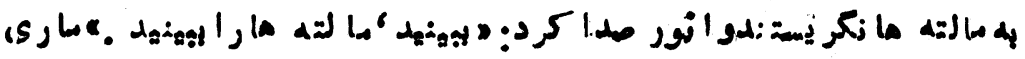

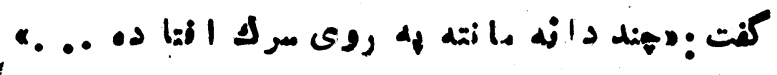

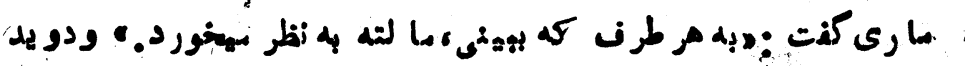

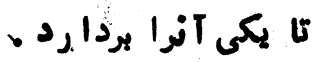

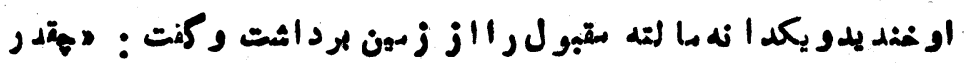

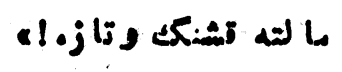

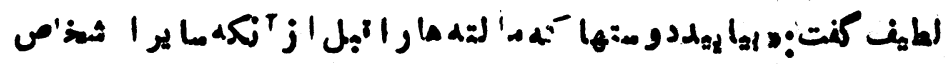

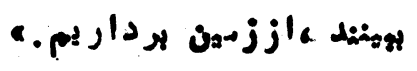

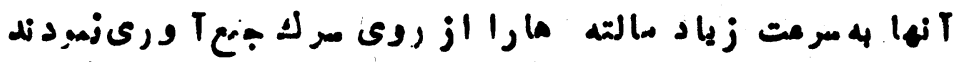

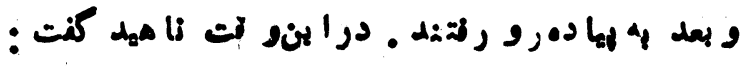




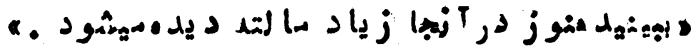

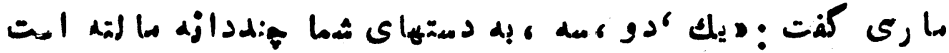

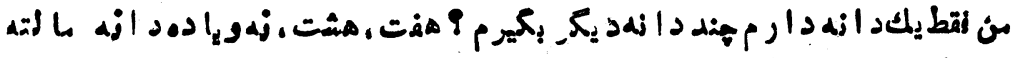

a د.

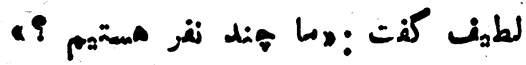

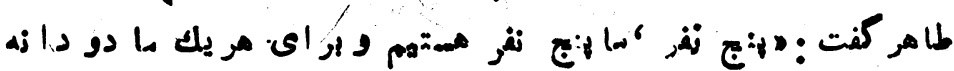

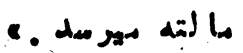

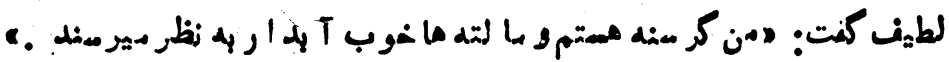

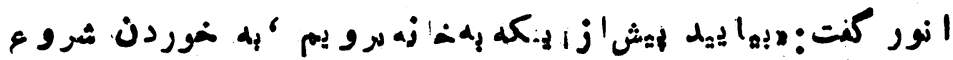

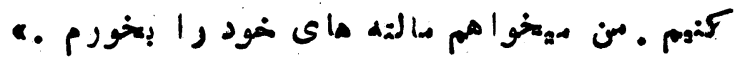

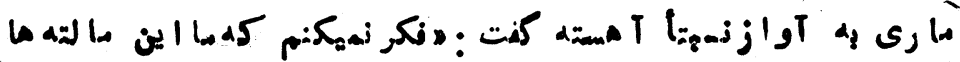

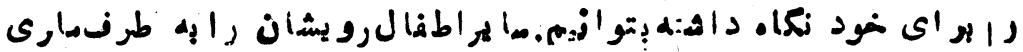

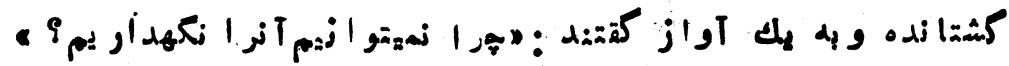

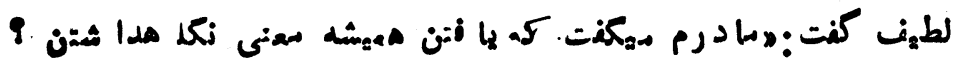

$$
\text { -. do d, is }
$$

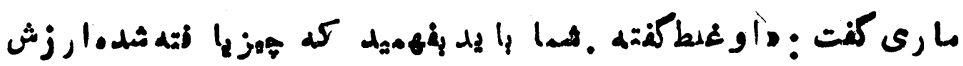

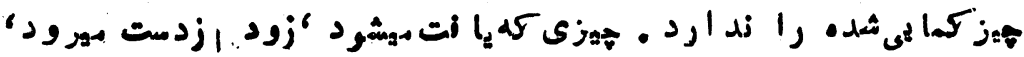

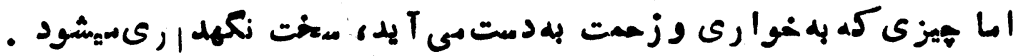

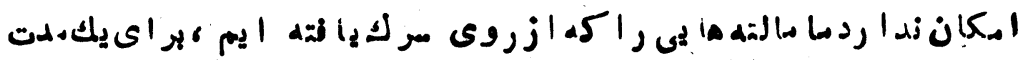

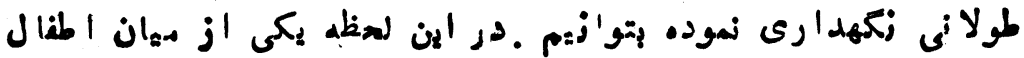

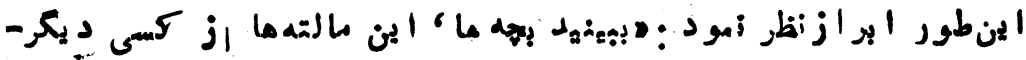

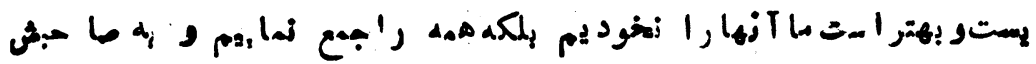
| مستمترد كنيم 


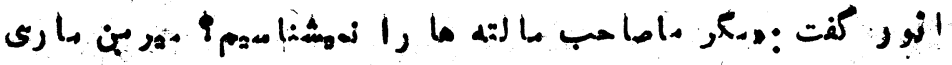

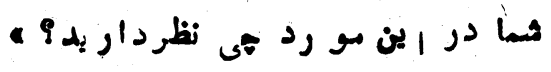

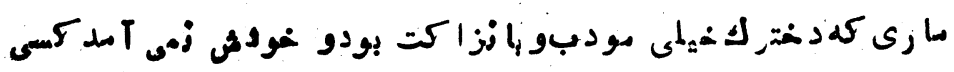

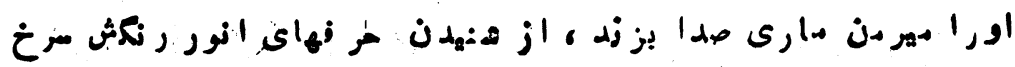

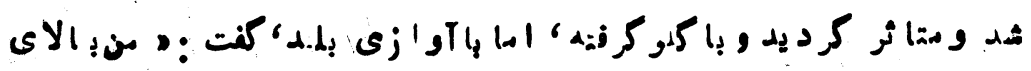

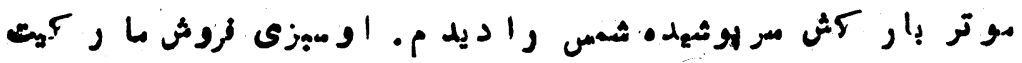

هـ

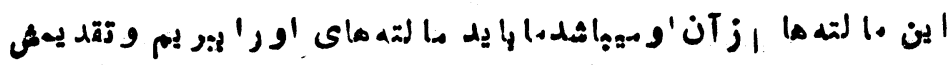

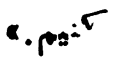

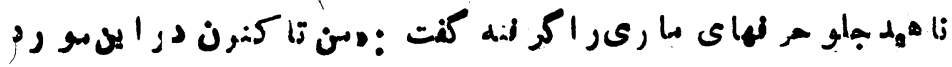

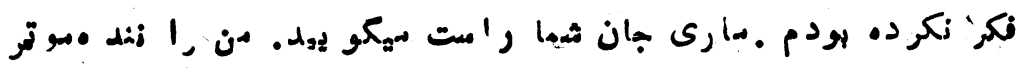

a

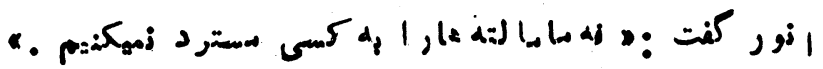

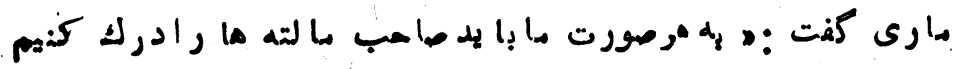

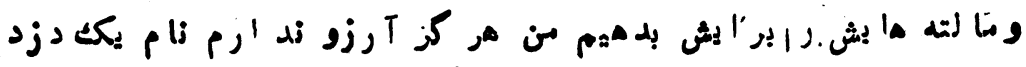

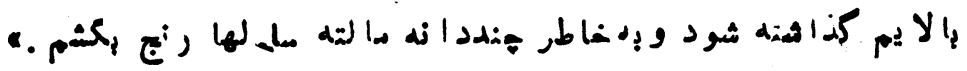

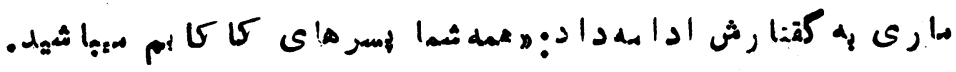

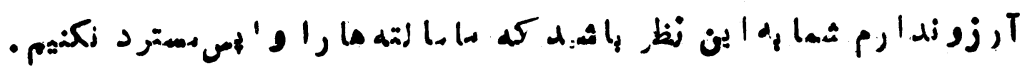

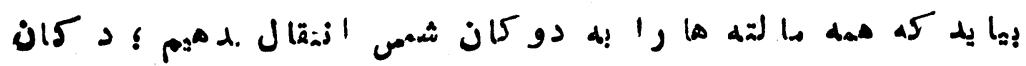

او دور زئست . او

انور درحا ليكه وضمث دكر كون كرد يده بود كفت: لمس أمير وم ؛

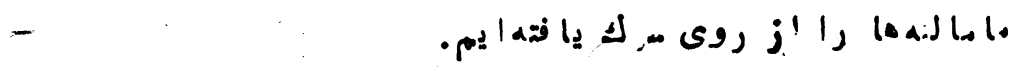

$-r-$ 


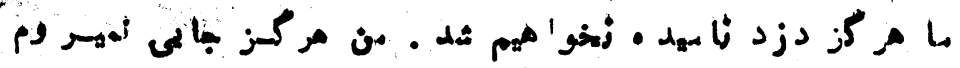

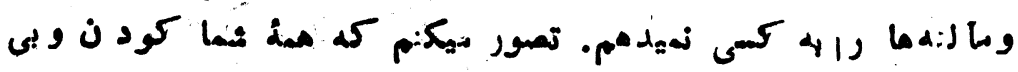

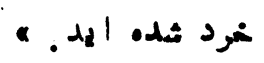

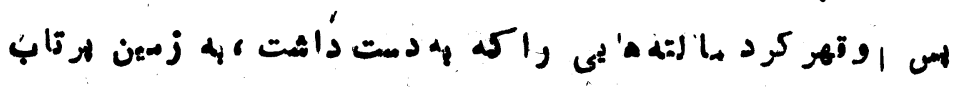

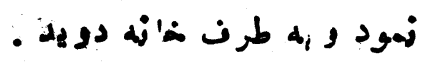

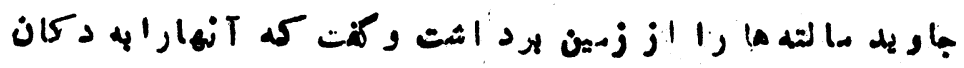

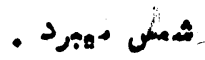

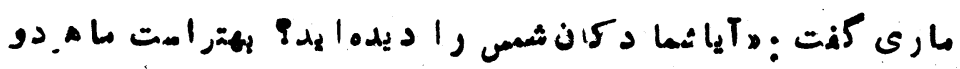

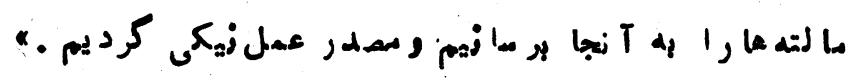

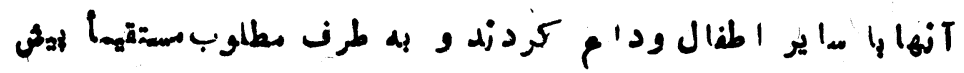

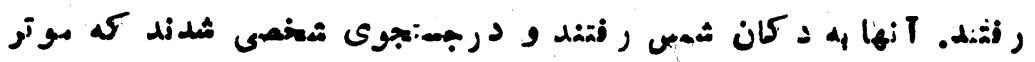

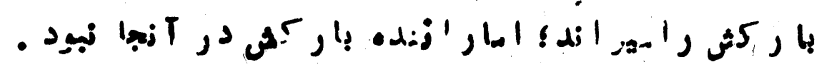

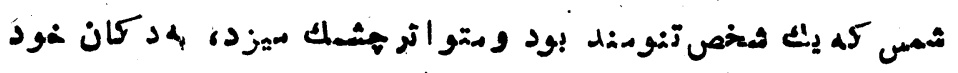

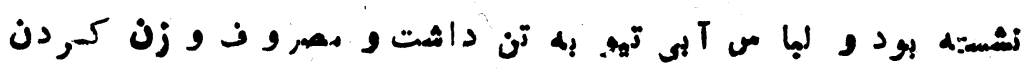

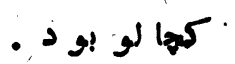

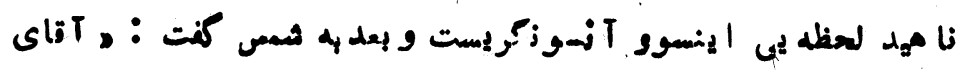

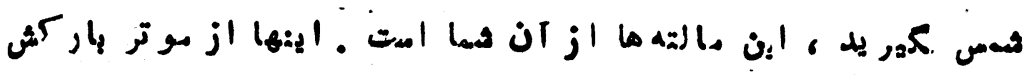

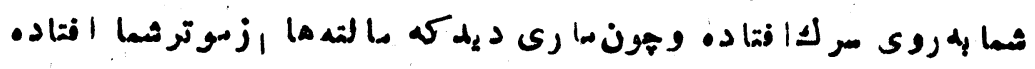

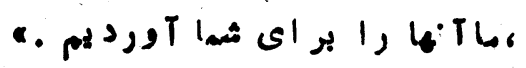

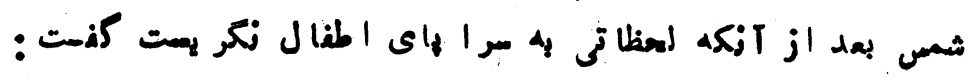

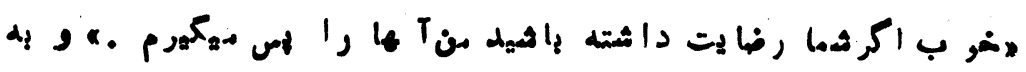

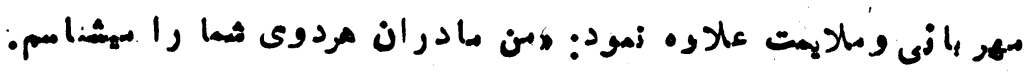




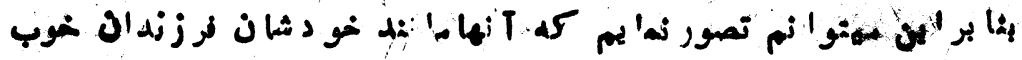

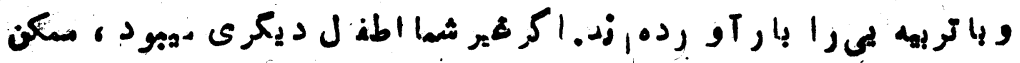

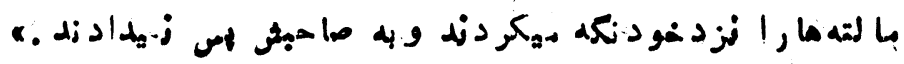

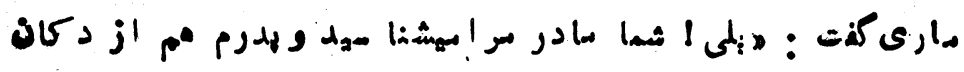

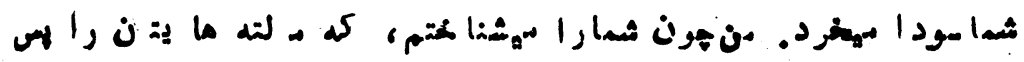

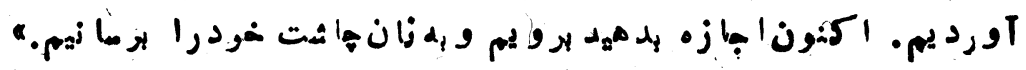

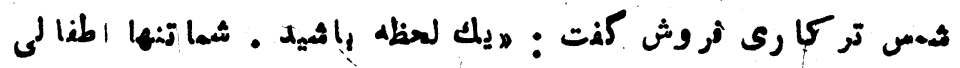

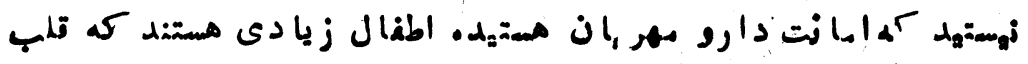

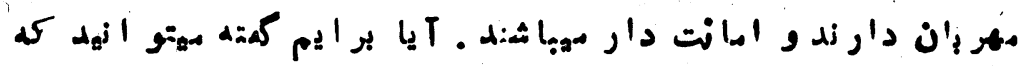

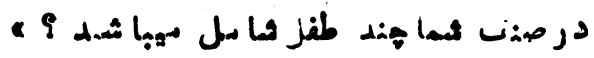

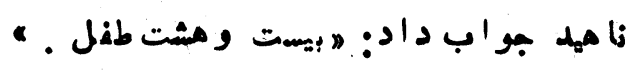

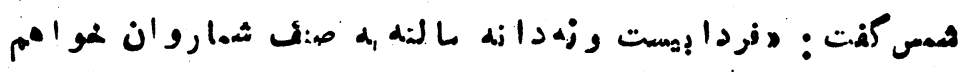

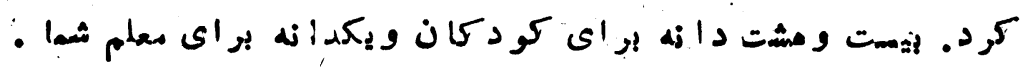

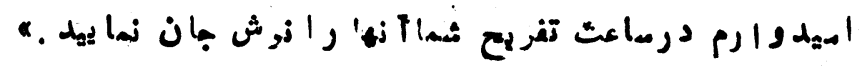

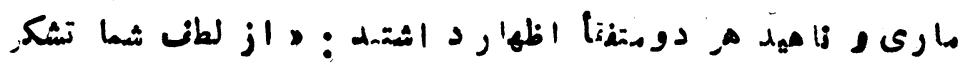

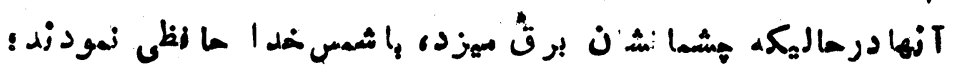

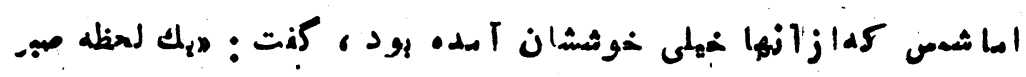

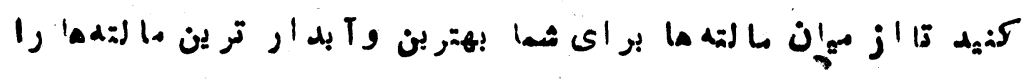
- ماندا

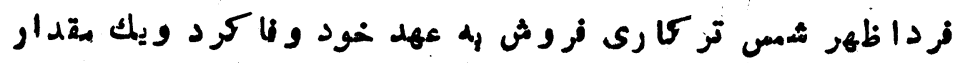

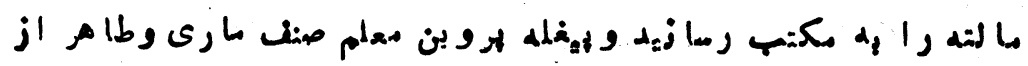

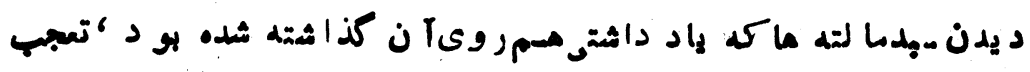
-0_ 


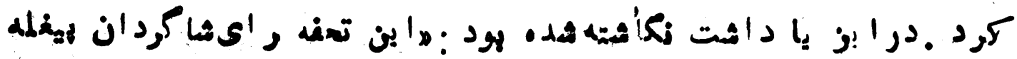

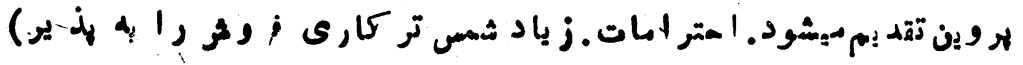

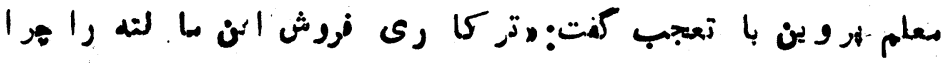

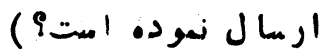

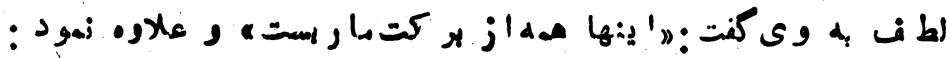

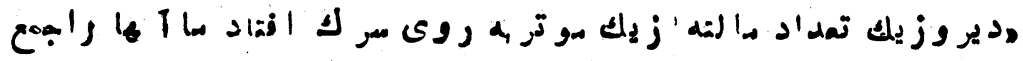

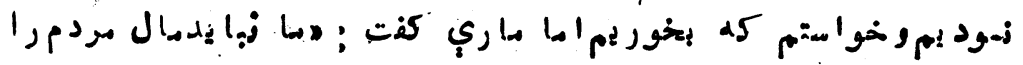

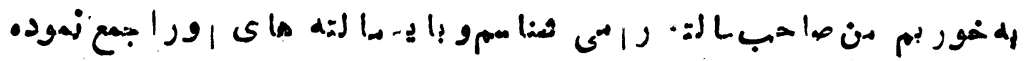

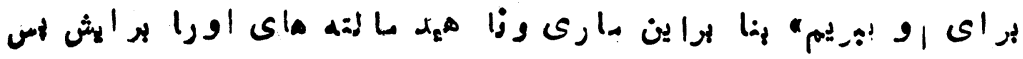

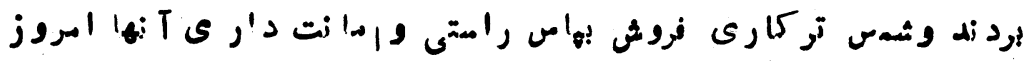

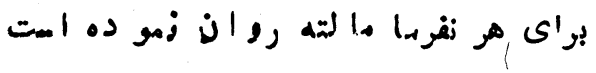

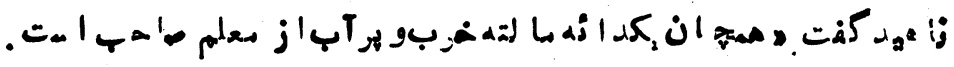

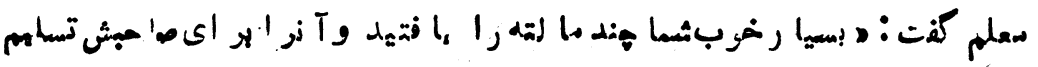

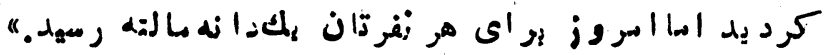

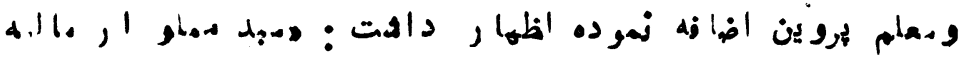

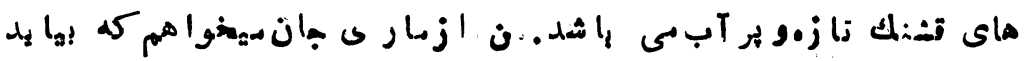

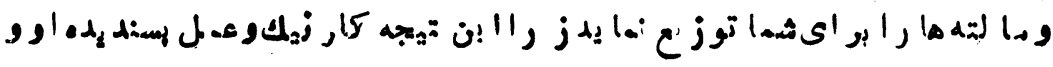

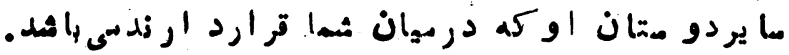

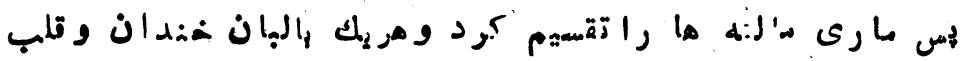

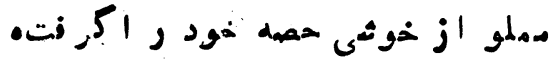

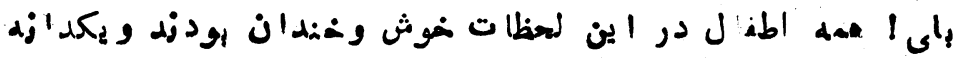

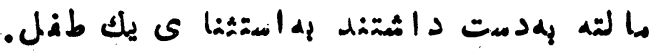




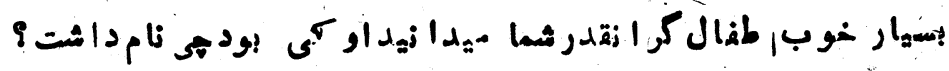

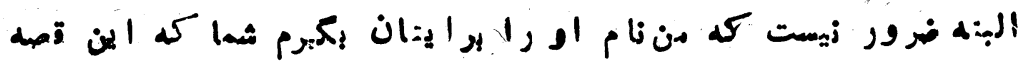

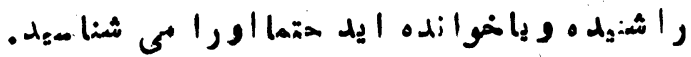

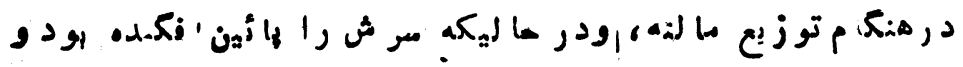

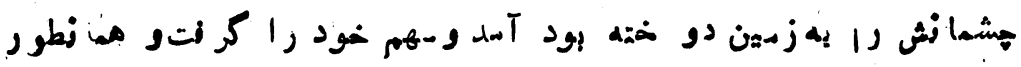

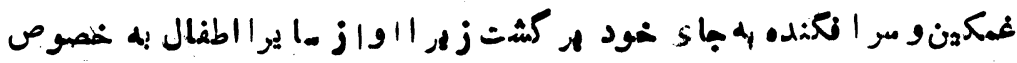

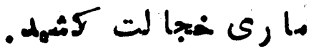

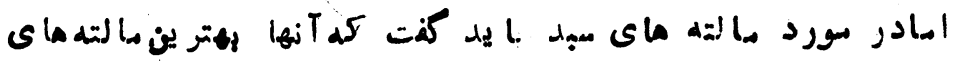

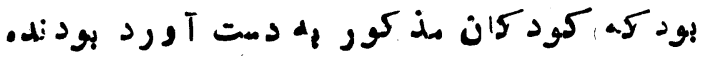

$-v-$ 
هليم ياشور باىقوى

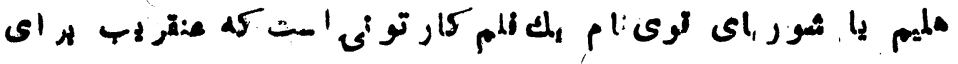

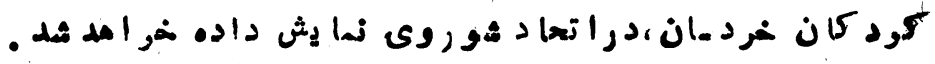

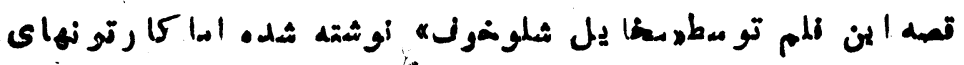

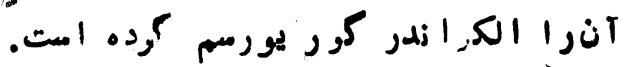

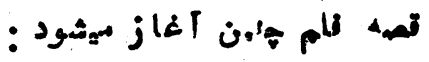

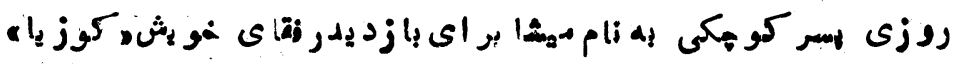

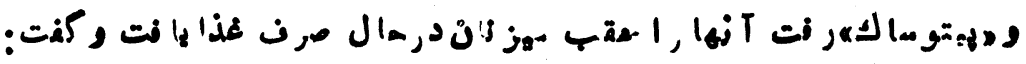

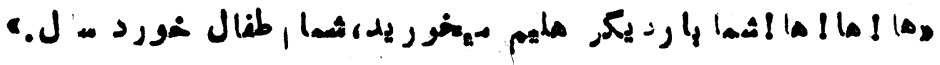

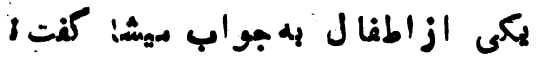

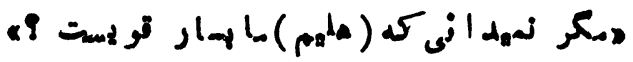

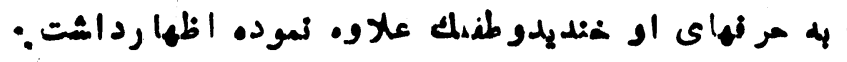

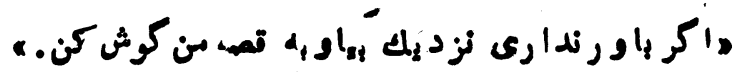
- $\wedge$ - . 


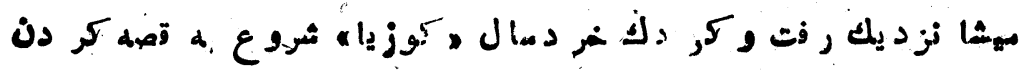

: نموده كنت

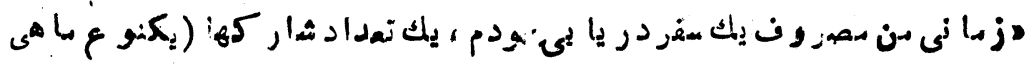

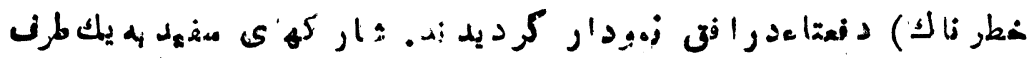

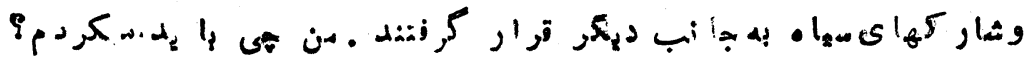

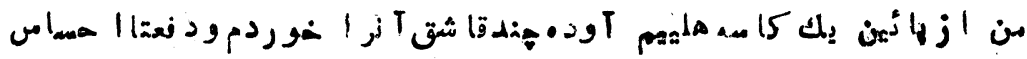

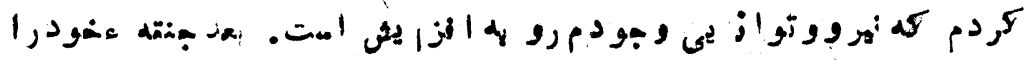

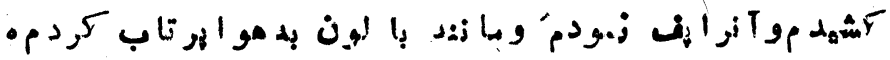

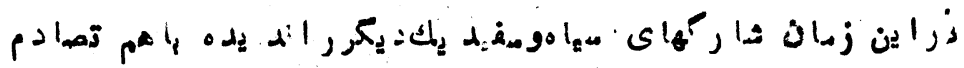

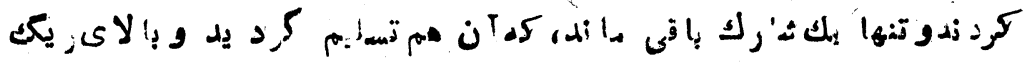

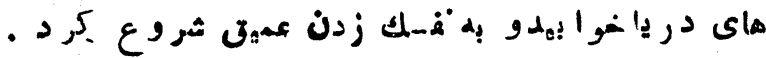

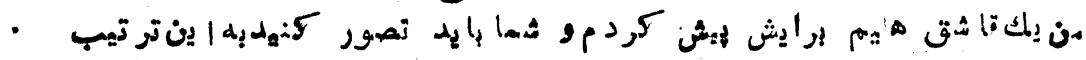

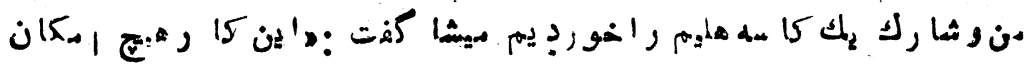

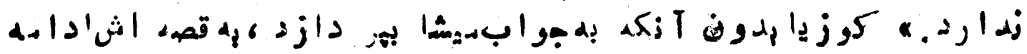

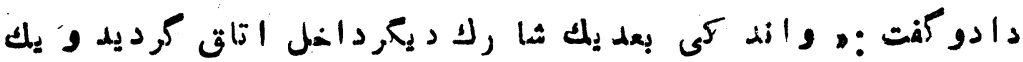

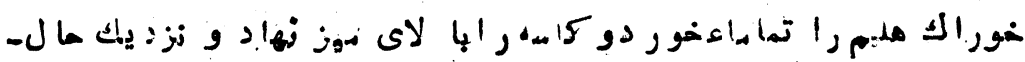

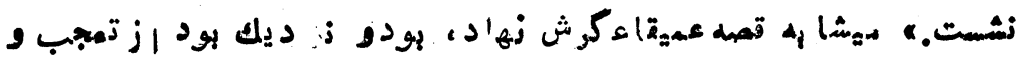

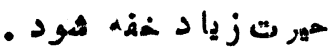

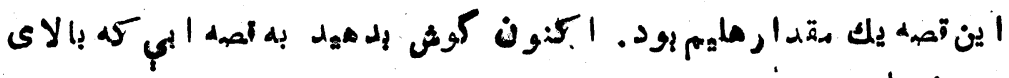

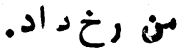

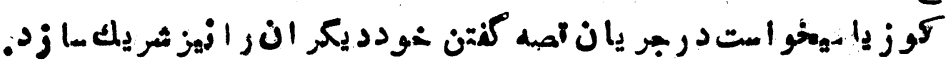

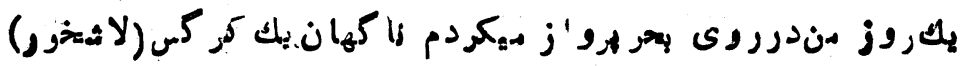

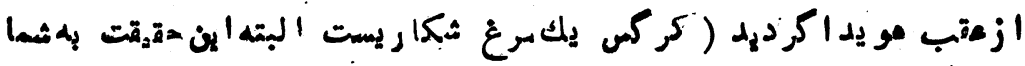

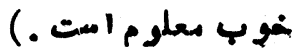

- $9-$ 


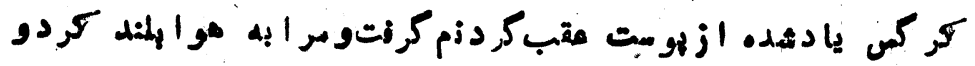

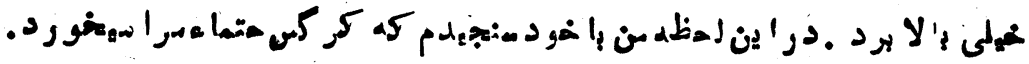

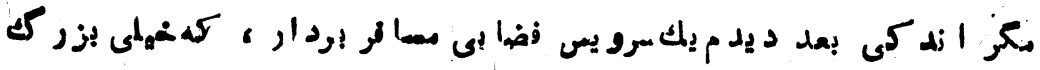

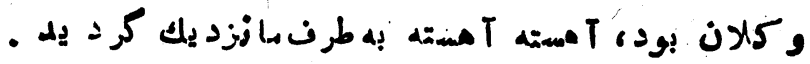

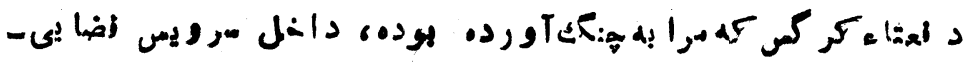

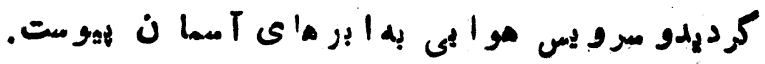

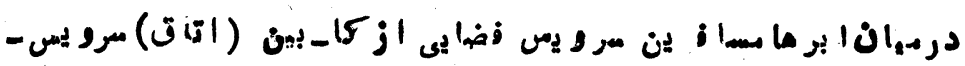

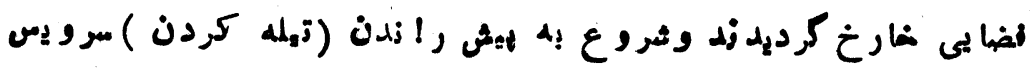

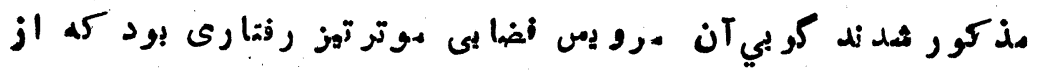

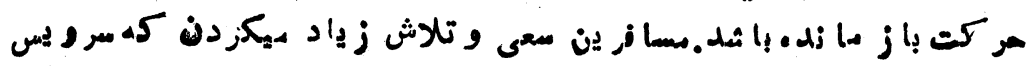

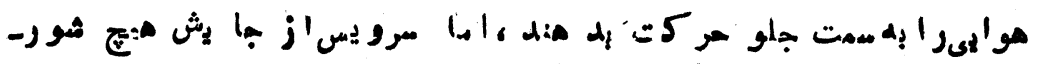

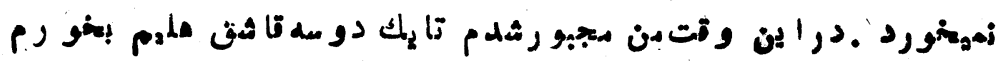

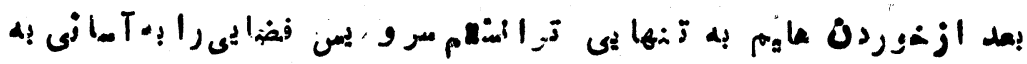

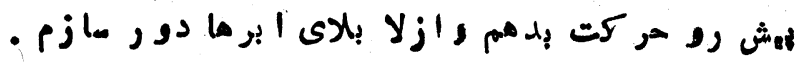

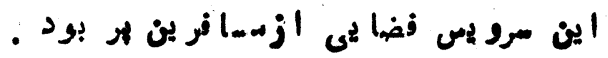

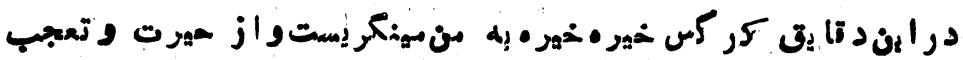

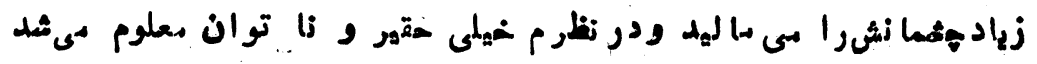

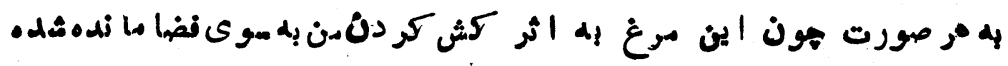

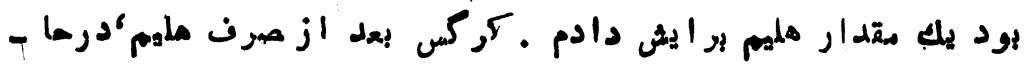

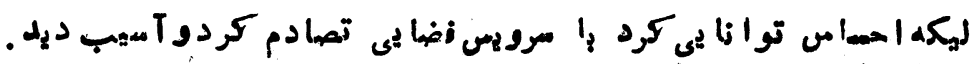

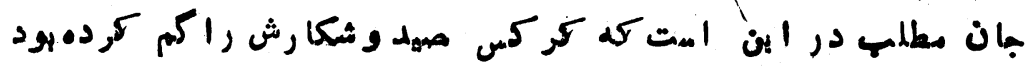

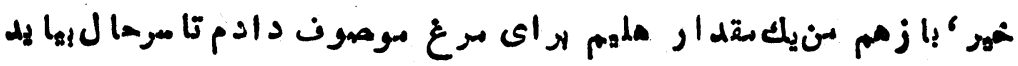

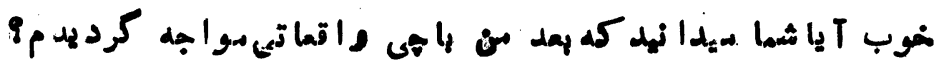
$-1 \cdot-$ 


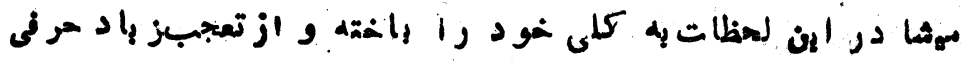

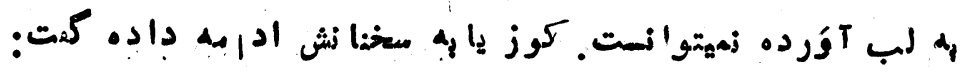

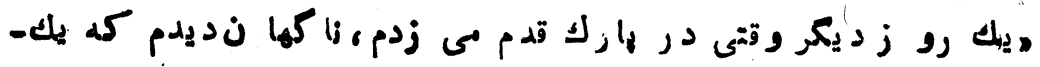

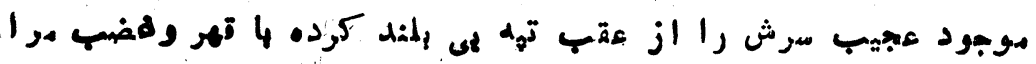

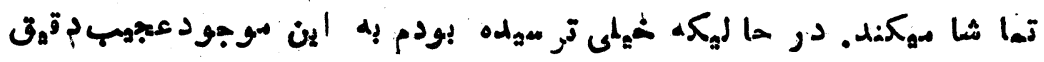

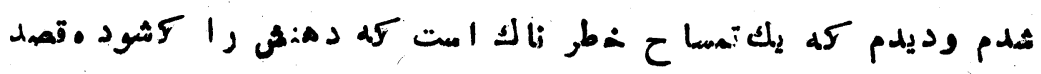

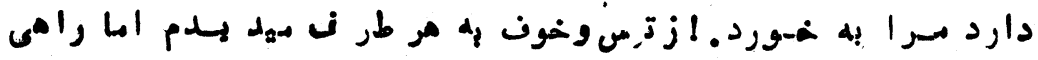

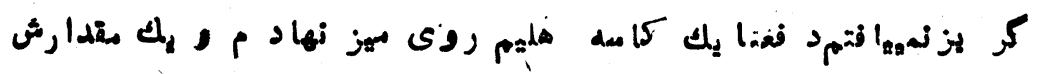

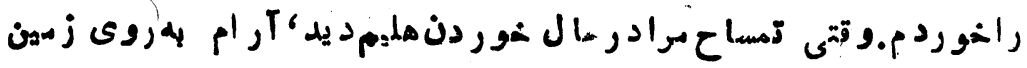

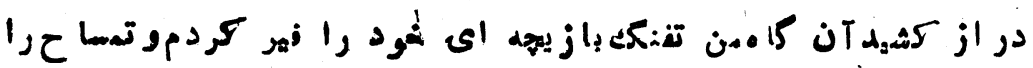

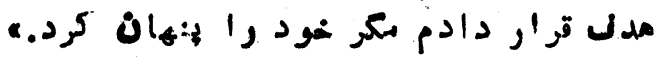

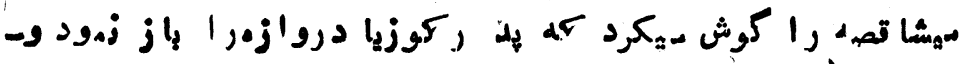
دا مخل اتا قكرد يد.

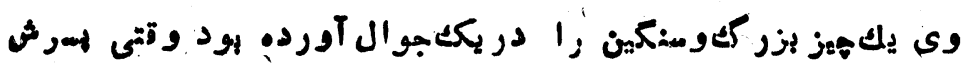

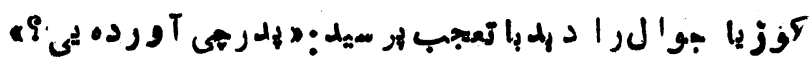

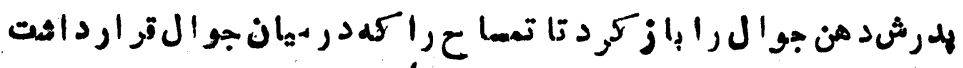

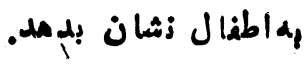

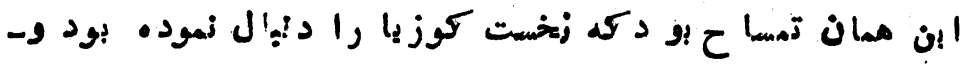
بعد كوز يا اورا مدف قر ار د'د مو تعقيب أموده بودهدر اين لجهظات

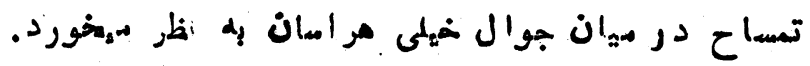

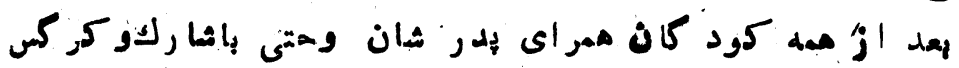

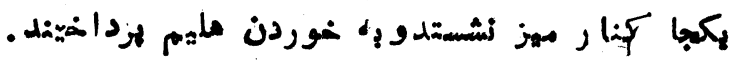
$-11,-$ 


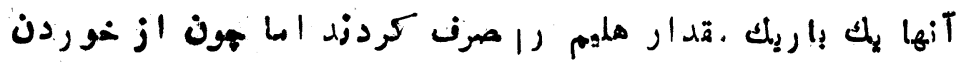

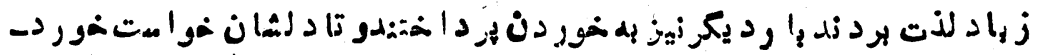

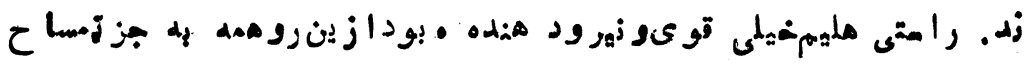

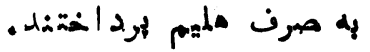

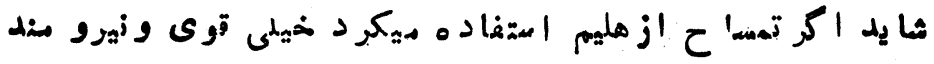

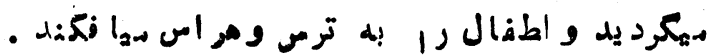

$-i r-$ 
درميانجاه

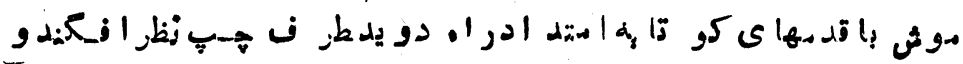

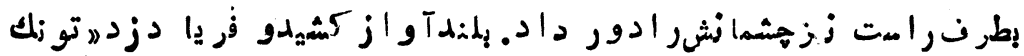

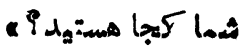

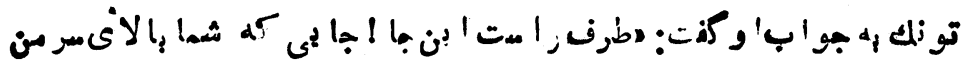

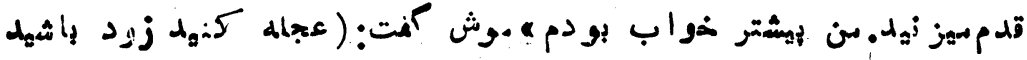

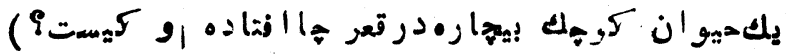

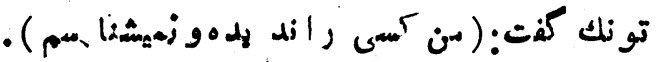

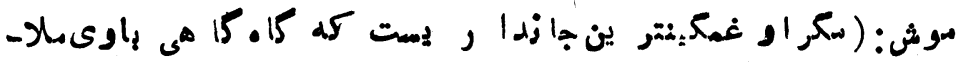

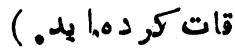

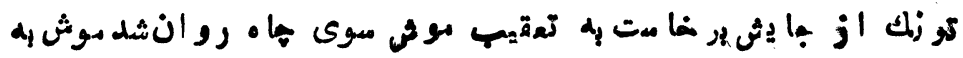

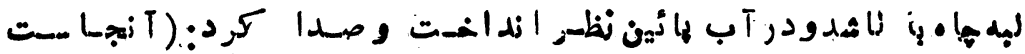

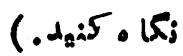

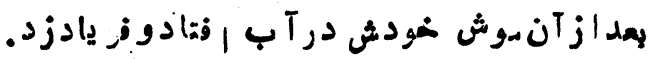

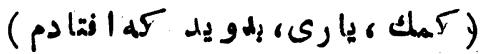

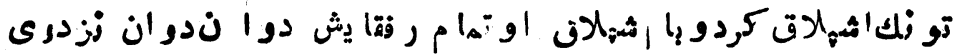

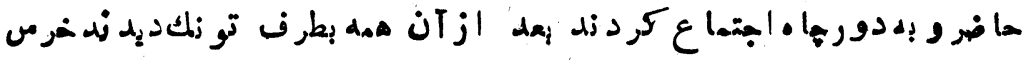

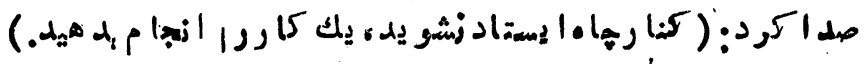

- 


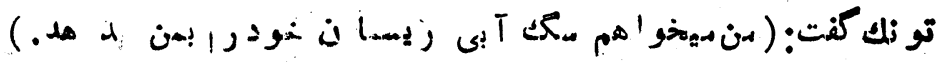

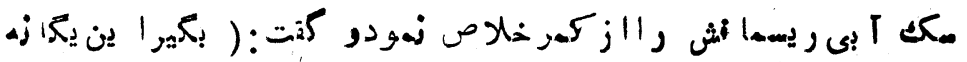

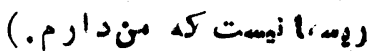

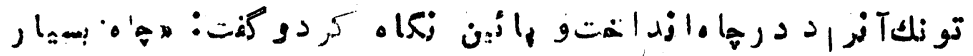

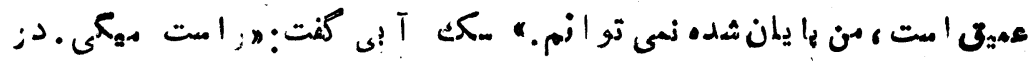

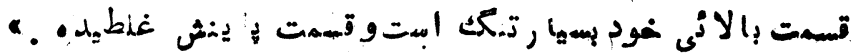

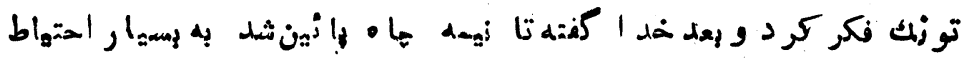

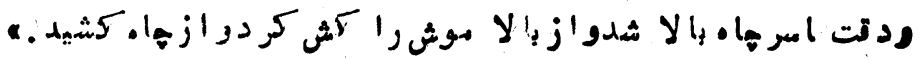

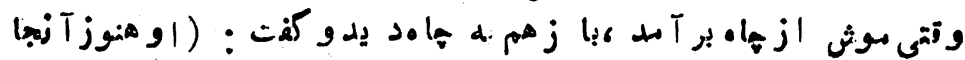

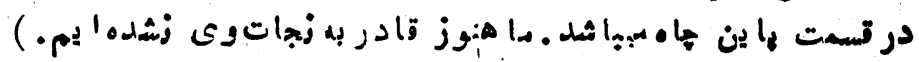

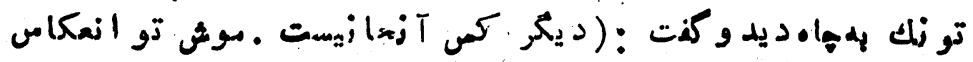

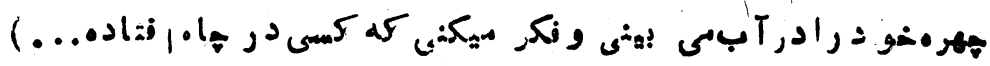

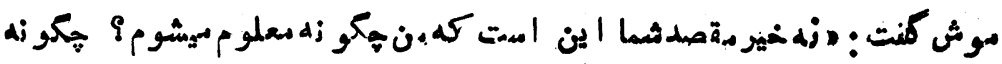

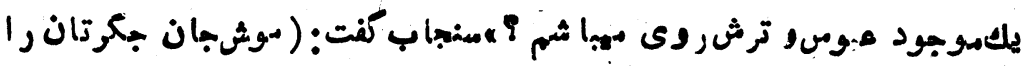

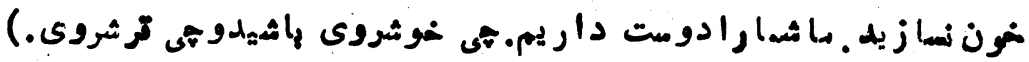

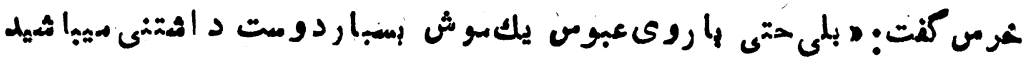

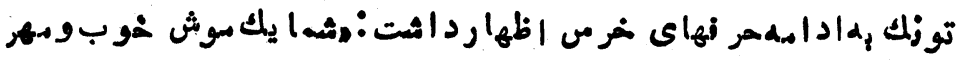

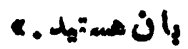

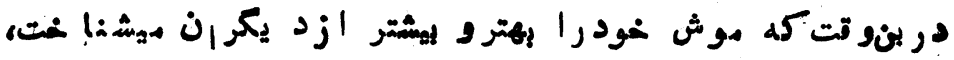

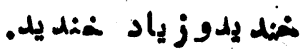

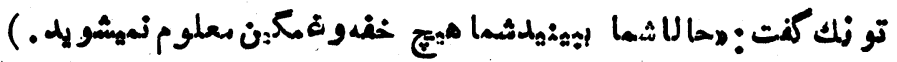

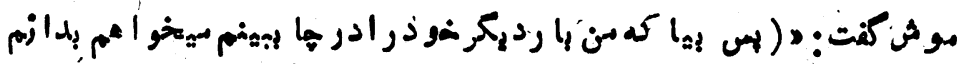

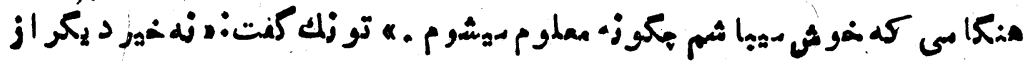

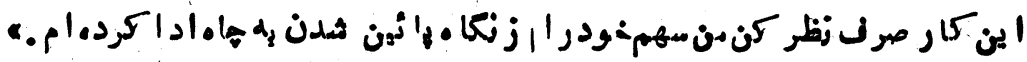

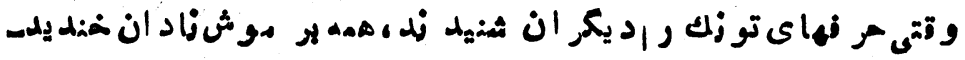

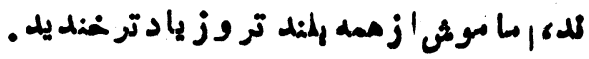
- IE - 


\section{عفريت ، جهيلنيسى}

\section{:}

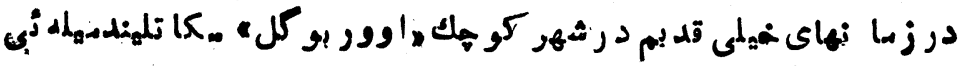

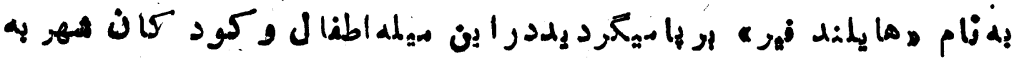

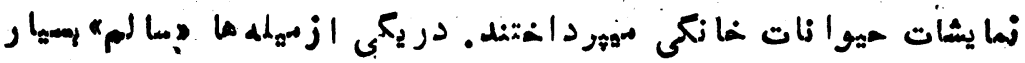

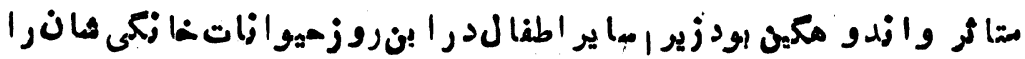

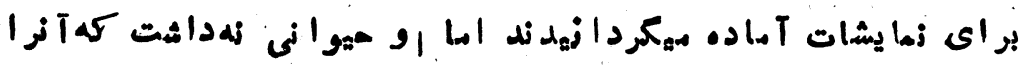

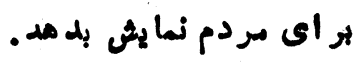

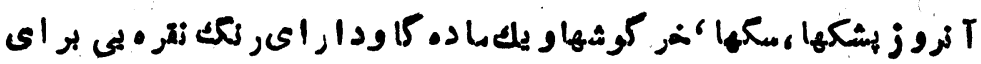

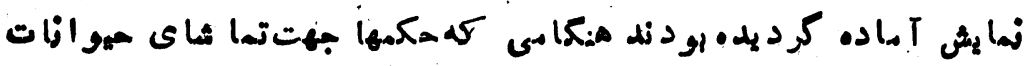

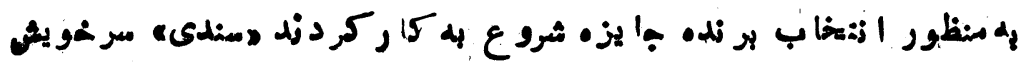

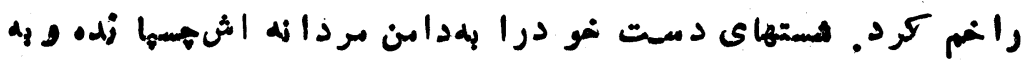

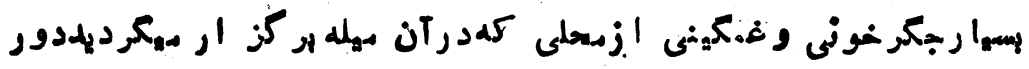

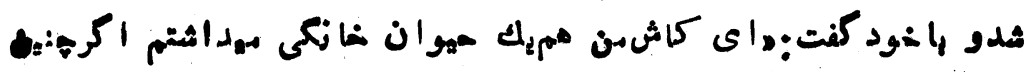

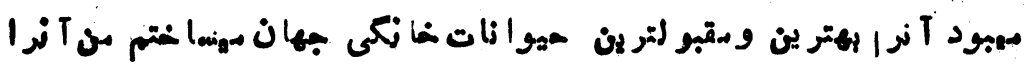

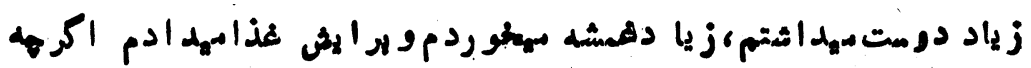

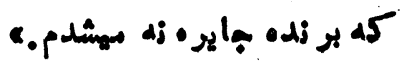




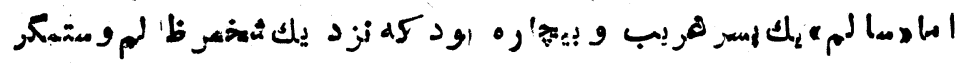

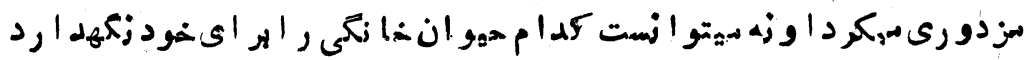

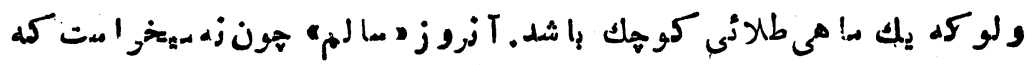

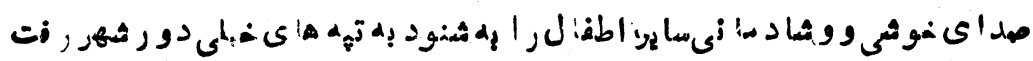

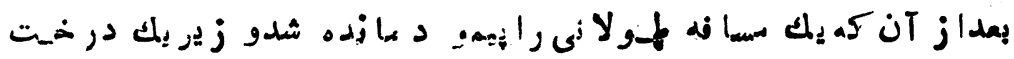

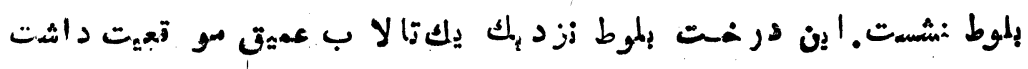

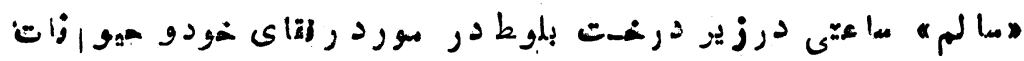

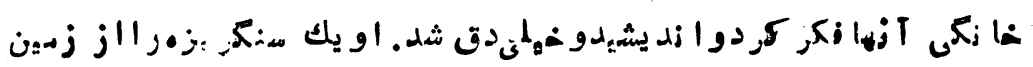

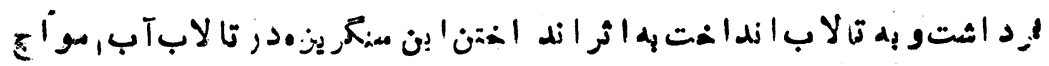

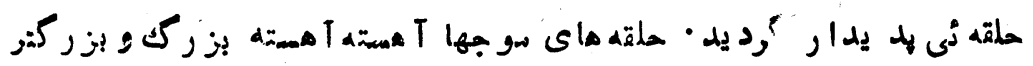

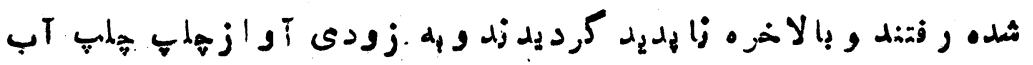

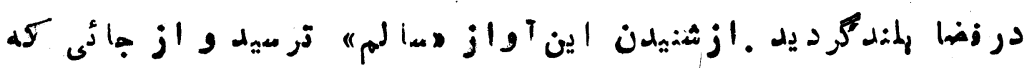

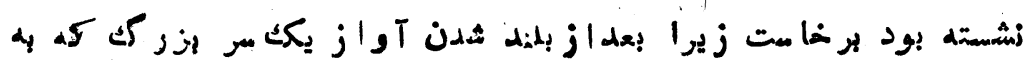

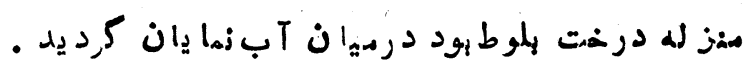

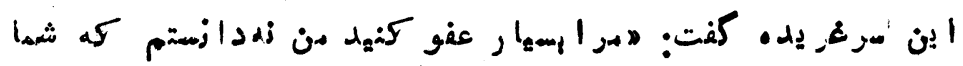

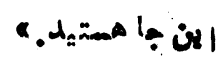

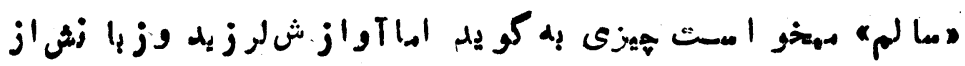

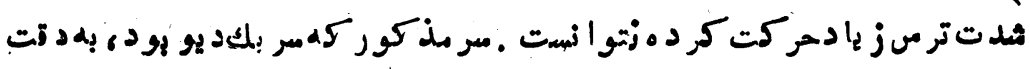

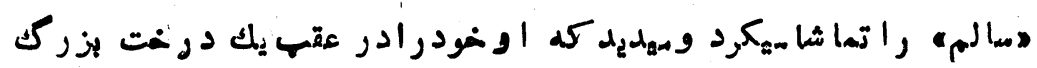

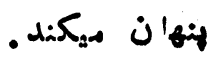

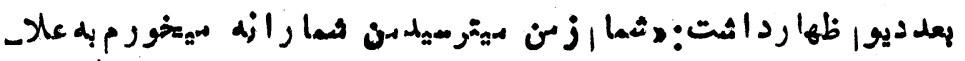

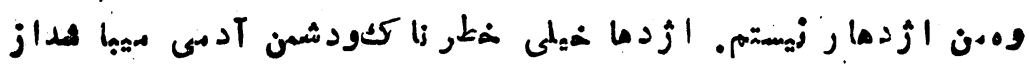

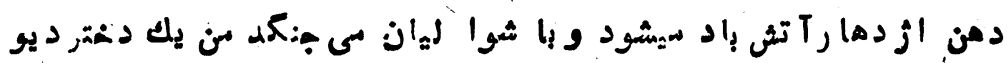

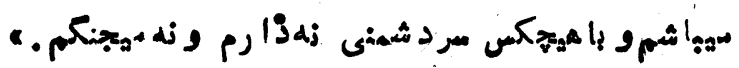




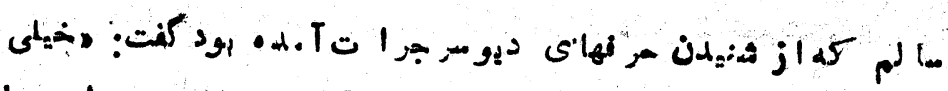

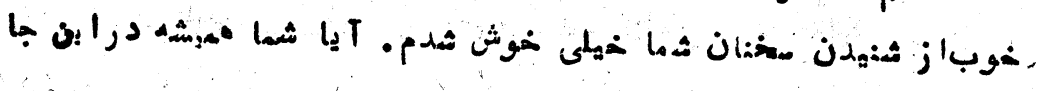

ز زلد.

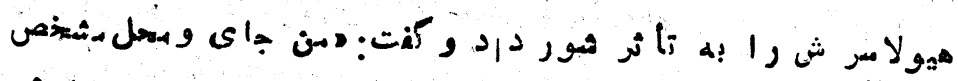

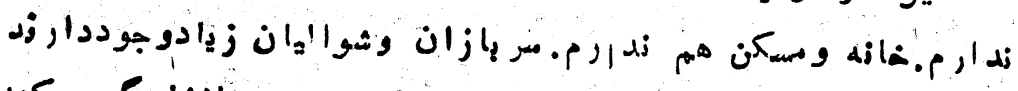

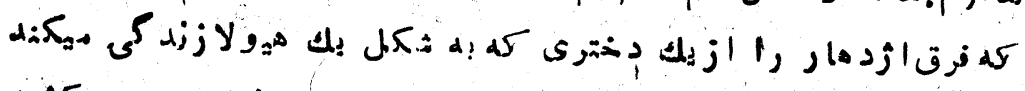

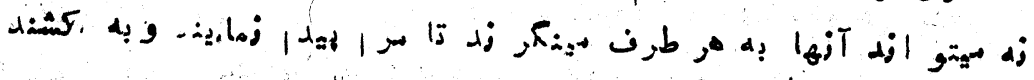

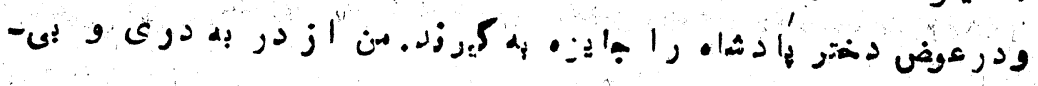

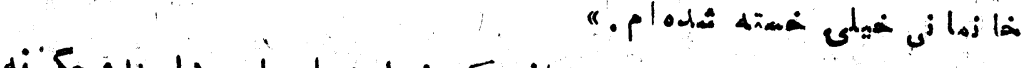

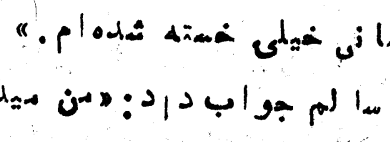

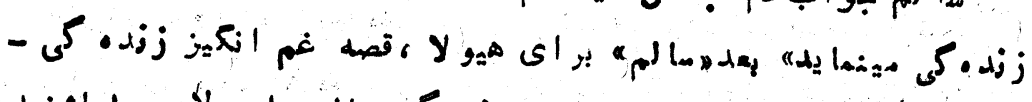

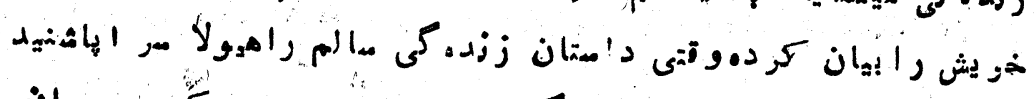

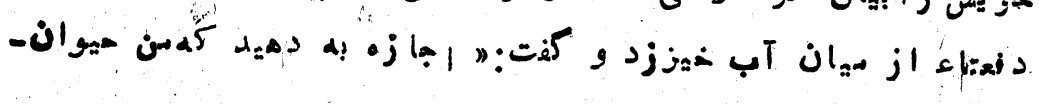

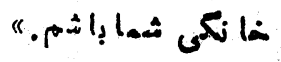

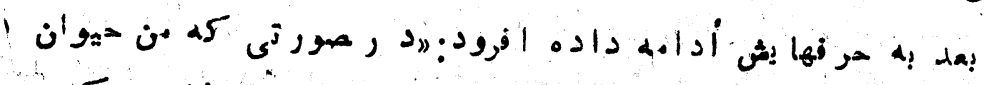

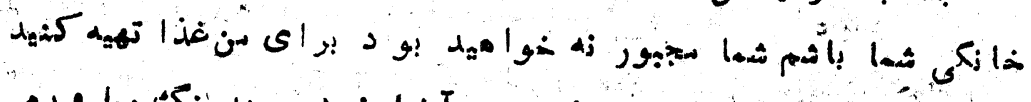

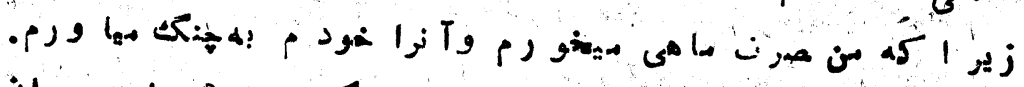

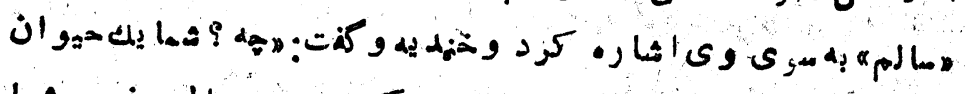

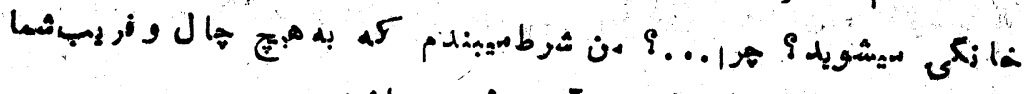

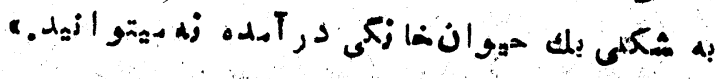

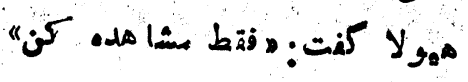

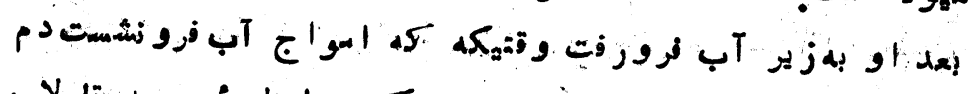

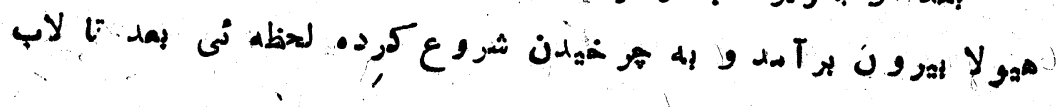

$$
-12=
$$




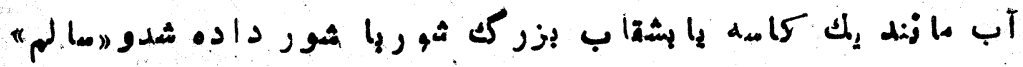

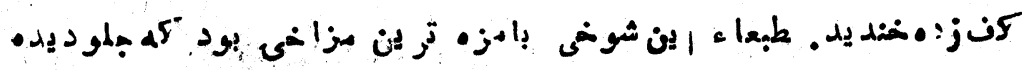

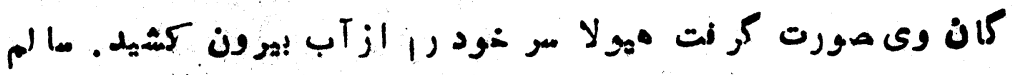

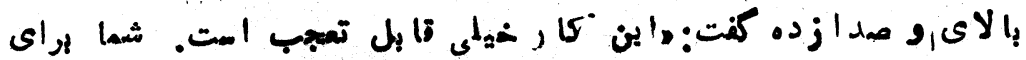

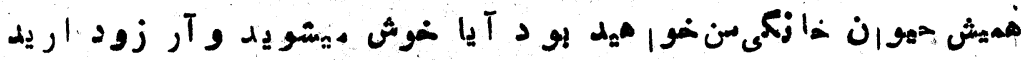

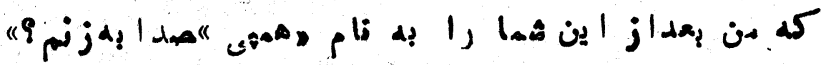

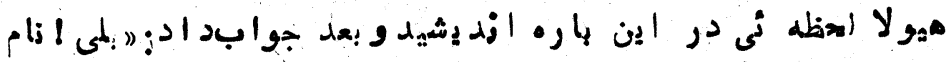

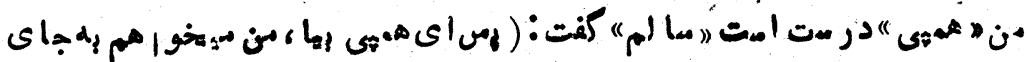

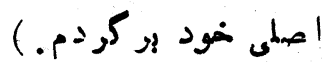

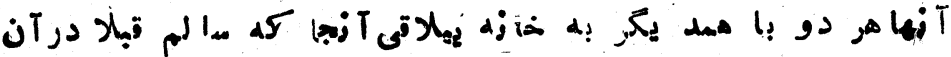

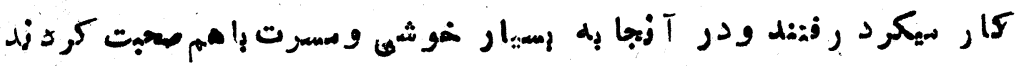

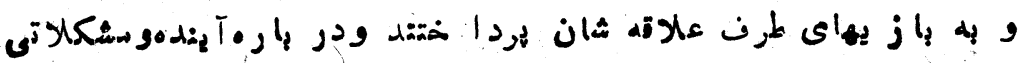

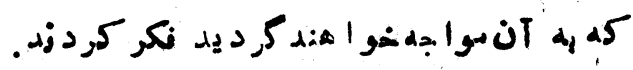

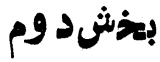

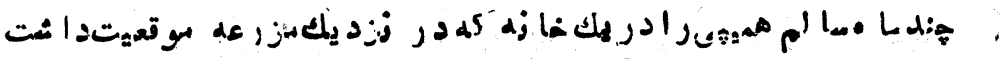

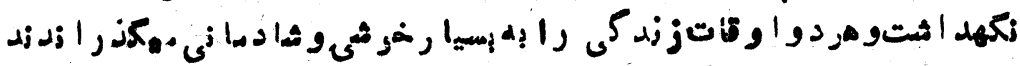

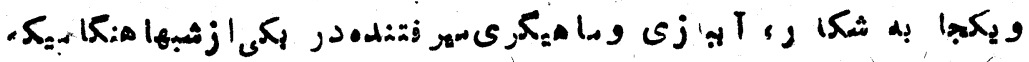

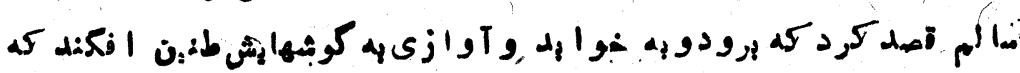

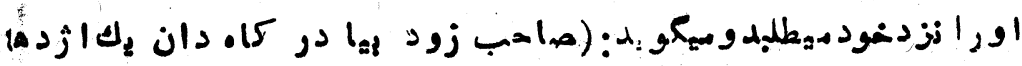

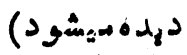

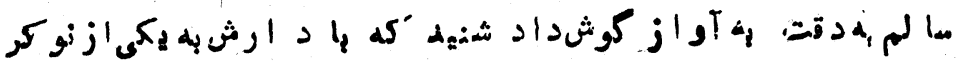

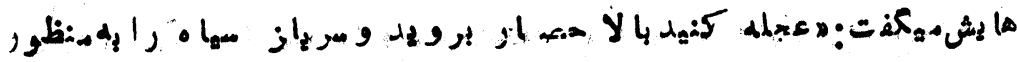

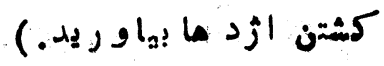




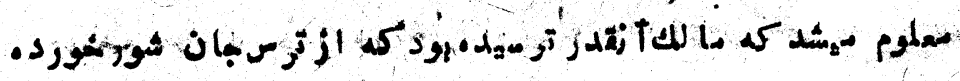

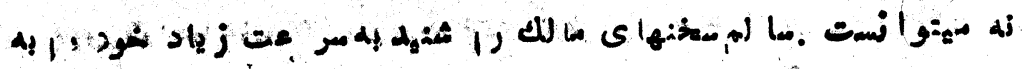

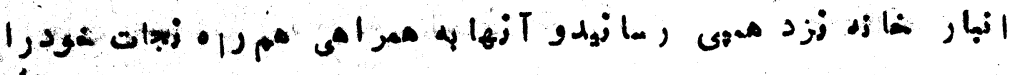

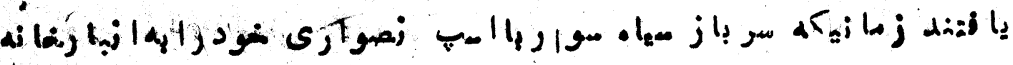

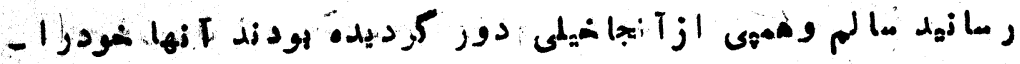

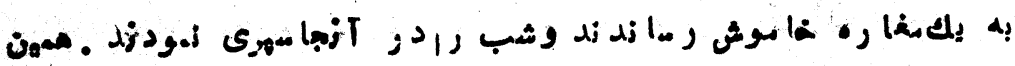

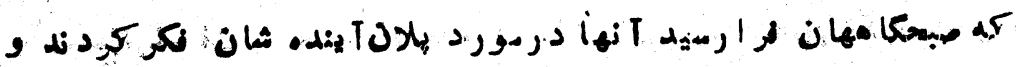

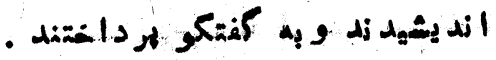

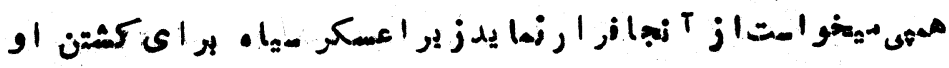

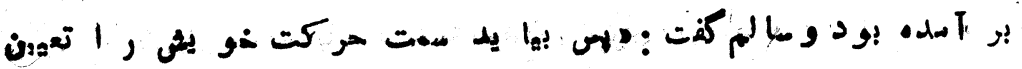

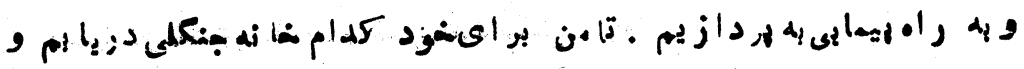

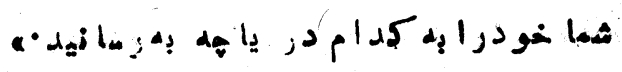

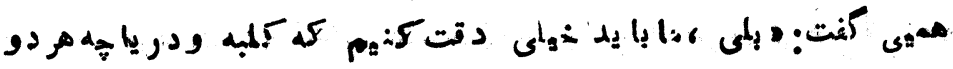

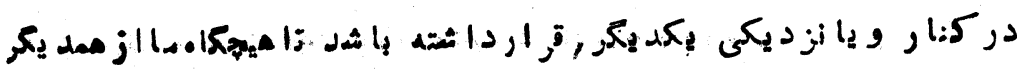

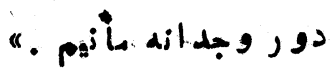

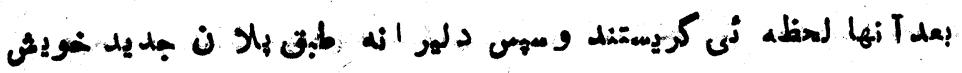

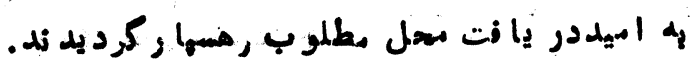
بخش سوم

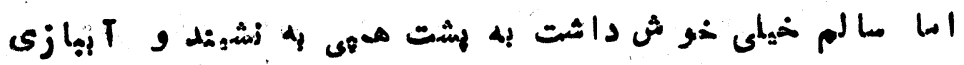

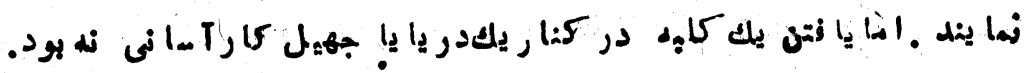

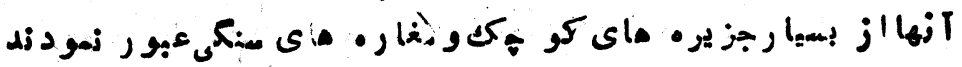

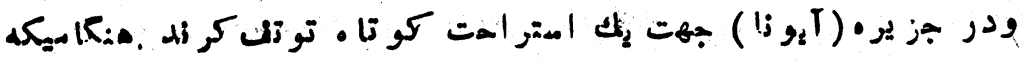

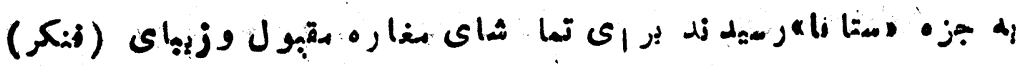

$$
-19-
$$




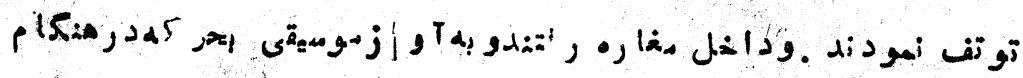

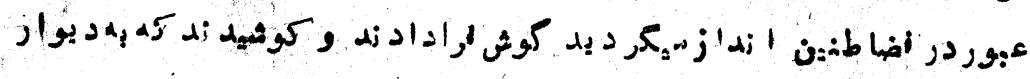

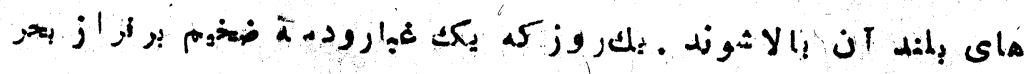

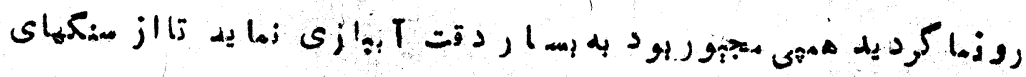

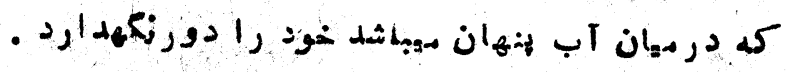

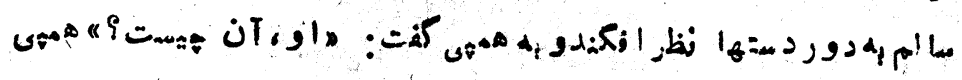

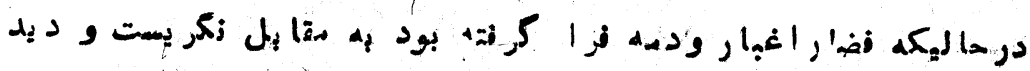

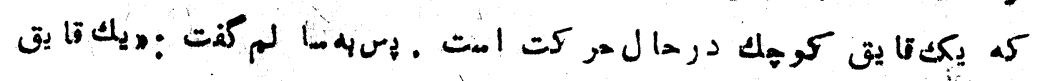

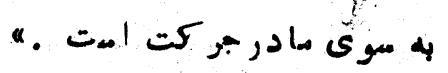

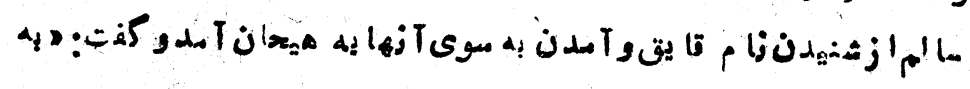

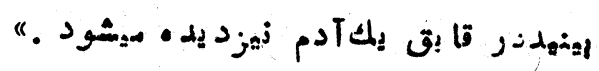

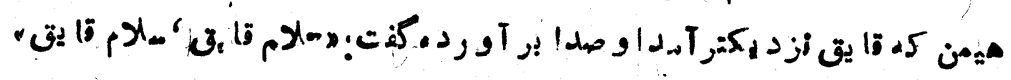

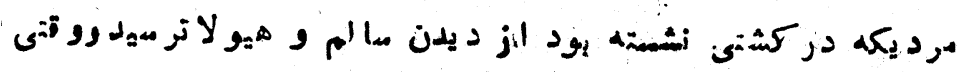

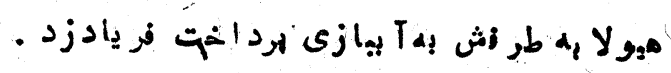

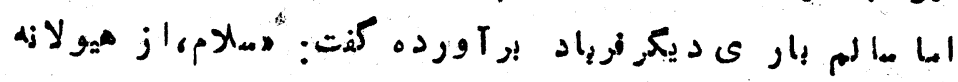

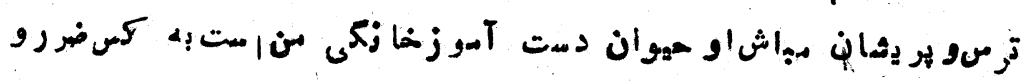

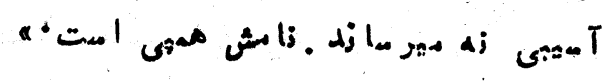

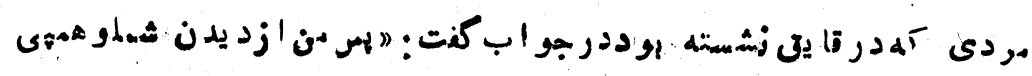

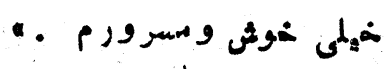

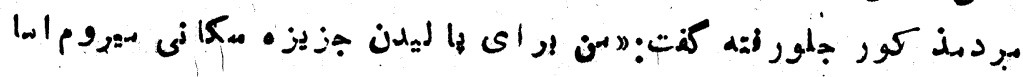

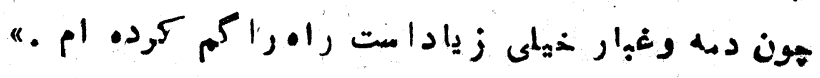

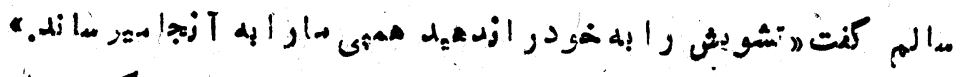

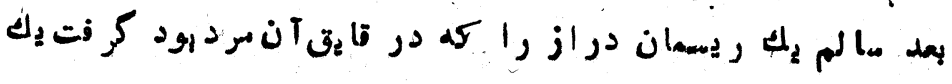




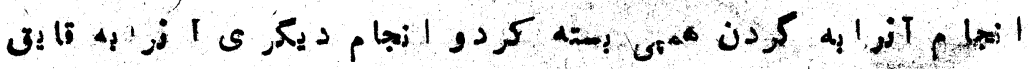
".joni pros.

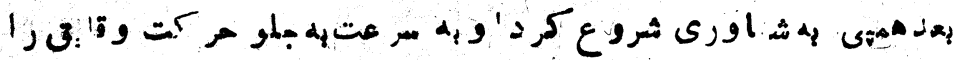

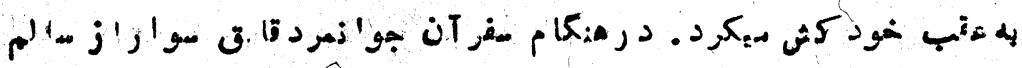

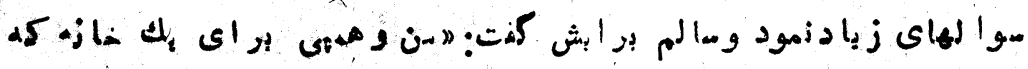

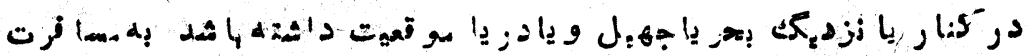

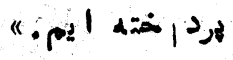

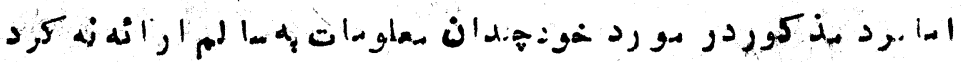

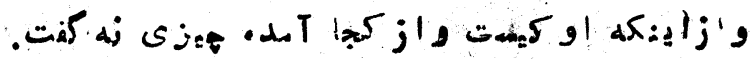

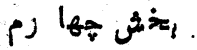

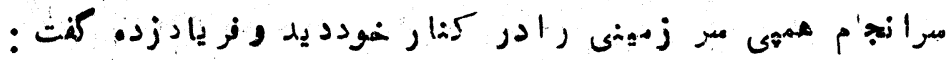

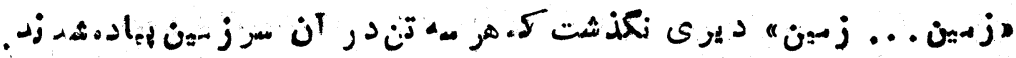

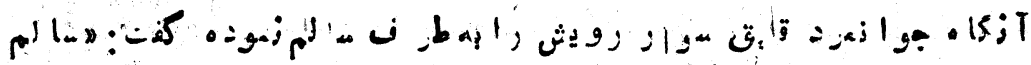

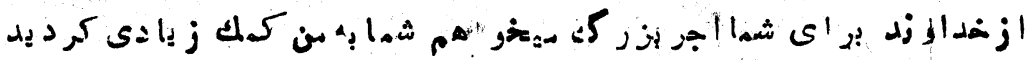

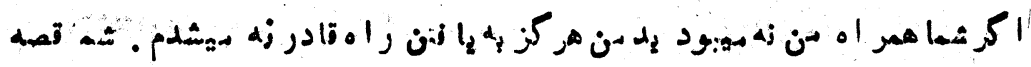

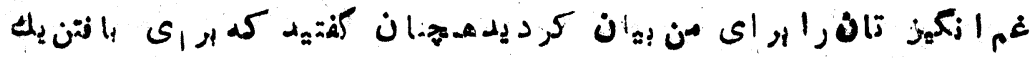

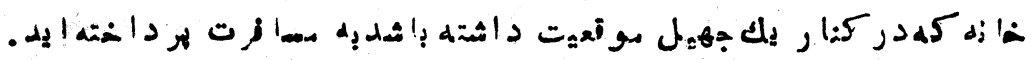

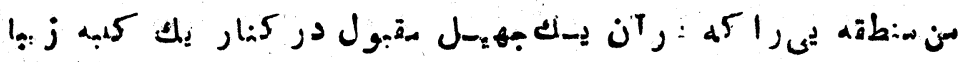

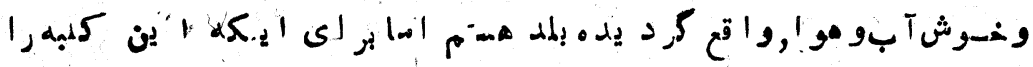

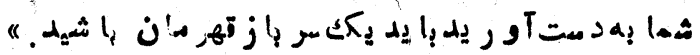

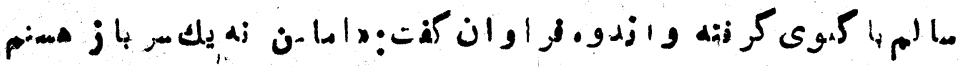

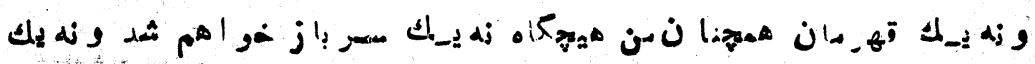

هورنان

- r 1. - 


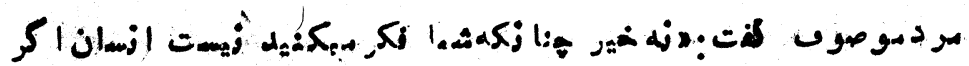

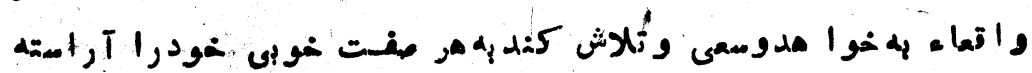

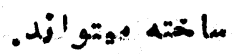

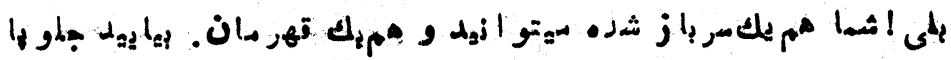

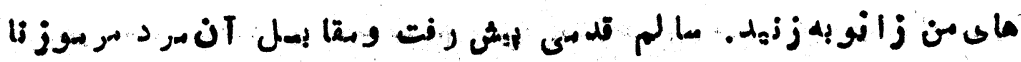

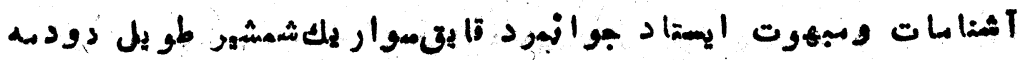

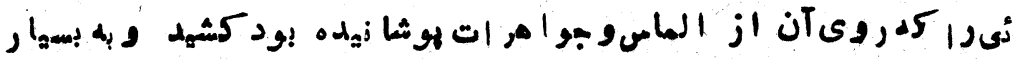

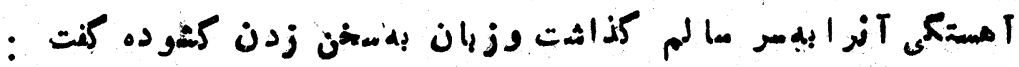

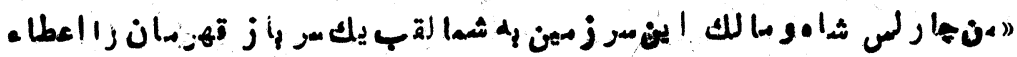

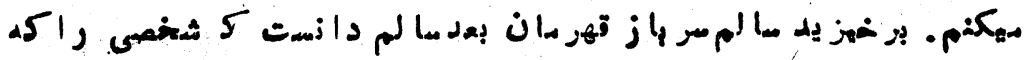

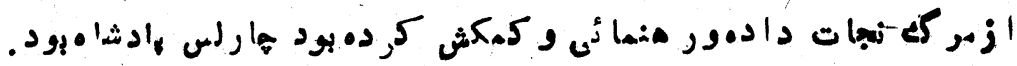

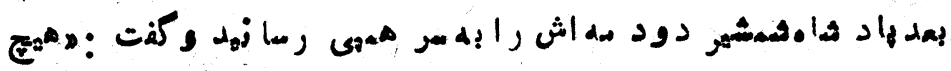

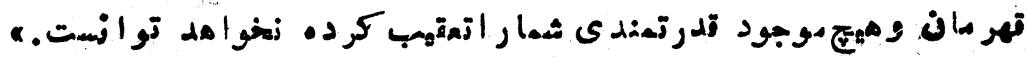

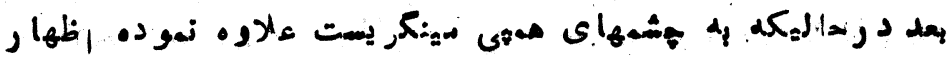

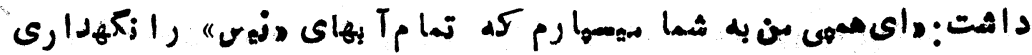

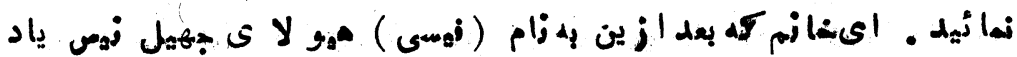

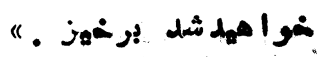

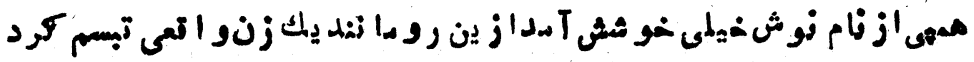

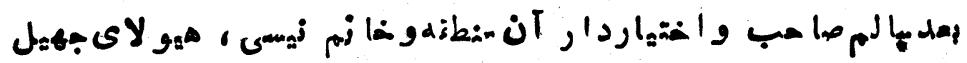

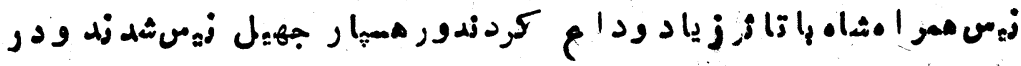

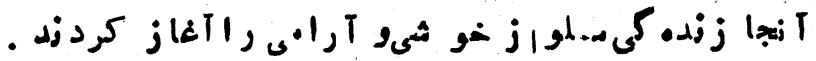

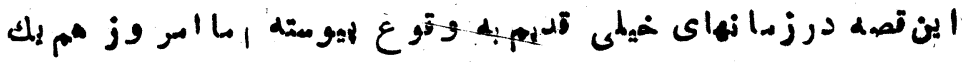

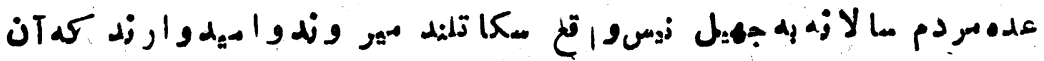

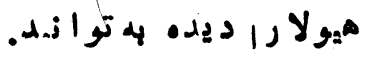



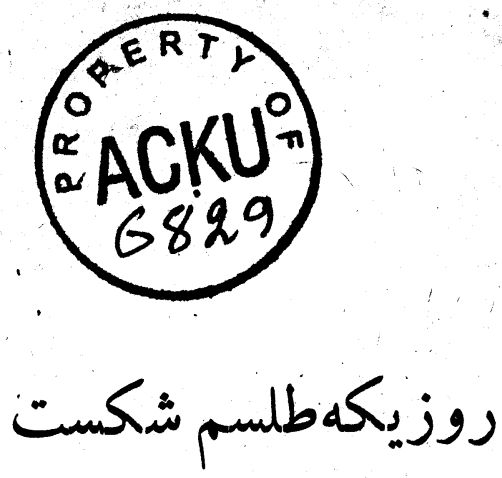

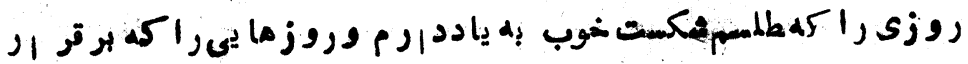

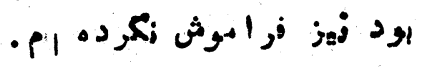

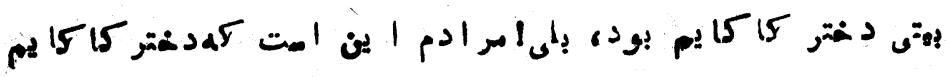

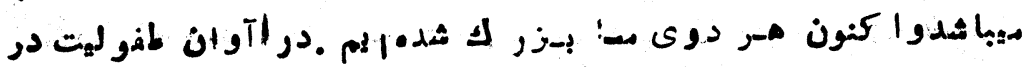

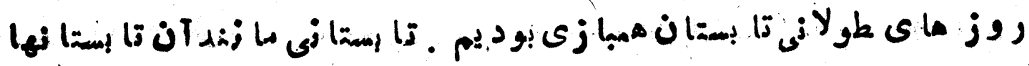

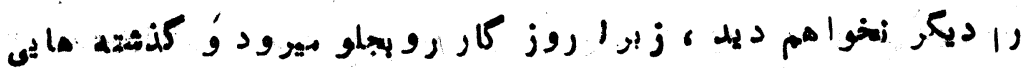

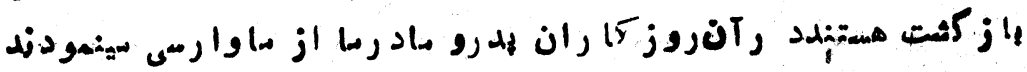

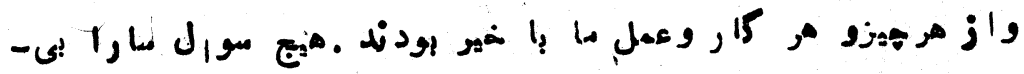

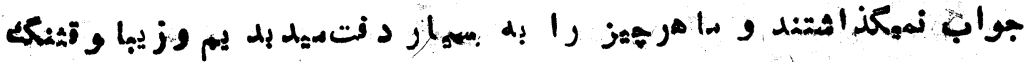

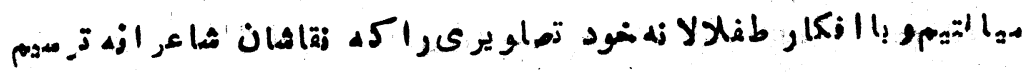

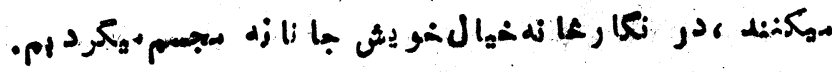

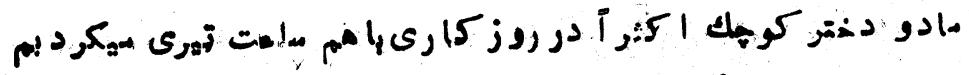

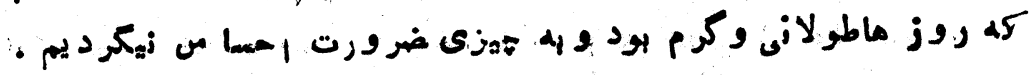

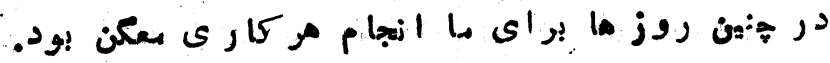

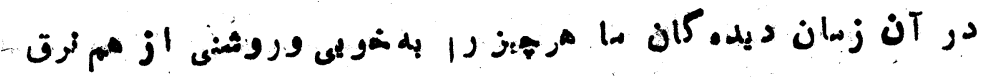

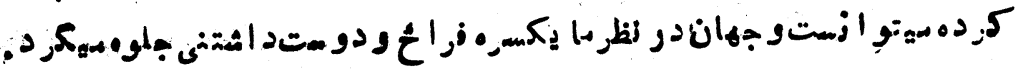




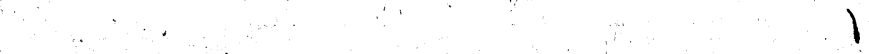

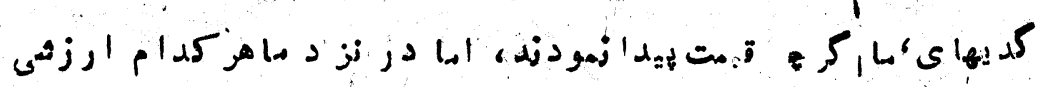

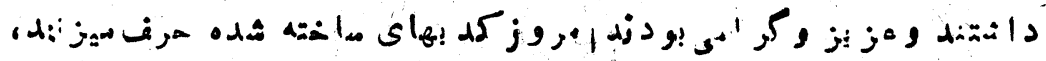

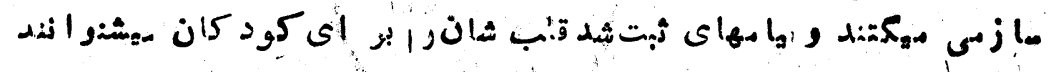

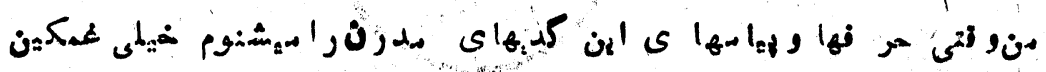

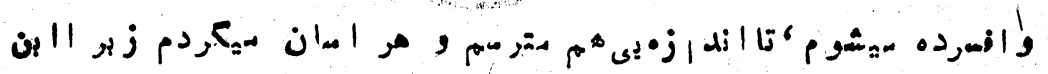

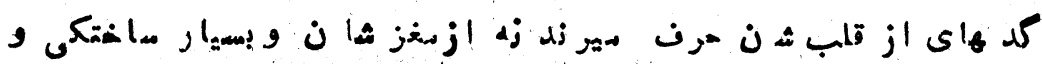

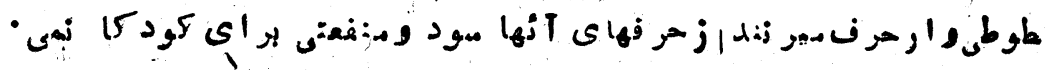

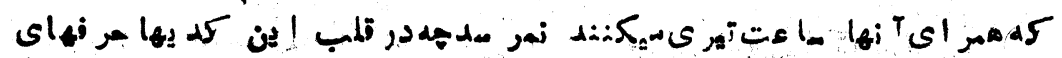

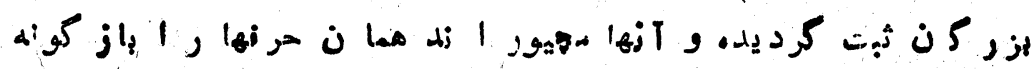

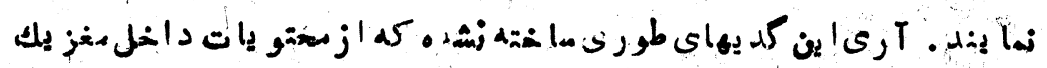

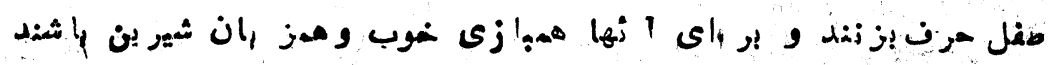

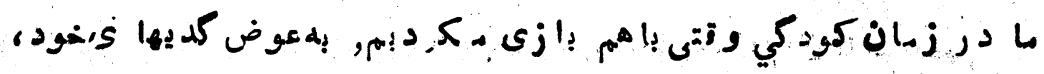

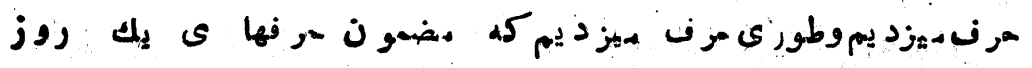

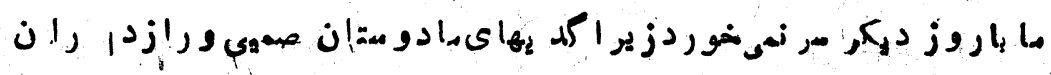

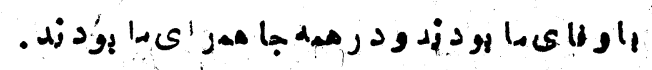

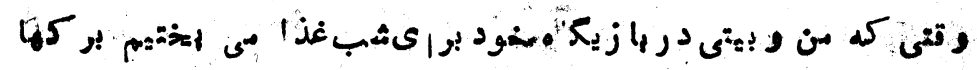

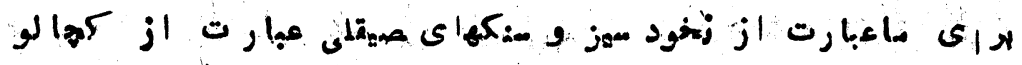

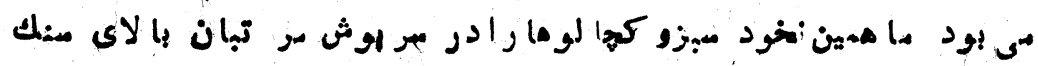

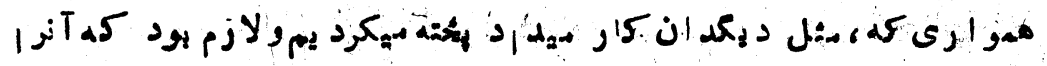

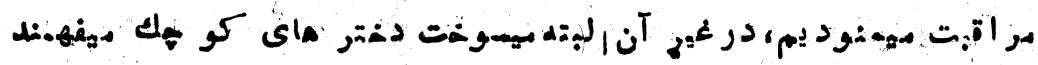

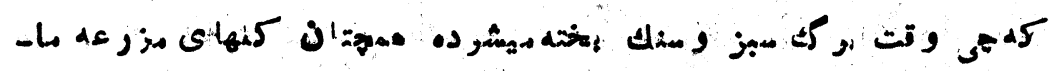

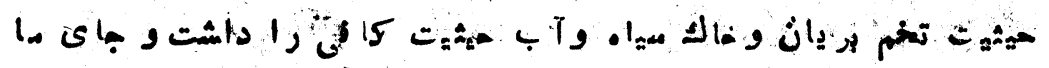
. 


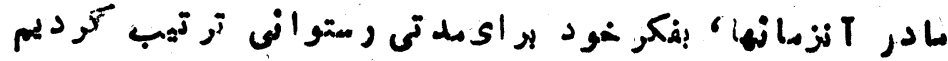

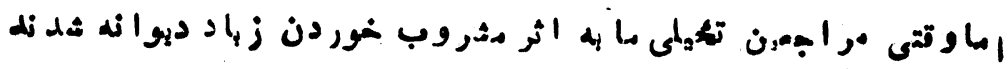

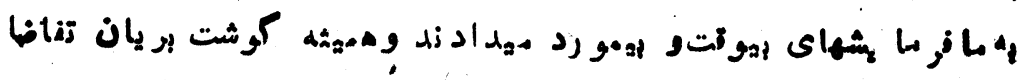

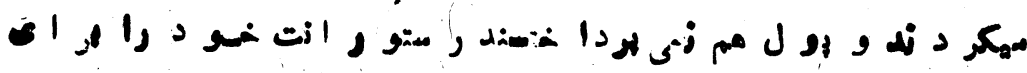

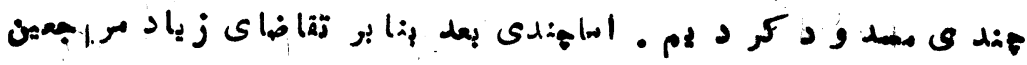

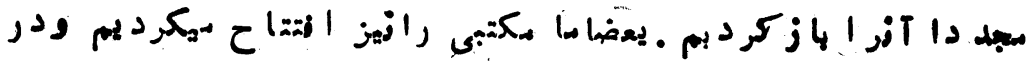

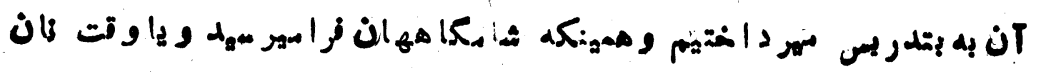

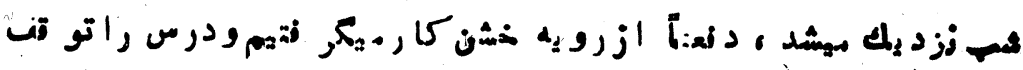

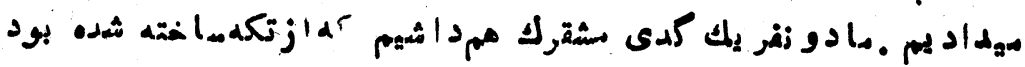

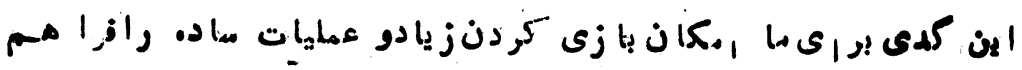

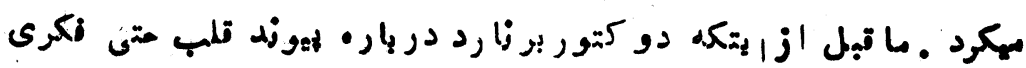

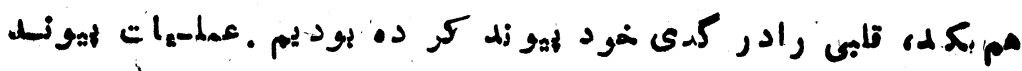

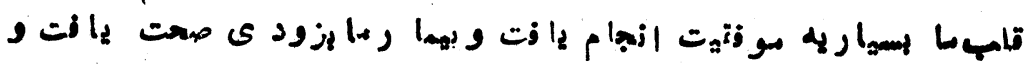

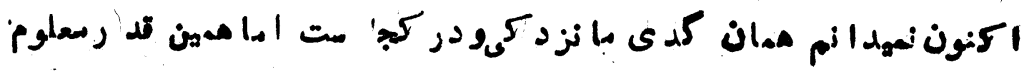

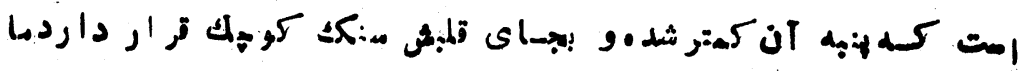

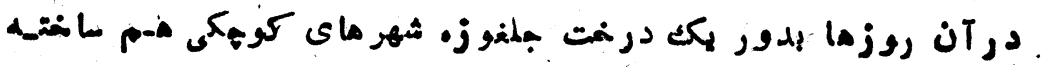

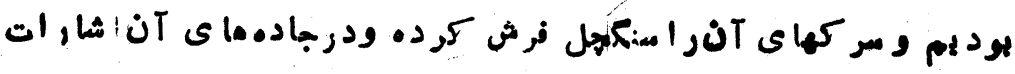

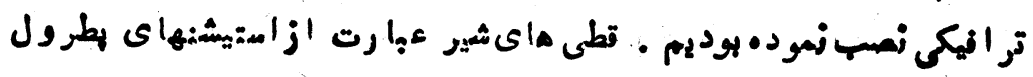

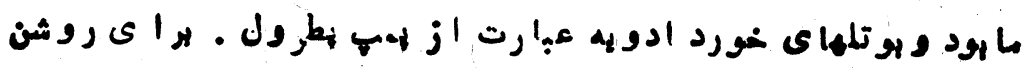

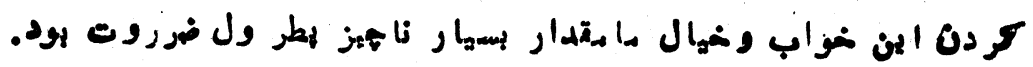

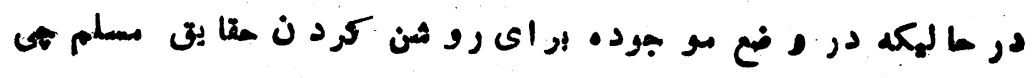

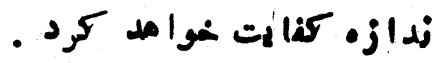

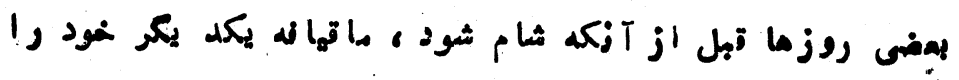




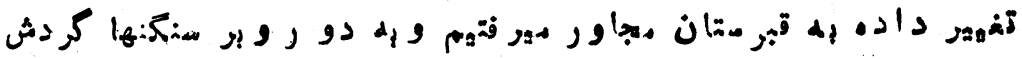

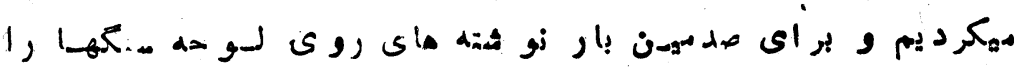

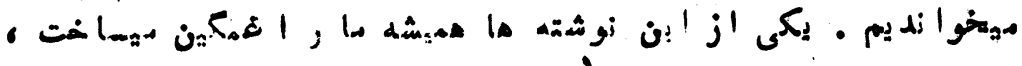

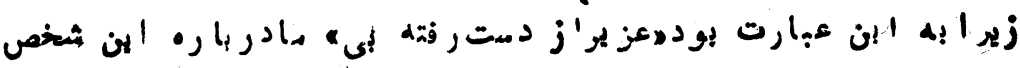

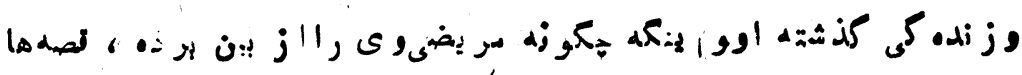

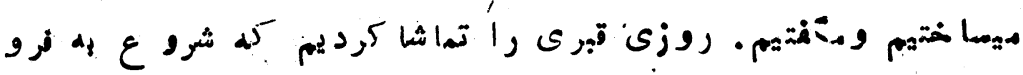

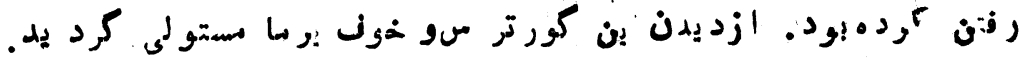

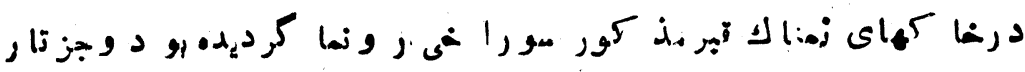

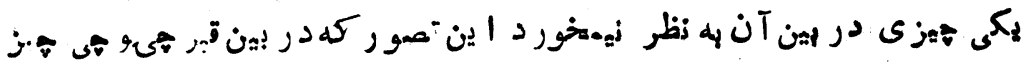

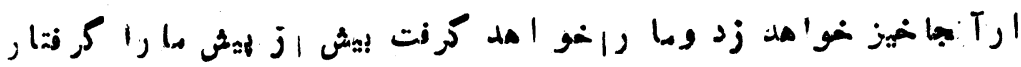

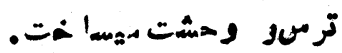

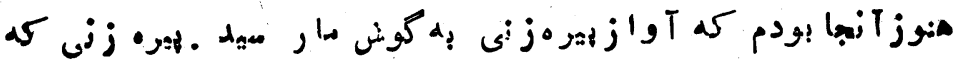

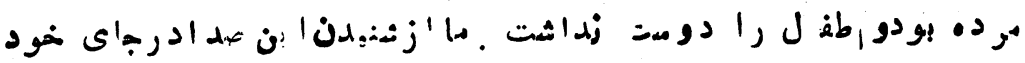

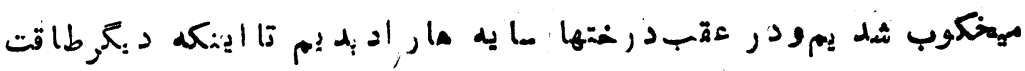

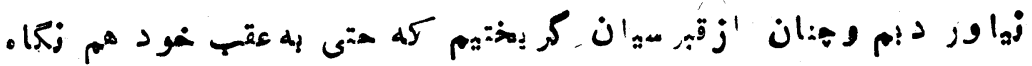

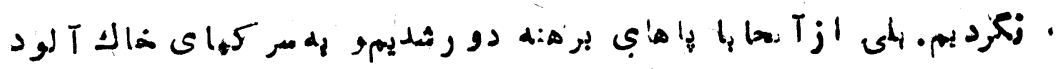

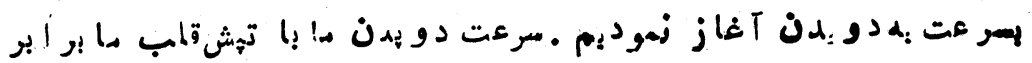

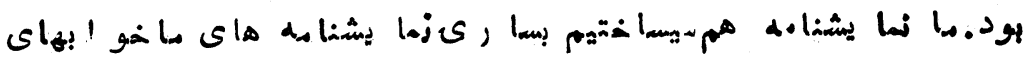

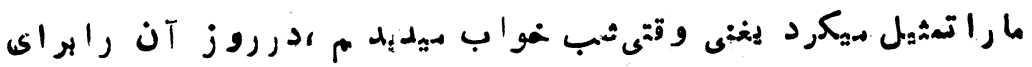

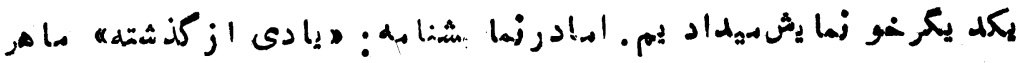

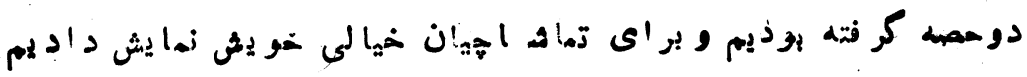

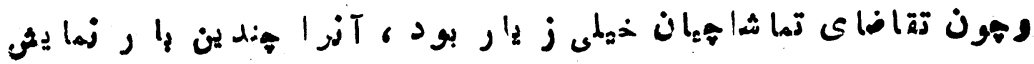
- pls 


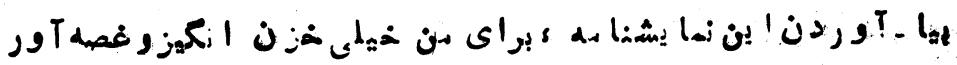

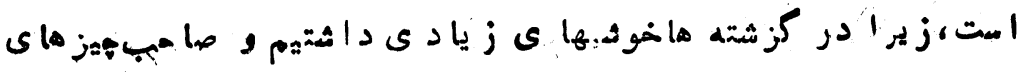

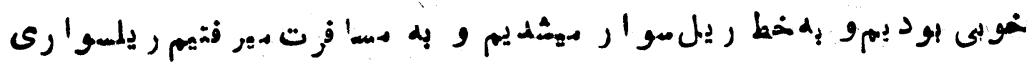

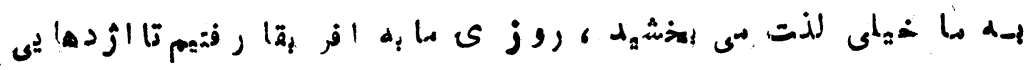

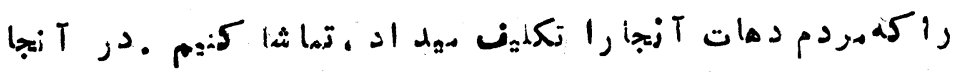

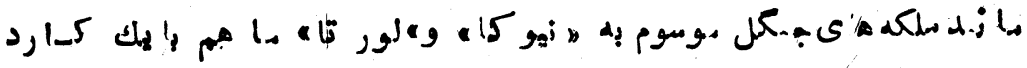

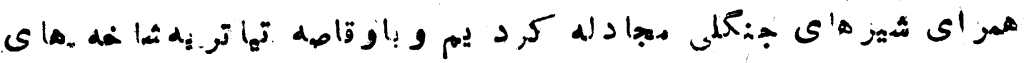

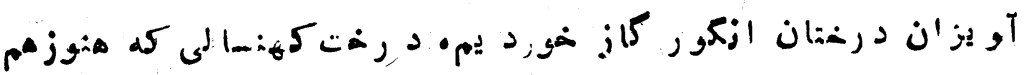

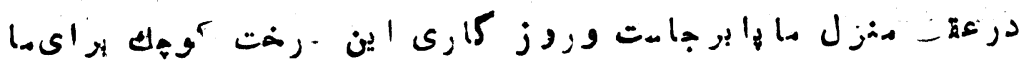

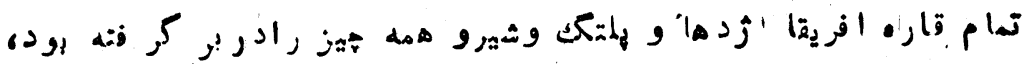

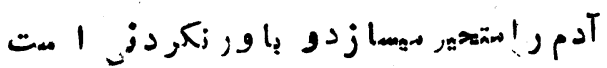

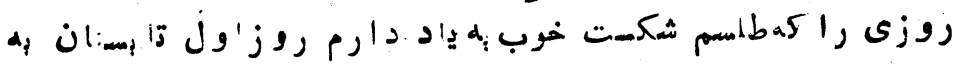

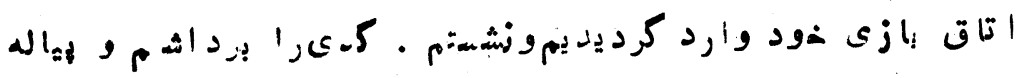

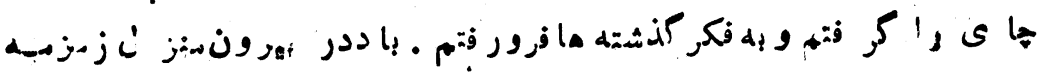

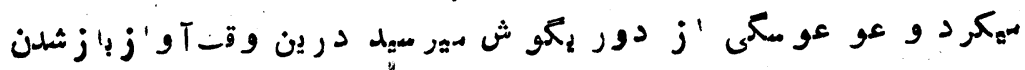

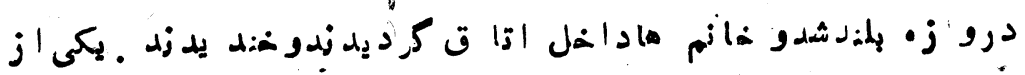

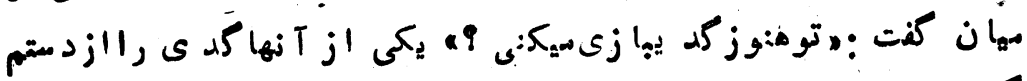

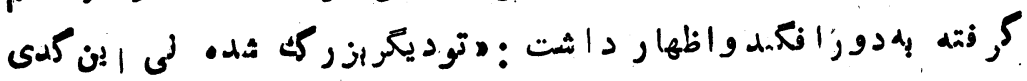

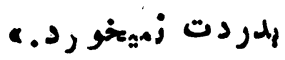

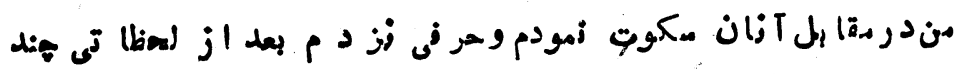

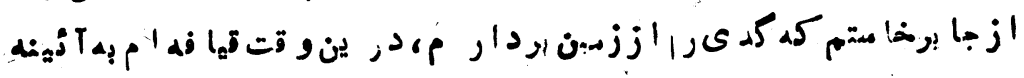

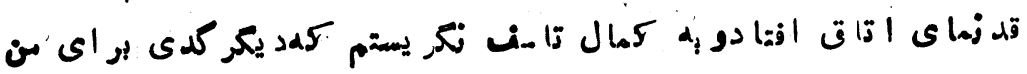

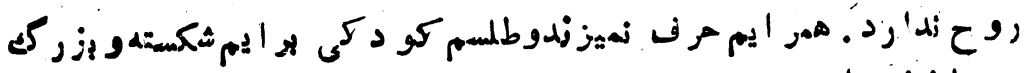

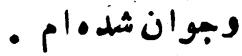

$-r V-$ 


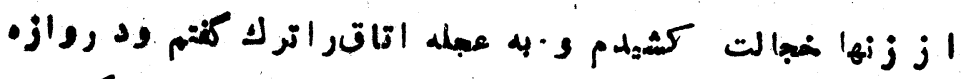

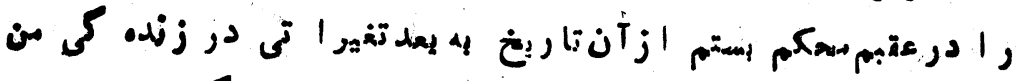

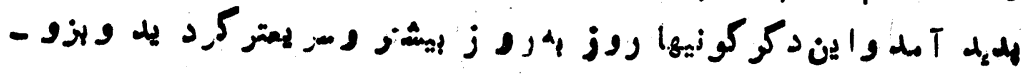

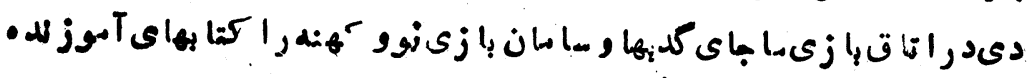

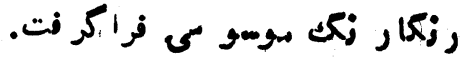

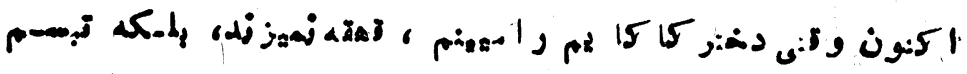

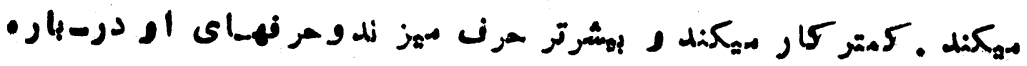

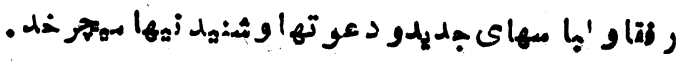

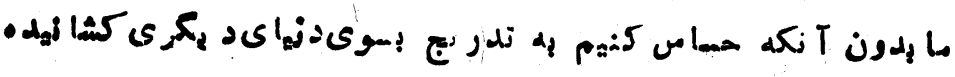

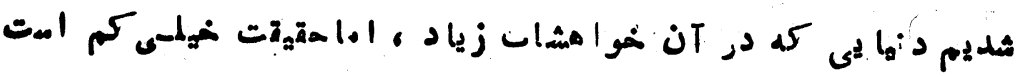

A 
يك سال عجيب

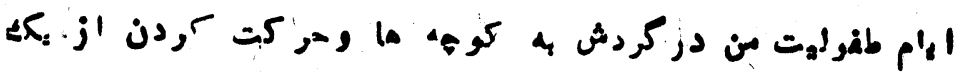

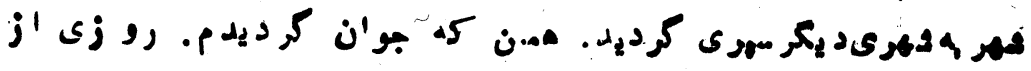

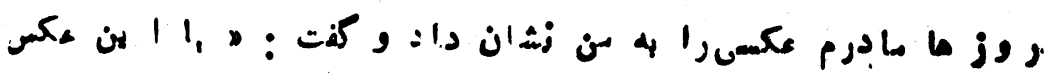

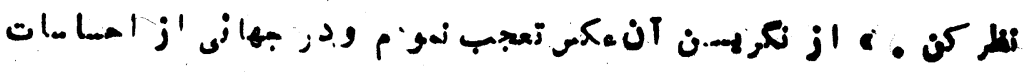

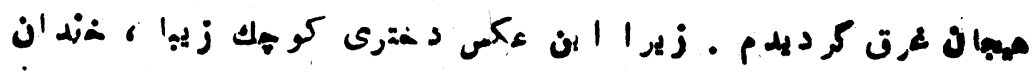

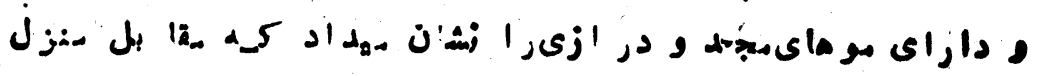

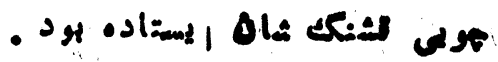

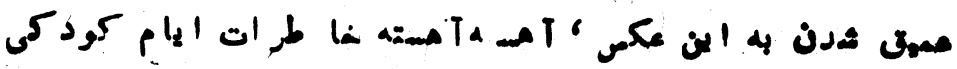

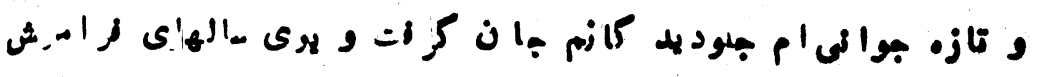

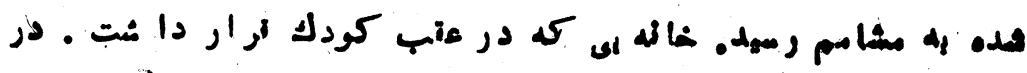

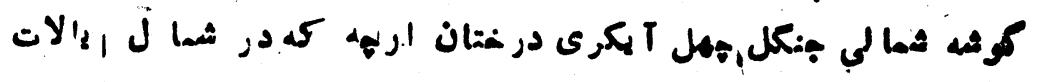

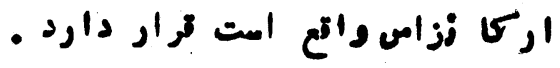

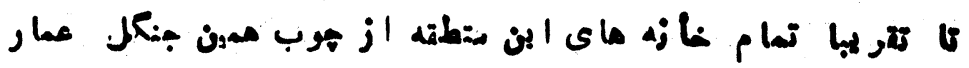

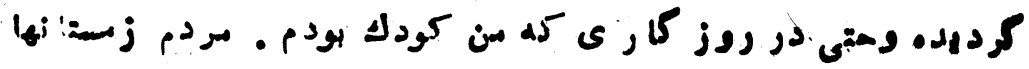

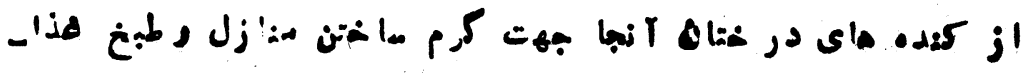

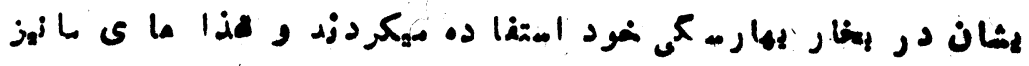

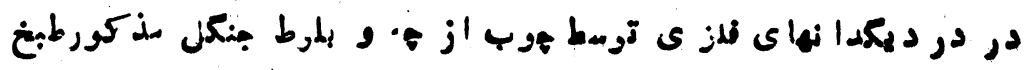

- di

- rq 


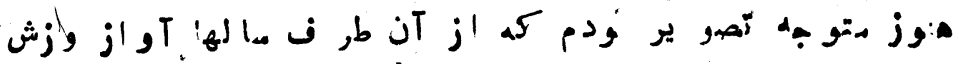

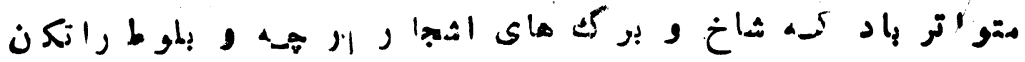

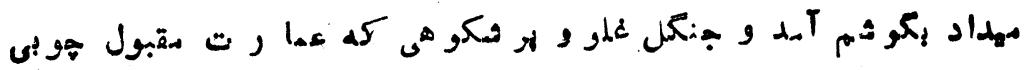

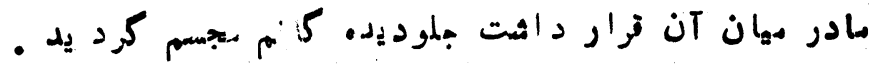

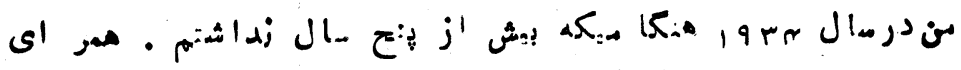

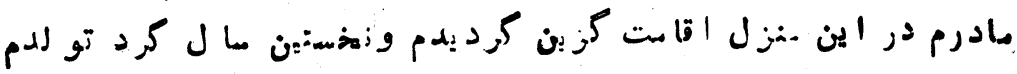

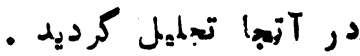

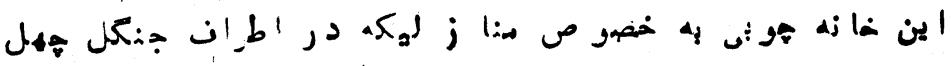

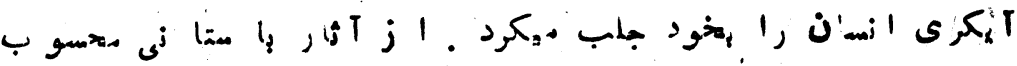

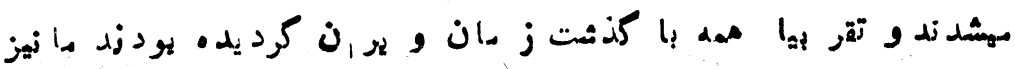

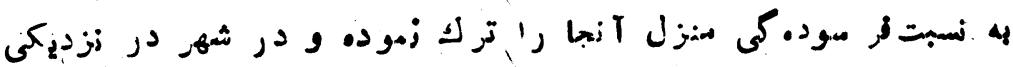

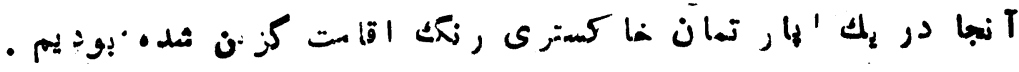

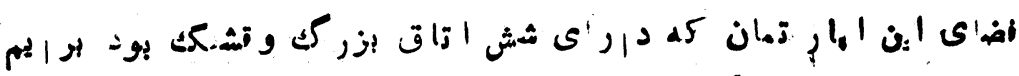

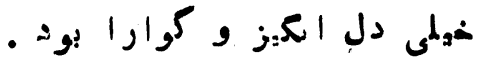

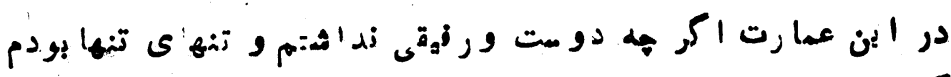

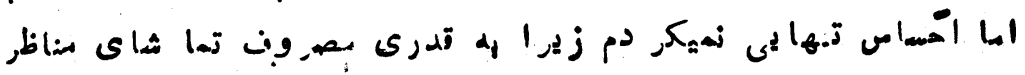

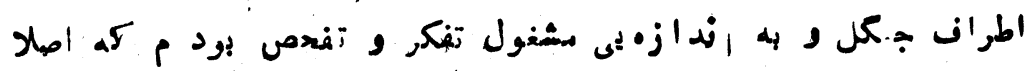

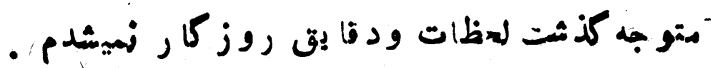

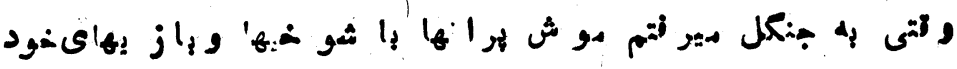

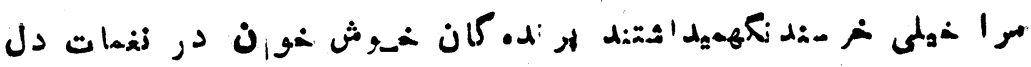

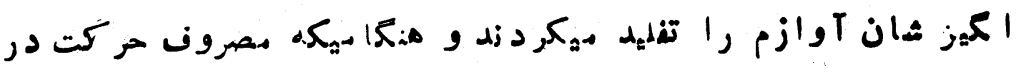

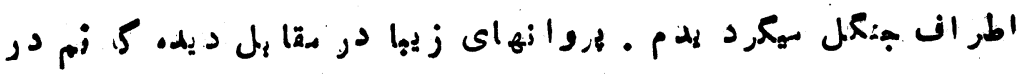

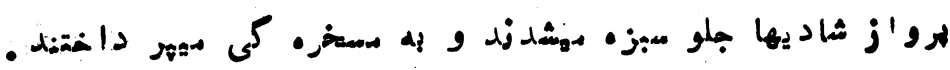

-r.- 


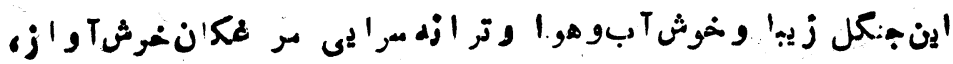

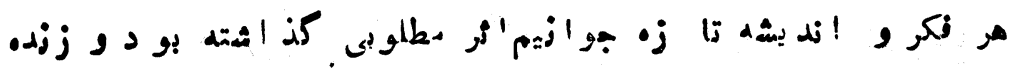

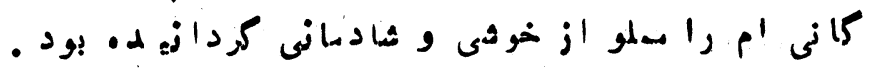

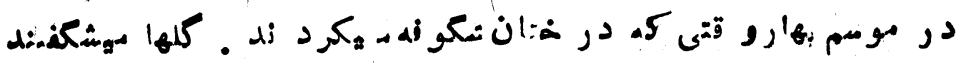

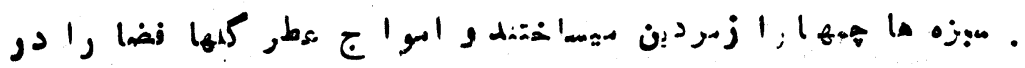

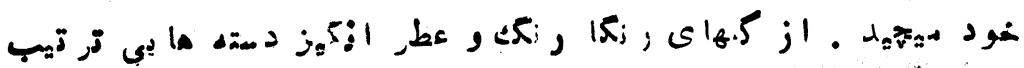

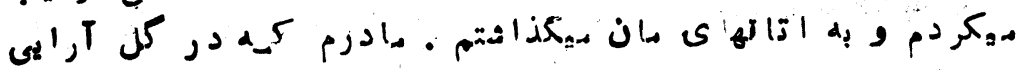

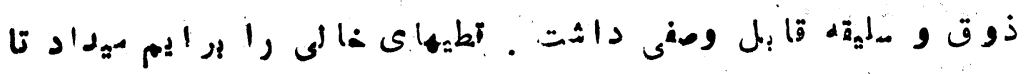

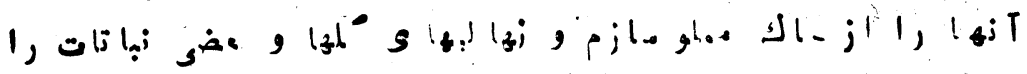

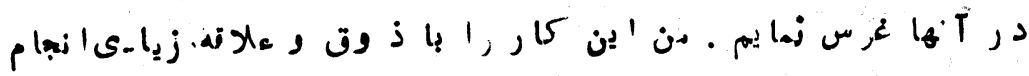

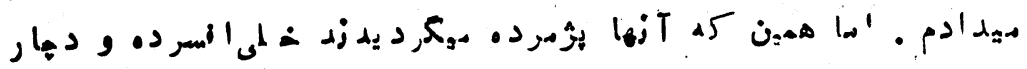

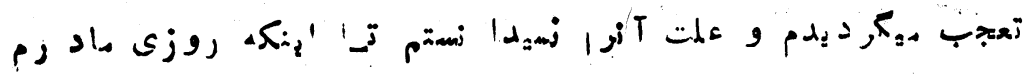

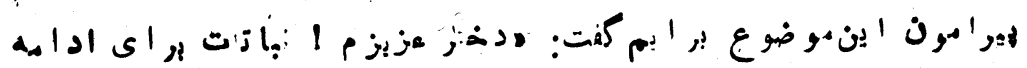

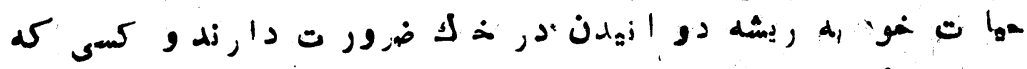

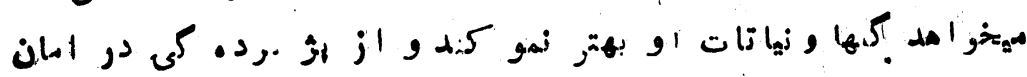

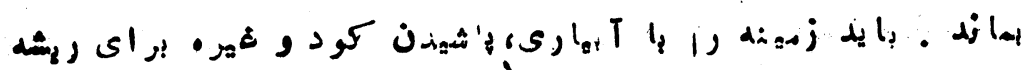

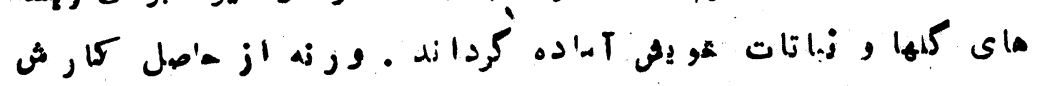

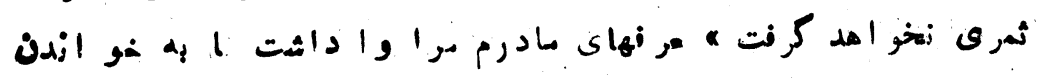

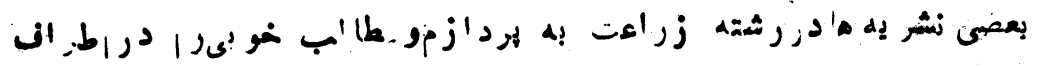

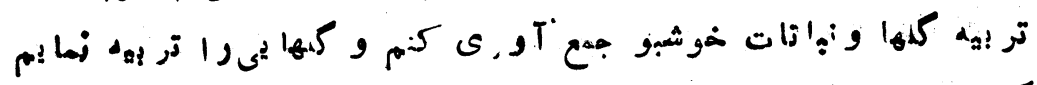

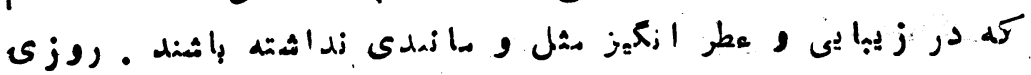

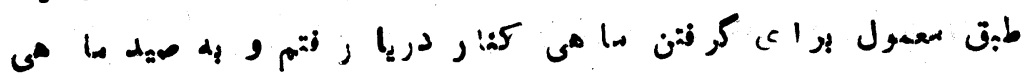

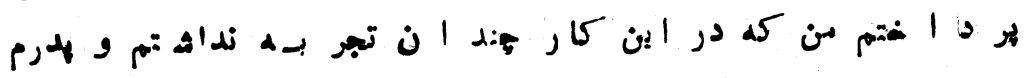

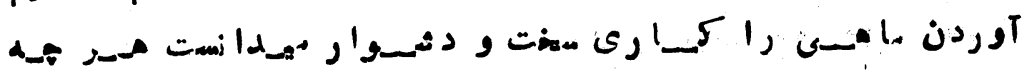

-ri- 


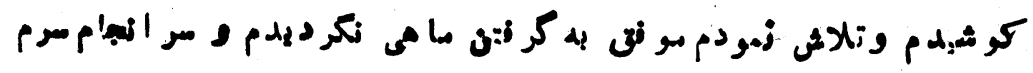

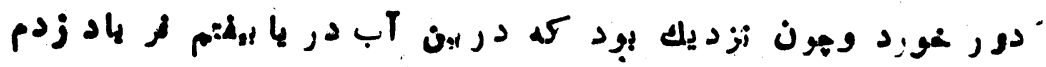

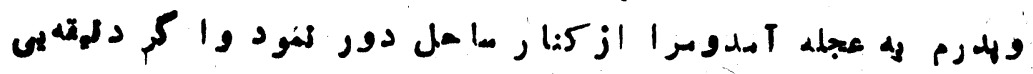

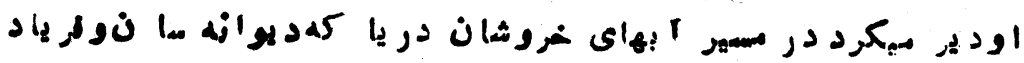

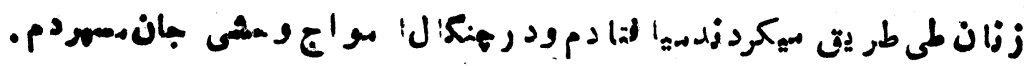

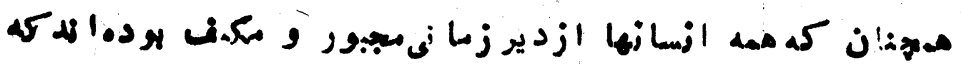

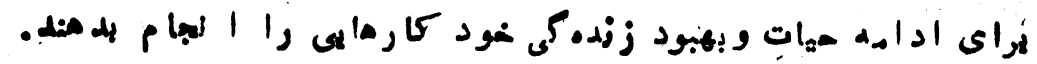

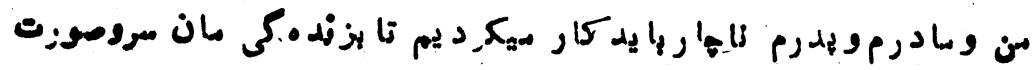

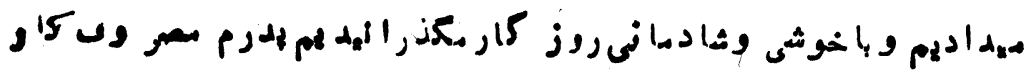

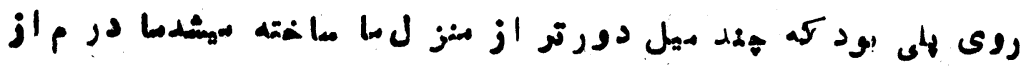

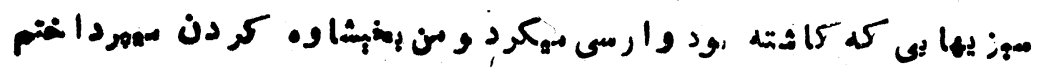

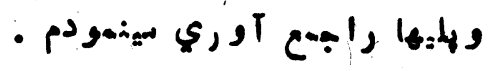

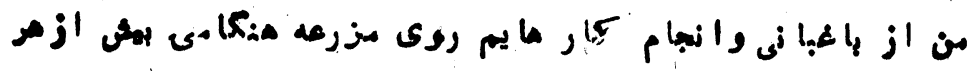

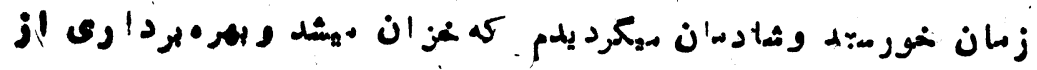

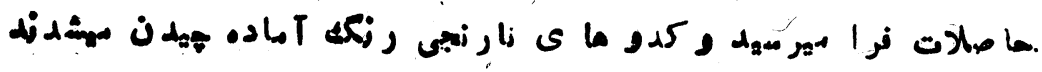

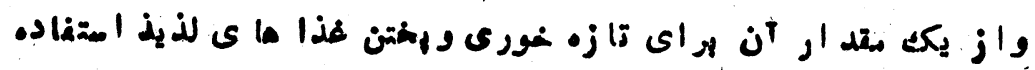

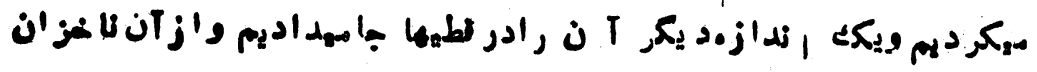

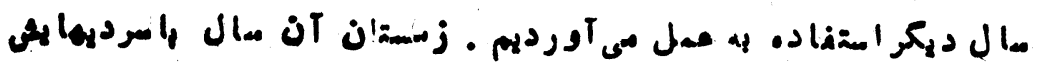

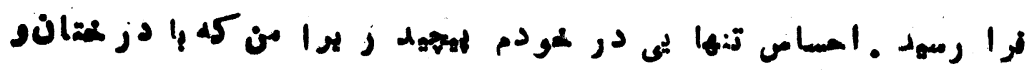

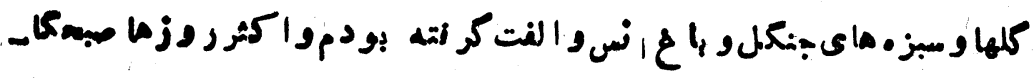

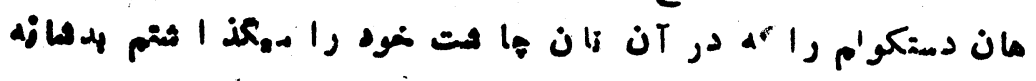

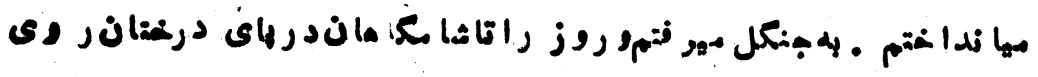

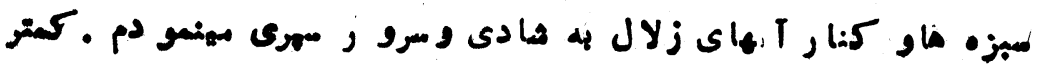




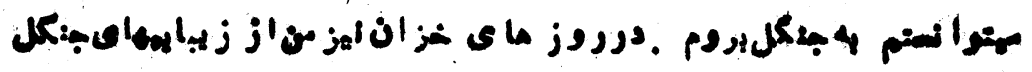

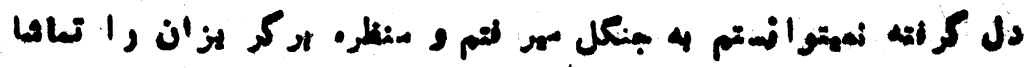

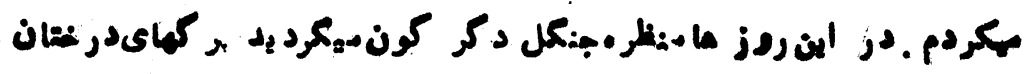

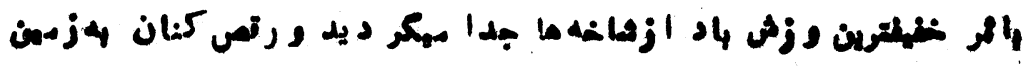

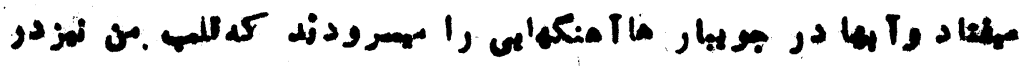

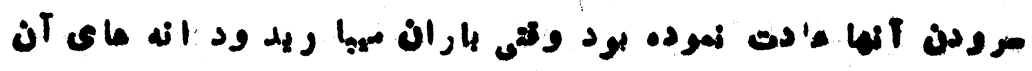

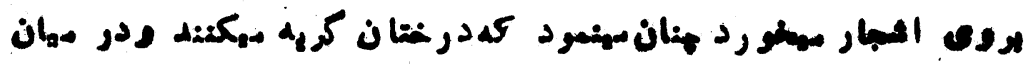

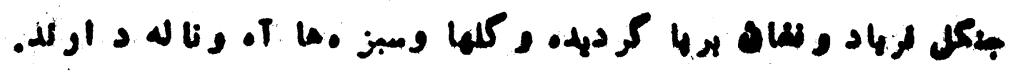

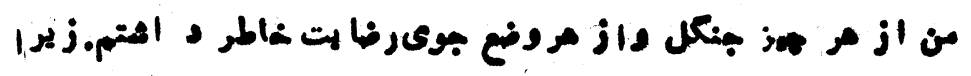

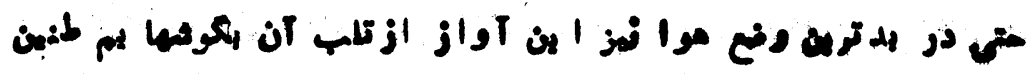
مها هن:

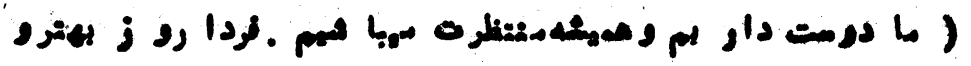

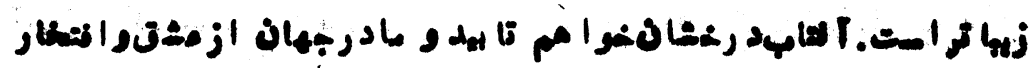

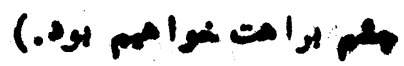

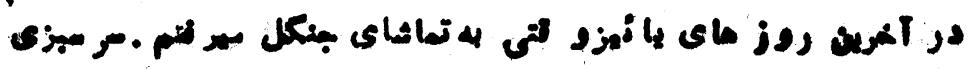

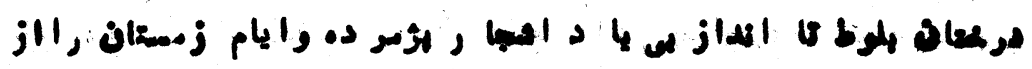

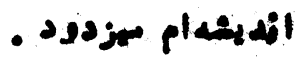

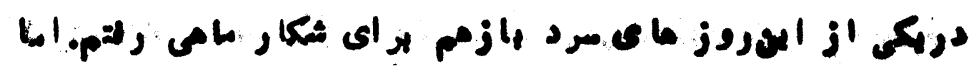

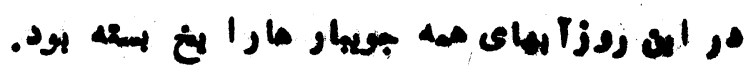

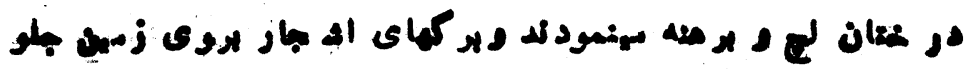

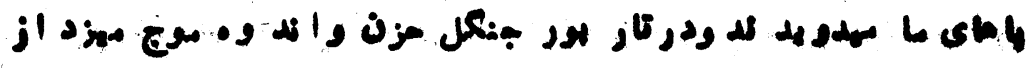

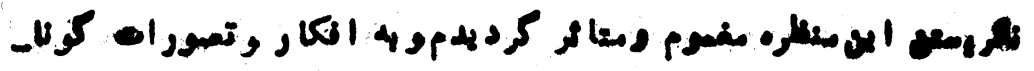

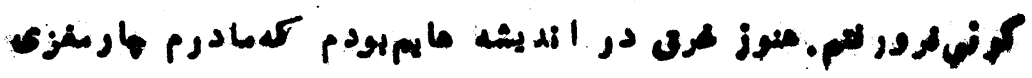

-rP- 


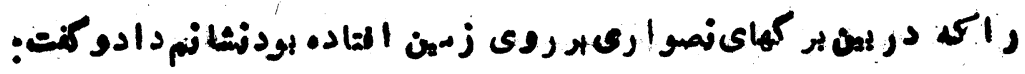

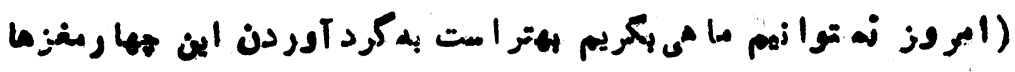

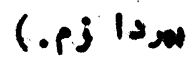

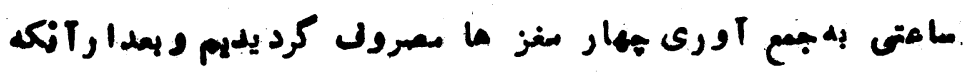

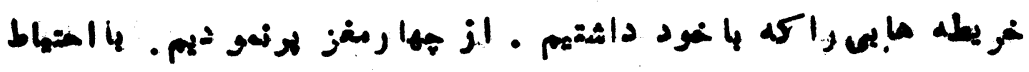

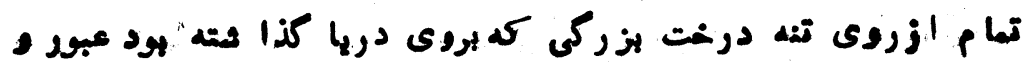

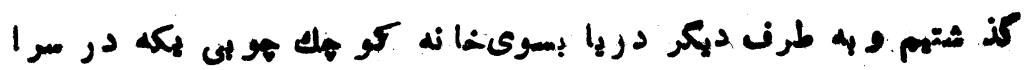

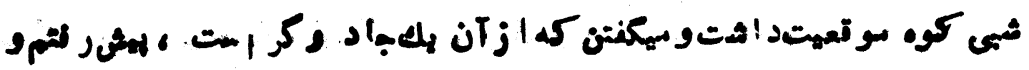

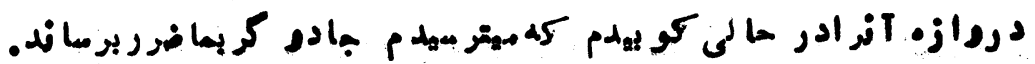

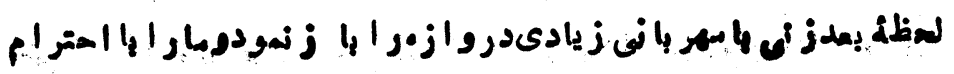

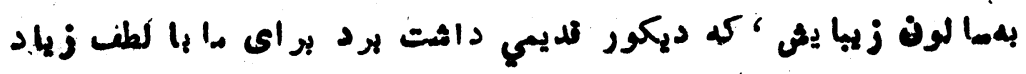

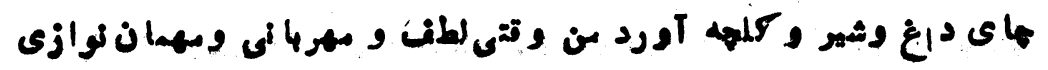

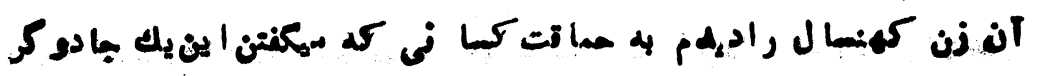

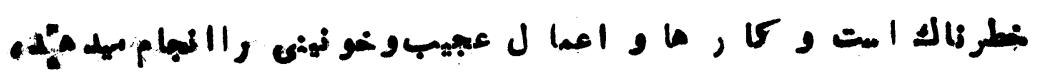

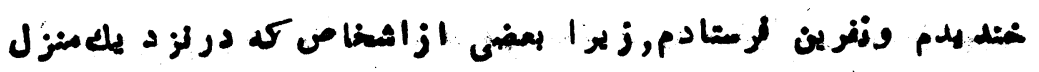

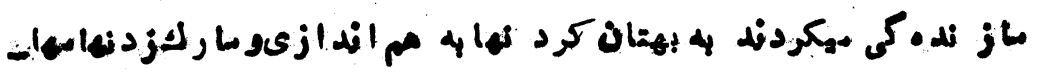

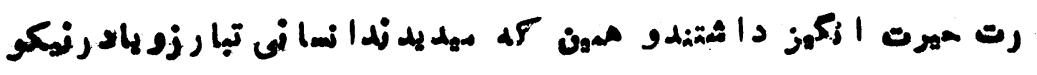

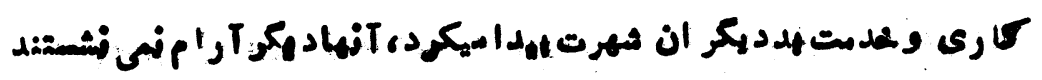

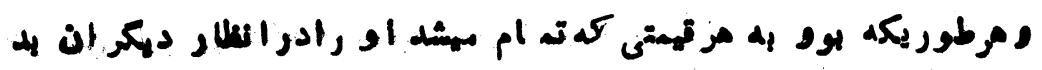

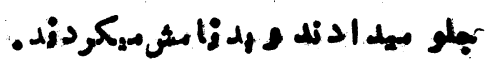

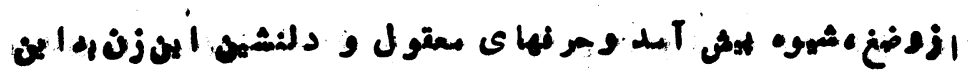

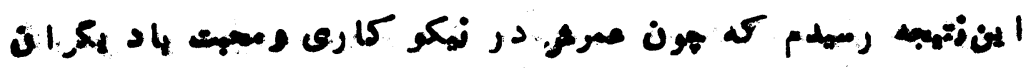

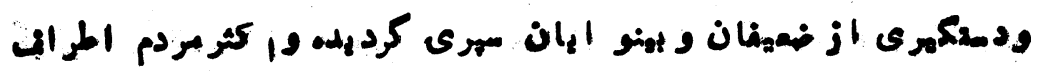




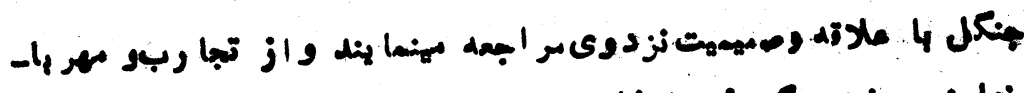

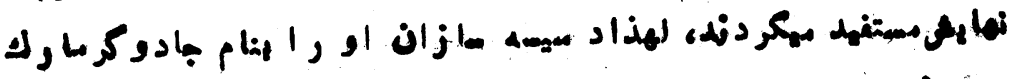

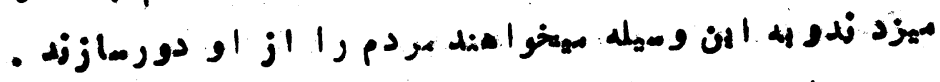

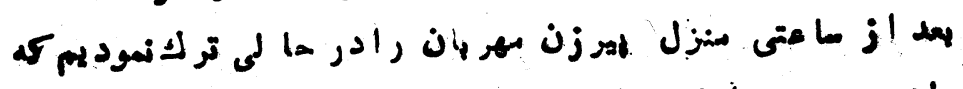

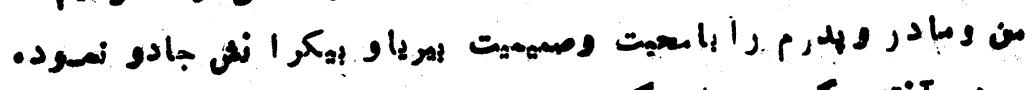

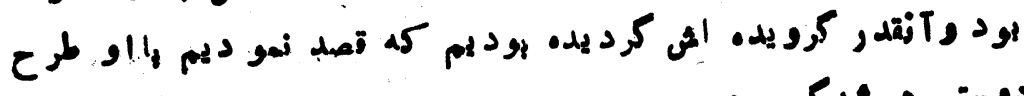

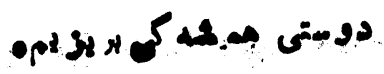

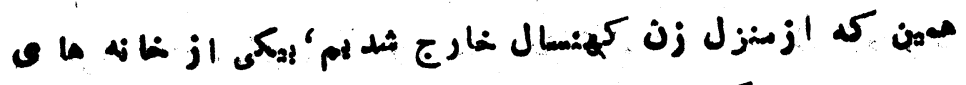

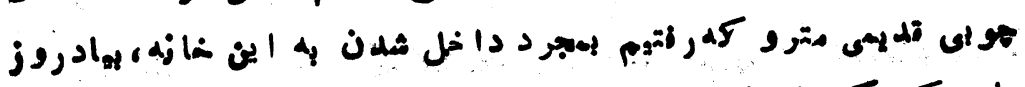

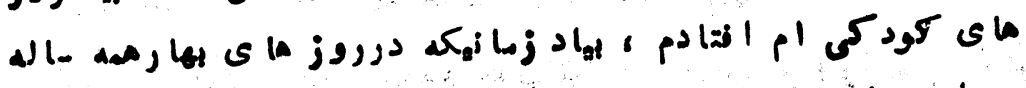

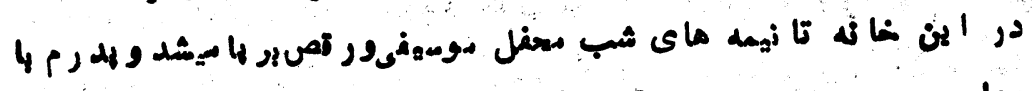

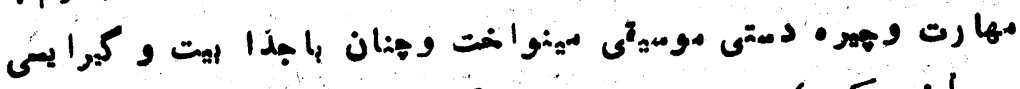

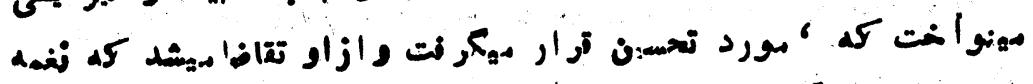

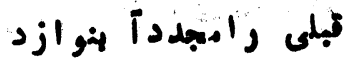

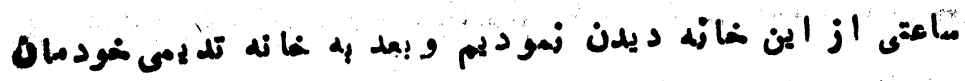

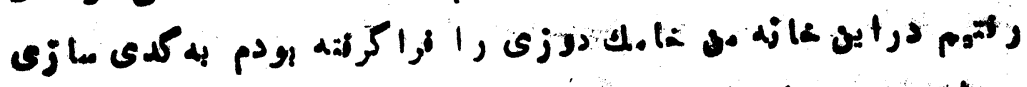

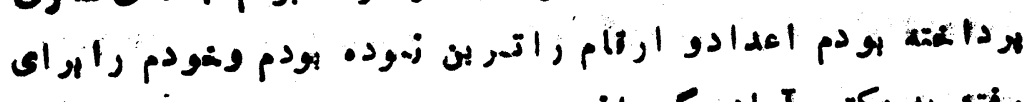

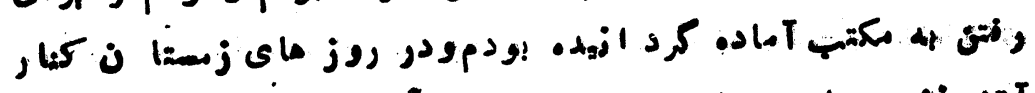

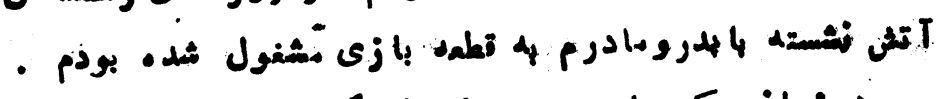

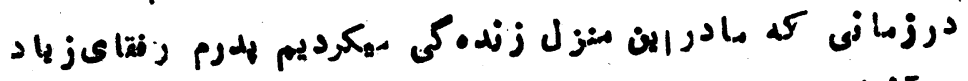

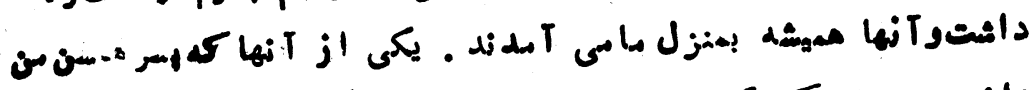

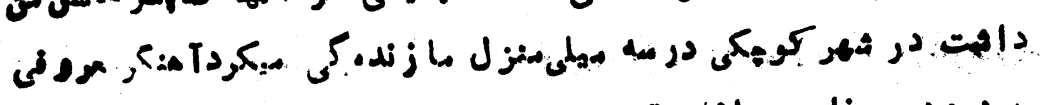

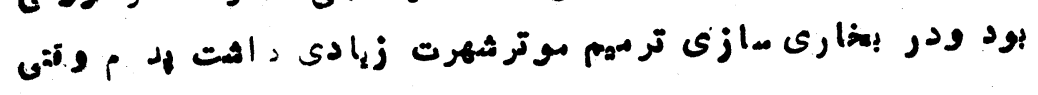




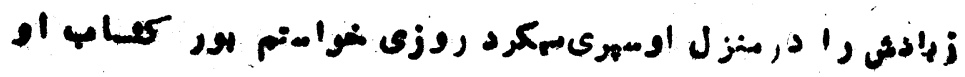

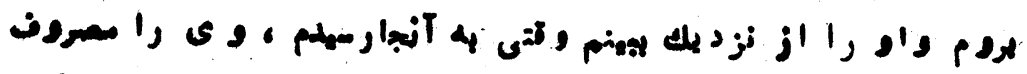

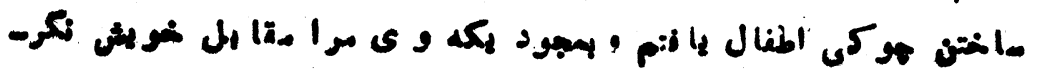

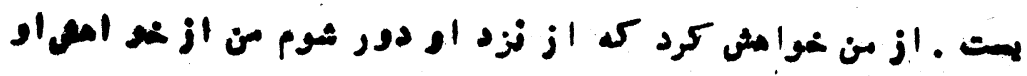

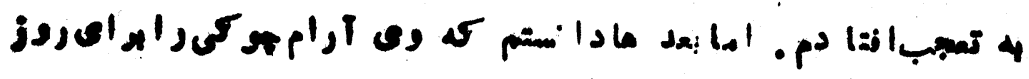

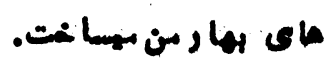

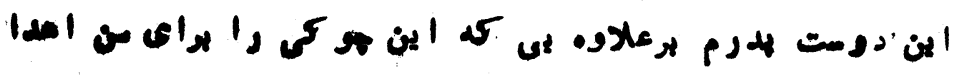

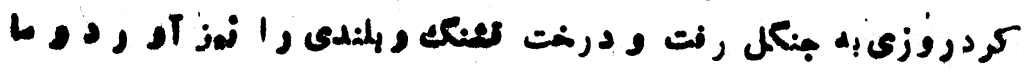

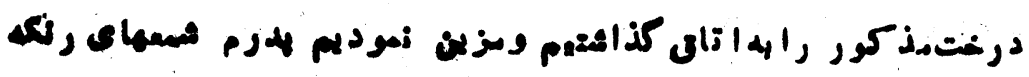

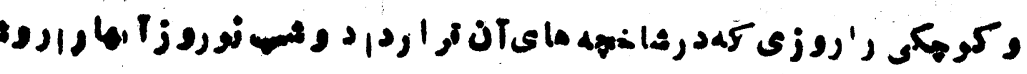

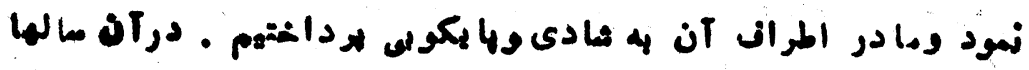

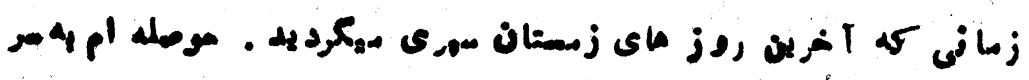

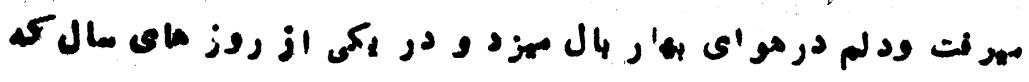

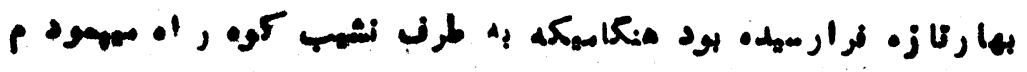

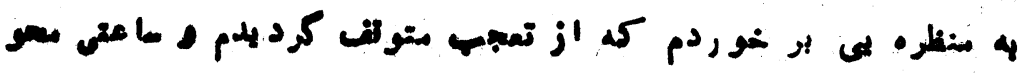

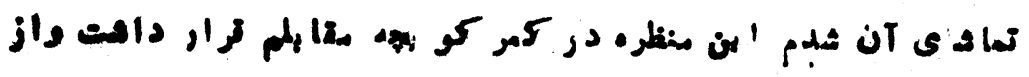

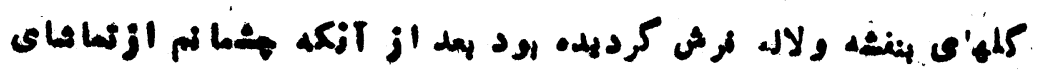

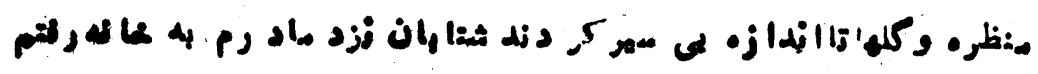
ومه ازjم:

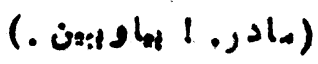

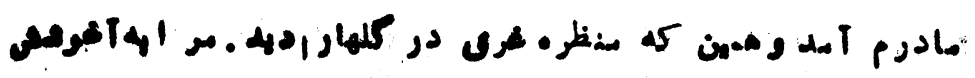
: هشردو كمت :

- 


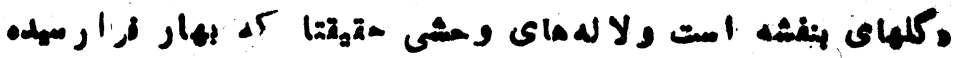

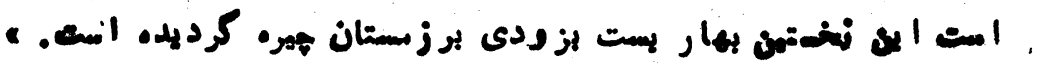

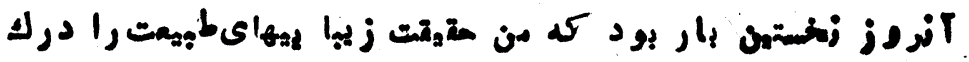

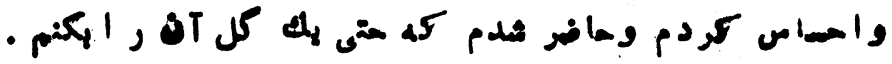

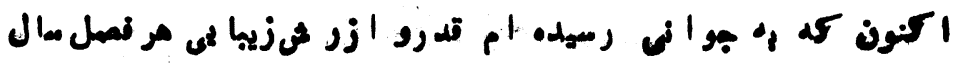

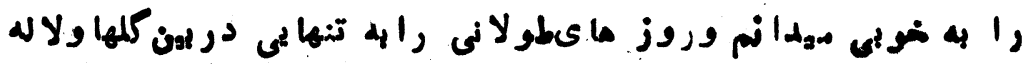

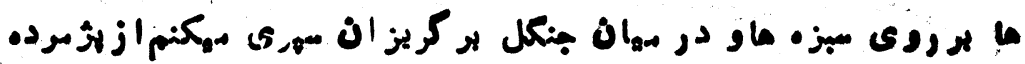

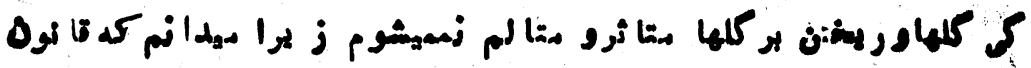

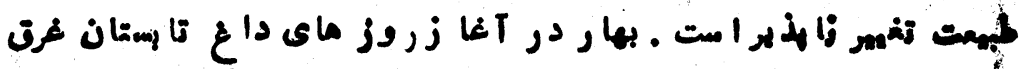

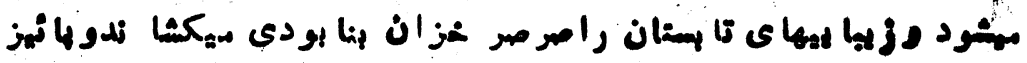

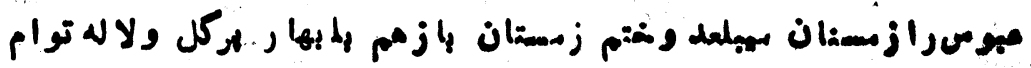

است

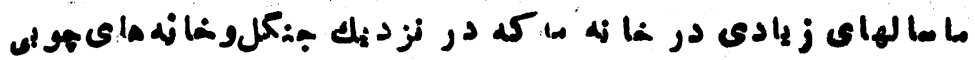

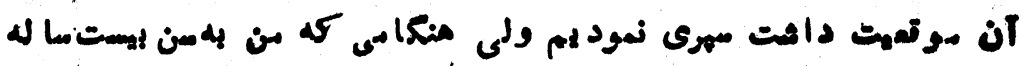

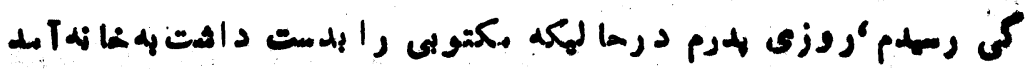

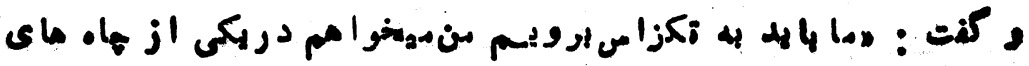
-

$-r v$ 
شوسككبا زيجه ميىشوخ

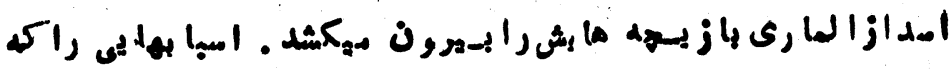

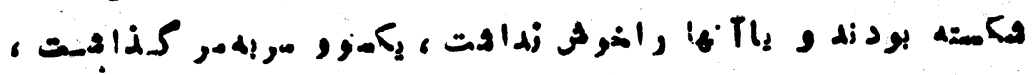

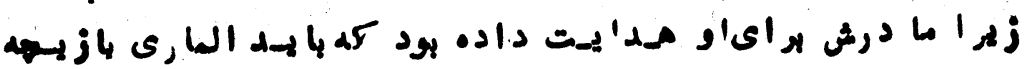

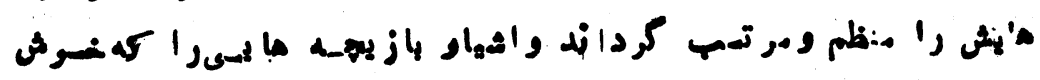

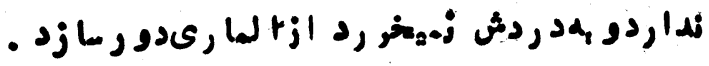

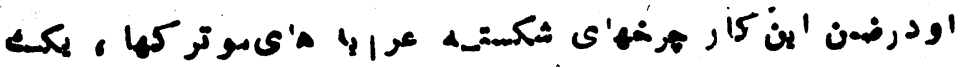

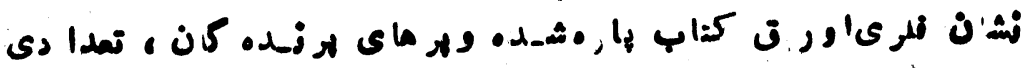

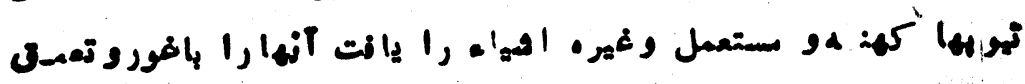

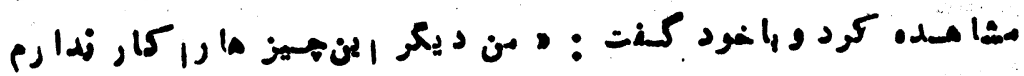

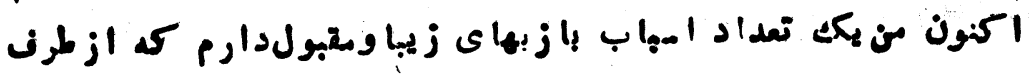

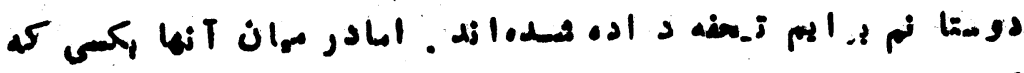

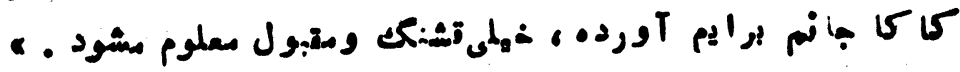

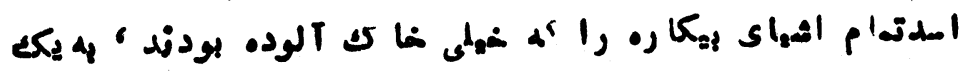

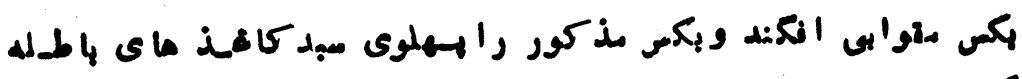

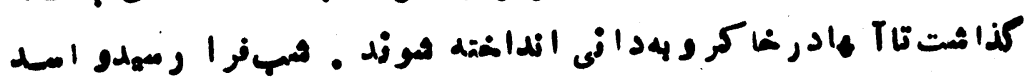

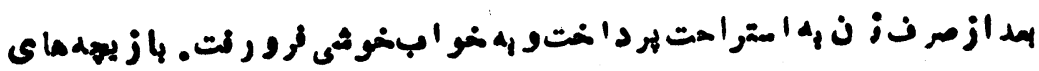

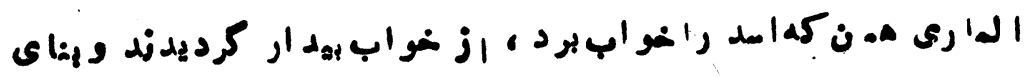

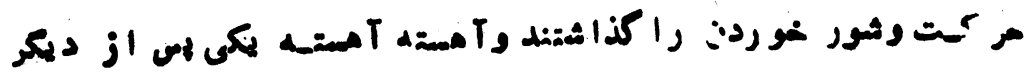

-rA - 


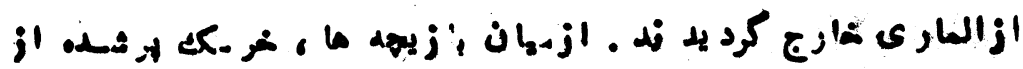

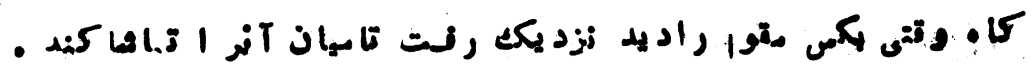

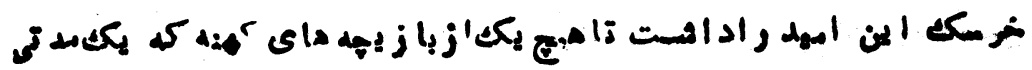

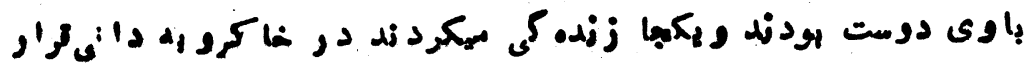

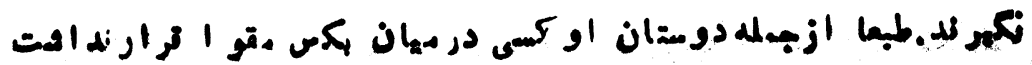

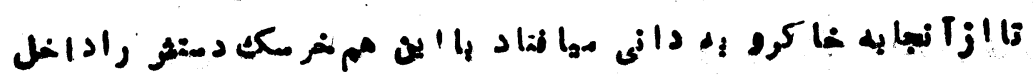

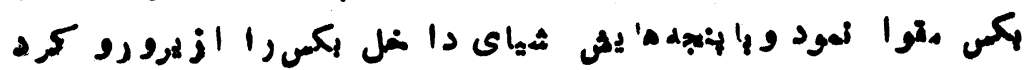

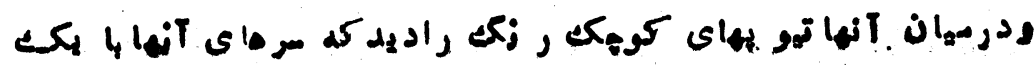

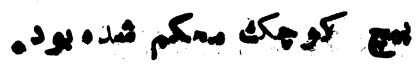

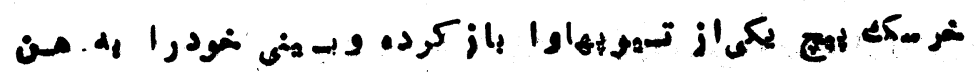

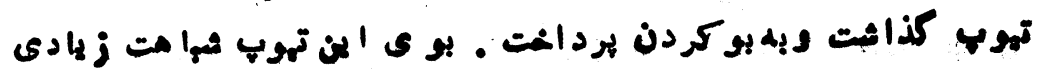

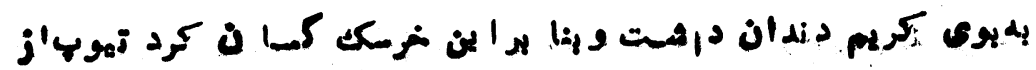

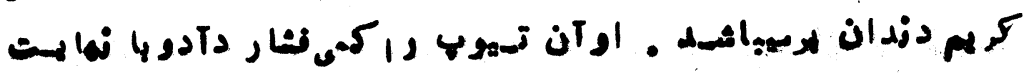

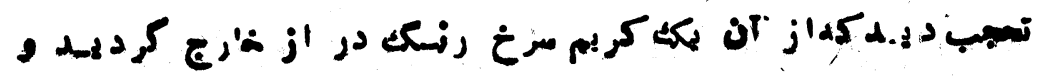

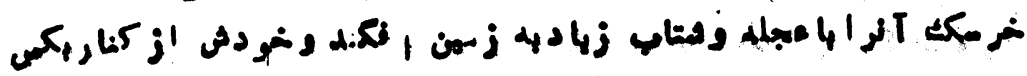

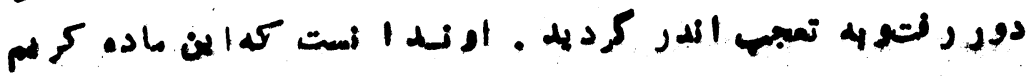

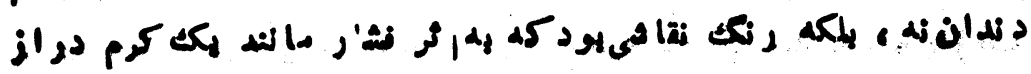
-

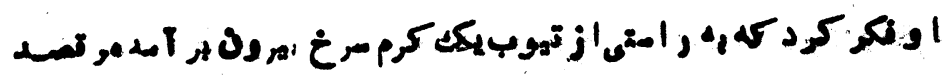

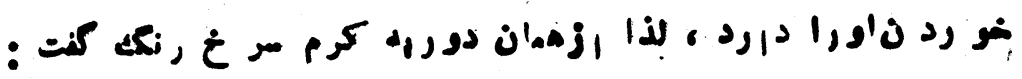

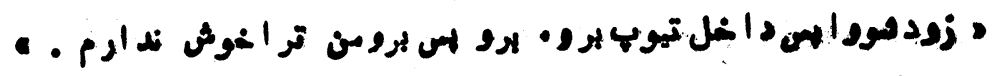

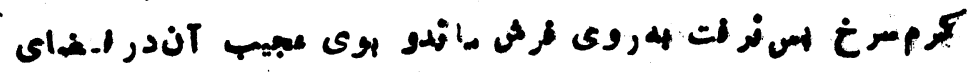

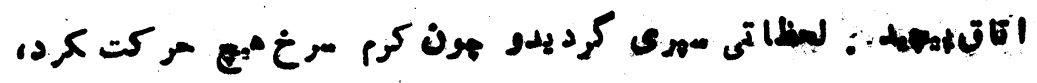
$\boldsymbol{r q}^{-}$ 


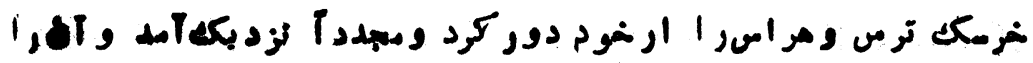

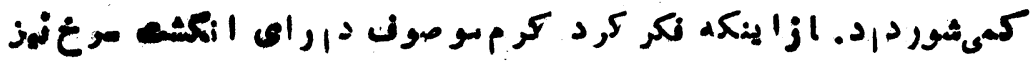

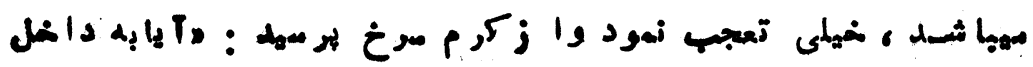

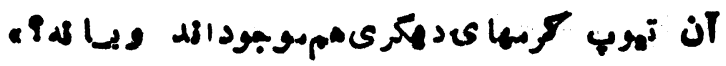

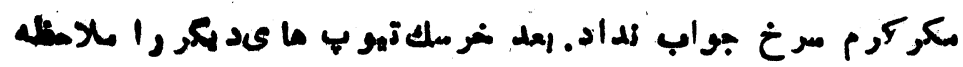

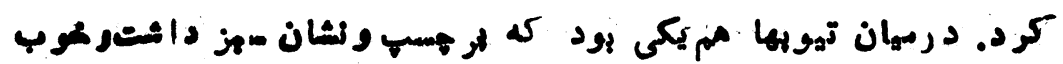

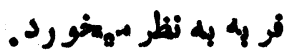

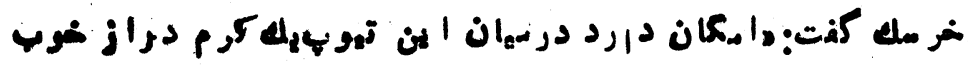

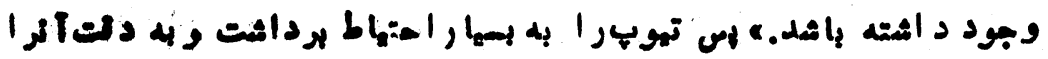

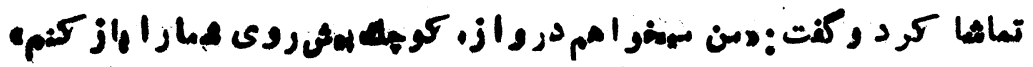

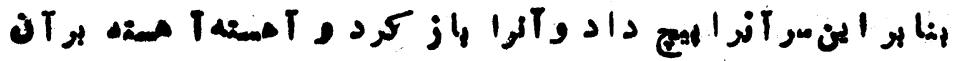

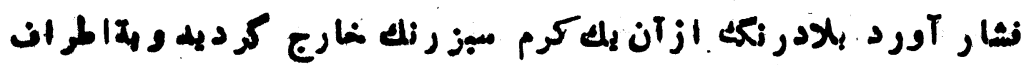

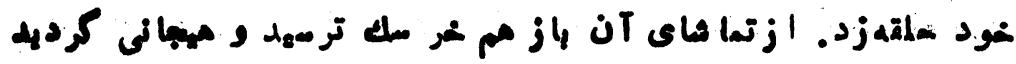

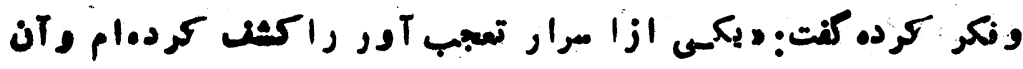

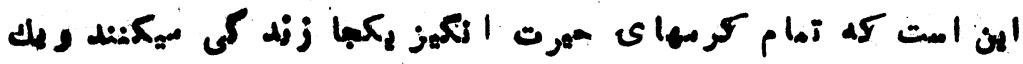

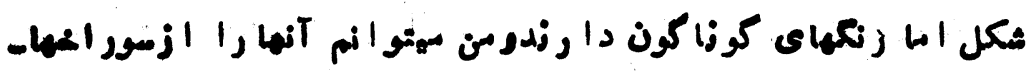

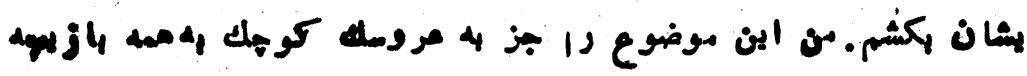

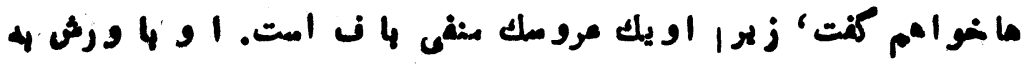

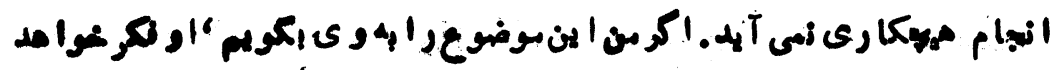

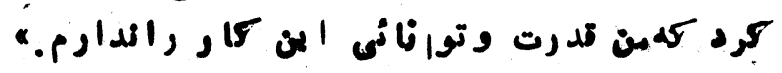

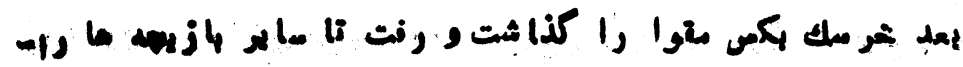

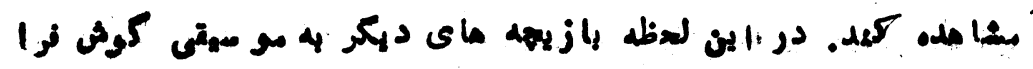

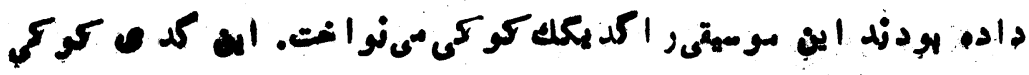




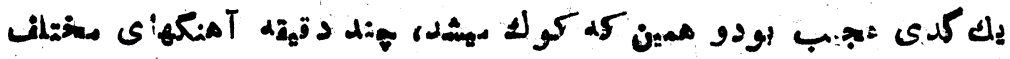

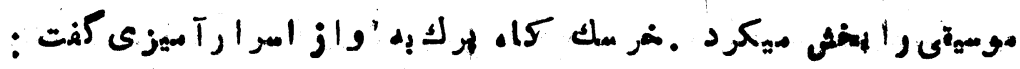

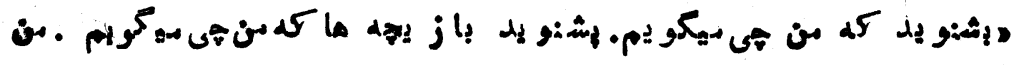

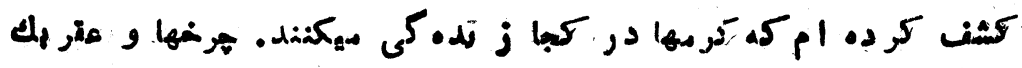

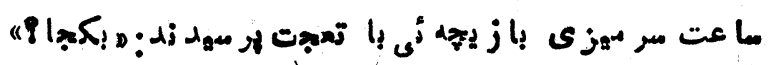

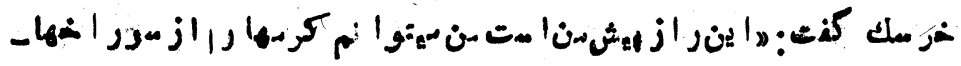

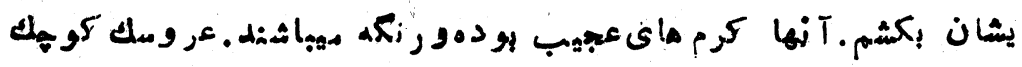

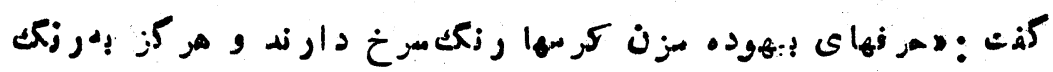

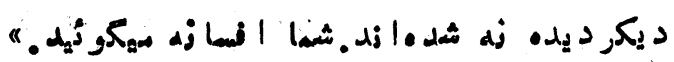

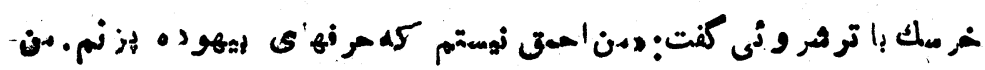

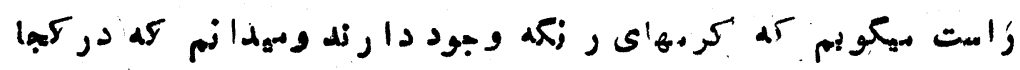

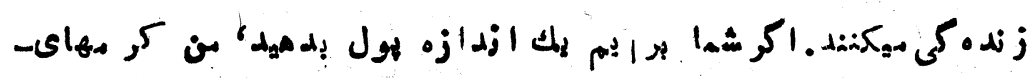

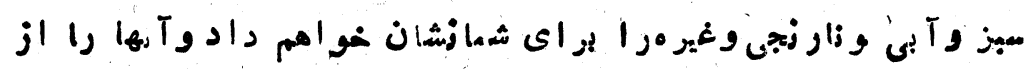

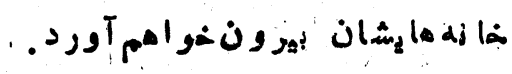

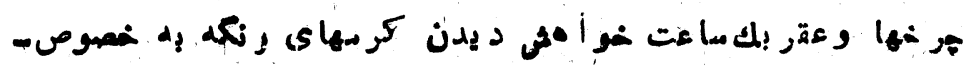

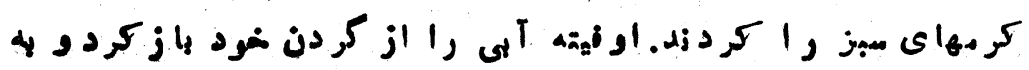

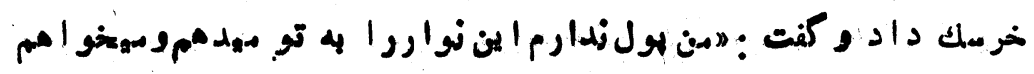

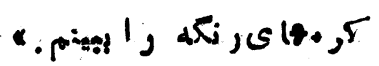

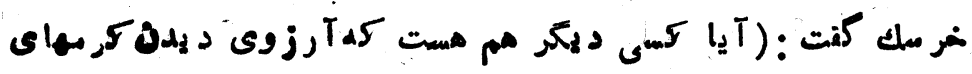

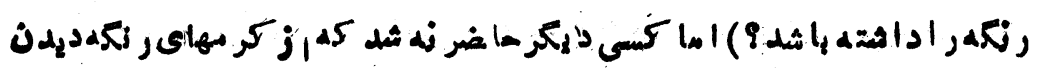

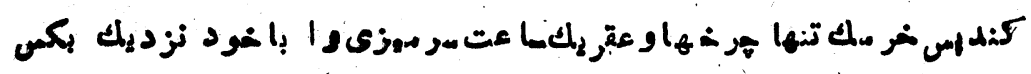

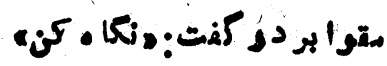




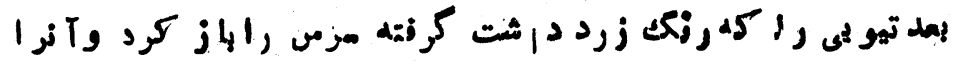

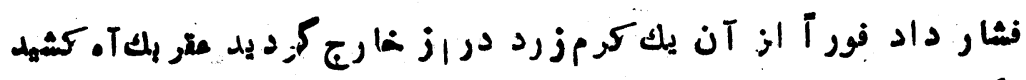
و 5 .

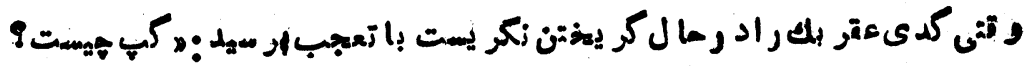

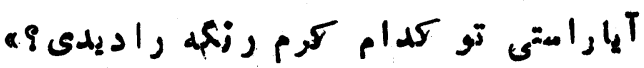

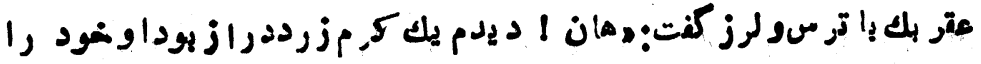

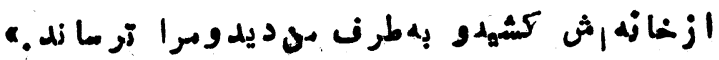

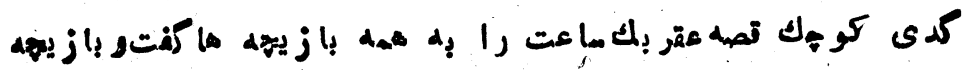

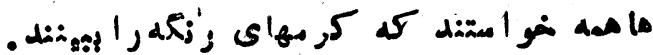

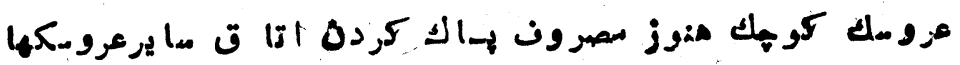

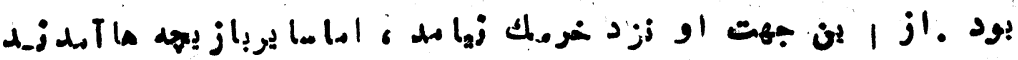

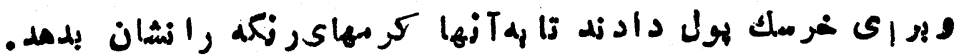

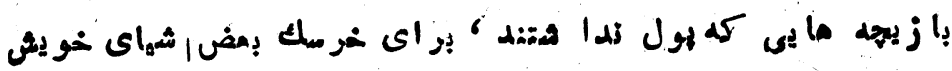

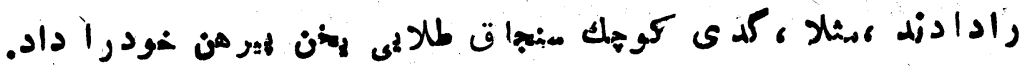

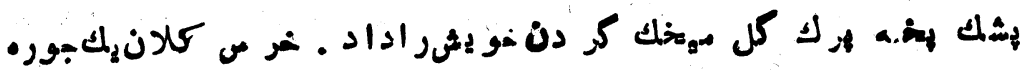

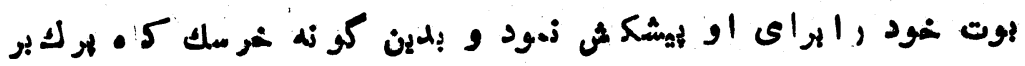

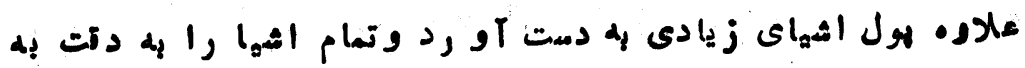

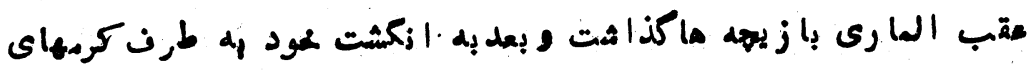

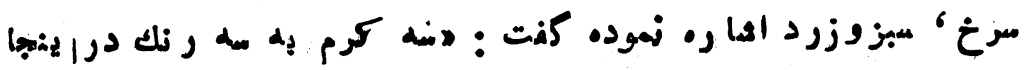

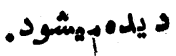

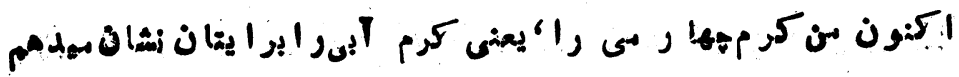

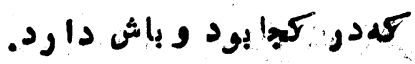

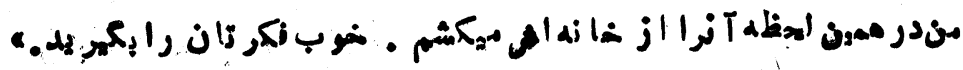
- 


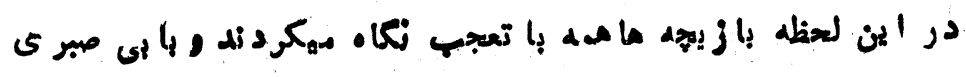

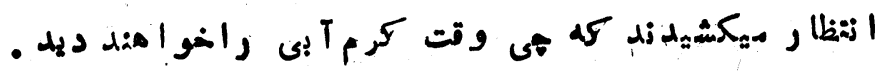

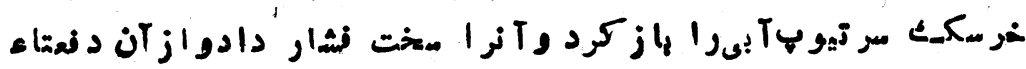

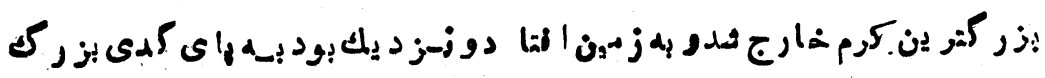

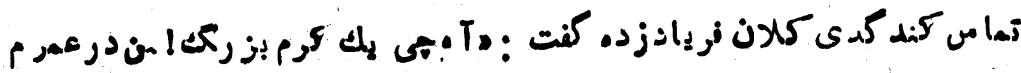

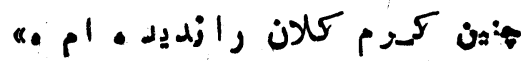

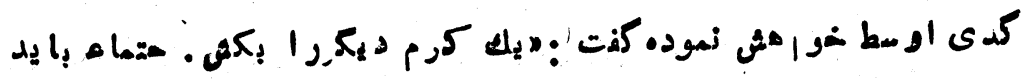

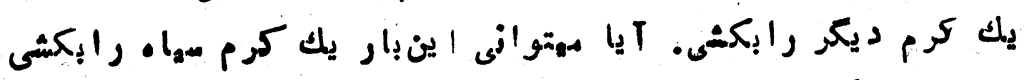

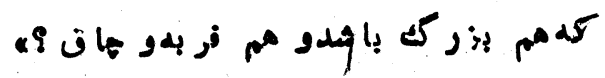

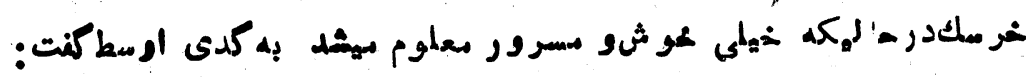

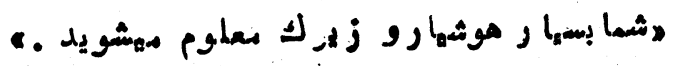

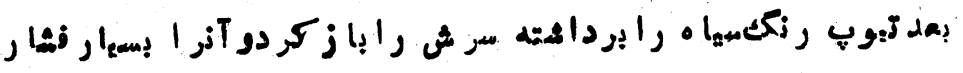

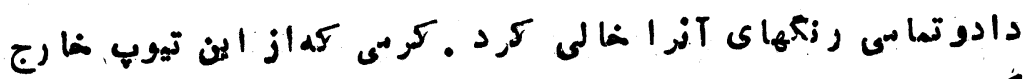

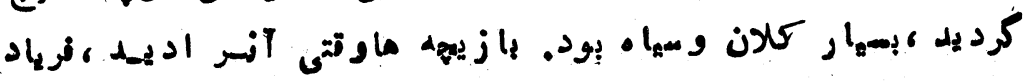

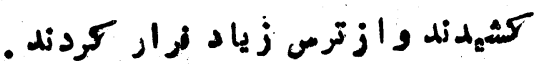

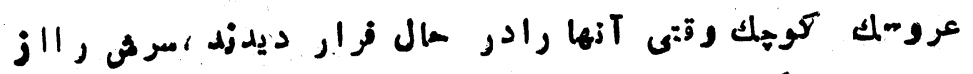

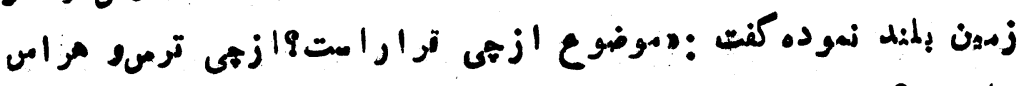
دار إند أن

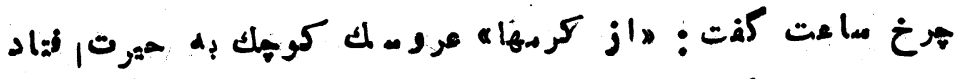

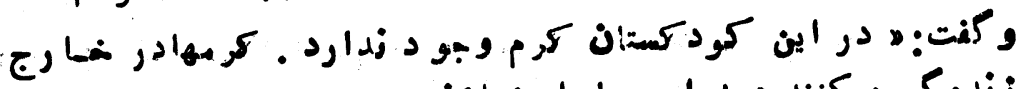

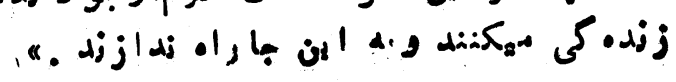

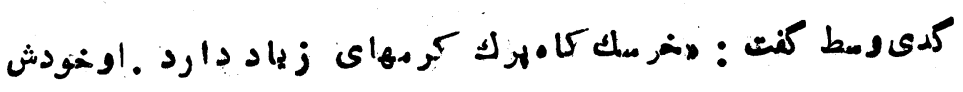

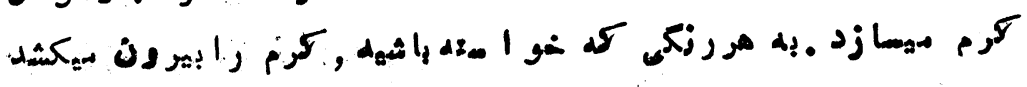

hre 


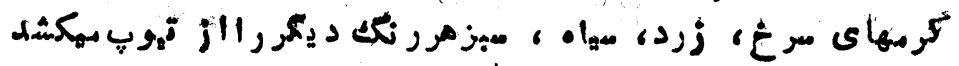

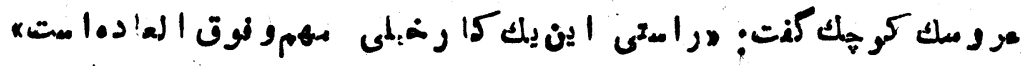

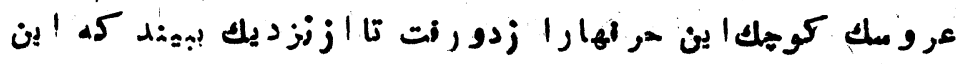

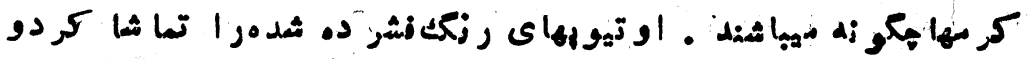

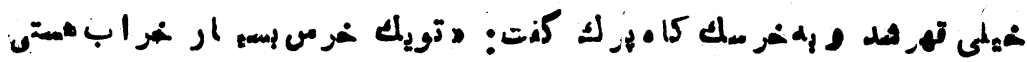

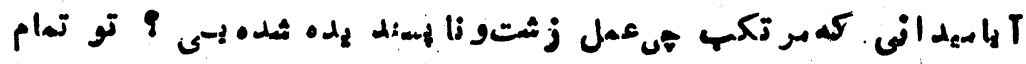

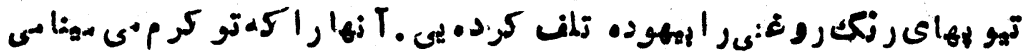

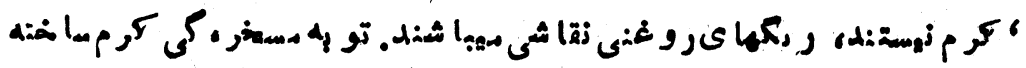

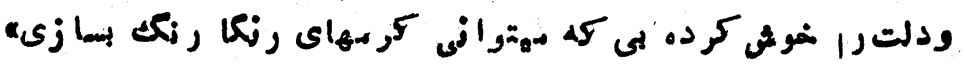

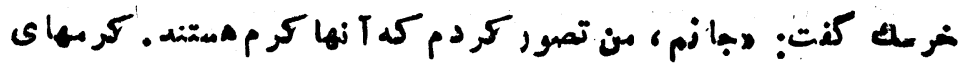

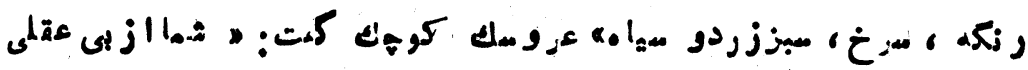

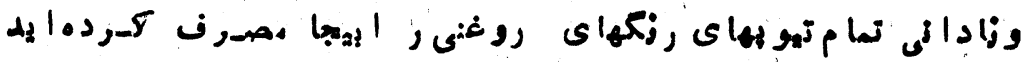

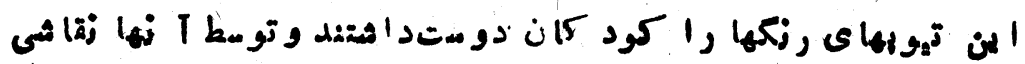

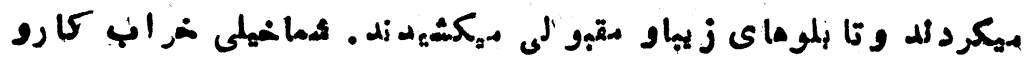

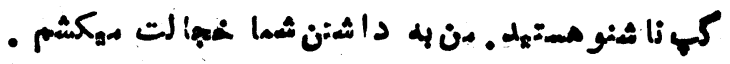

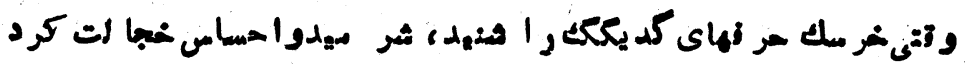

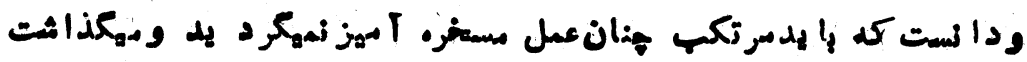

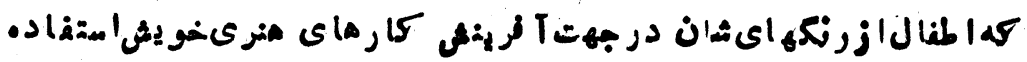

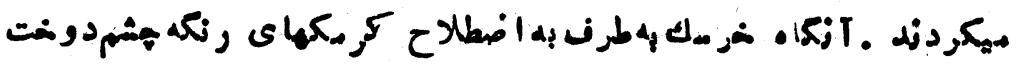

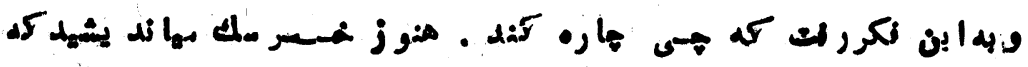

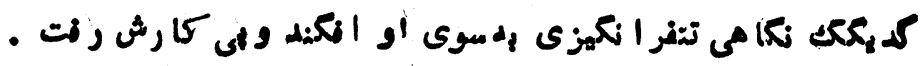

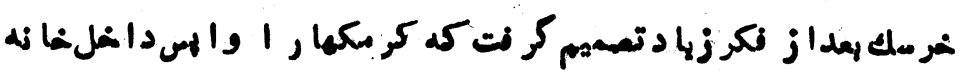

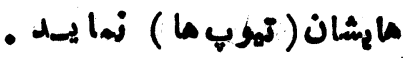

סיזי 


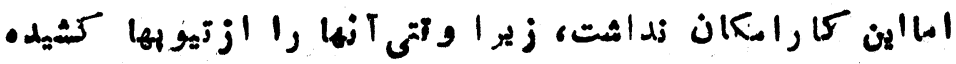

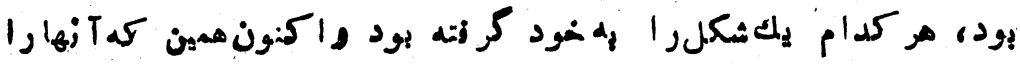

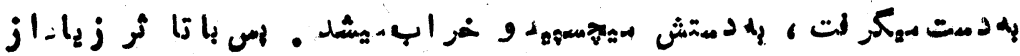

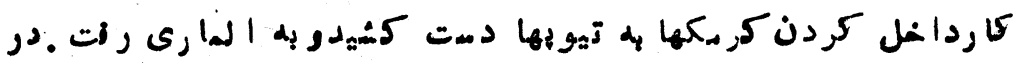

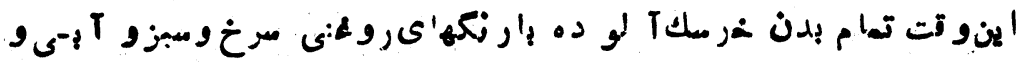

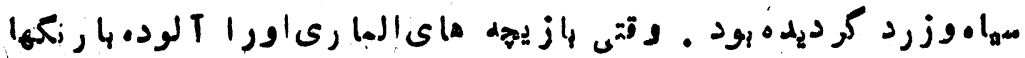

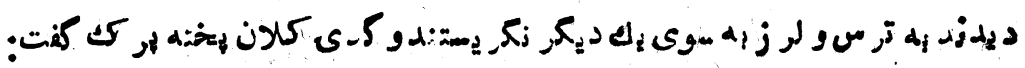
"

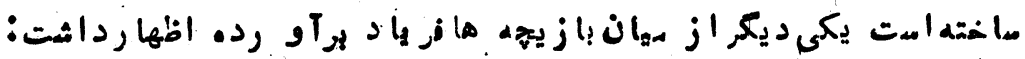

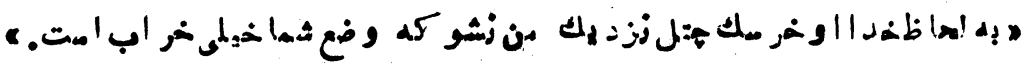

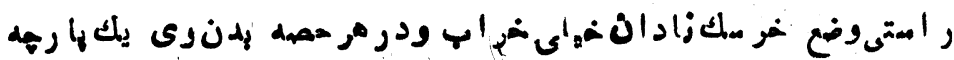

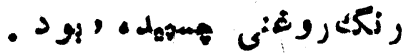

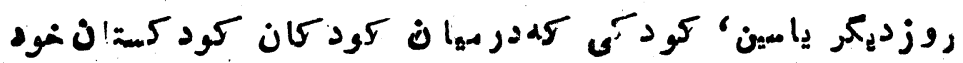

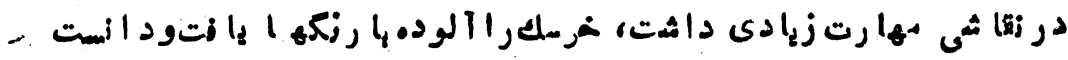

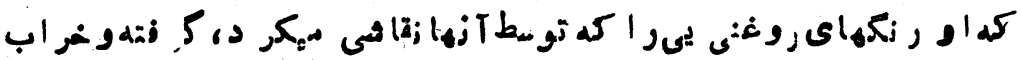

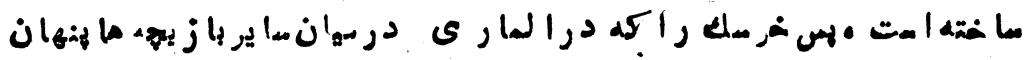

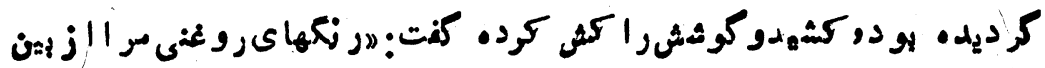

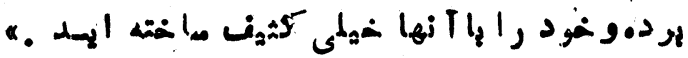

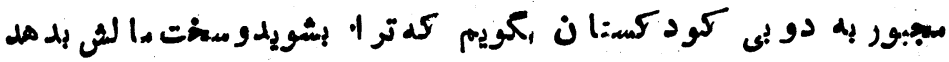

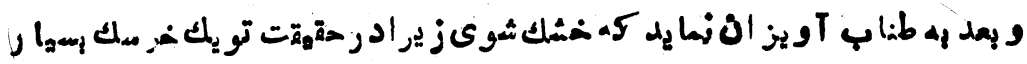

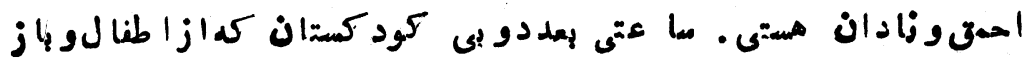

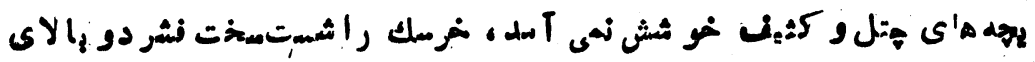

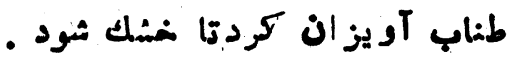
mo- 


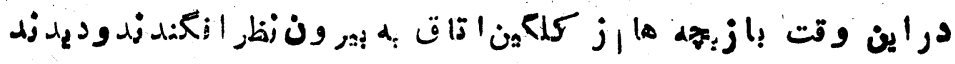

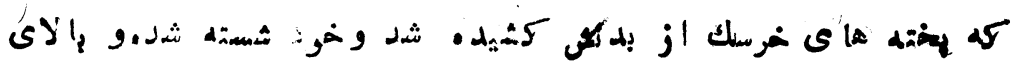

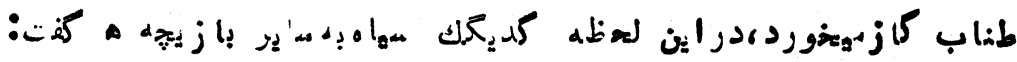

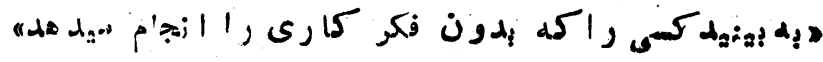

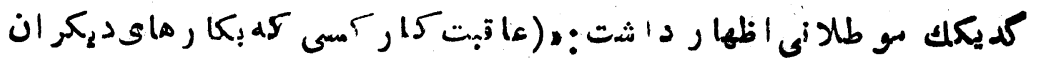

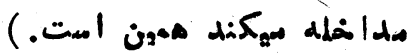

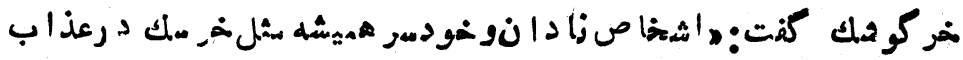

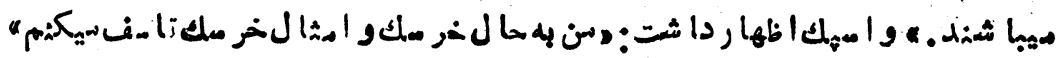

ary- 


\section{شُيرينى جو بكدار}

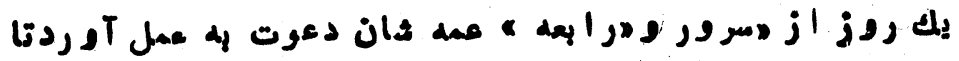

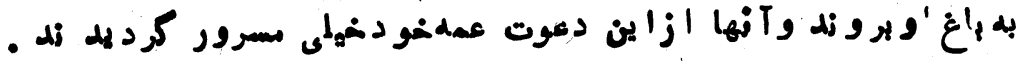

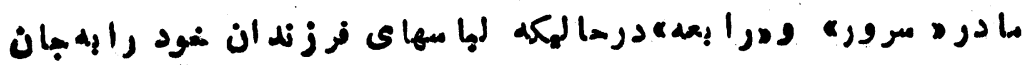

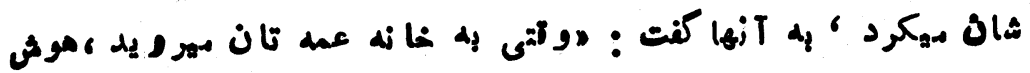

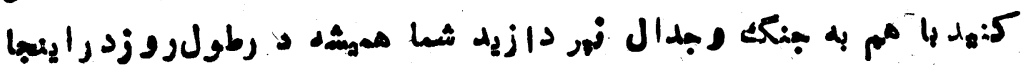

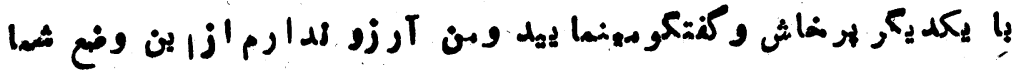

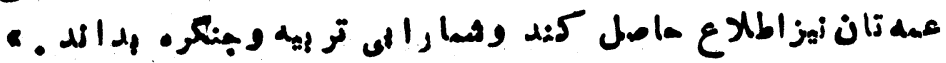

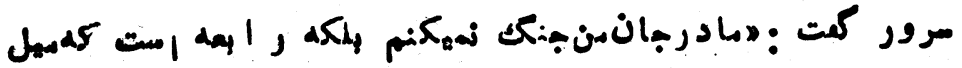

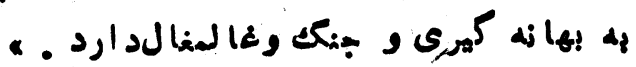

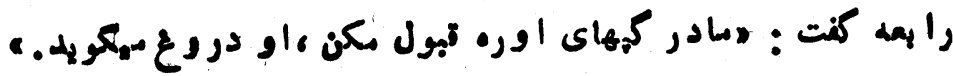

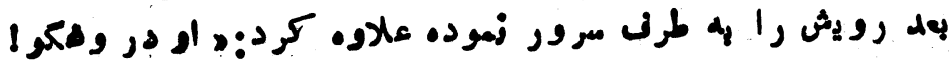

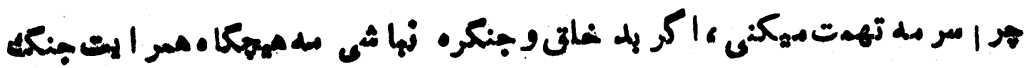

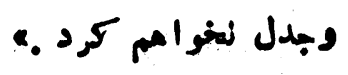

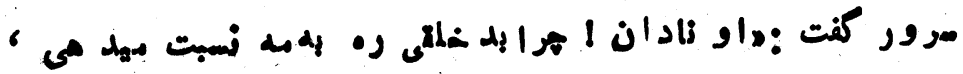

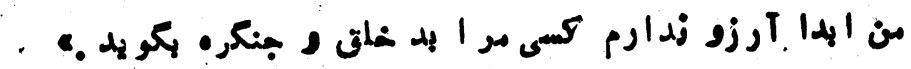

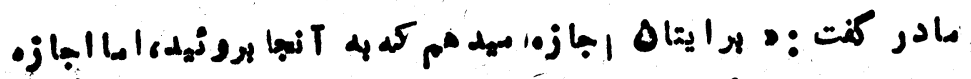

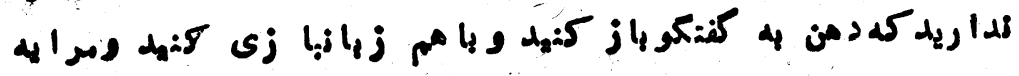

$$
-4 e^{-1}
$$




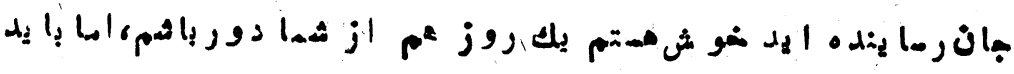

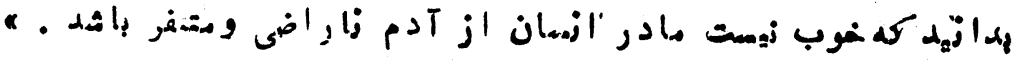

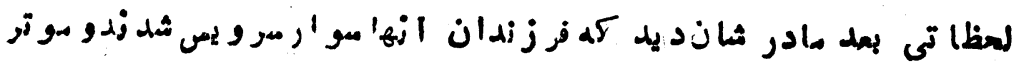

مر كت كرد د

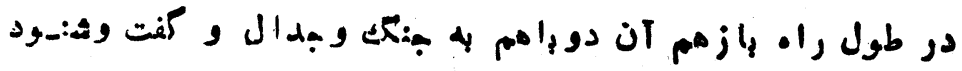

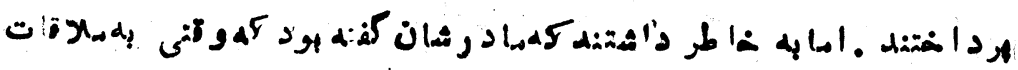

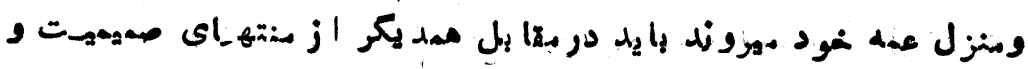

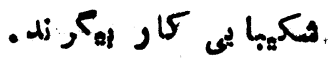

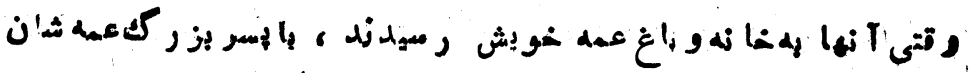

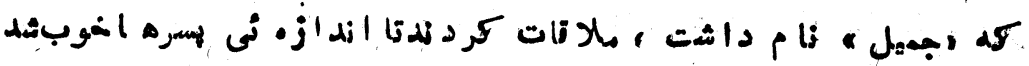

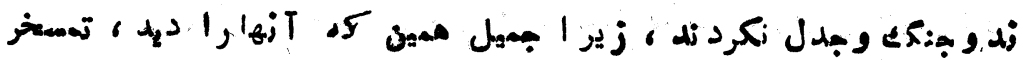

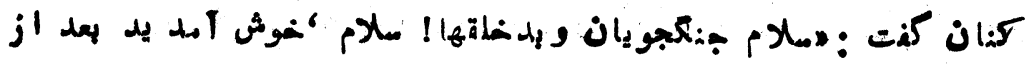

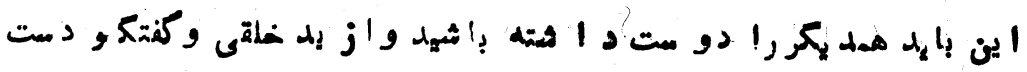

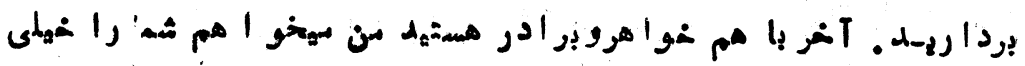

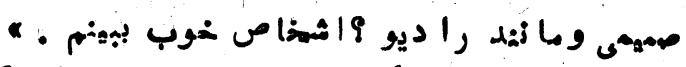

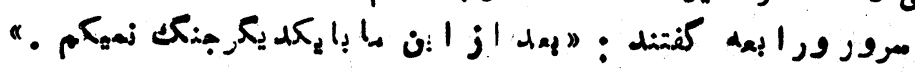

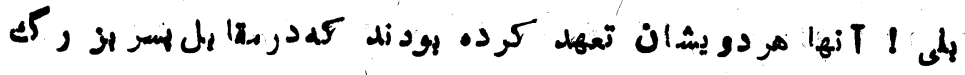

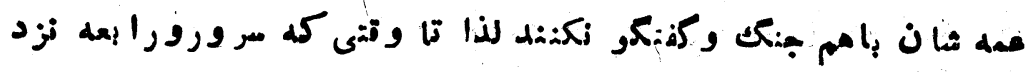

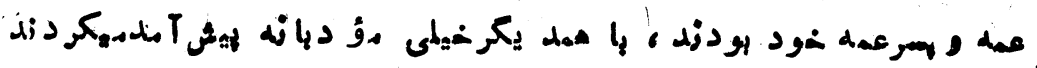

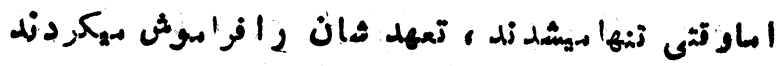

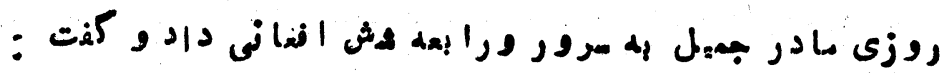

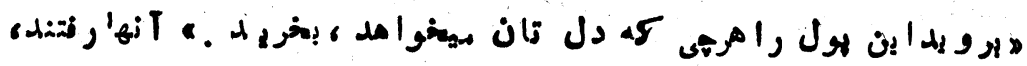

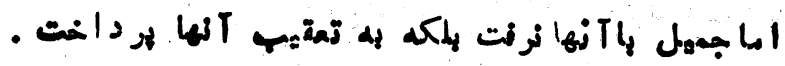

- 


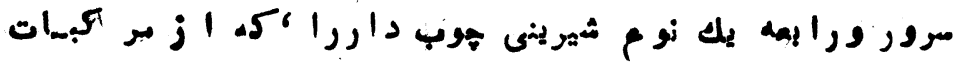

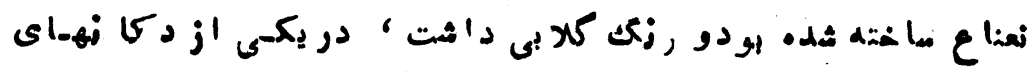
ثمرانى فرونى دايد أهد.

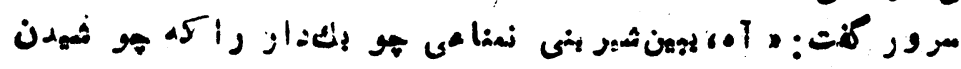

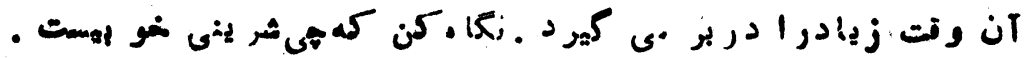

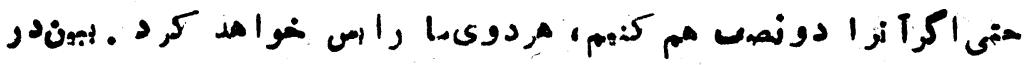

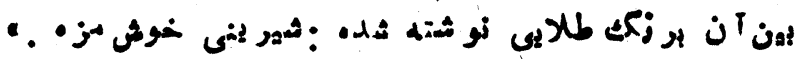

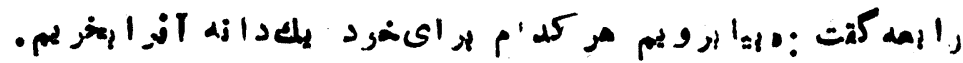

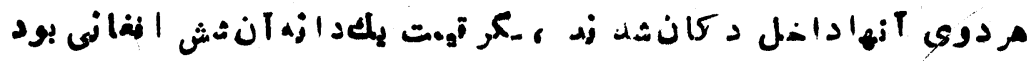

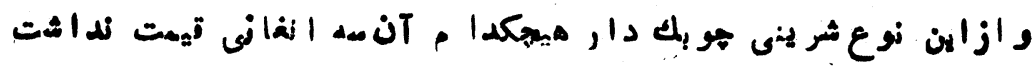

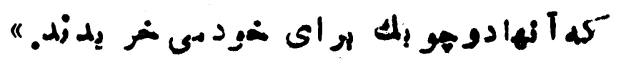

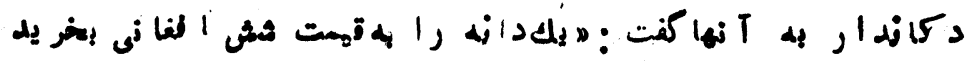

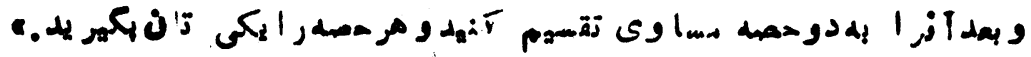

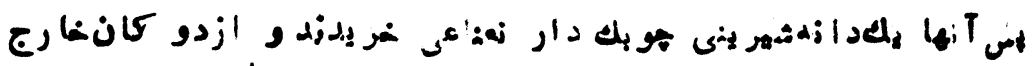

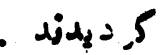

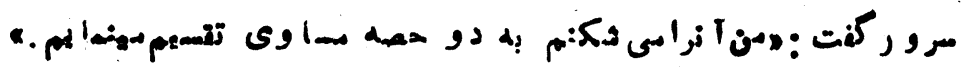

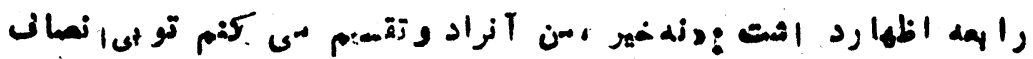

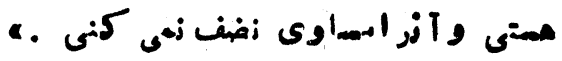

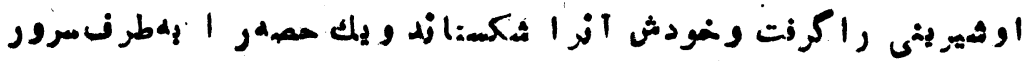

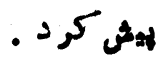

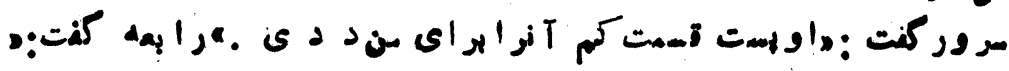

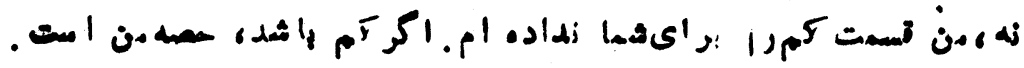

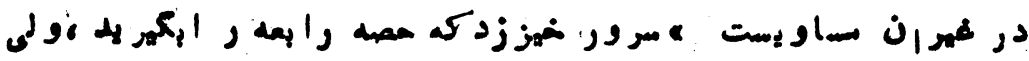

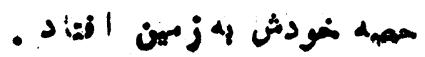




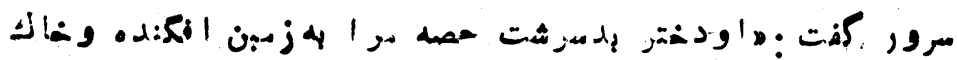

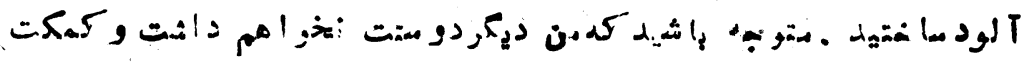

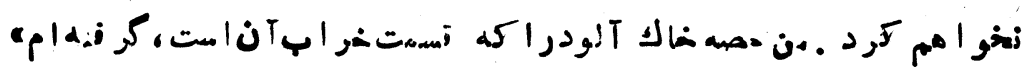

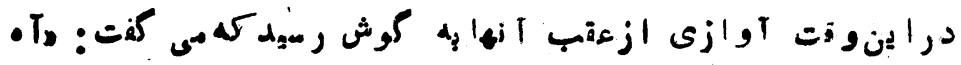

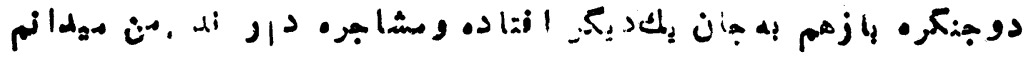

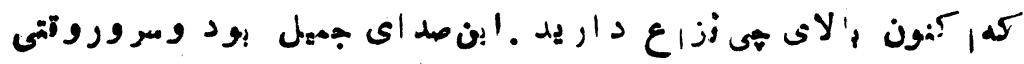

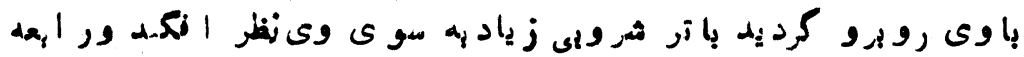

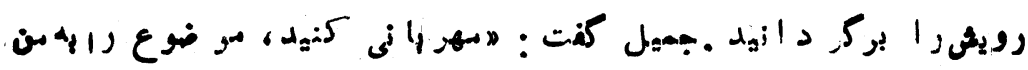

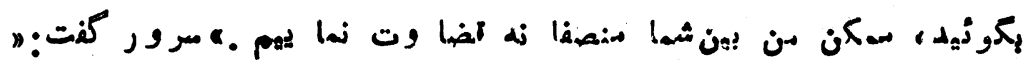

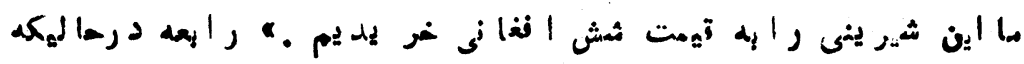

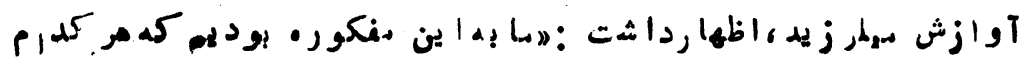

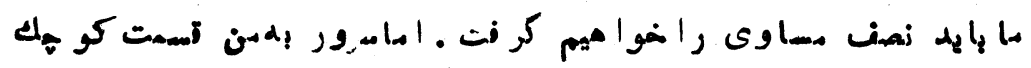

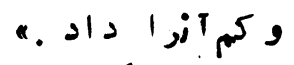

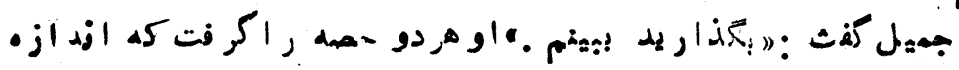

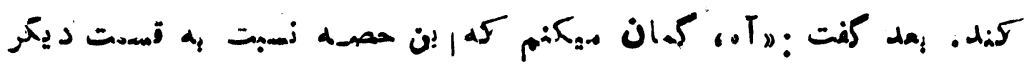

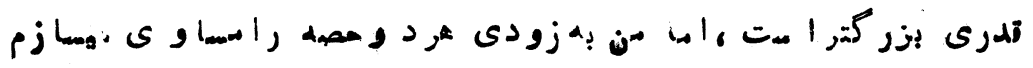

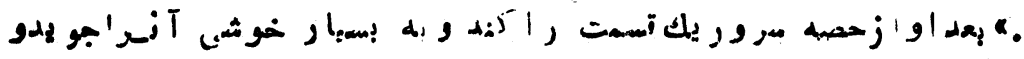

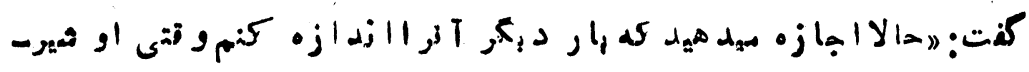

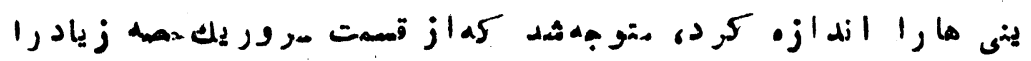

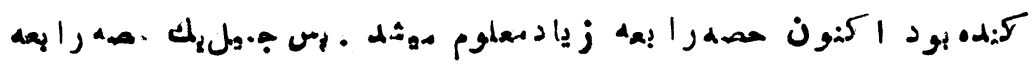

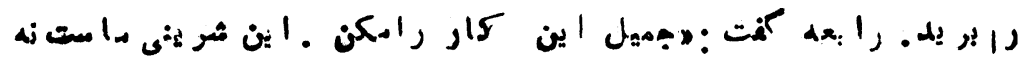
ازتو . رئ

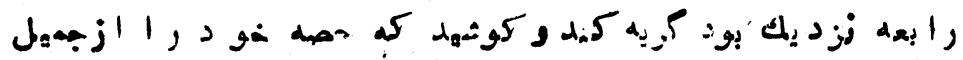

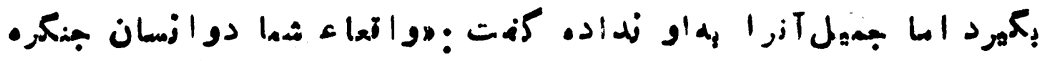




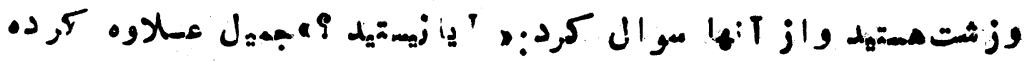

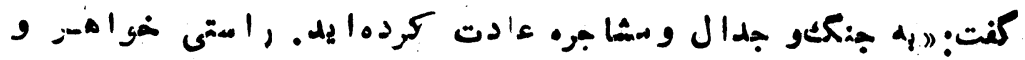

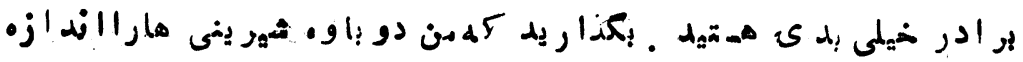

كنم.

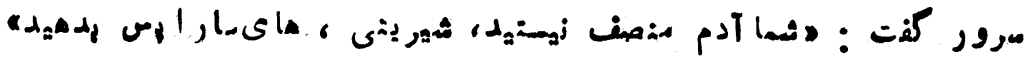

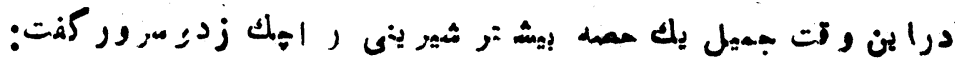

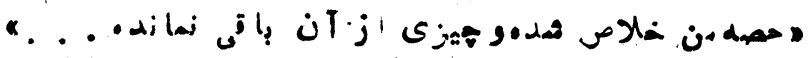

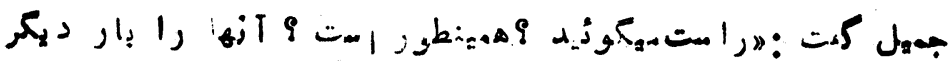

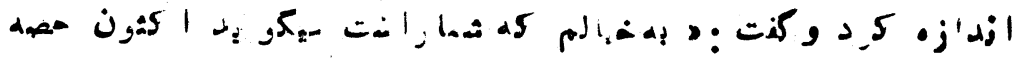

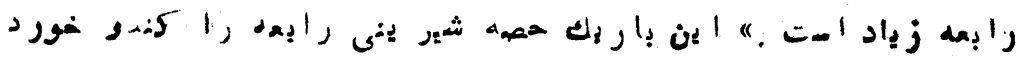

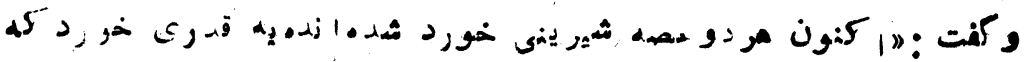

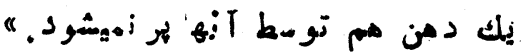

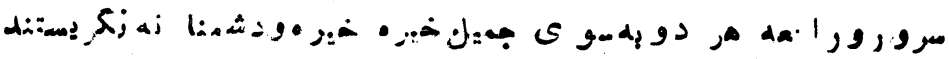

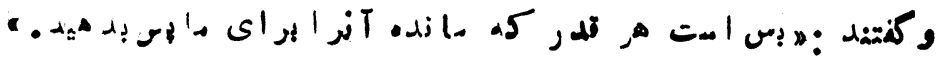

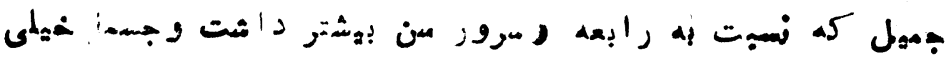

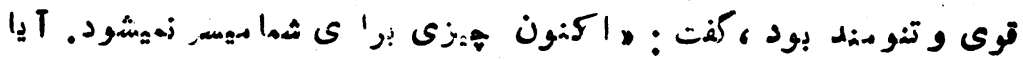

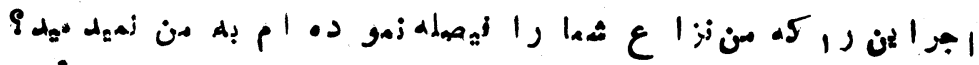

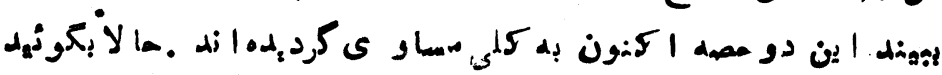

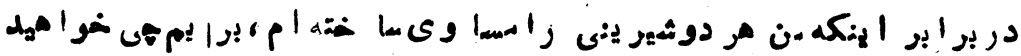

asia

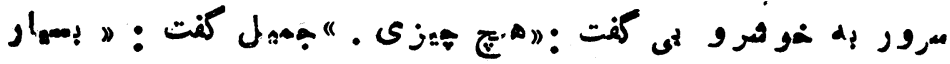

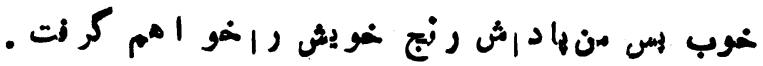

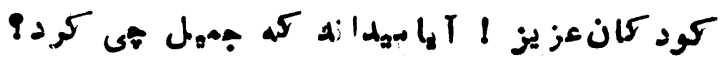

$-01-$ 
بله إ اومر دو همه ر' به دمن غود كذا ثت وبه بو هدن شروع

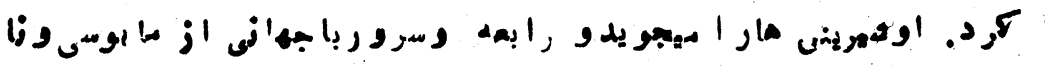

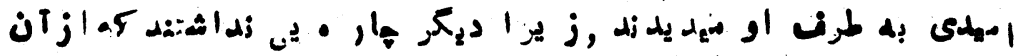

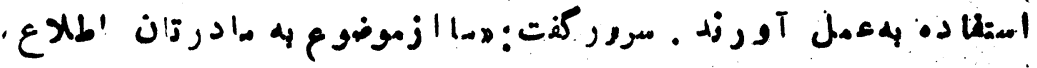

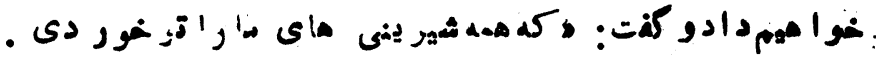

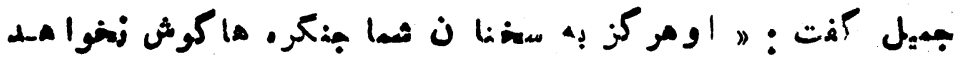

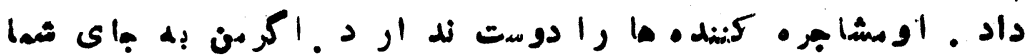

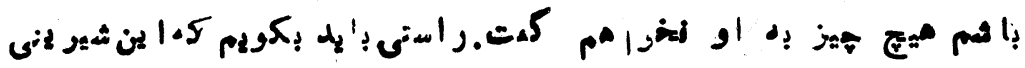

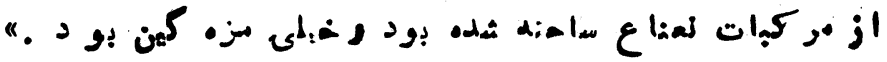

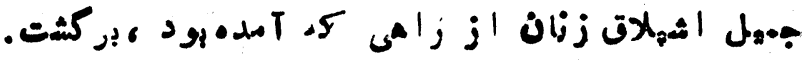

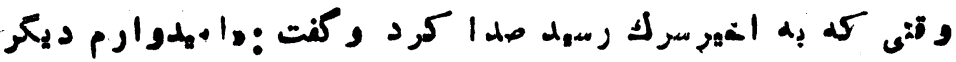

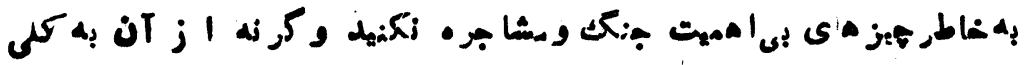

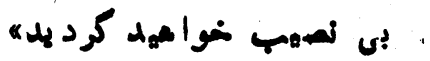

- ${ }^{0} r$ 


\section{مادر كالاىنومرافر اموشنكنى}

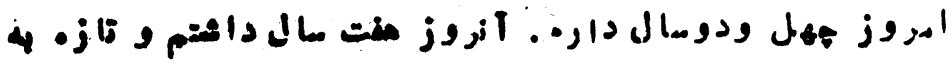

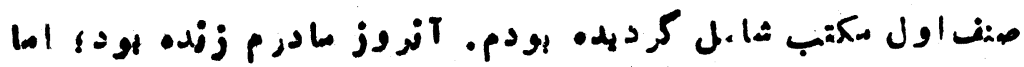

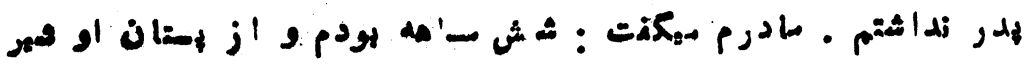

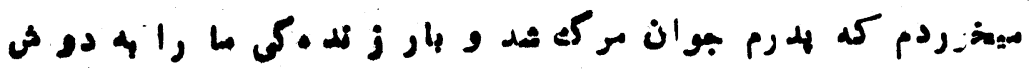
او كذن ثـت .

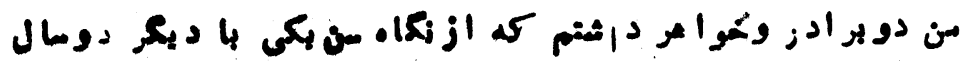

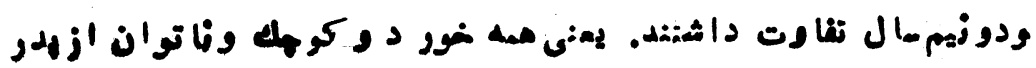

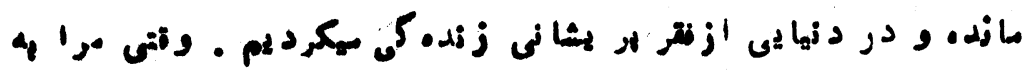

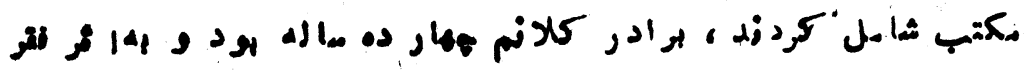

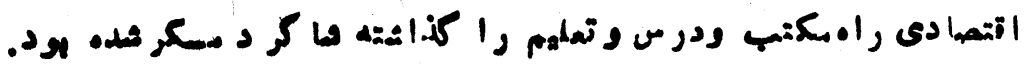

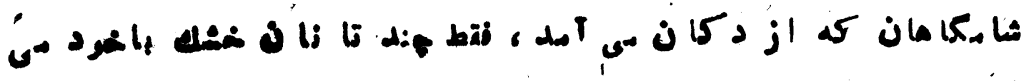

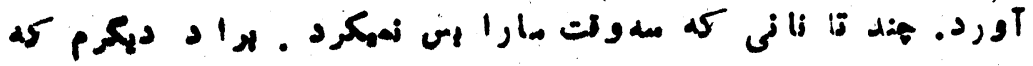

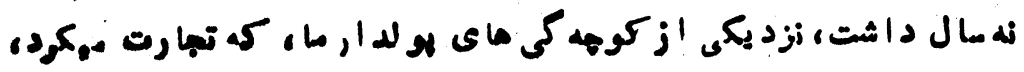

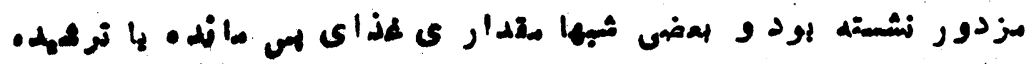

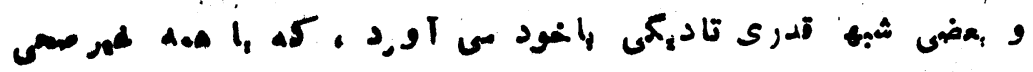

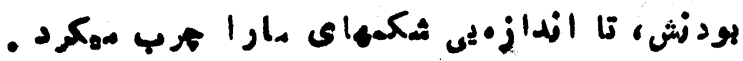




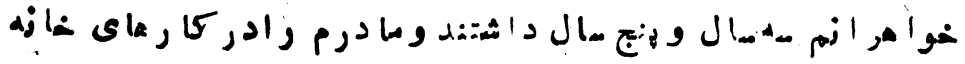

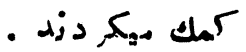

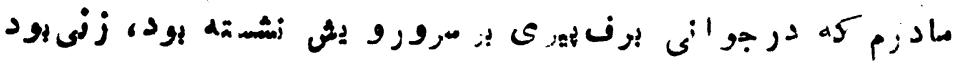

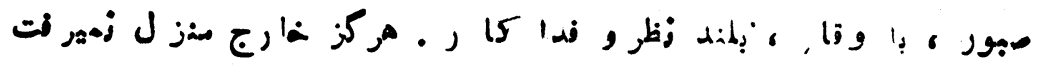

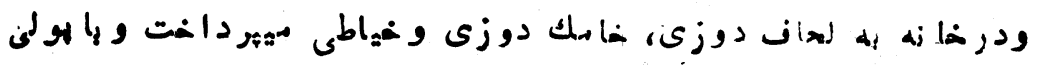

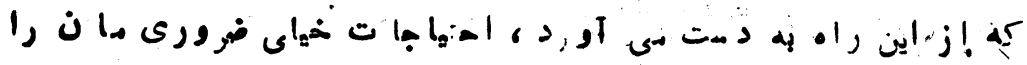

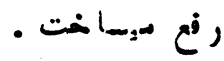

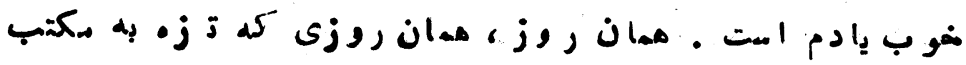

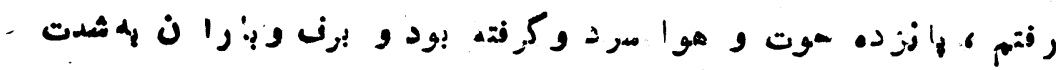

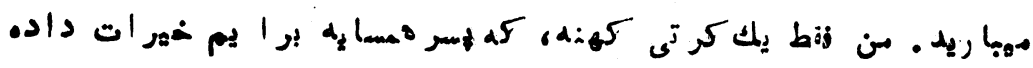

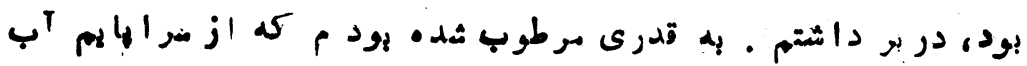

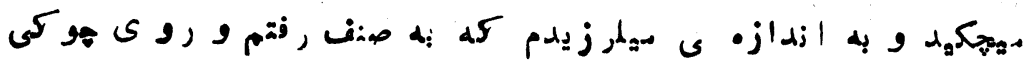

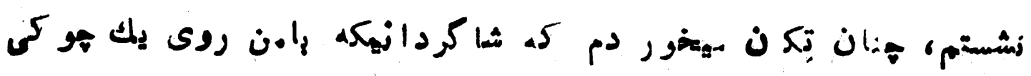

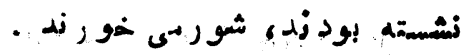

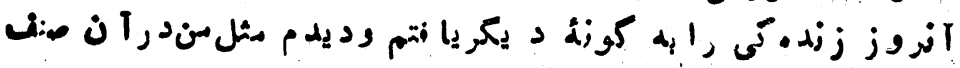

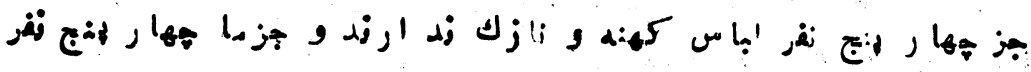

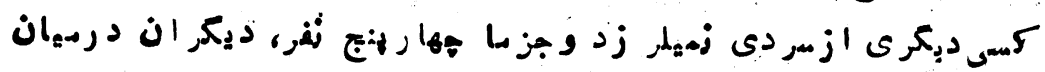

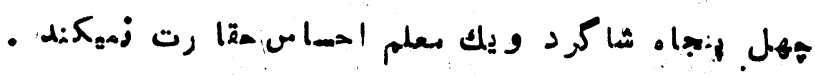

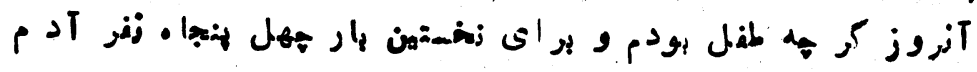

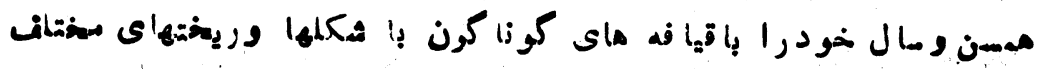

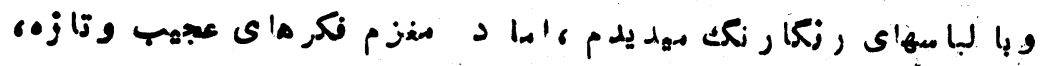

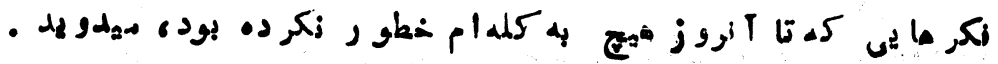

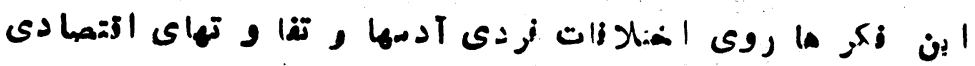

- $\Lambda_{\mathbf{s}} \dot{\dot{x}} \overrightarrow{\nabla_{2}}$

$-{ }^{\circ}$ 


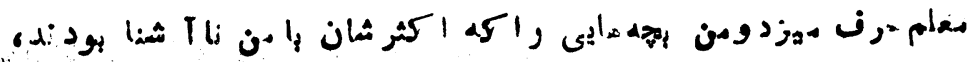

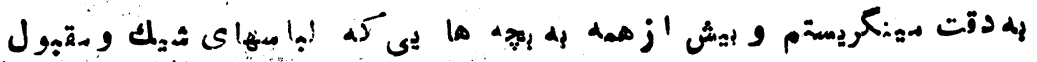

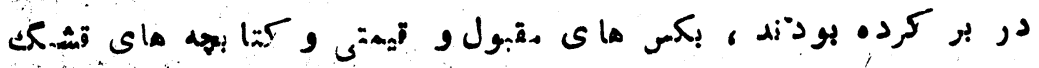

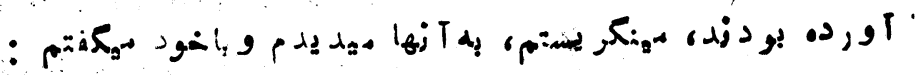

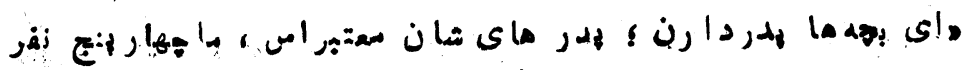

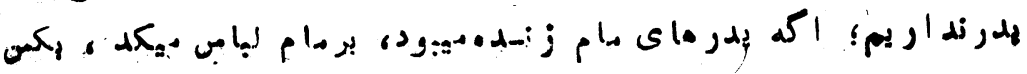

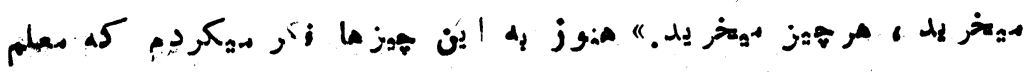

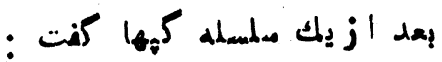

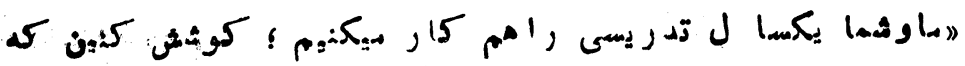

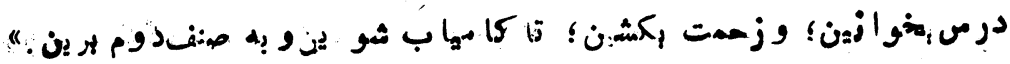

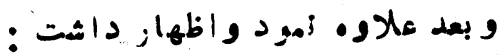

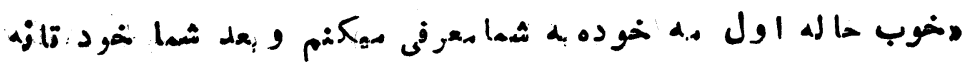

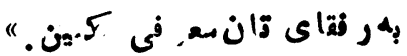

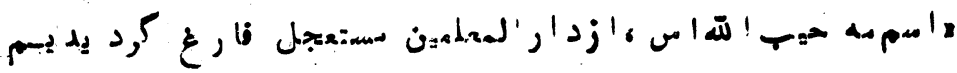

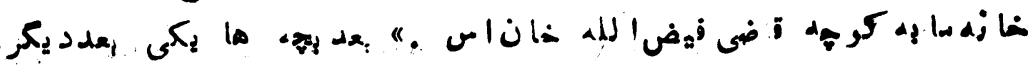

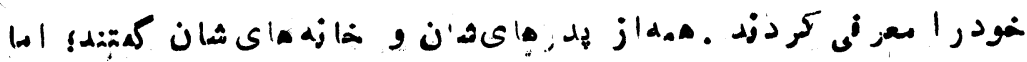

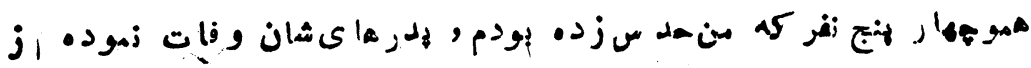

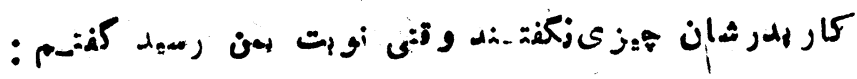

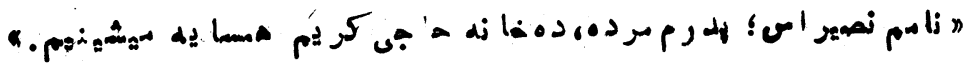

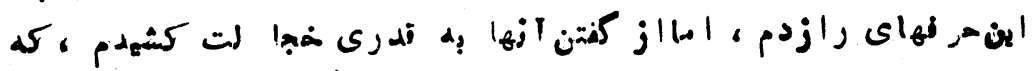

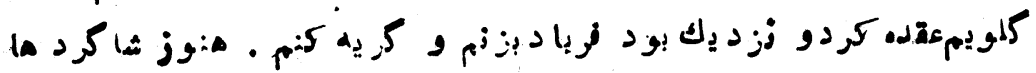

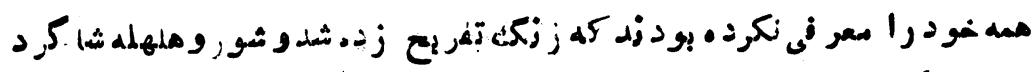

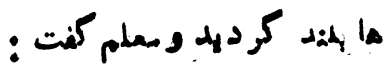

- $00-$ 


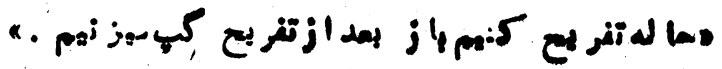

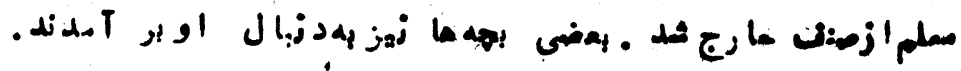

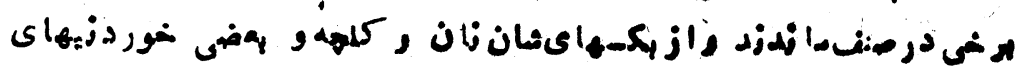

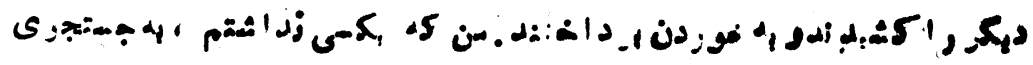

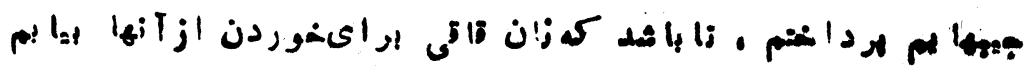

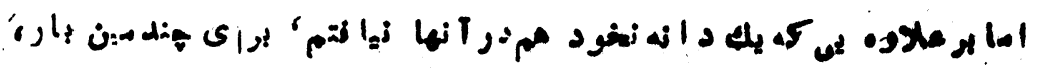

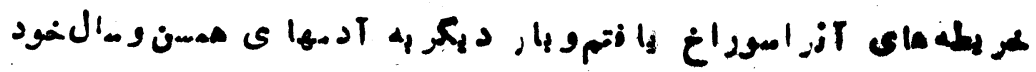

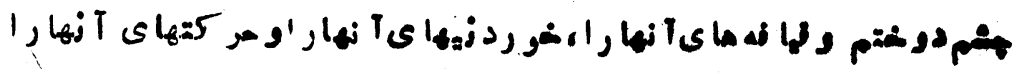

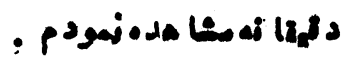

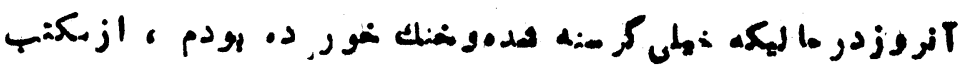

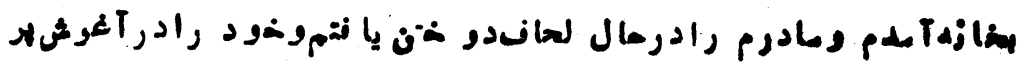

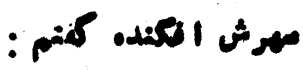

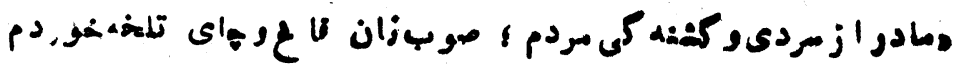

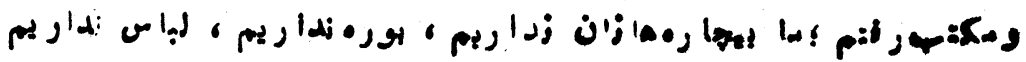

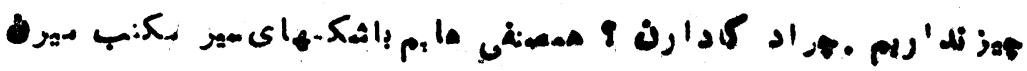

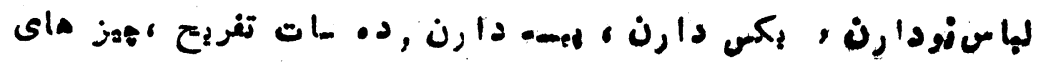

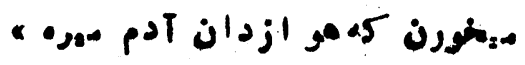

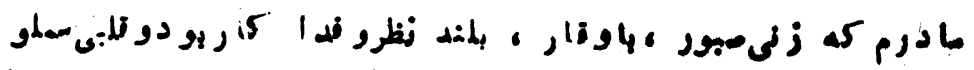

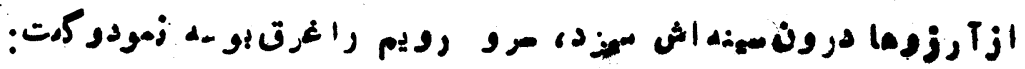

$$
\text { -... . S1, 1s, }
$$

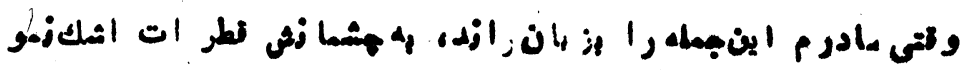

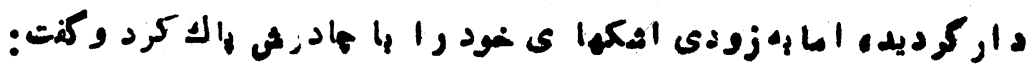

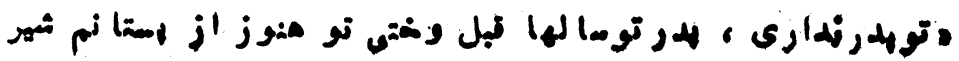




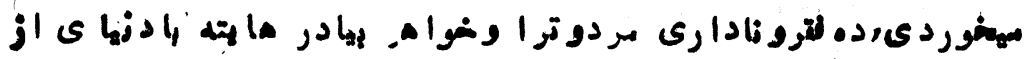

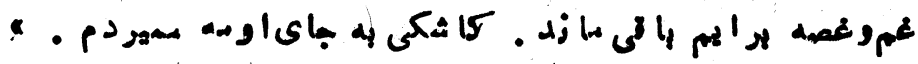

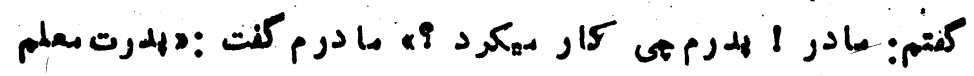
x.د4

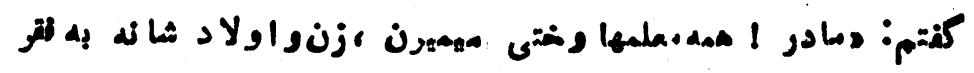

$$
\text { a } 9 \text {. }
$$

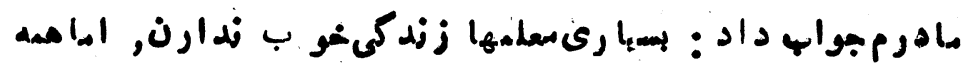

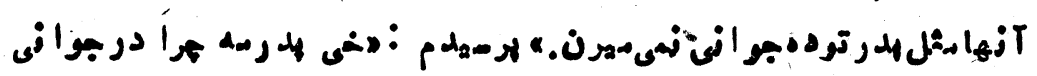

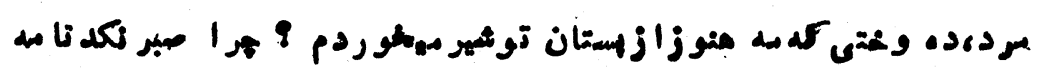

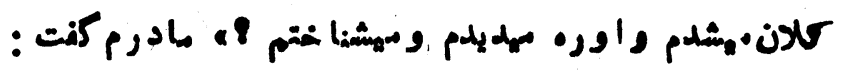

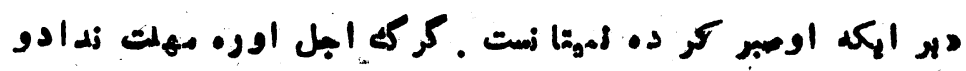

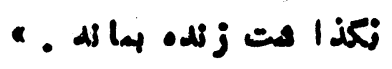

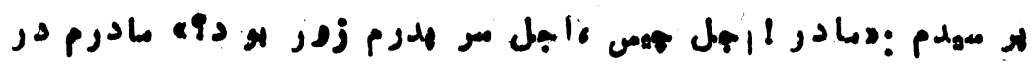

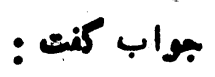

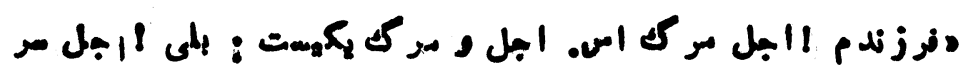

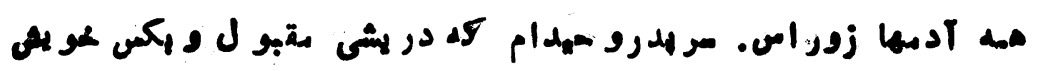

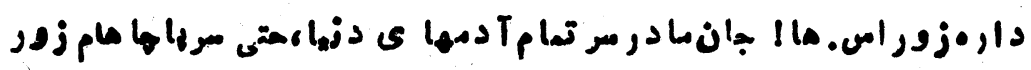
ام. د.

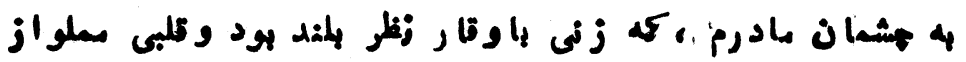

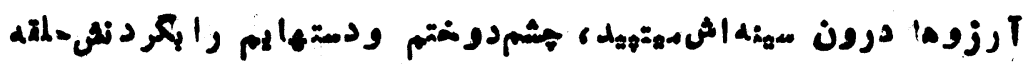

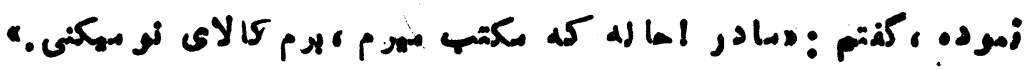

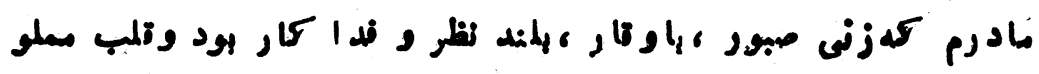

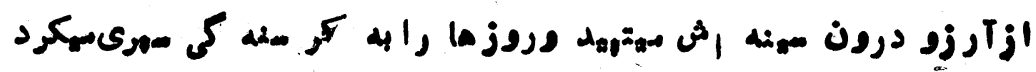




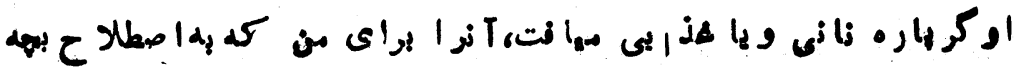

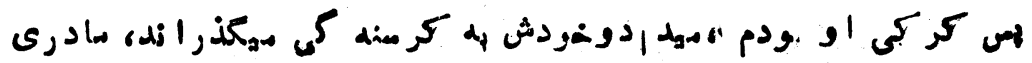

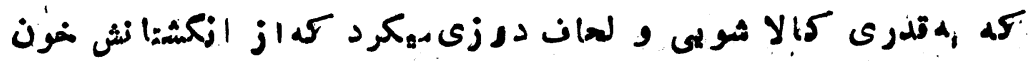

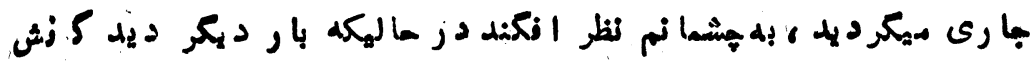

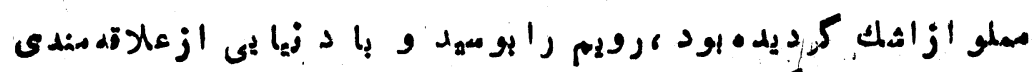

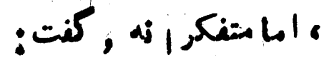

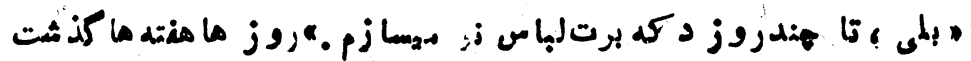

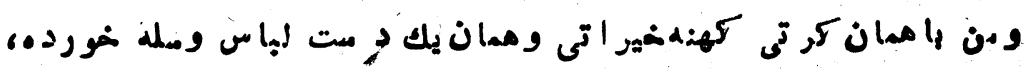

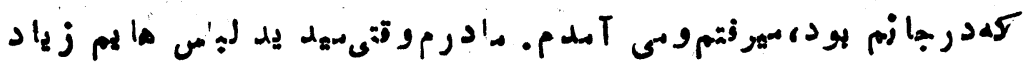

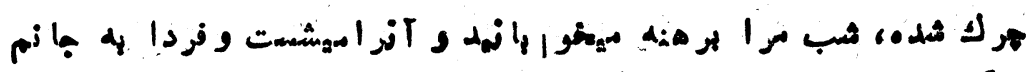

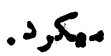

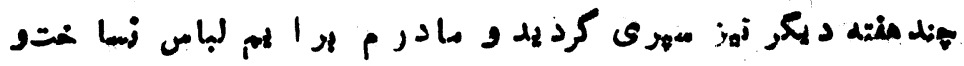

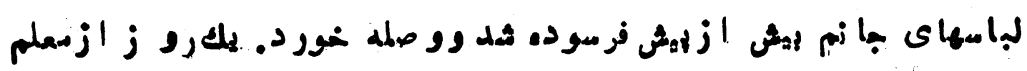

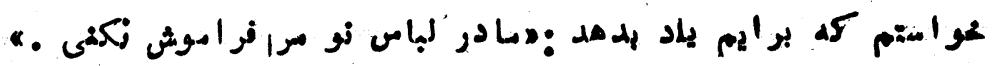

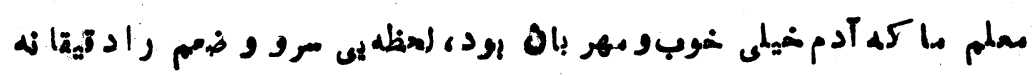

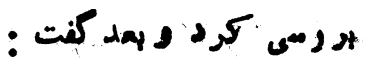

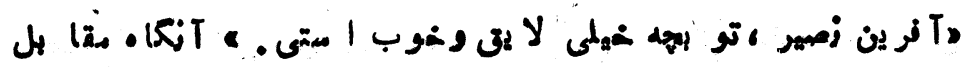

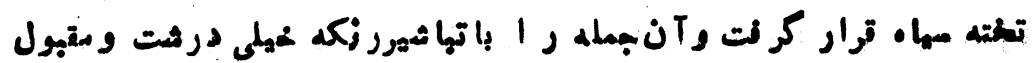

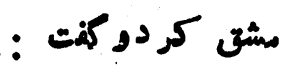

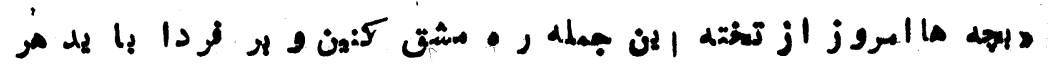

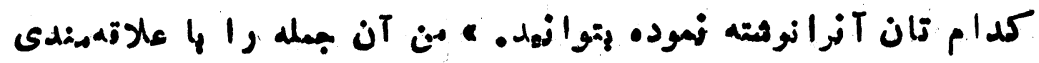

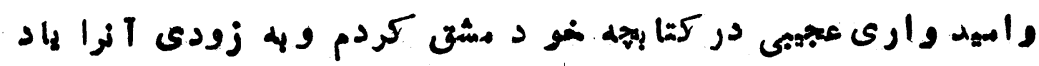

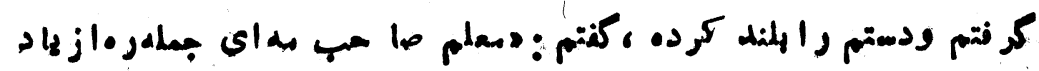

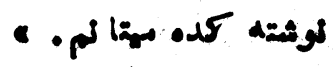




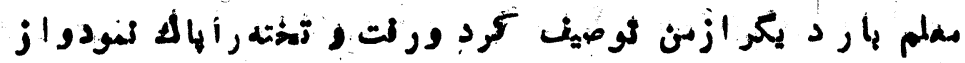

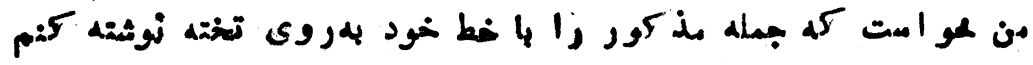

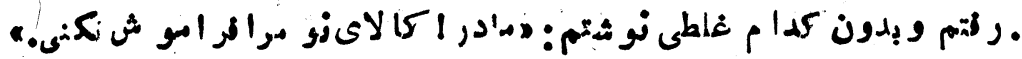

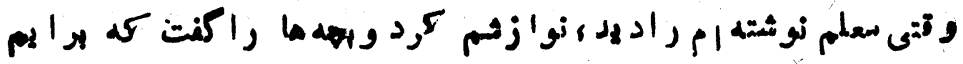

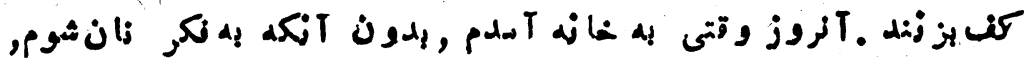

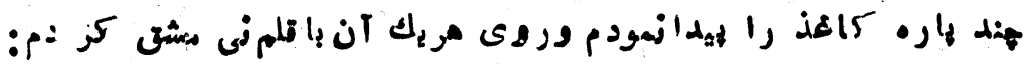

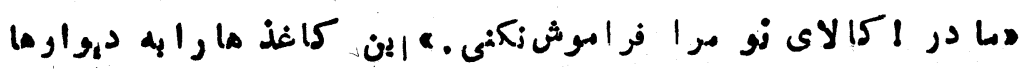

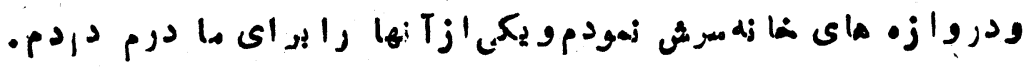

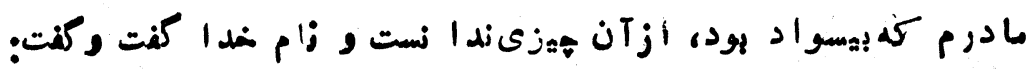

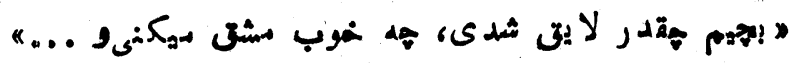

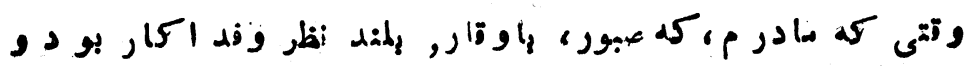

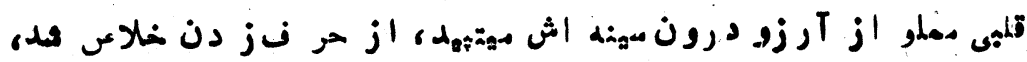

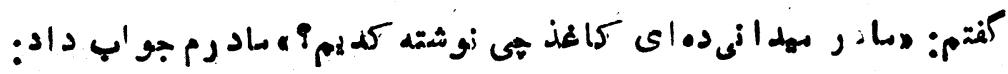

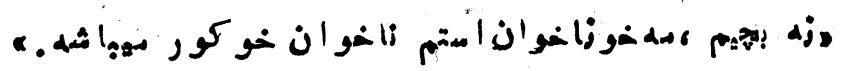

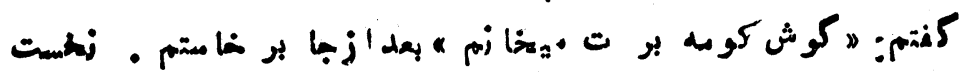

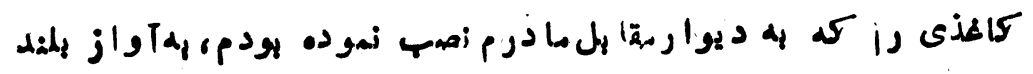

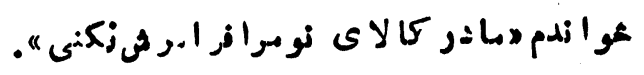

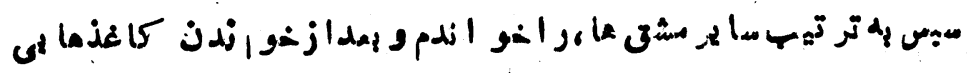

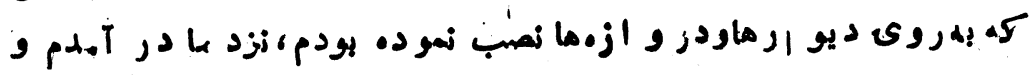

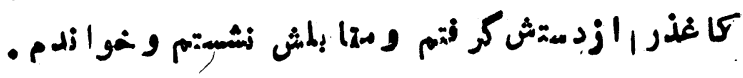

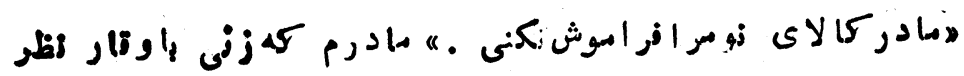

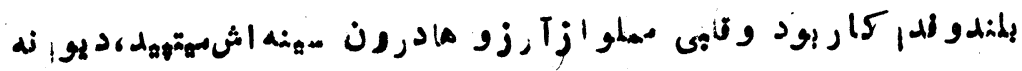




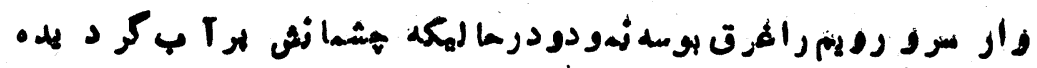

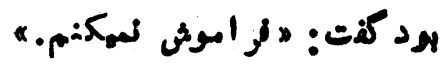

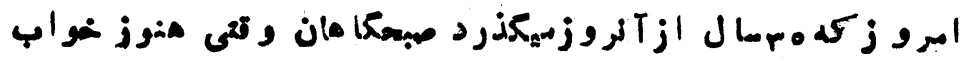

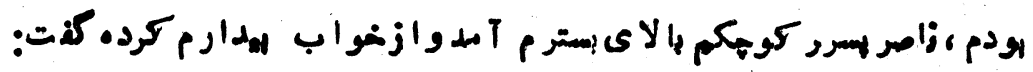

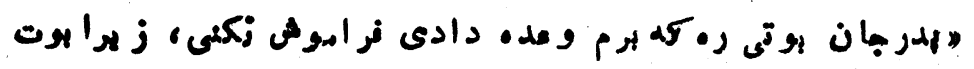

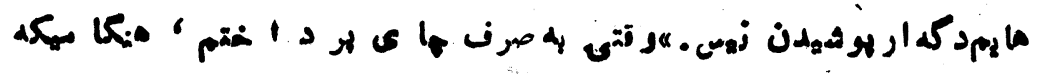

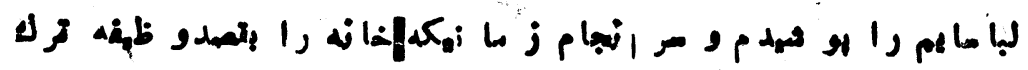

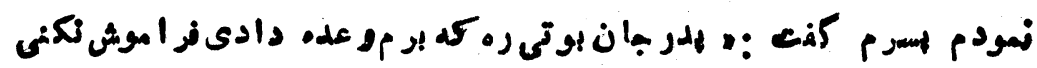

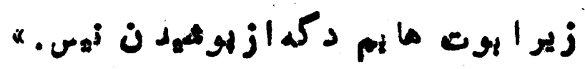

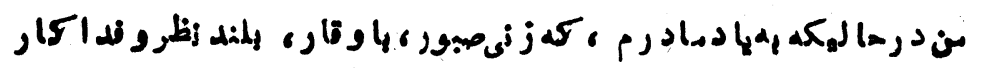

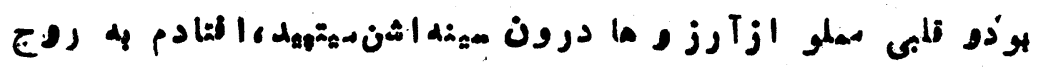

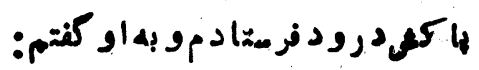

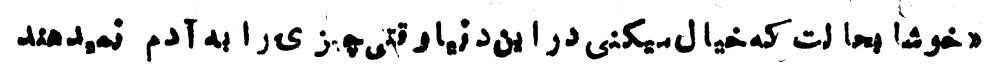

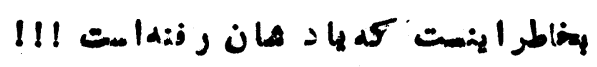




\section{اندوختهيىازكارودانش}

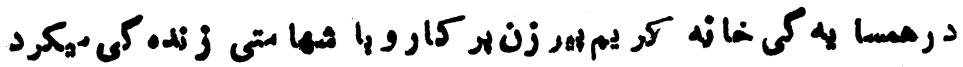

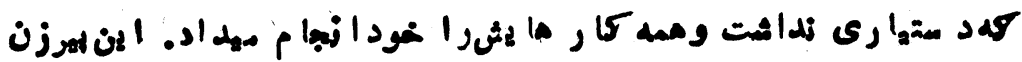

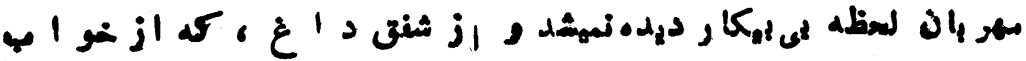

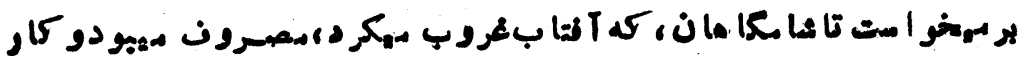
مهرد د.

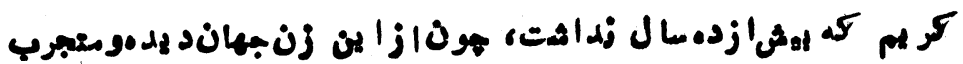

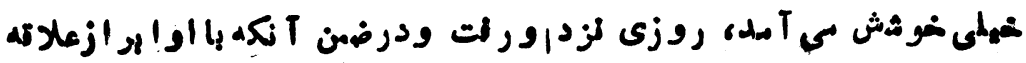

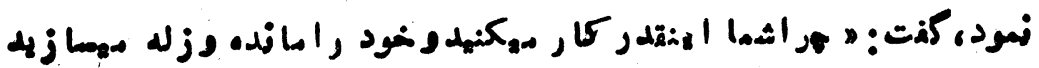

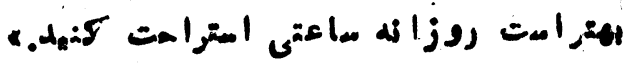

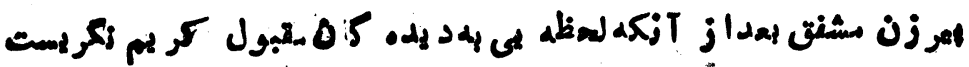

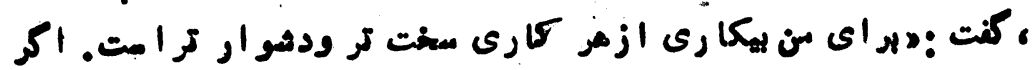

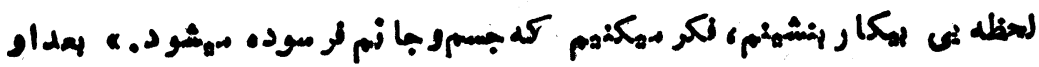

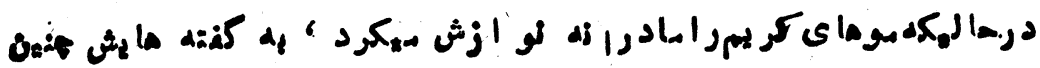

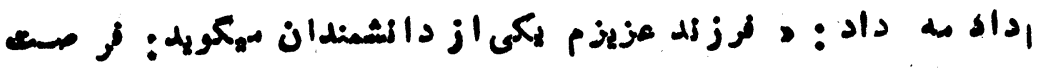

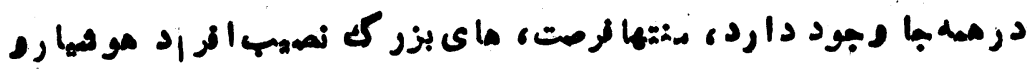

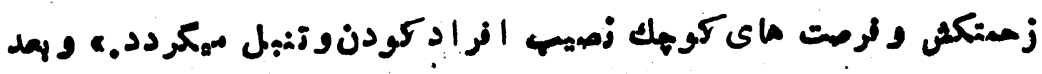

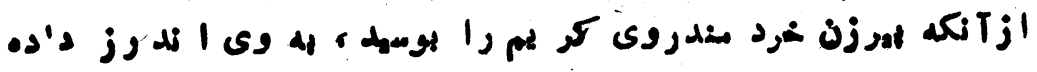




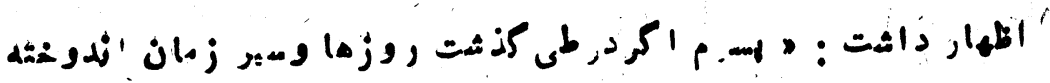

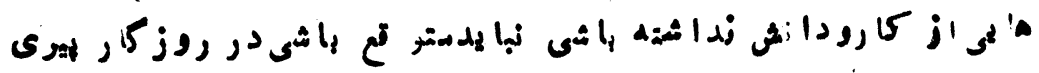

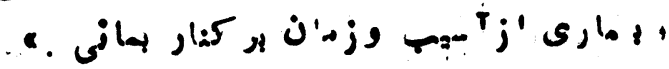

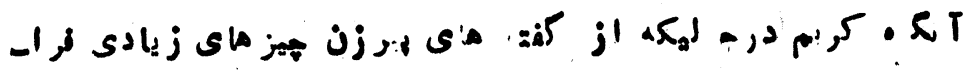

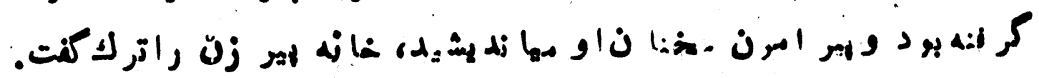




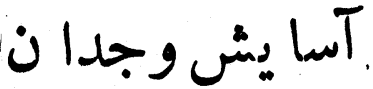

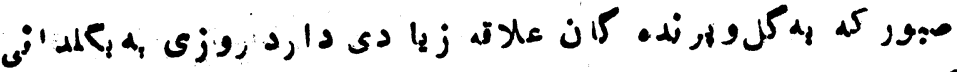

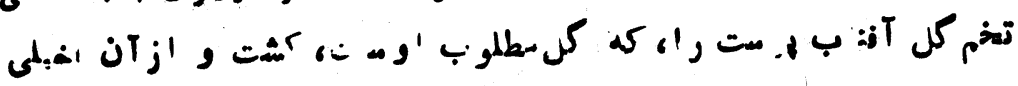

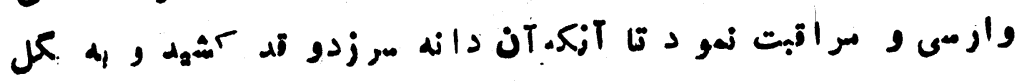

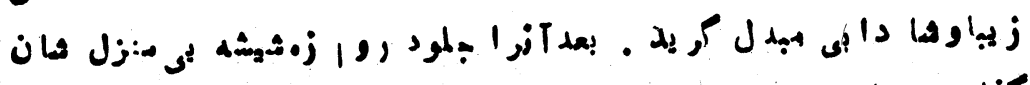

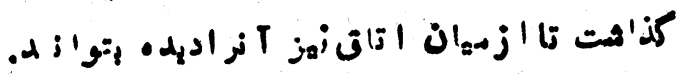

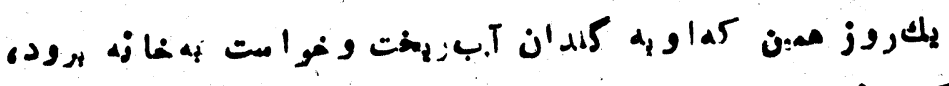

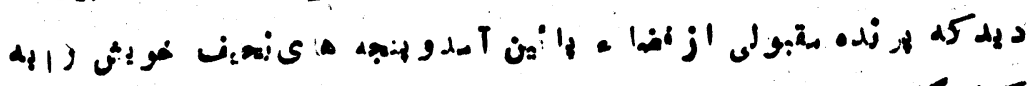

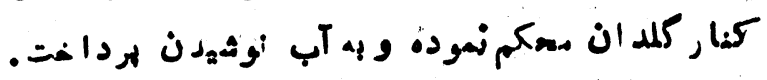

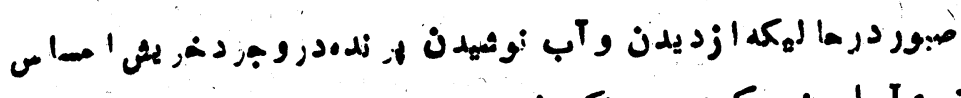

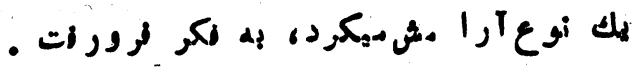

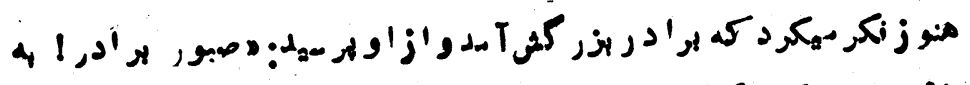

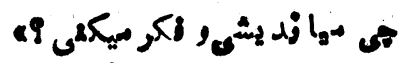

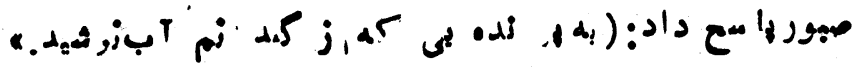

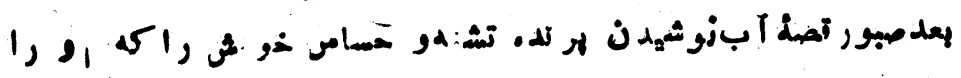

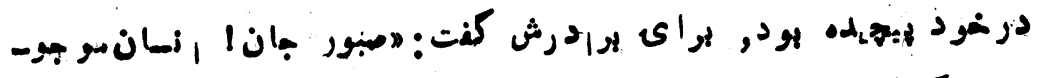

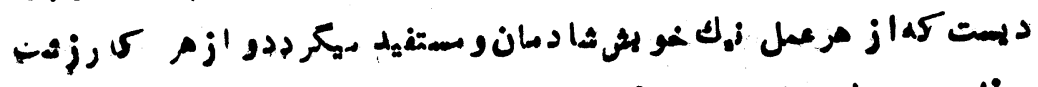

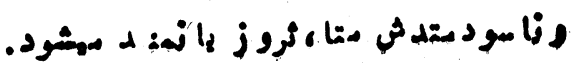




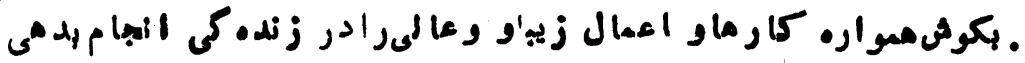

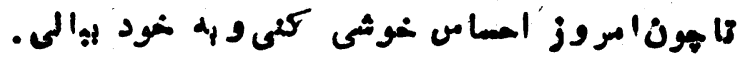

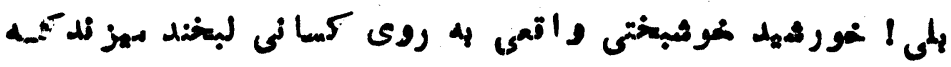

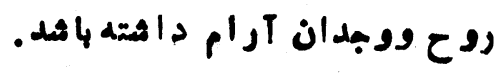

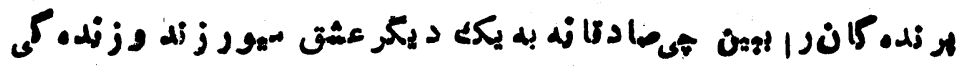

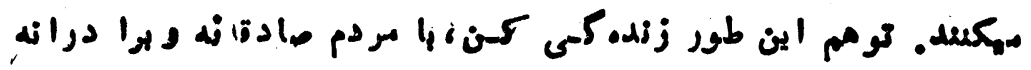

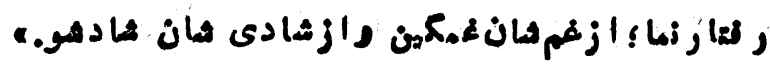

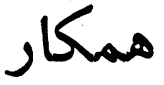

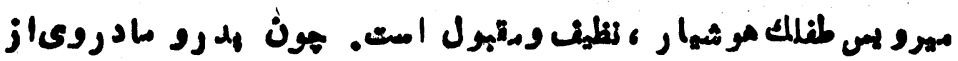

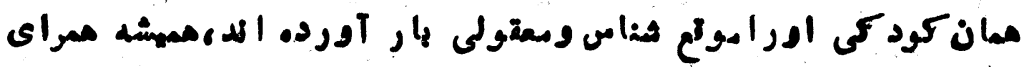

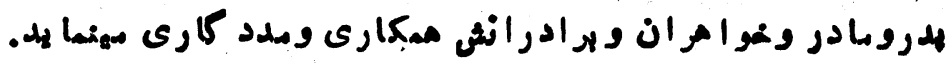

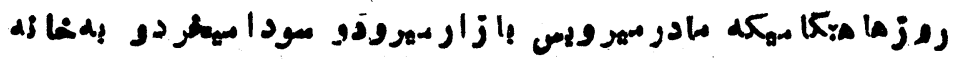

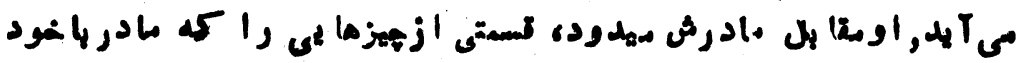

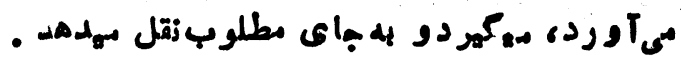

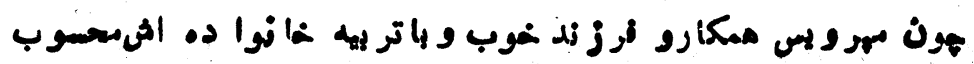

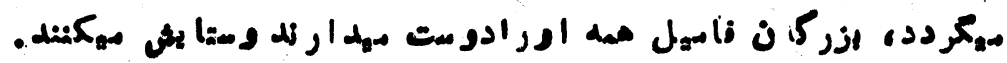

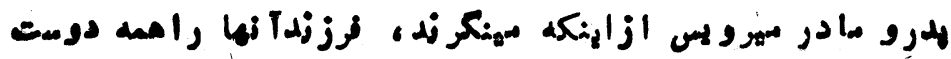

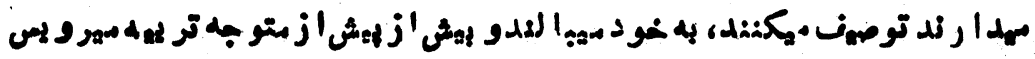

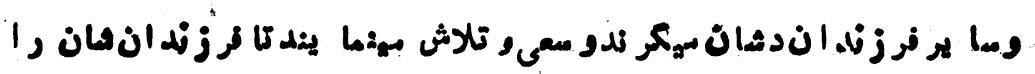

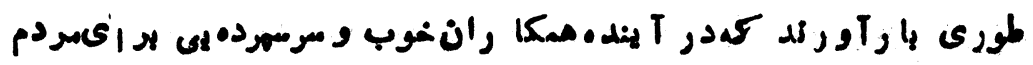

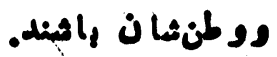


محمود و احمد

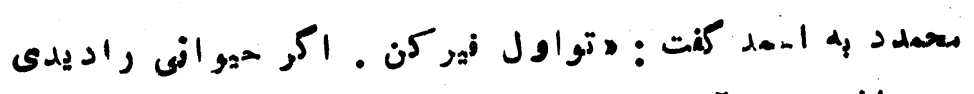

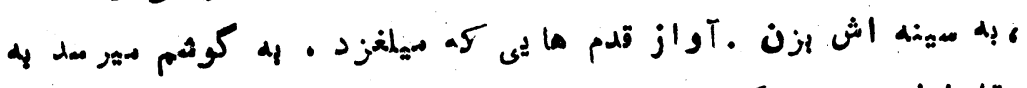

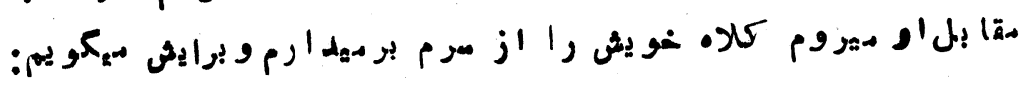

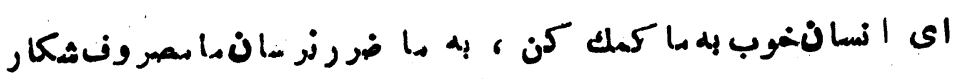

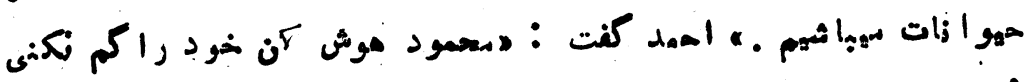

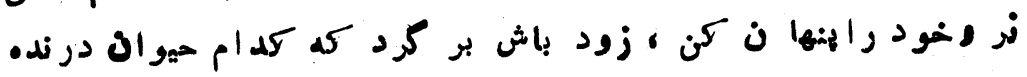

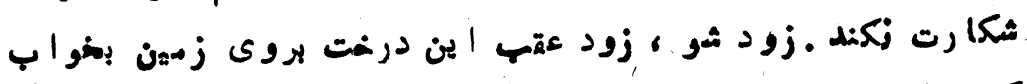

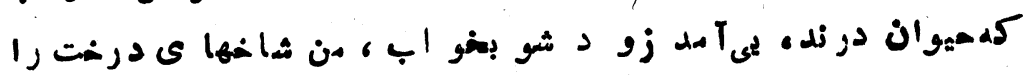

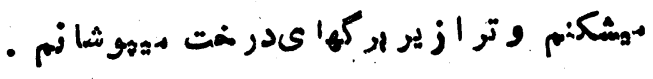

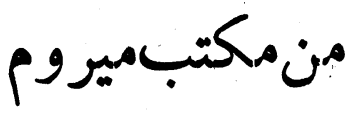

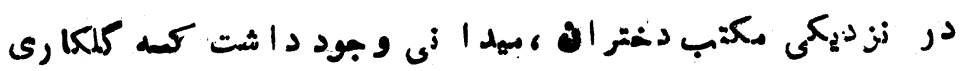

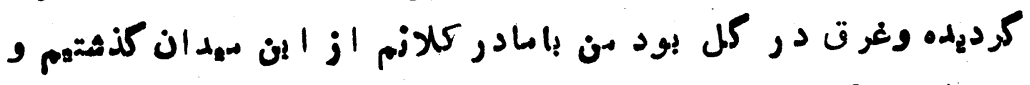

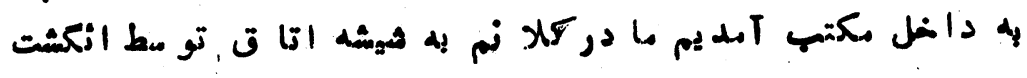

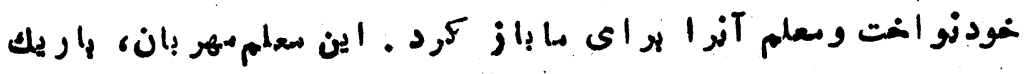

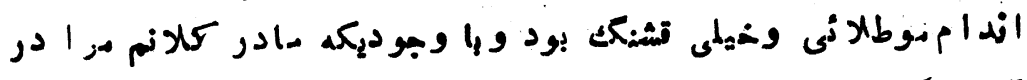

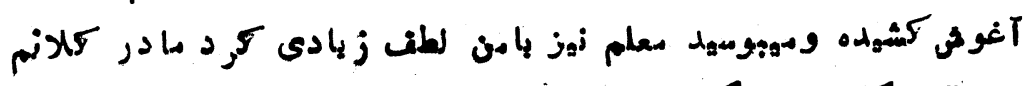

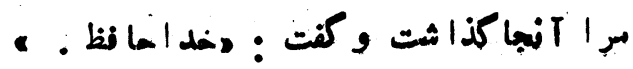

$-40-$ 


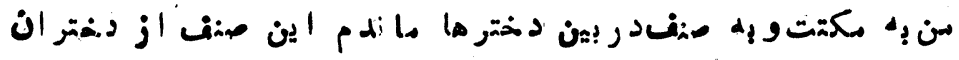

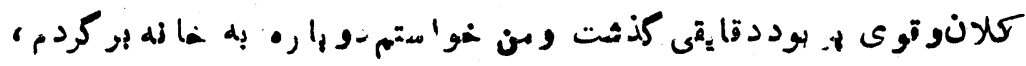

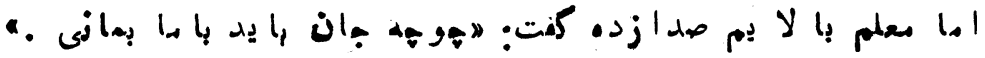

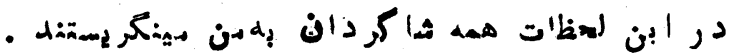

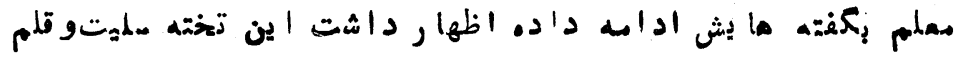

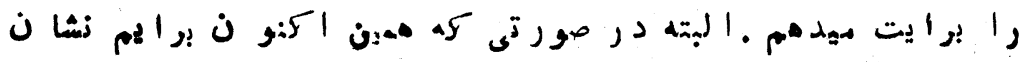

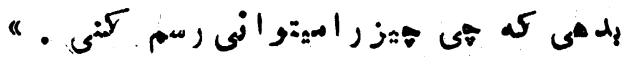

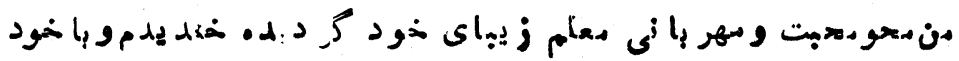

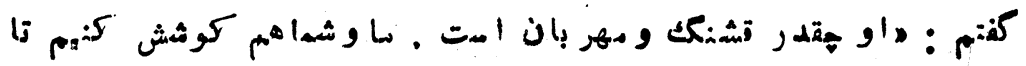

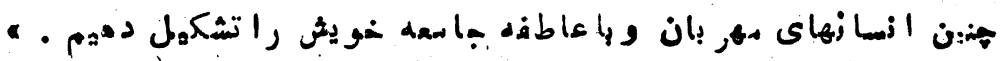

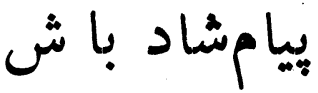

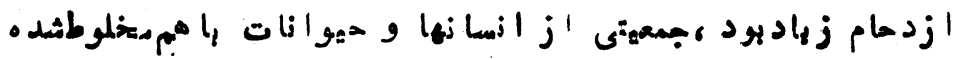

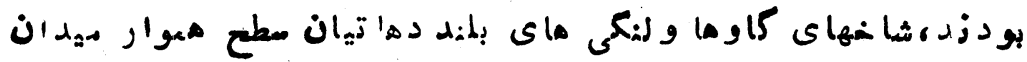

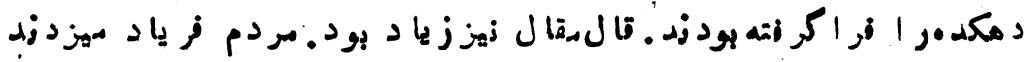

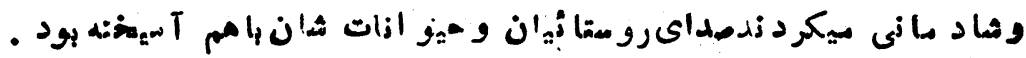

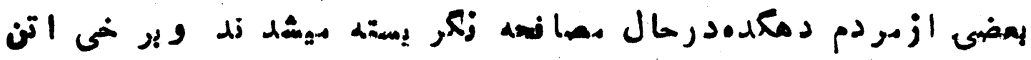

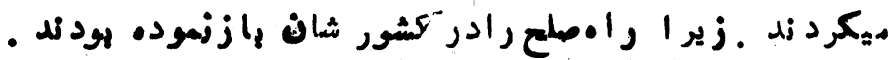

همبازىخوبت

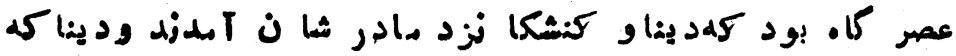

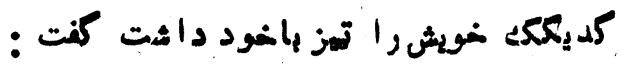

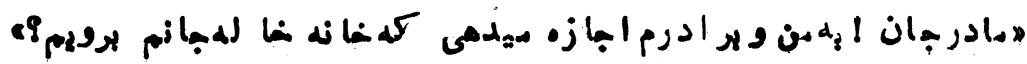
$-77-$ 


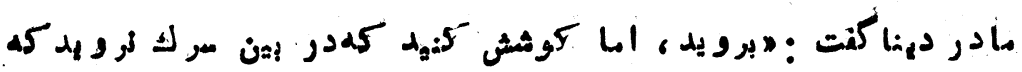

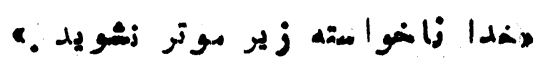

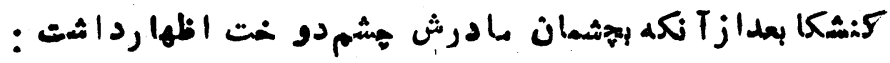

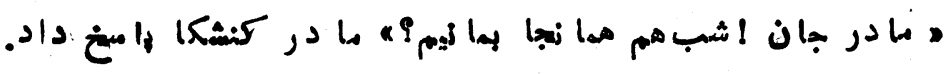

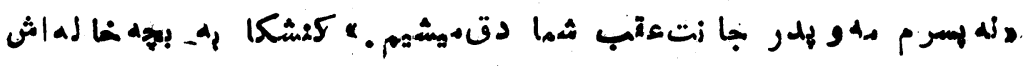

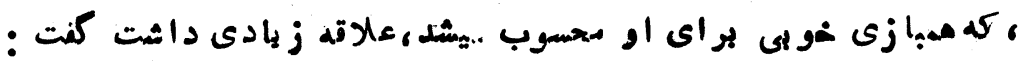

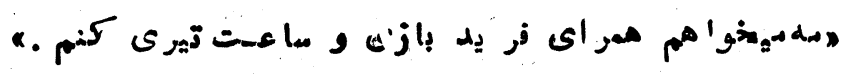

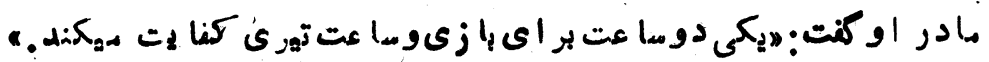

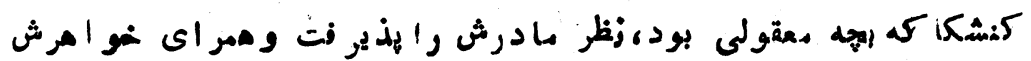

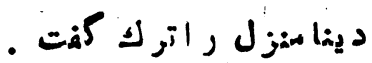

\section{حقوق زن}

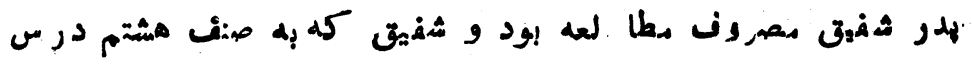

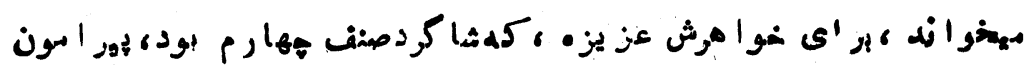

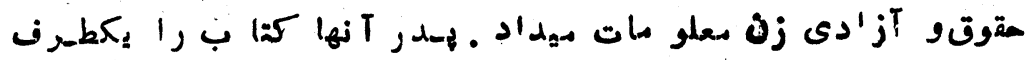

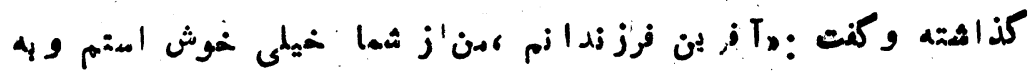

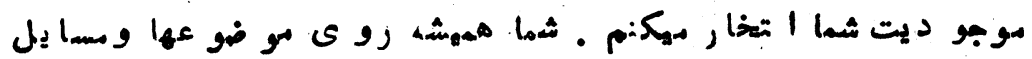

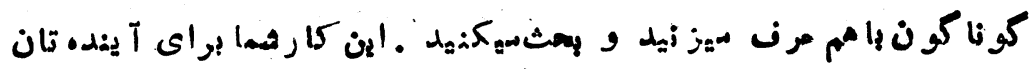

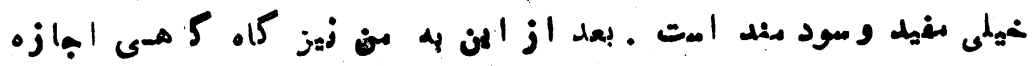

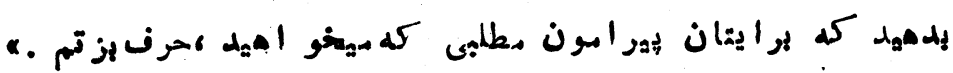

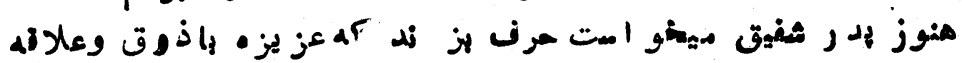

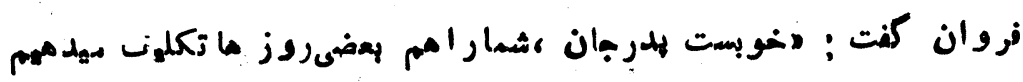

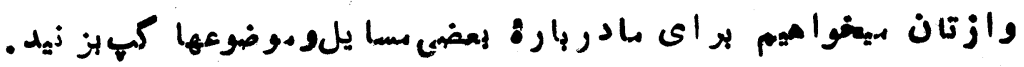




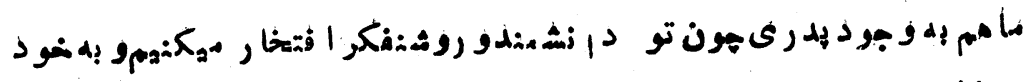

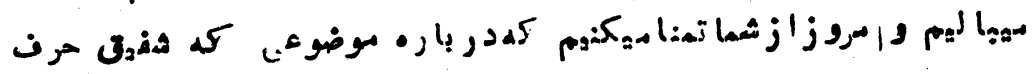

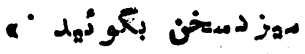

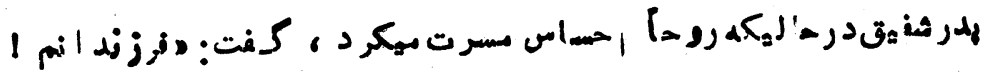

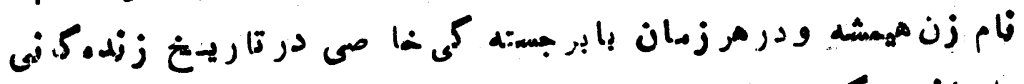

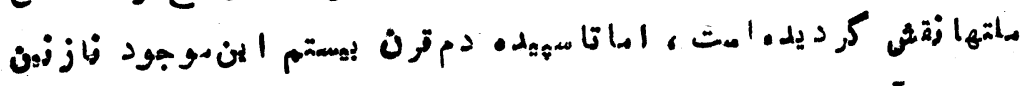

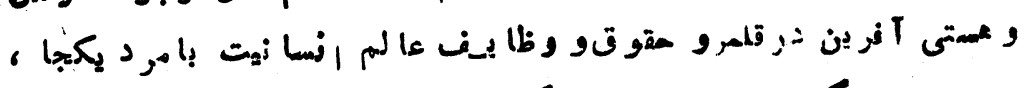

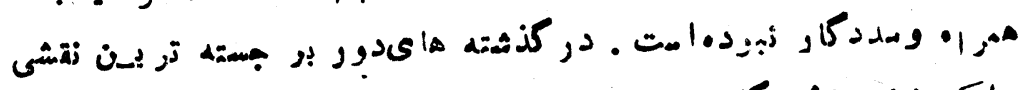

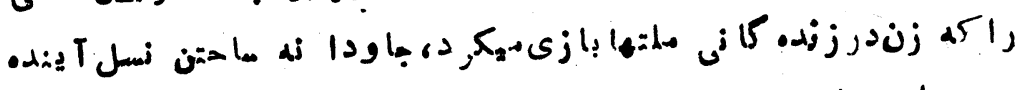

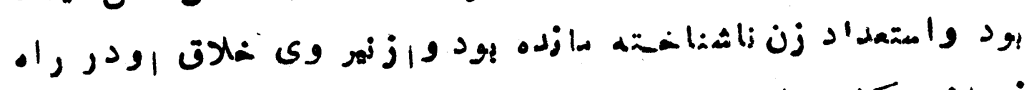

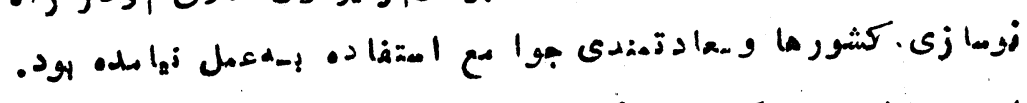

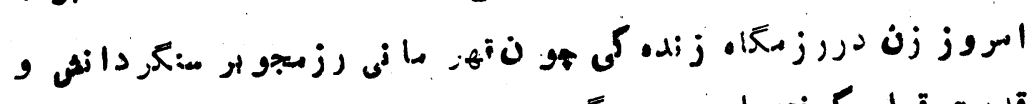

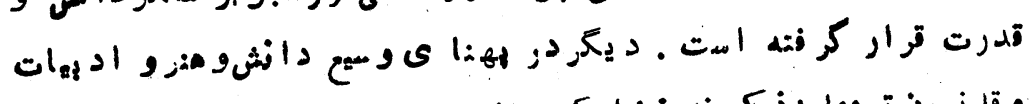

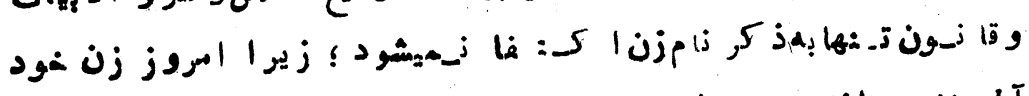

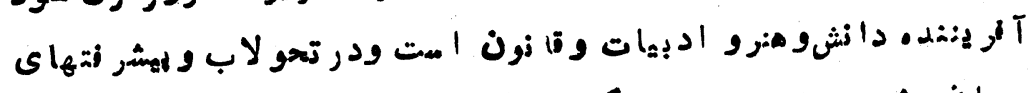

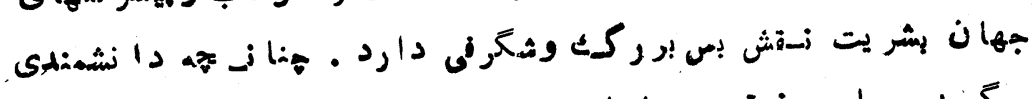

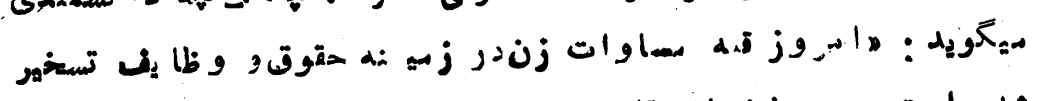

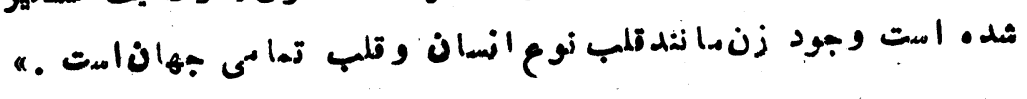

- บ1- 


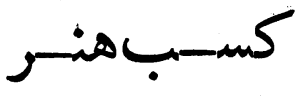

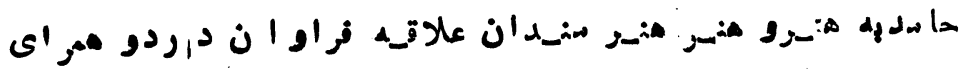

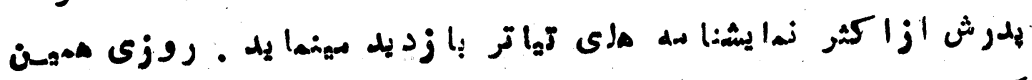

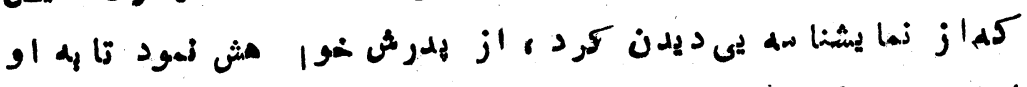

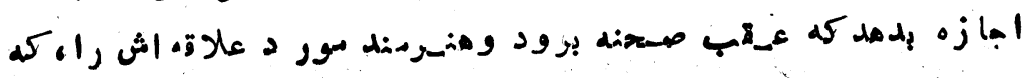

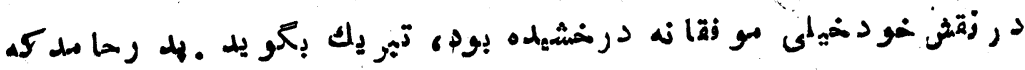

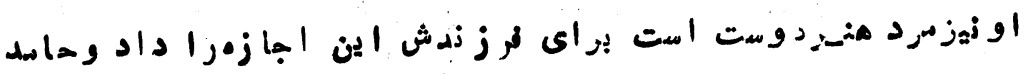

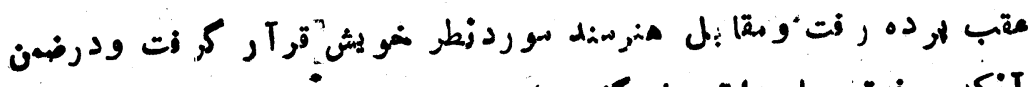

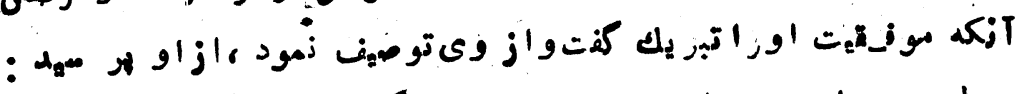

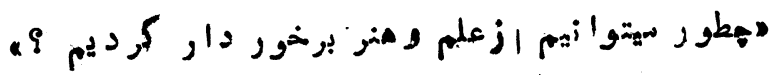

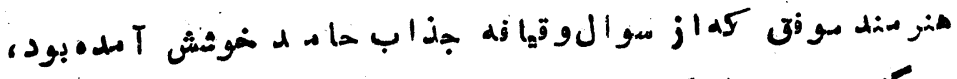

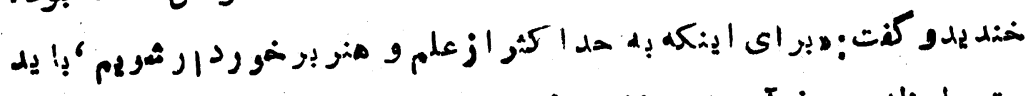

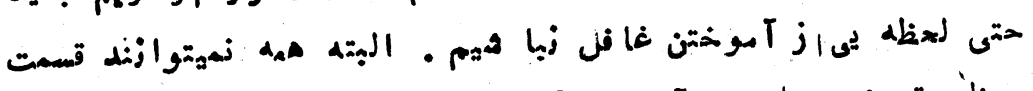

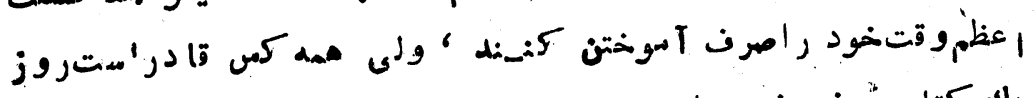

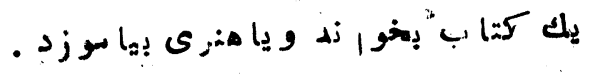

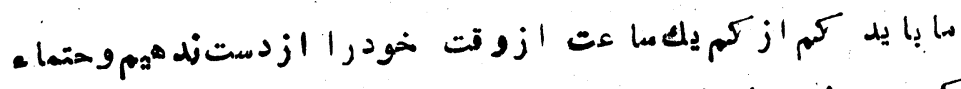

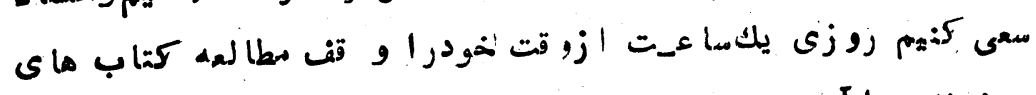

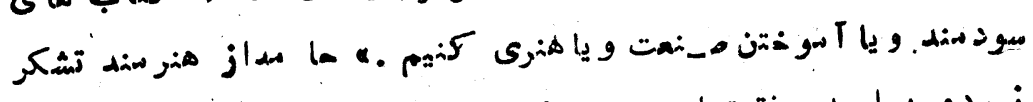

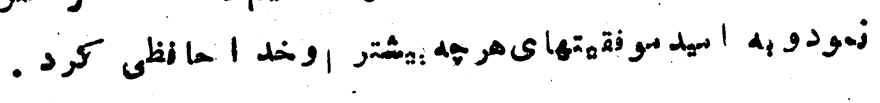


كار

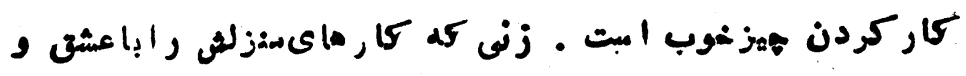

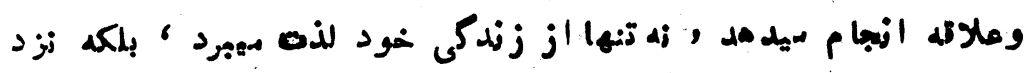

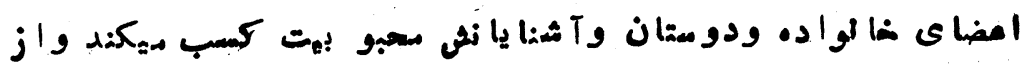

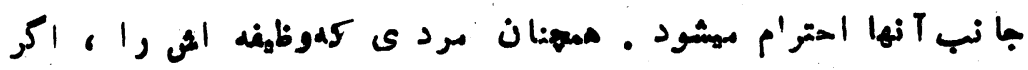

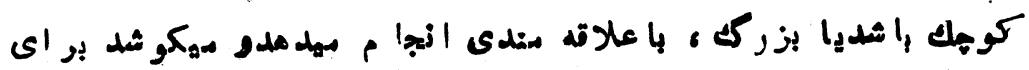

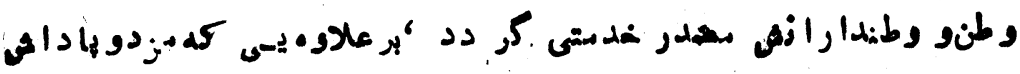

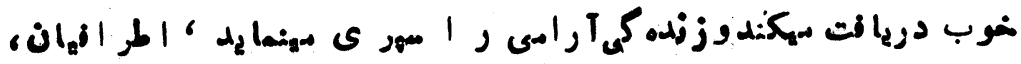

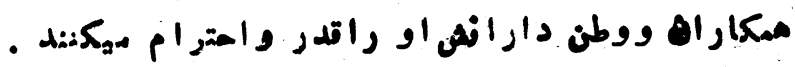

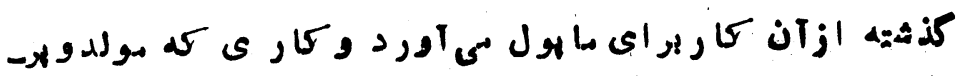

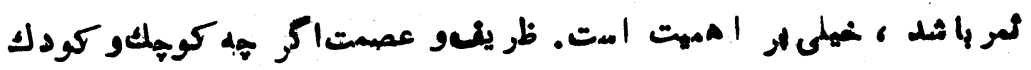

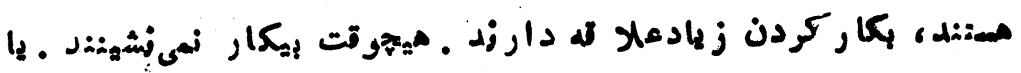

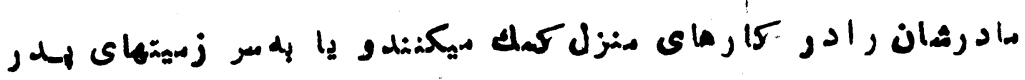

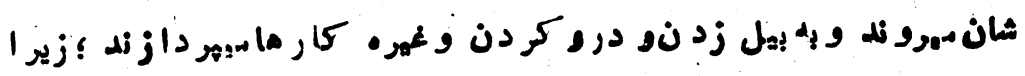

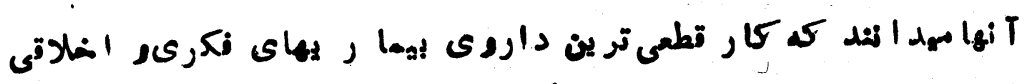

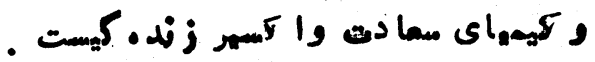

$-v \cdot-$ 


\section{درشفق داغ}

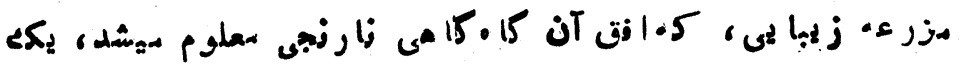

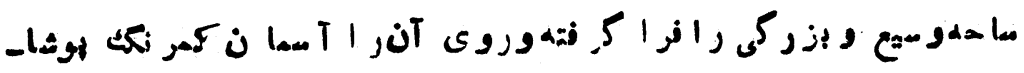

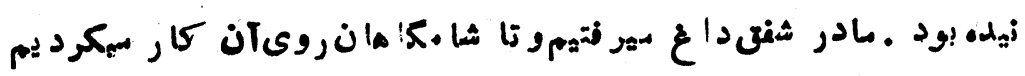

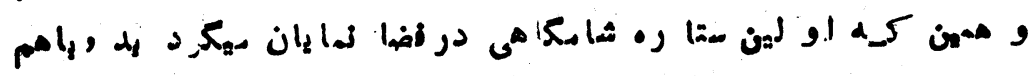

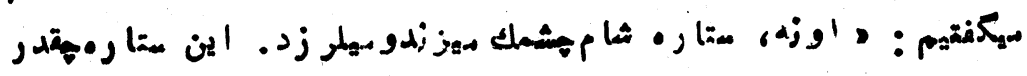

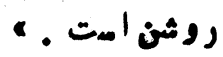

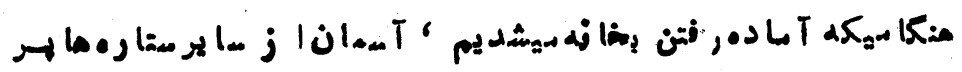

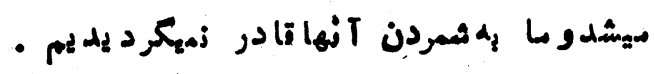

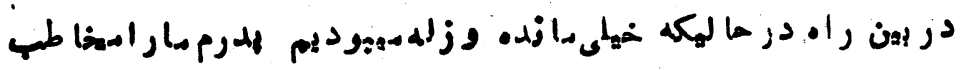

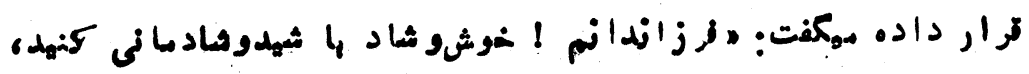

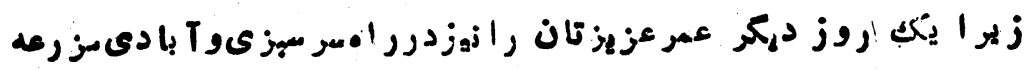

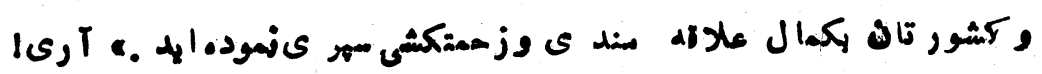

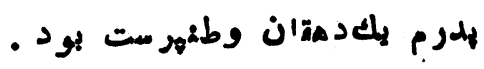

$$
\text { فراز خركو ش }
$$

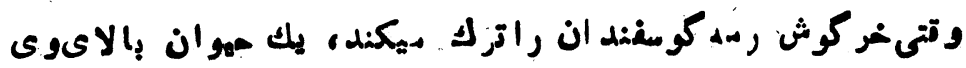

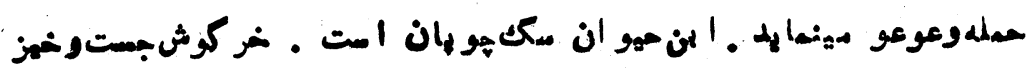

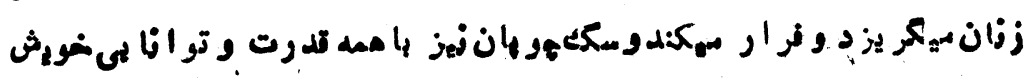

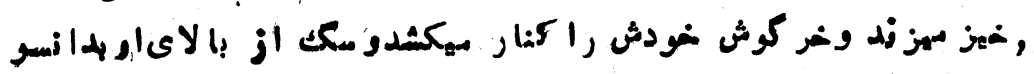

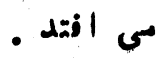

$$
-21
$$




\section{1 at}

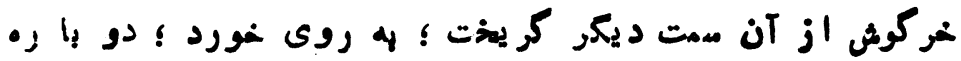

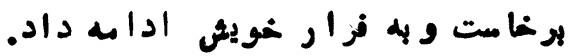

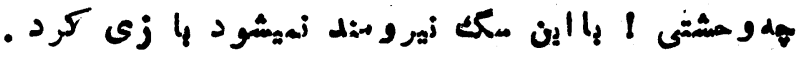

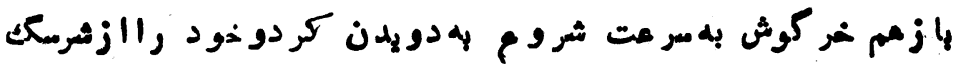

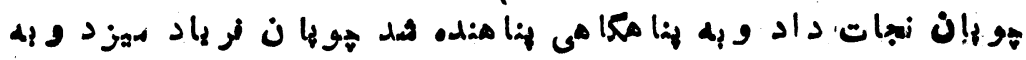

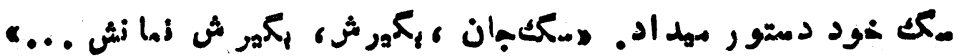

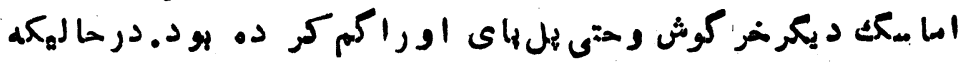

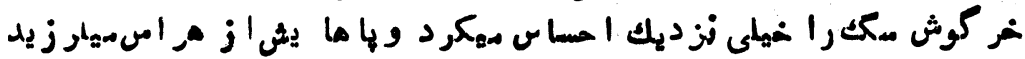

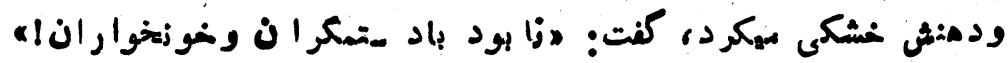

\section{v.}

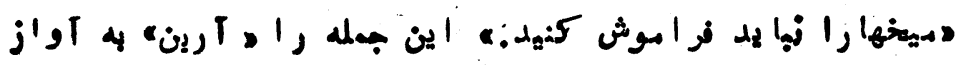

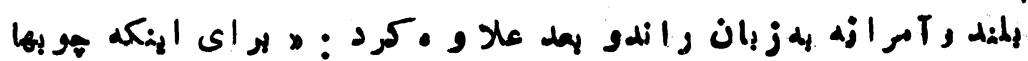

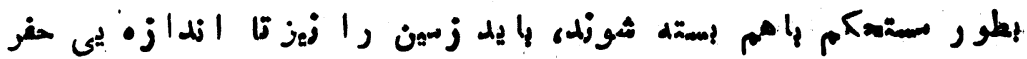

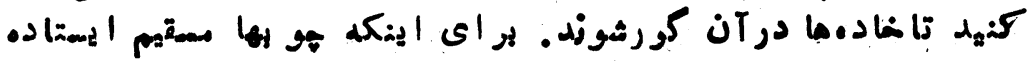

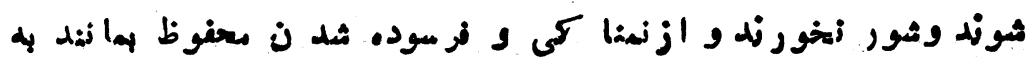

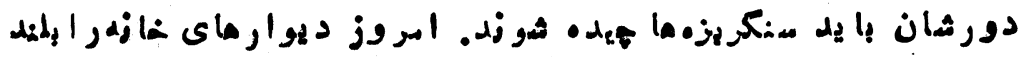

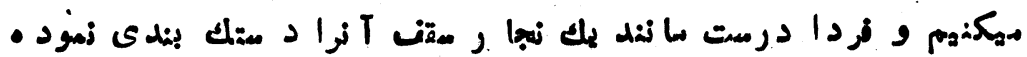

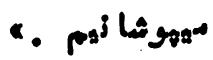

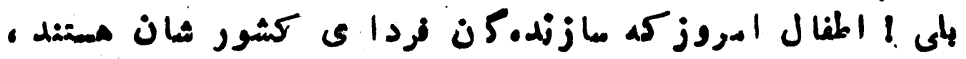

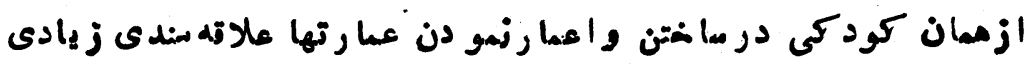

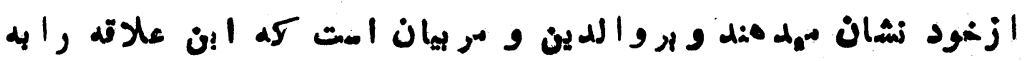

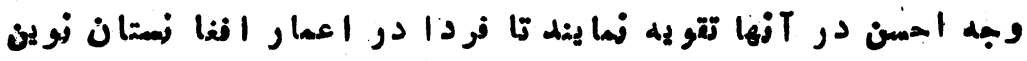

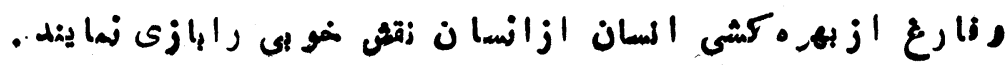




\section{جواب معقول}

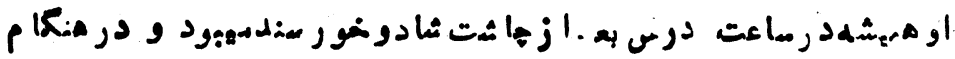

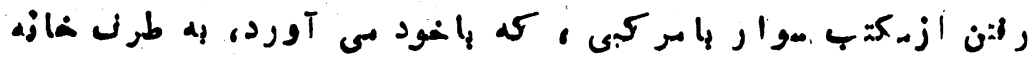

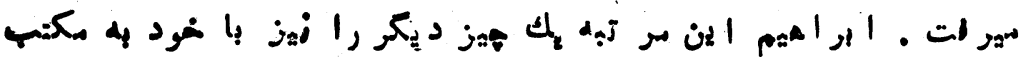

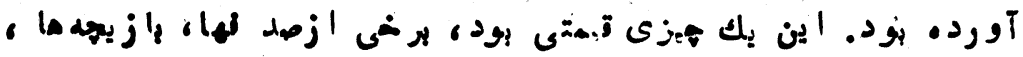

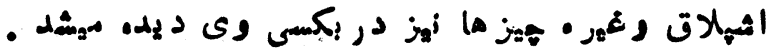

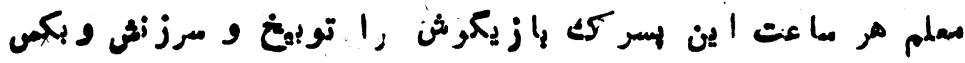

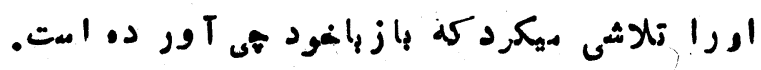

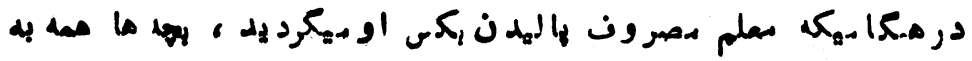

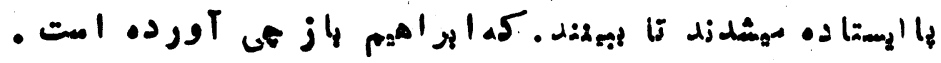

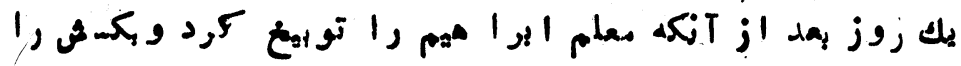

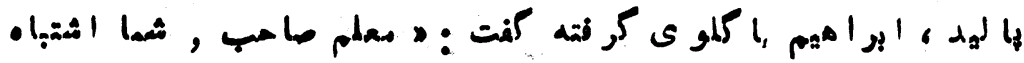

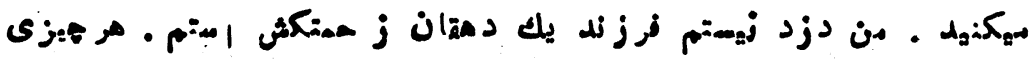

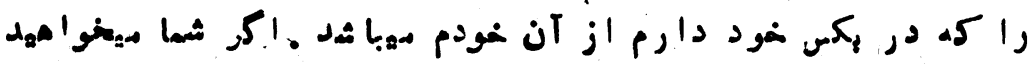

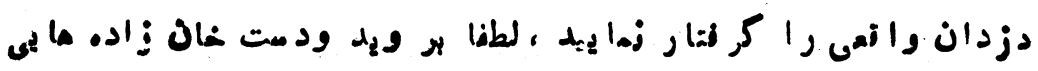

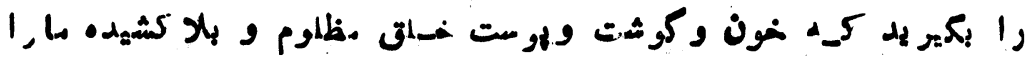

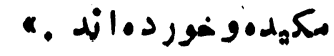
$-v_{v^{\prime}}$ 


\section{شكارجىمصروه}

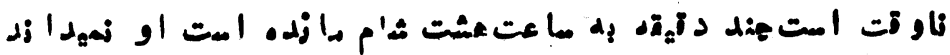

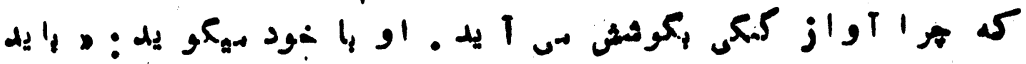

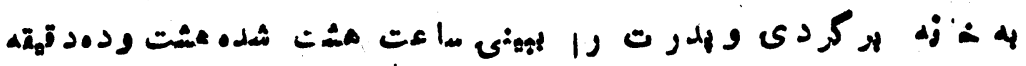

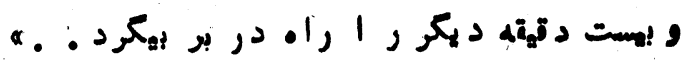

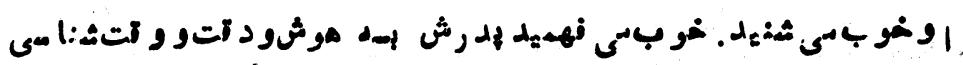

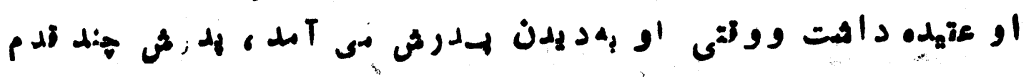

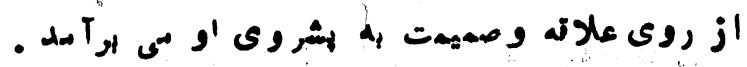

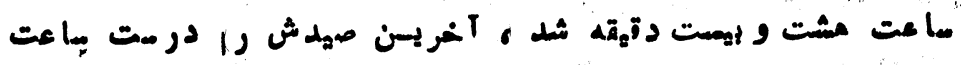

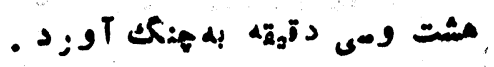

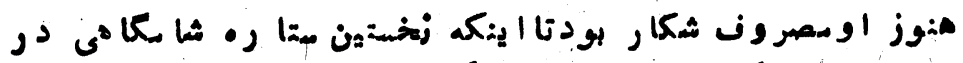

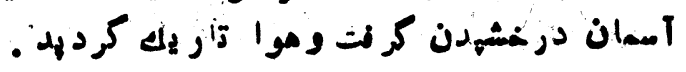

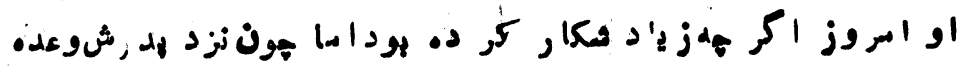

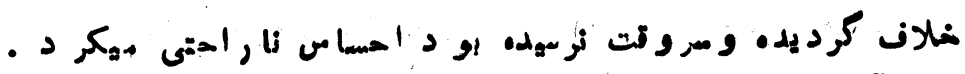
آر الرف

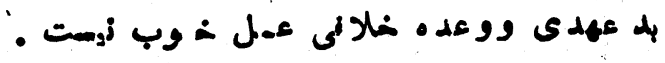


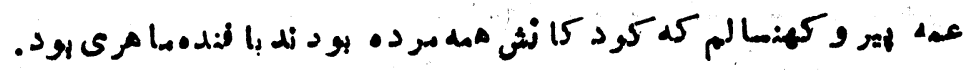

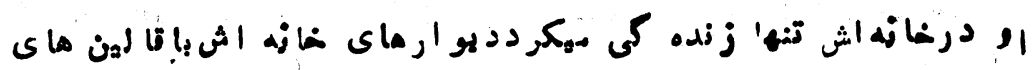

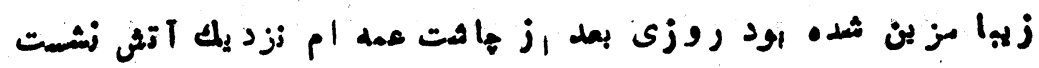

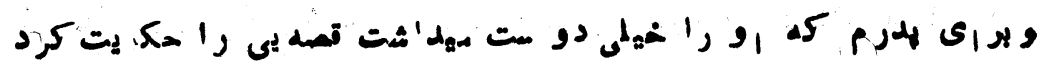

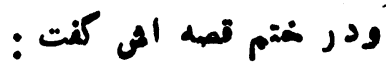




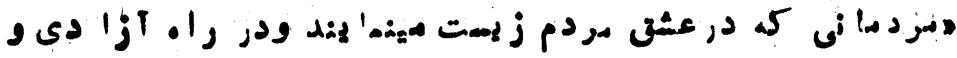

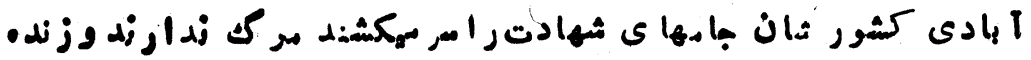

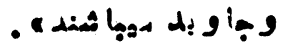

بيمارى خور دسرى

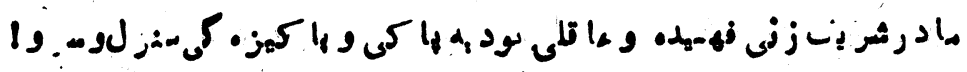

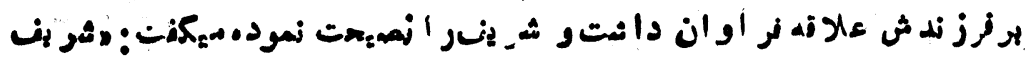

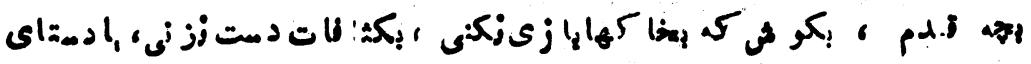

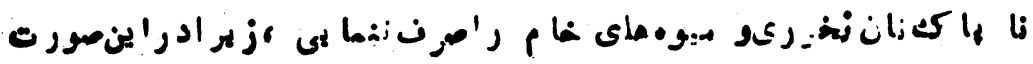

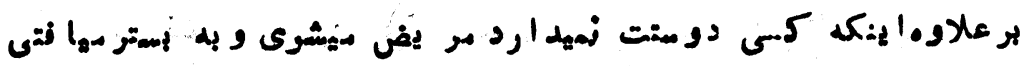

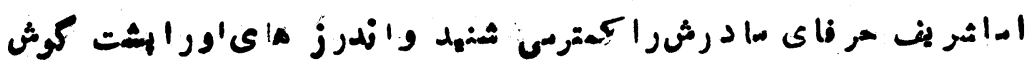

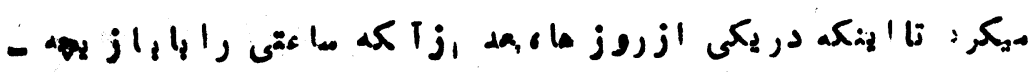

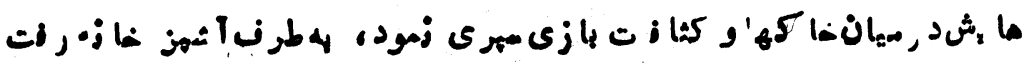

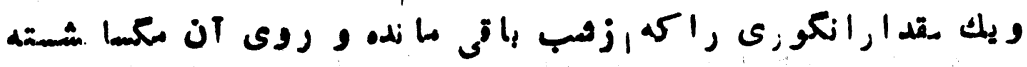

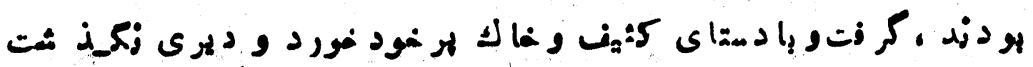

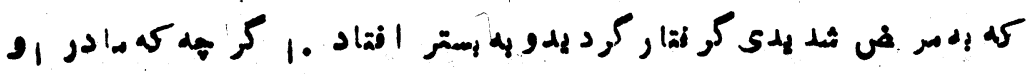

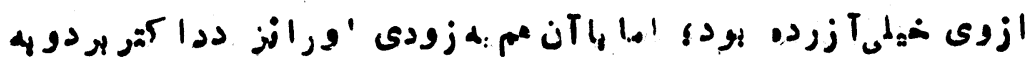

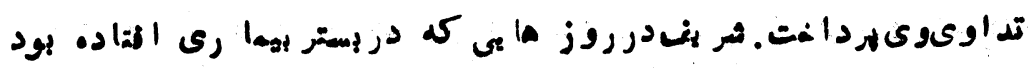

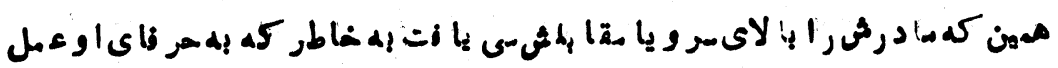

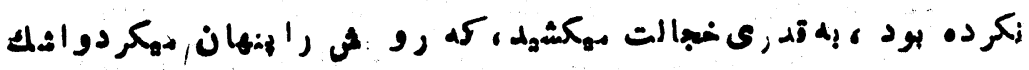

مير يسنت.

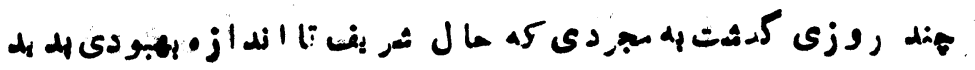

$$
-v_{0}
$$




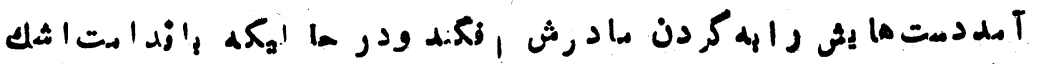

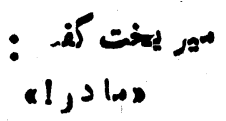

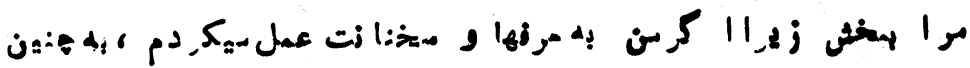

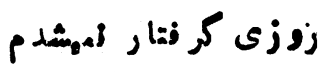

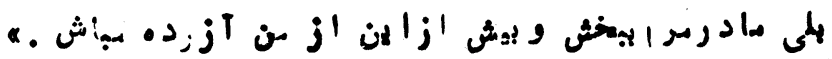

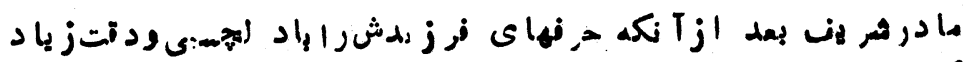

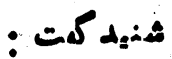

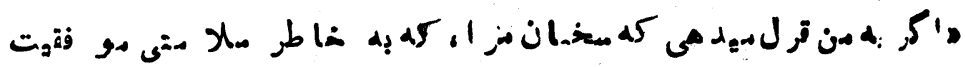

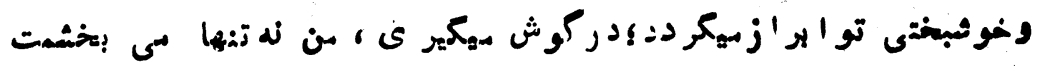

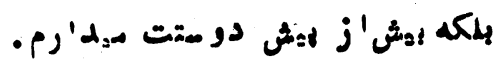

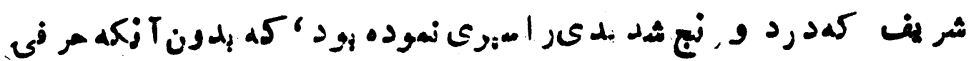

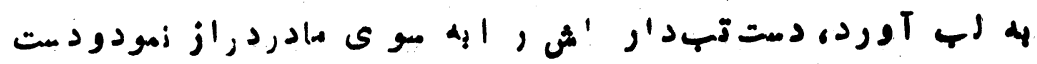

$$
\text { هو اطف اورالشرده.. }
$$

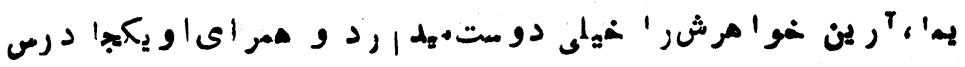

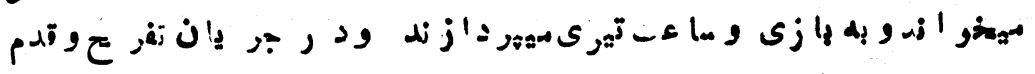

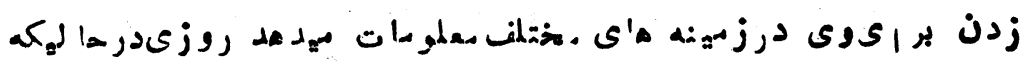

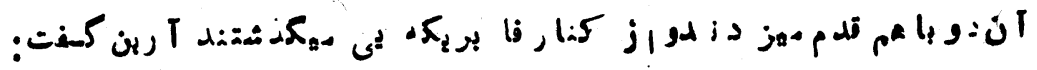

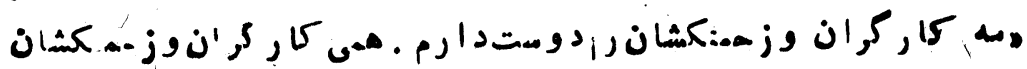

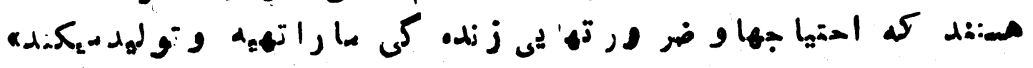

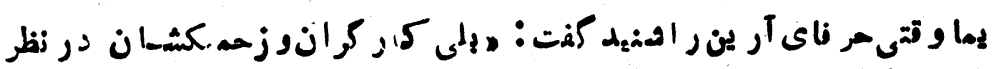

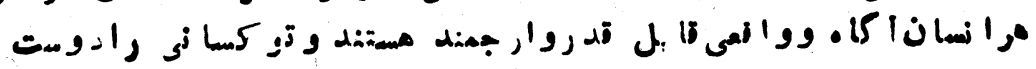

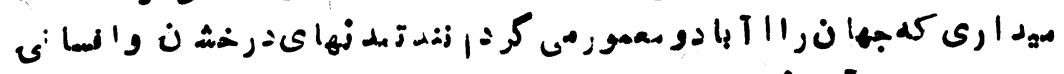

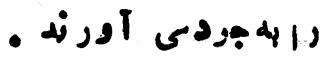


بيمارى

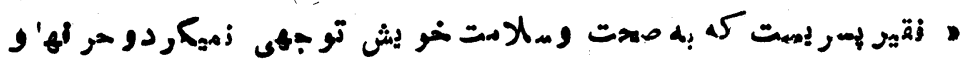

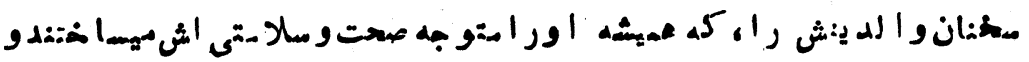

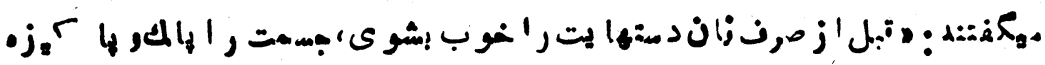

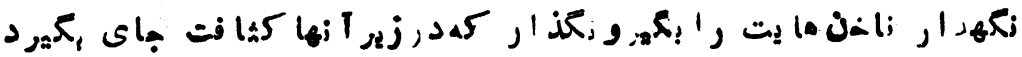

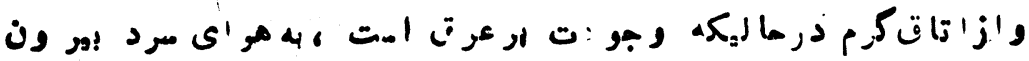

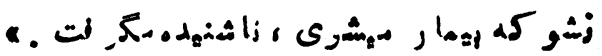

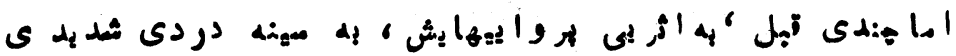

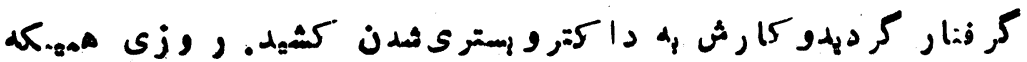

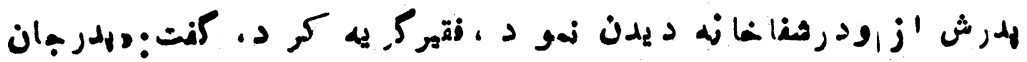

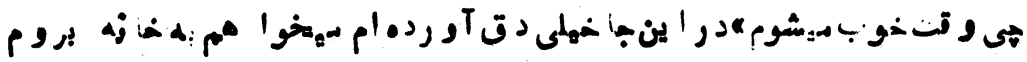

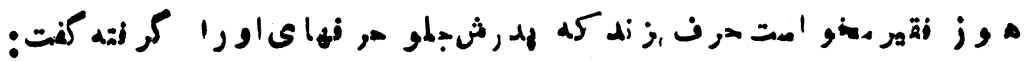

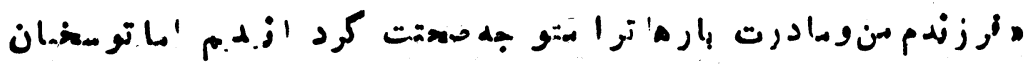

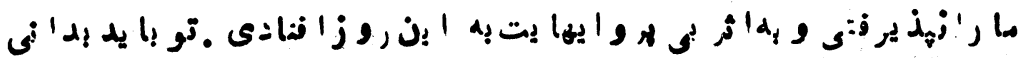

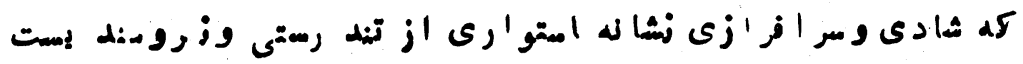

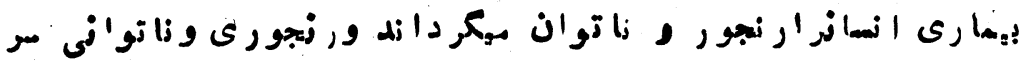

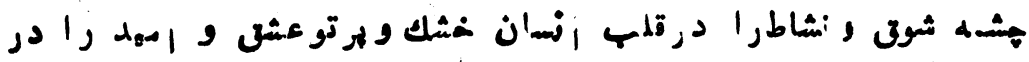

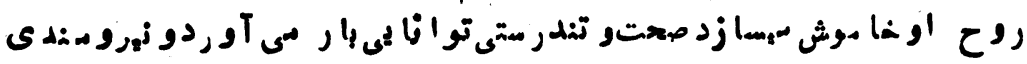

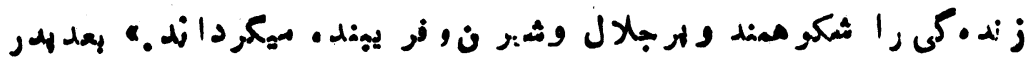
- vv_. 


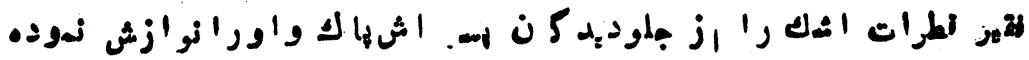

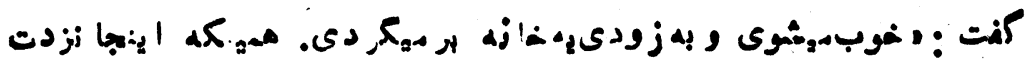

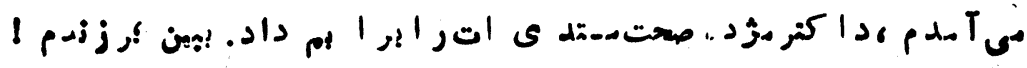

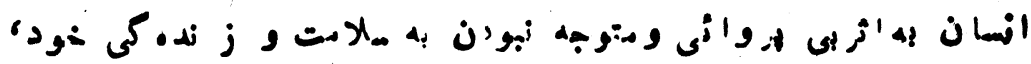

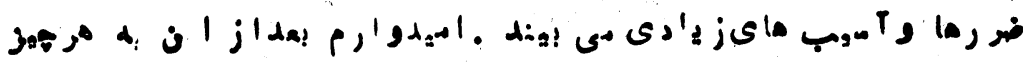

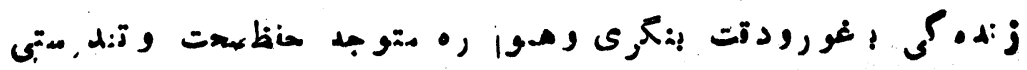

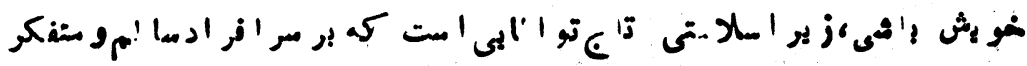

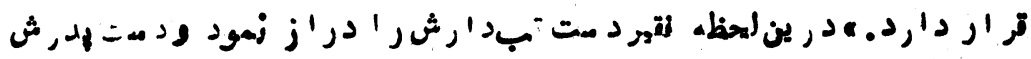

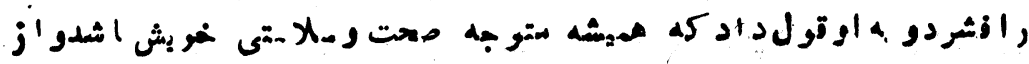

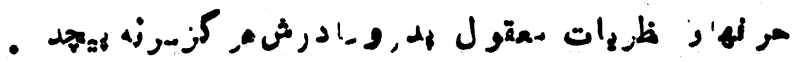

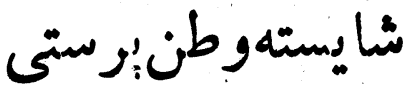

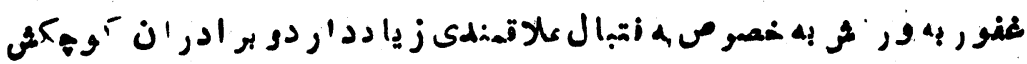

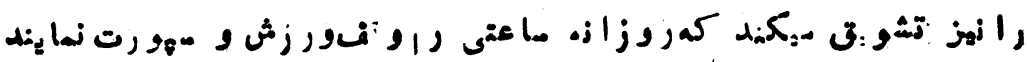

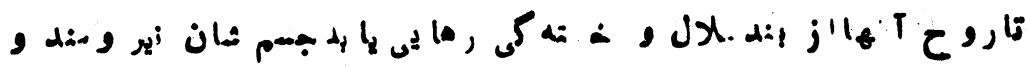

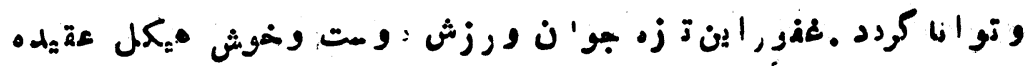

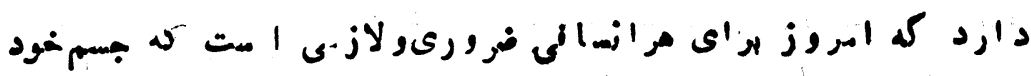

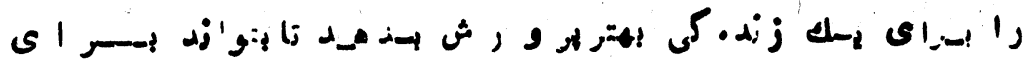

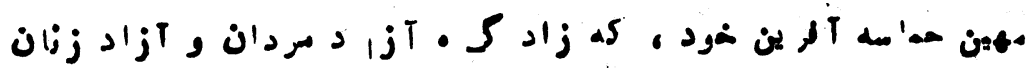

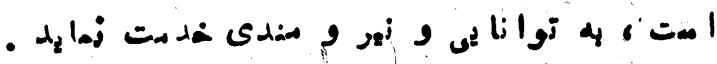

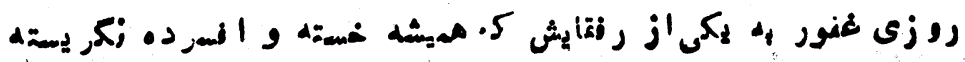

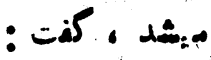
$-v_{\wedge}-$ 


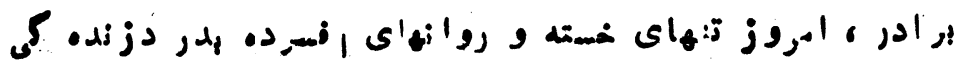

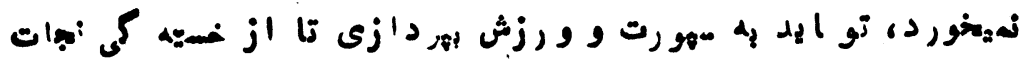

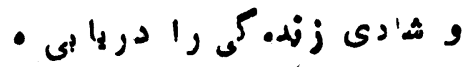

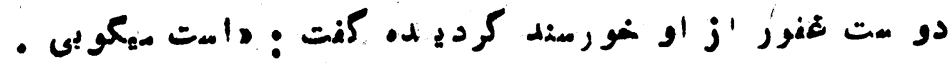

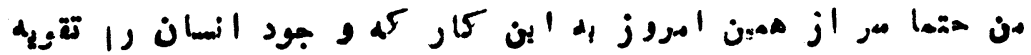

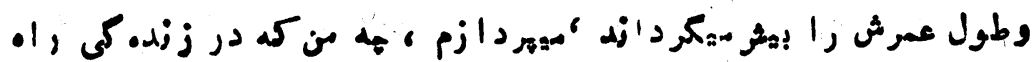

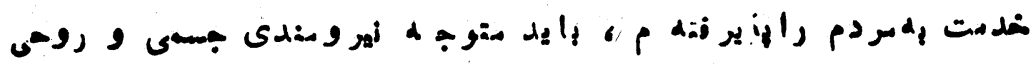

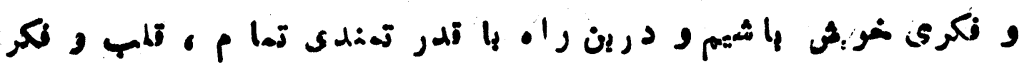

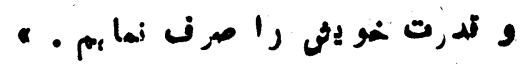

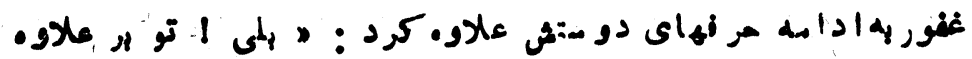

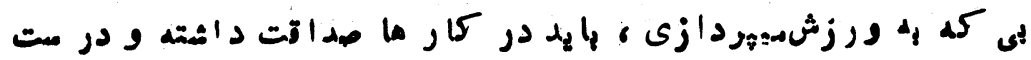

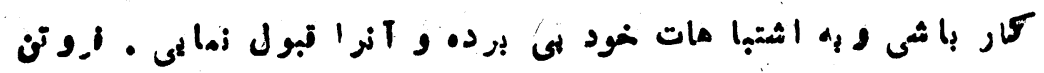

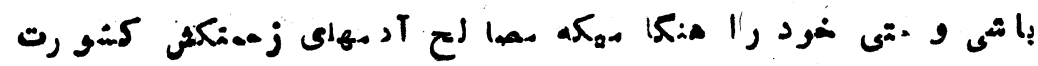

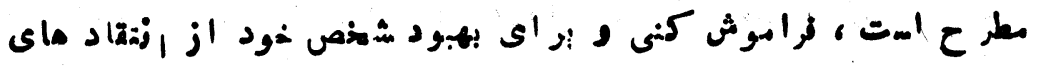

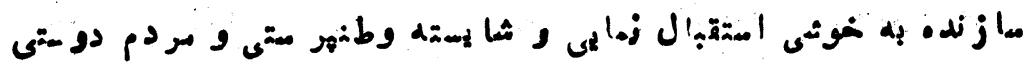

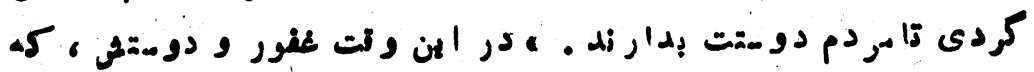

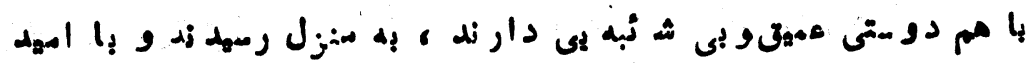

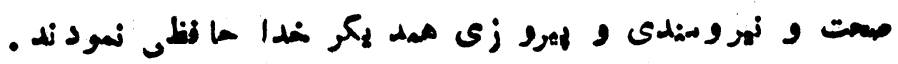




\section{انسان انساند و ست}

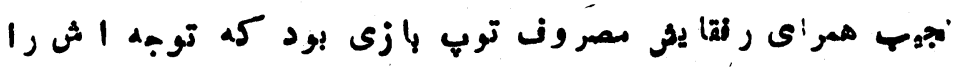

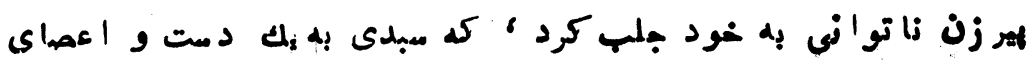

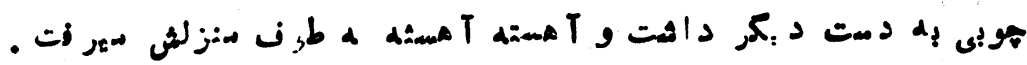

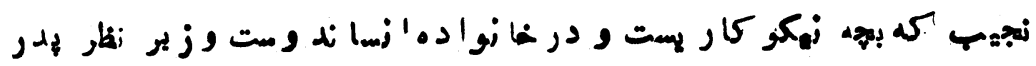

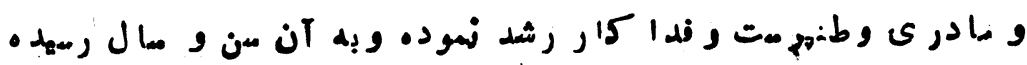

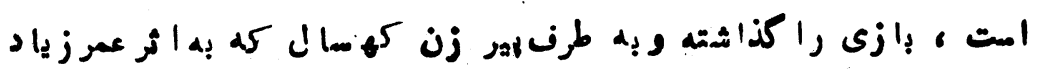

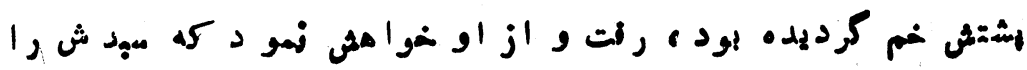

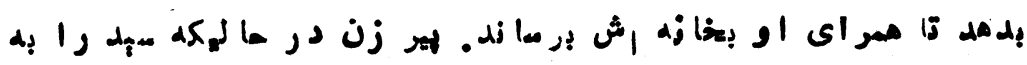

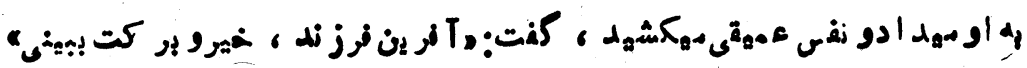

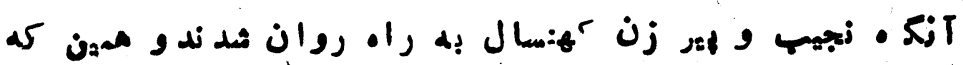

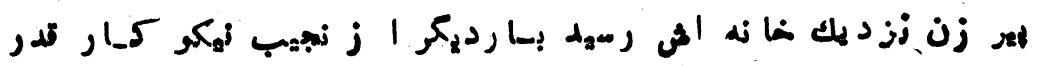

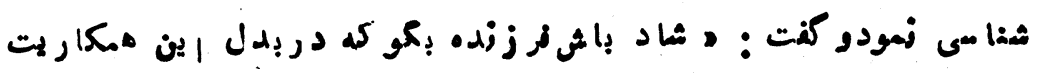

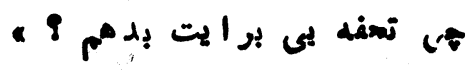

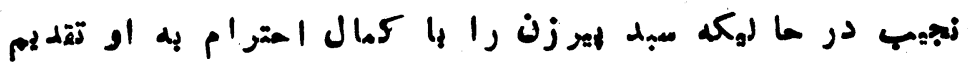

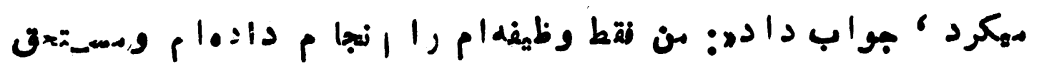

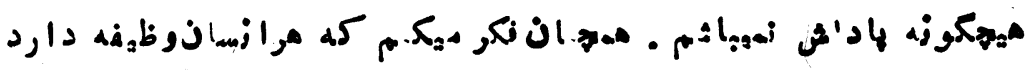

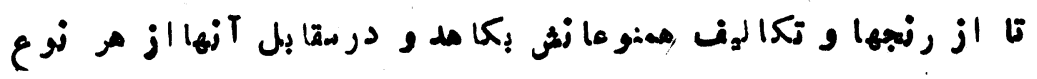

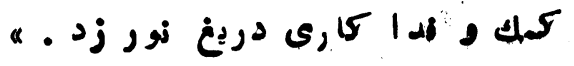




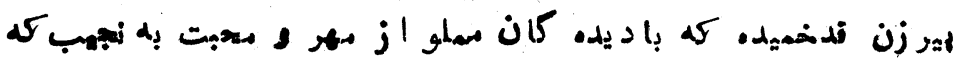

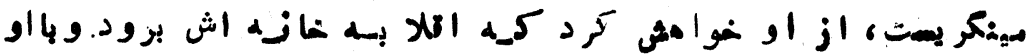

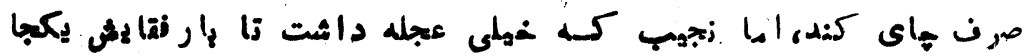

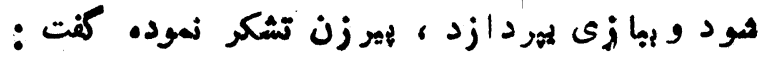

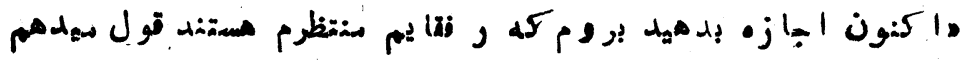

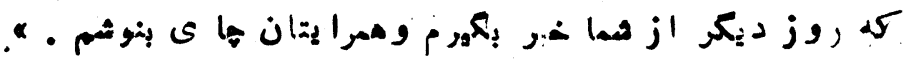

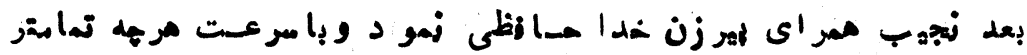

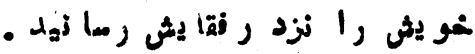

:

ظر يف بـه 'ظر يفه خوا مر بزر كثن كفت:

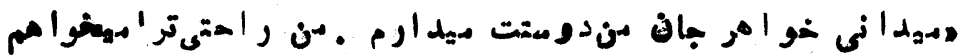

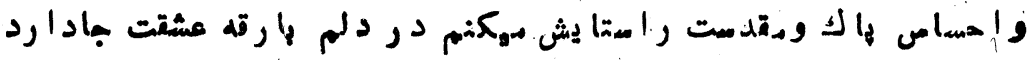

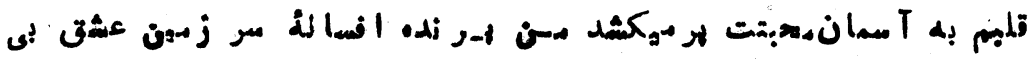

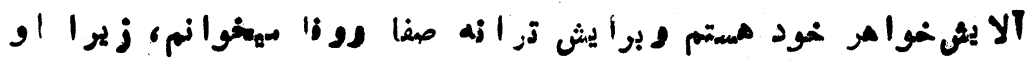

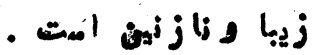

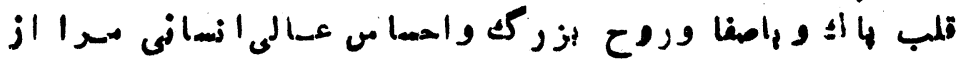

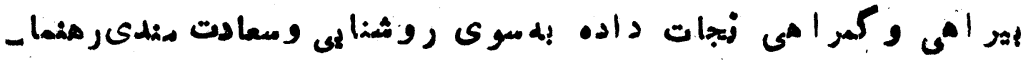

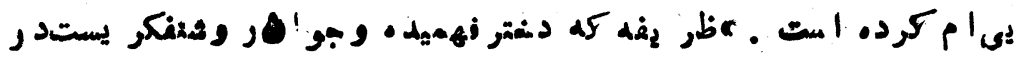

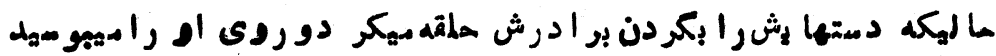

: So

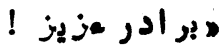

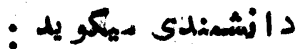

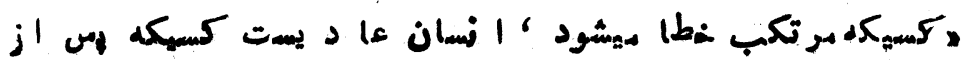

$-11-$ 


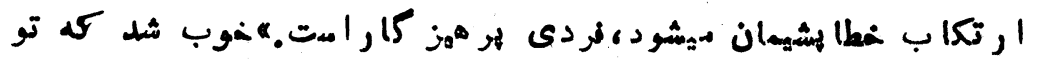

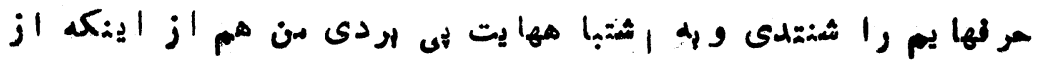

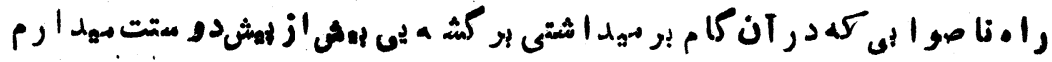

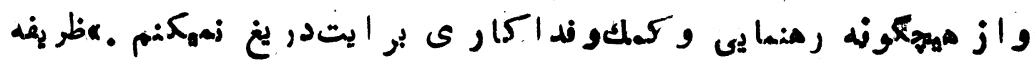

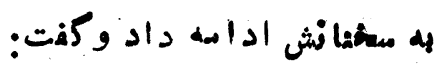

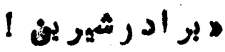

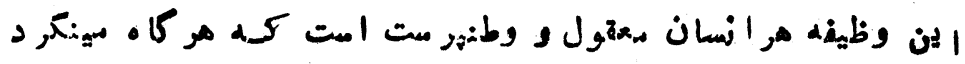

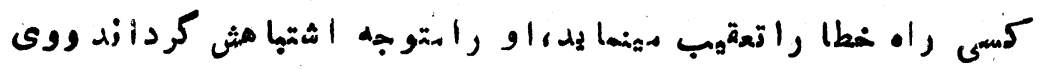

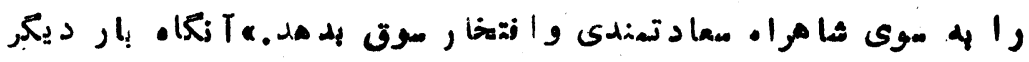

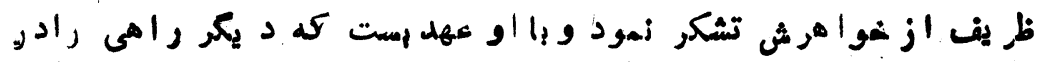

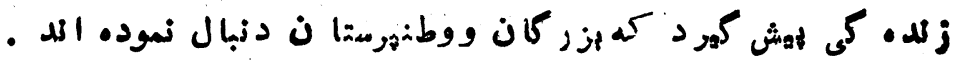
و طنيّ

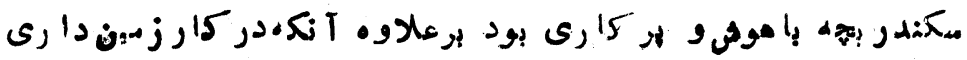

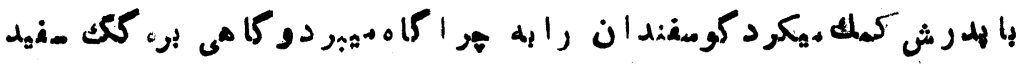

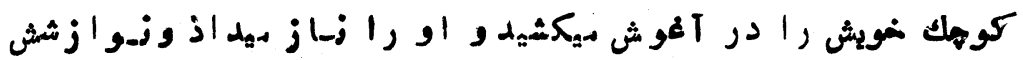

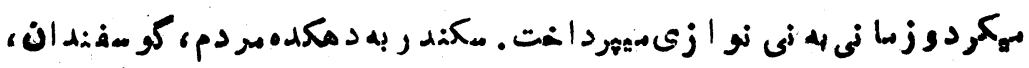

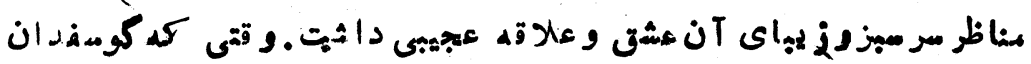

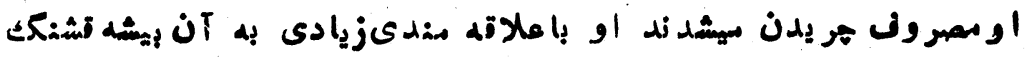

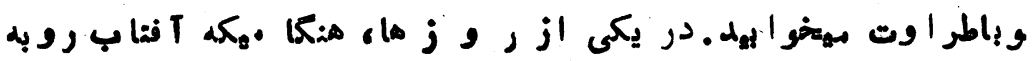

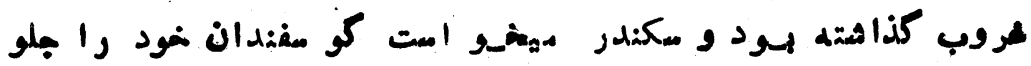

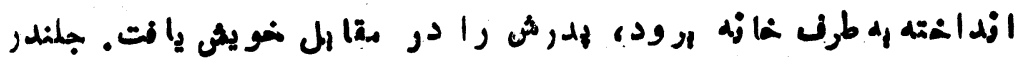

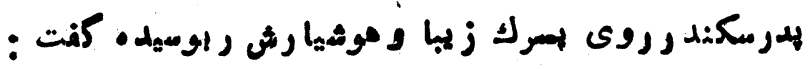
-Ar- 


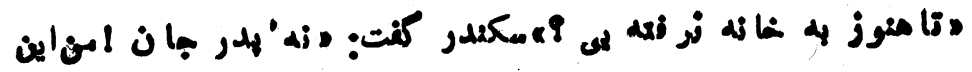

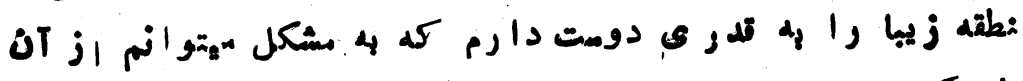

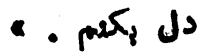

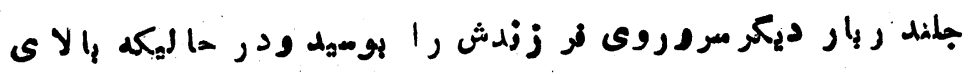

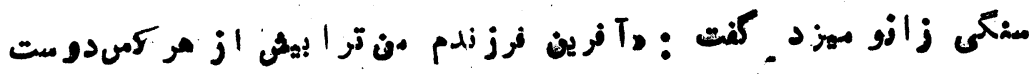

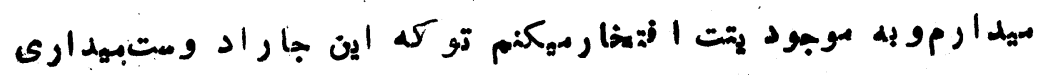

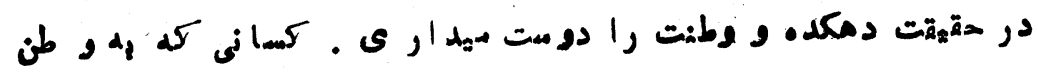

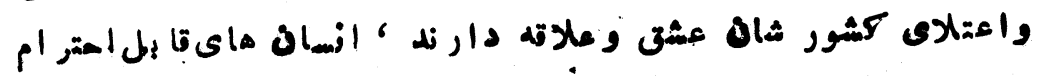

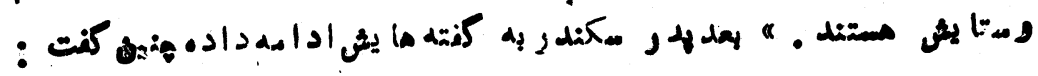

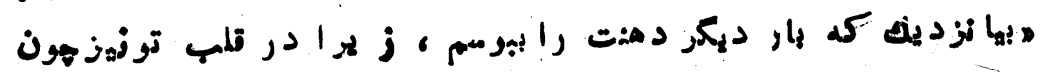

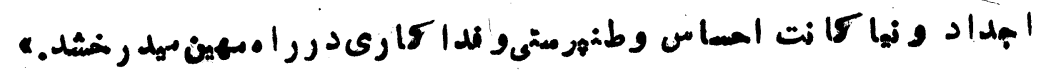

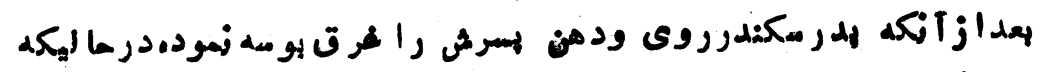

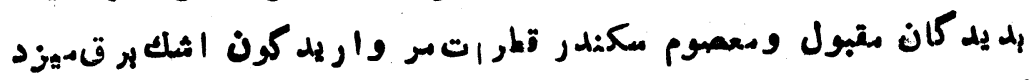

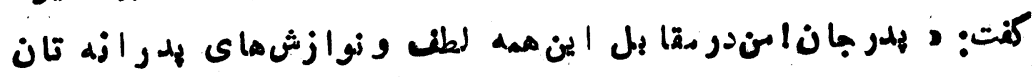

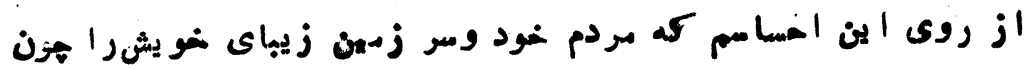

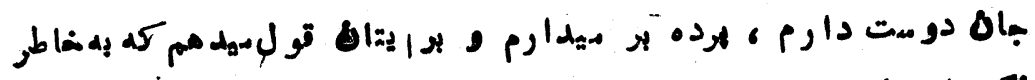

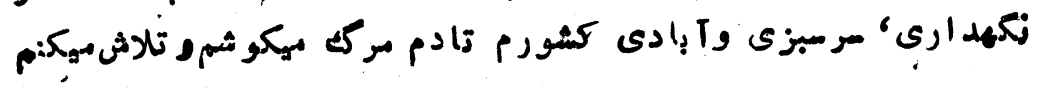


او به آيندهمينگ

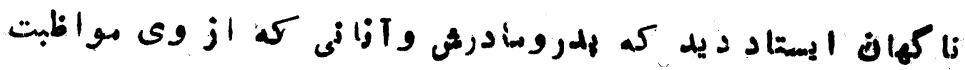

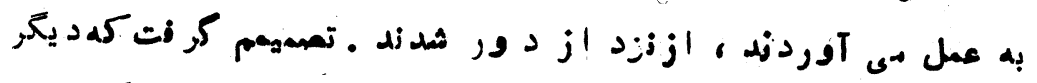

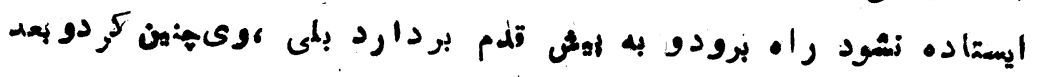

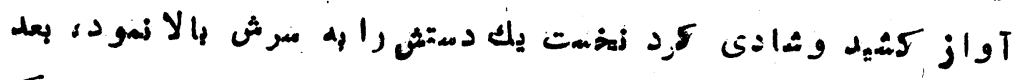

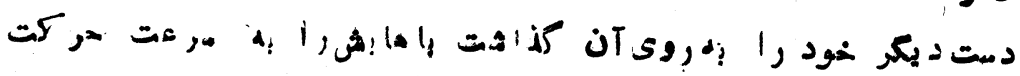

- د

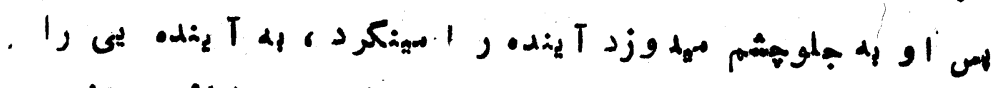

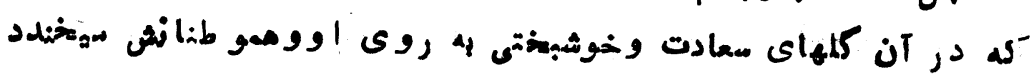

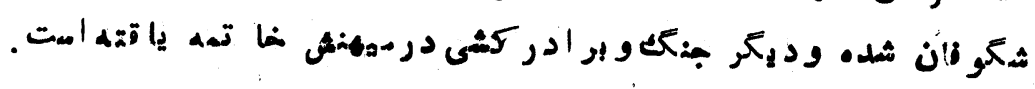

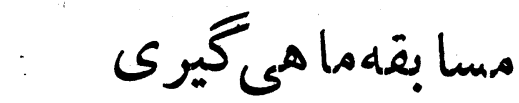

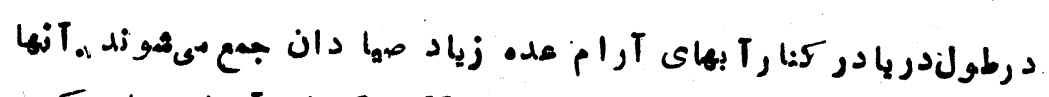

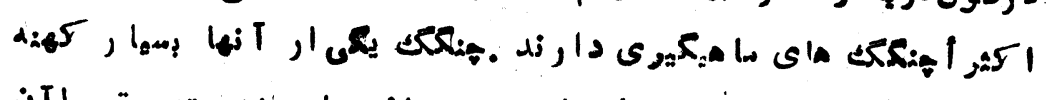

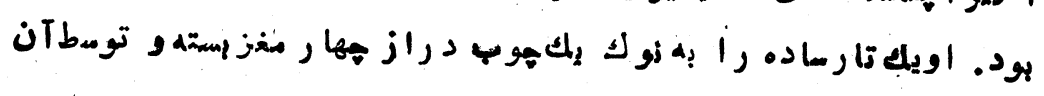

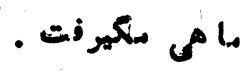

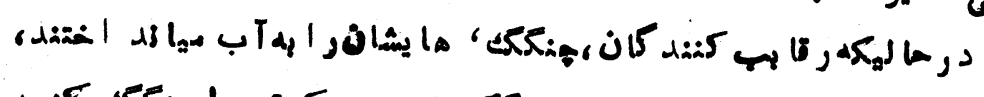

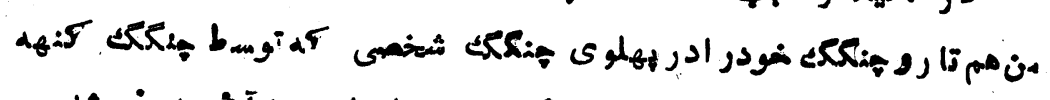

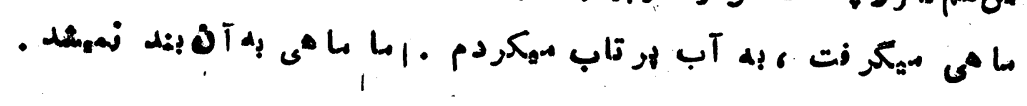
$-\wedge \varepsilon-$ 


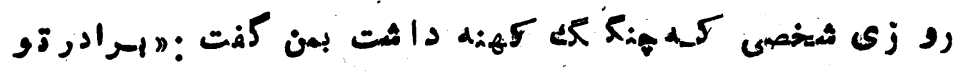

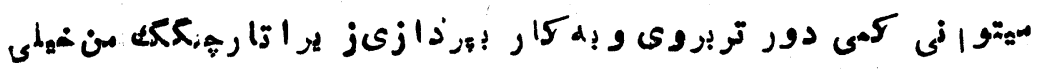

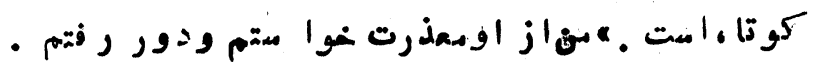

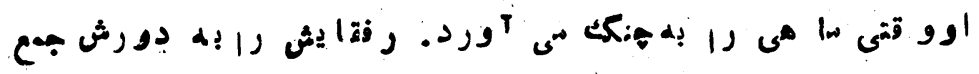

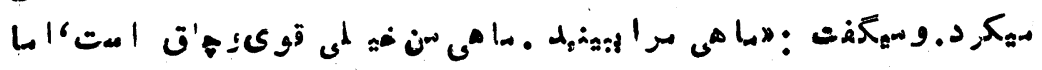

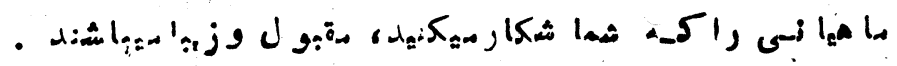

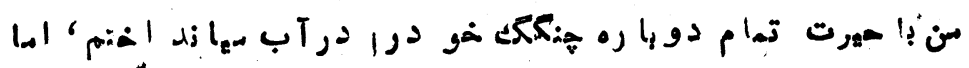

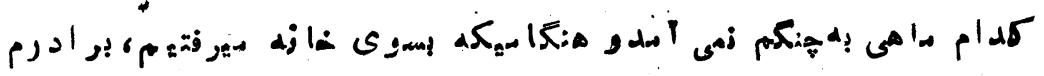

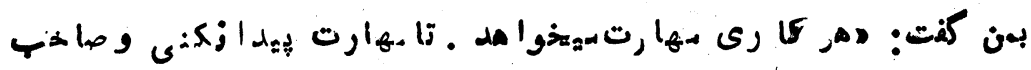

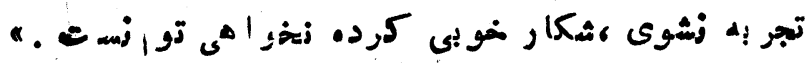

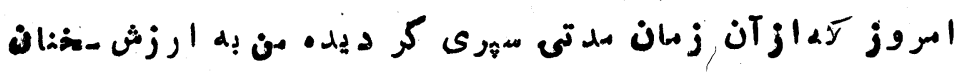

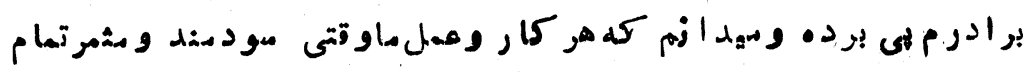

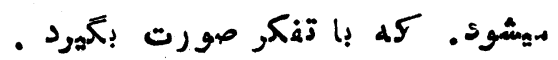

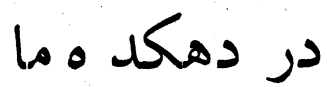

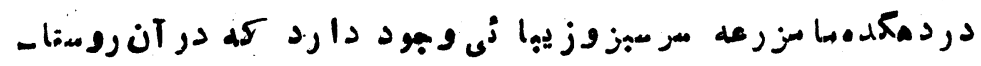

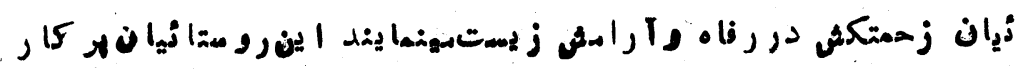

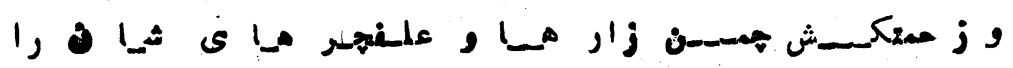

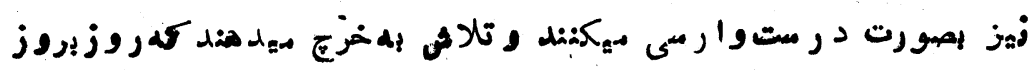

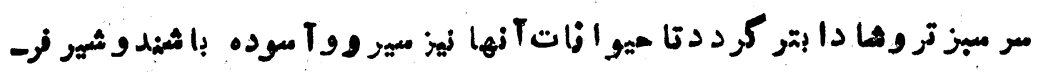

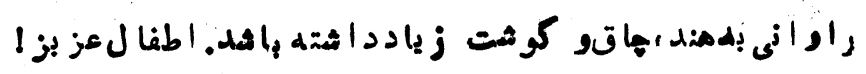

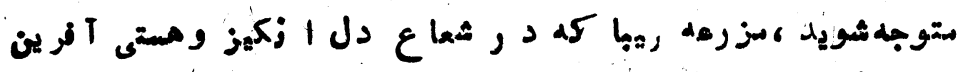

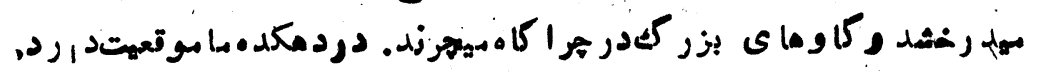

$-\hat{\circ}$ 


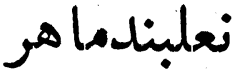

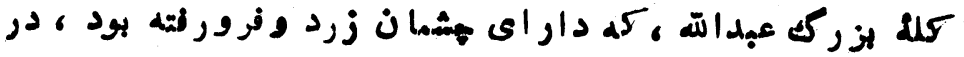

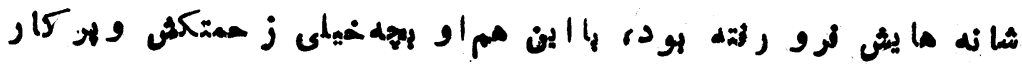

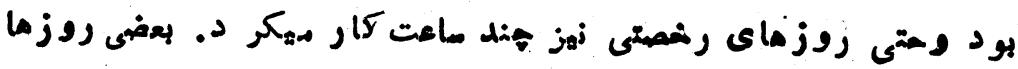

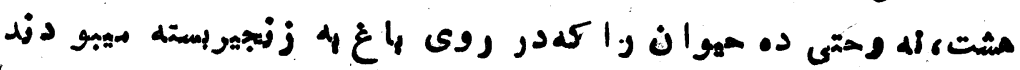

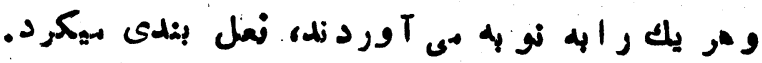

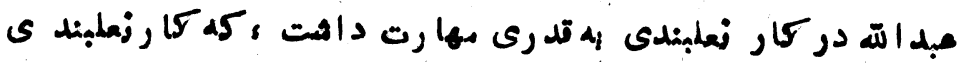

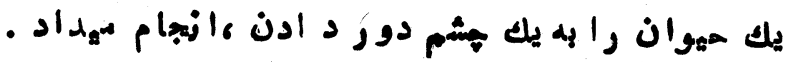

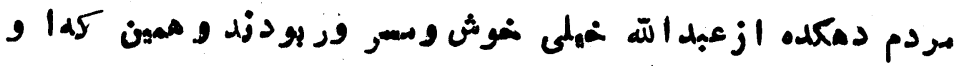

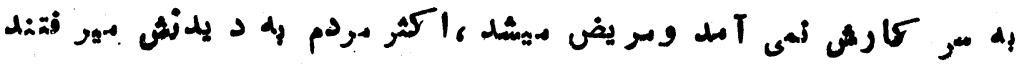

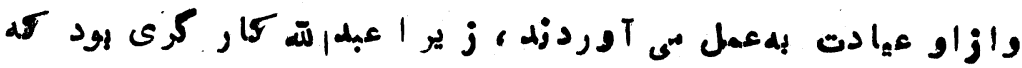

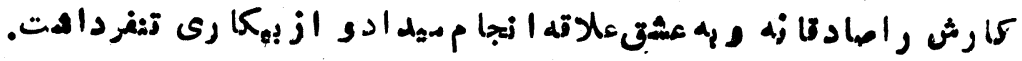

\section{لويى (7 أ)وو جايلو سان}

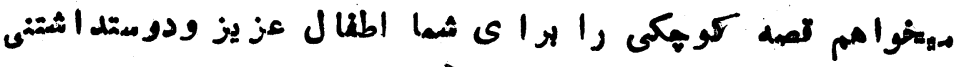

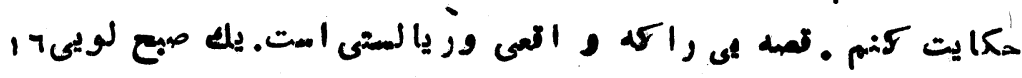

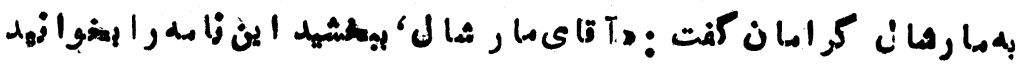

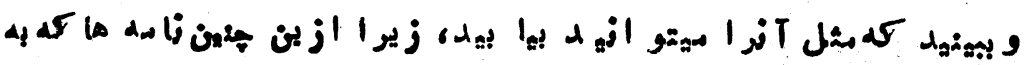

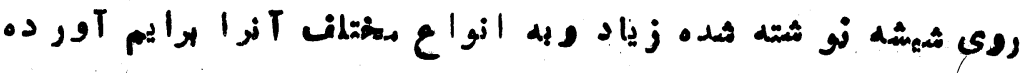

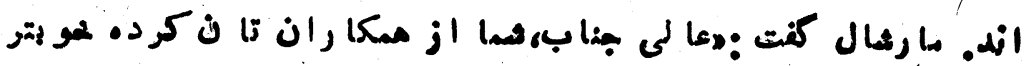




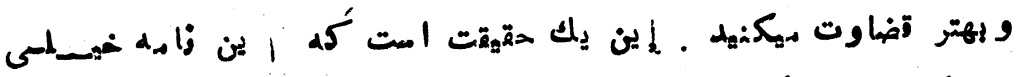

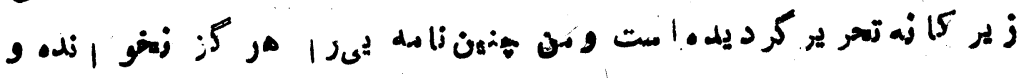

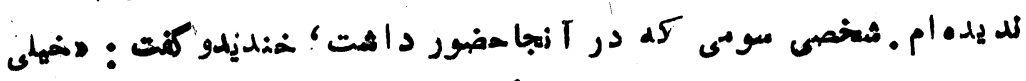

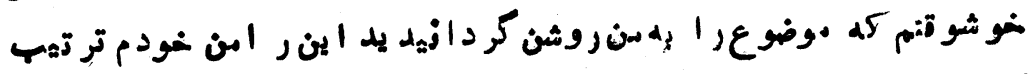

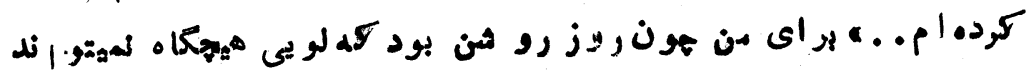

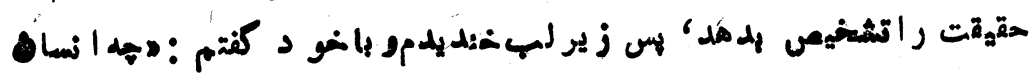

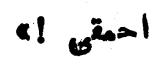

\section{قانلفرو كر هاسيُّ}

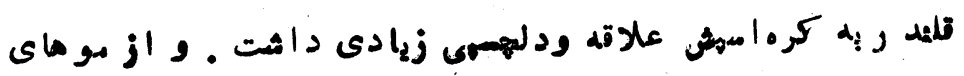

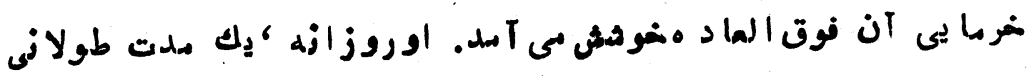

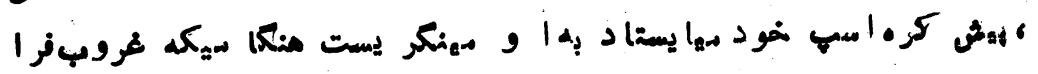

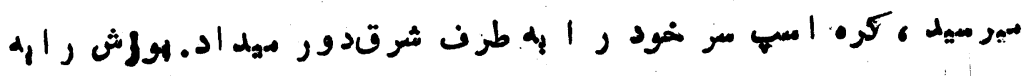

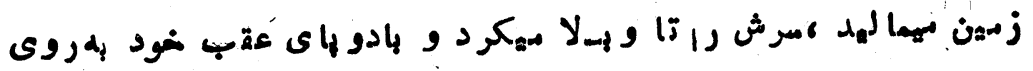

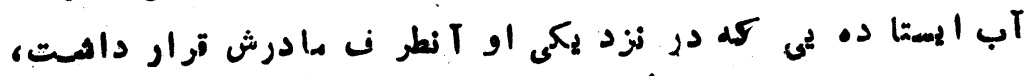

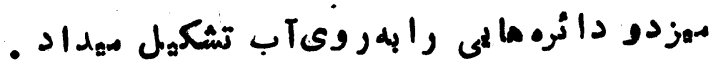

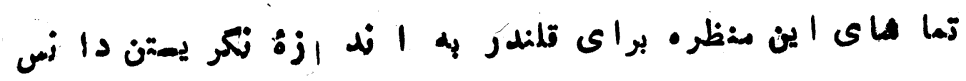

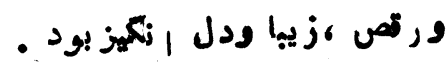




\section{نخستين دز دى}

زا زو هر كز در عمرش شدزدى زكرد • بود ، اهـا فرداى روزى كه

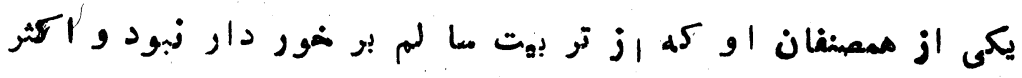

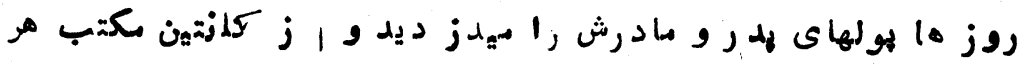

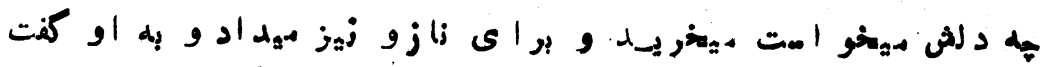

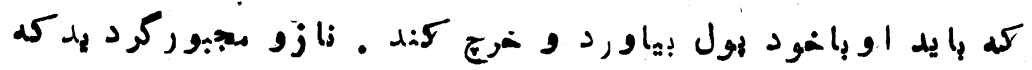

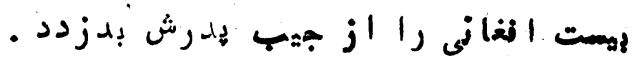

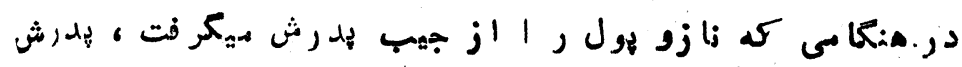

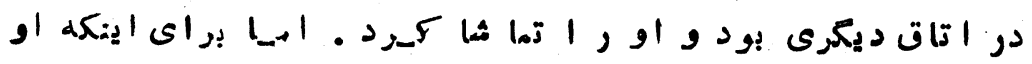

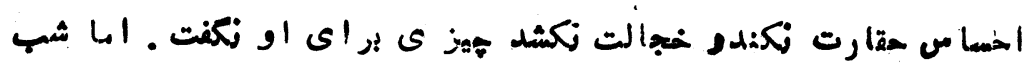

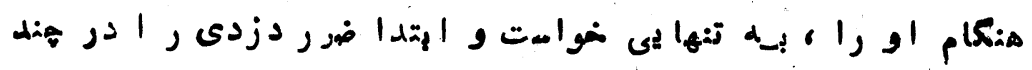

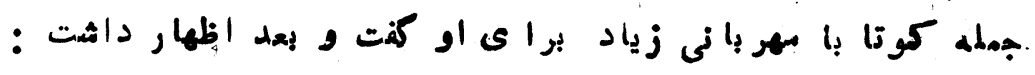

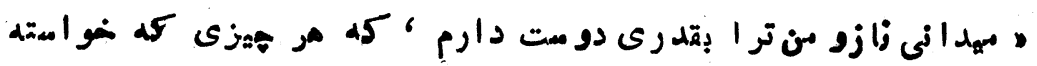

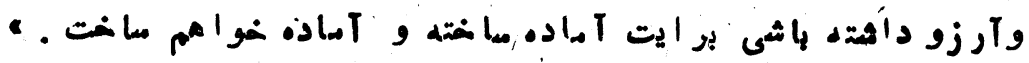

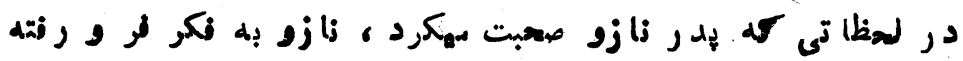

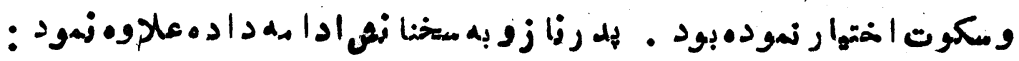

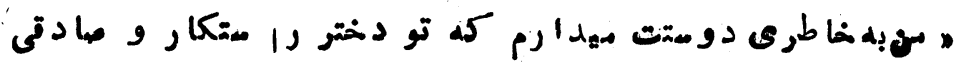

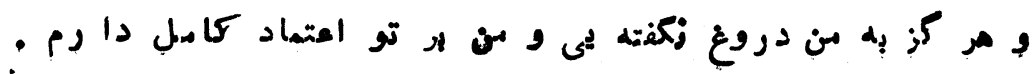




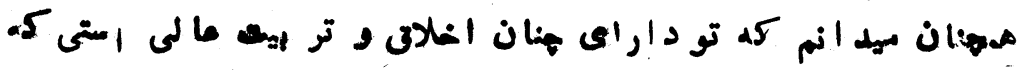

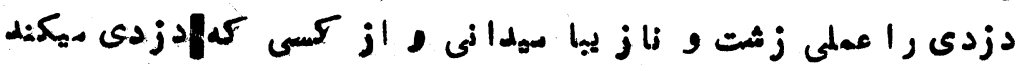
، تنفر دارى .

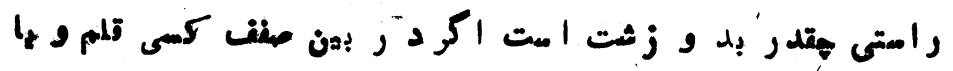

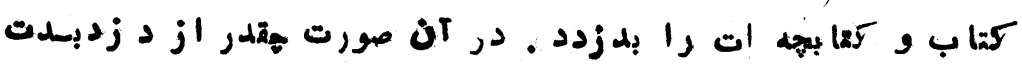

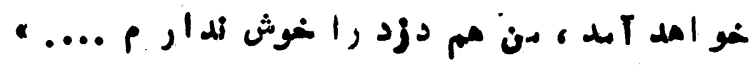

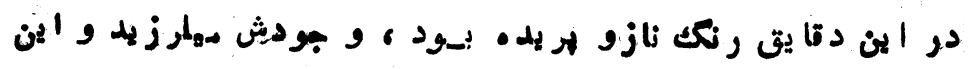

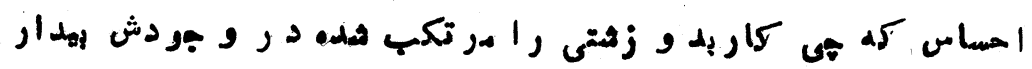
كرد يده روده

بجه شُخ

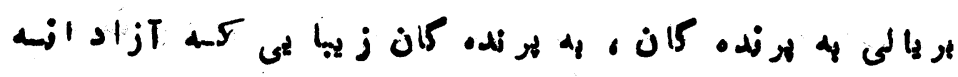

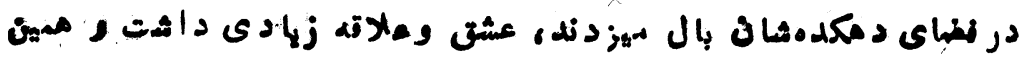

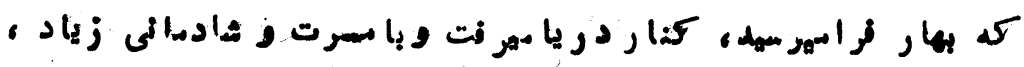

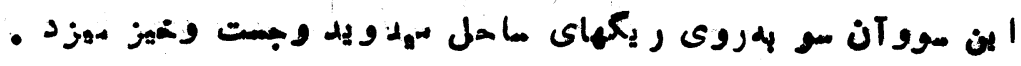

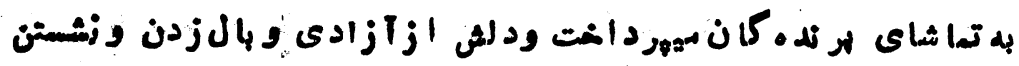

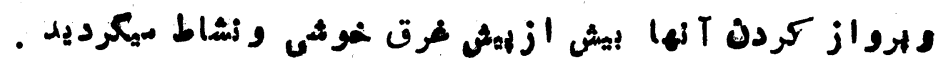

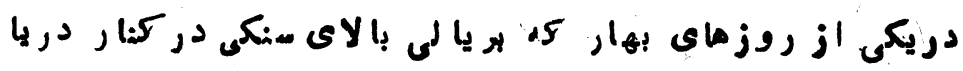

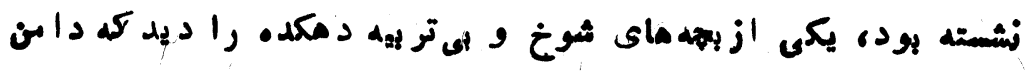

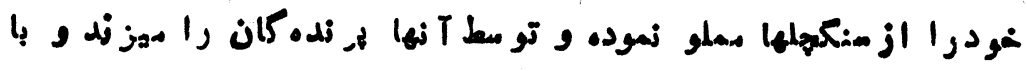

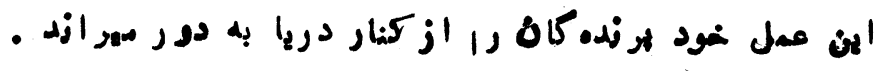

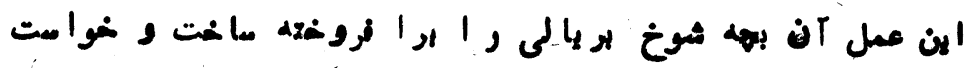

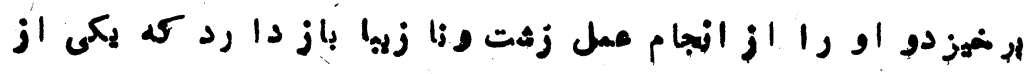

$-\wedge 9-$ 


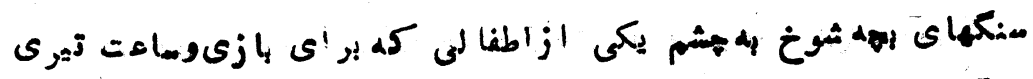

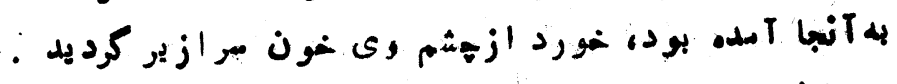

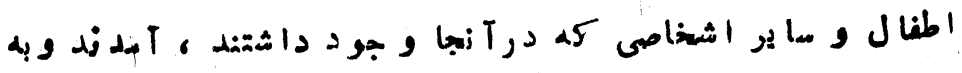

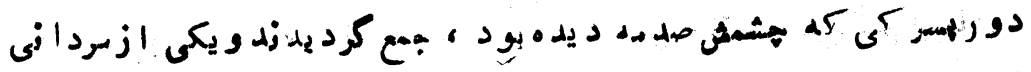

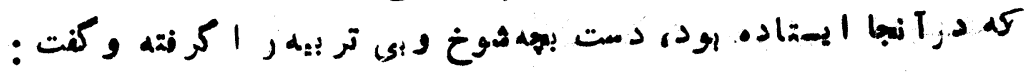

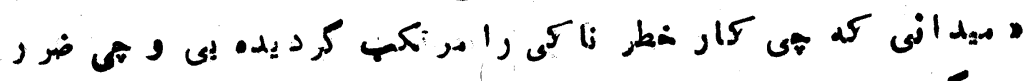

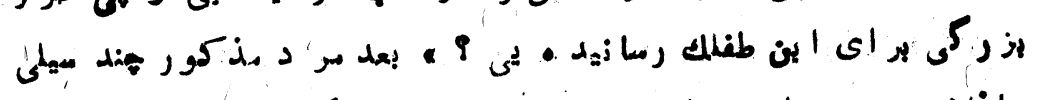

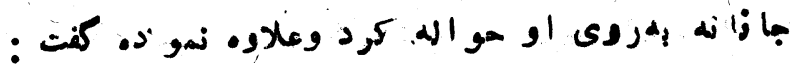

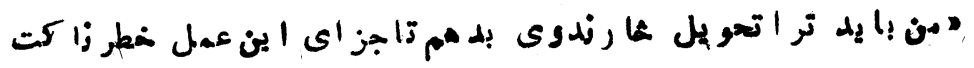
- . vara 1ر

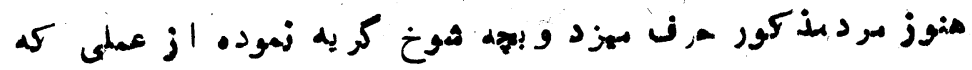

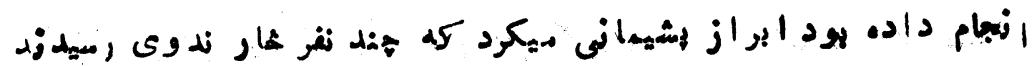

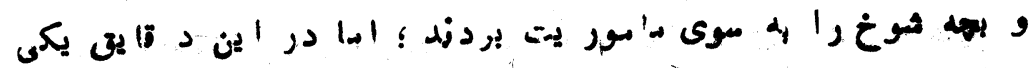

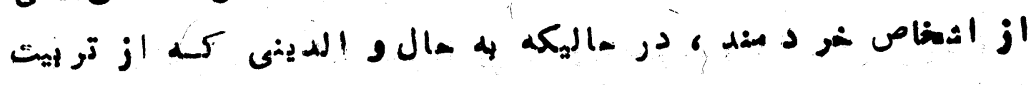

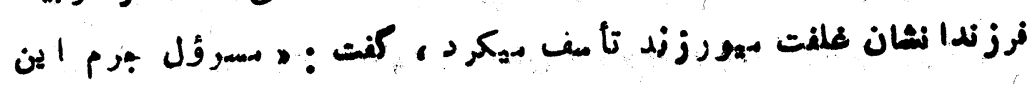

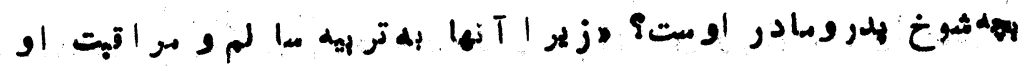
توجهى مبذول ألهاشتها ند . 
دختر تنبل

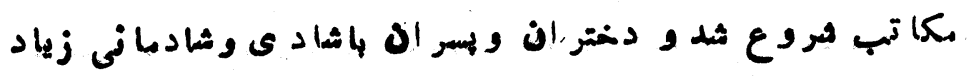

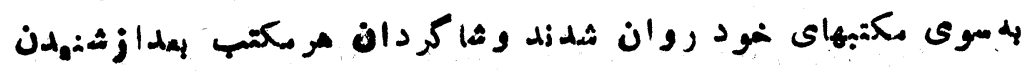

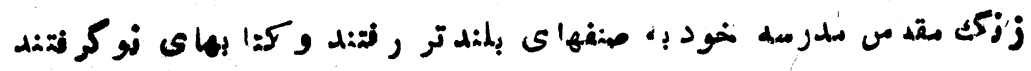

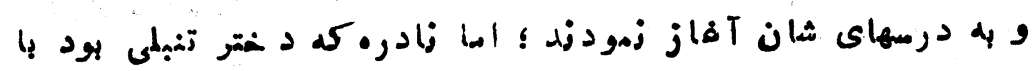

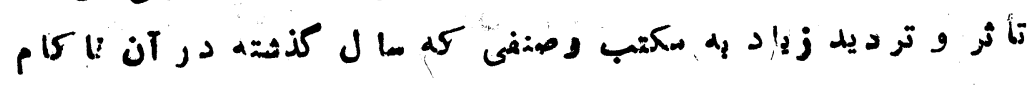

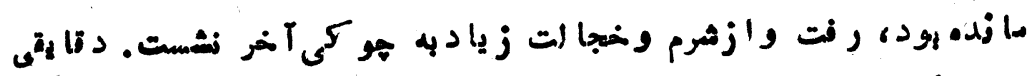

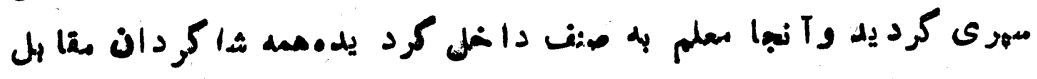

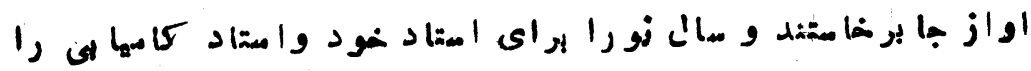

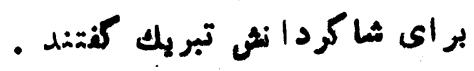

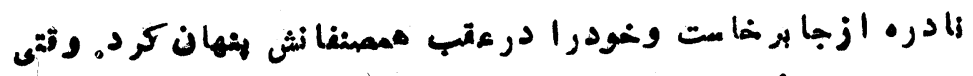

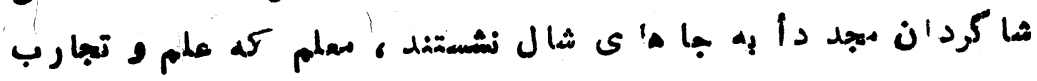

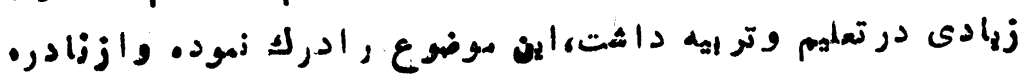

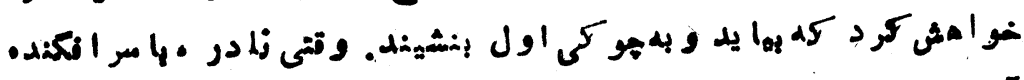

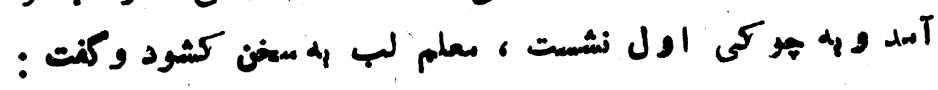

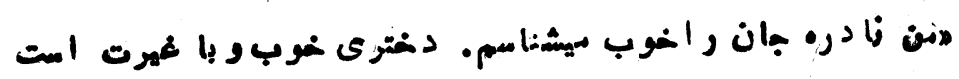

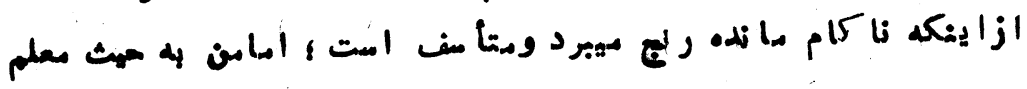

$-91-$ 


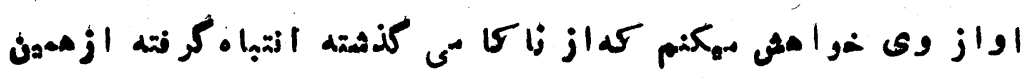

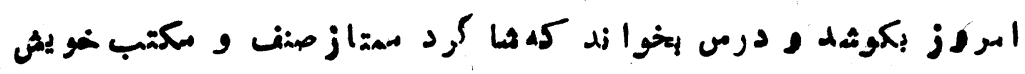

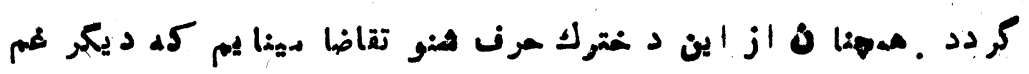

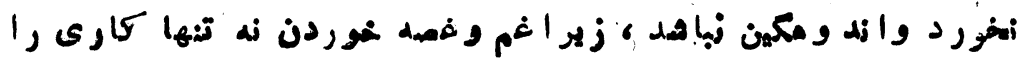

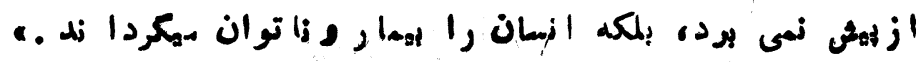

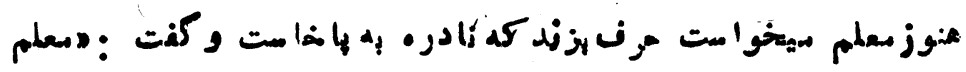

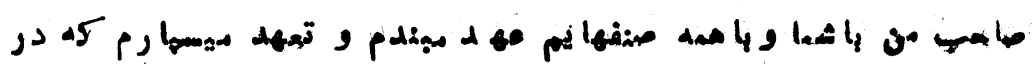

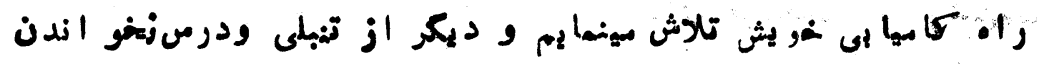

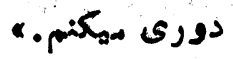

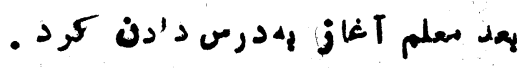


نويسنده بهزمها ركس

على با باوجهرل

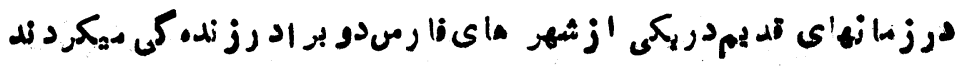

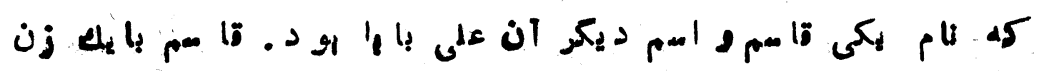

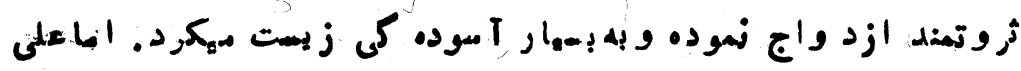

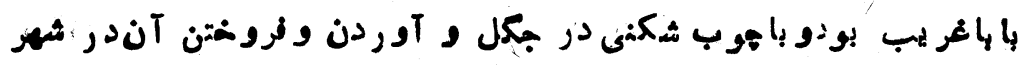

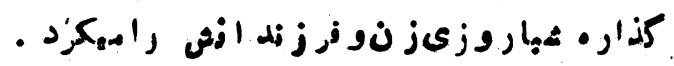

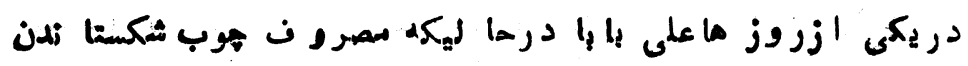

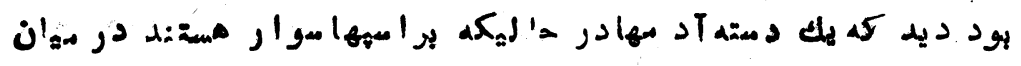

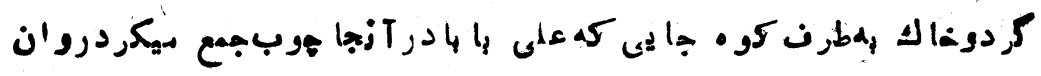

مي بأشند.

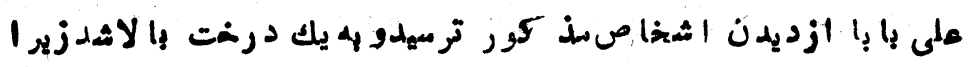

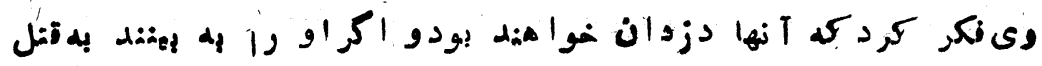

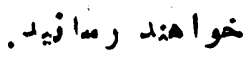

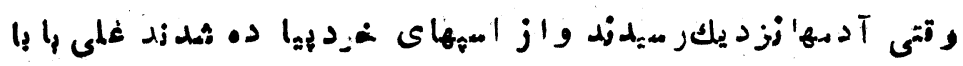

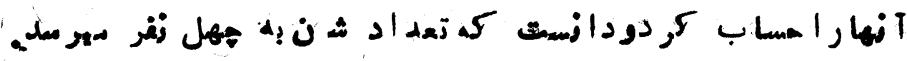

$-9 \mu-$ 


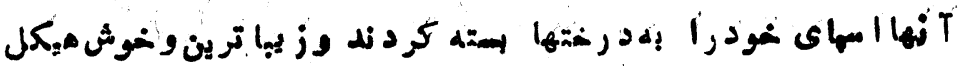

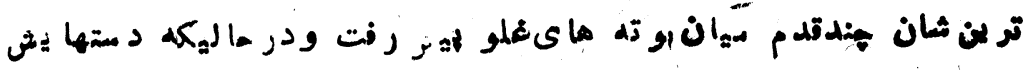

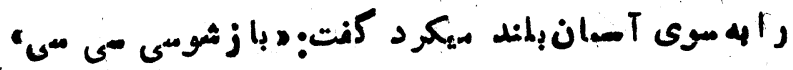

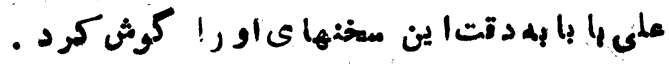

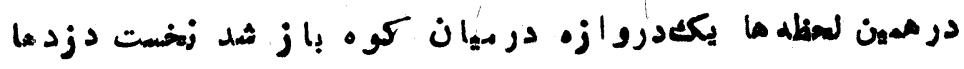

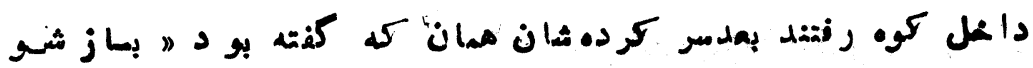

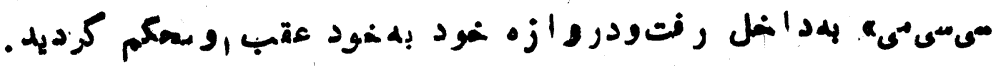

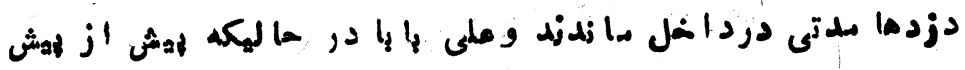

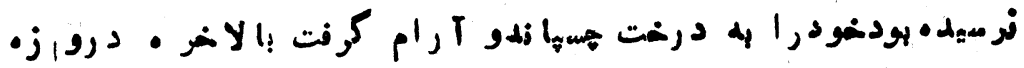

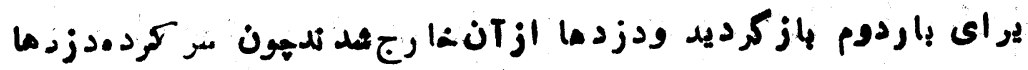

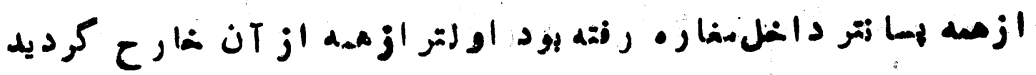

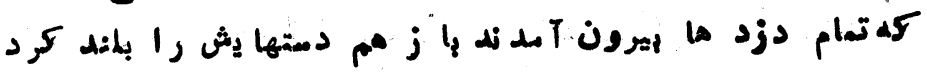

و

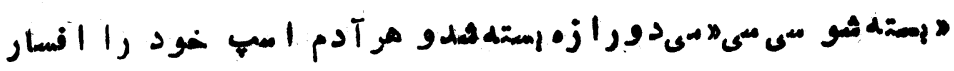

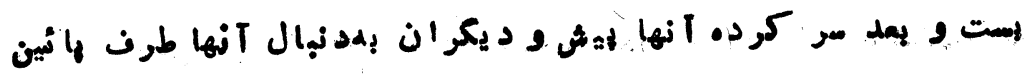

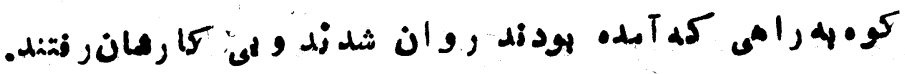

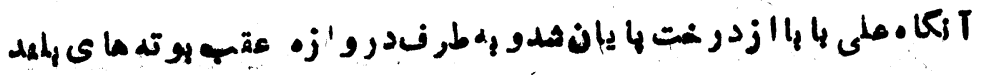

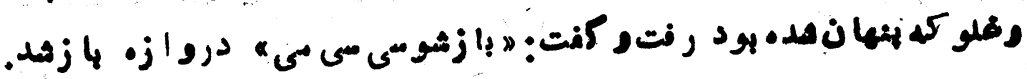

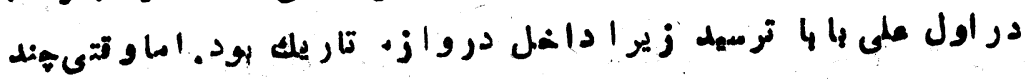

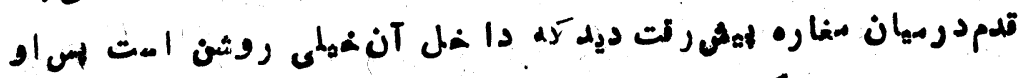

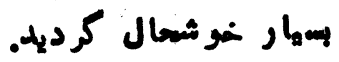

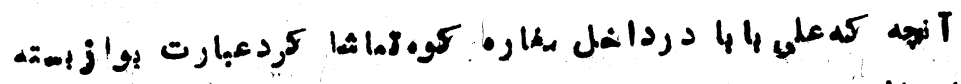

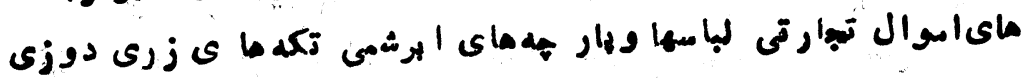
$-9 \varepsilon$ 


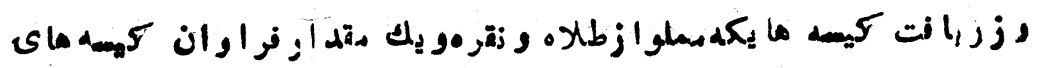

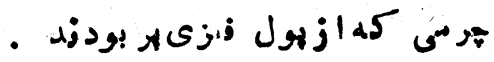

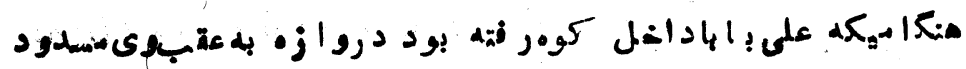

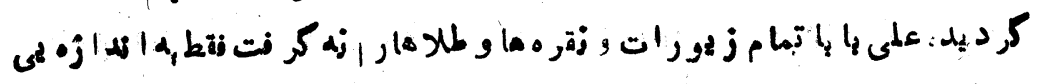

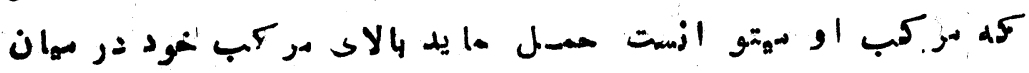

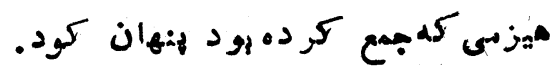

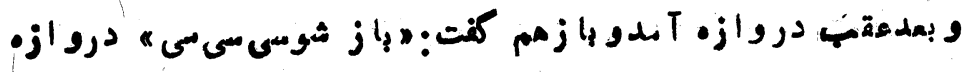

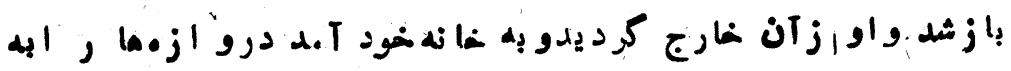

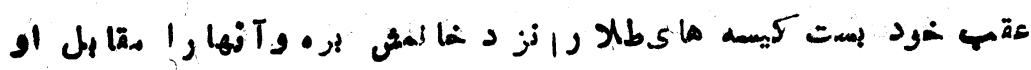

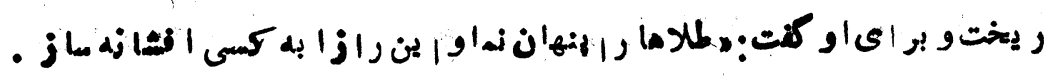

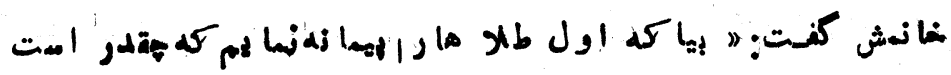

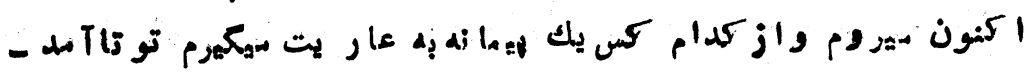

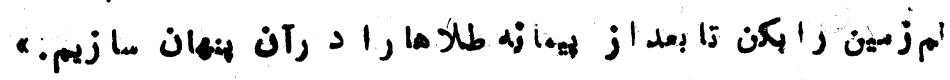

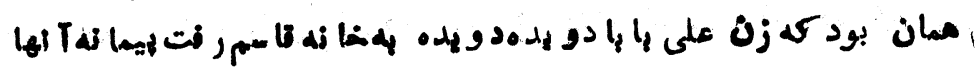

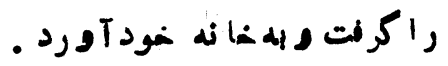

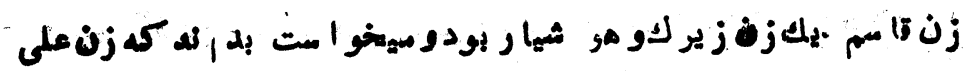

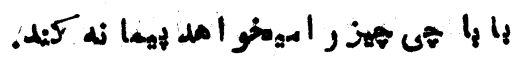

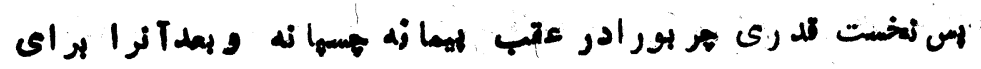

زنهلى

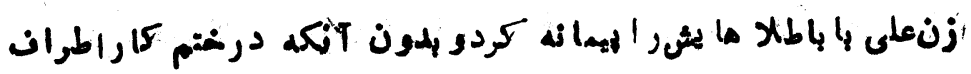

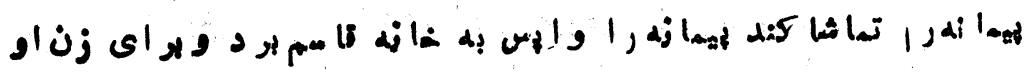

- تمسلمبم كرد

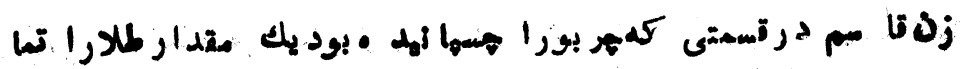

$-90-$ 


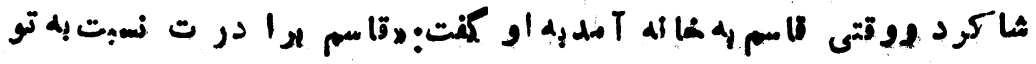

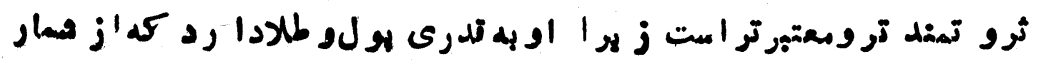

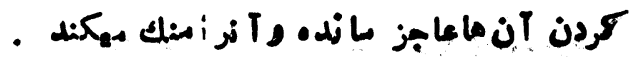

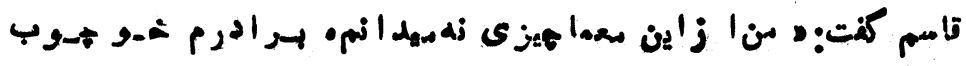

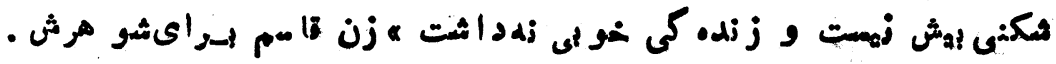

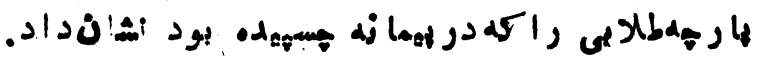

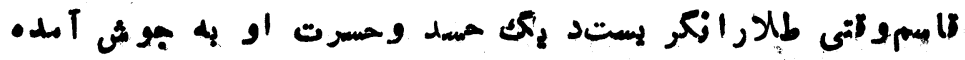

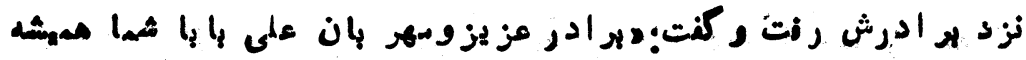

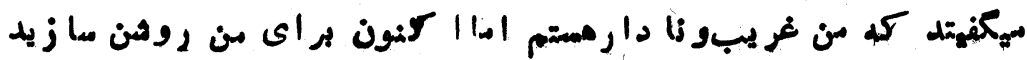

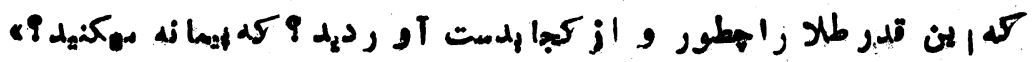

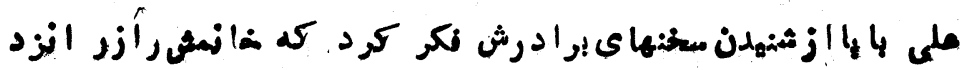

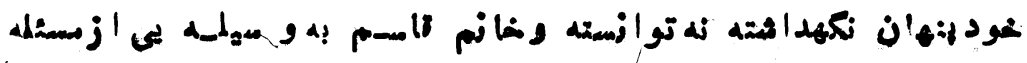

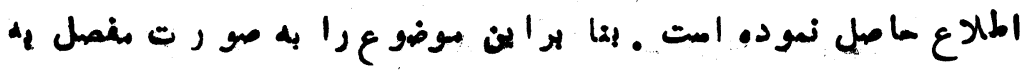

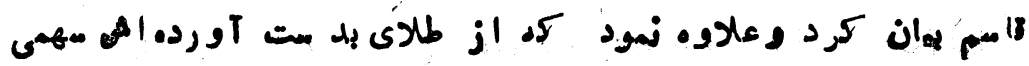

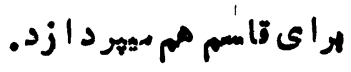

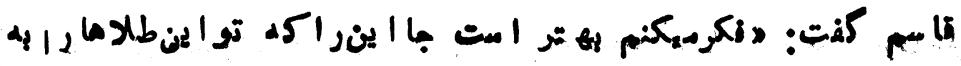

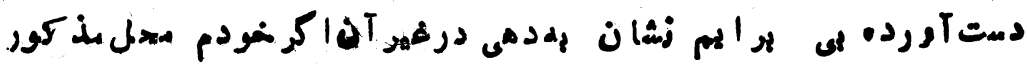

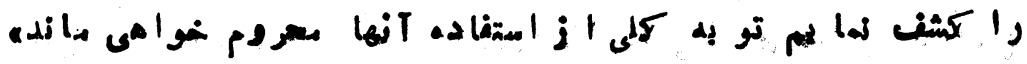

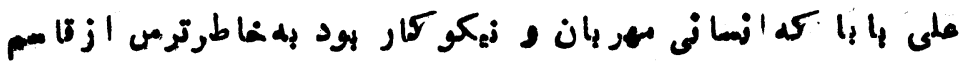

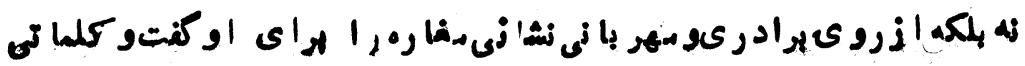

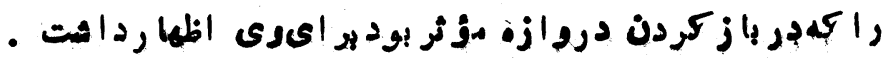

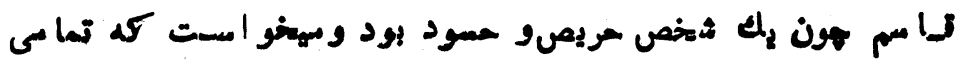

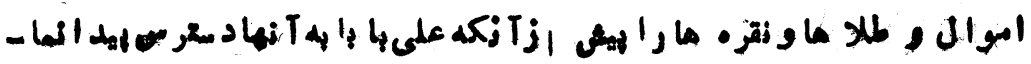

$-47-$ 


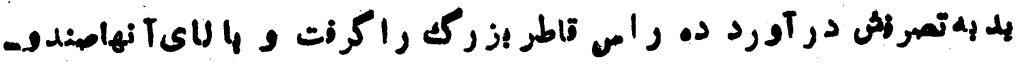

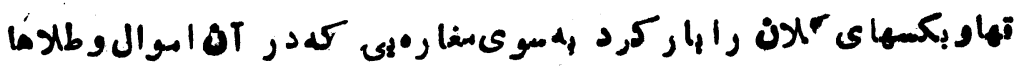

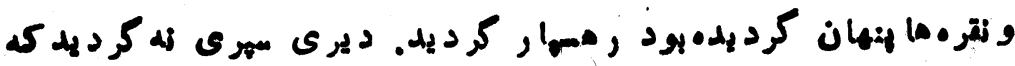

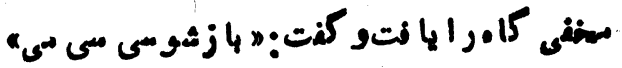

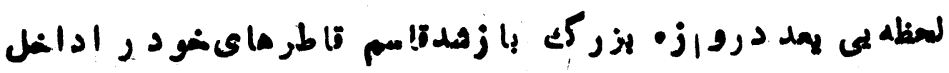

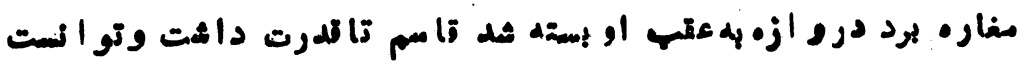

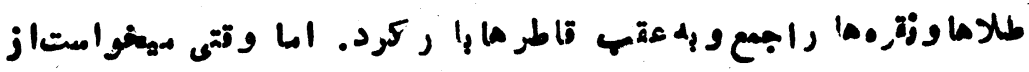

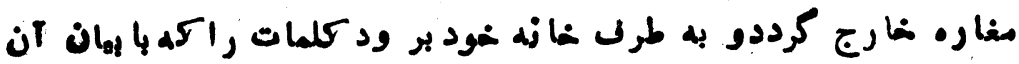

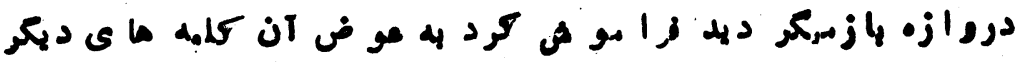

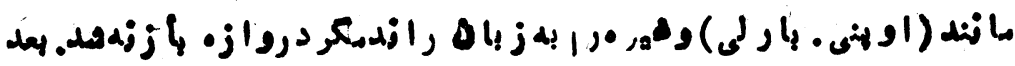

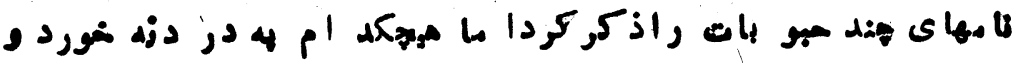

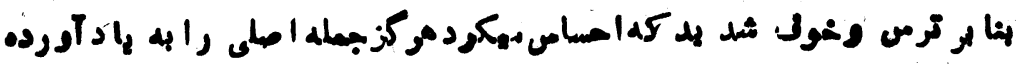

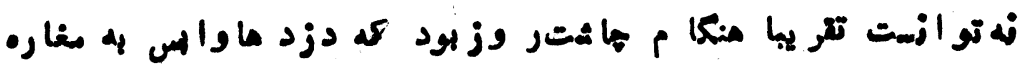

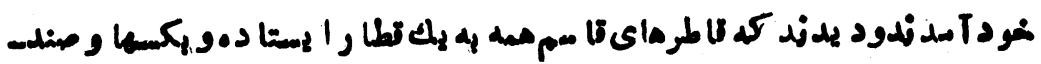
و كماى

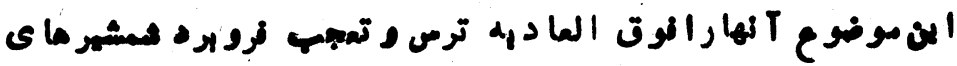

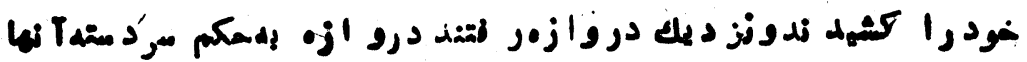

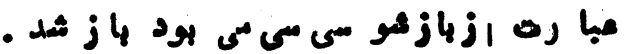

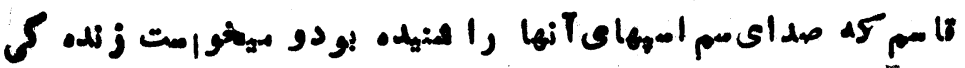

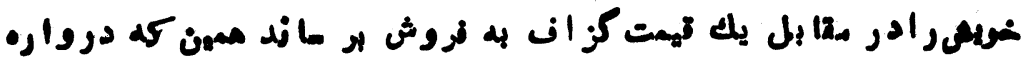

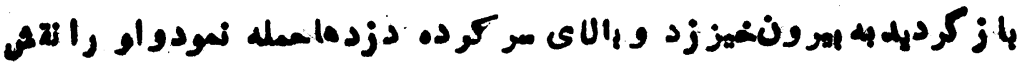

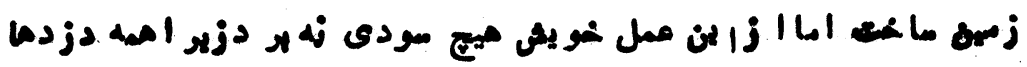

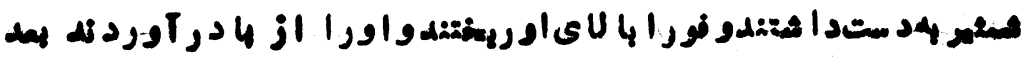
$-9 v-$ 


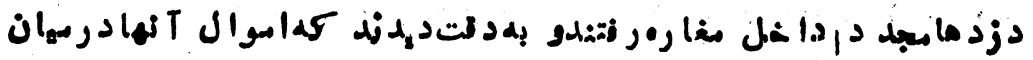

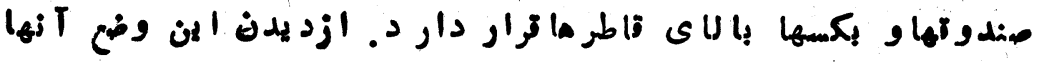

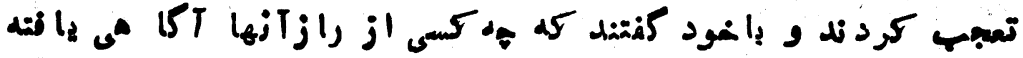

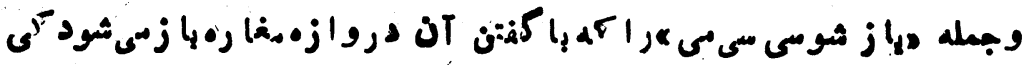

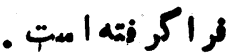

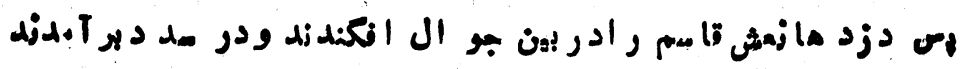

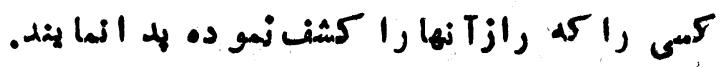
* * *

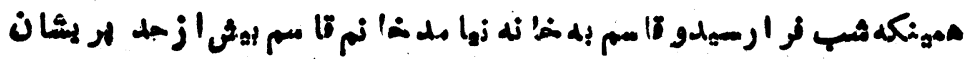

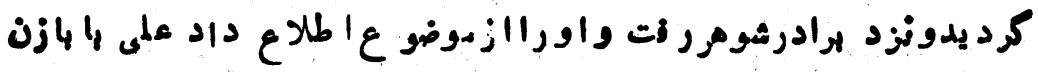

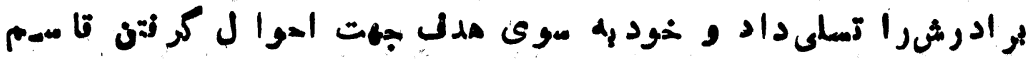

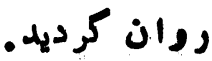

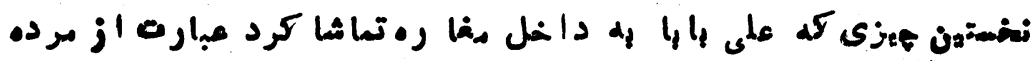

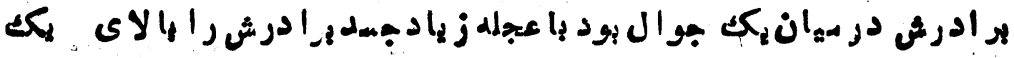

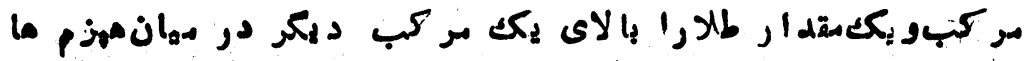

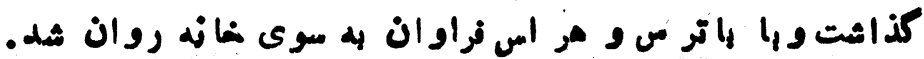

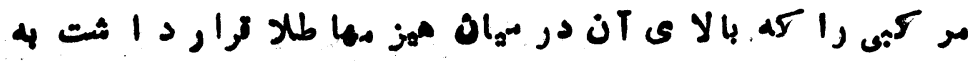

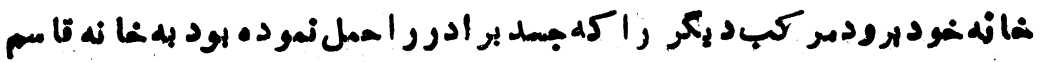

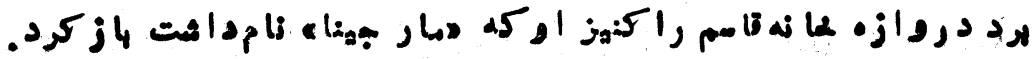

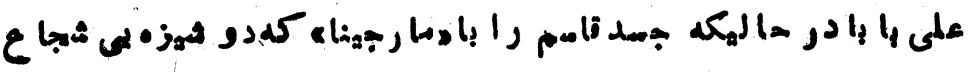

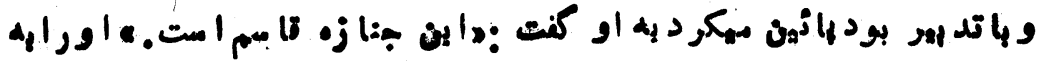

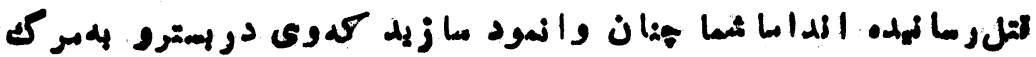




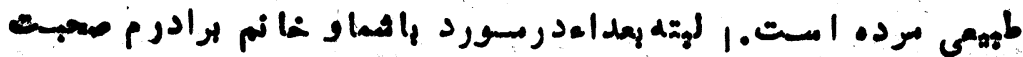

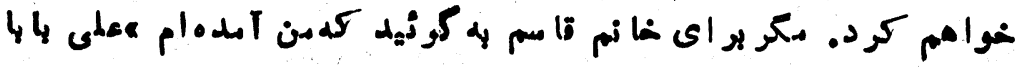

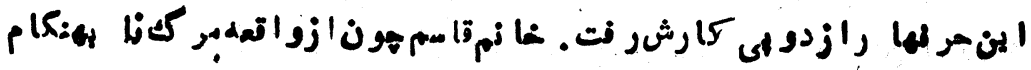

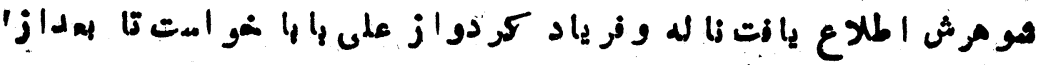

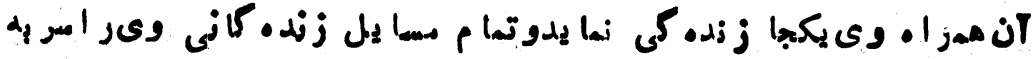

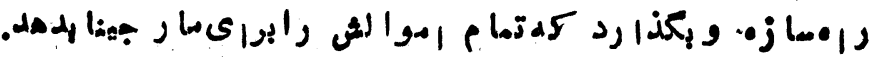

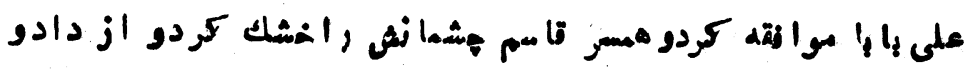

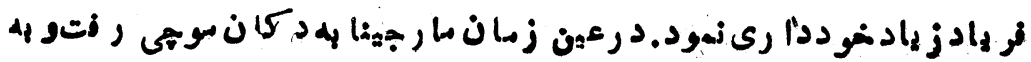

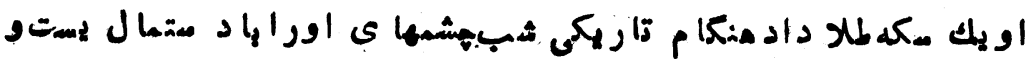

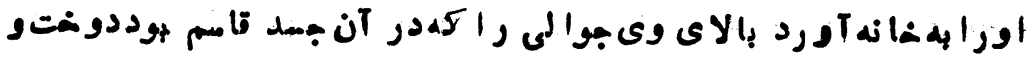

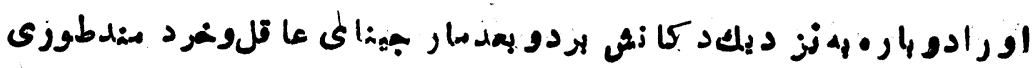

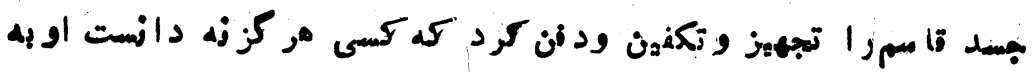

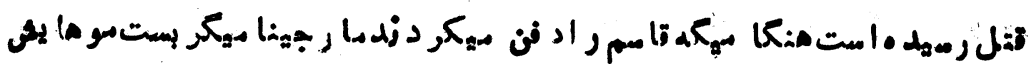

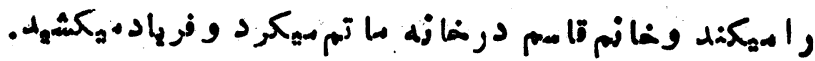

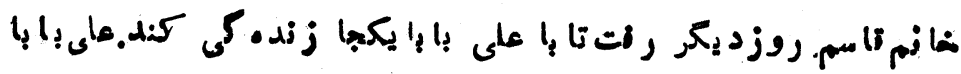

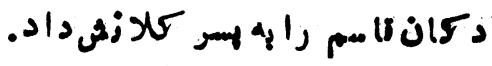
* * *

\section{: آكيونازد}

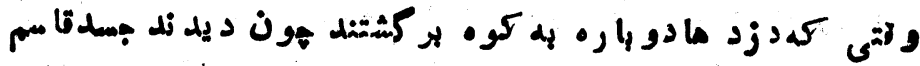

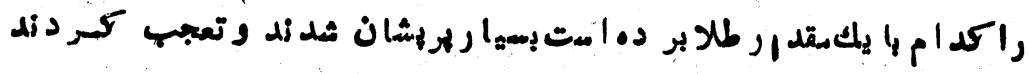

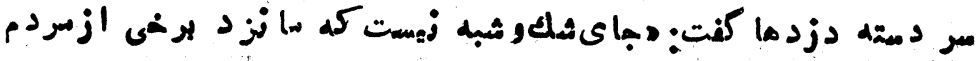

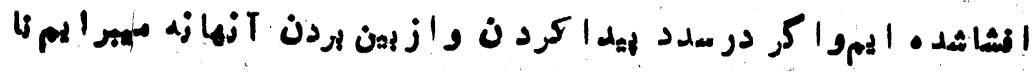

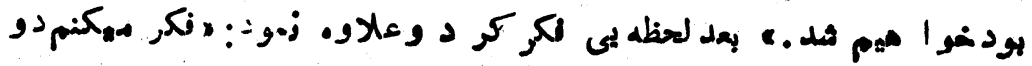




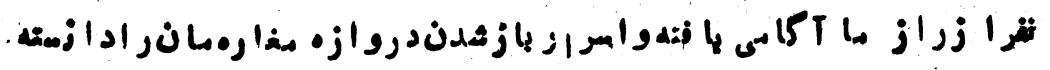

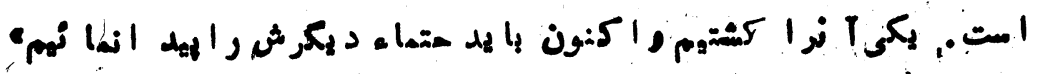

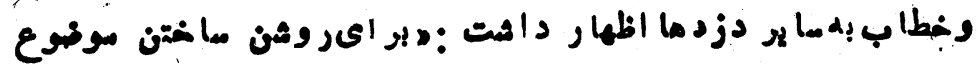

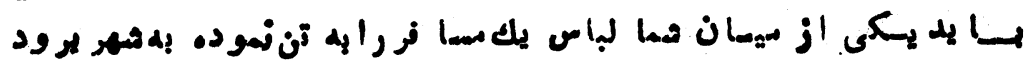

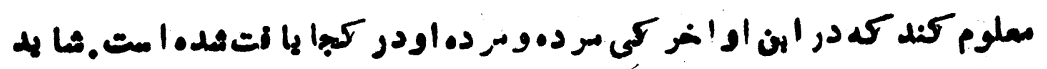

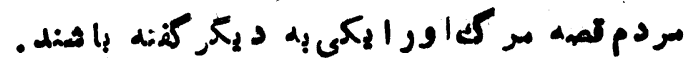

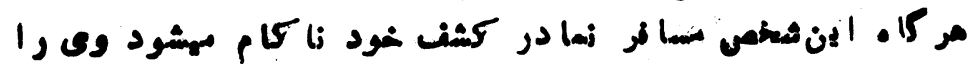

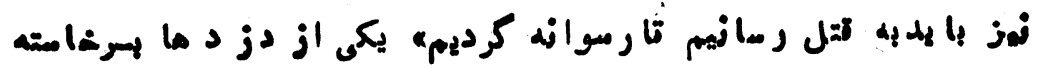

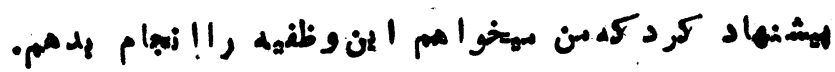

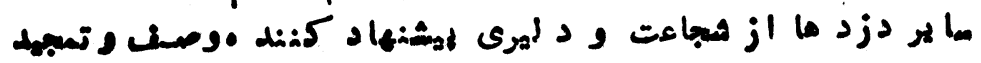

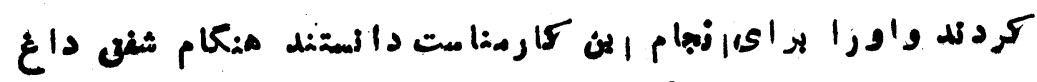

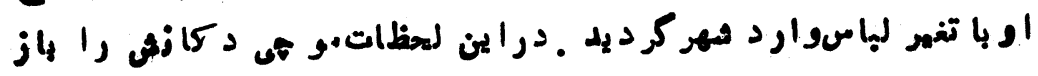

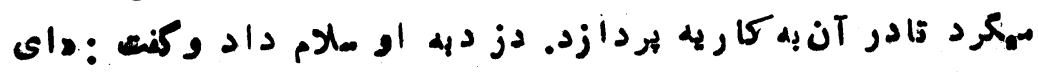

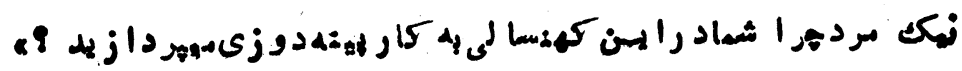

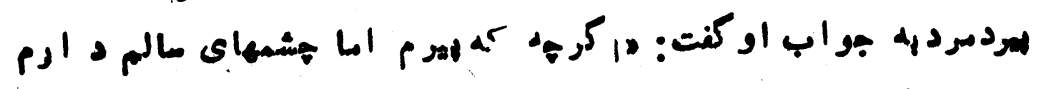

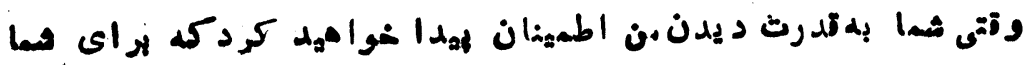

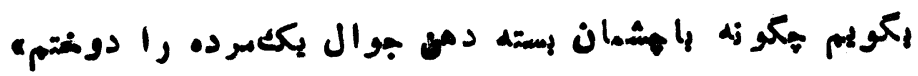

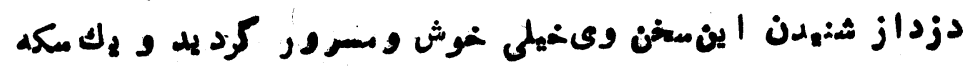

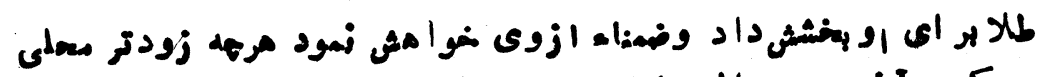

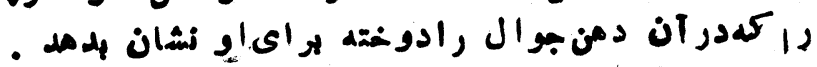

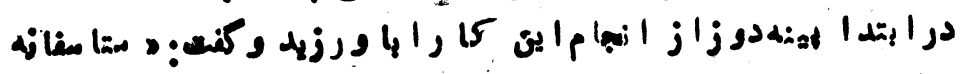

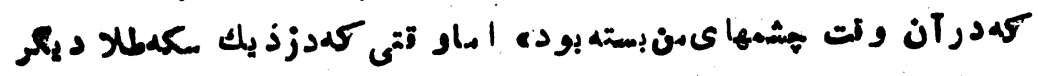

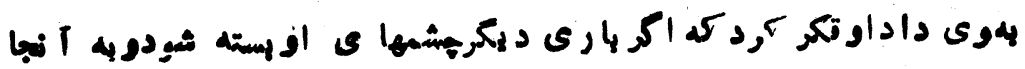

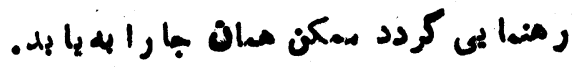




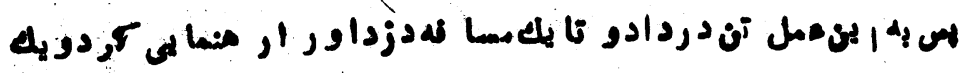

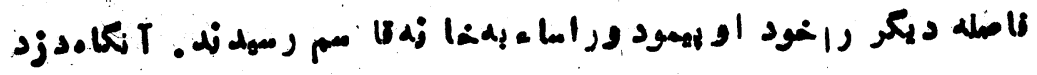

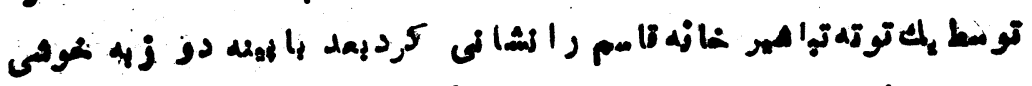

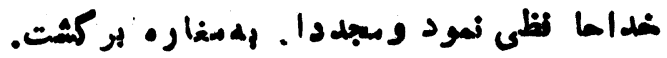

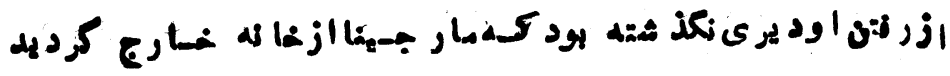

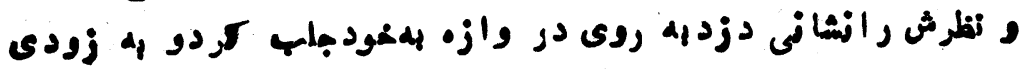

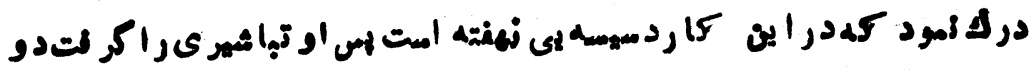

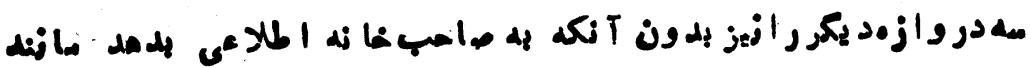

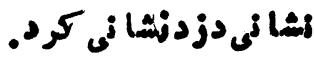

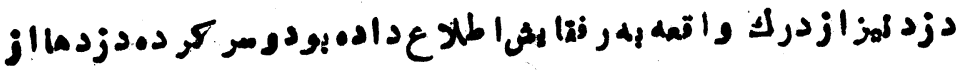

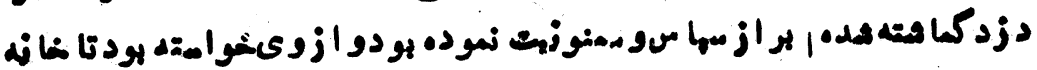

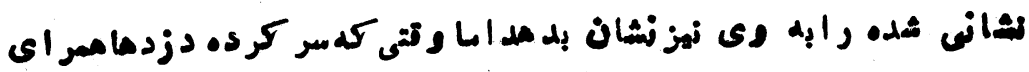

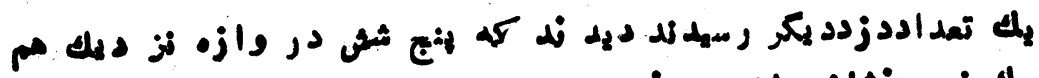

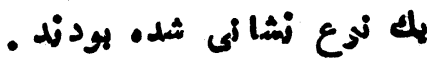

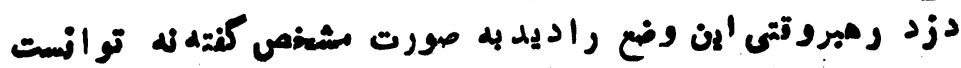

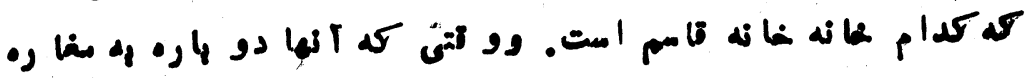

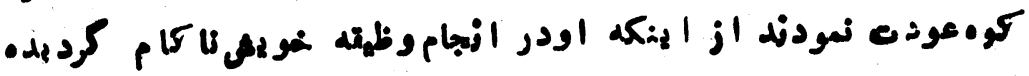

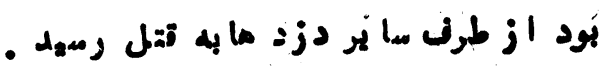

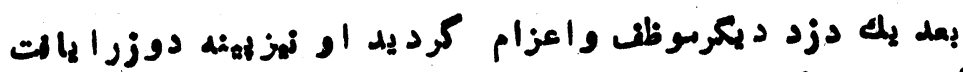

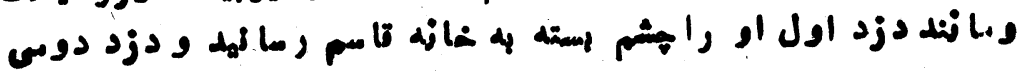

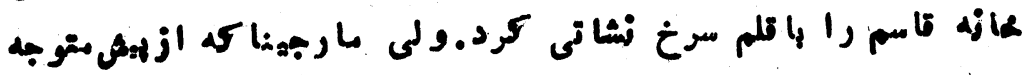

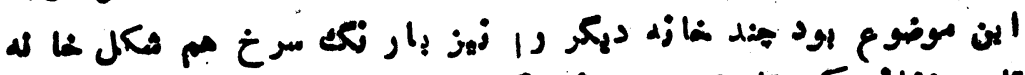

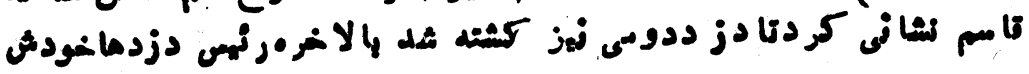

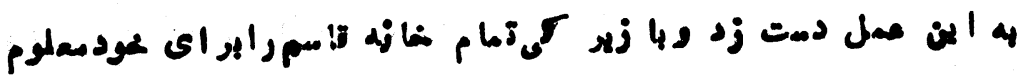
$-1 \cdot 1$ 


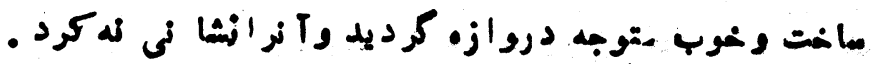

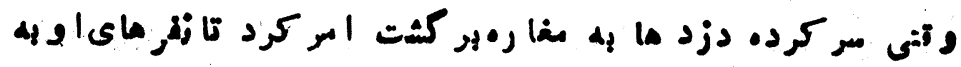

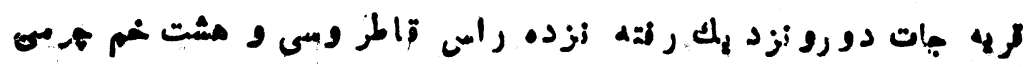

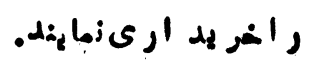

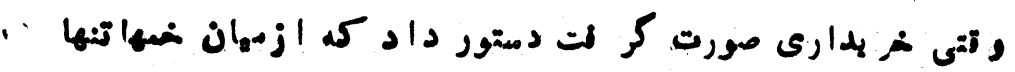

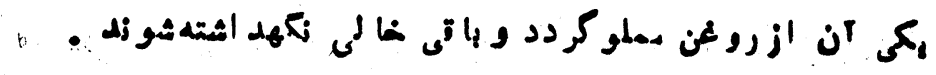

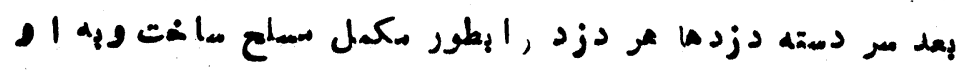

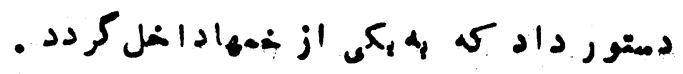

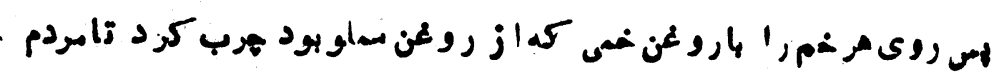

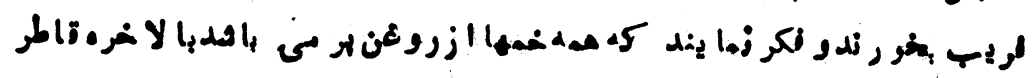

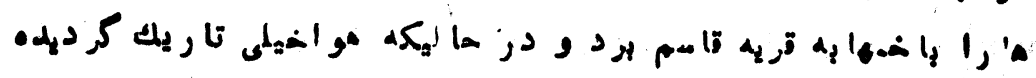

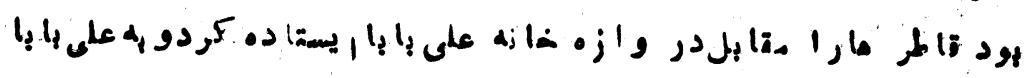

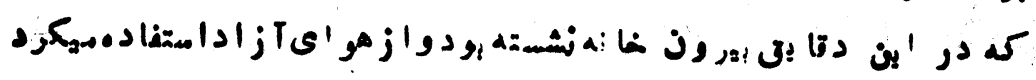

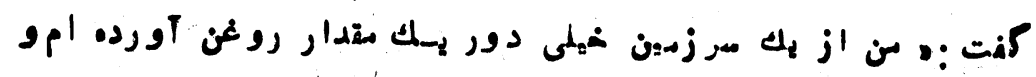

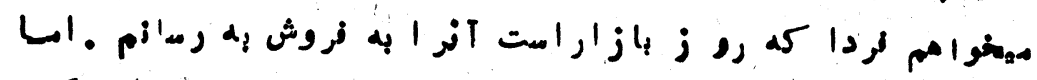

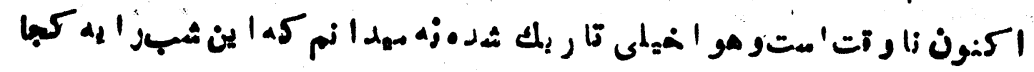

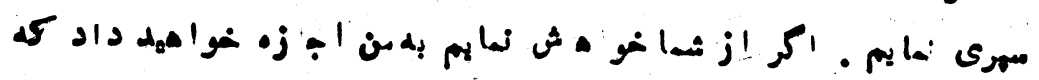

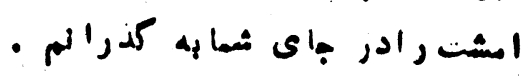

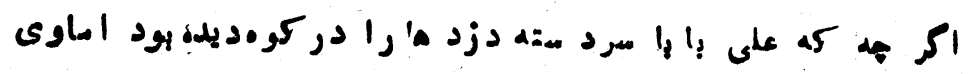

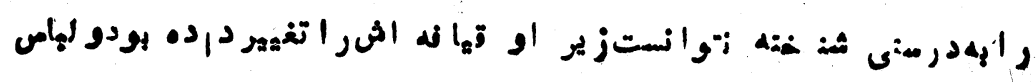

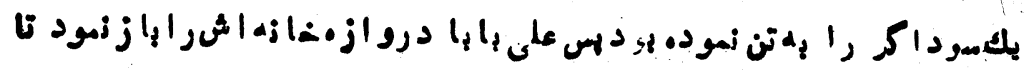

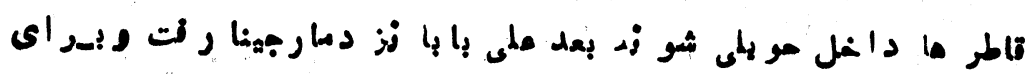

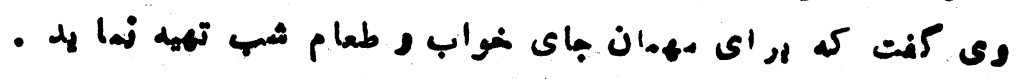




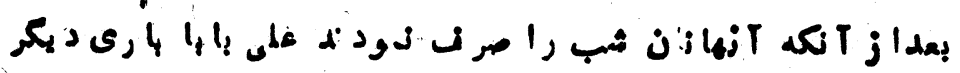

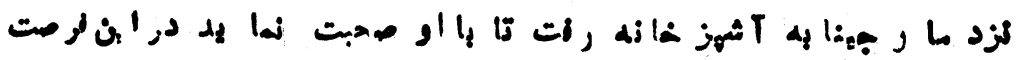

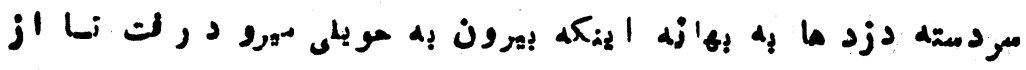

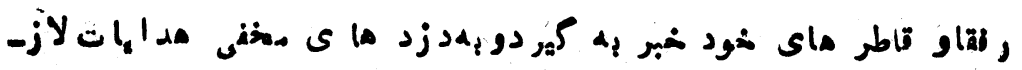

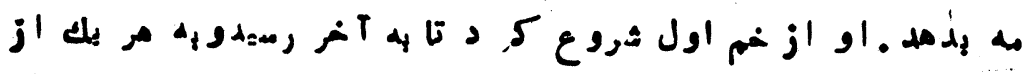

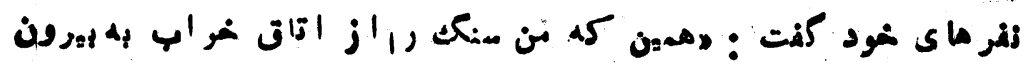

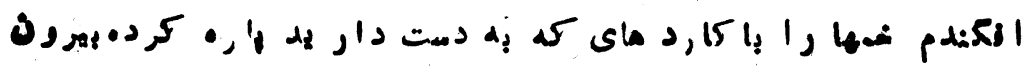

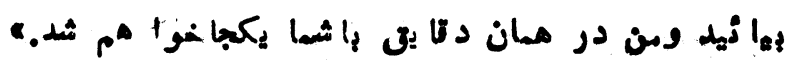

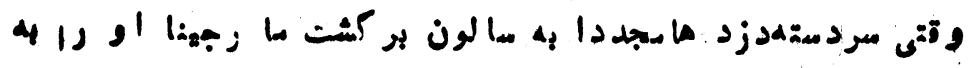

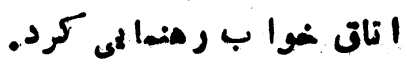

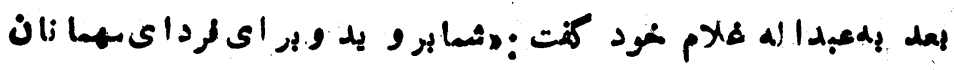

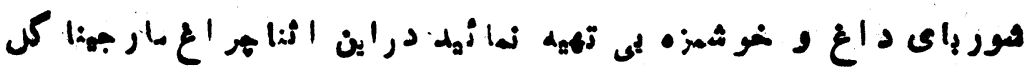

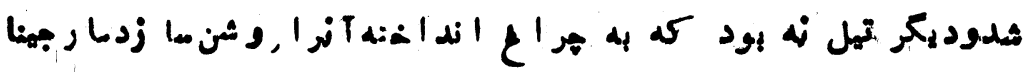

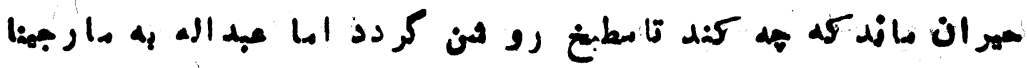

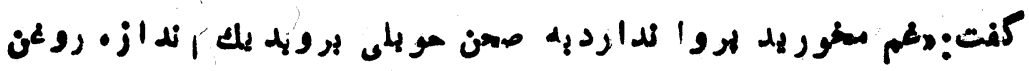

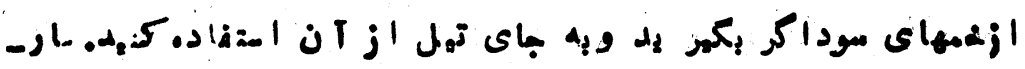

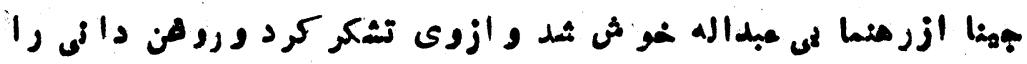

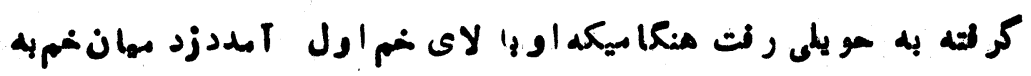

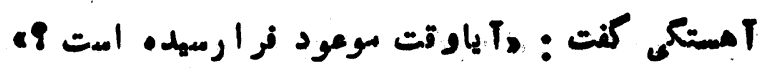

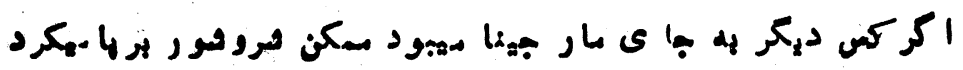

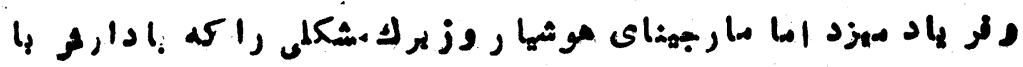

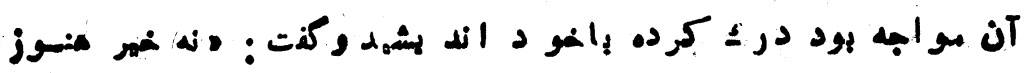

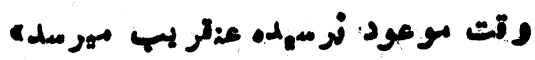
$-1 . r$ 


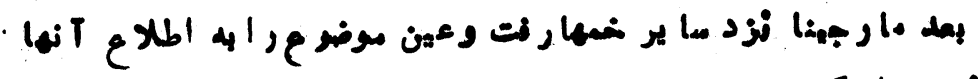

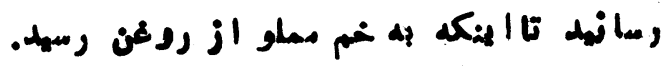

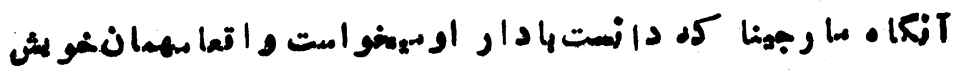

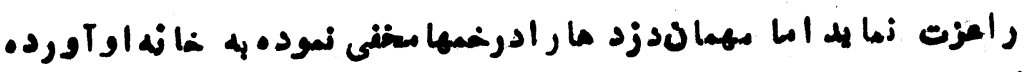
-

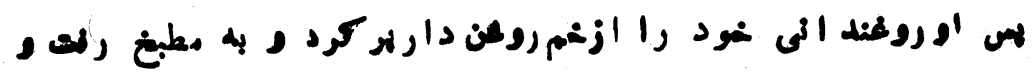

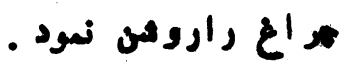

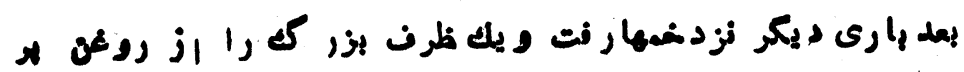

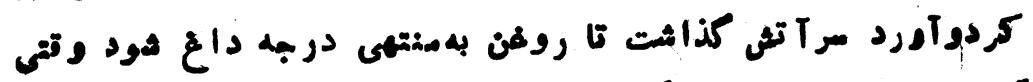

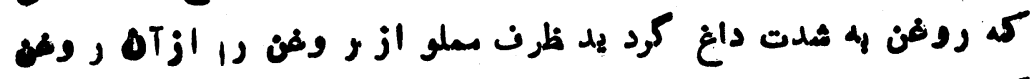

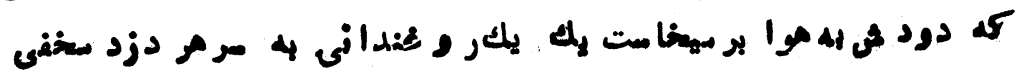

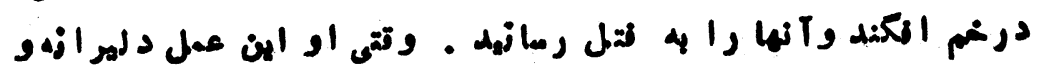

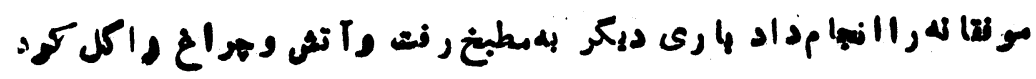

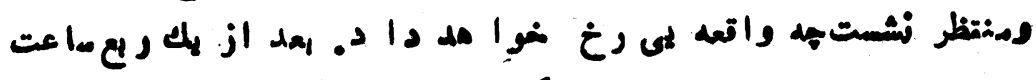

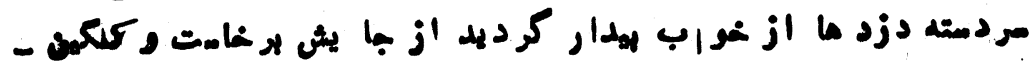

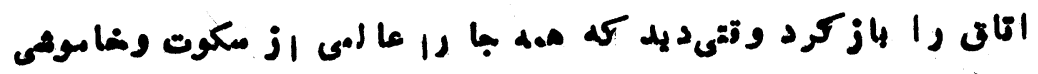

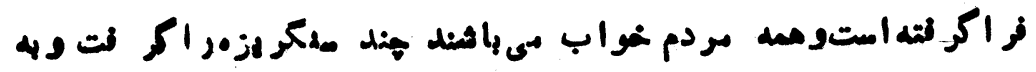

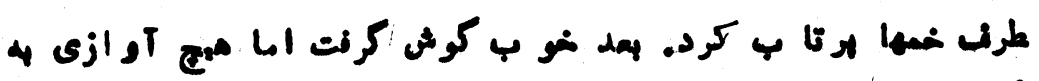

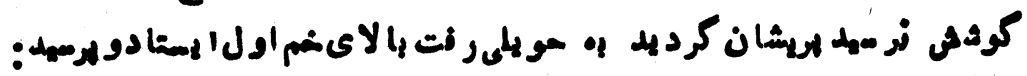
Sad.

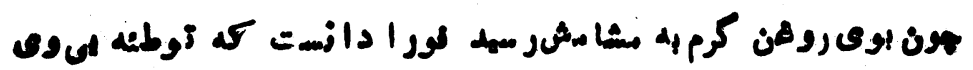

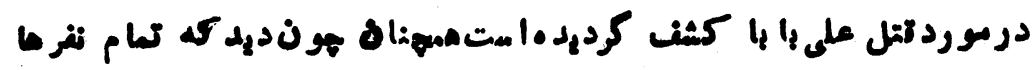

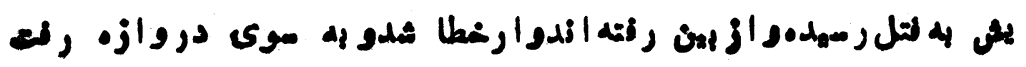




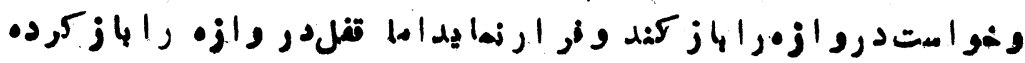
زتو ا نست .

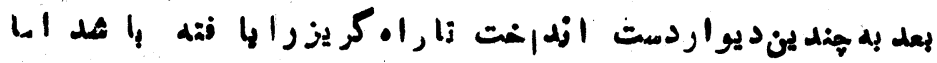

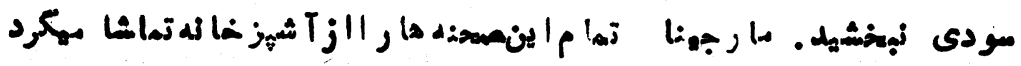

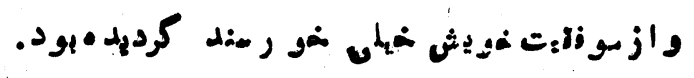

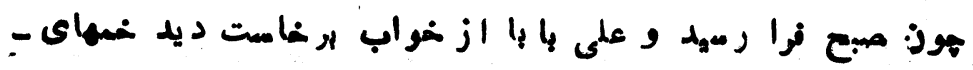

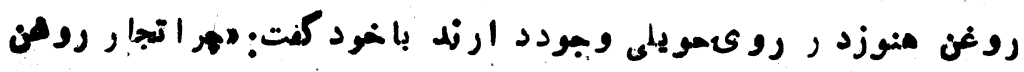

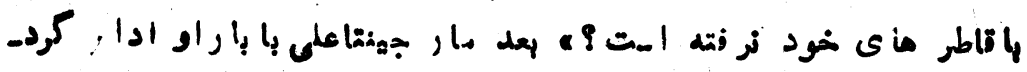

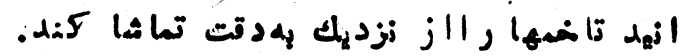

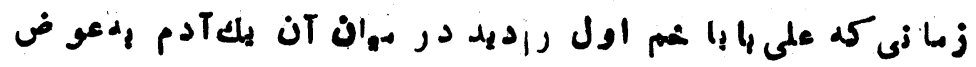

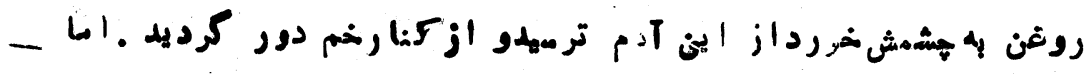

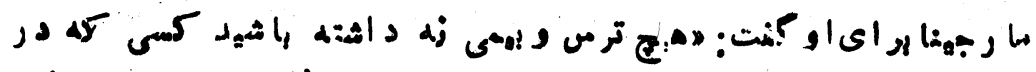

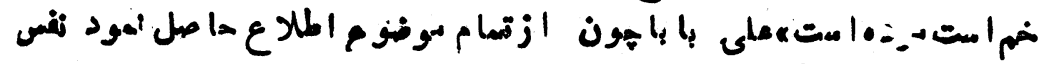

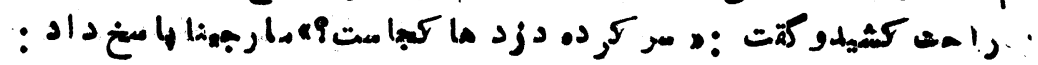

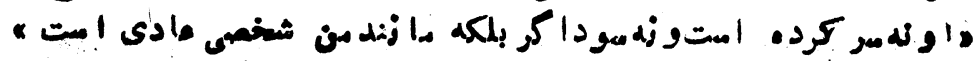

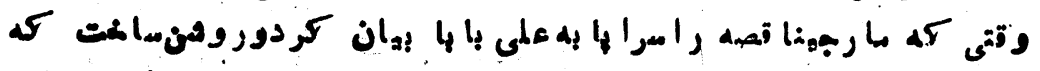

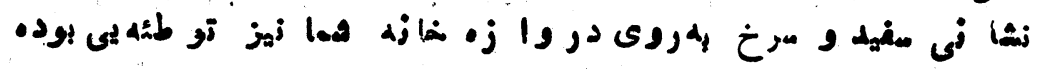

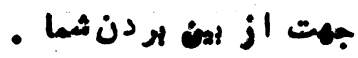

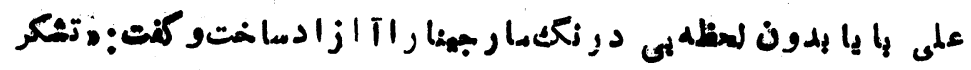

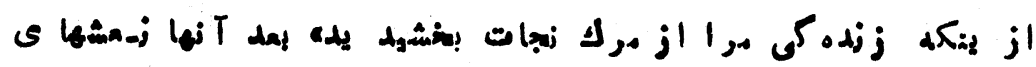

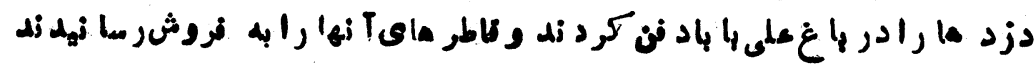

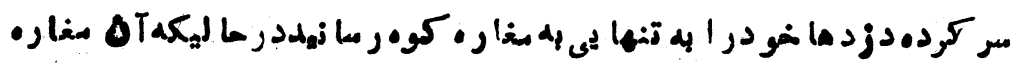

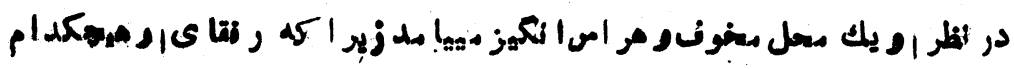

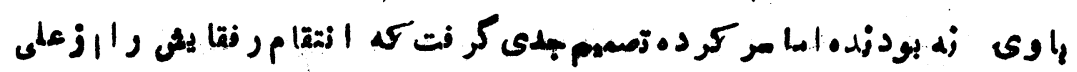

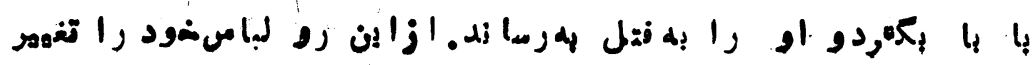




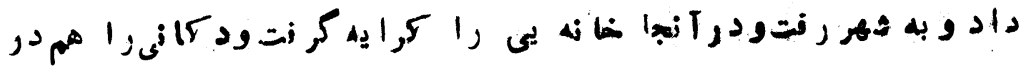

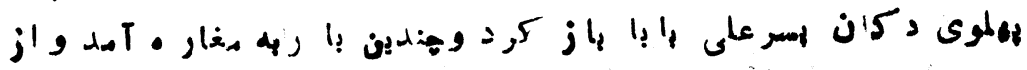

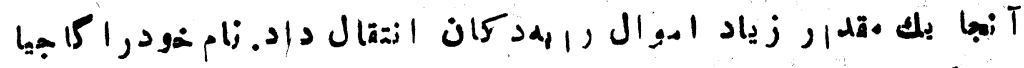

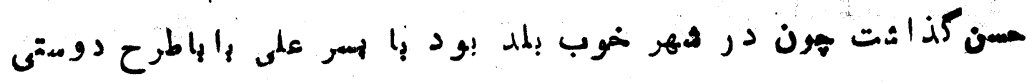

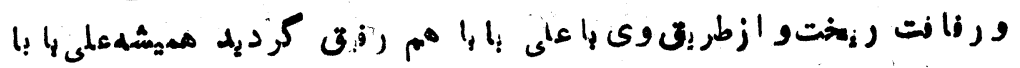

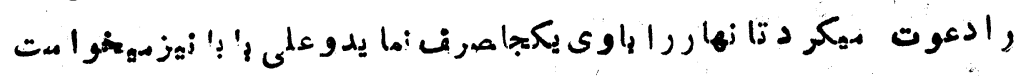

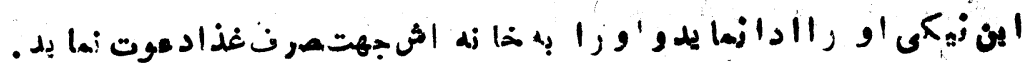

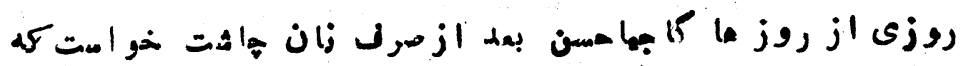

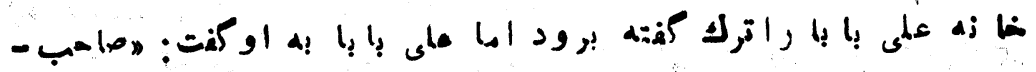

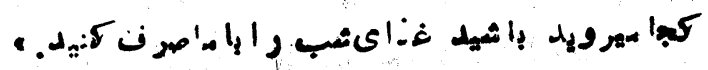

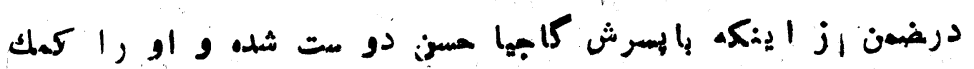

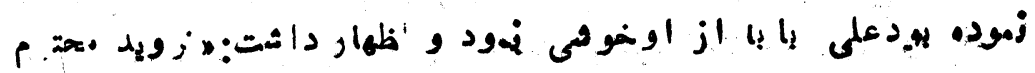

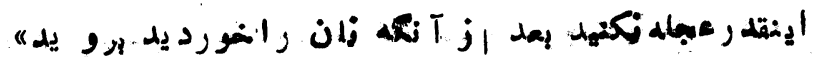

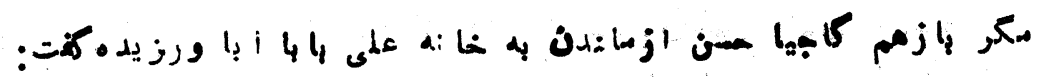

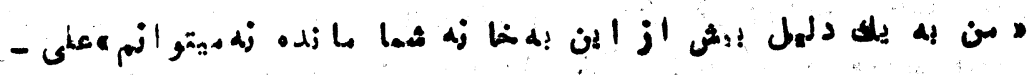

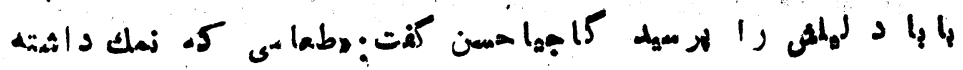

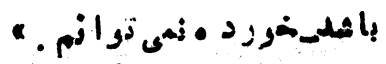

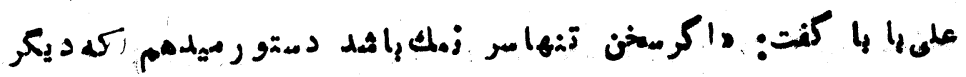

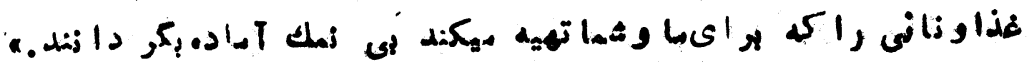

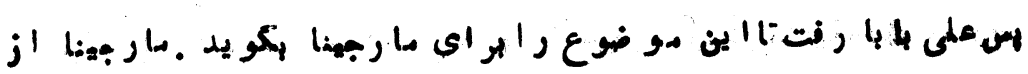

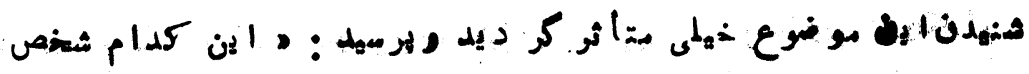

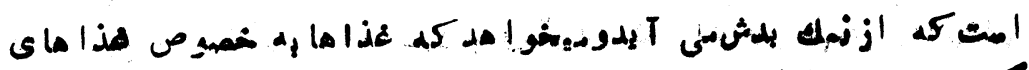

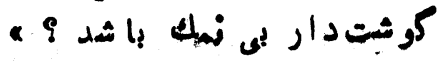


على 4 با در بهواب او كفت : , يلك أدم هومب و صادق است. لذا

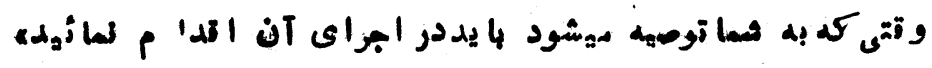

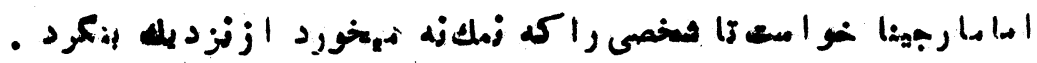

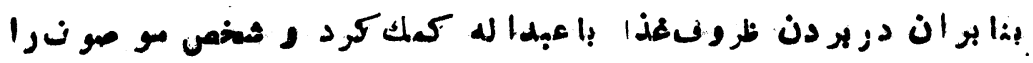

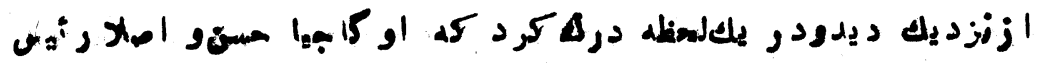

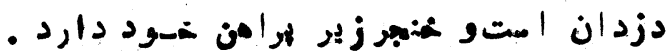

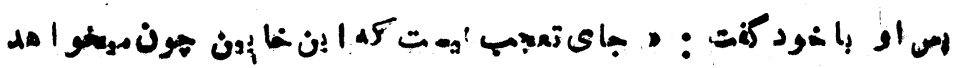

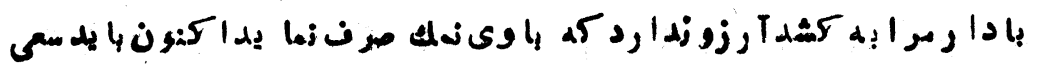

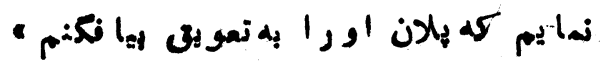

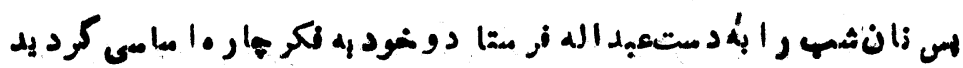

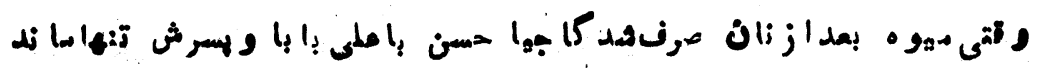

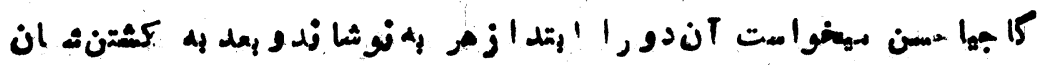

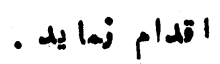

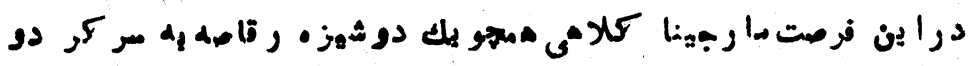

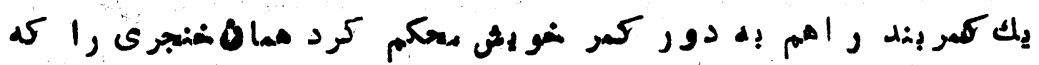

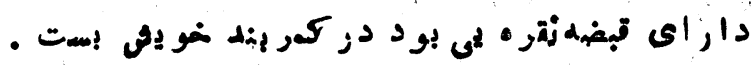

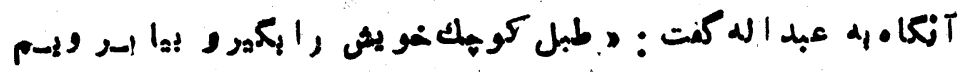

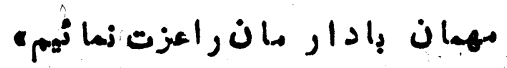

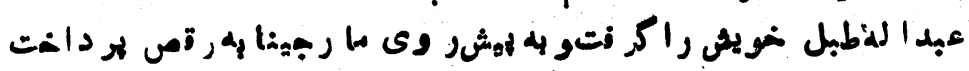

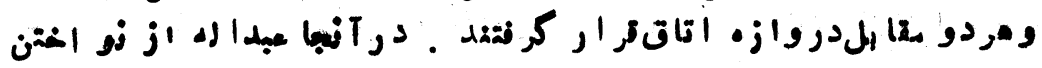

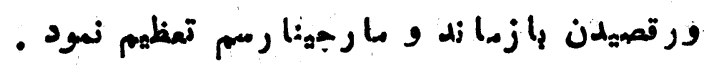

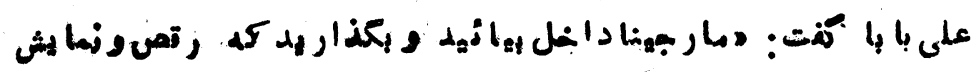

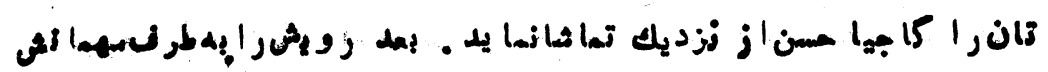

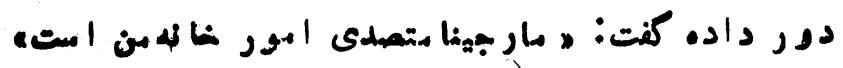




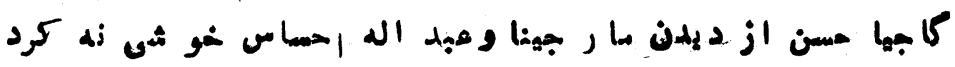

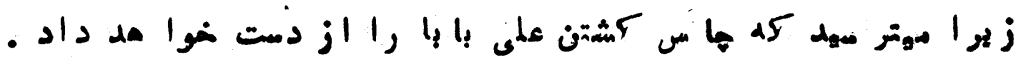

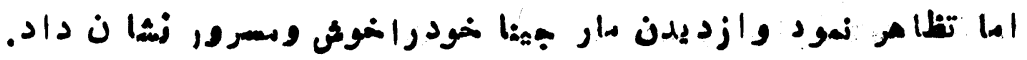

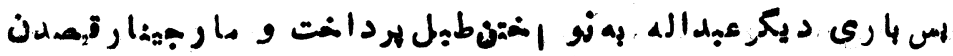

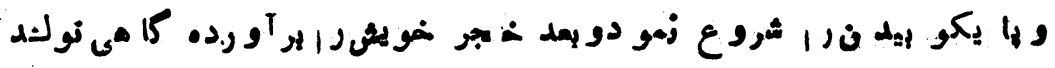

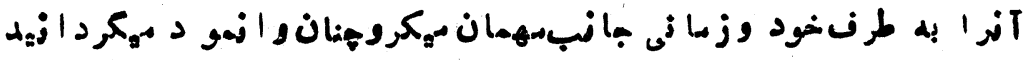

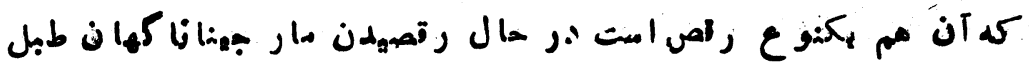

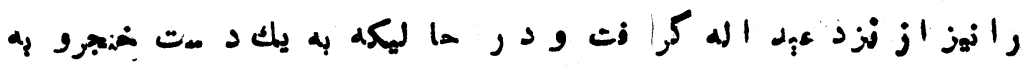

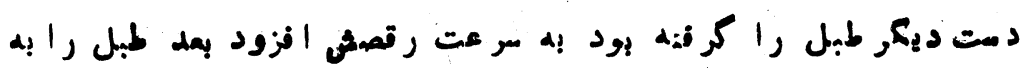

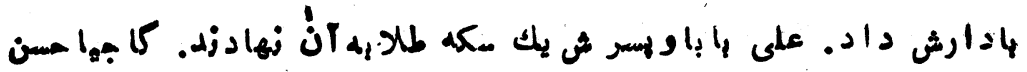

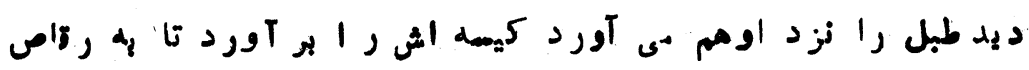

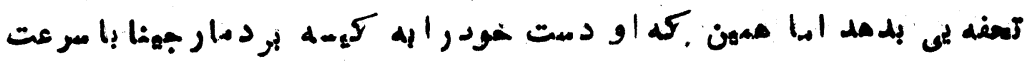

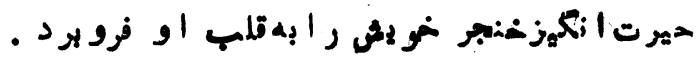

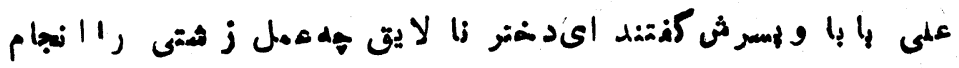

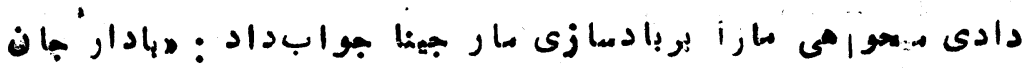

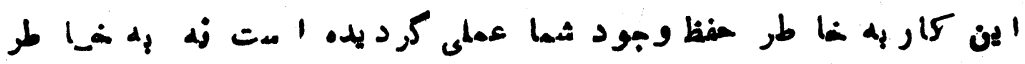

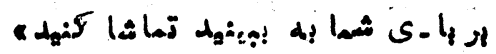

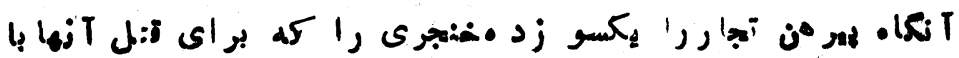

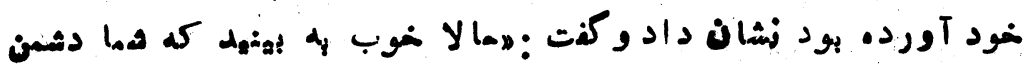

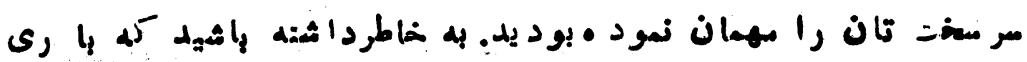

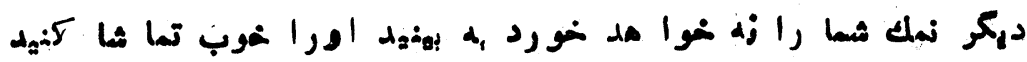

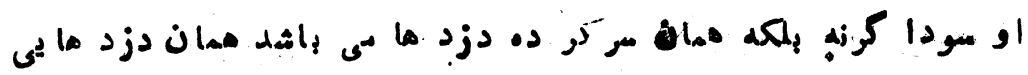

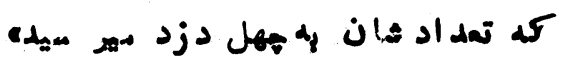
$-1 \cdot 1-$ 


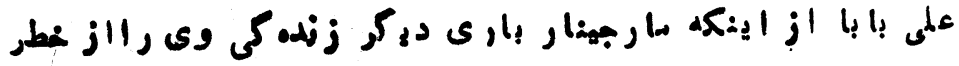

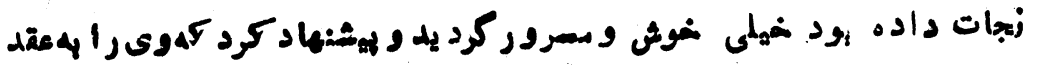

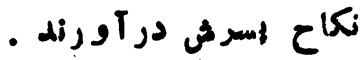

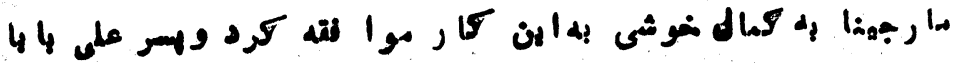
باكنيز زيرك وهوشيار هلدرش ازدو إع نمود و مسنل عر ومى آنها

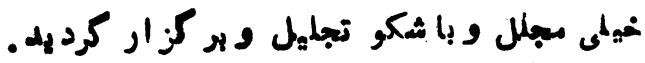

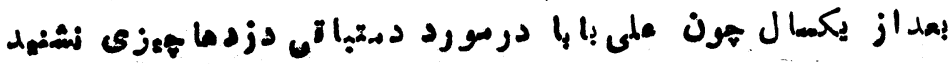

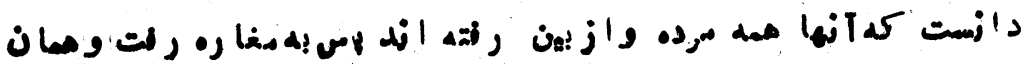

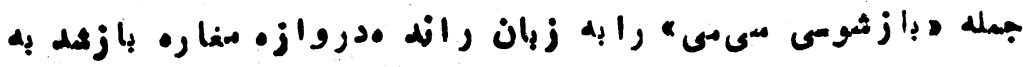

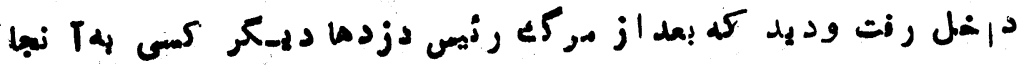

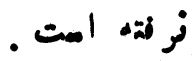

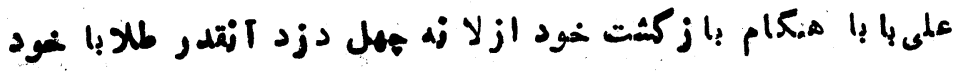

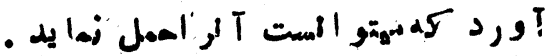

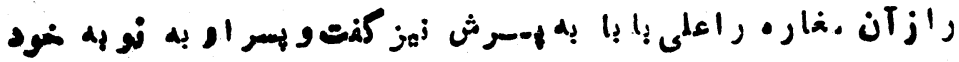

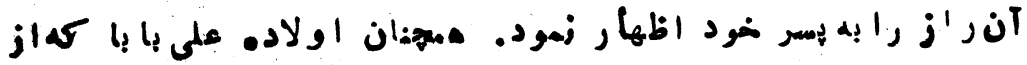

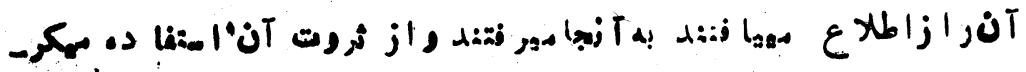

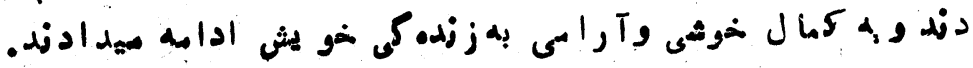

$-1 \cdot 9-$ 
تيسيو سقهرمان

: تصنش اول:

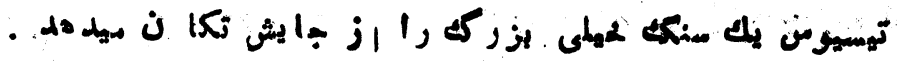

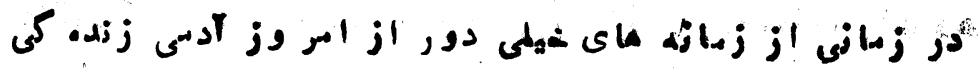

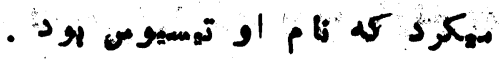

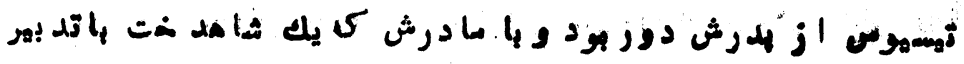

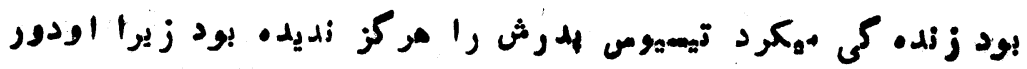

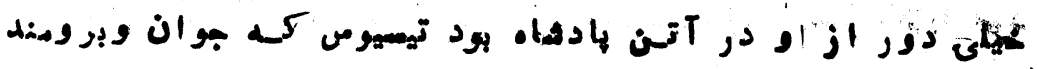

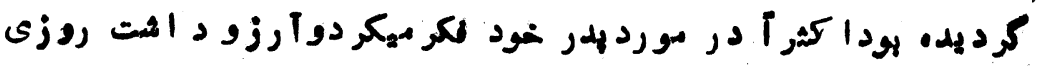
أ

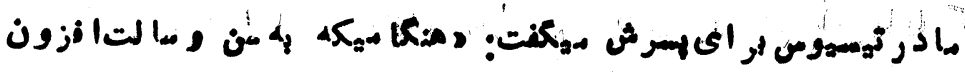

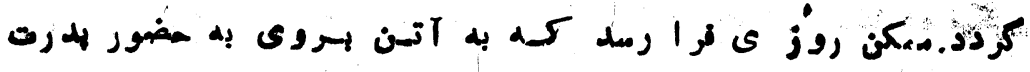

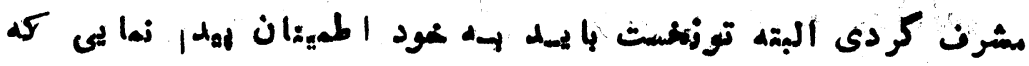

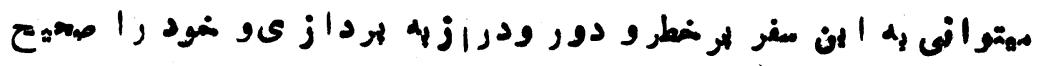

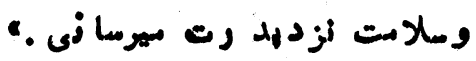

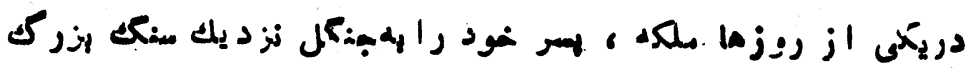

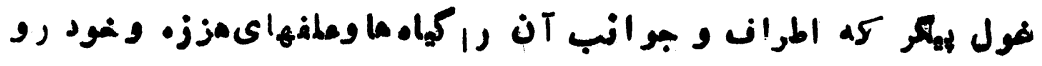

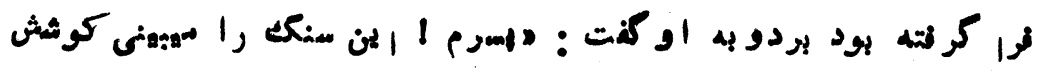

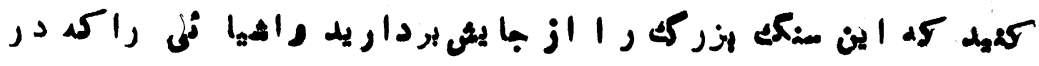

$-11 \cdot-$ 


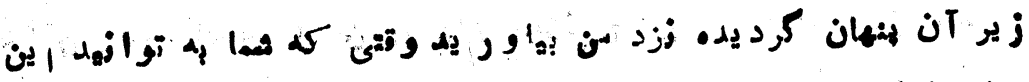

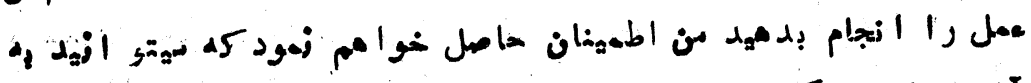

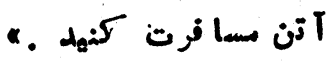

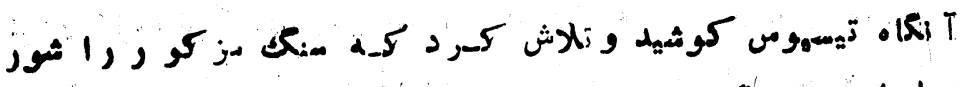

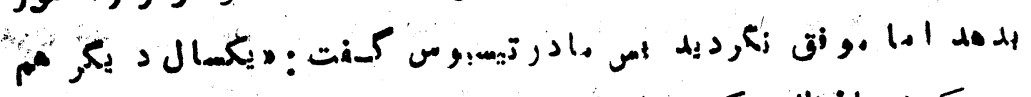

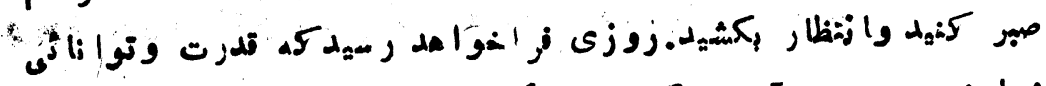

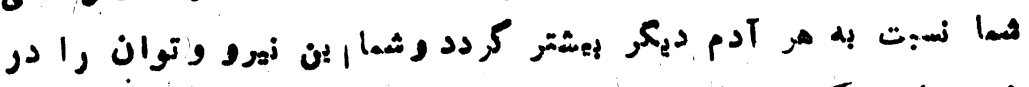

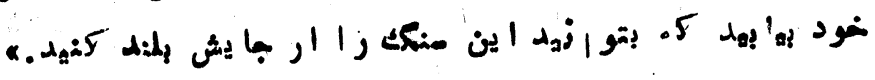

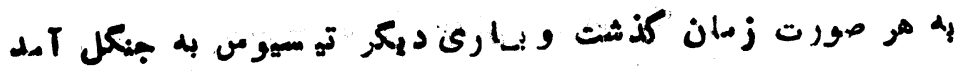

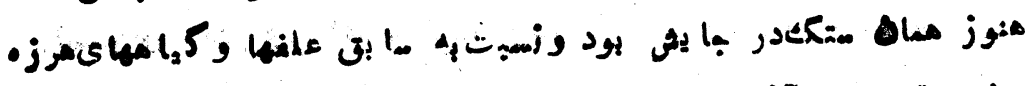

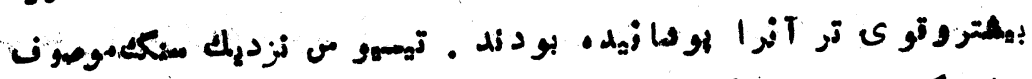

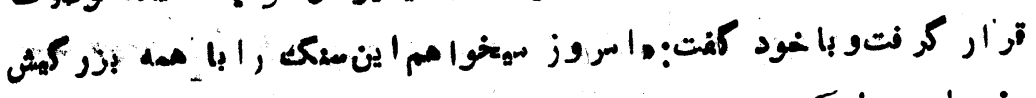

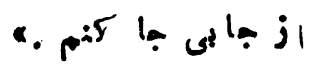

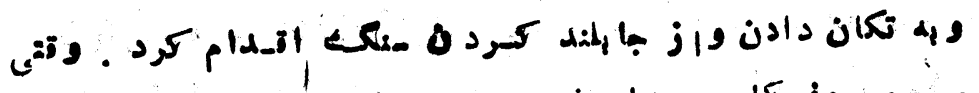

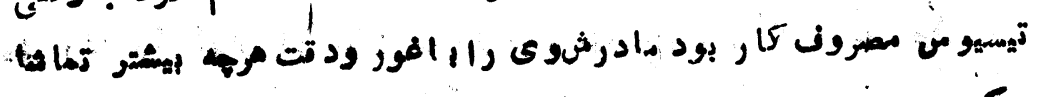

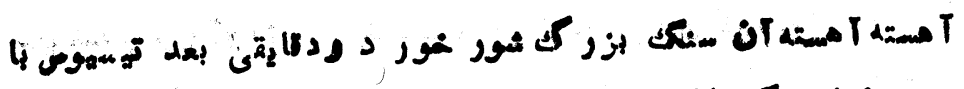

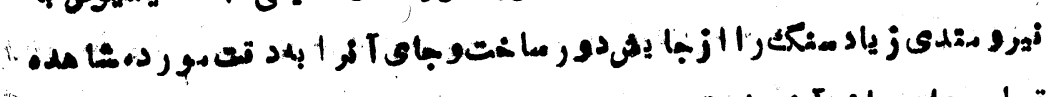

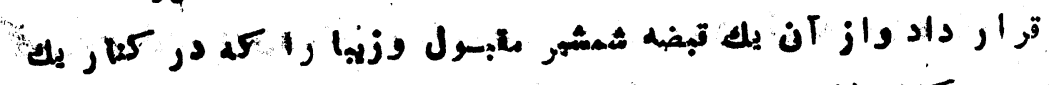

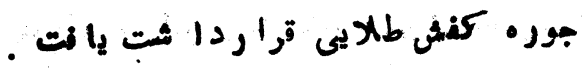

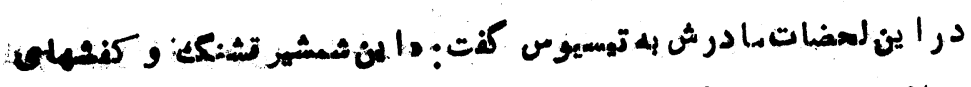

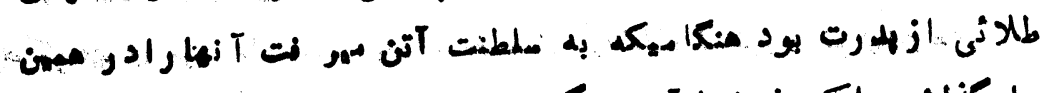

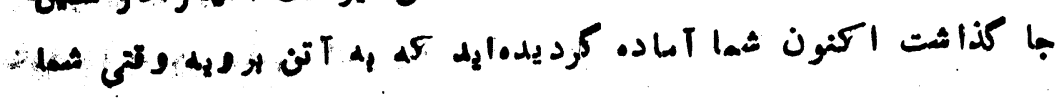




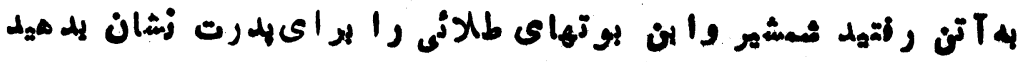

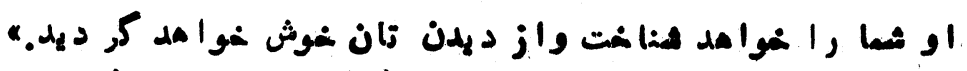

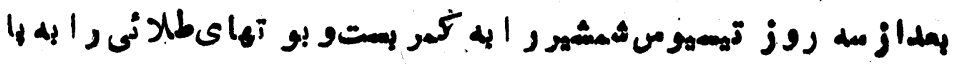

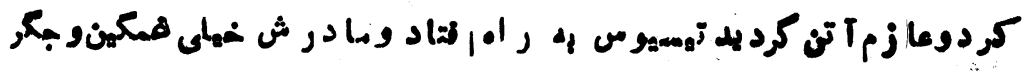

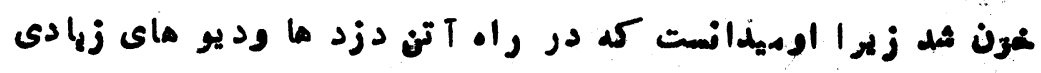

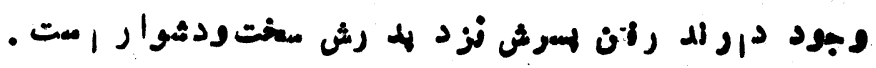

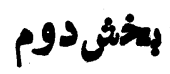

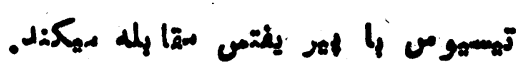

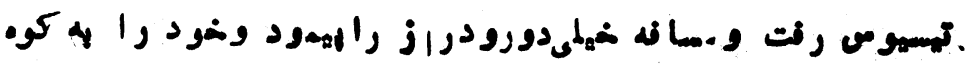

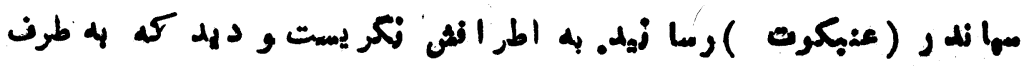

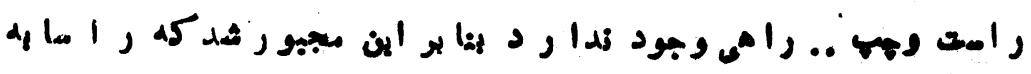

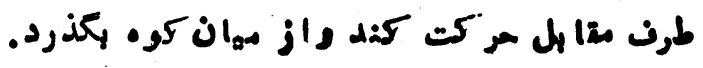

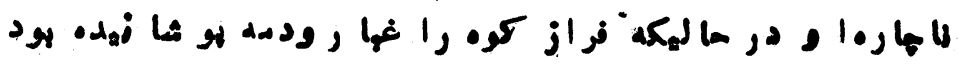

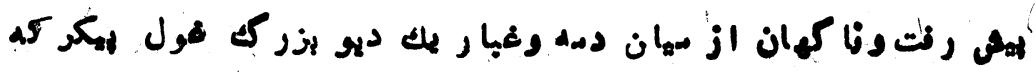

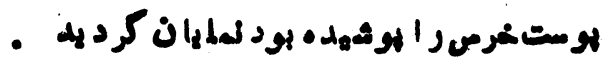

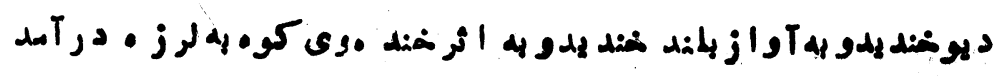

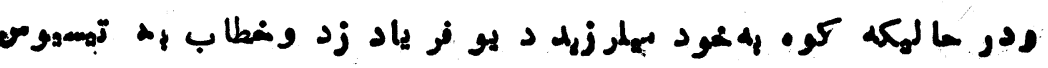

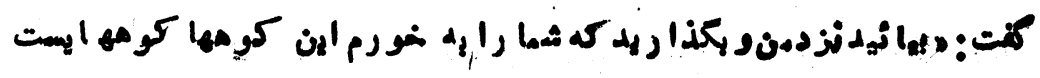

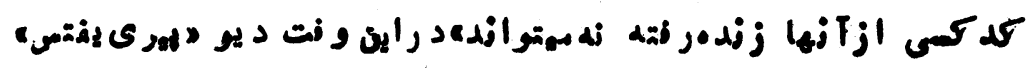

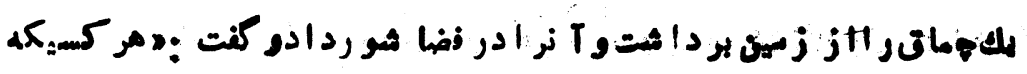

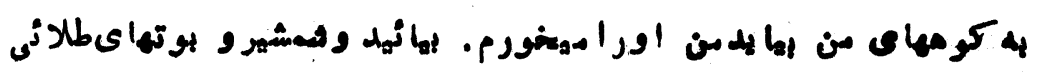

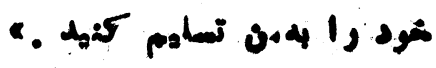

$-11 r-$ 


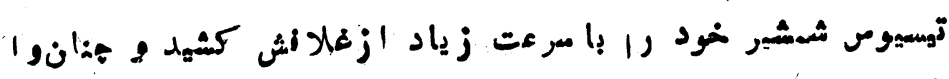

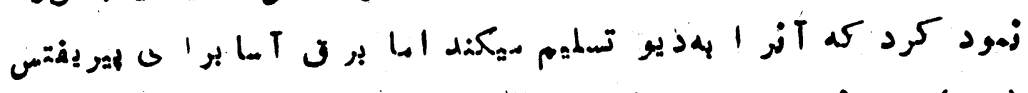

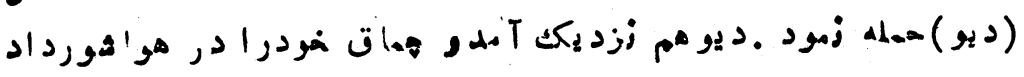

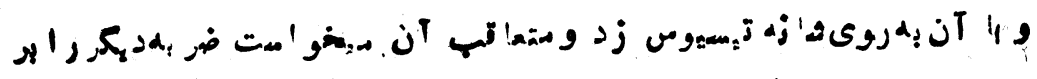

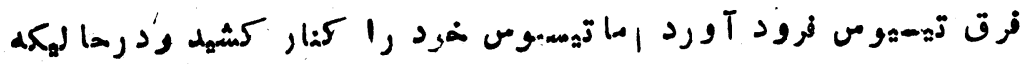

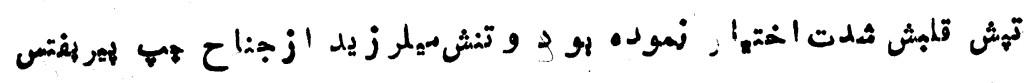

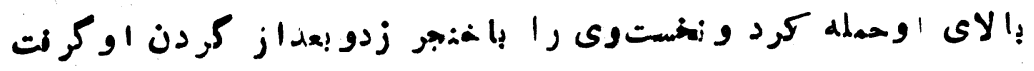

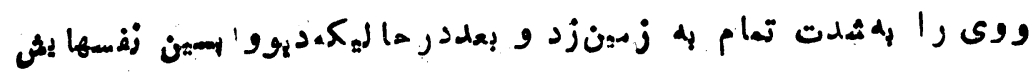

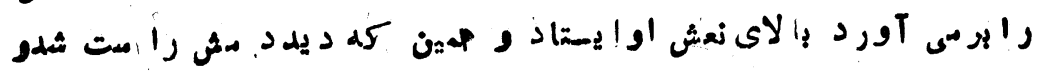

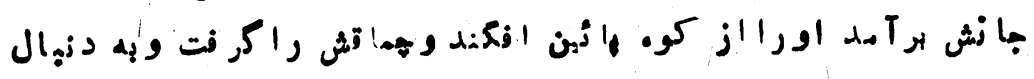

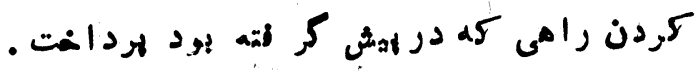

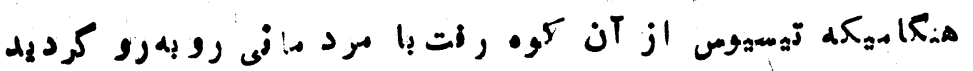

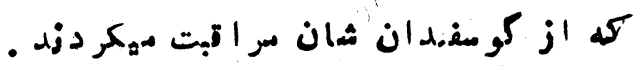

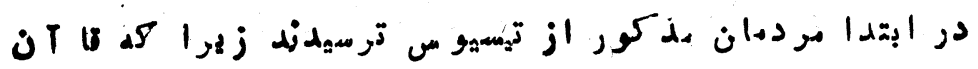

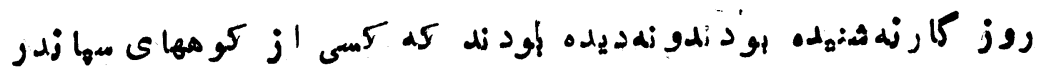

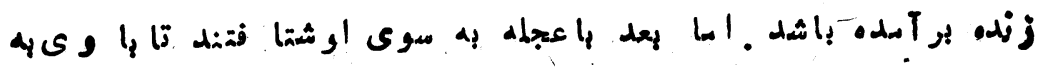

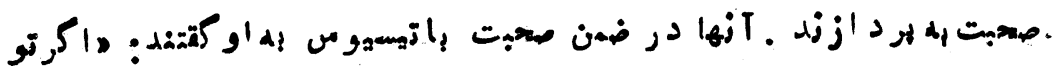

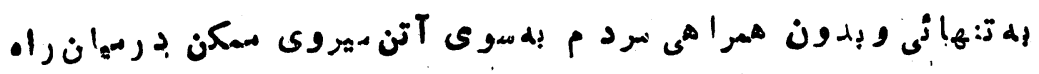
دزدان ترابه تهلي بر مان زنده.

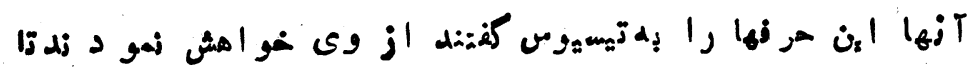

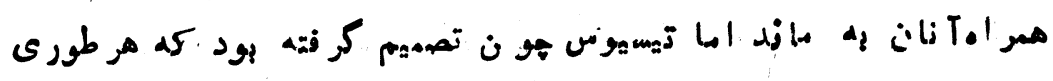

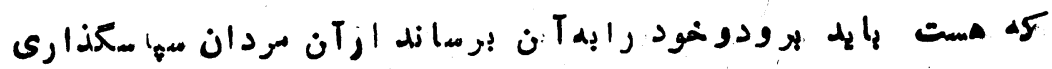

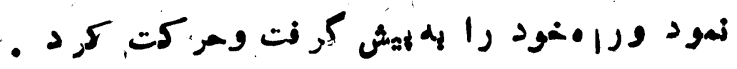

$-110-$ 


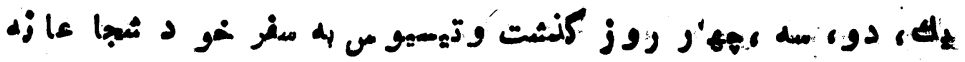

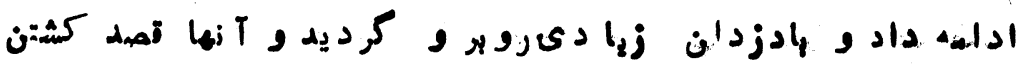

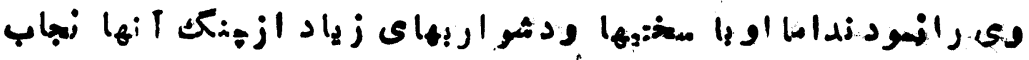

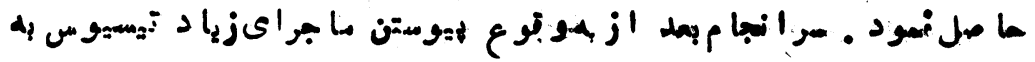

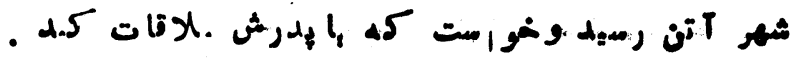

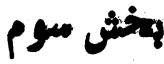

توسميوم در آ تن

در آتن تعداد زعا دى راز مردم د ر مورد دما مرت ، شهاعت و

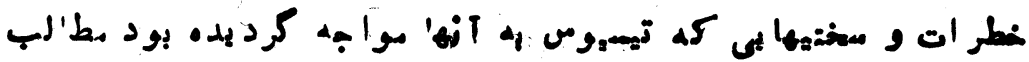

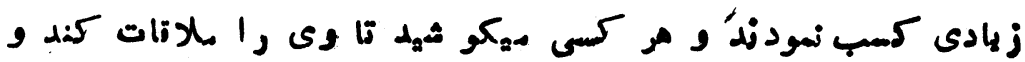

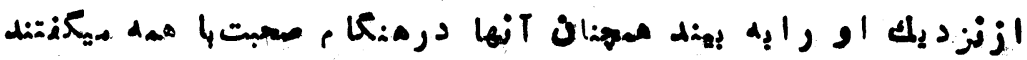

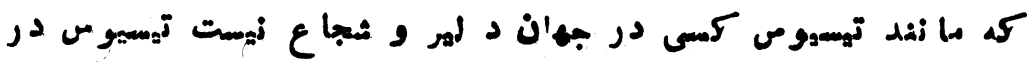

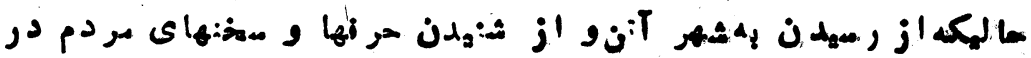

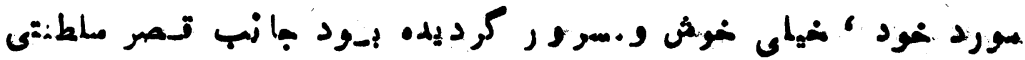

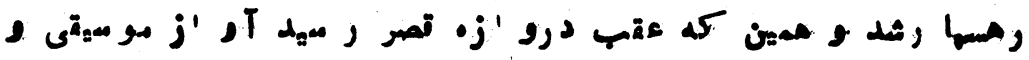

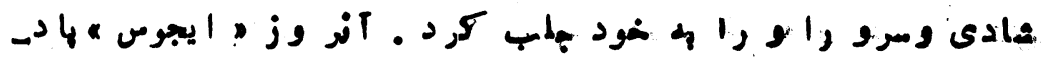

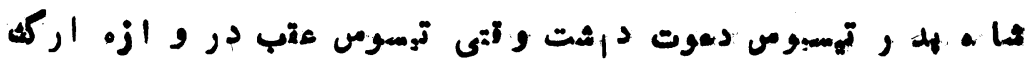

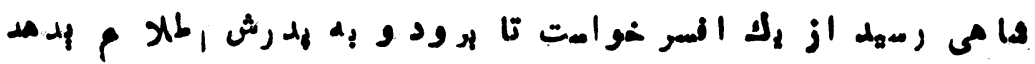

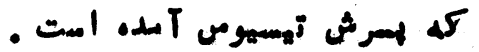

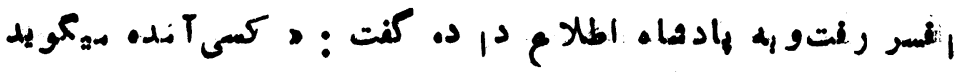

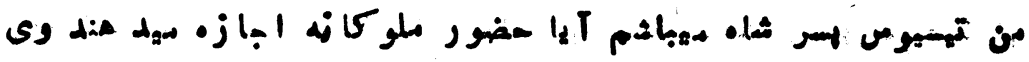

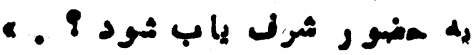

$-11 m$ 


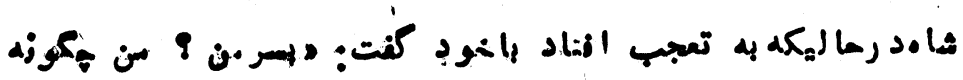

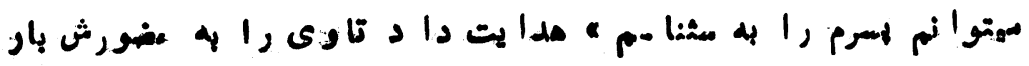

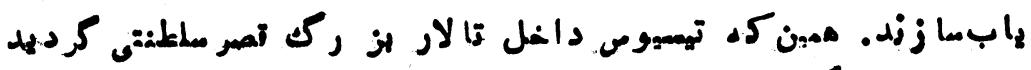

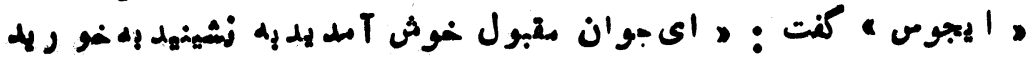

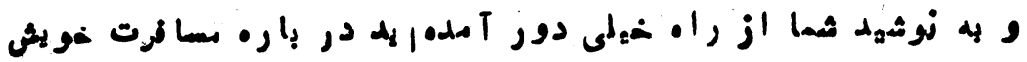

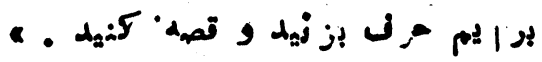

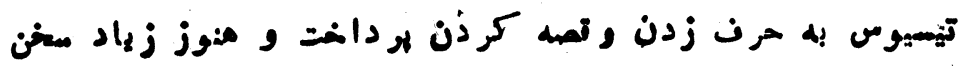

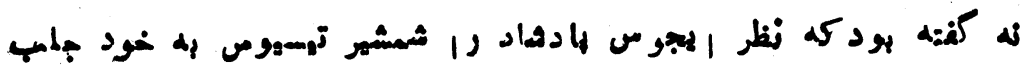

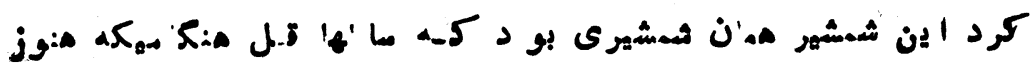

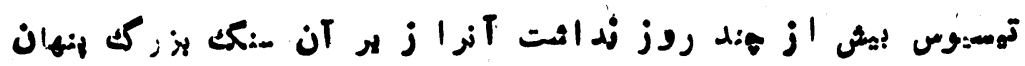

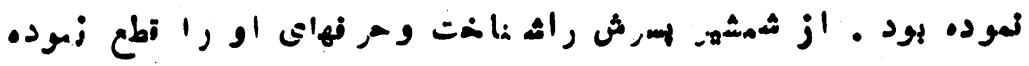

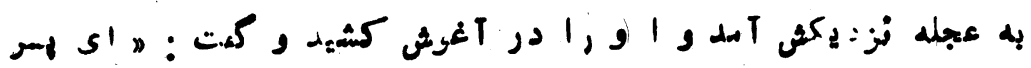

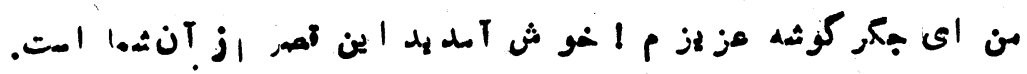

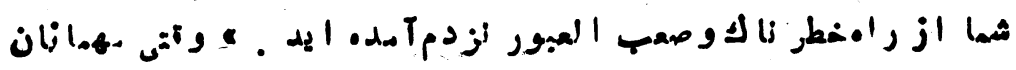

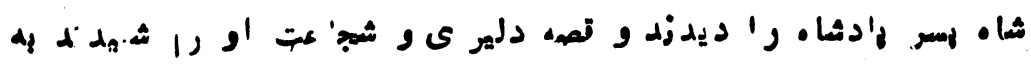

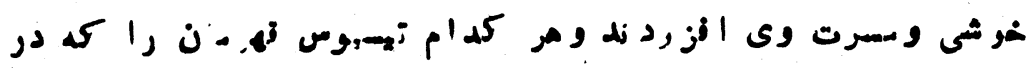

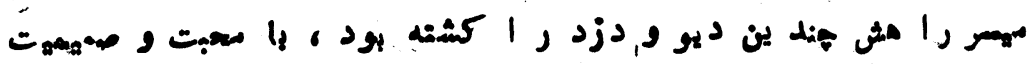

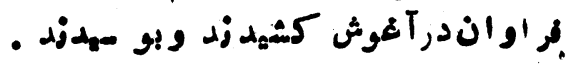

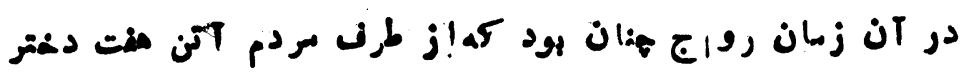

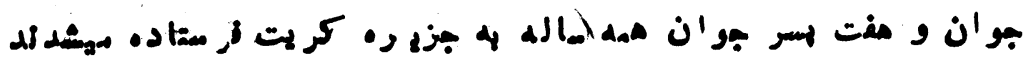

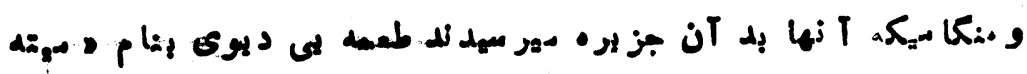

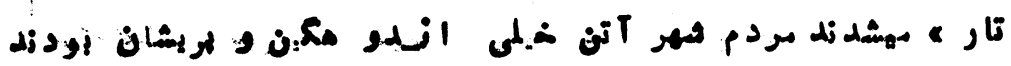

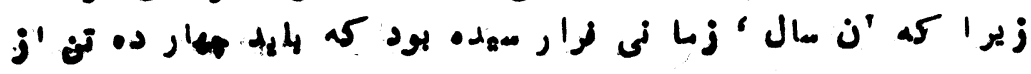

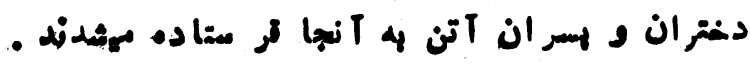
$-110-$ 


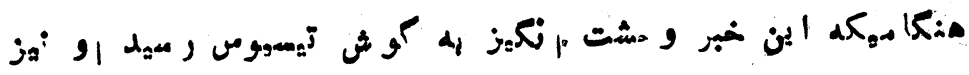

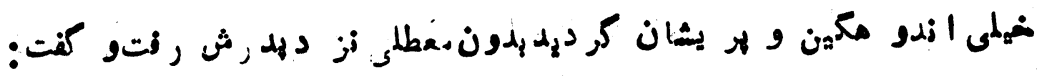

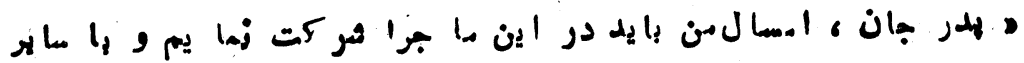

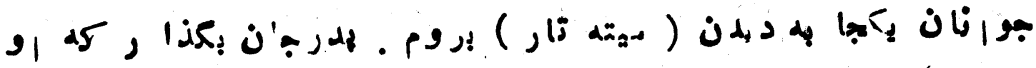

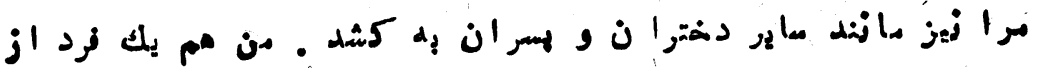

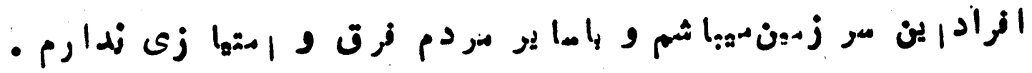

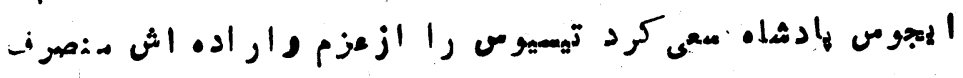

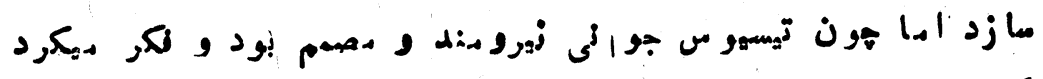

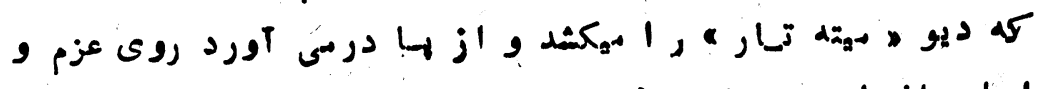

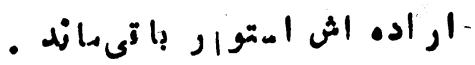

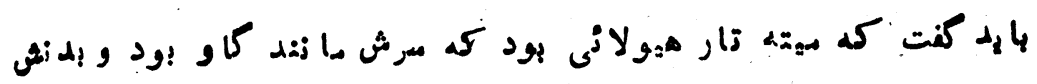

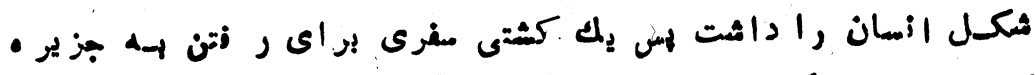

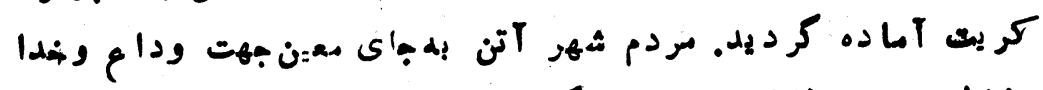

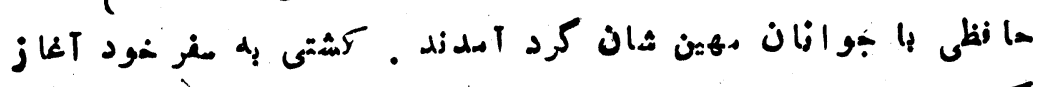

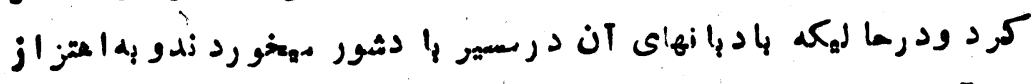

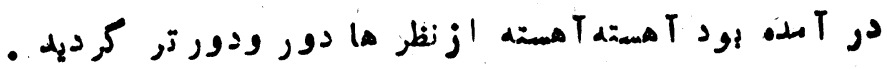

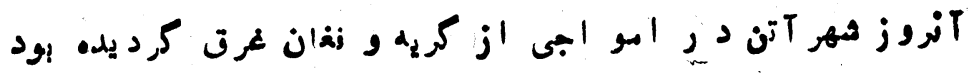

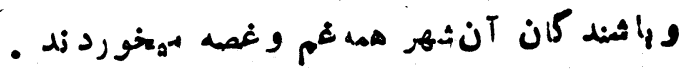

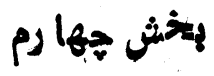

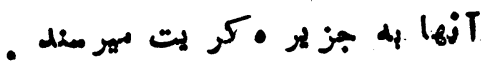

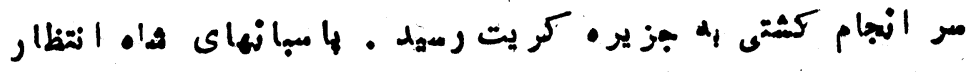

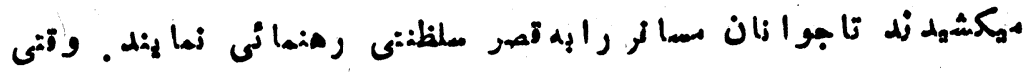

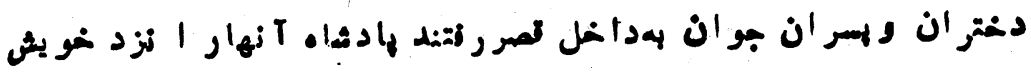




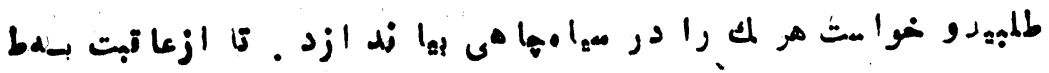

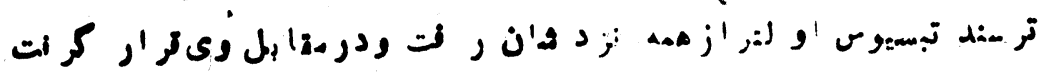

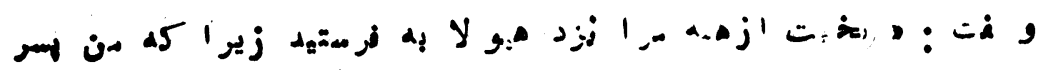

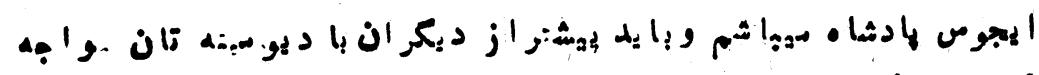
كر مد م

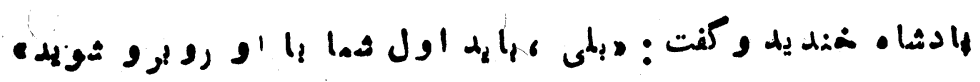

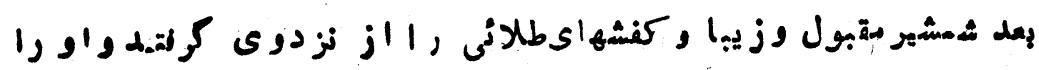

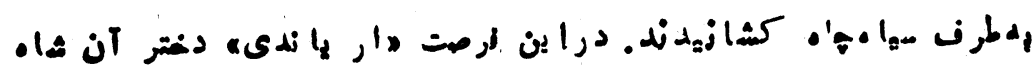

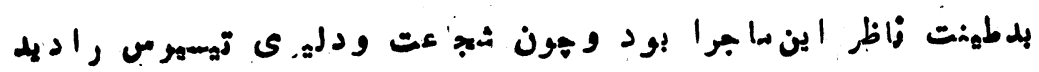

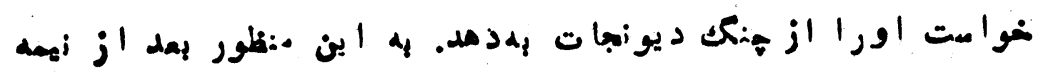

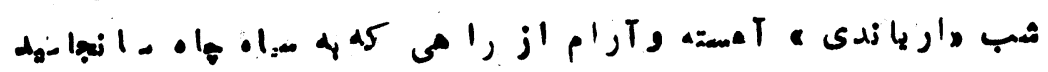

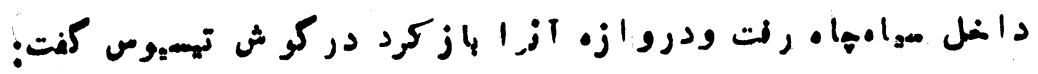

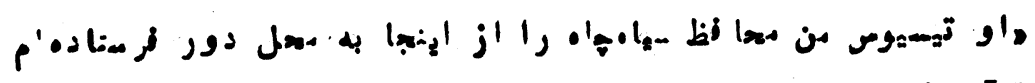

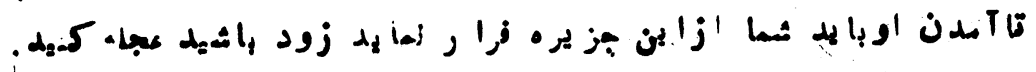

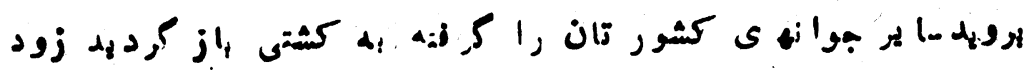

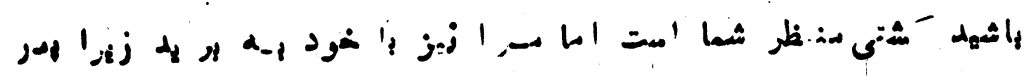

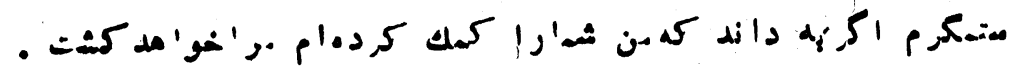

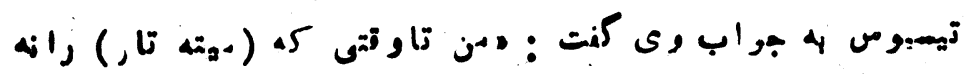

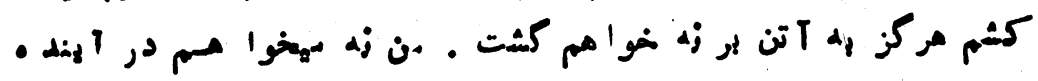

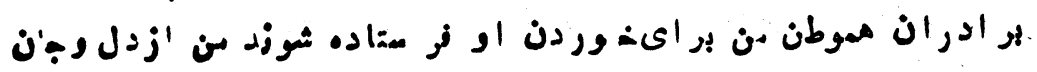

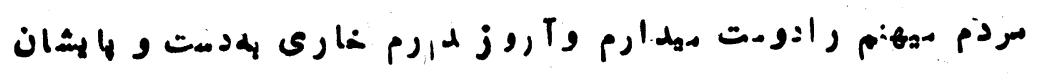

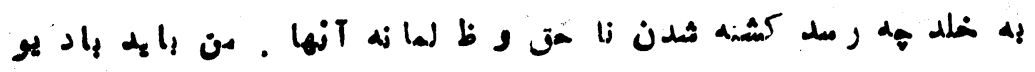

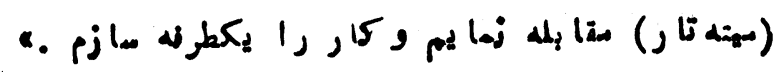




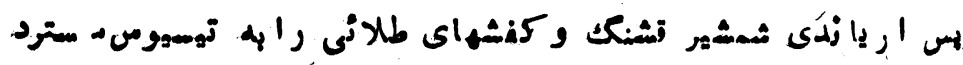

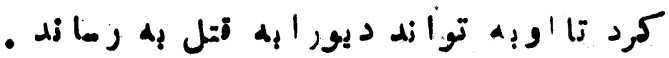

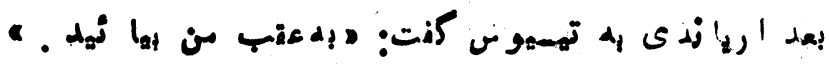

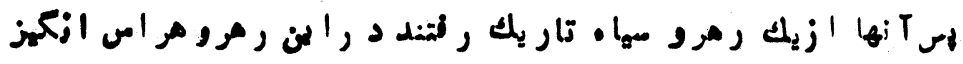

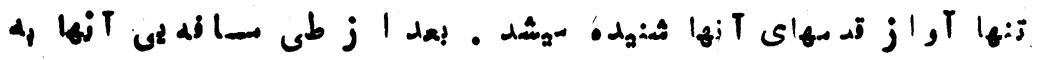

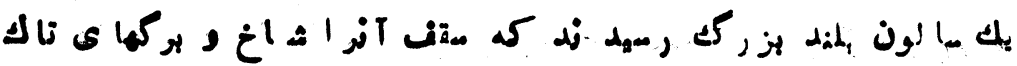

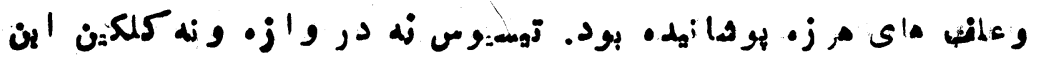

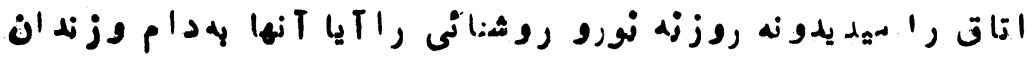

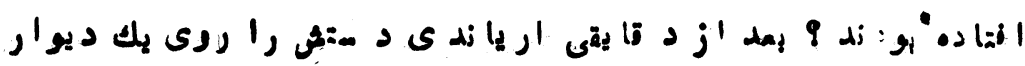

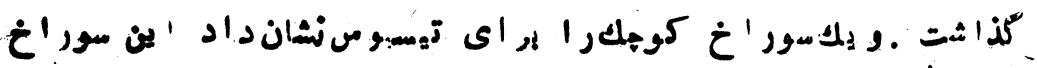

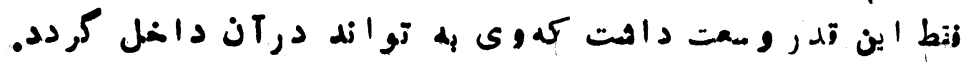

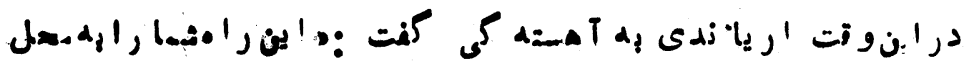

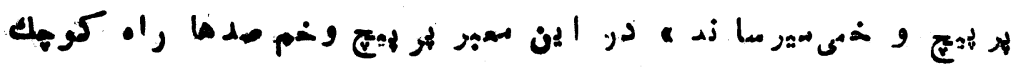

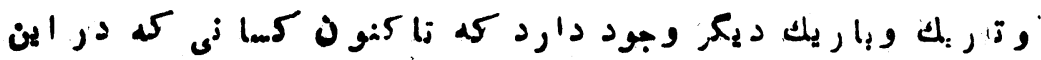

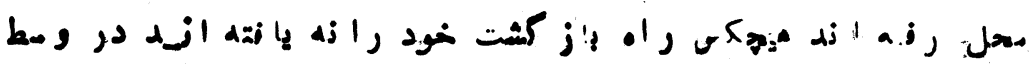

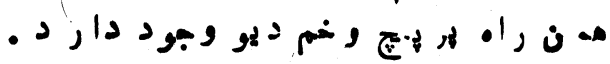

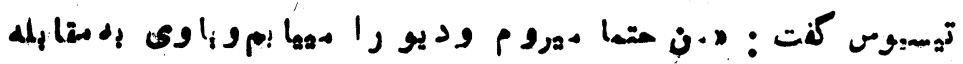

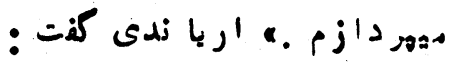

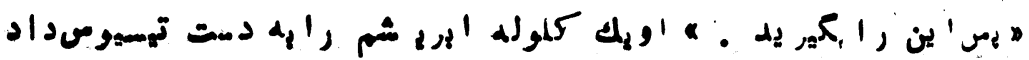

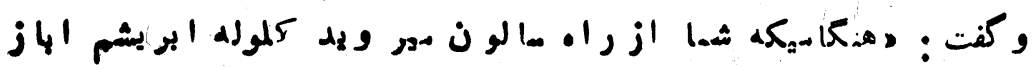

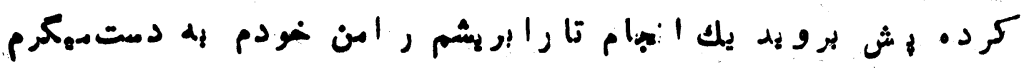

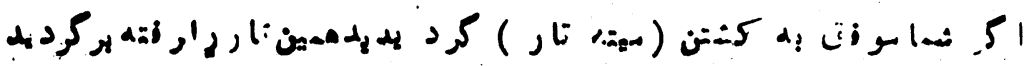

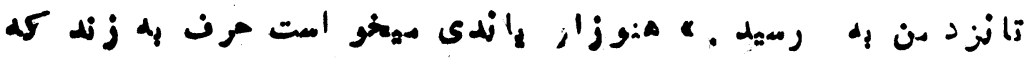
$-1,1-$ 


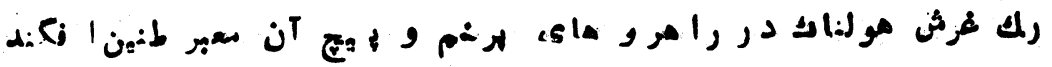

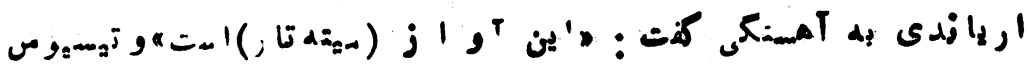

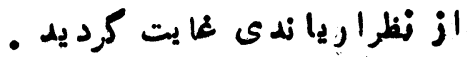

:

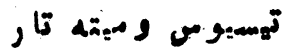

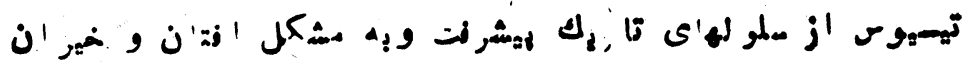

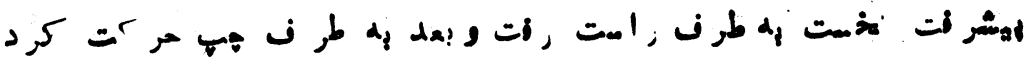

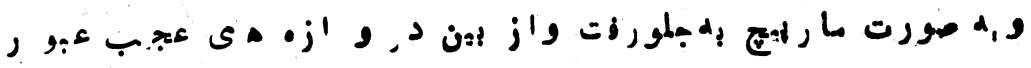

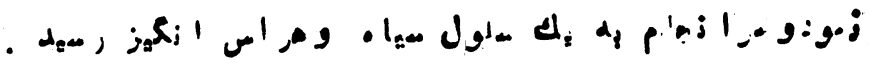

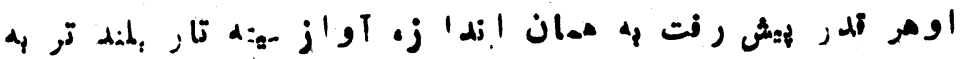

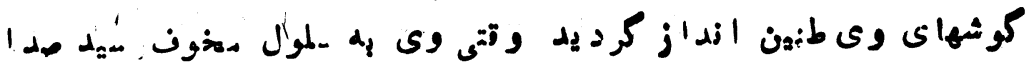

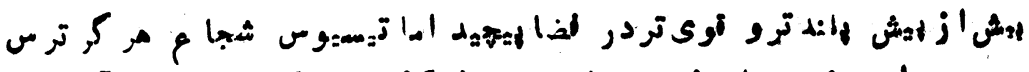

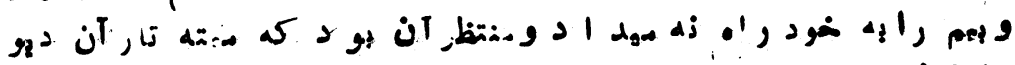

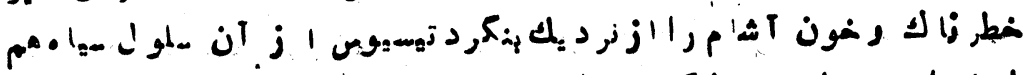

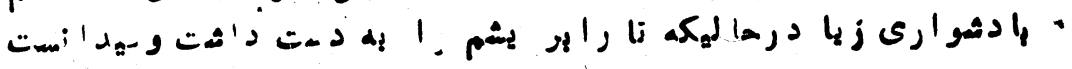

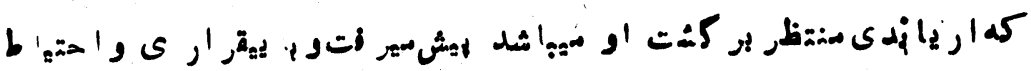

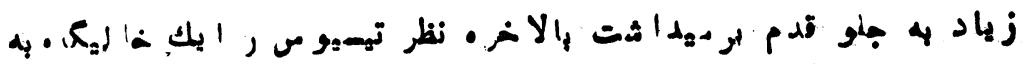

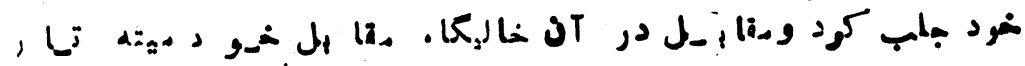

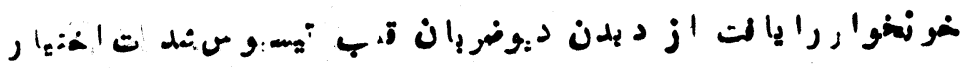

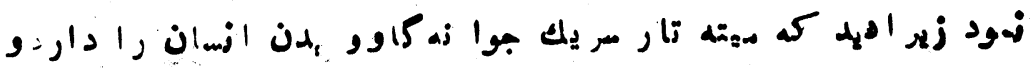

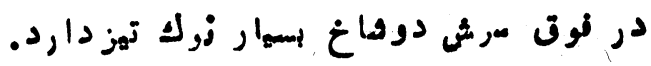

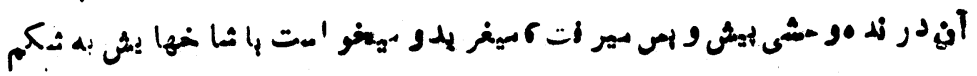

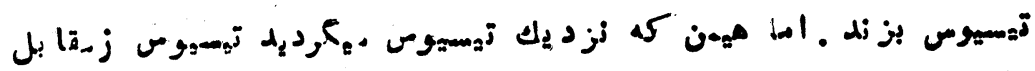
$-119-$ 


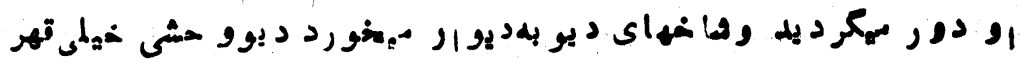

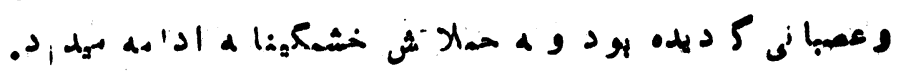

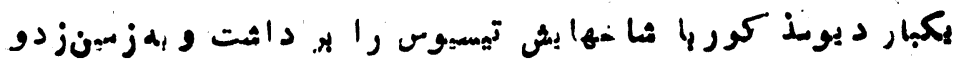

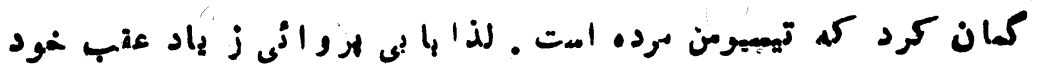

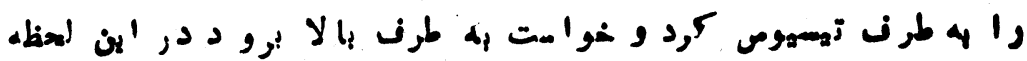

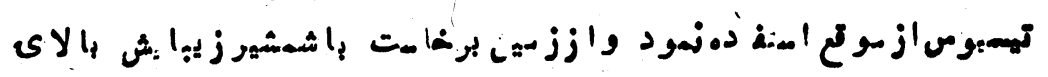

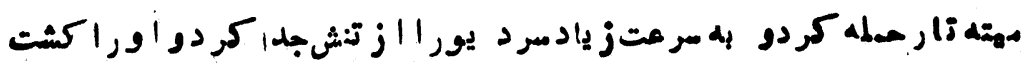

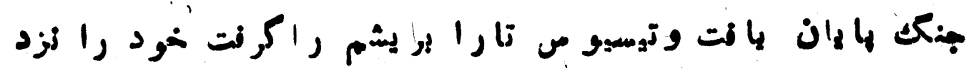

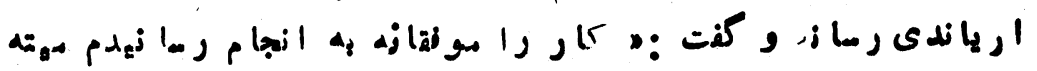

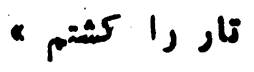

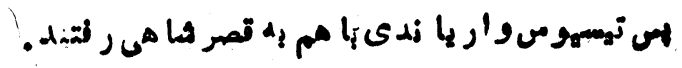

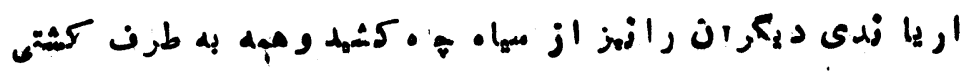

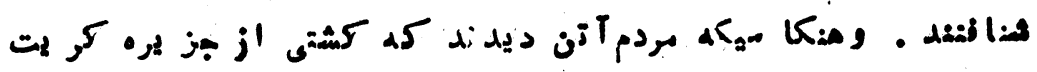

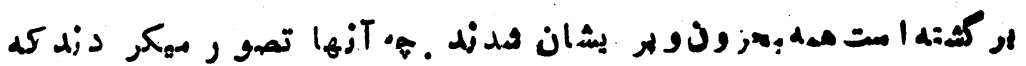

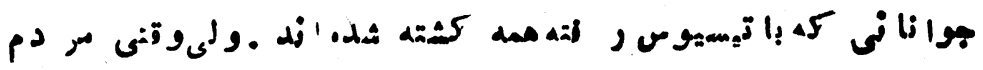

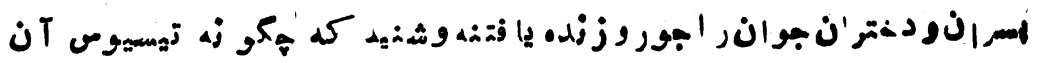

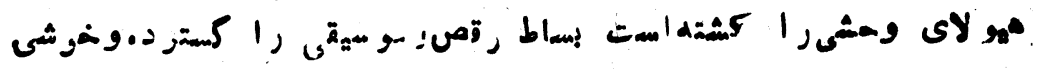

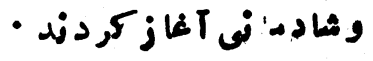

$$
\begin{aligned}
& \text { كمكمفزمايش داستانى }
\end{aligned}
$$

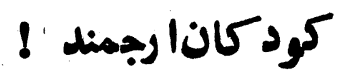

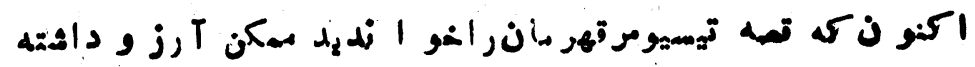

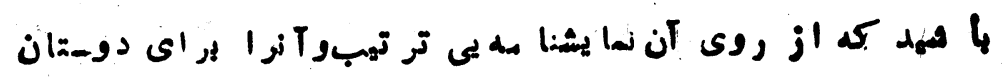

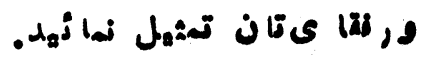




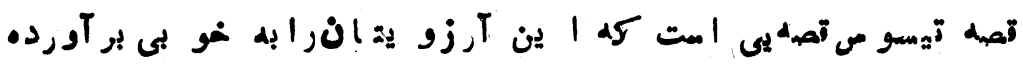

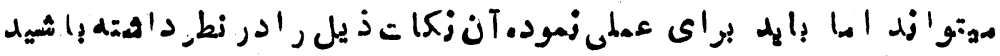

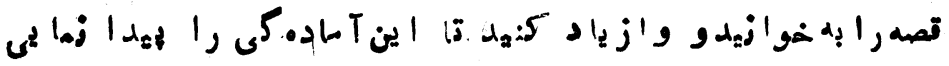

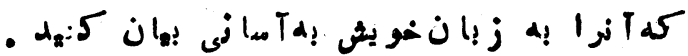

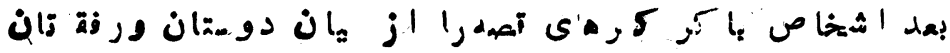

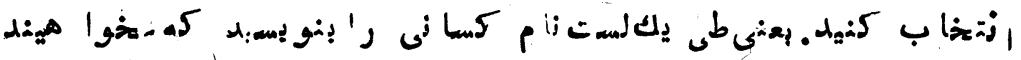

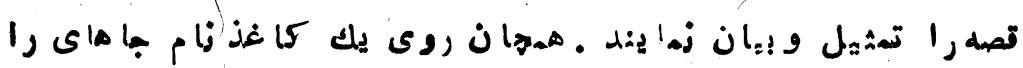

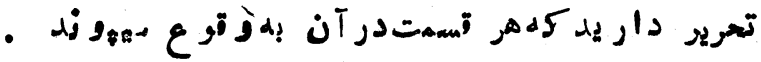

$-|r|-$ 


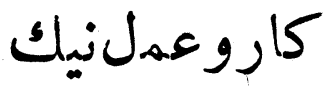

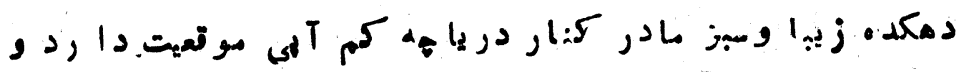

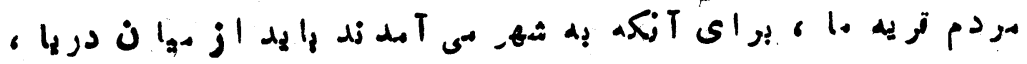

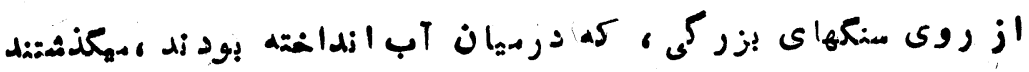

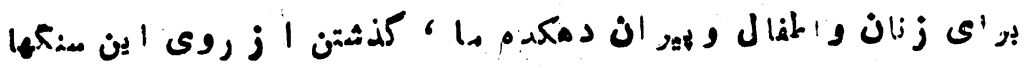

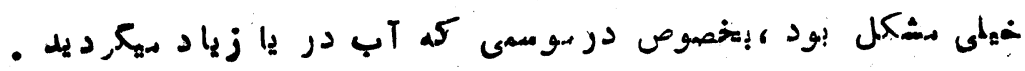

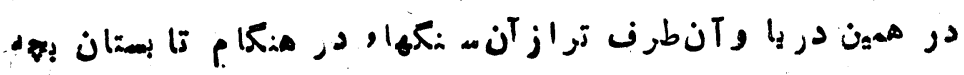

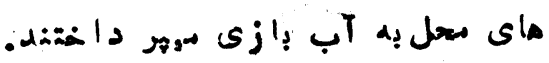

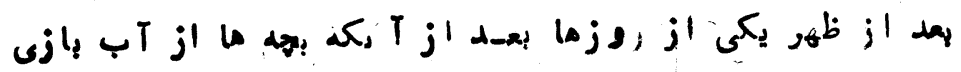

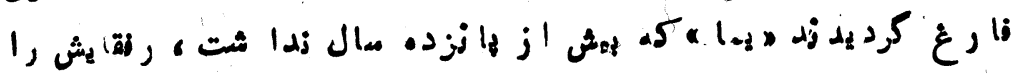
:

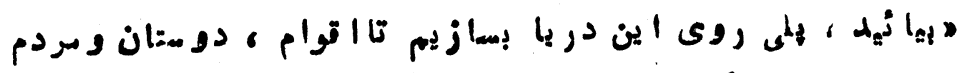

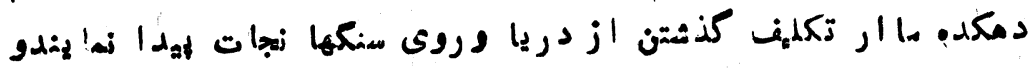

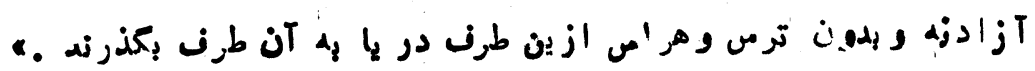

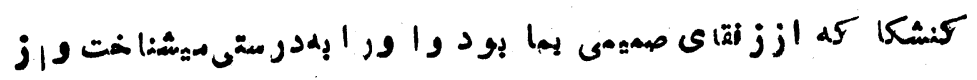

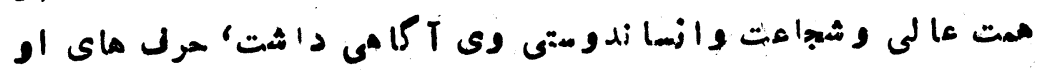

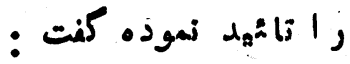

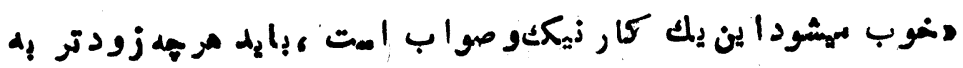
$-1 r r-$ 


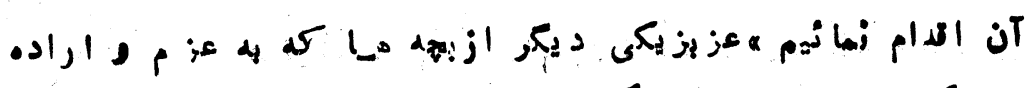
:

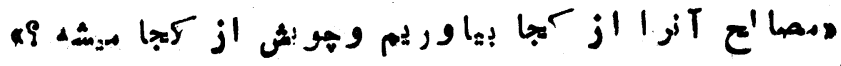

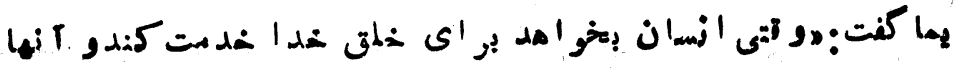

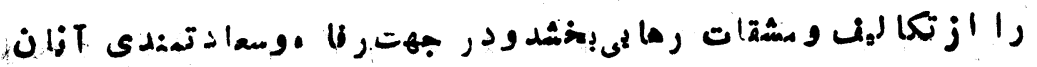

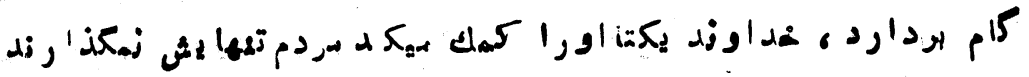

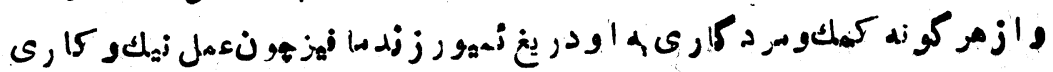

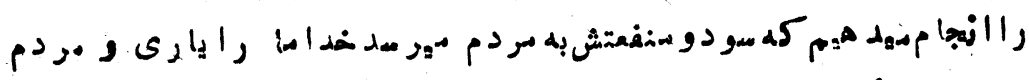

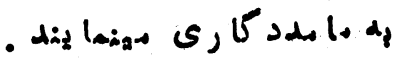

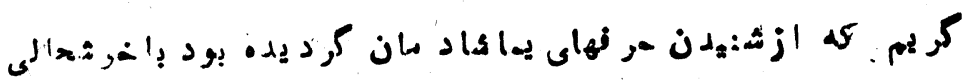

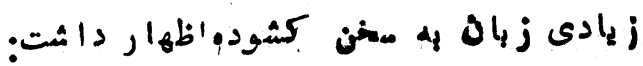

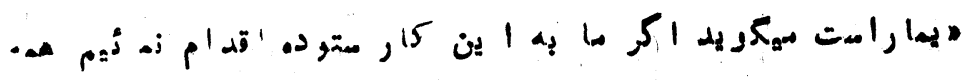

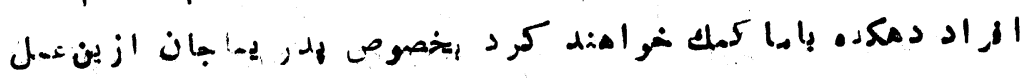

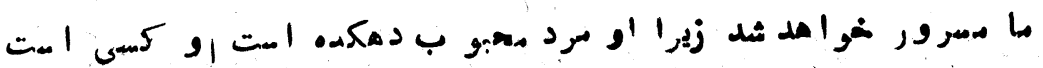

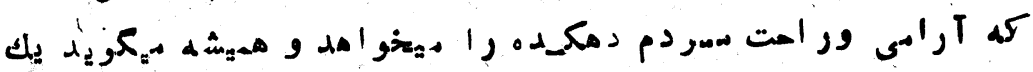

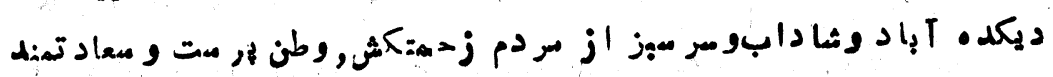

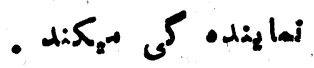

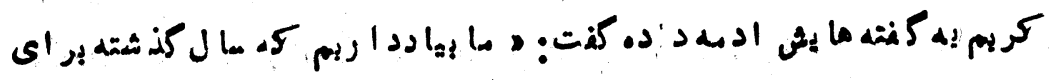

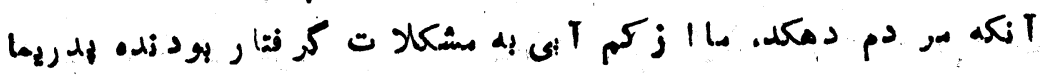

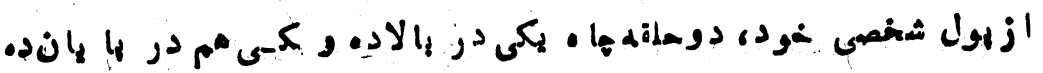
هiر نمود.

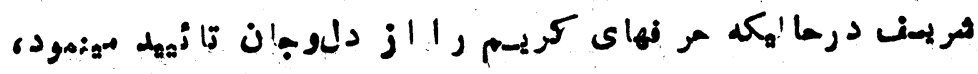
إ -1 rr 


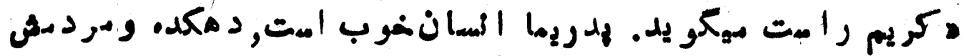

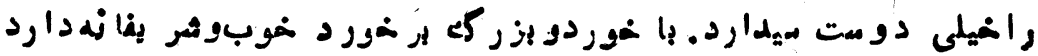

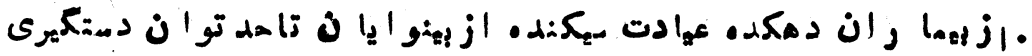

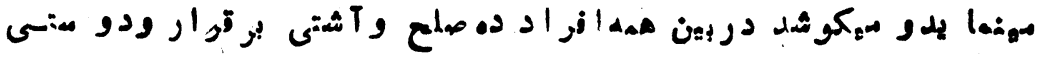

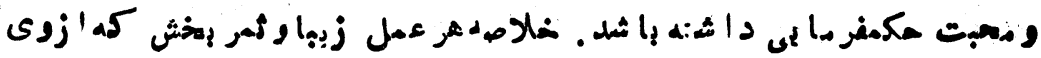

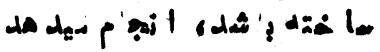

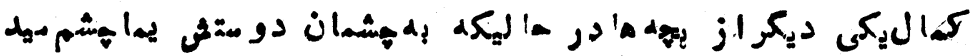
وخت، كمت:

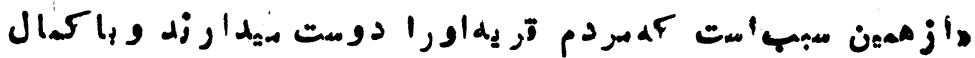

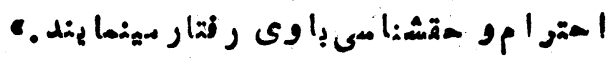

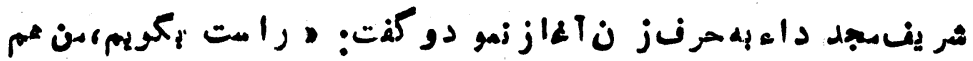

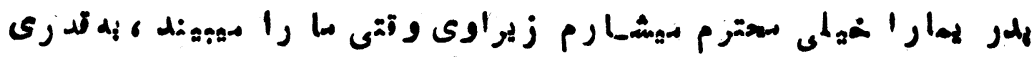

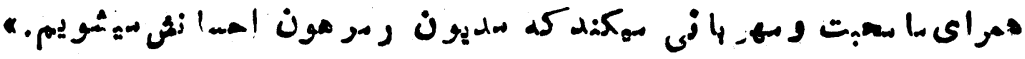

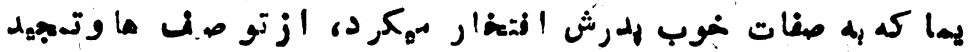

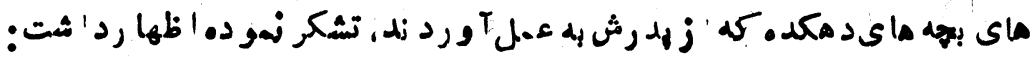

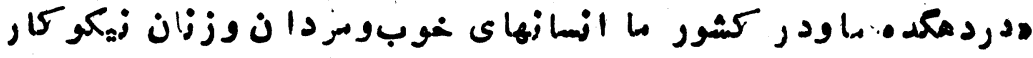

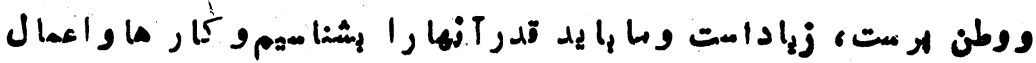

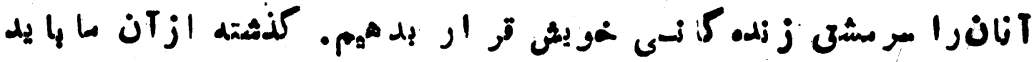

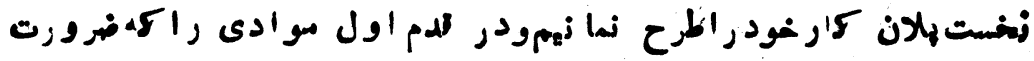

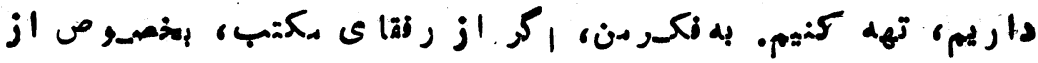

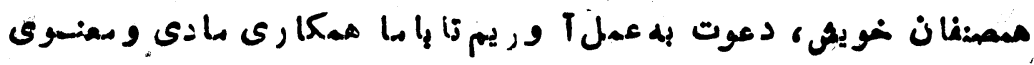

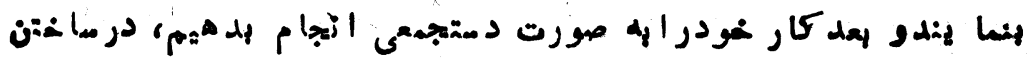

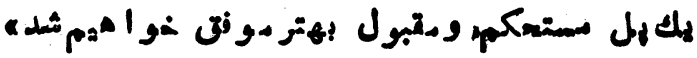




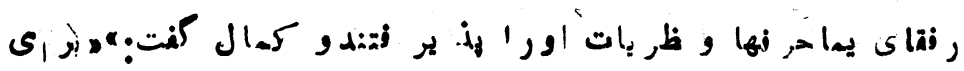

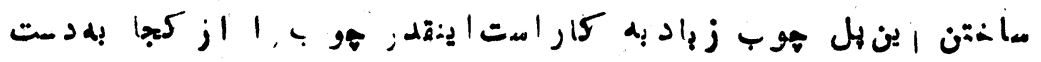

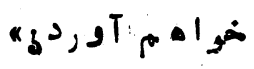

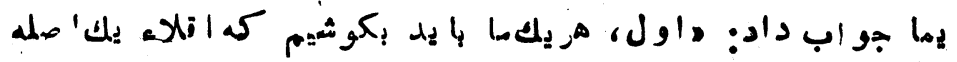

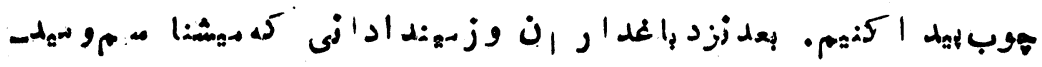

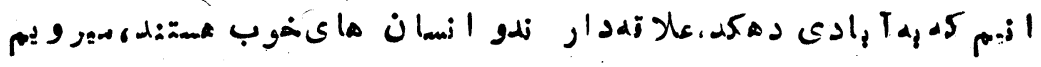

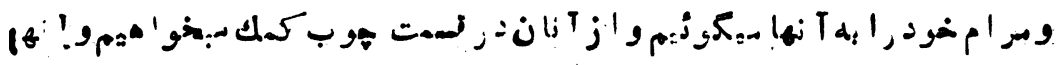

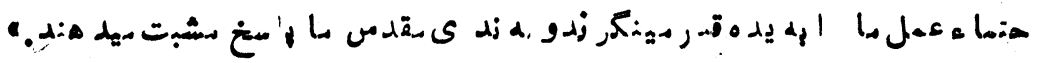

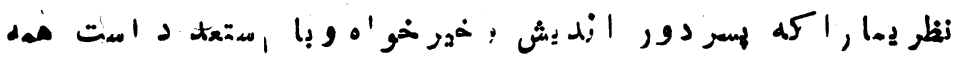
.

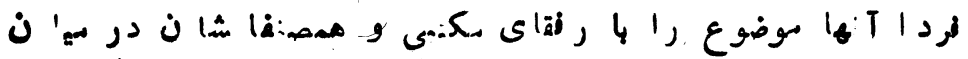

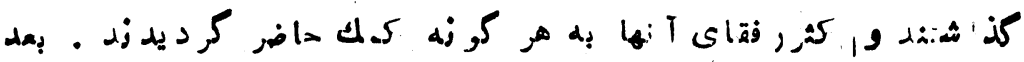

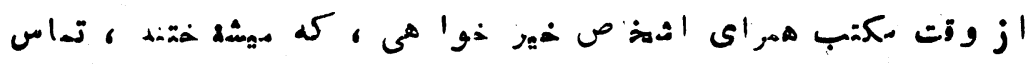

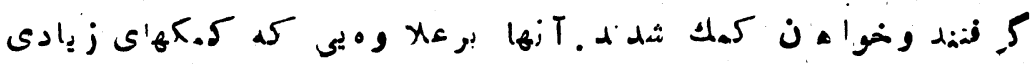

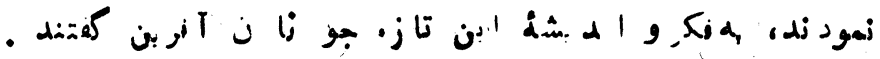
* * *

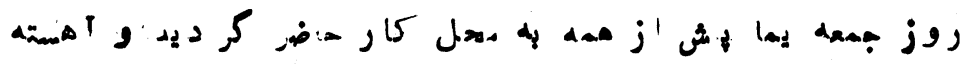

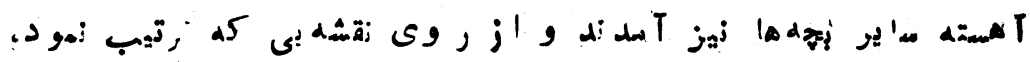

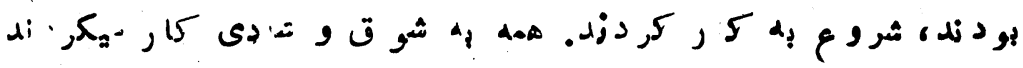

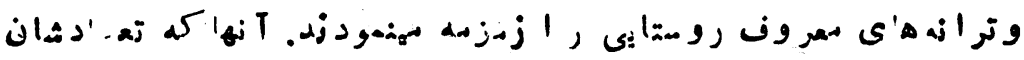

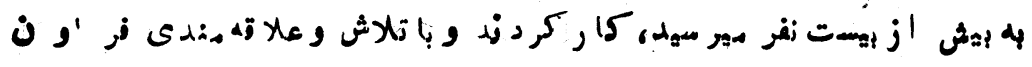

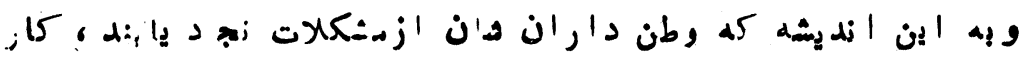

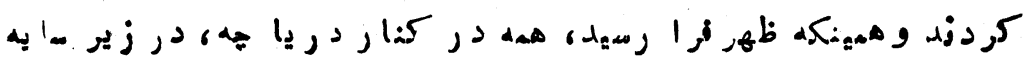

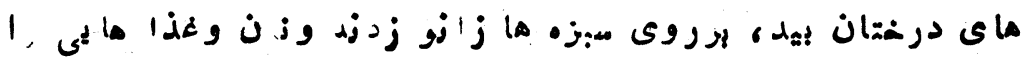

$-160-$ 


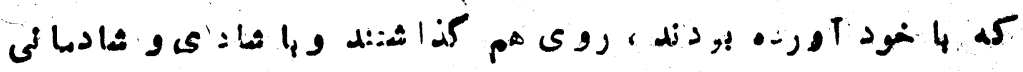

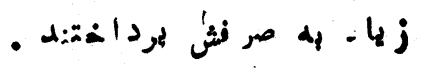

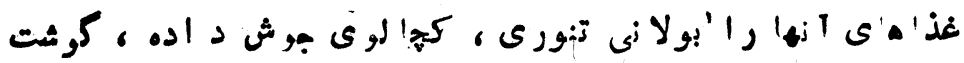

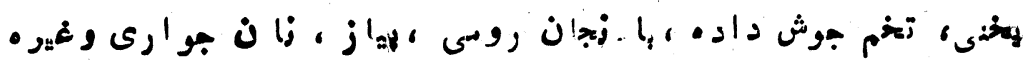

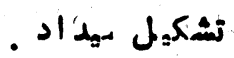

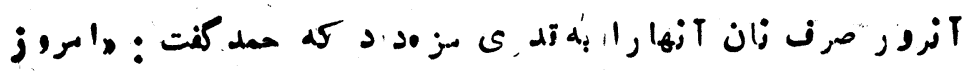

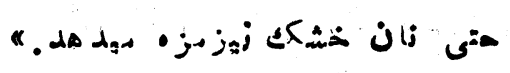

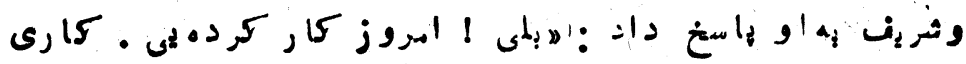

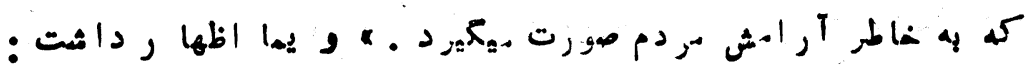

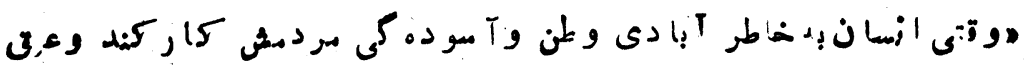

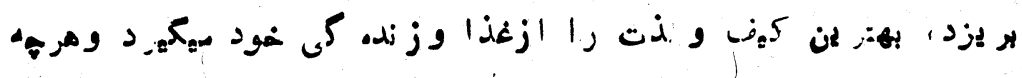

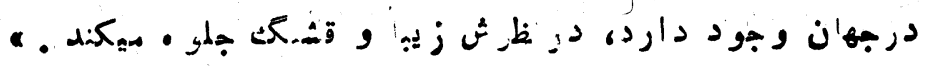

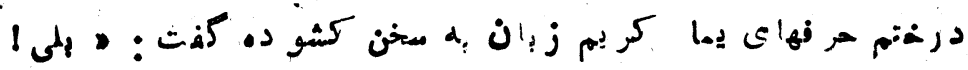

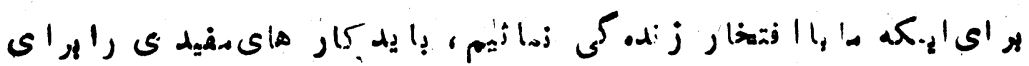

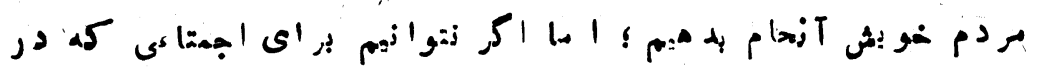

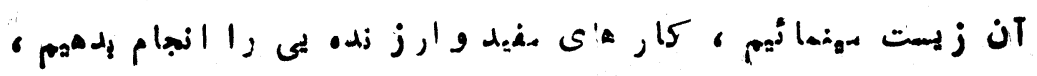

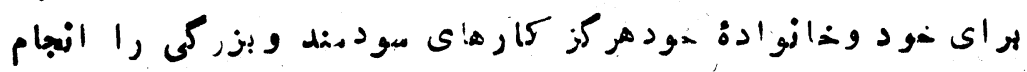

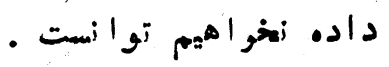

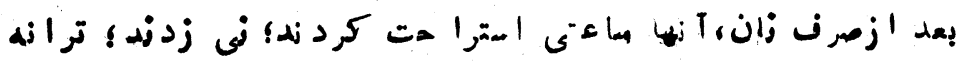

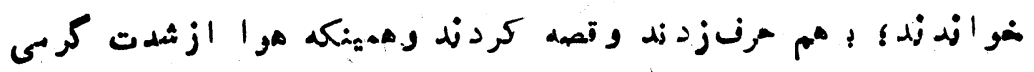

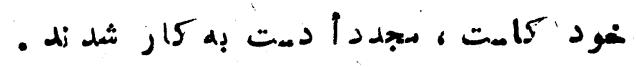

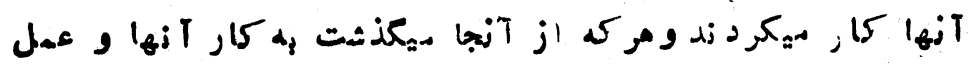

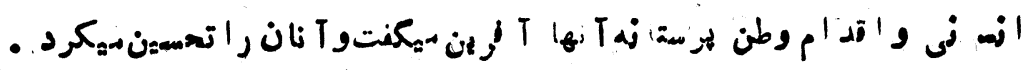




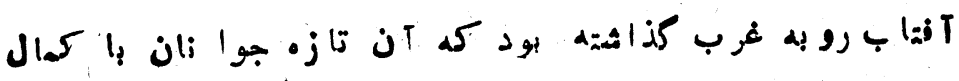

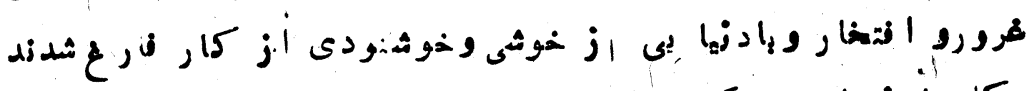

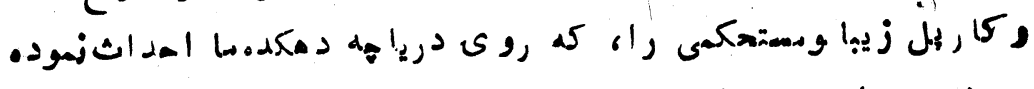

ك

آ

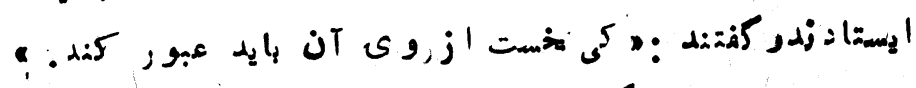

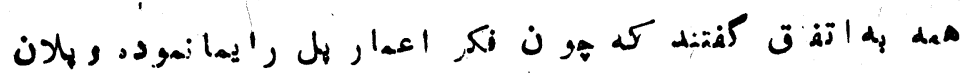

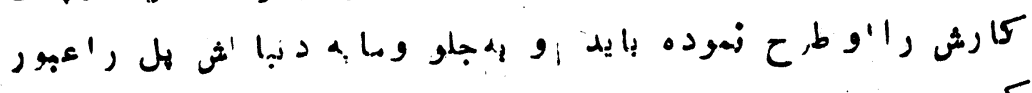

كن

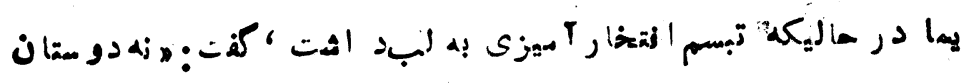

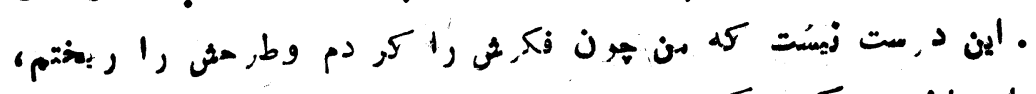

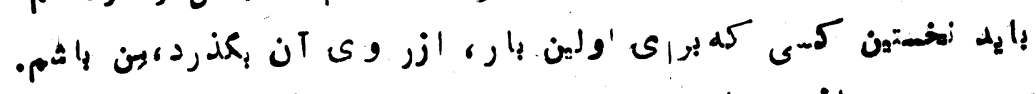

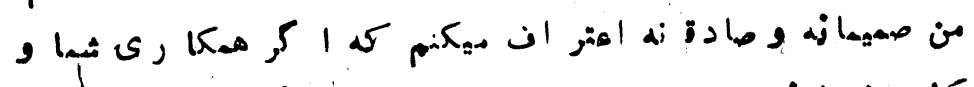

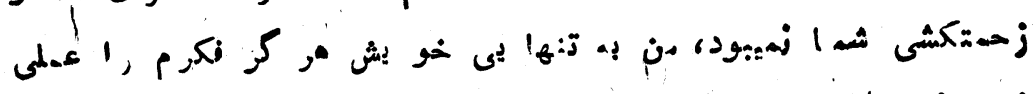

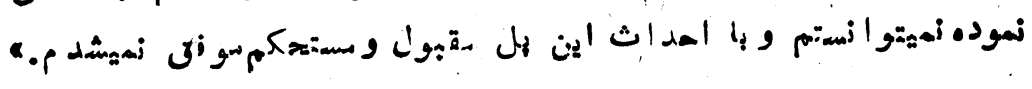

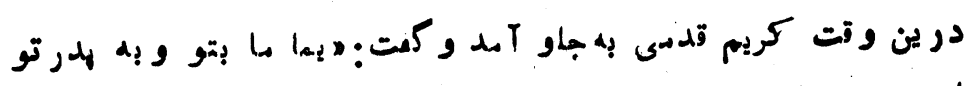

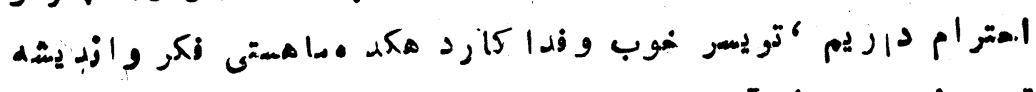

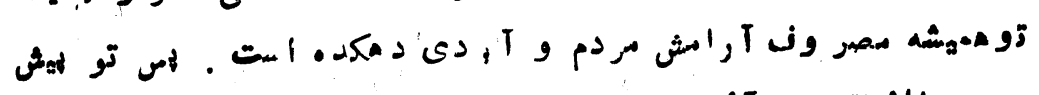

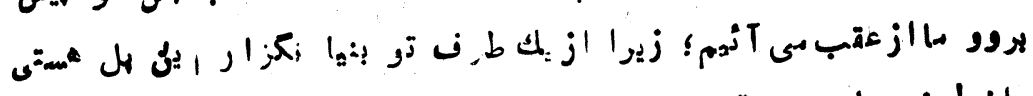

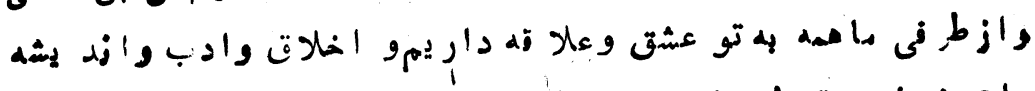

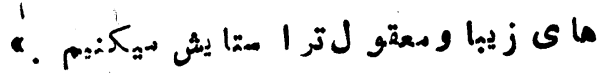

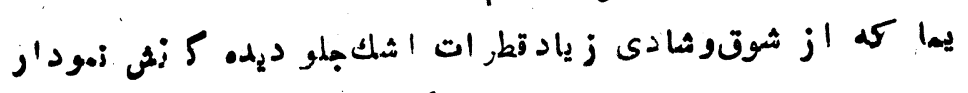

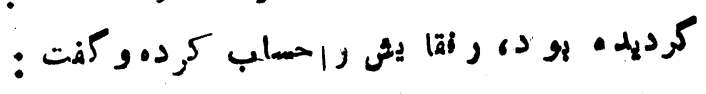
$-1 r v-$ 


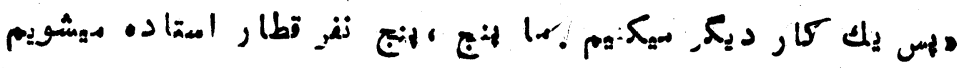

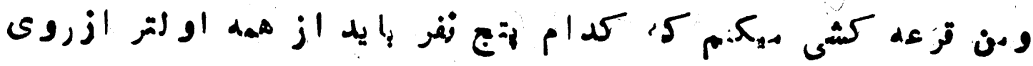
*

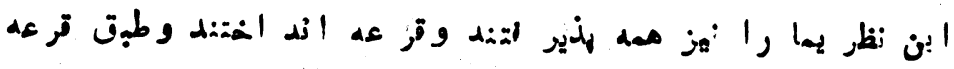

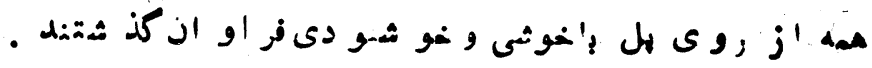

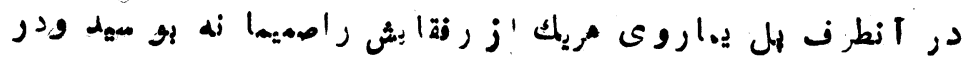

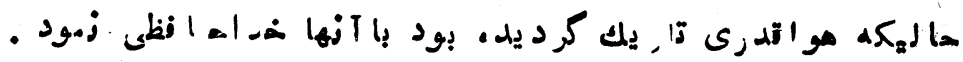

* * *

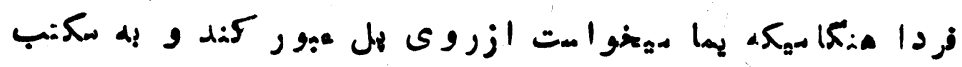

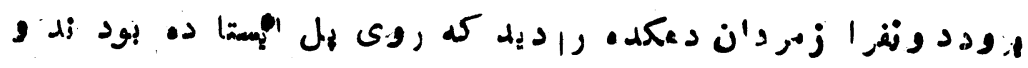

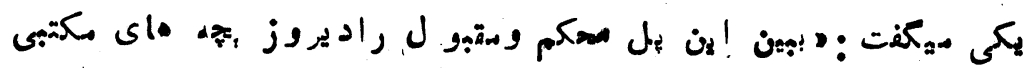

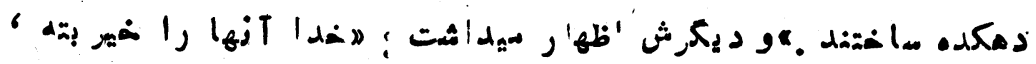

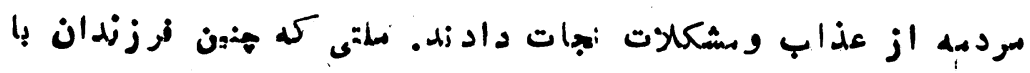

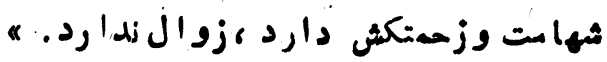

- ira- 


\section{جوبتراشير}

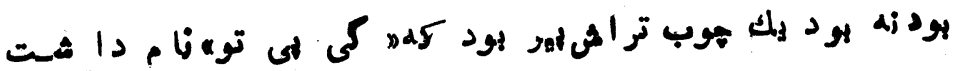

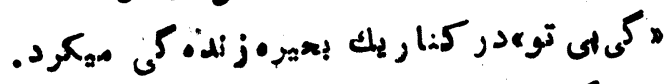

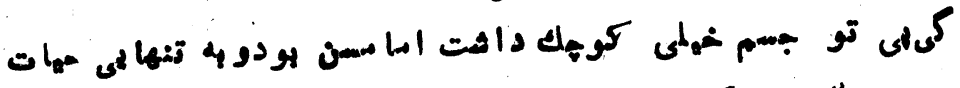

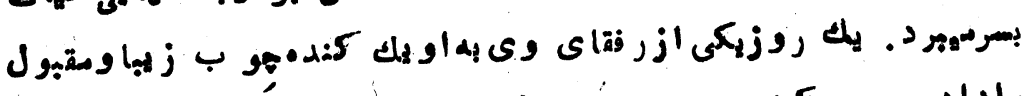

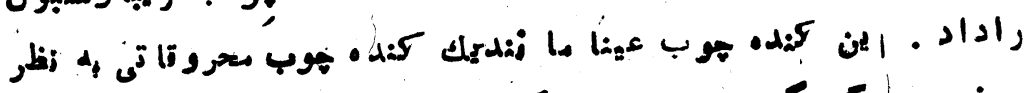

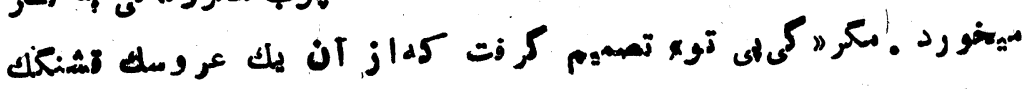

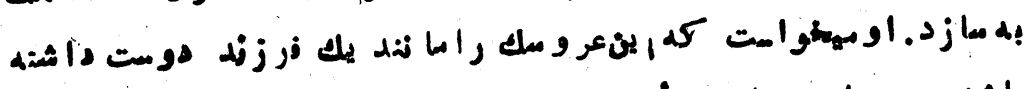

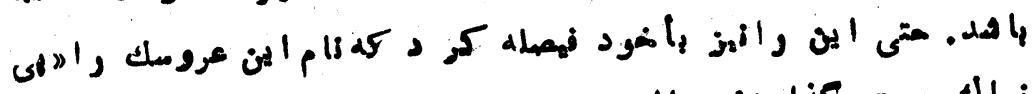

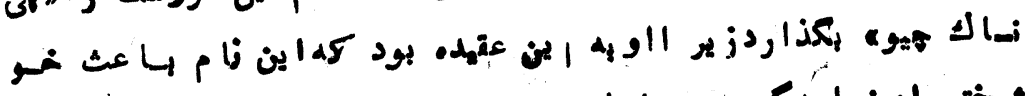

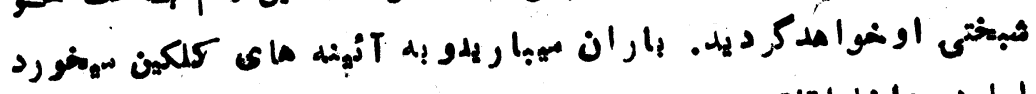

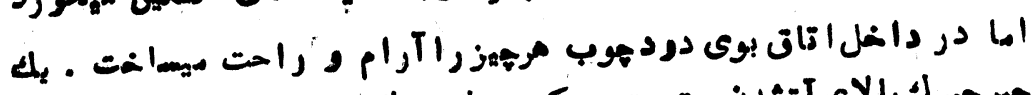

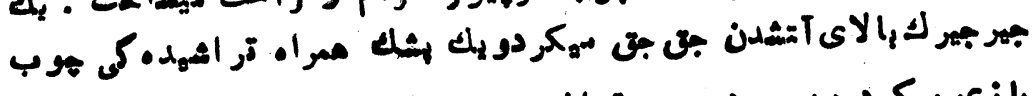

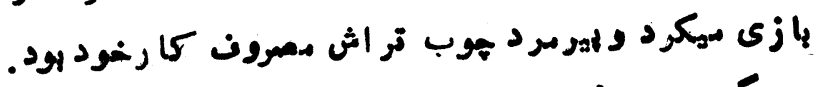

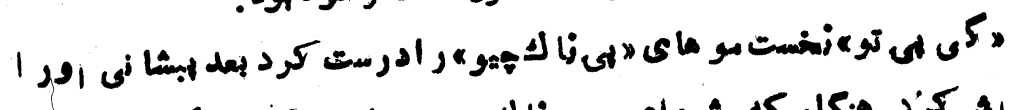

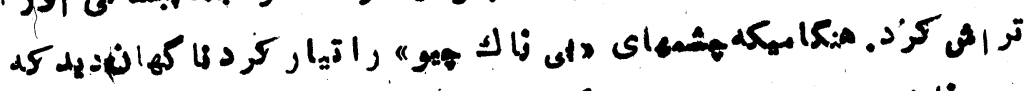

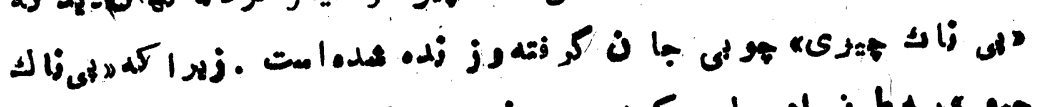

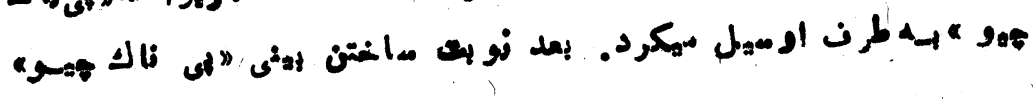




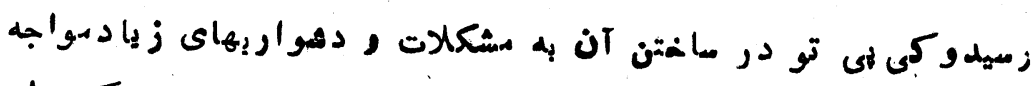

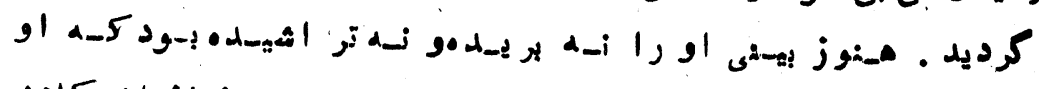

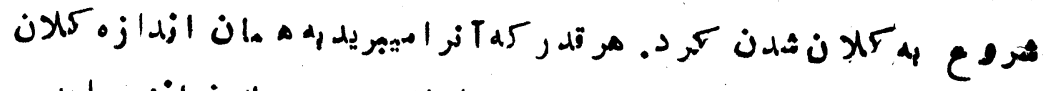

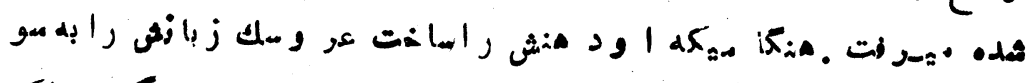

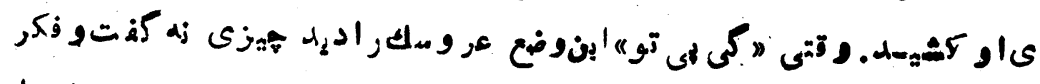

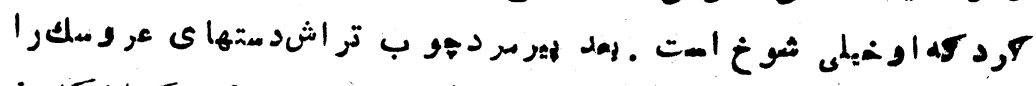

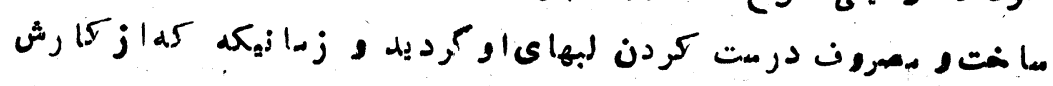

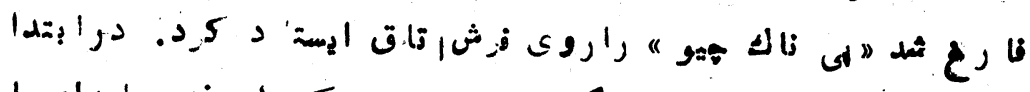

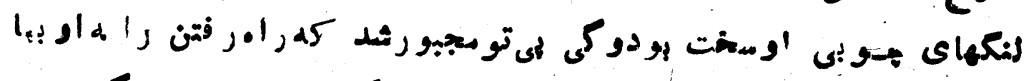

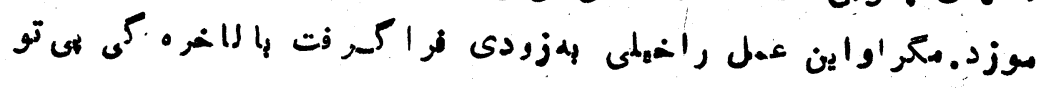

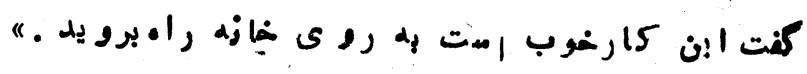

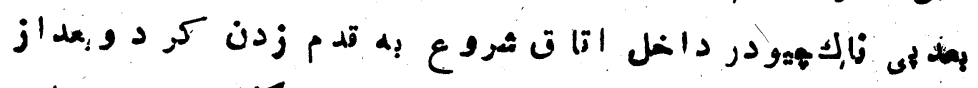

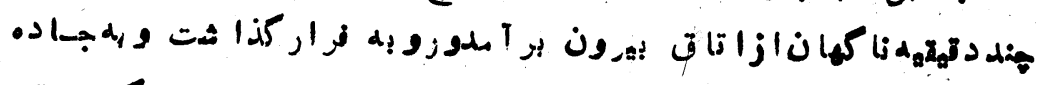

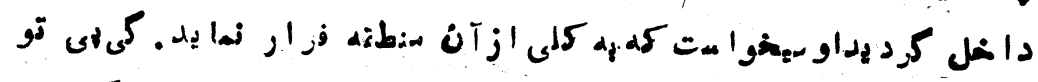

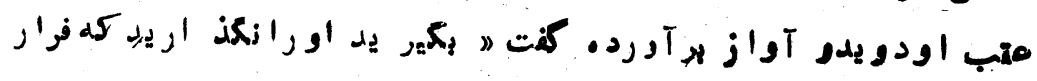

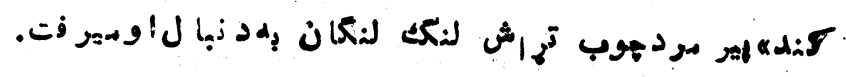

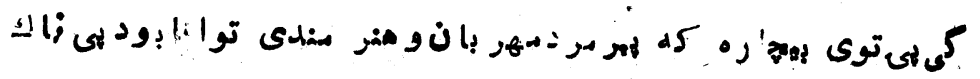

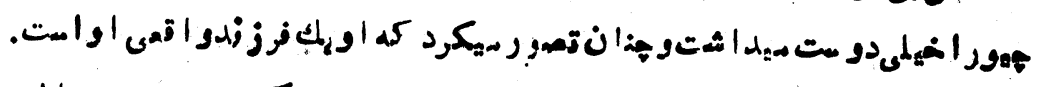

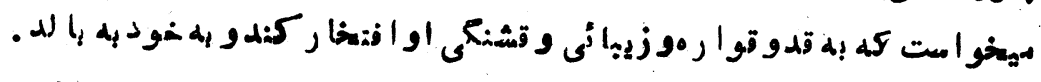

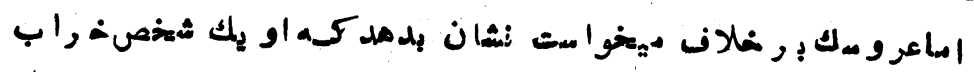

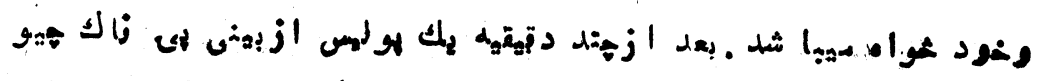

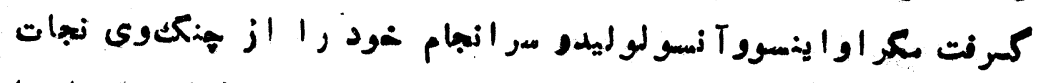

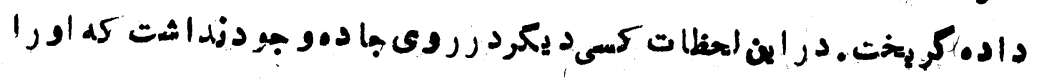




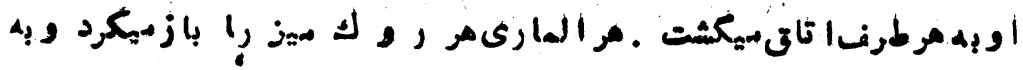

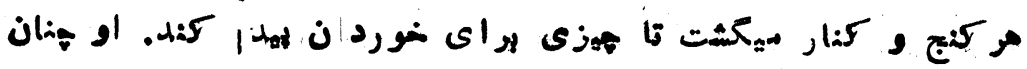

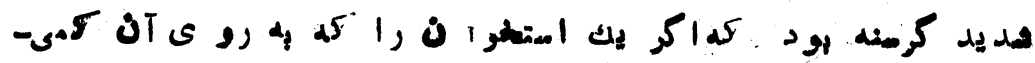

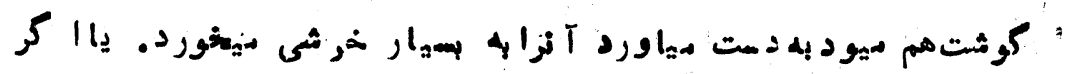

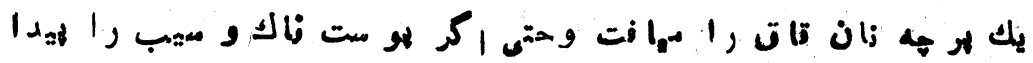

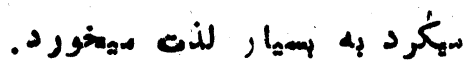

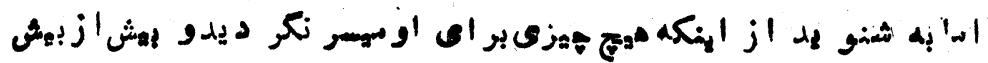

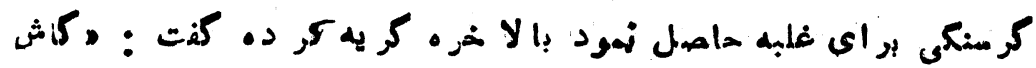

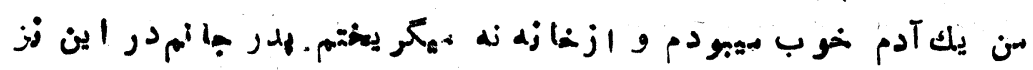

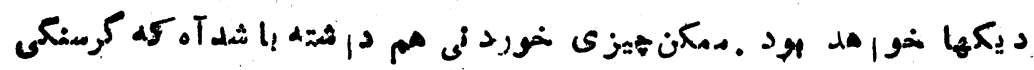

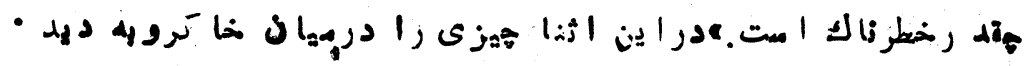

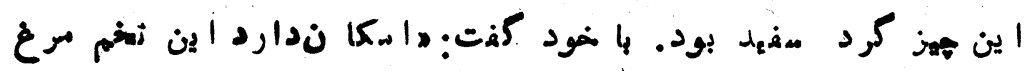

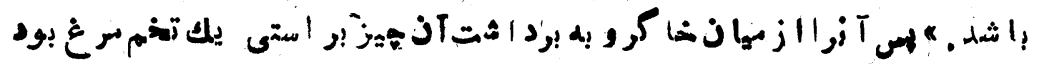

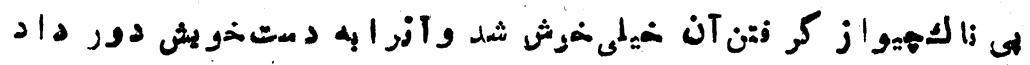

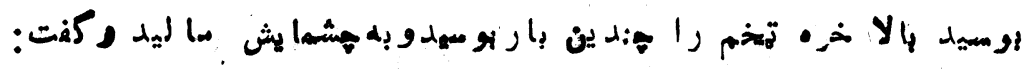

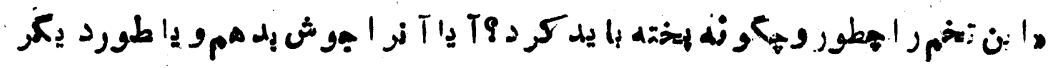

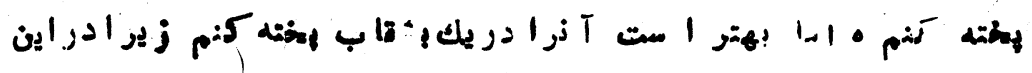

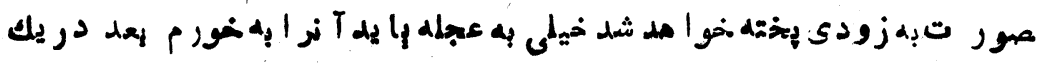

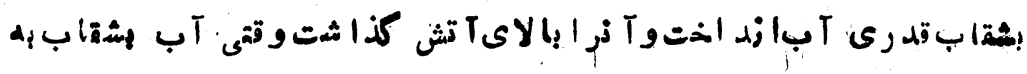

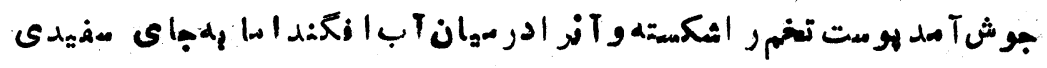

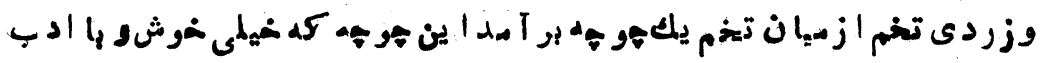

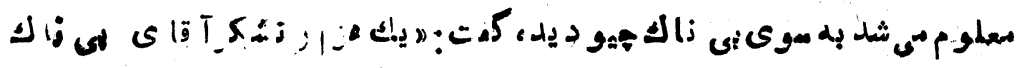




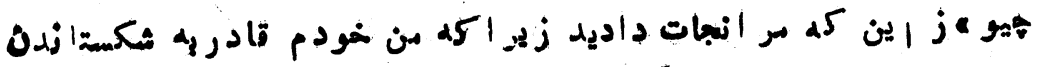

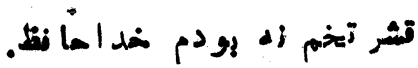

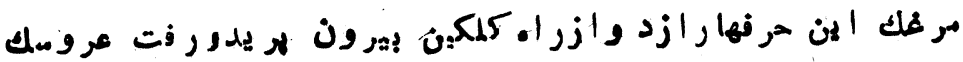

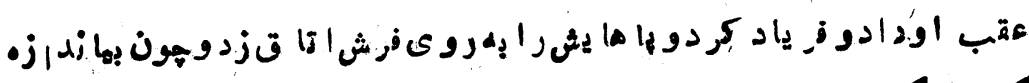

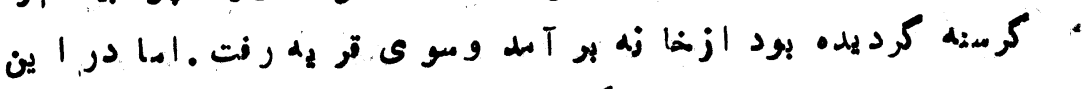

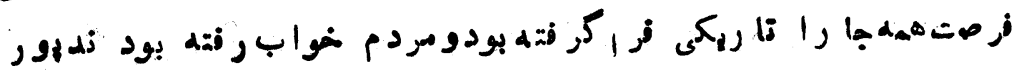

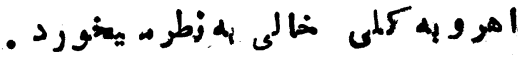

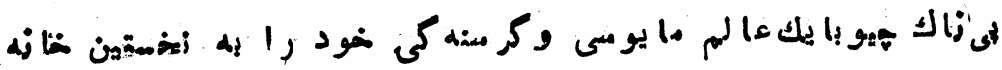

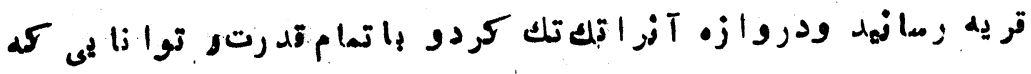

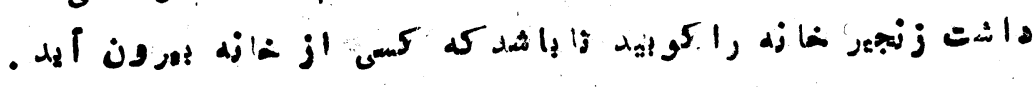

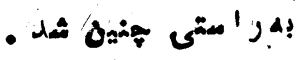

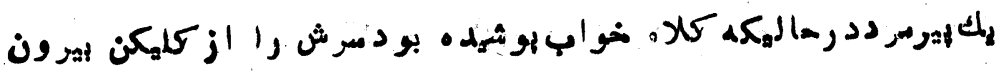

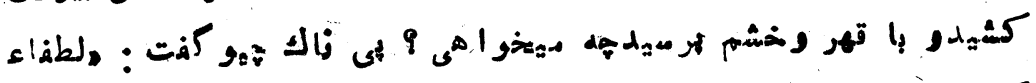

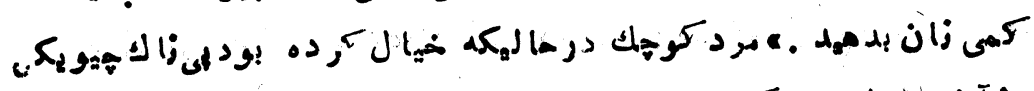

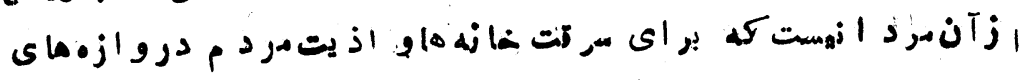

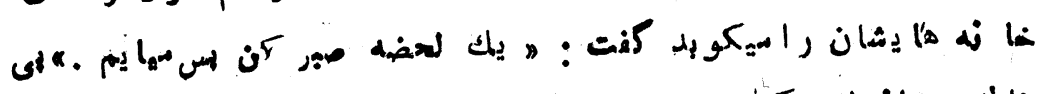

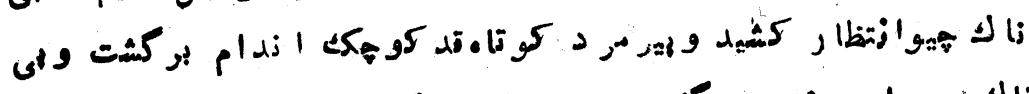

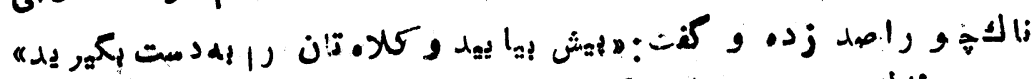

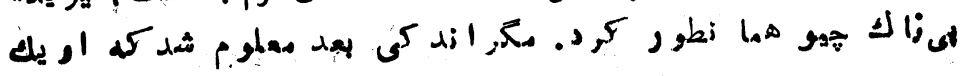

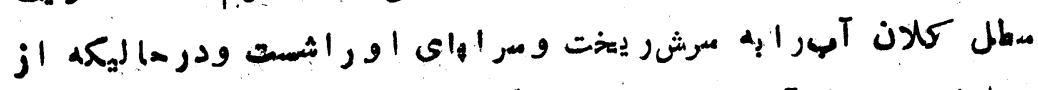

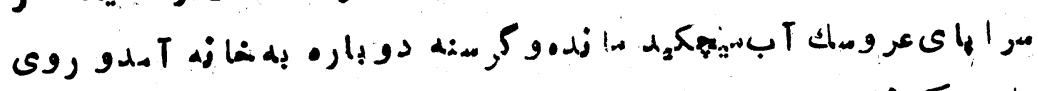

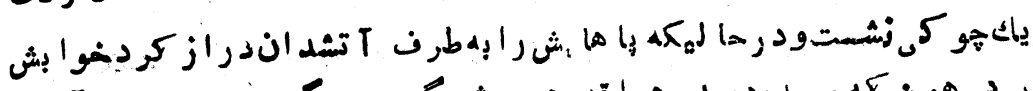

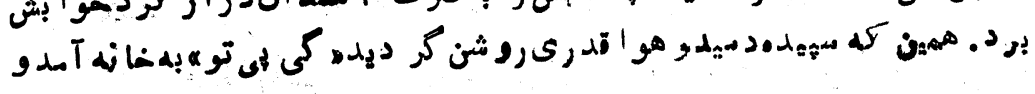




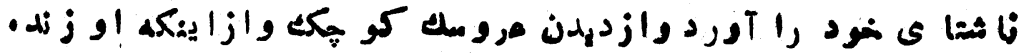

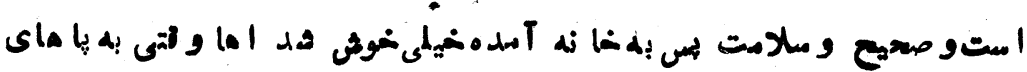

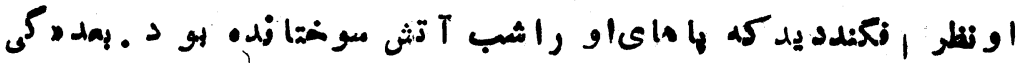

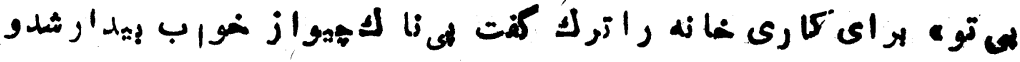

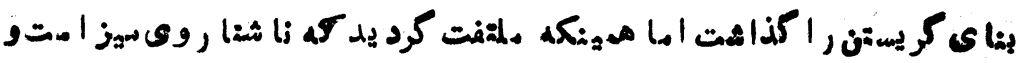

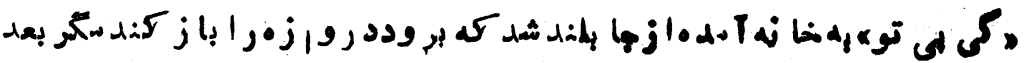

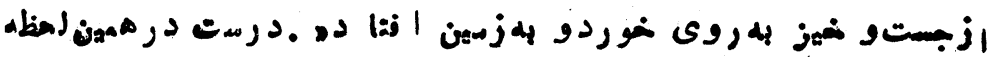

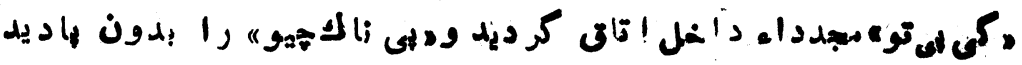

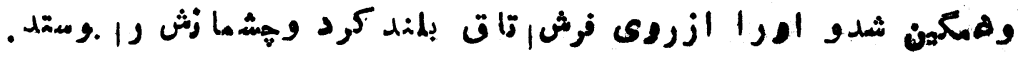

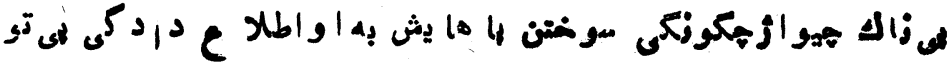

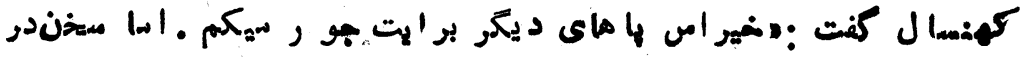

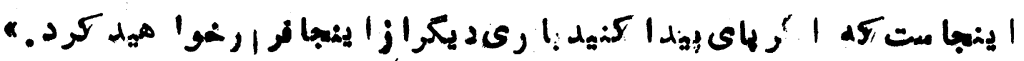

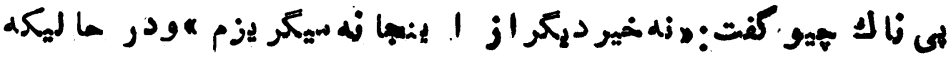

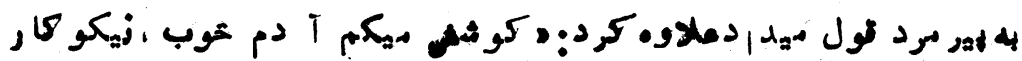

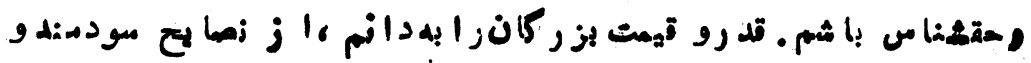

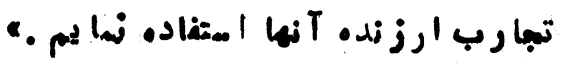

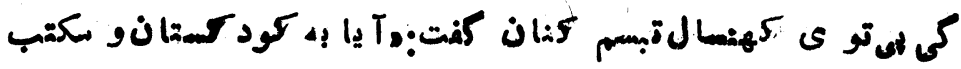

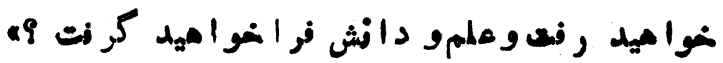

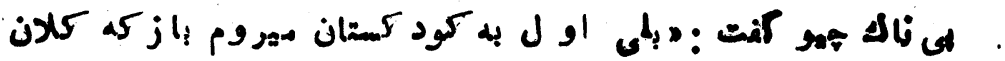

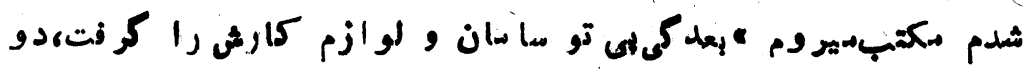

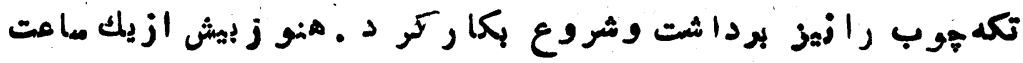

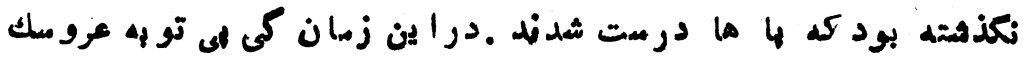

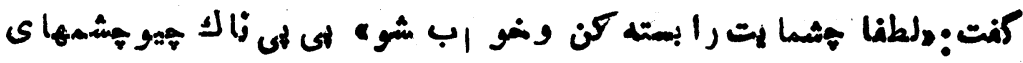




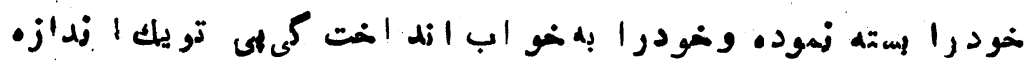

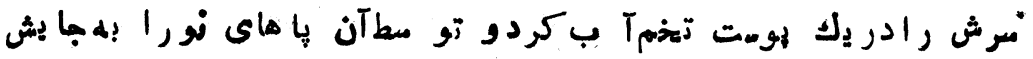
.

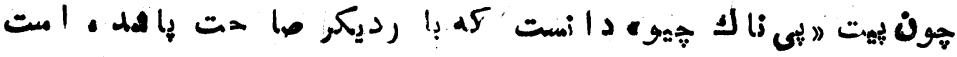

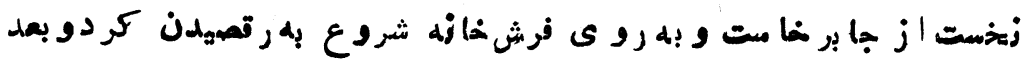

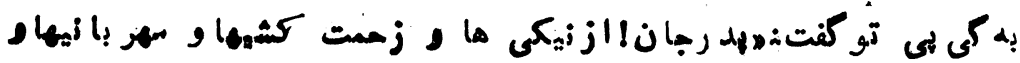

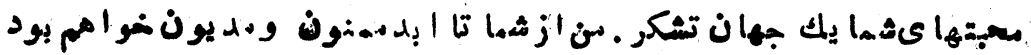

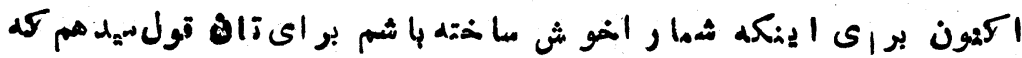

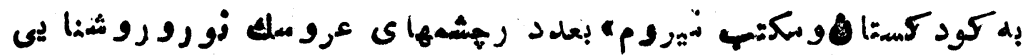

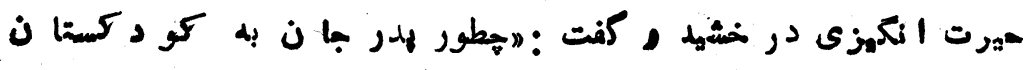

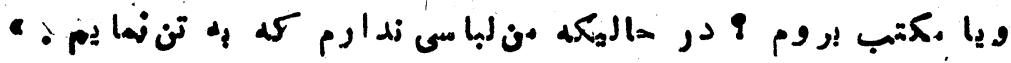

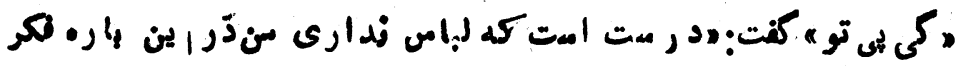

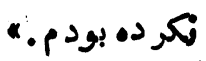

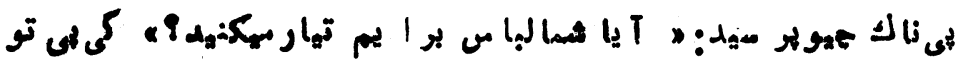

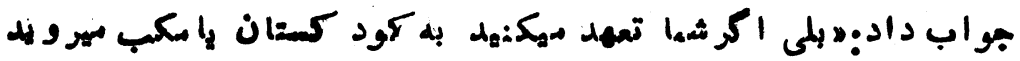

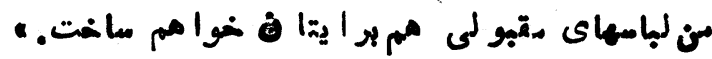

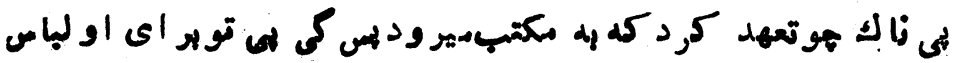

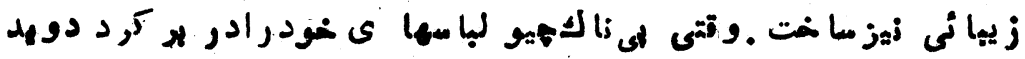

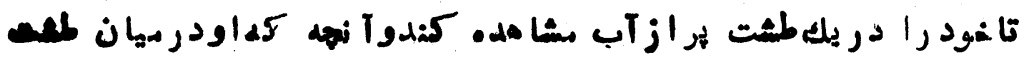

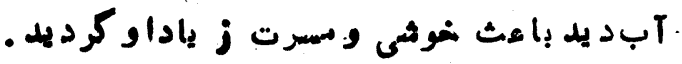

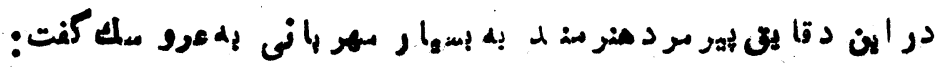

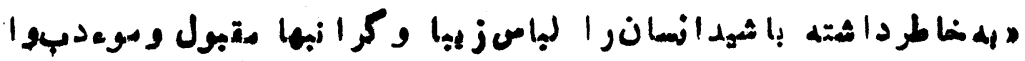




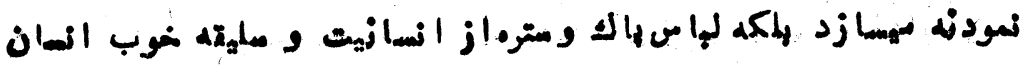

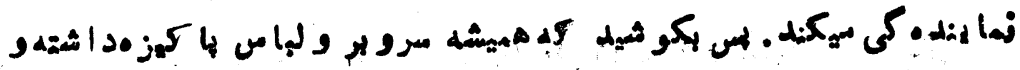

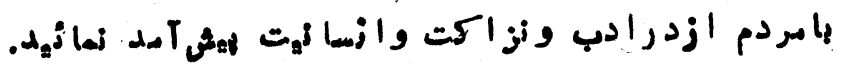

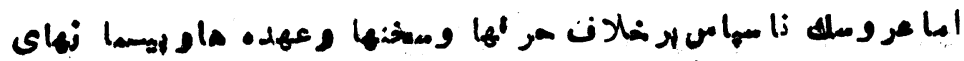

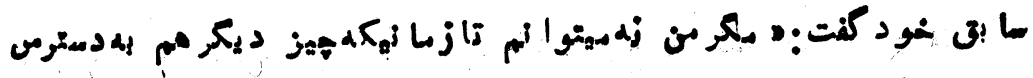

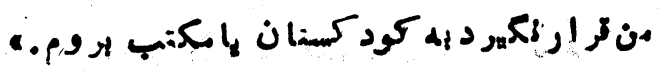

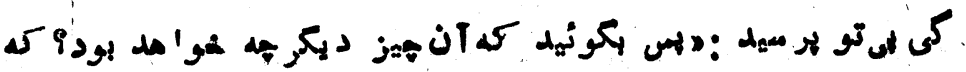

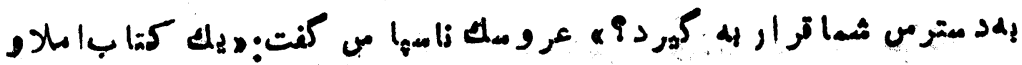

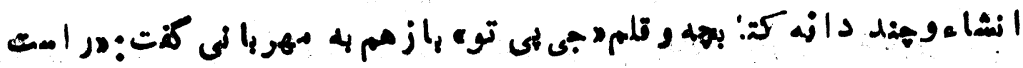

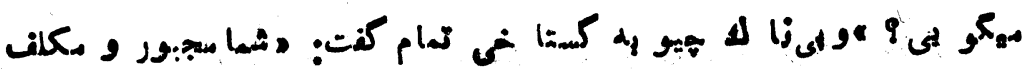

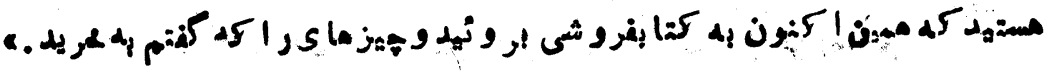

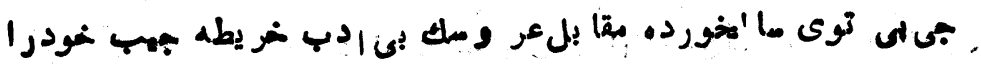

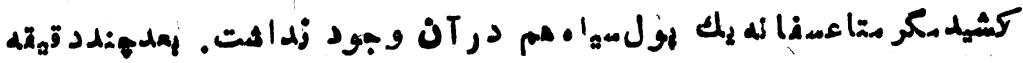

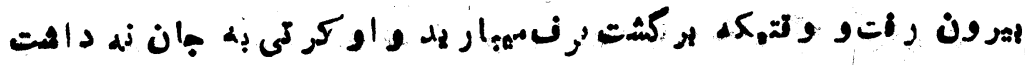

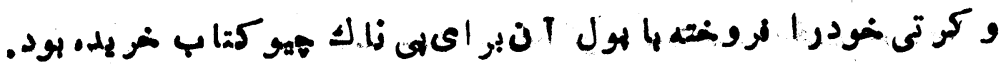

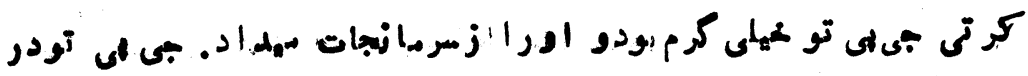

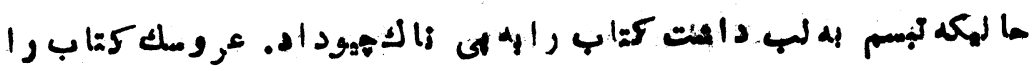

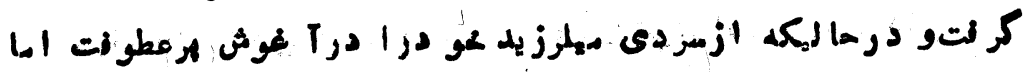

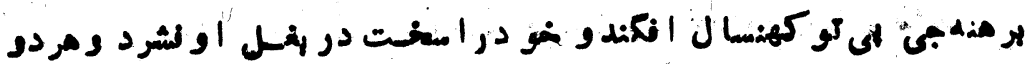

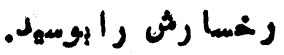

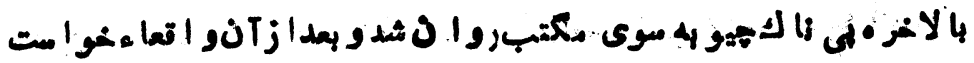
تا يك آدم غوب الرآد. 


\section{تياقترع وبسلة}

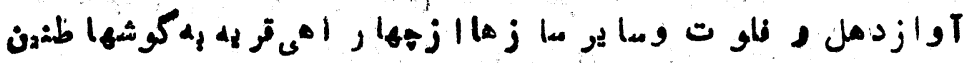

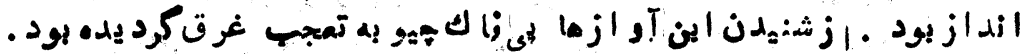

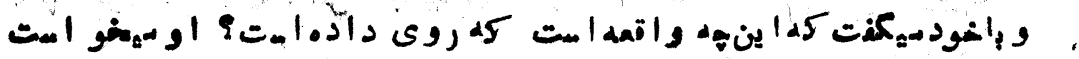

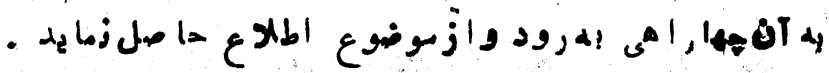

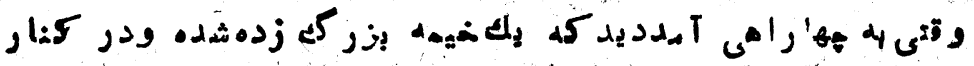

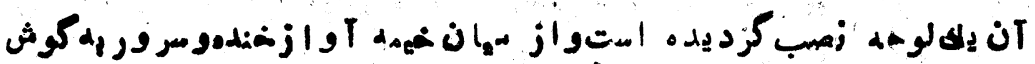
مهو ميد.

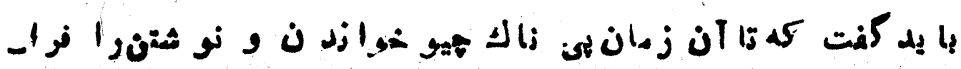

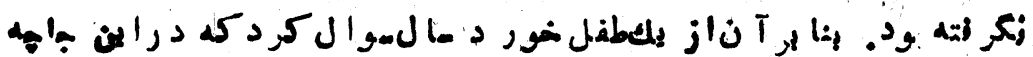

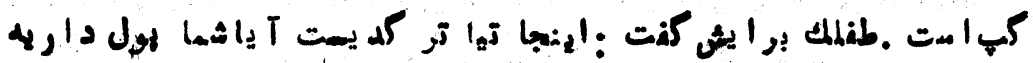

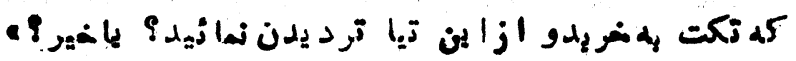

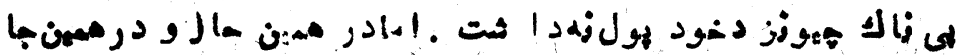

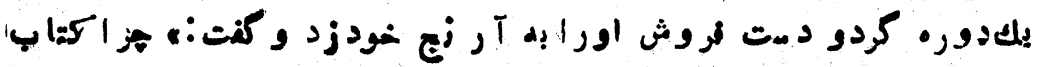

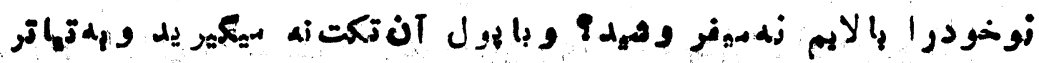

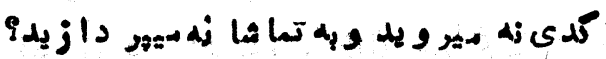

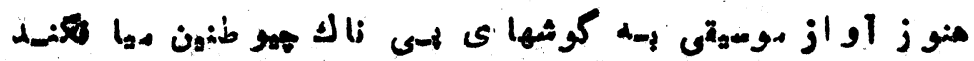

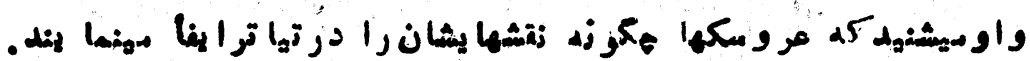

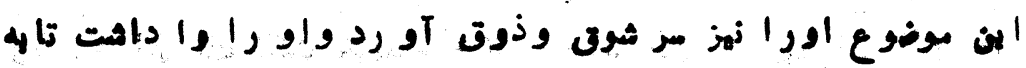

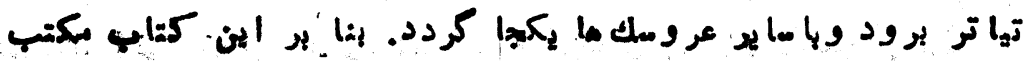

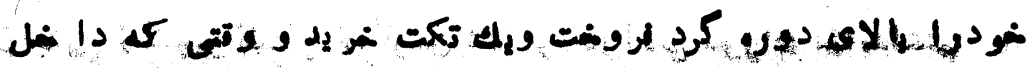

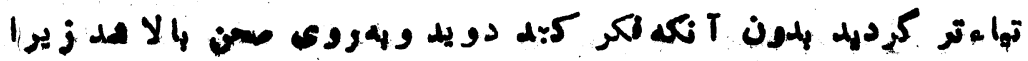




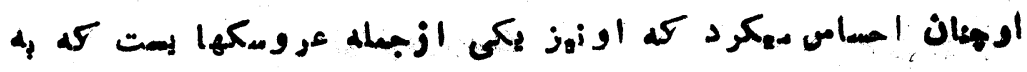

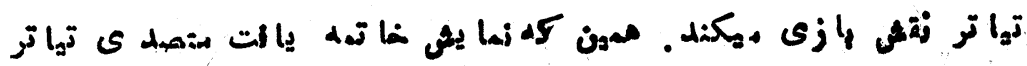

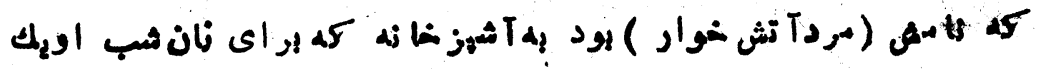

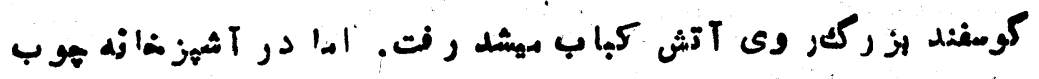

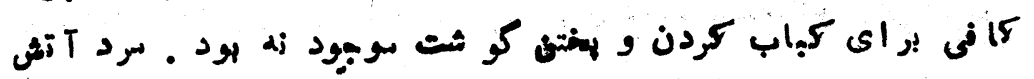

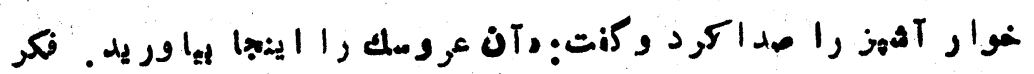

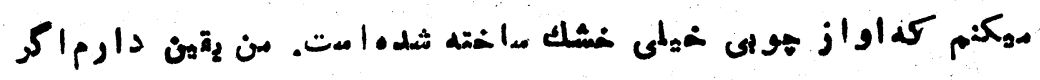

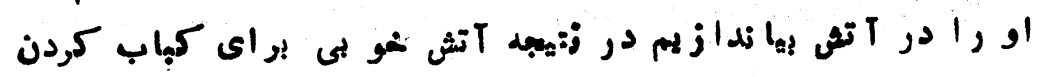

آماده دوعكردد . .

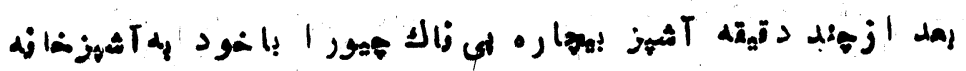

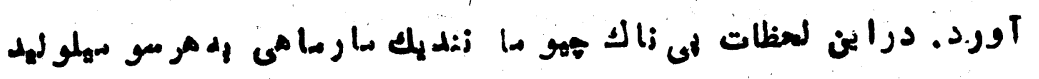

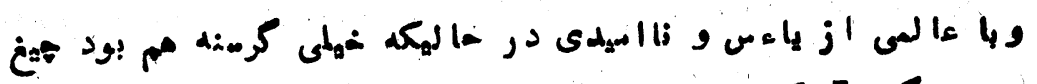

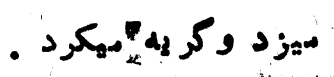

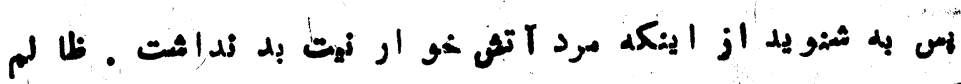

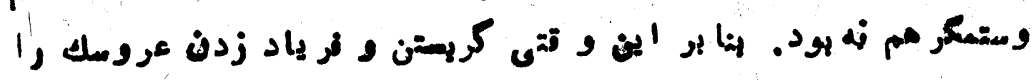

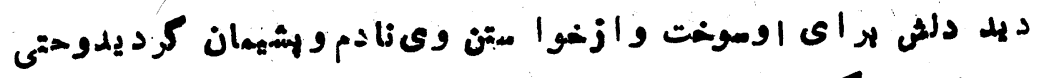

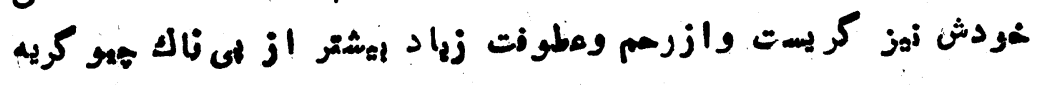

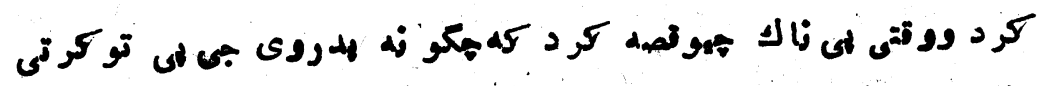

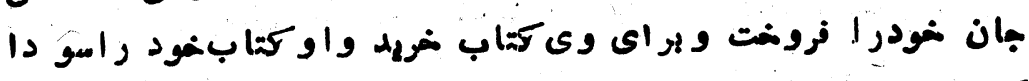

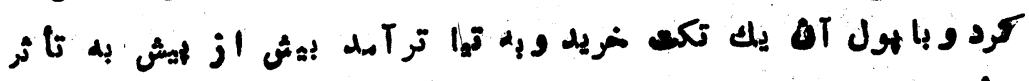

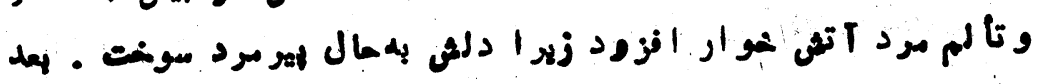

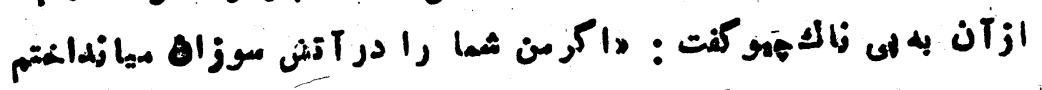

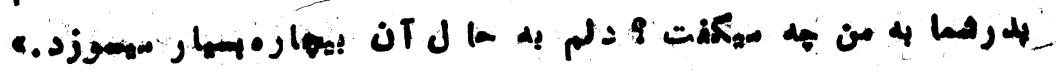

tira 


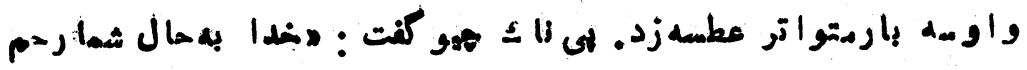

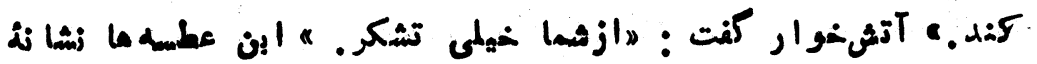

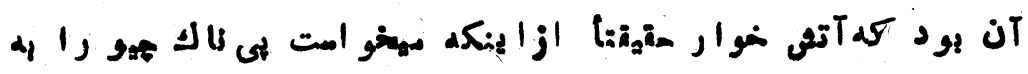

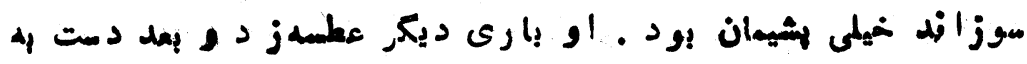

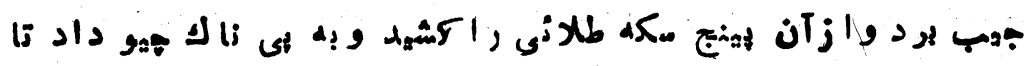

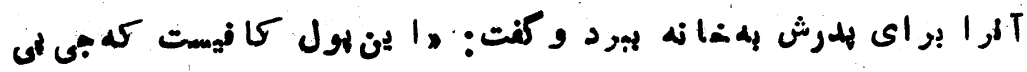

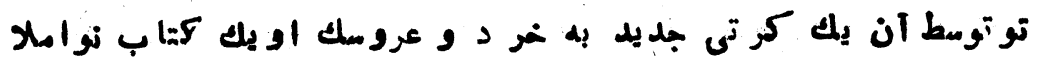

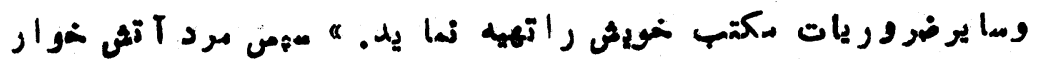

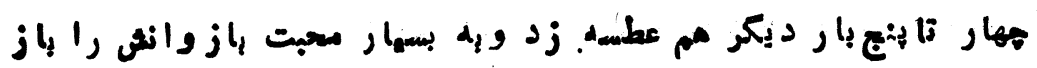

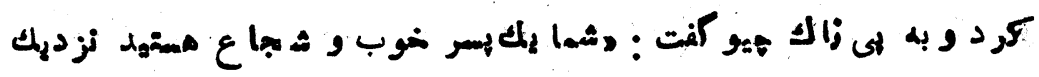

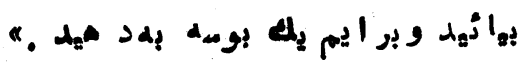

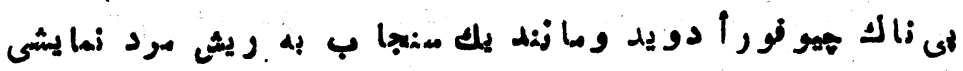

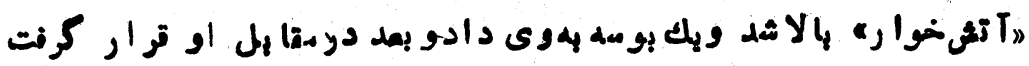

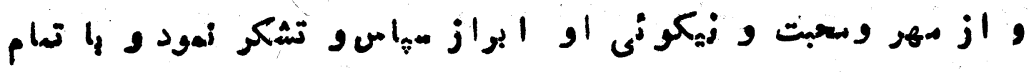

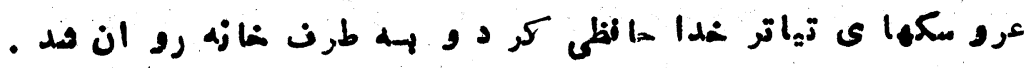

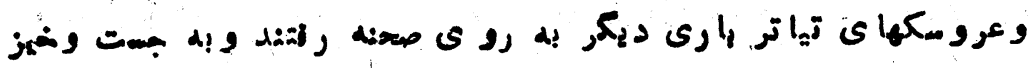

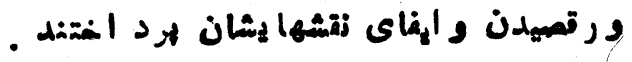

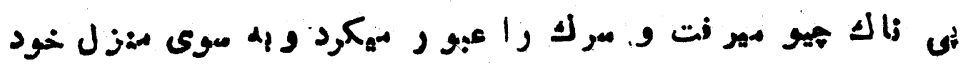

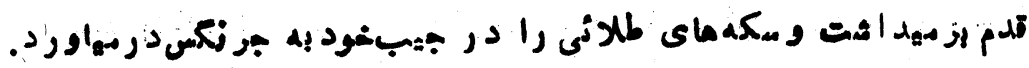

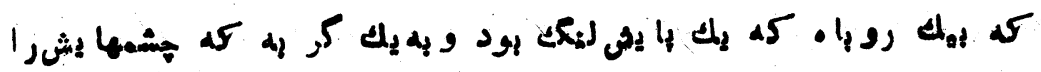

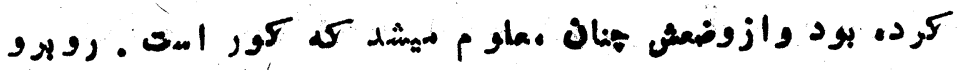

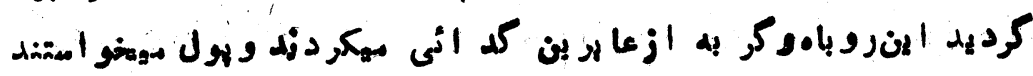

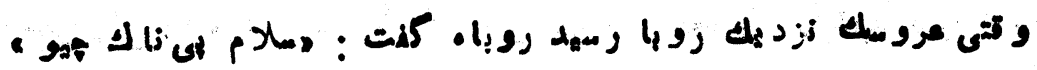
Irq- 


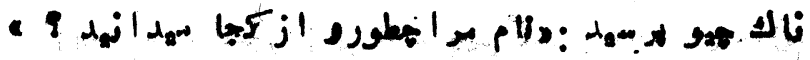

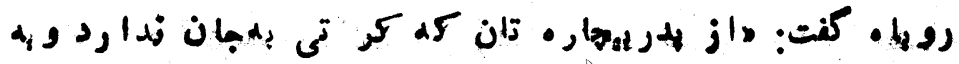

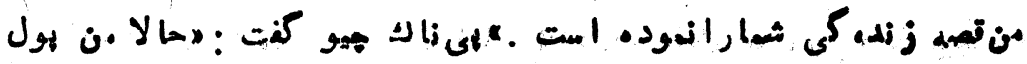

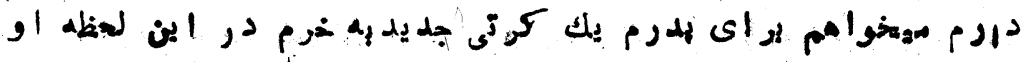

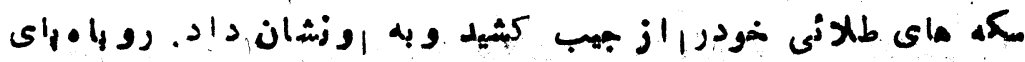

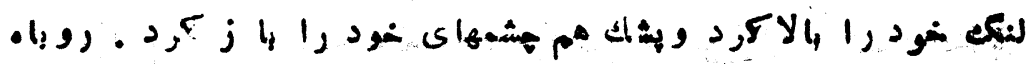

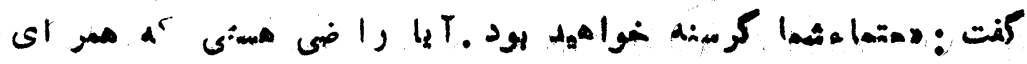

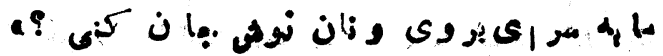

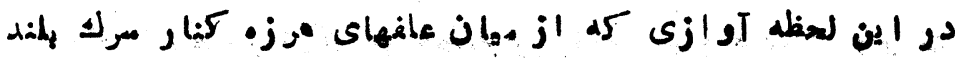

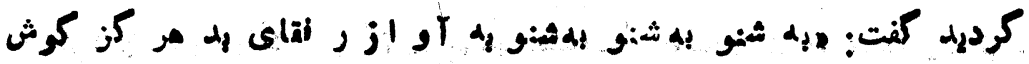

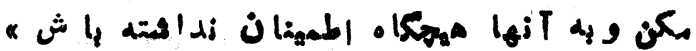

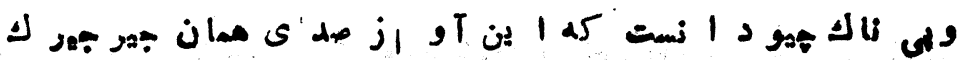

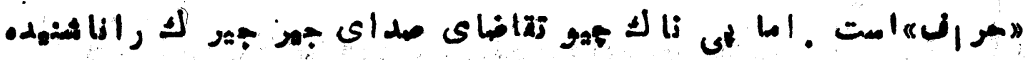

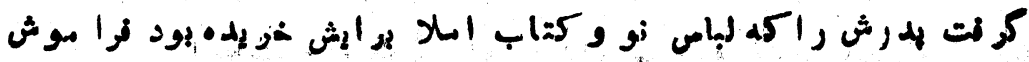

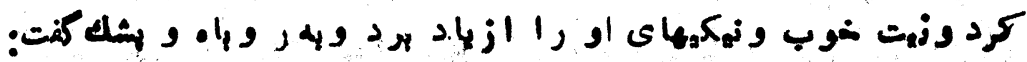

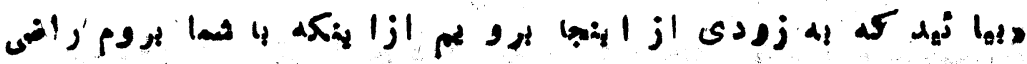
an

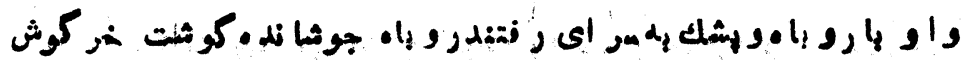

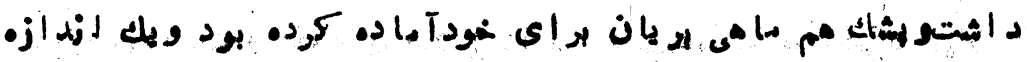

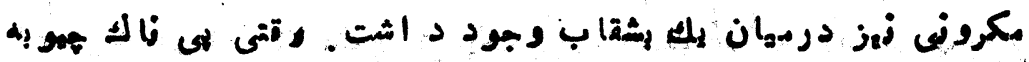

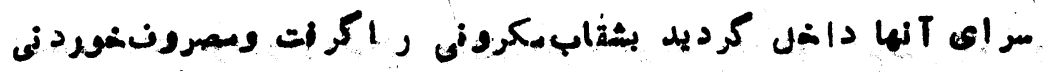

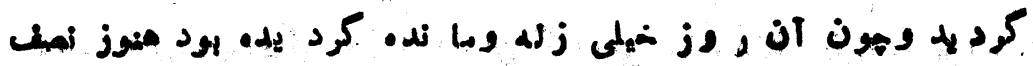

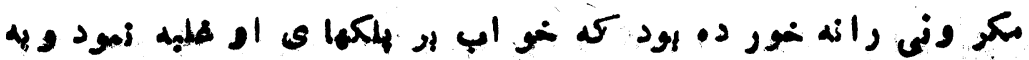

$-1 \varepsilon$. 


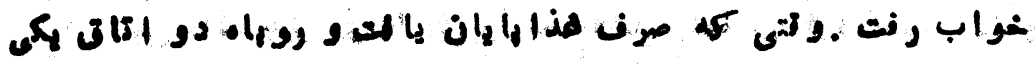

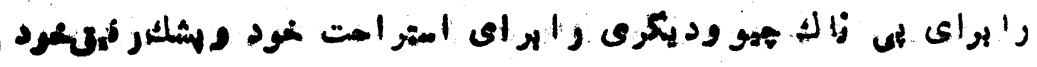

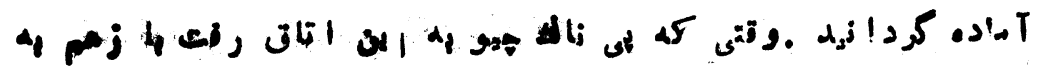

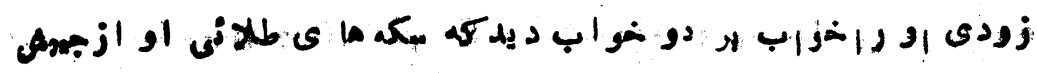

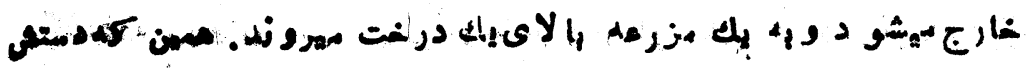

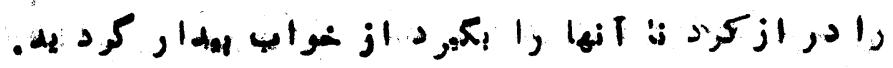

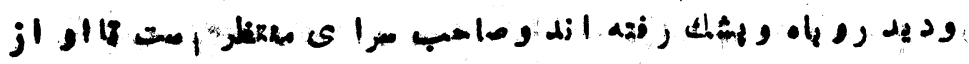

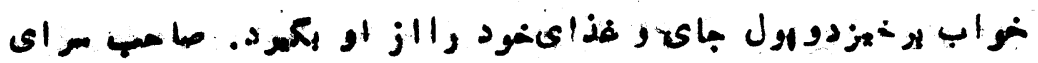

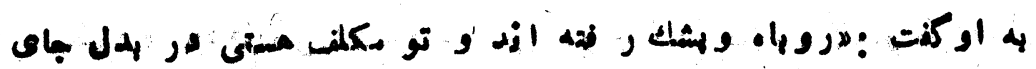

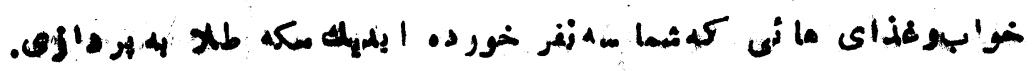

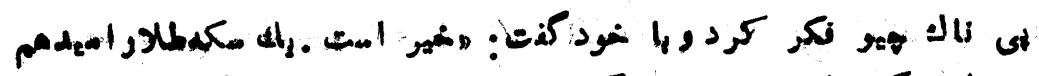

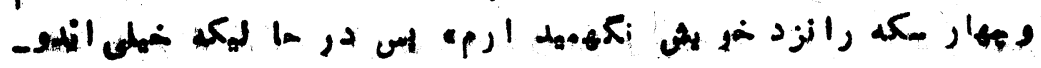

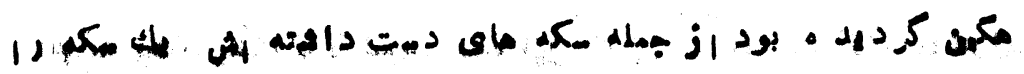

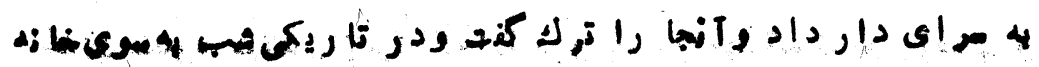

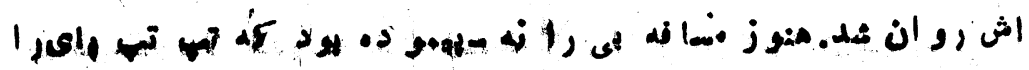

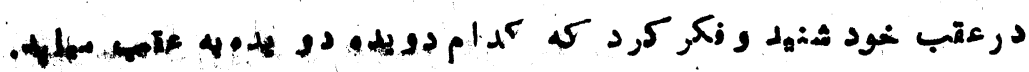

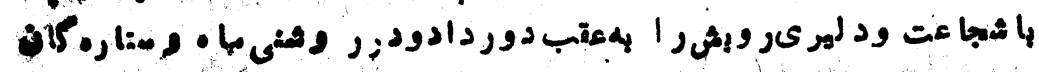

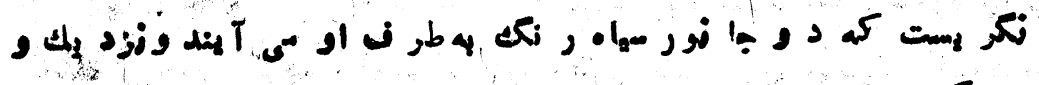

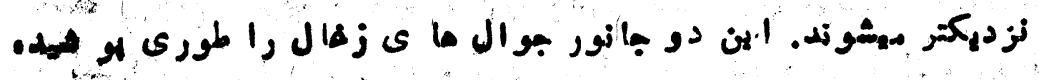

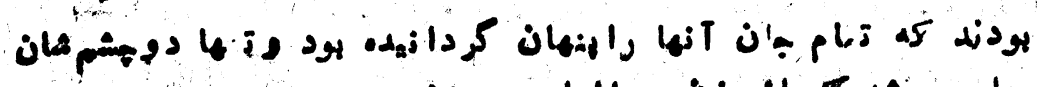

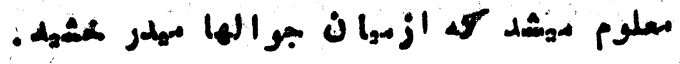

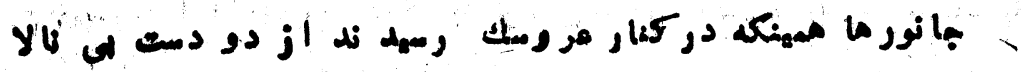

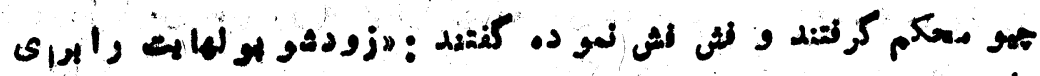
cod 6 


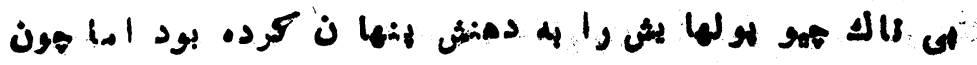

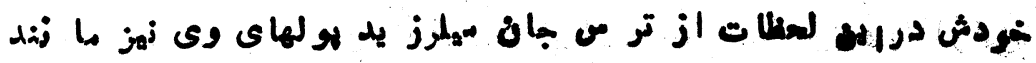

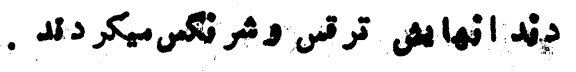

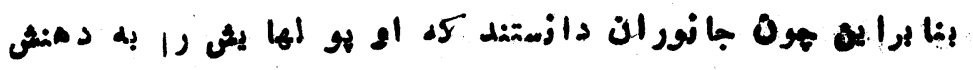

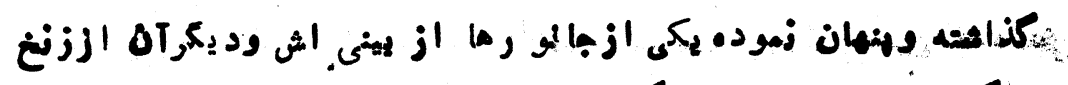

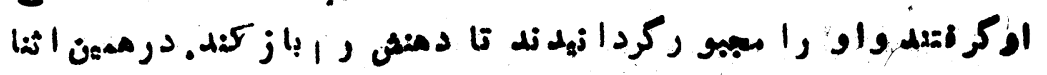

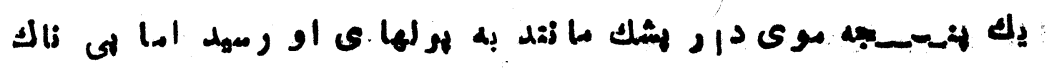

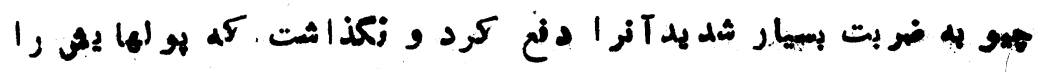

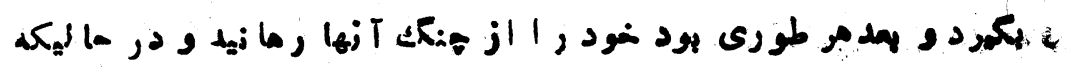

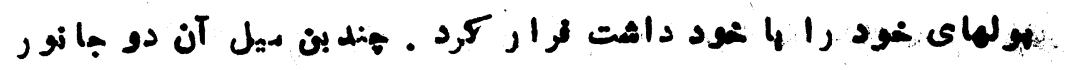

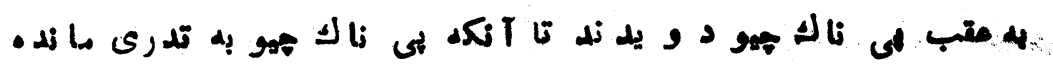

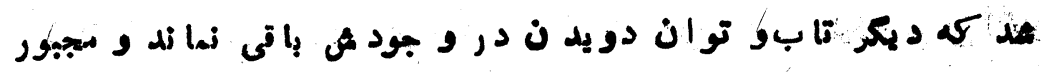

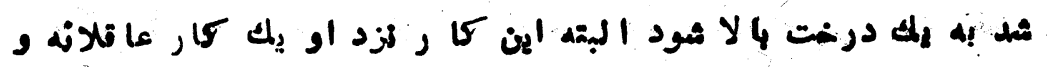

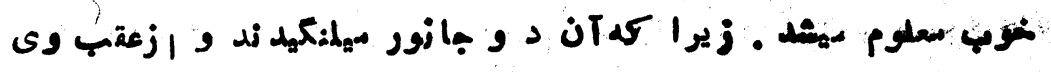

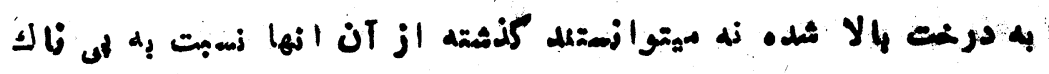

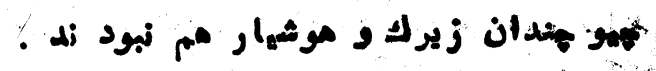

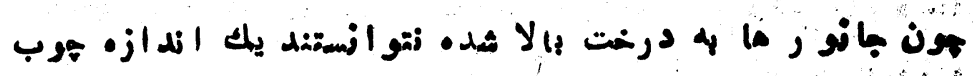

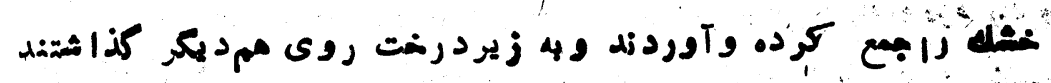

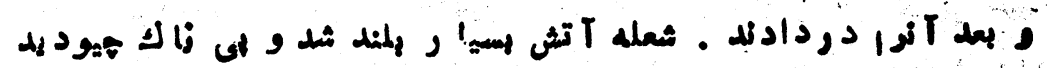

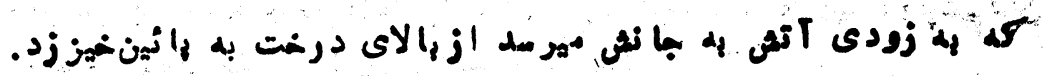

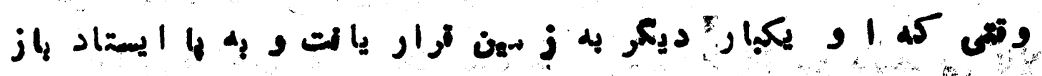

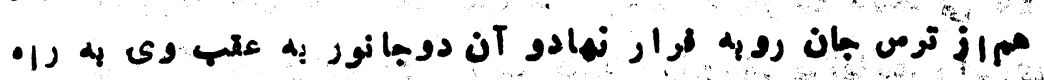

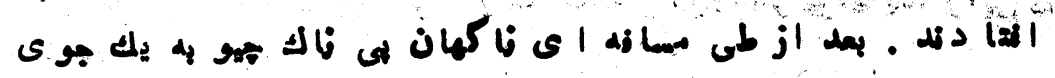




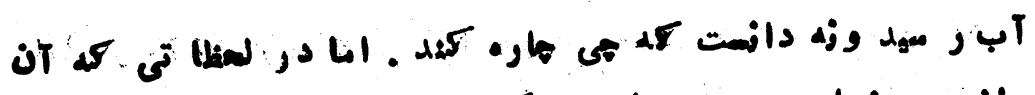

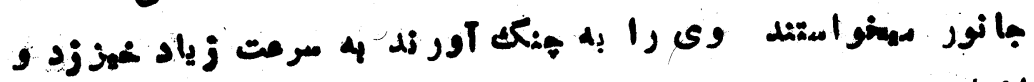

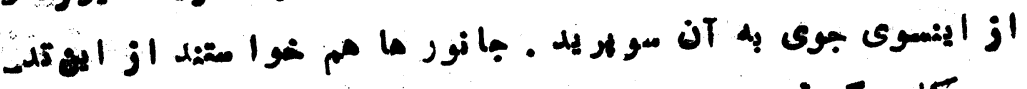

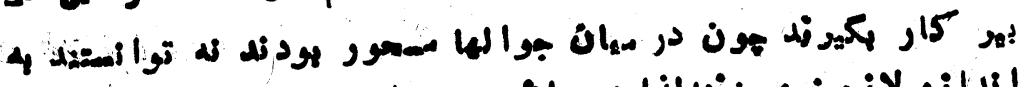

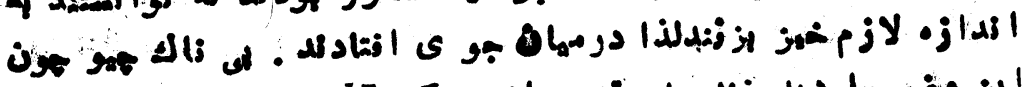

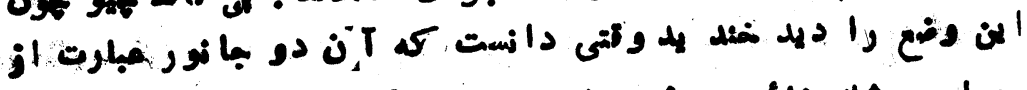

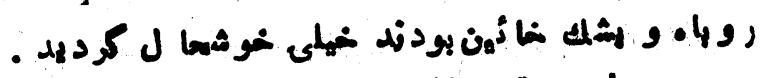

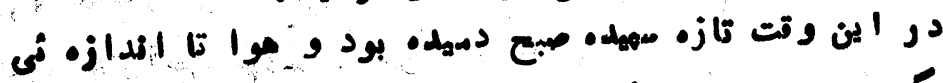

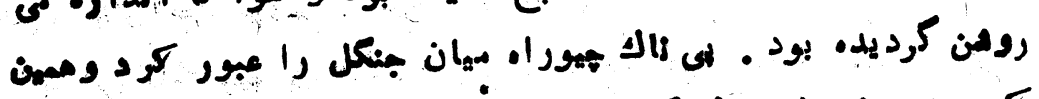

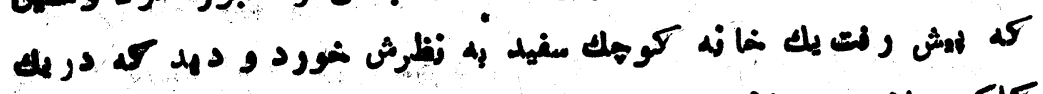

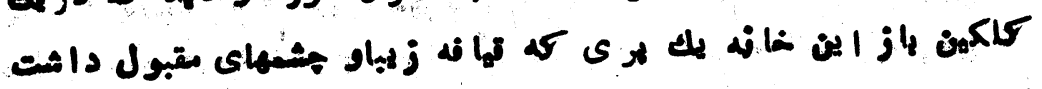

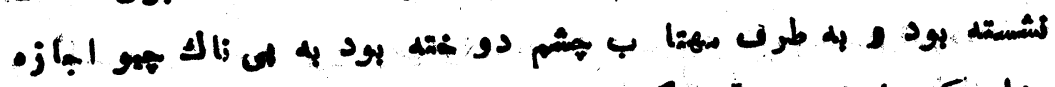

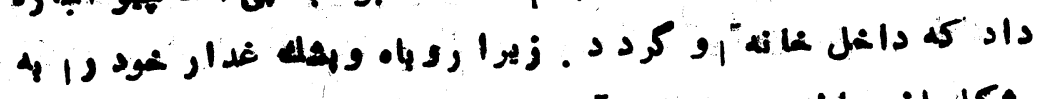

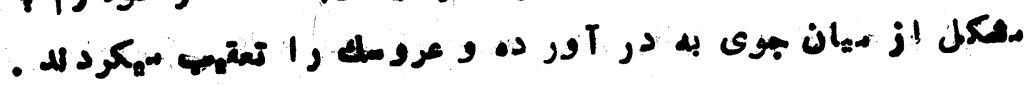

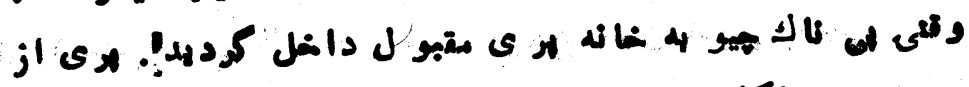

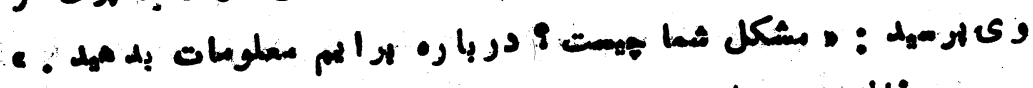

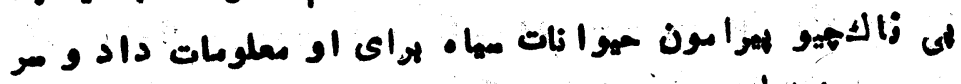

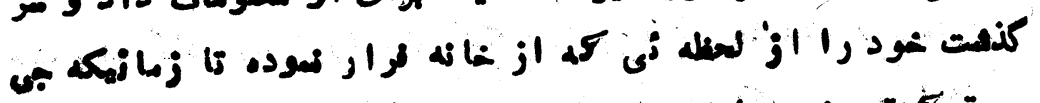

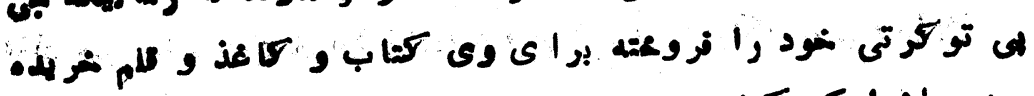

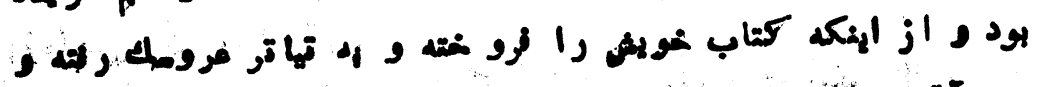

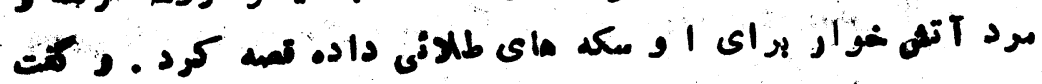

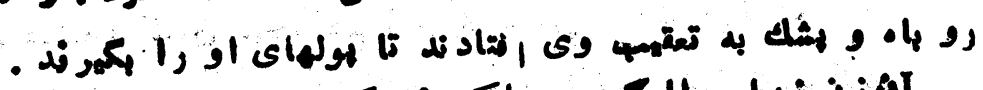

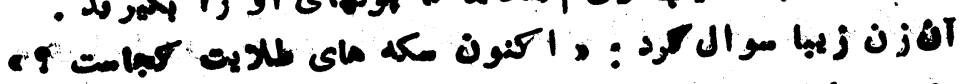

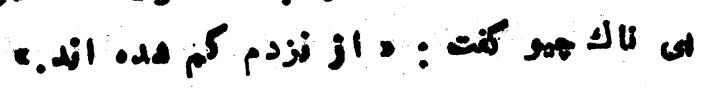
-isr- 


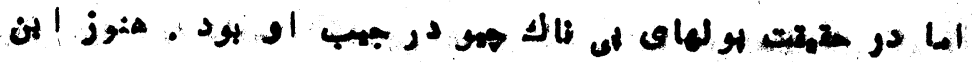

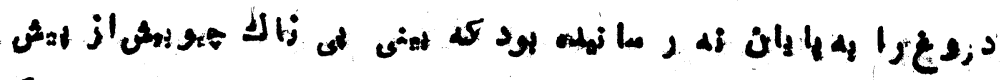

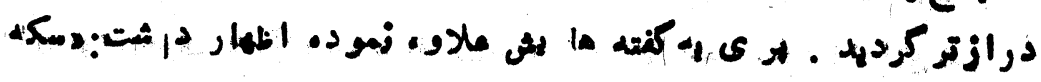

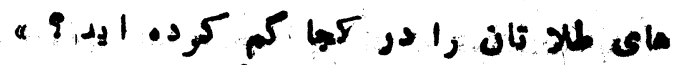

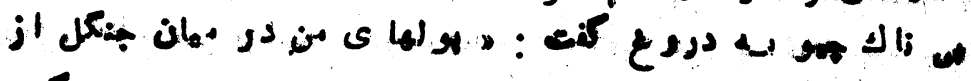

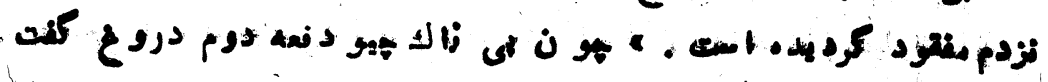

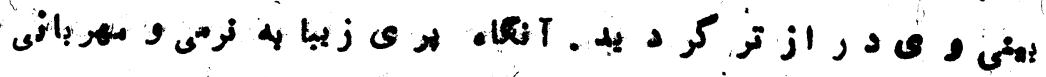

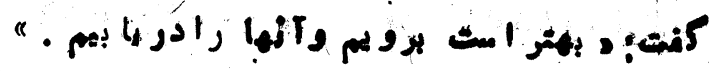

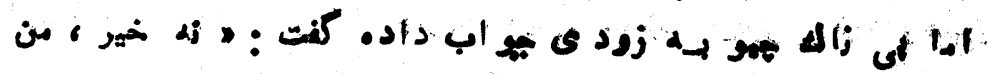

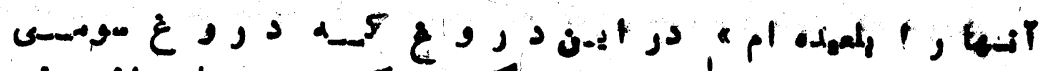

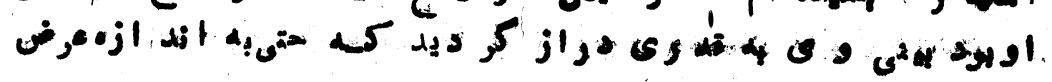

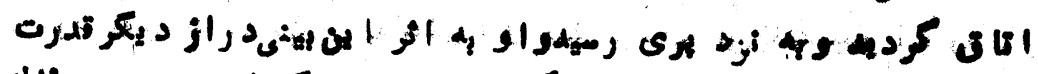

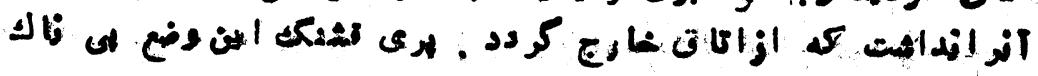

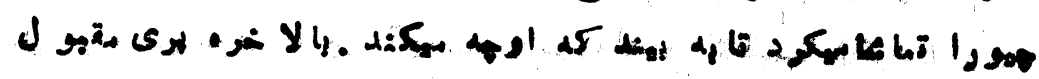

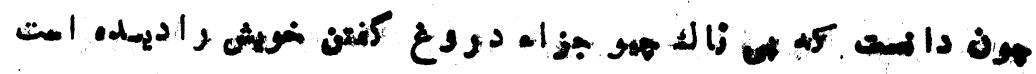

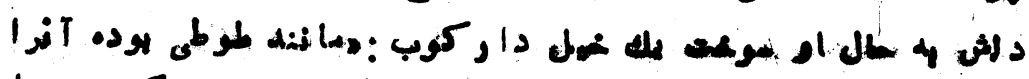

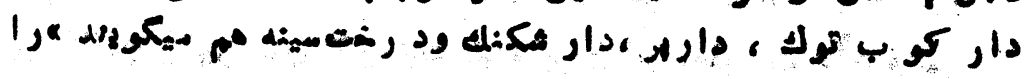

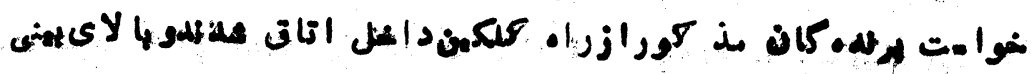

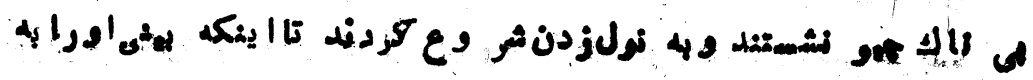

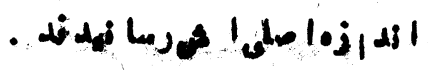

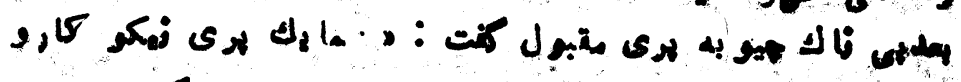

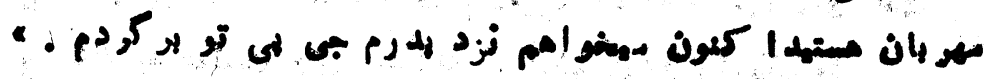

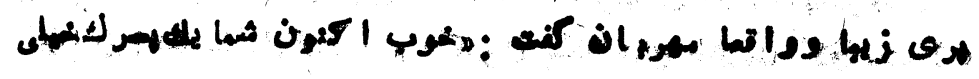

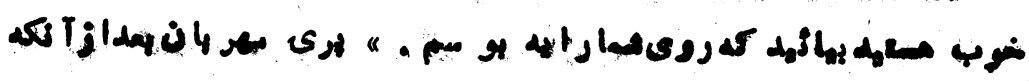




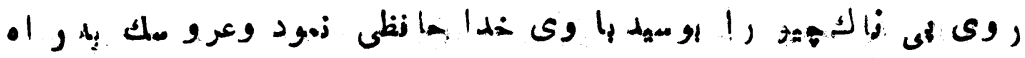

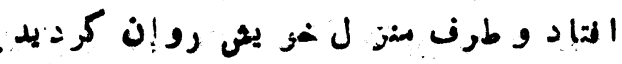

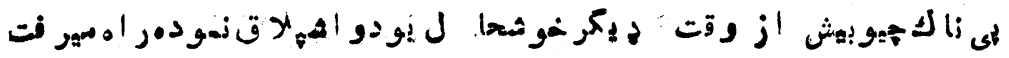

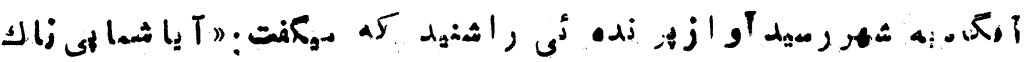
* 9 (

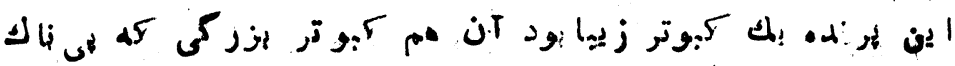

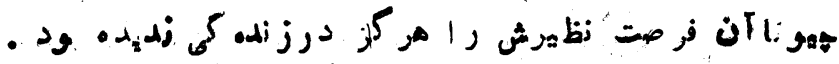

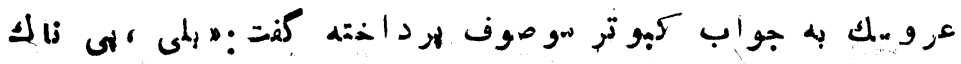

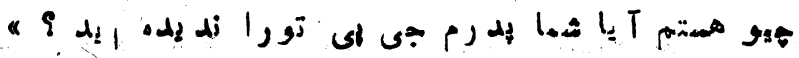

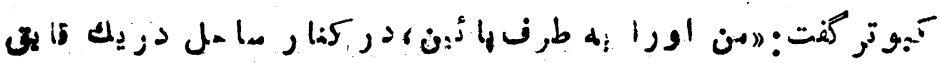

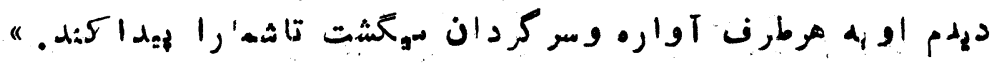

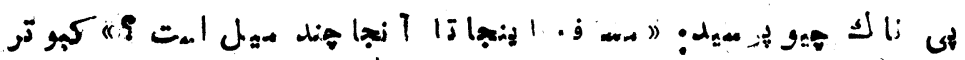

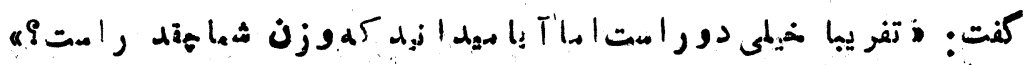

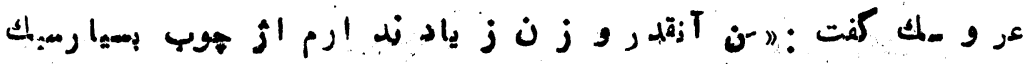

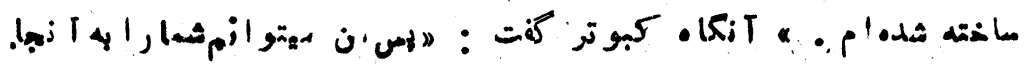

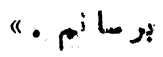

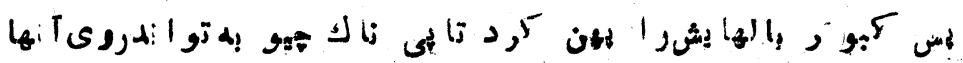

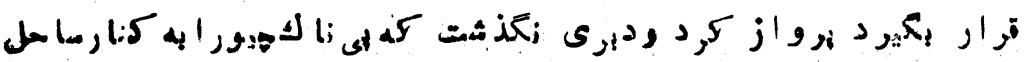

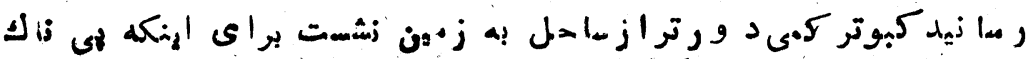

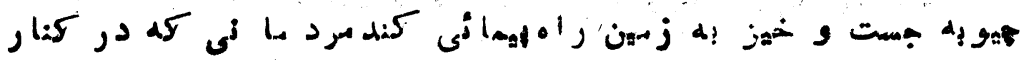

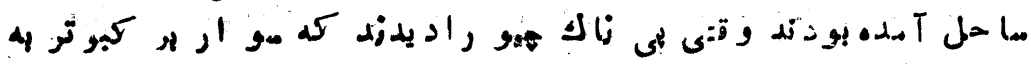

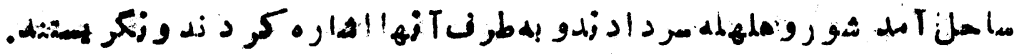

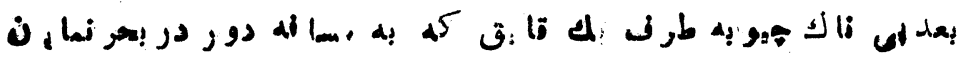
e. $-1 \varepsilon 0-$ 


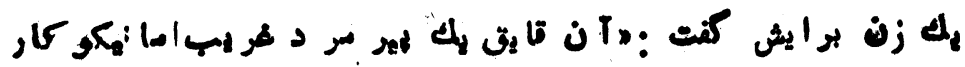

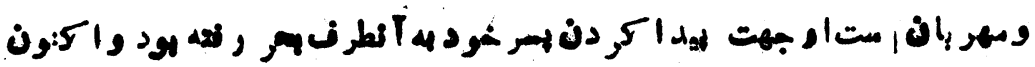

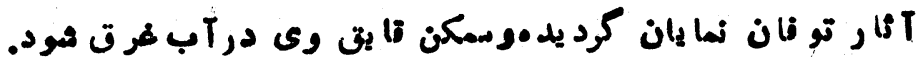

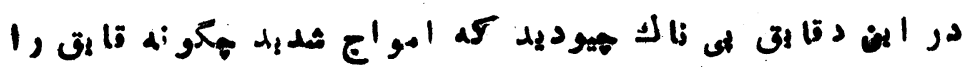

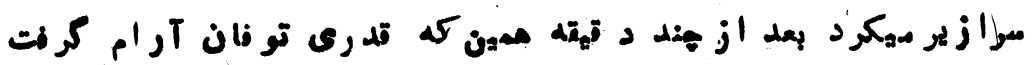

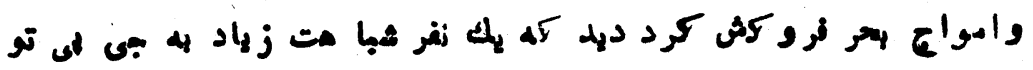

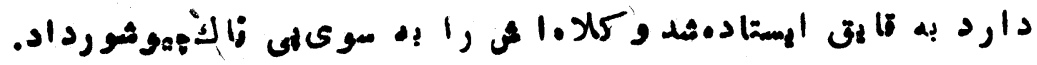

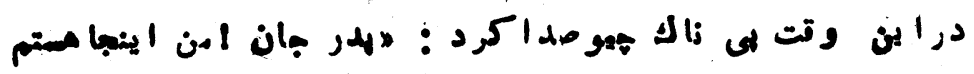

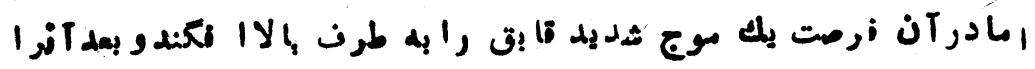

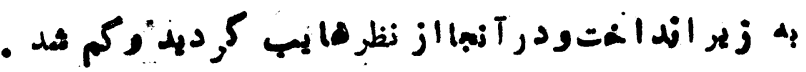

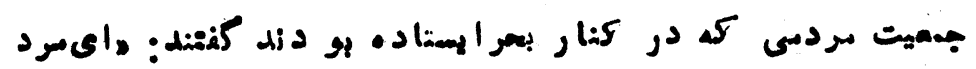

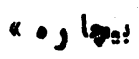

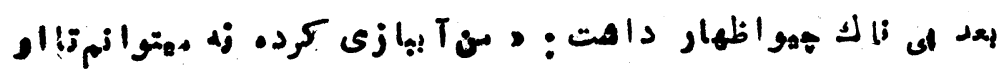

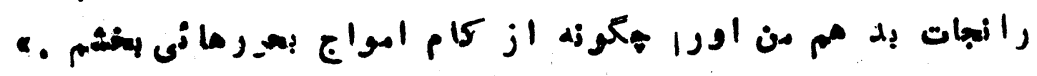

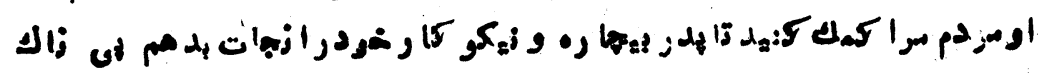

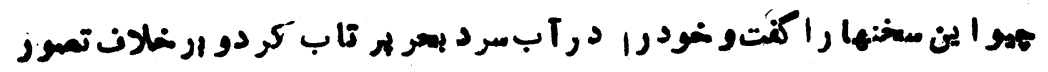

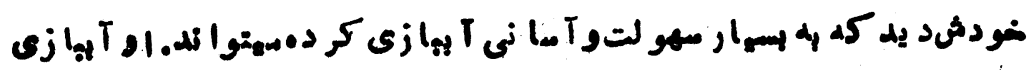

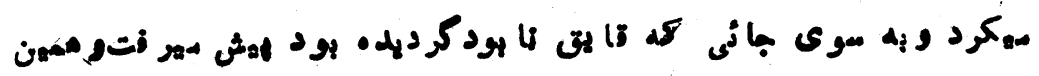

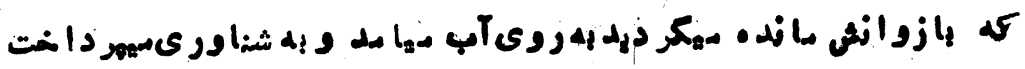

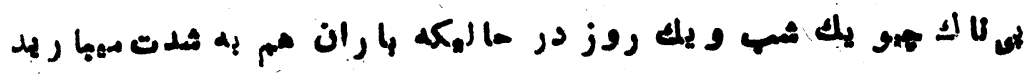

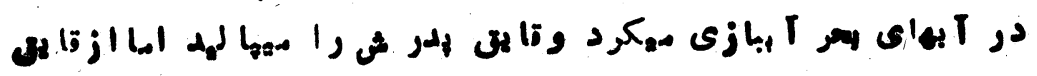

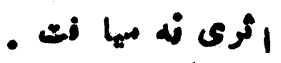

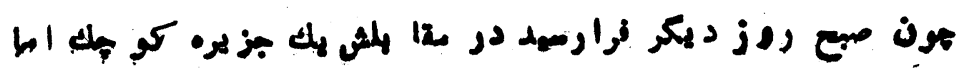




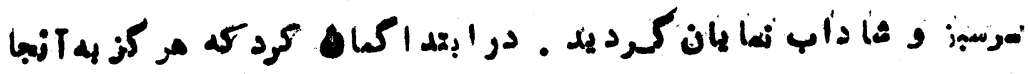

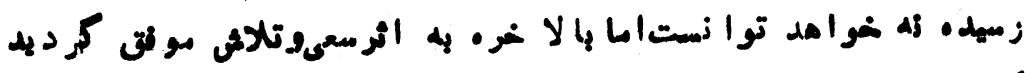

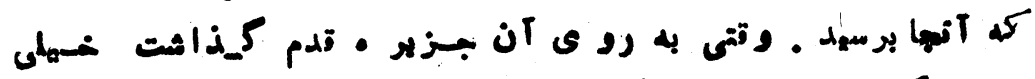

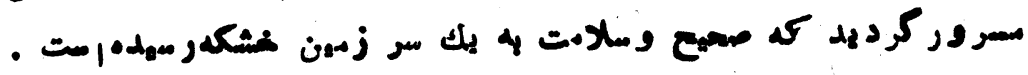

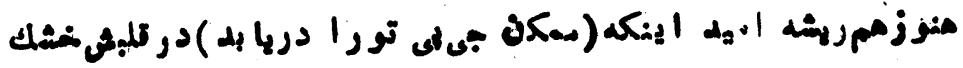

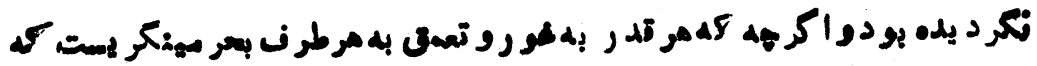

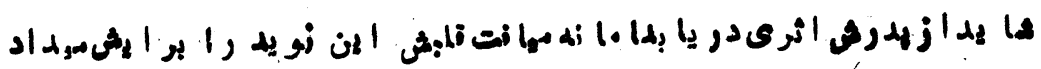

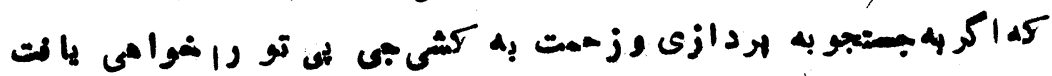

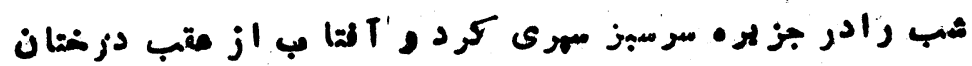

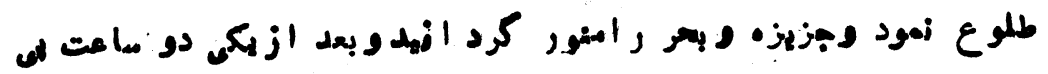

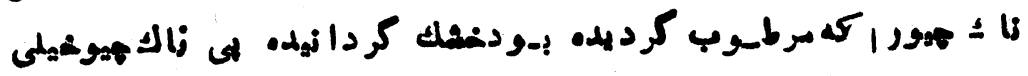

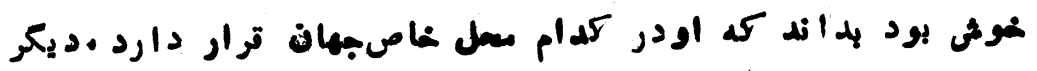

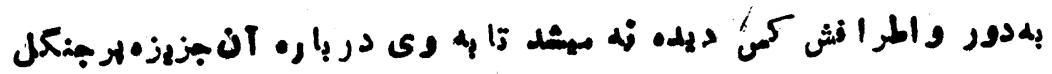

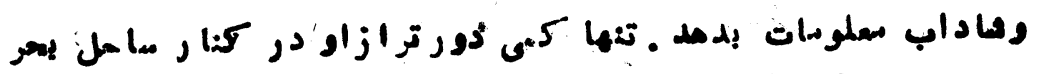

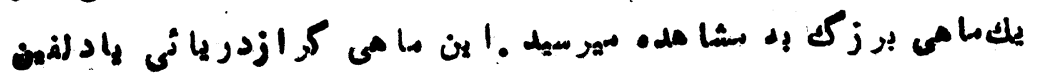

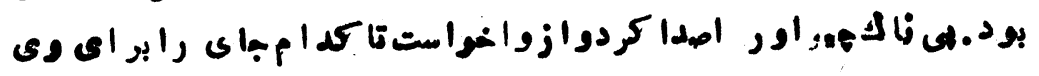

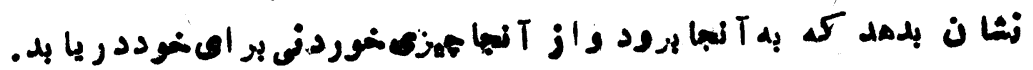

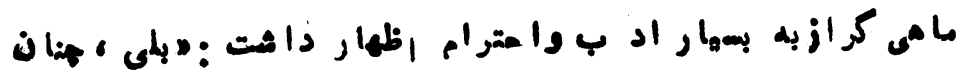

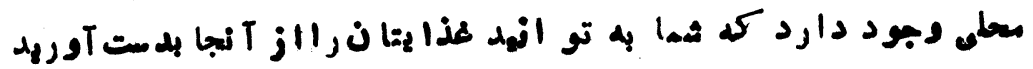

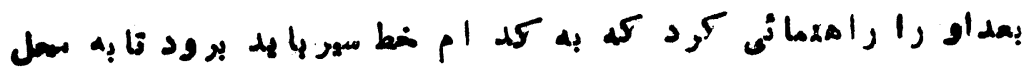

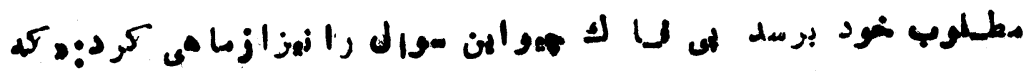

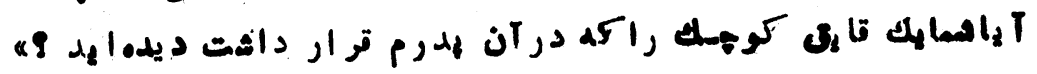

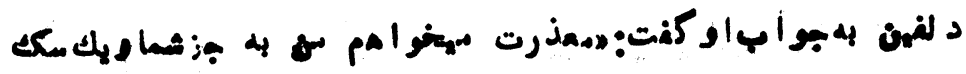




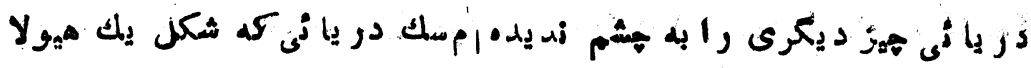

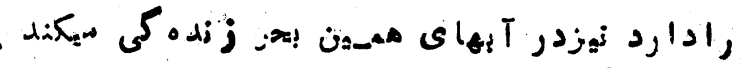

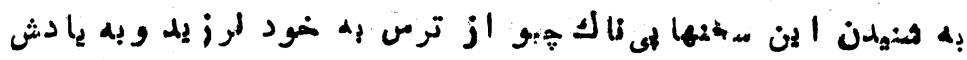

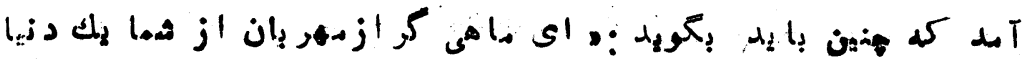

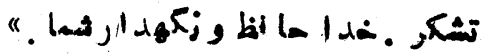

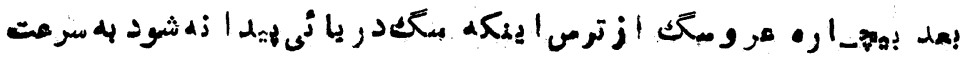

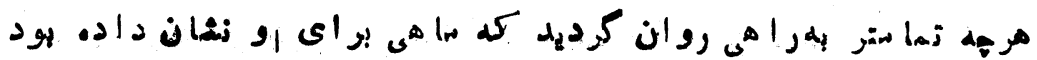

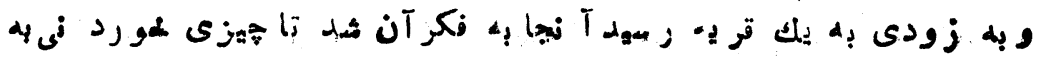

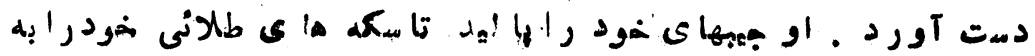

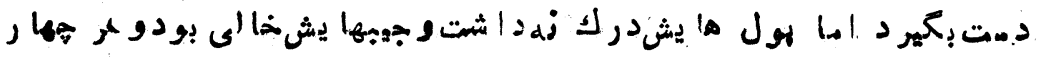

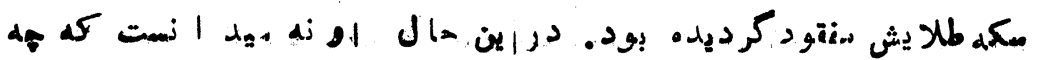

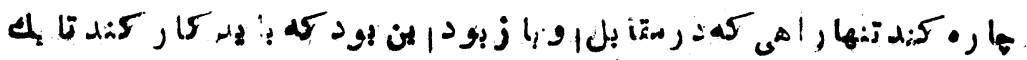

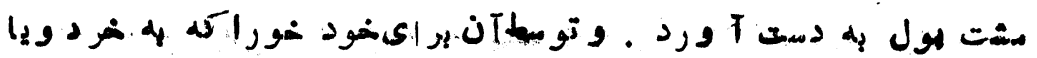

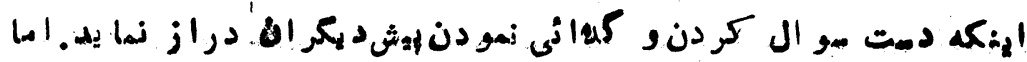

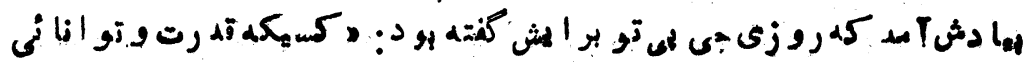

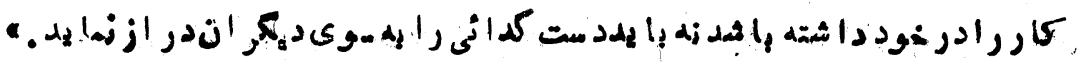

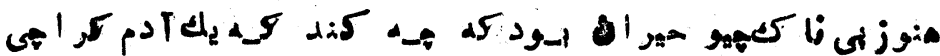

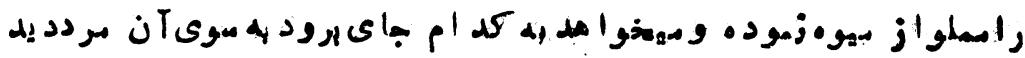

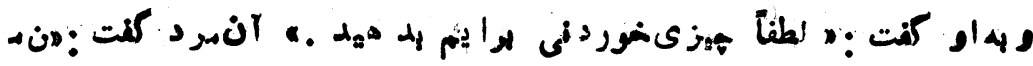

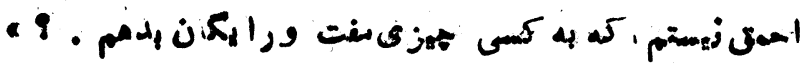

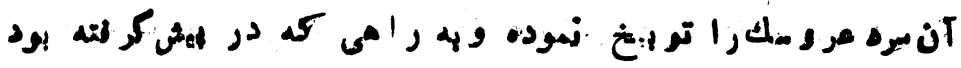

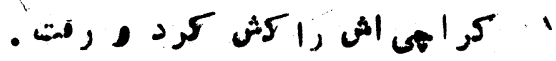

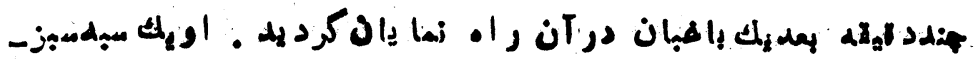

$-1 \sim \wedge-$ 


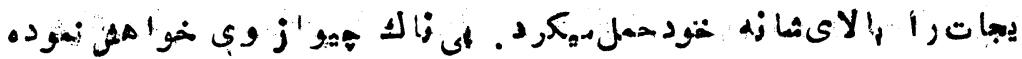

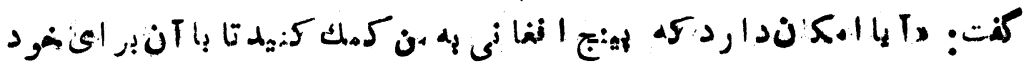

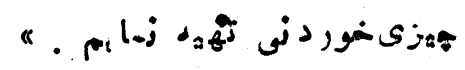

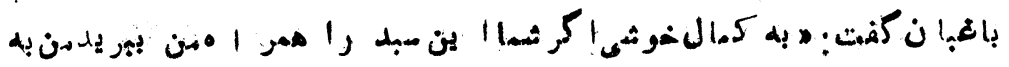

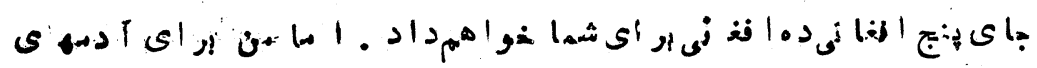

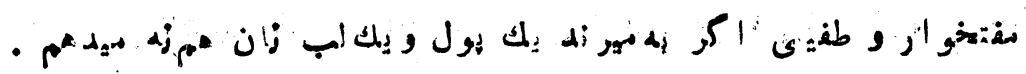

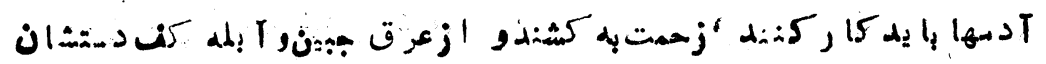

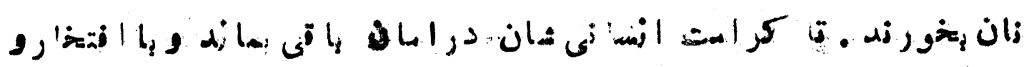

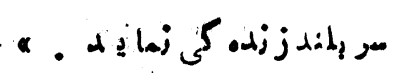

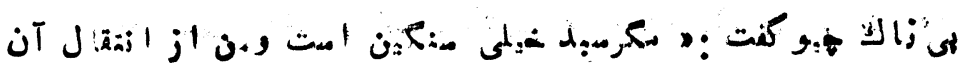

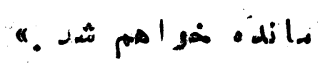

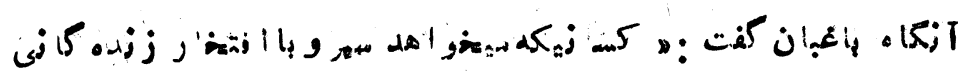

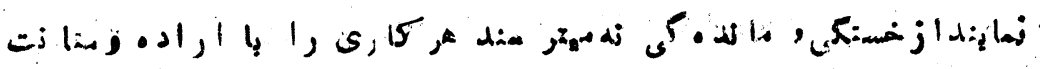

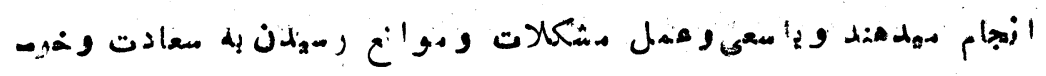

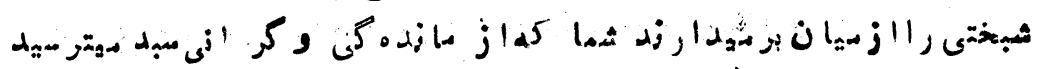

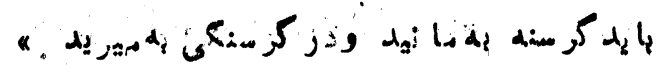

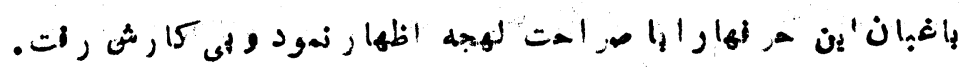

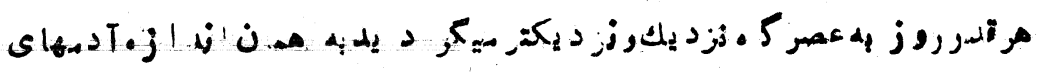

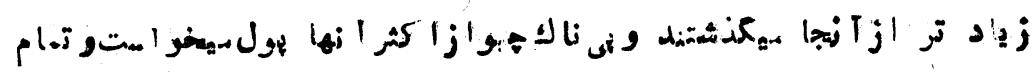

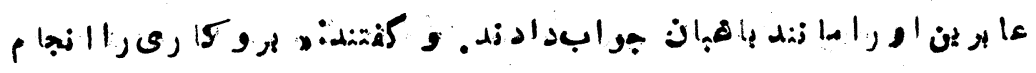

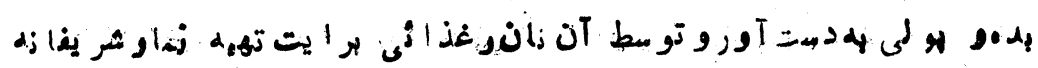

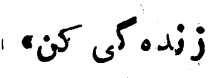

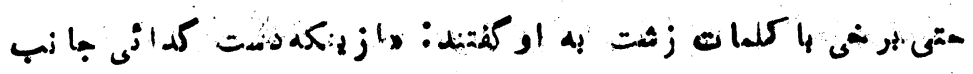




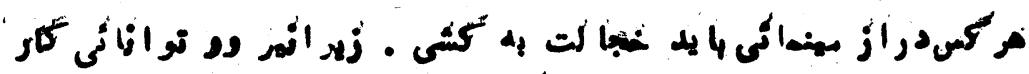

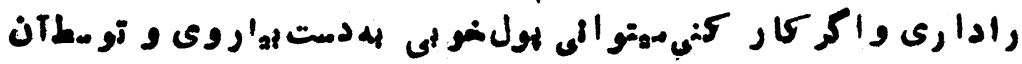

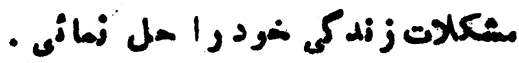

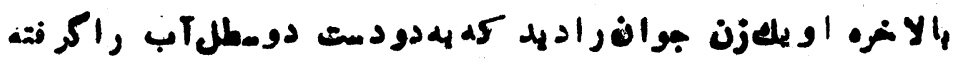

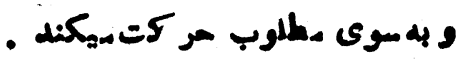

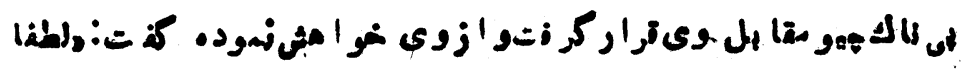

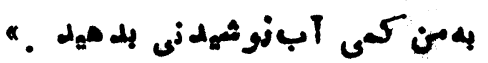

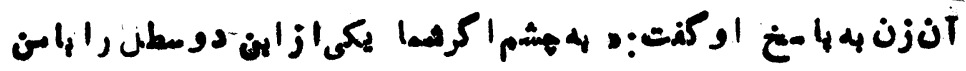

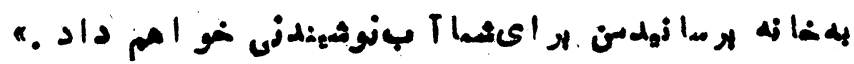

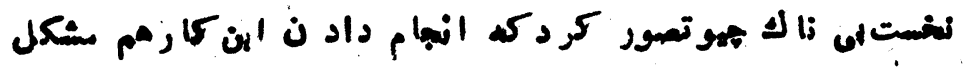

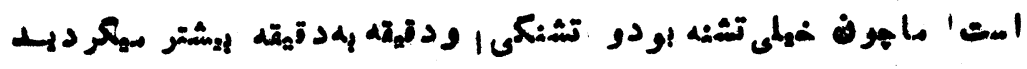

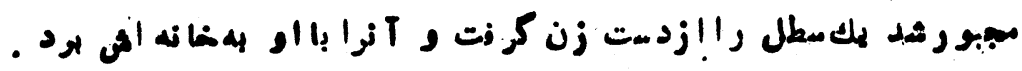

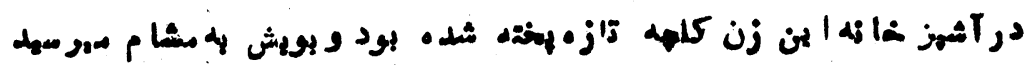

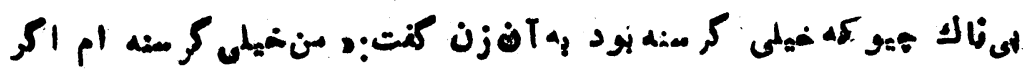

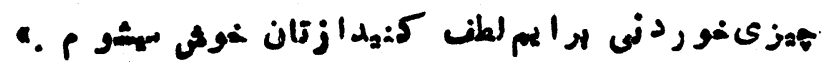

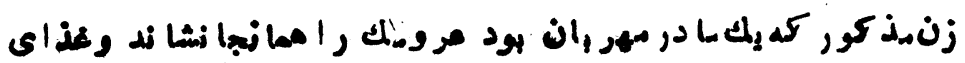

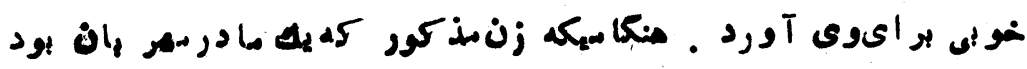

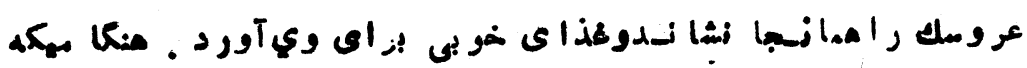

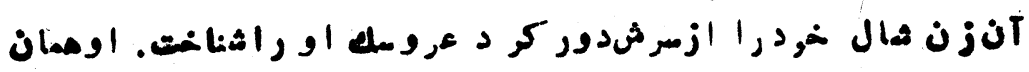

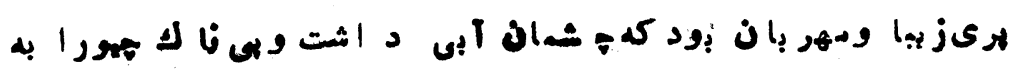

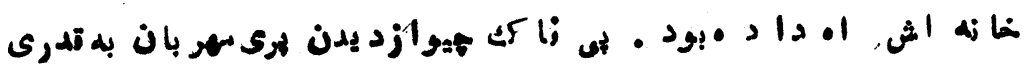

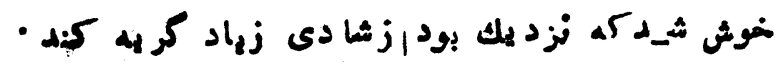

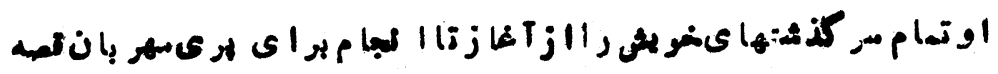

$-10 .-$ 


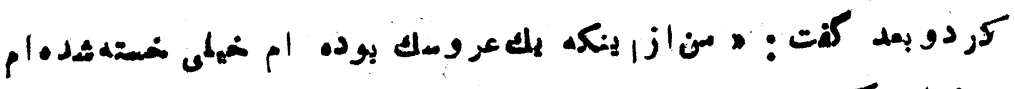

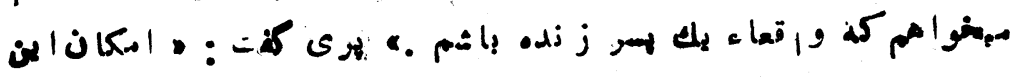

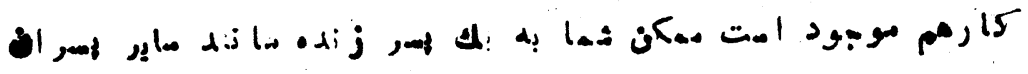

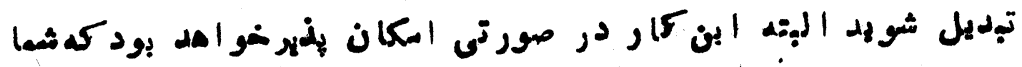

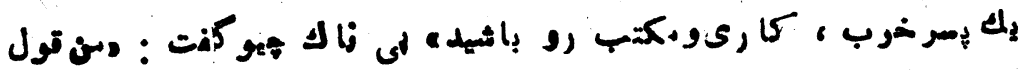

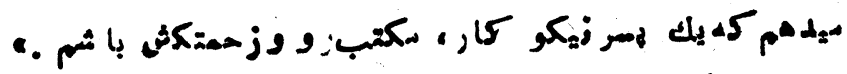

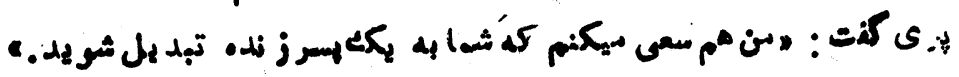

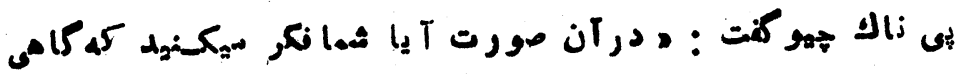

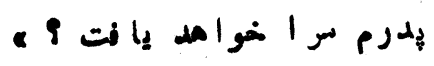

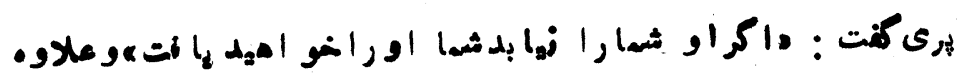

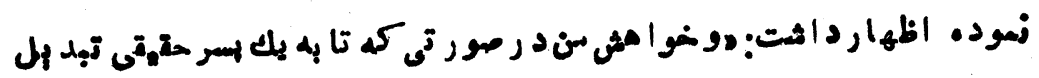

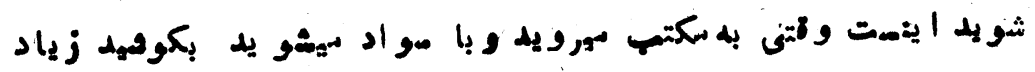

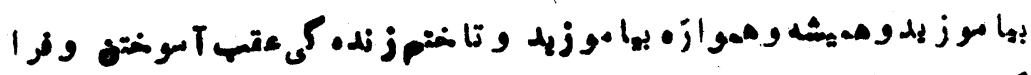

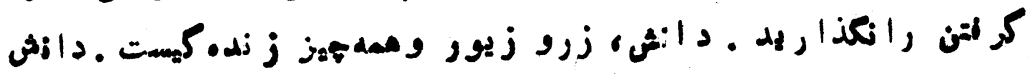

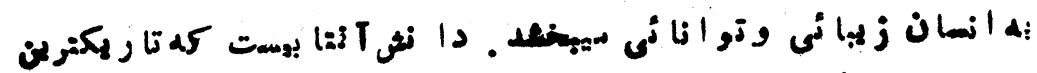

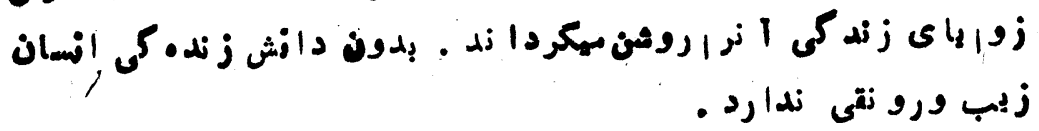

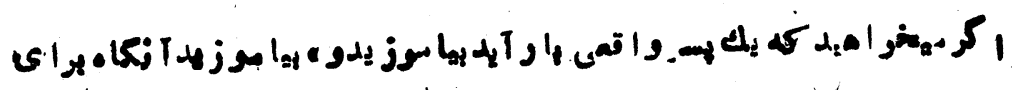

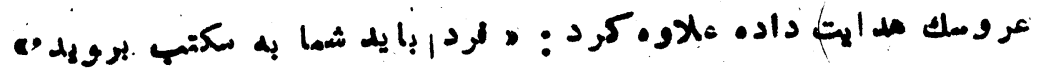

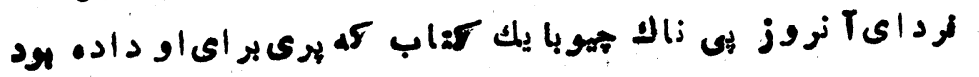

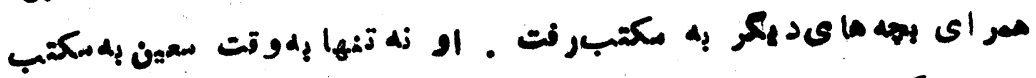

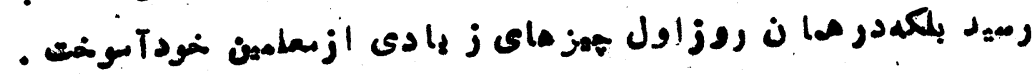

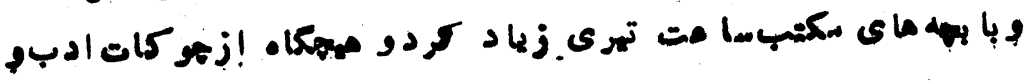




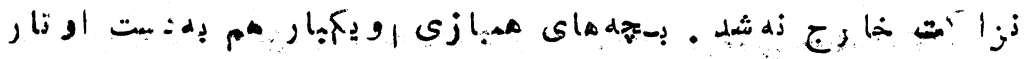

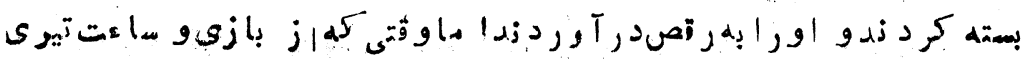

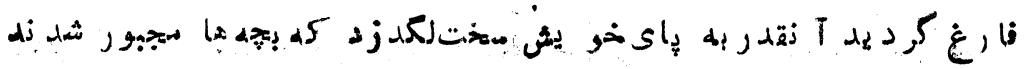

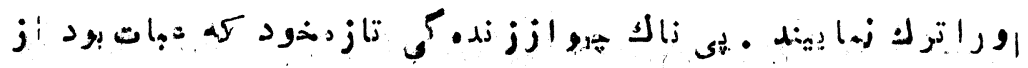

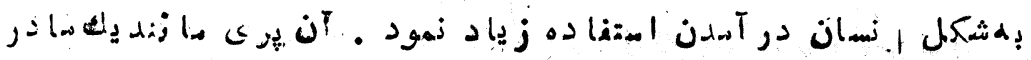

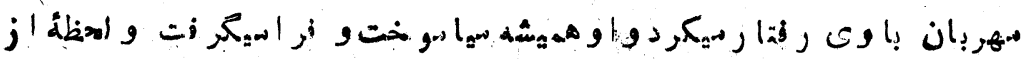

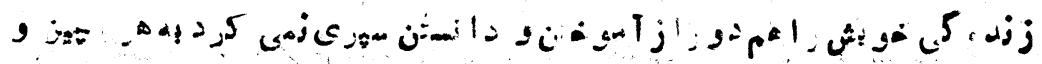

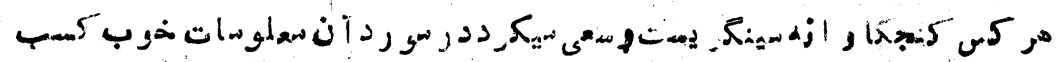

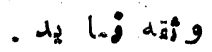

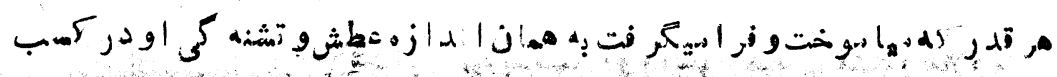

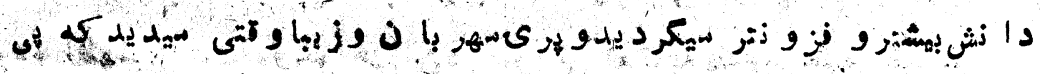

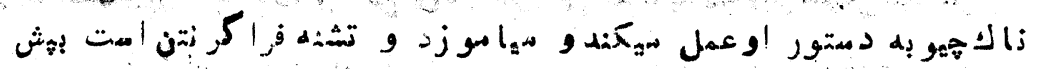

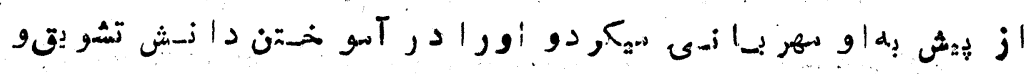

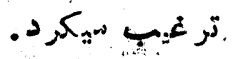

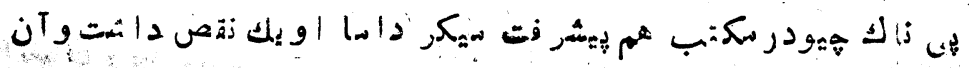

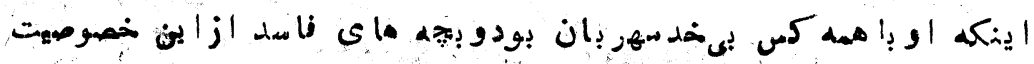

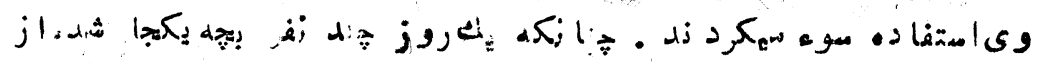

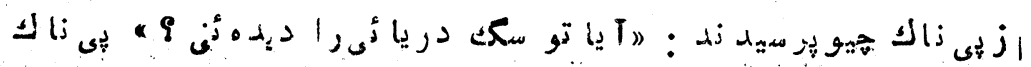

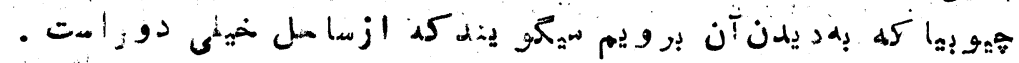

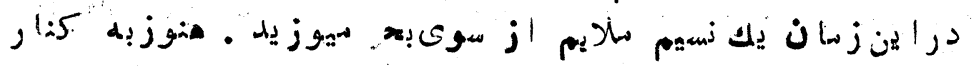

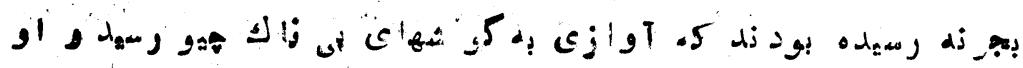

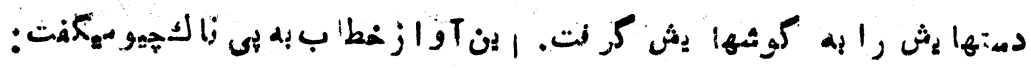

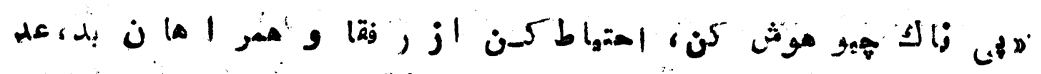

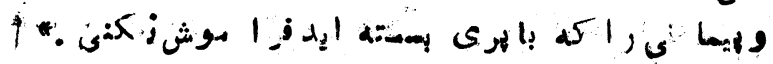




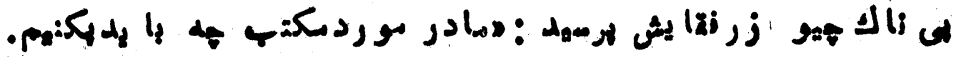

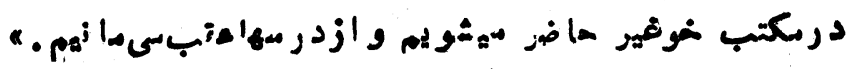

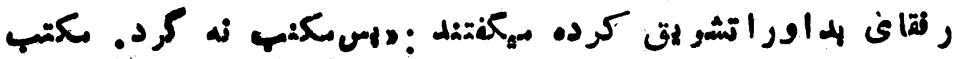

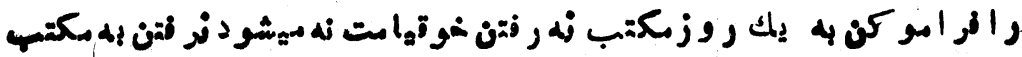

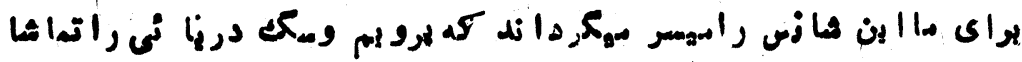
كنمب.

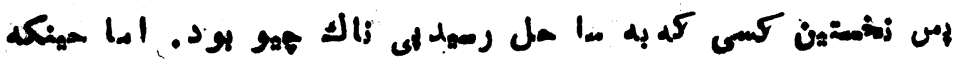

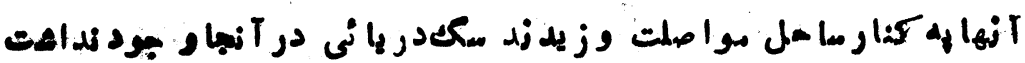

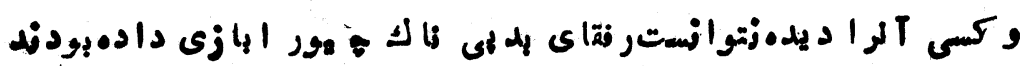

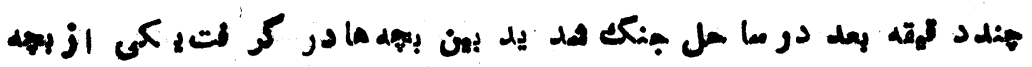

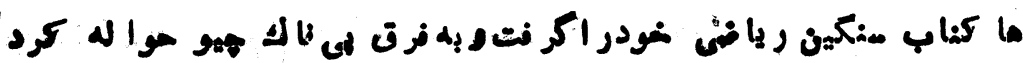

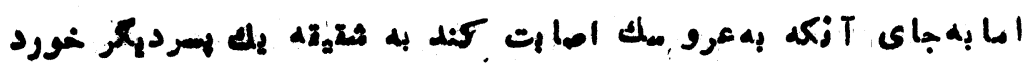

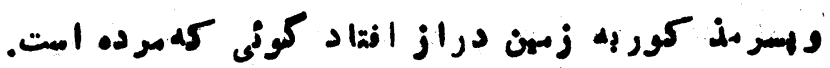

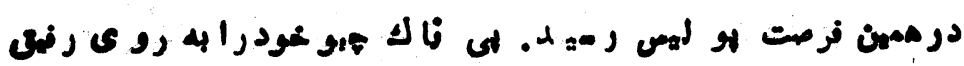

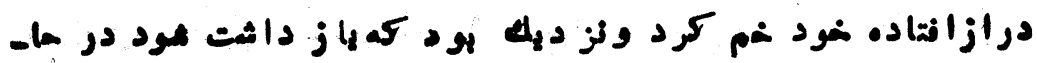

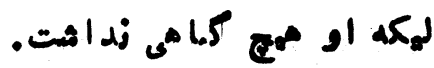

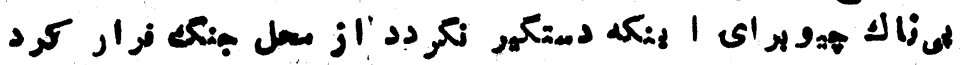

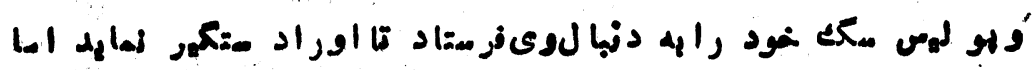

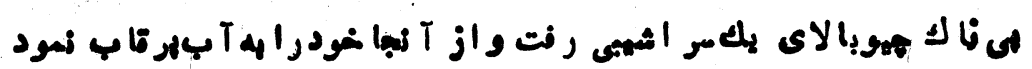

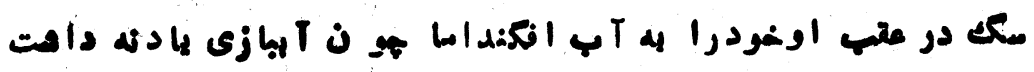

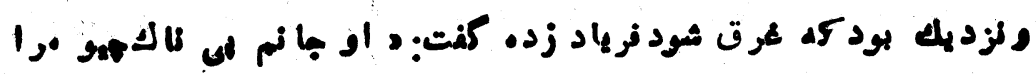

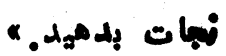

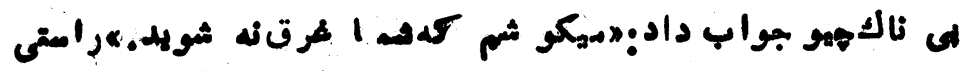

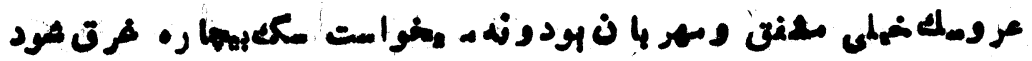




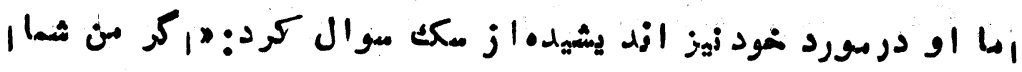

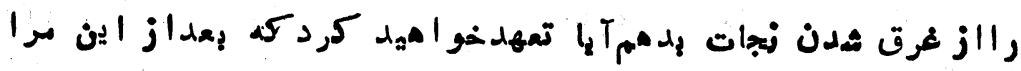

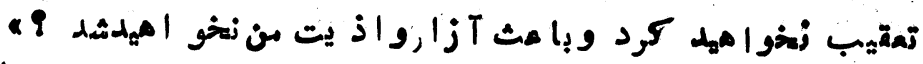

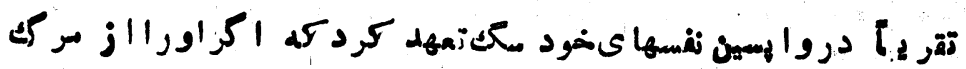

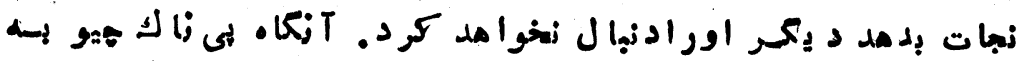

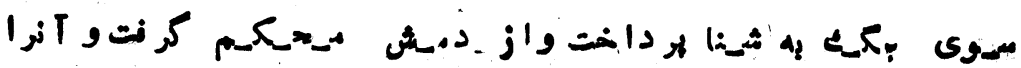

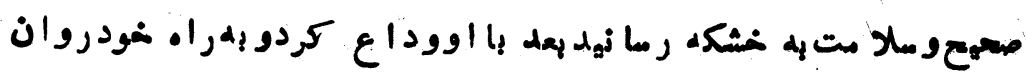

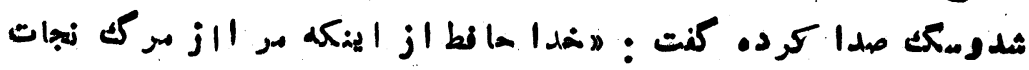

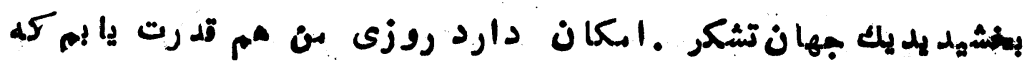

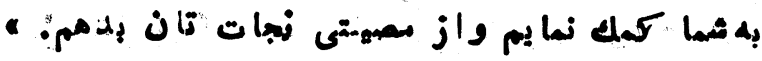

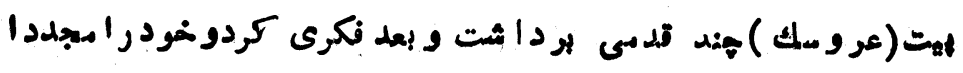

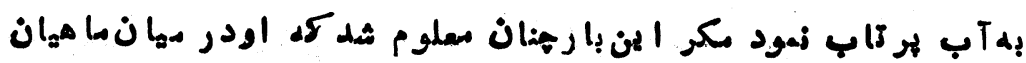

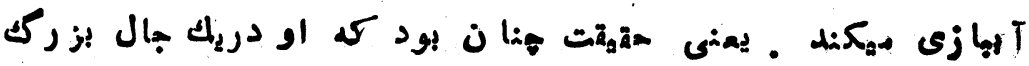

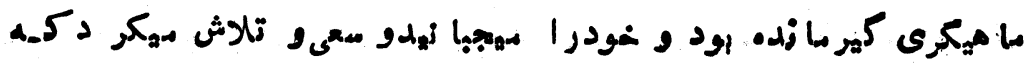

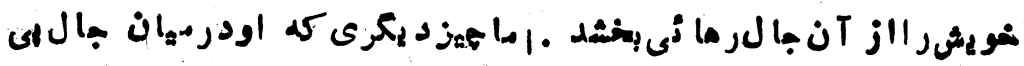

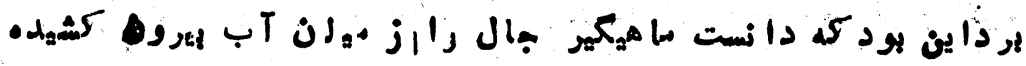

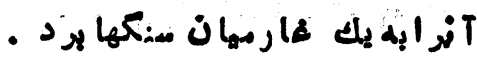

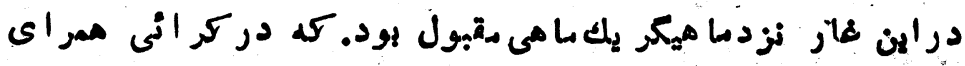

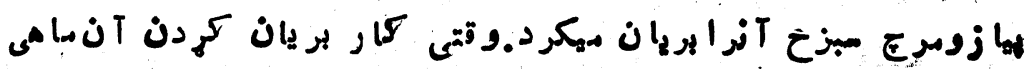

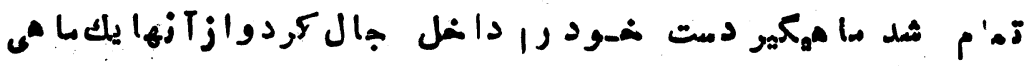

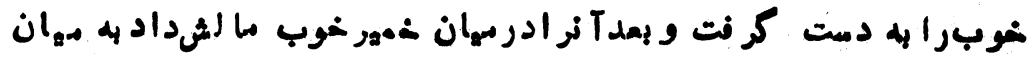

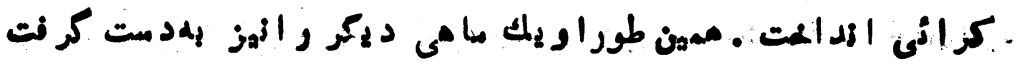

$-10 \mathrm{mo}$ 


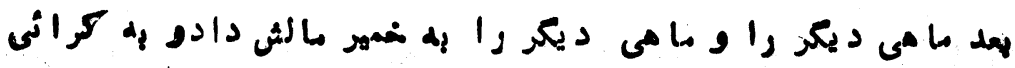

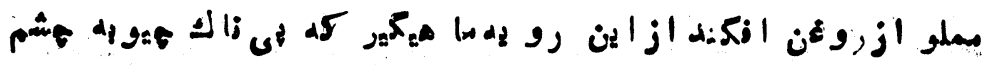

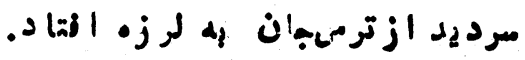

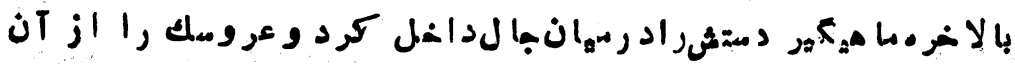

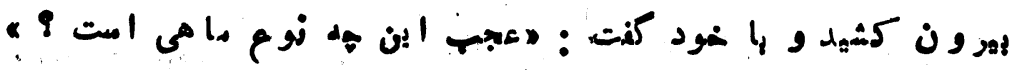

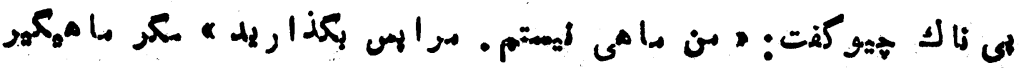

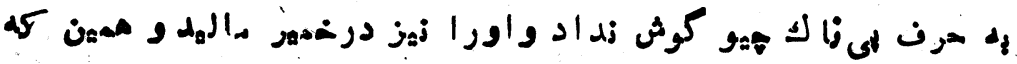

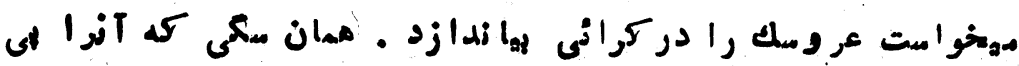

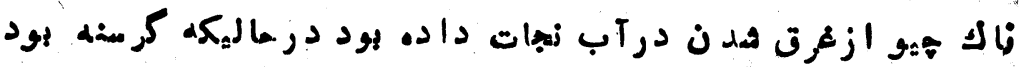

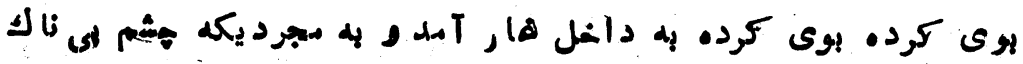

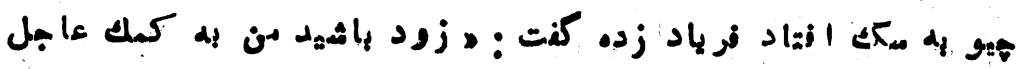

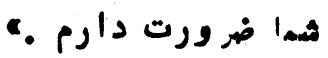

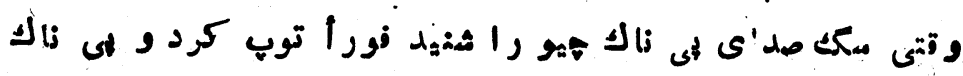

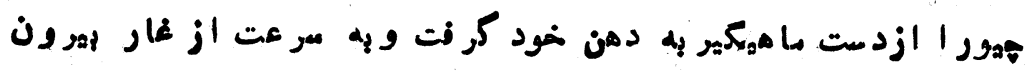

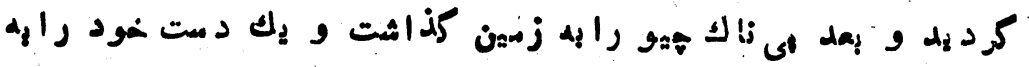

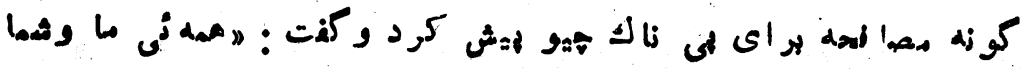

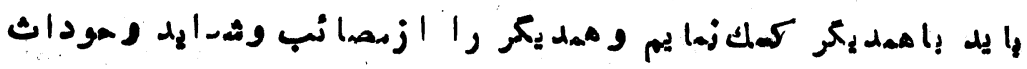

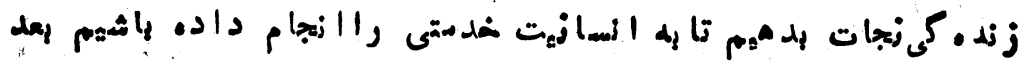

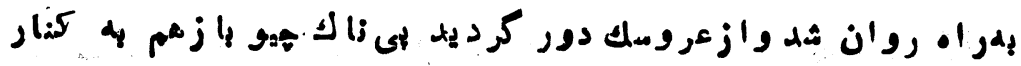

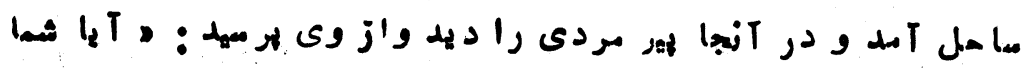

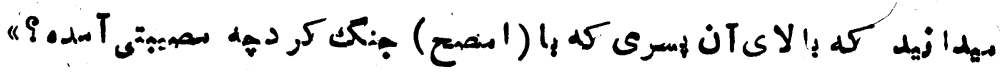

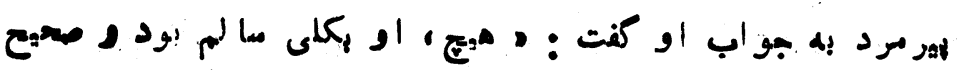

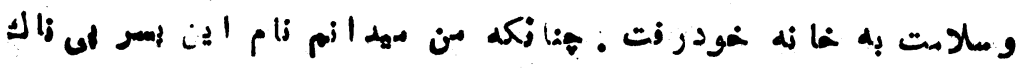
$-100-$ 


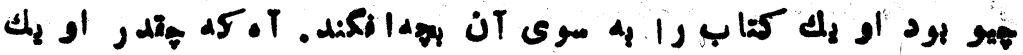

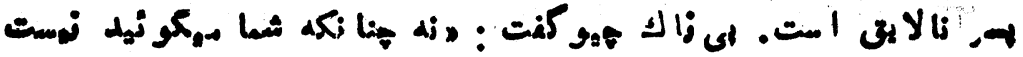

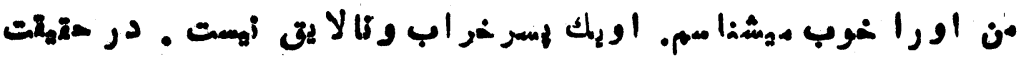

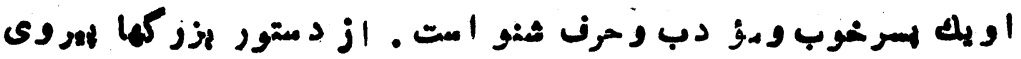

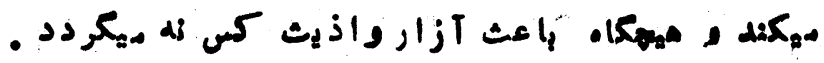

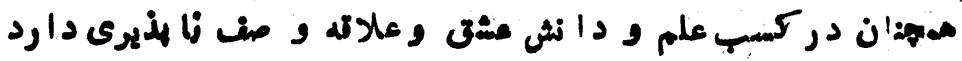

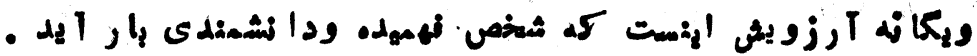

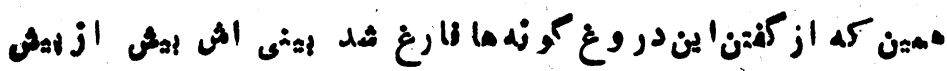

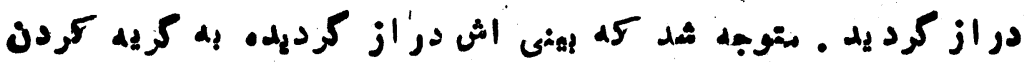

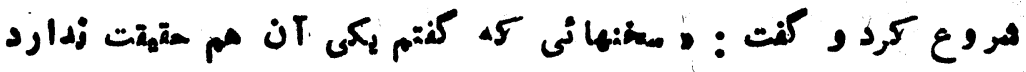

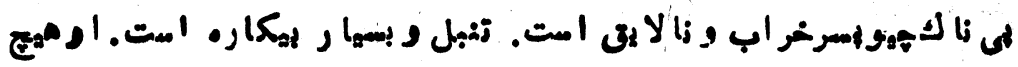

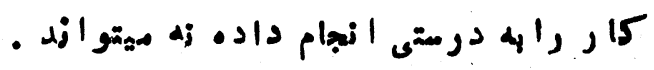

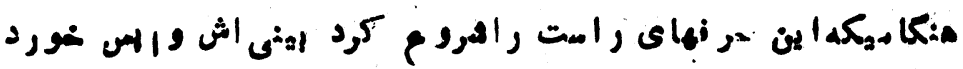

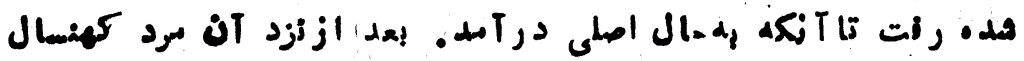

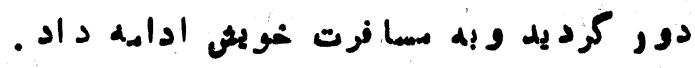

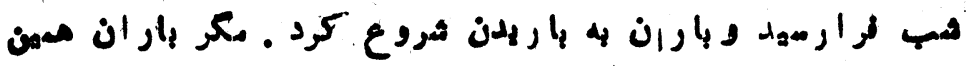

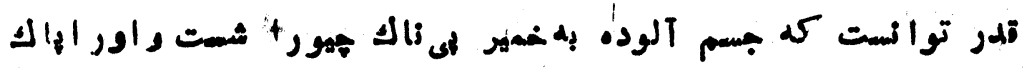

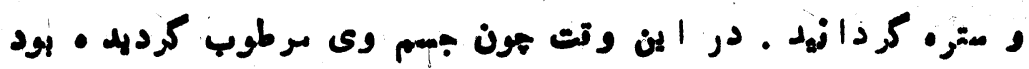

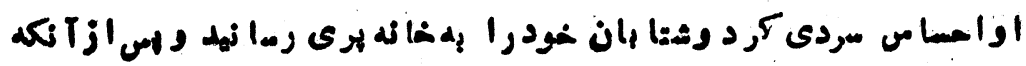

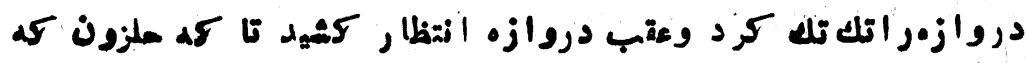

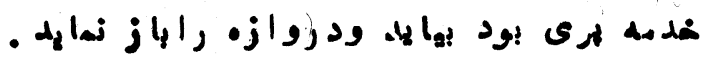

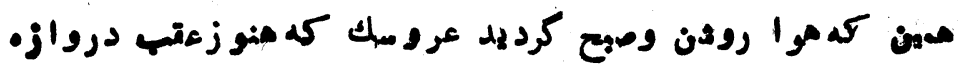

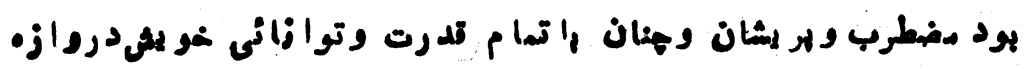




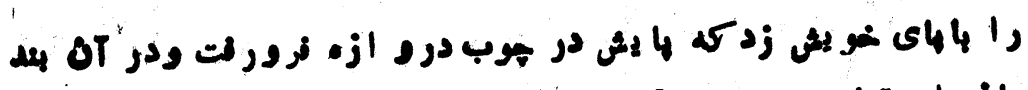

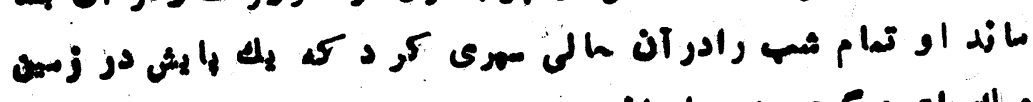

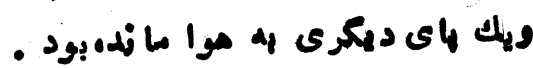

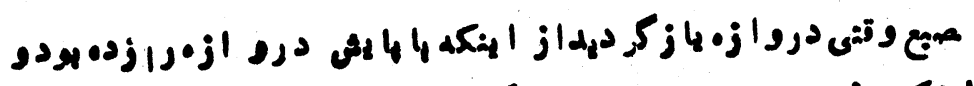

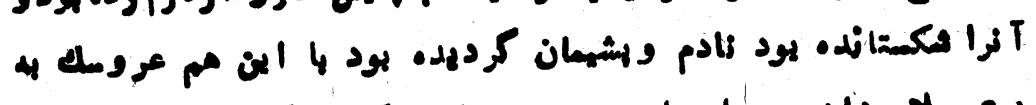

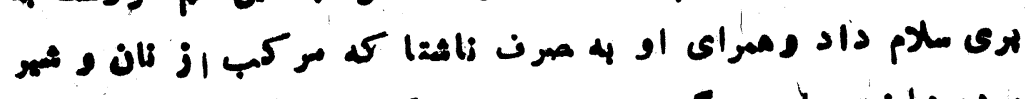

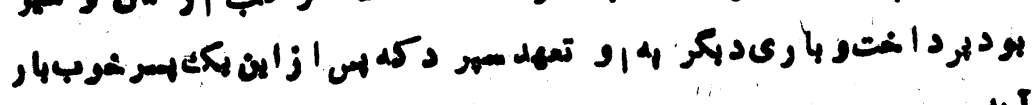

II

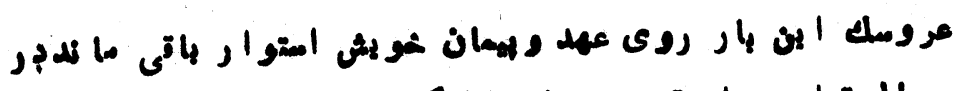

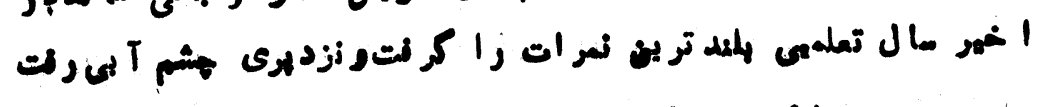

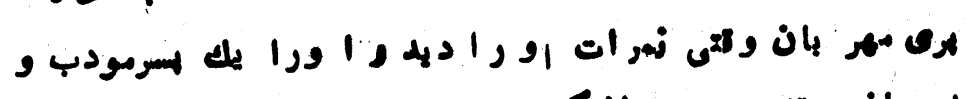

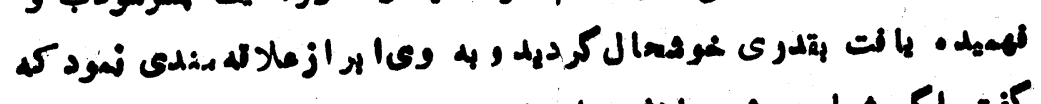

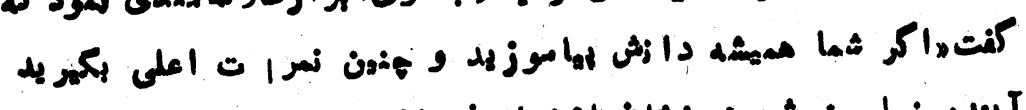

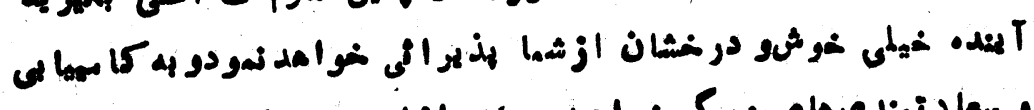

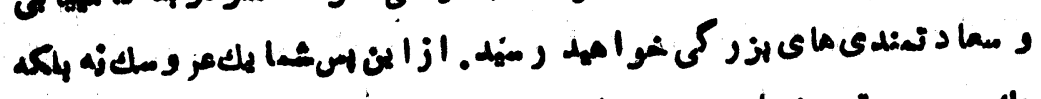

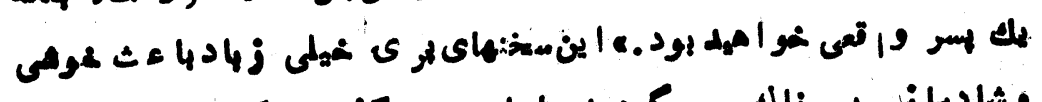

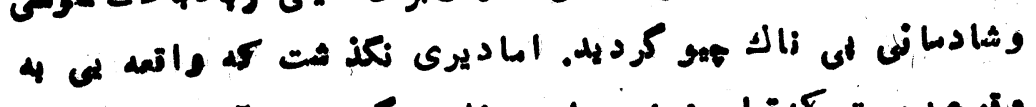

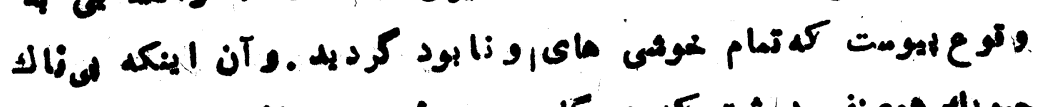

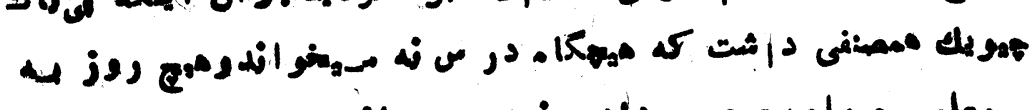

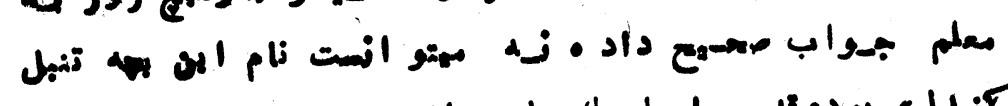

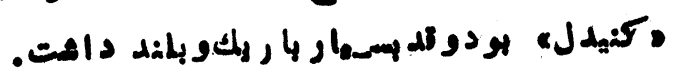

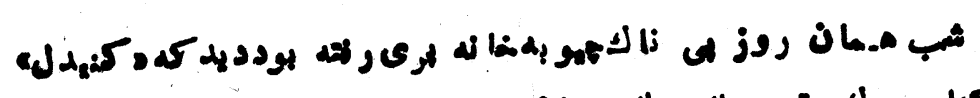

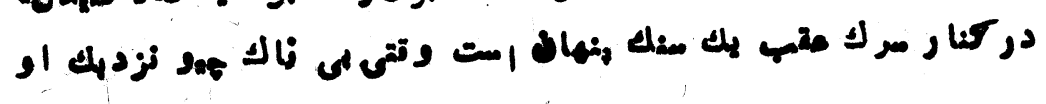

$-10 \mathrm{~V}-$ 


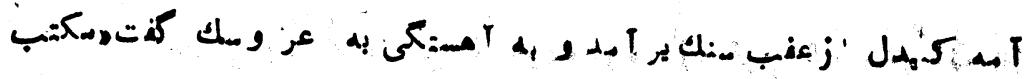

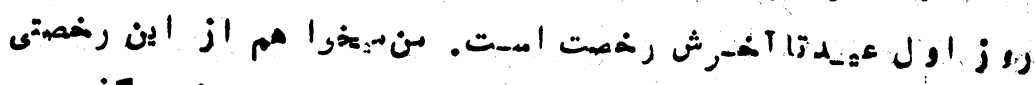

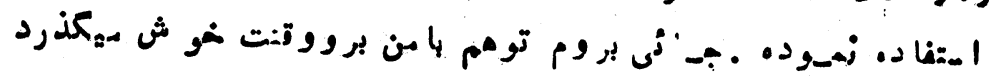

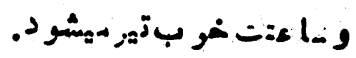

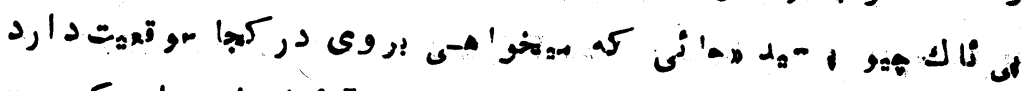

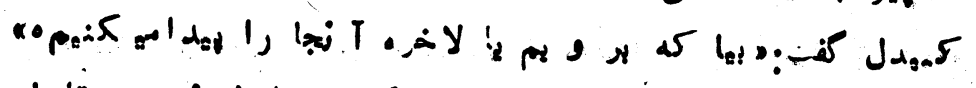

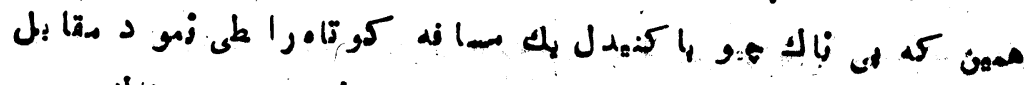

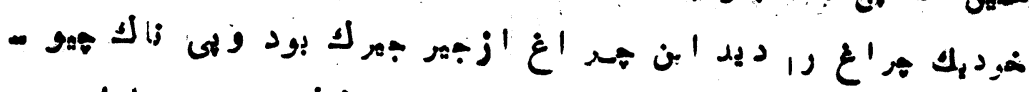

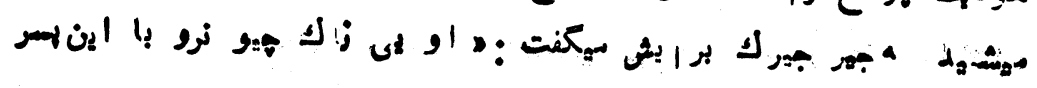

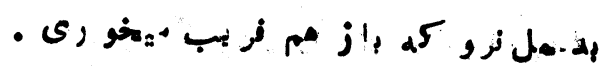

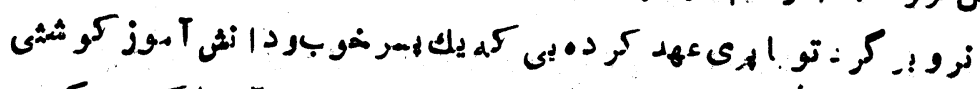

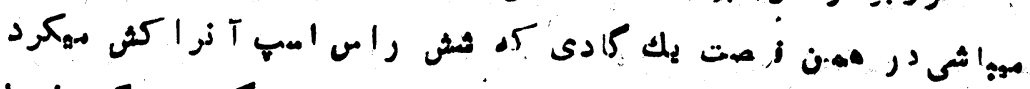

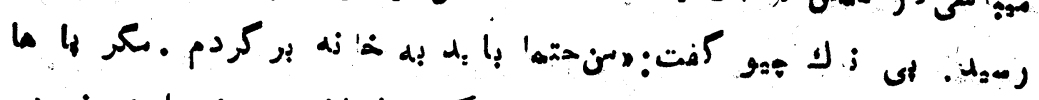

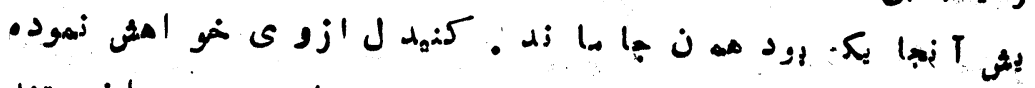

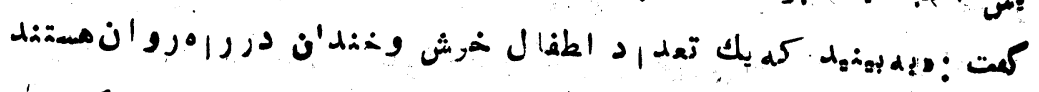

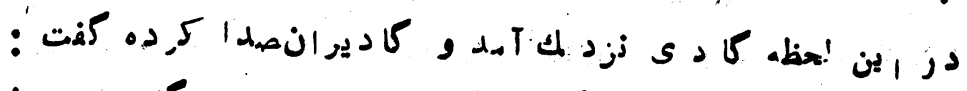

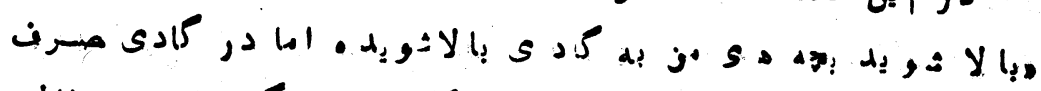

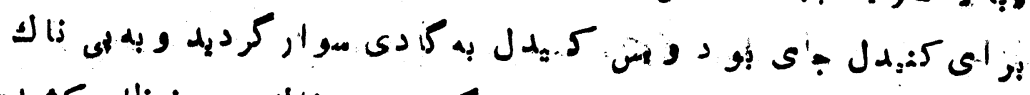

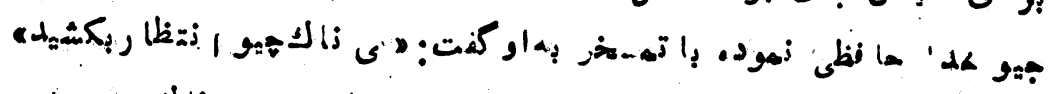

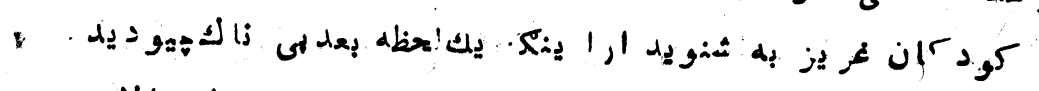

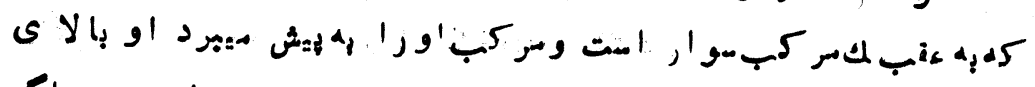

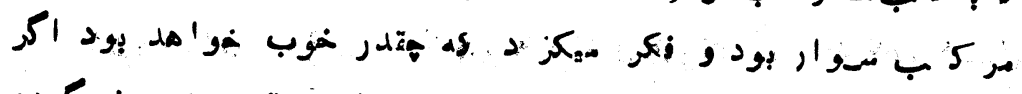

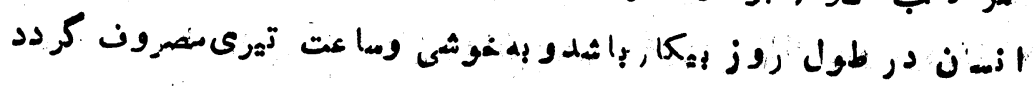




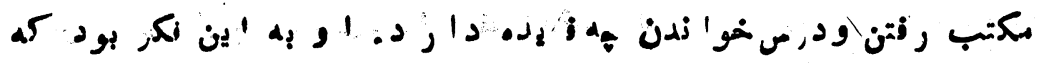

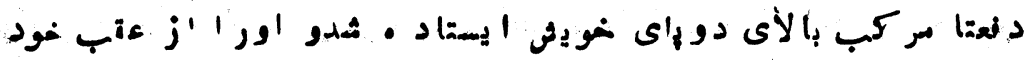

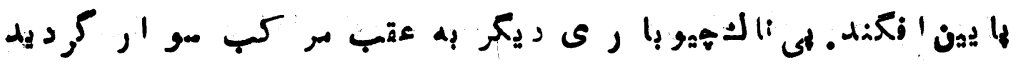

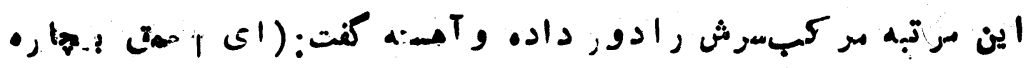

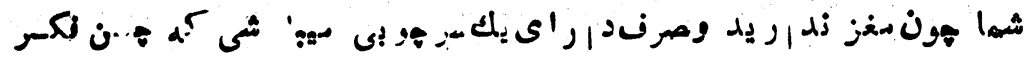

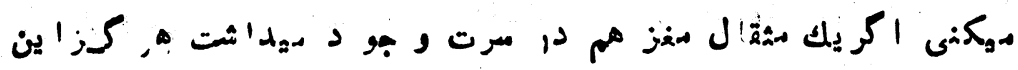

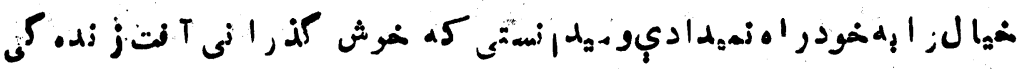

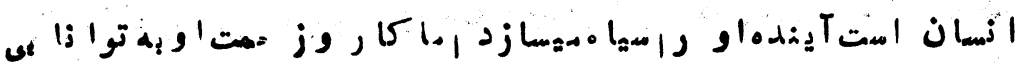

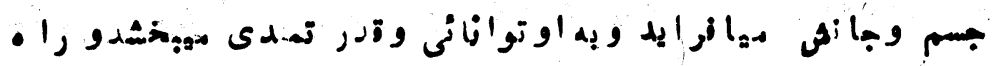

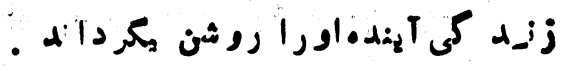

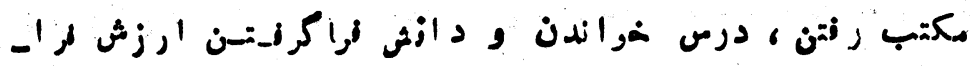

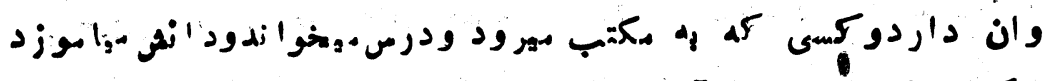

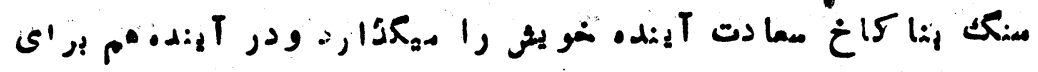

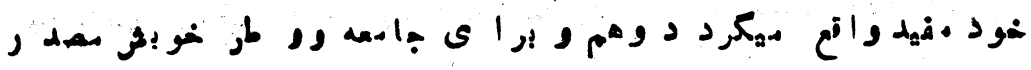

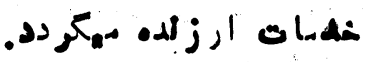

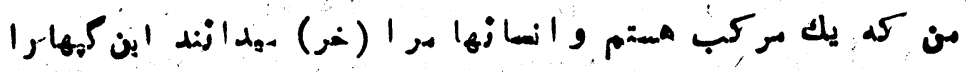

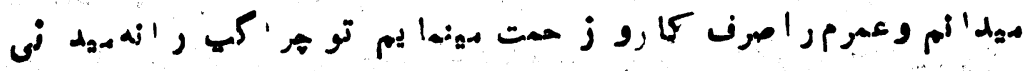

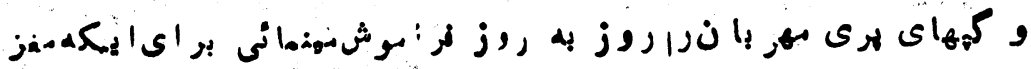

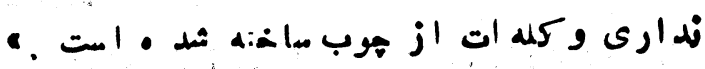

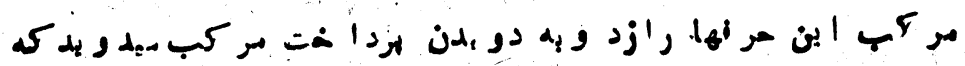

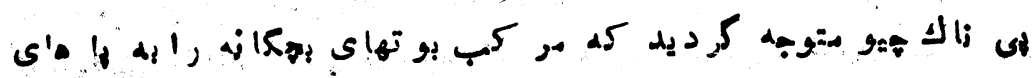

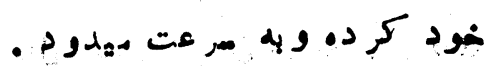

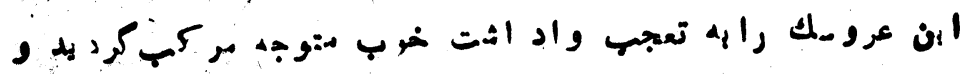
$-109-$ 


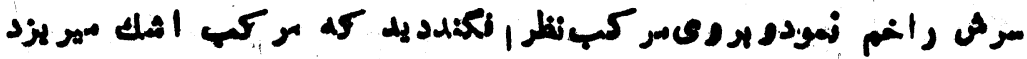

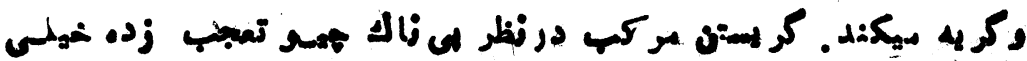

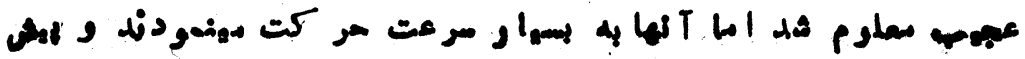

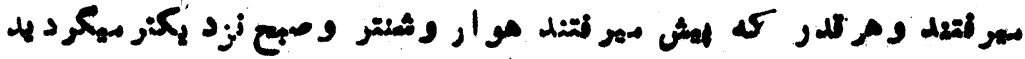

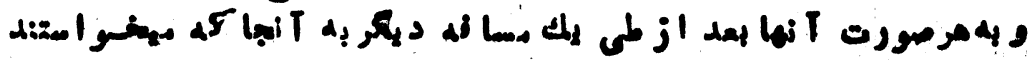

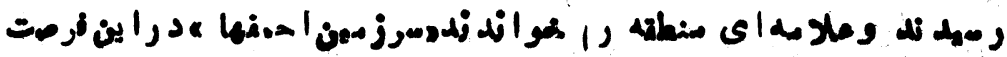

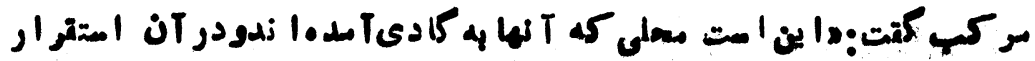

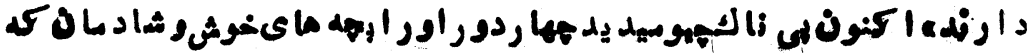

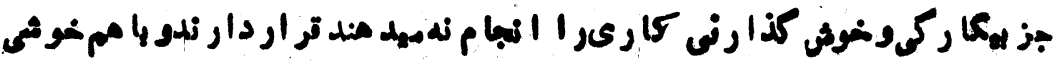

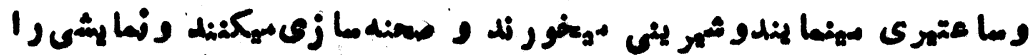

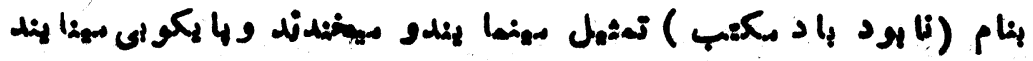

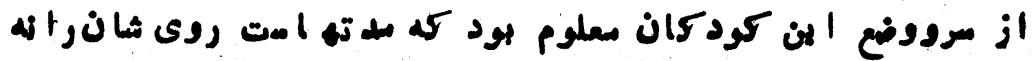

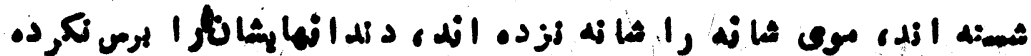

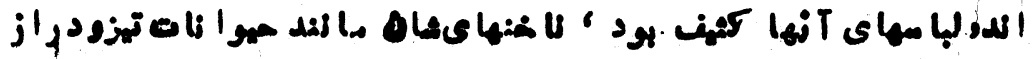

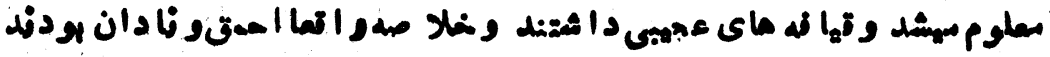

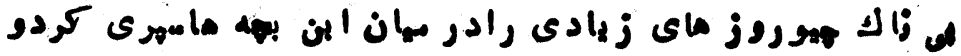

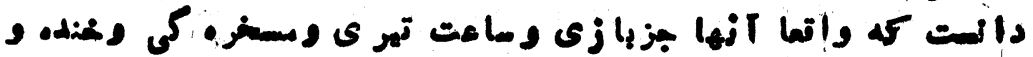

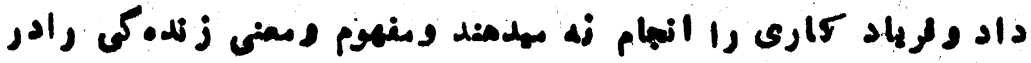

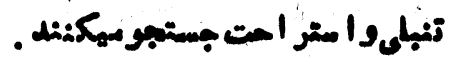

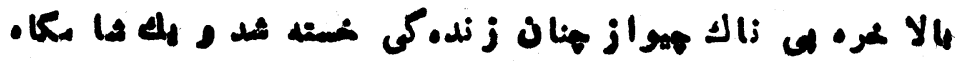

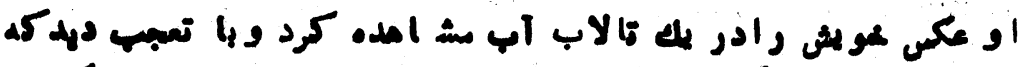

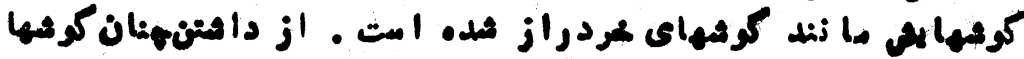

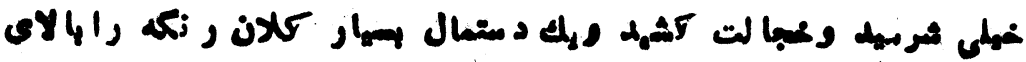
1 


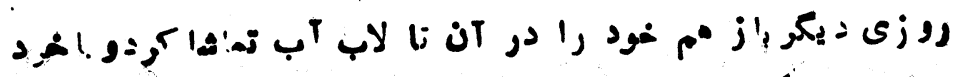

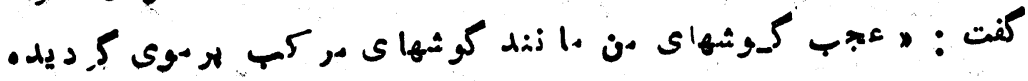

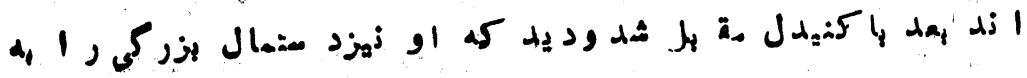

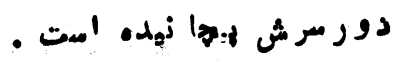

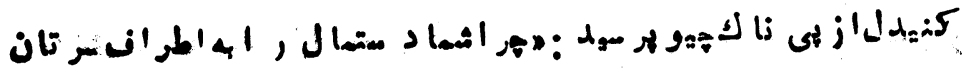

Q

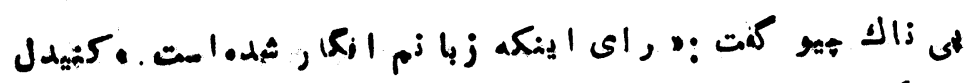

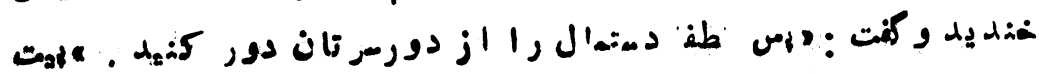

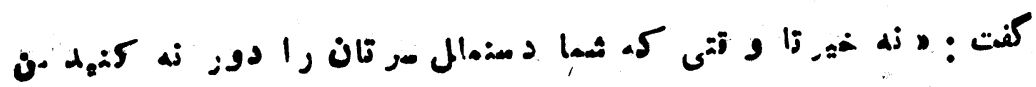

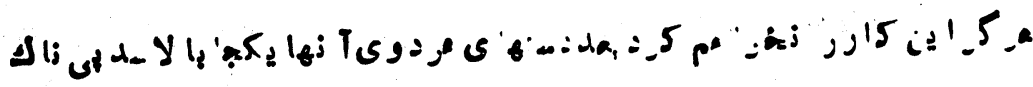

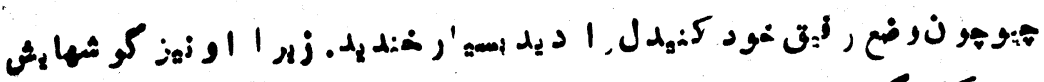

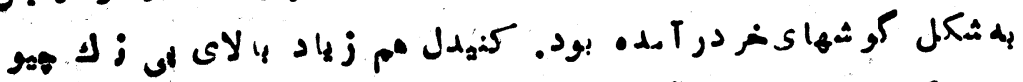

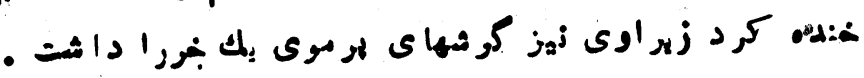

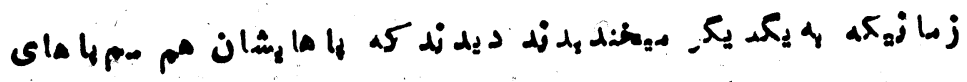

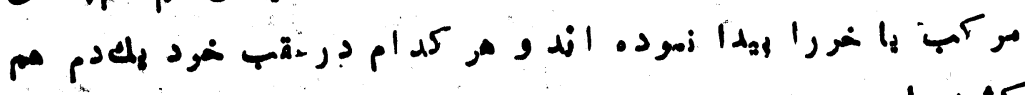

.

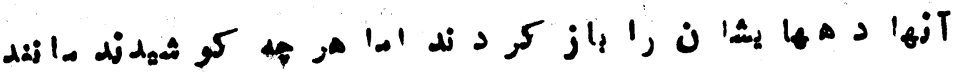

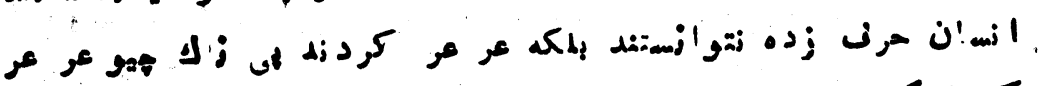

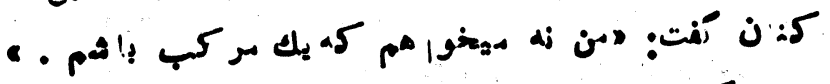

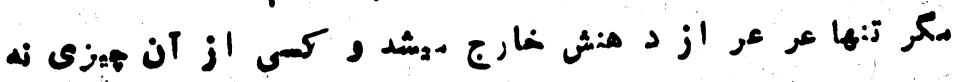

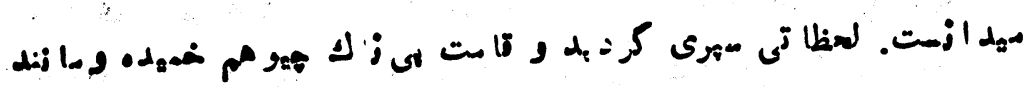

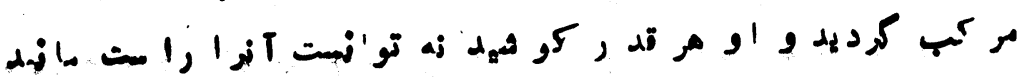
$-171-$ 


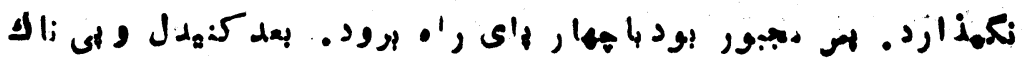

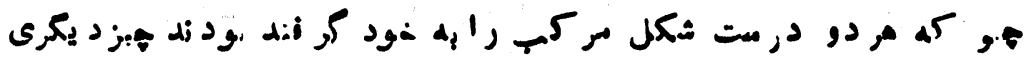

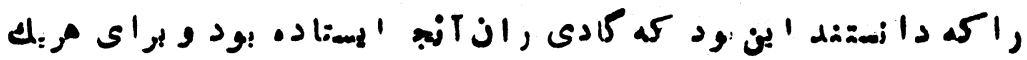

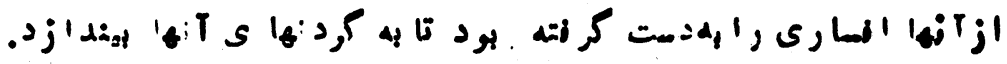

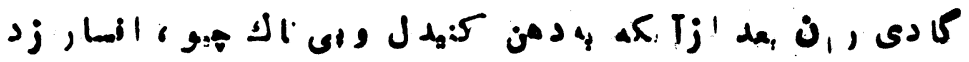

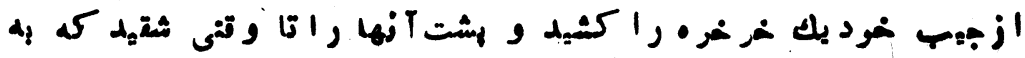

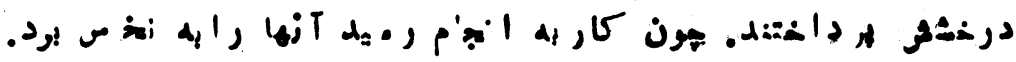

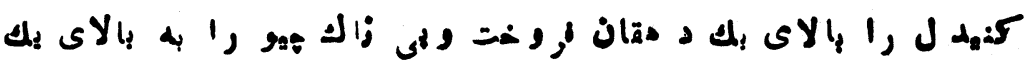

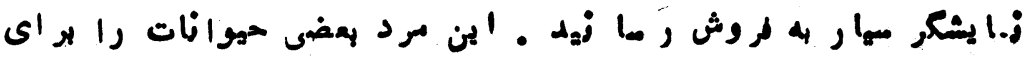

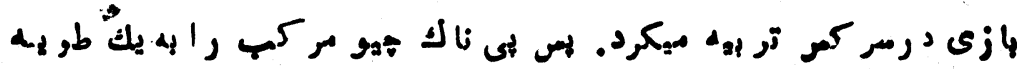

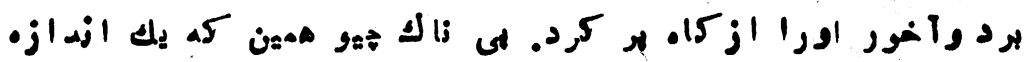

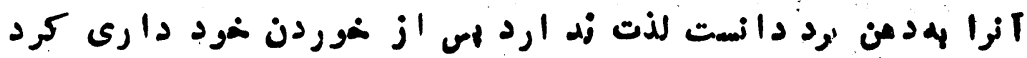

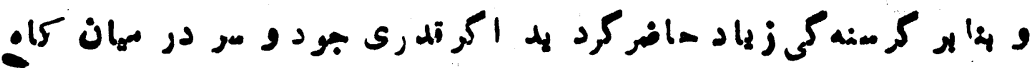

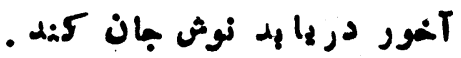

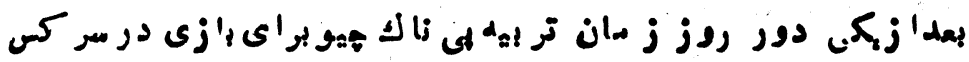

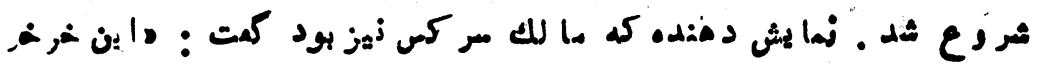

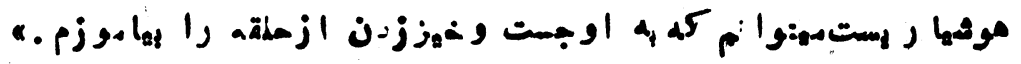

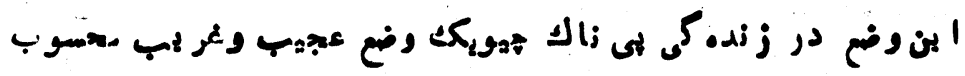

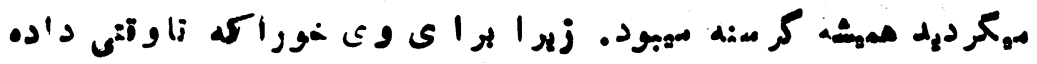

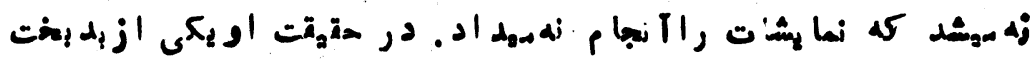

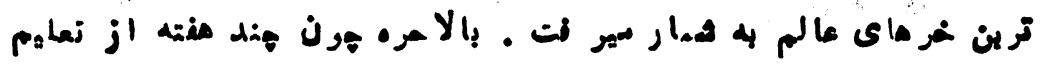

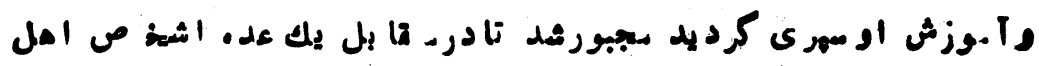

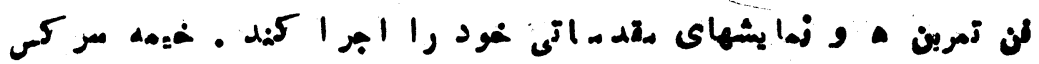

- lar 


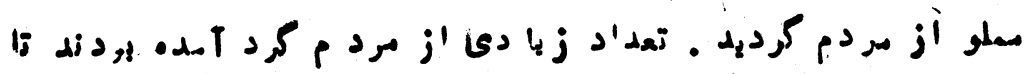

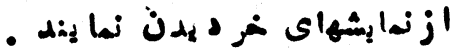

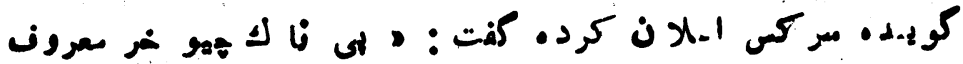

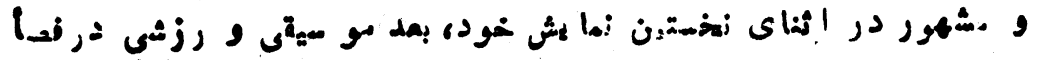

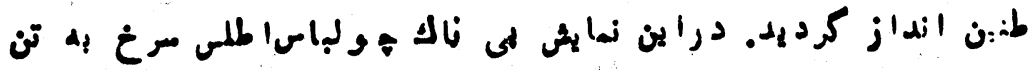

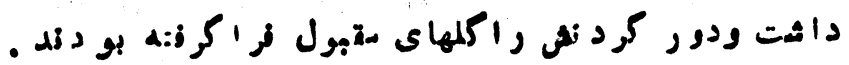

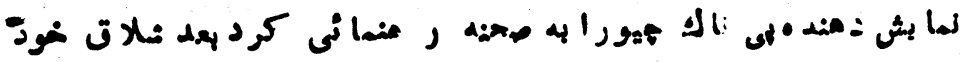

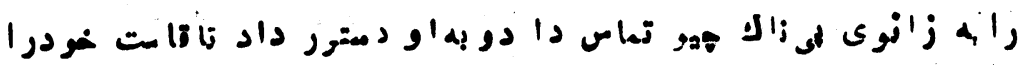

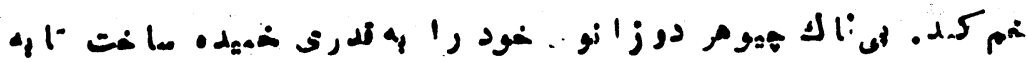

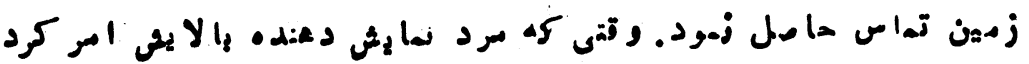

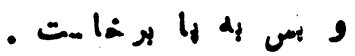

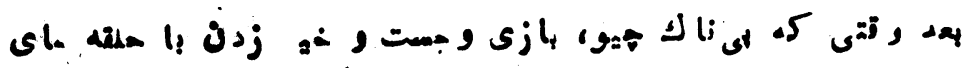

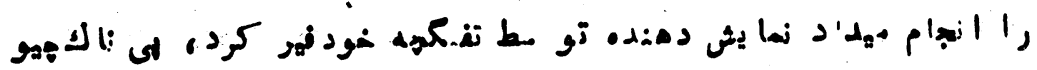

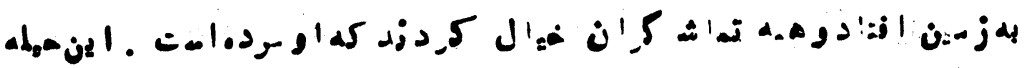

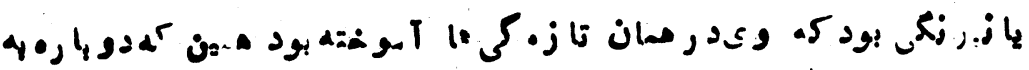

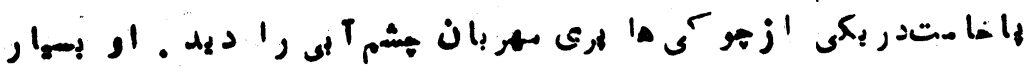

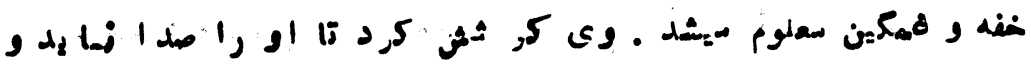

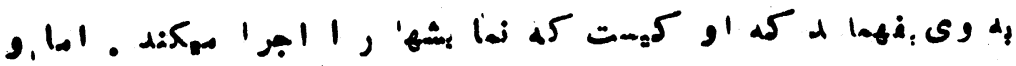

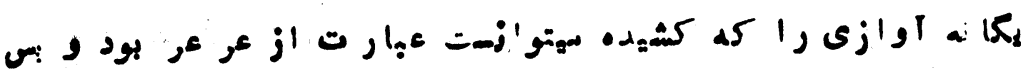

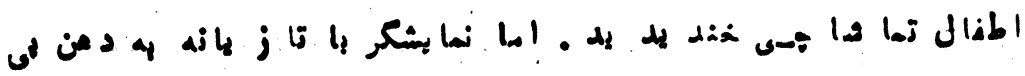

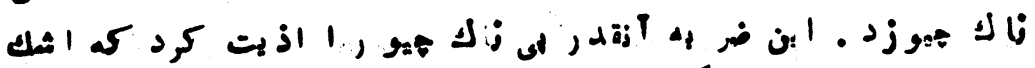

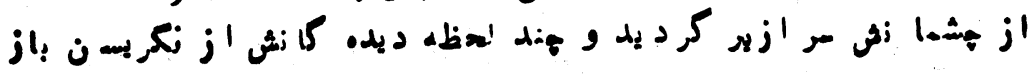

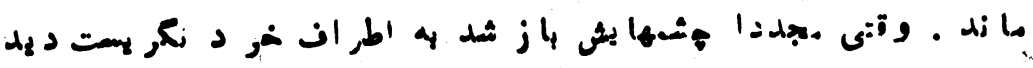

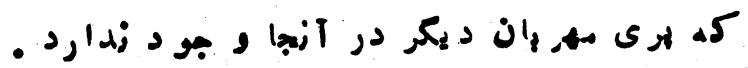

$-17 r-$ 


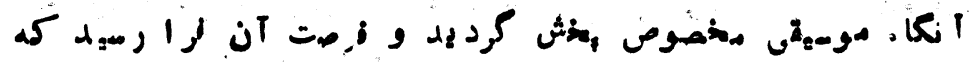

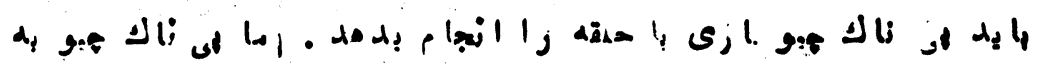

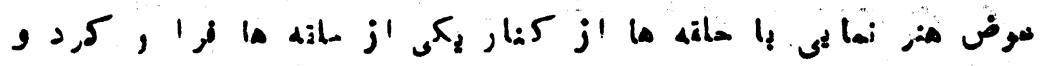

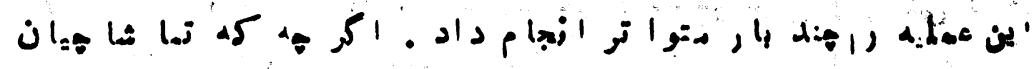

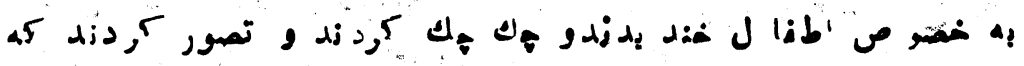

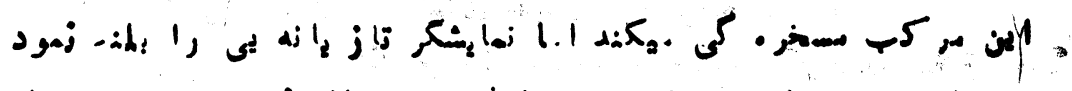

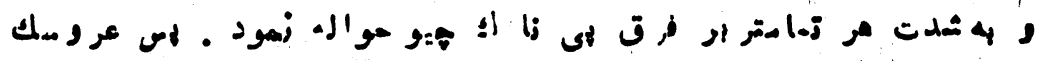

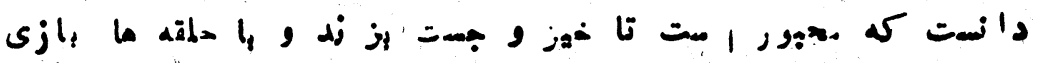

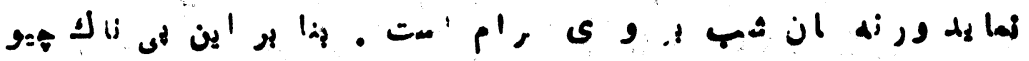

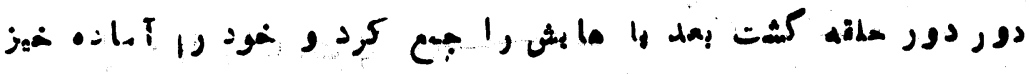

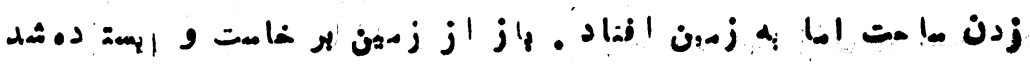

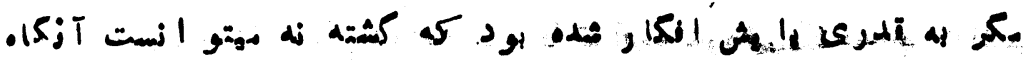

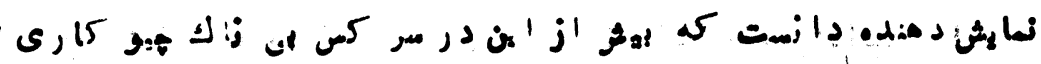

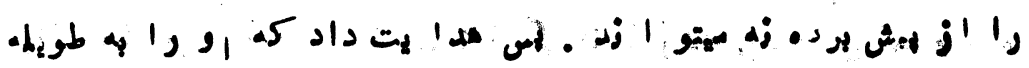

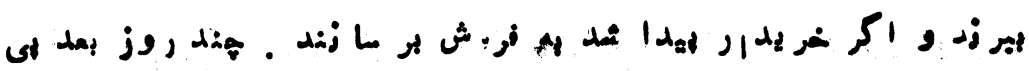

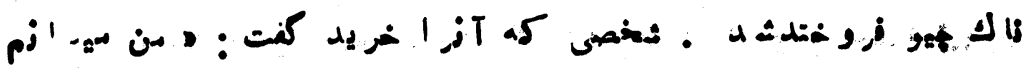

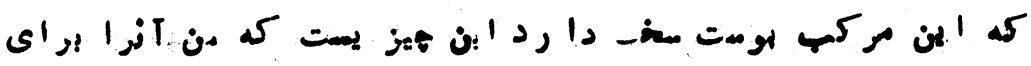

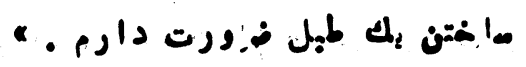

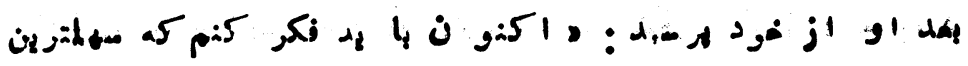

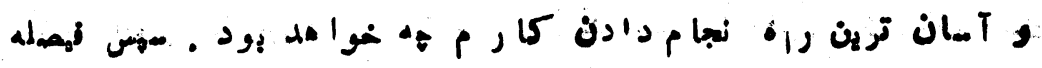

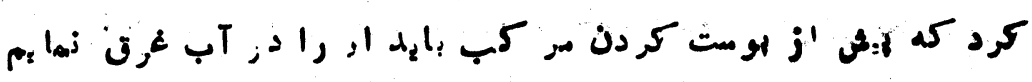

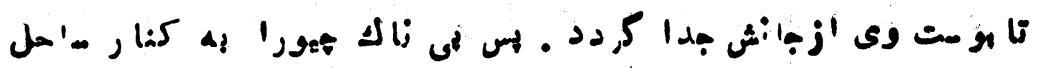

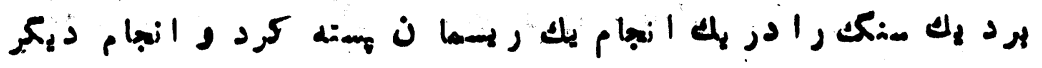

$-17 m-$ 


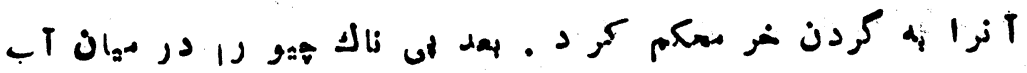

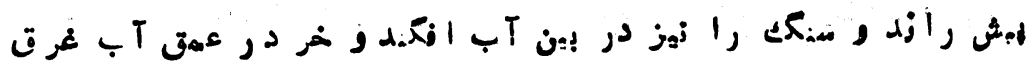

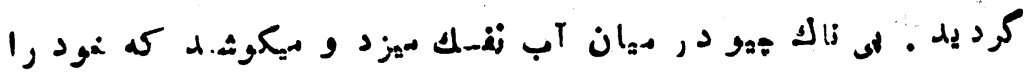

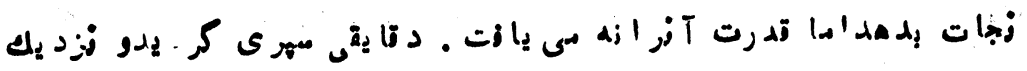

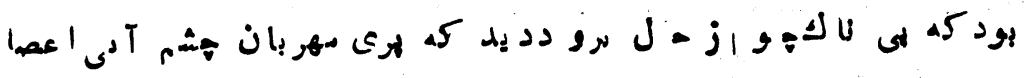

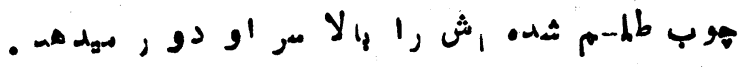

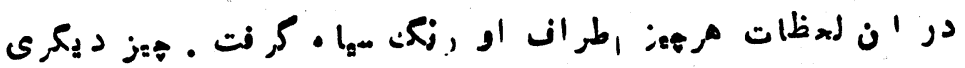

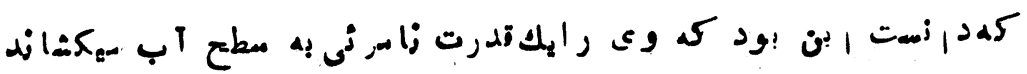

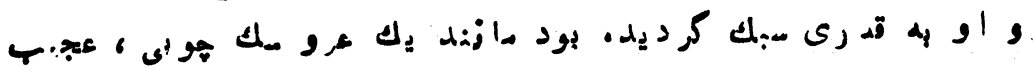

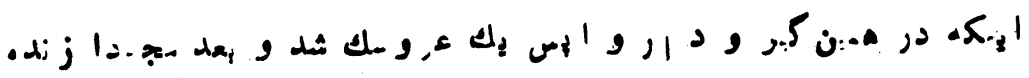

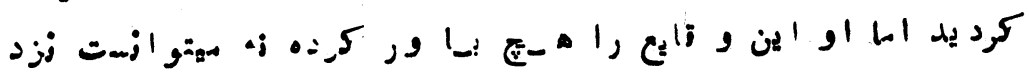

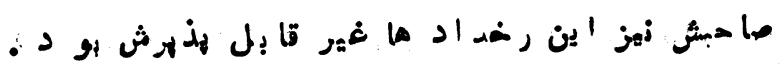

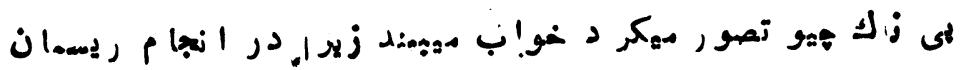

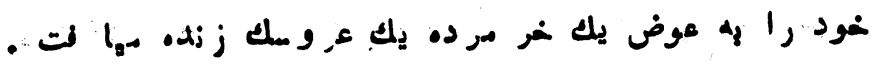

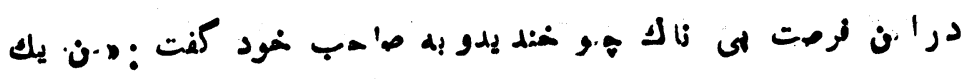

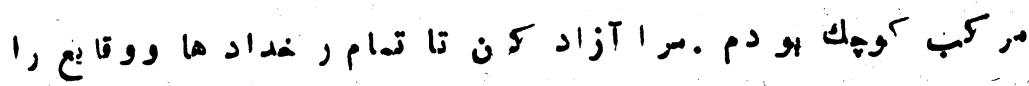

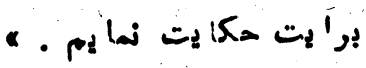

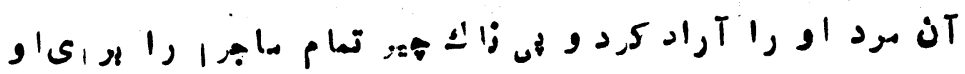

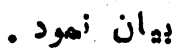

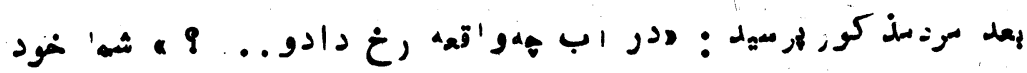

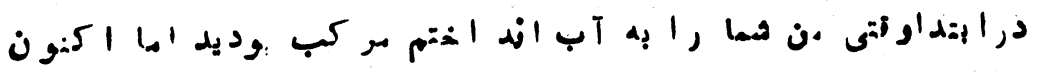

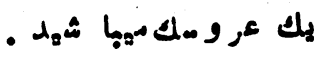

$-170-$ 


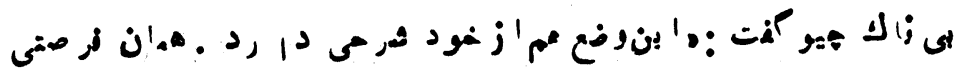

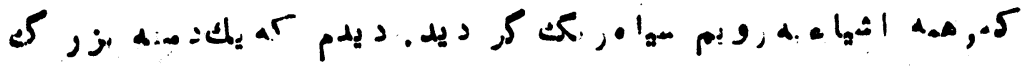

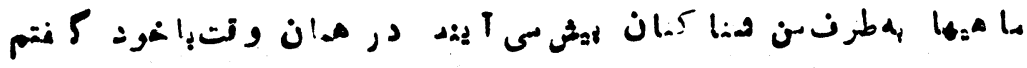

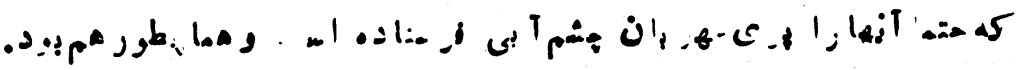

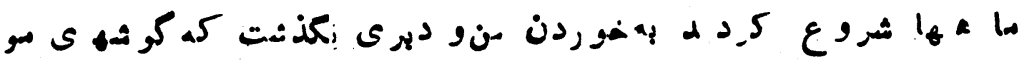

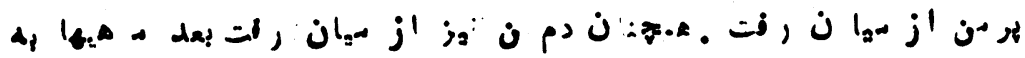

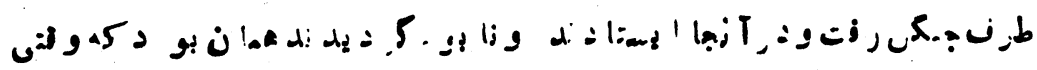

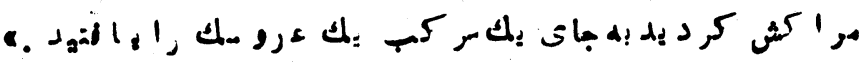

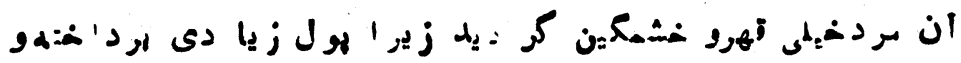
ه:ز

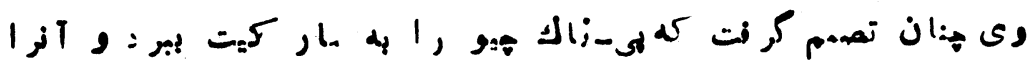

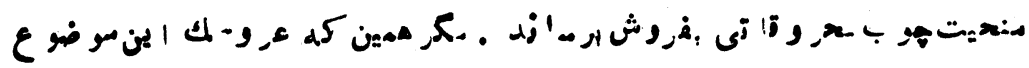

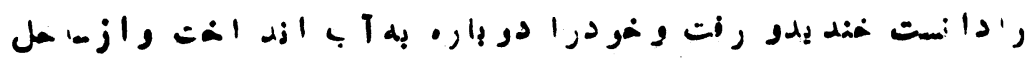

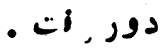

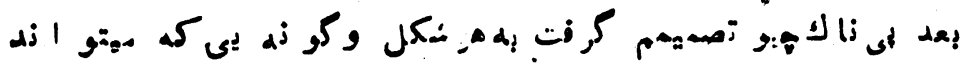

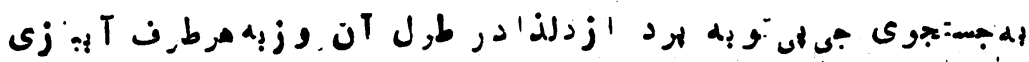

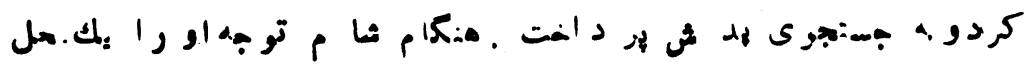

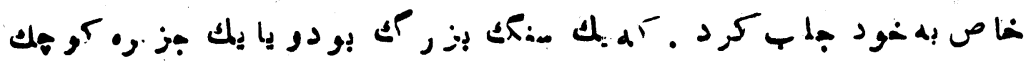

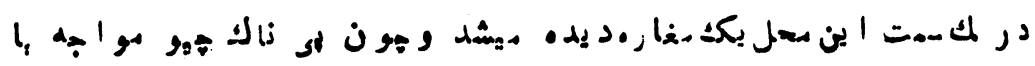

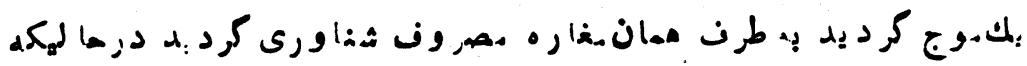

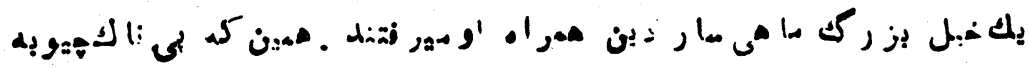

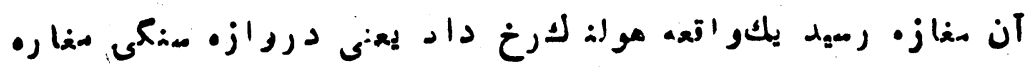

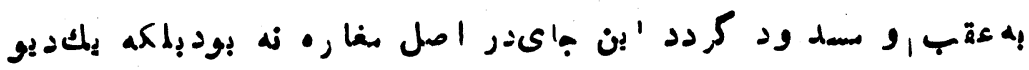
$-177-$ 


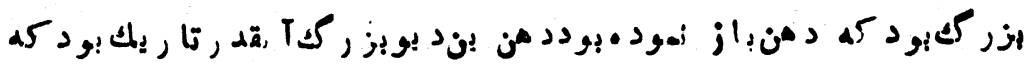

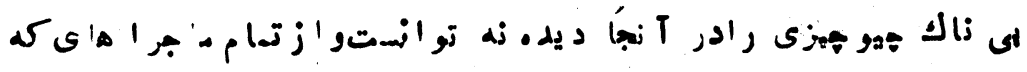

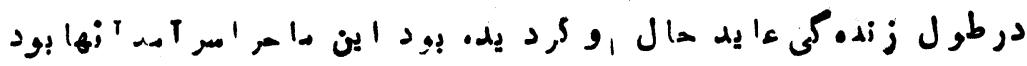

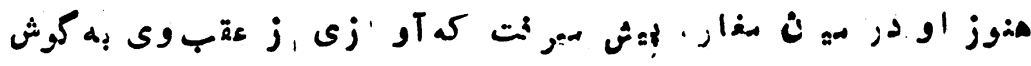

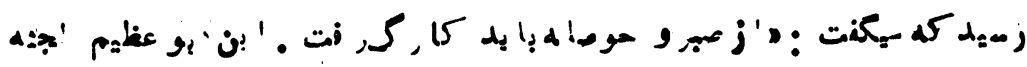

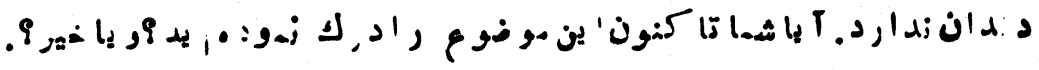

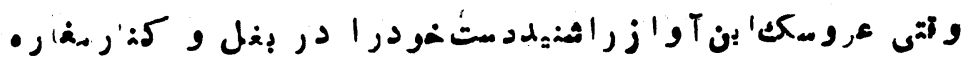

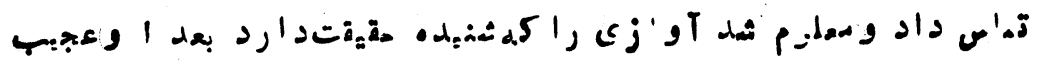

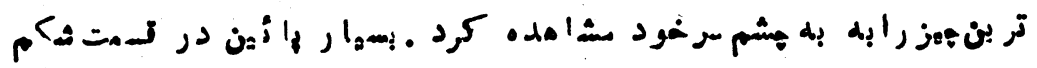

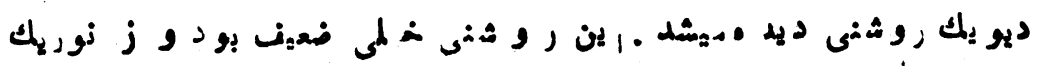

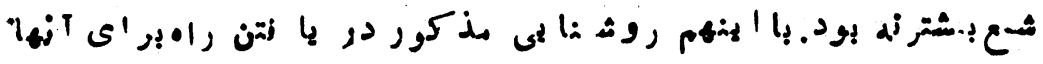

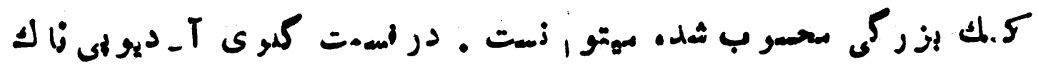

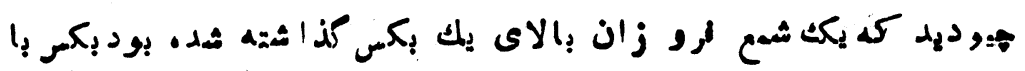

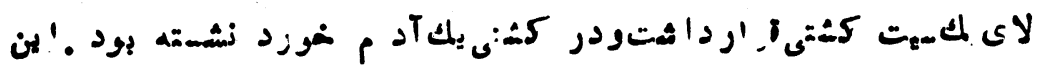

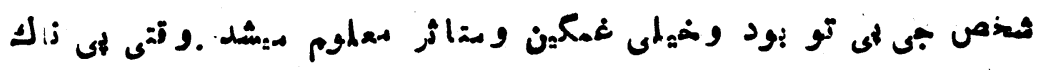

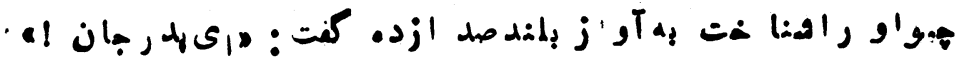

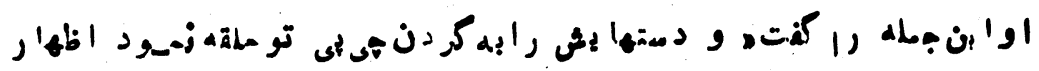

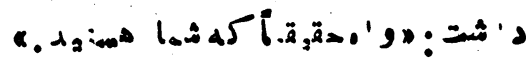

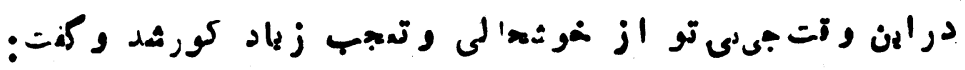

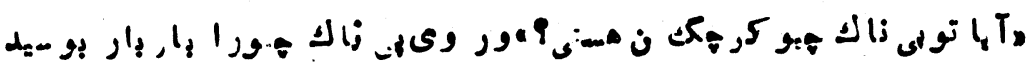

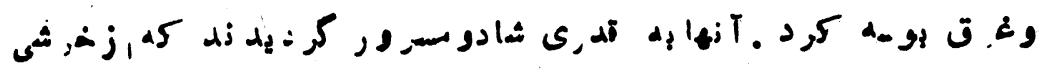

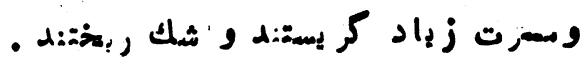

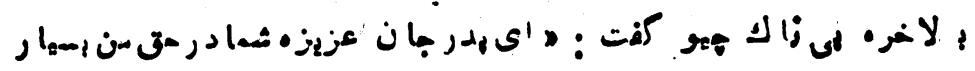
$-17 V_{0}$ 


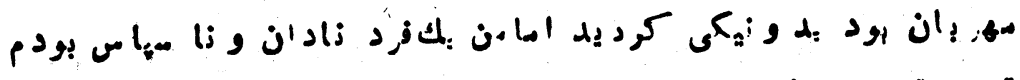

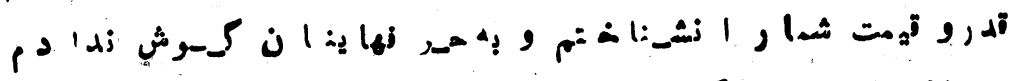

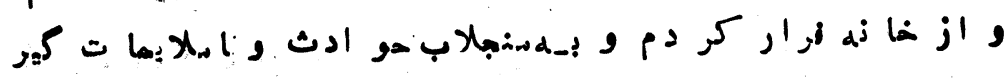

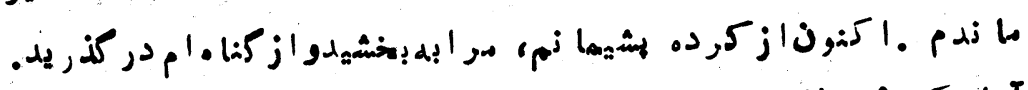

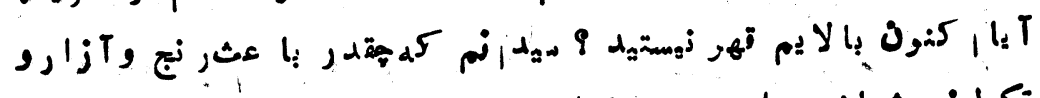

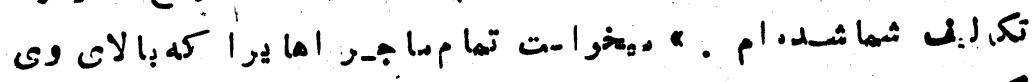

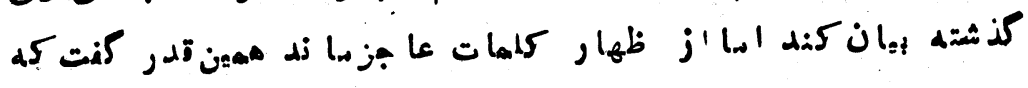

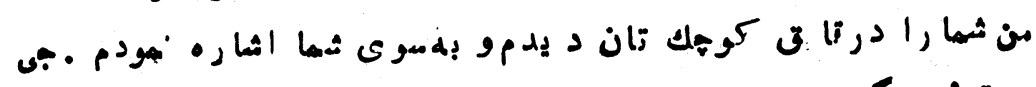

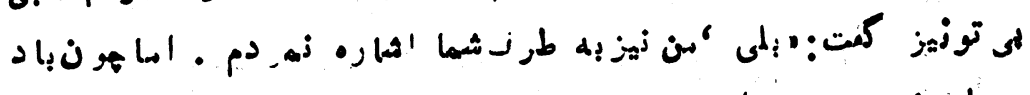

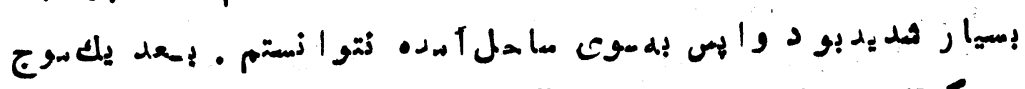

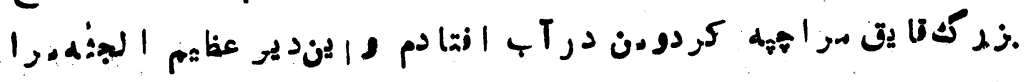

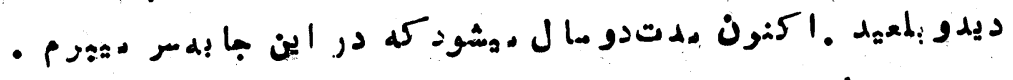

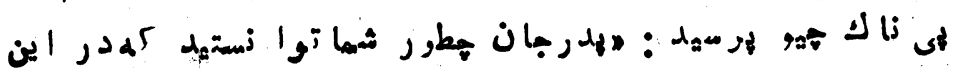
مدت ز نده إما زيد

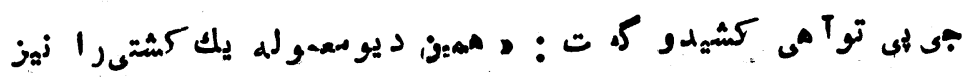

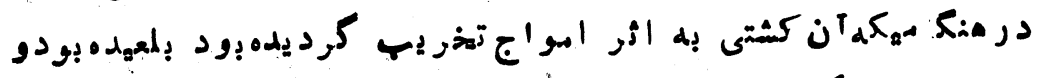

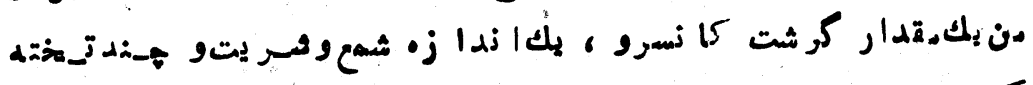

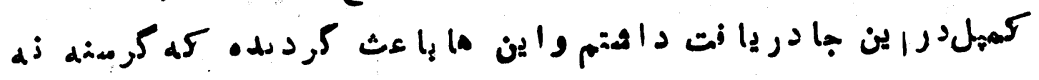

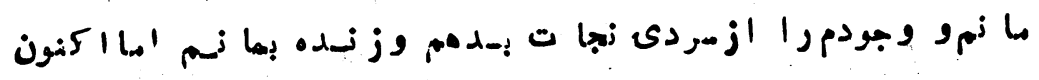

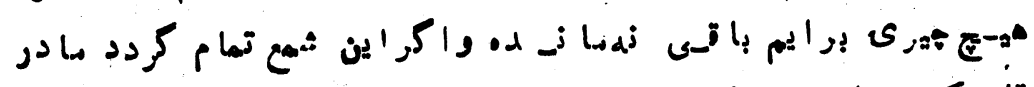

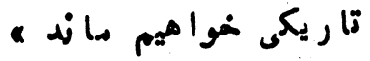

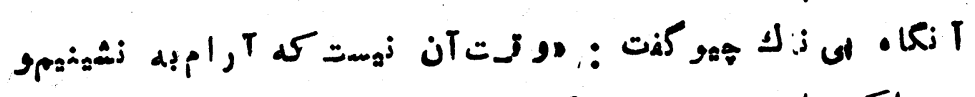

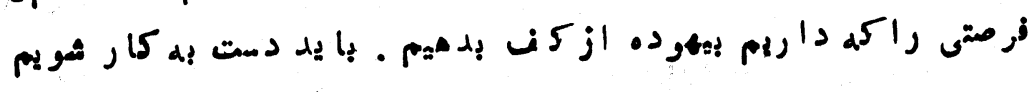




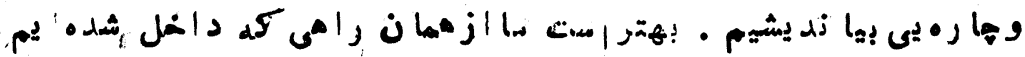

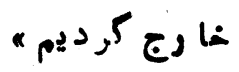

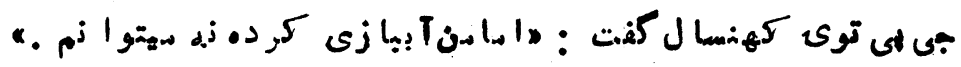

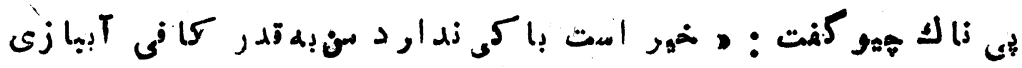

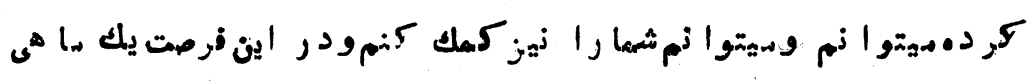

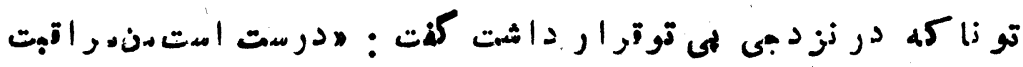

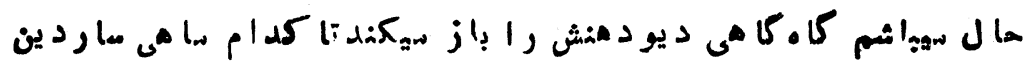

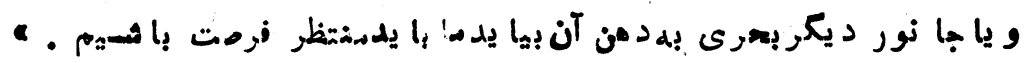

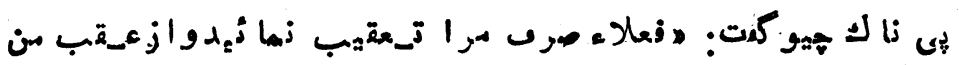

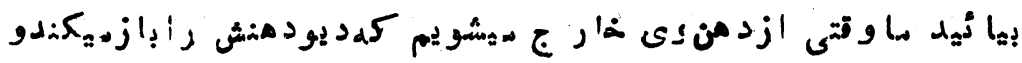

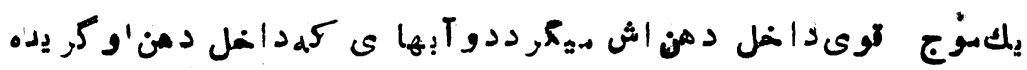

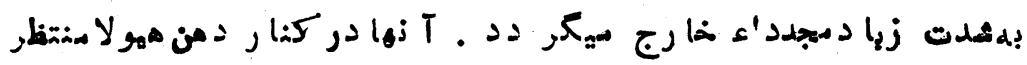

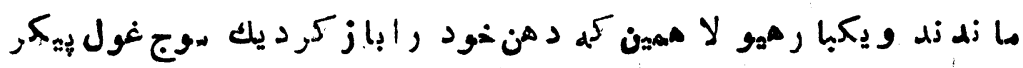

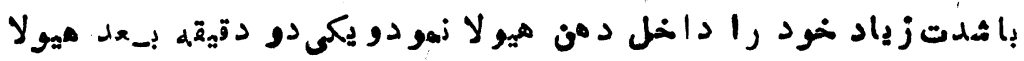

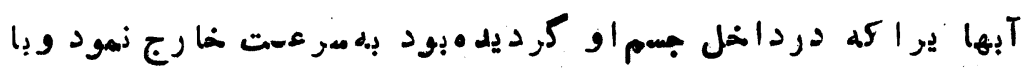

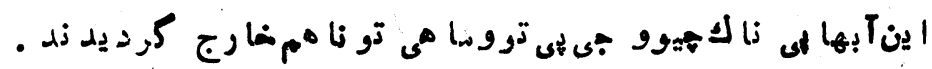

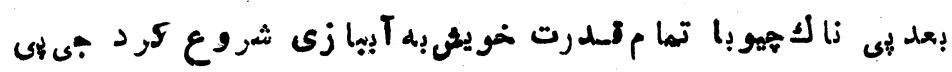

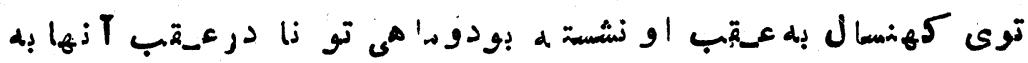

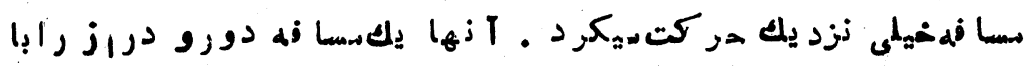

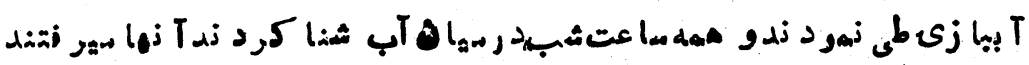

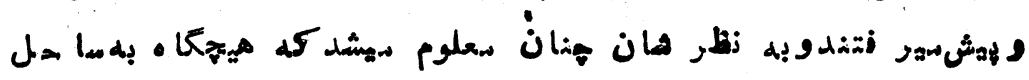

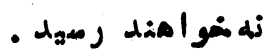

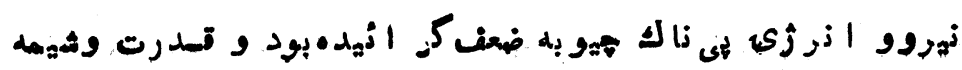




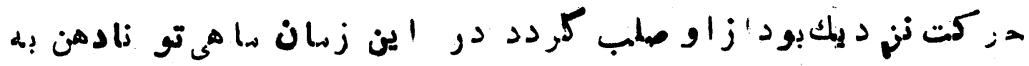

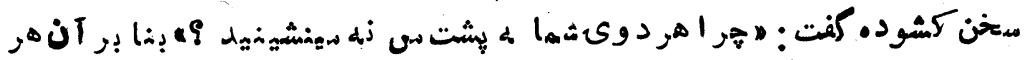

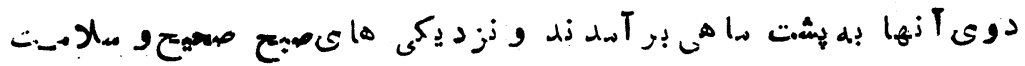

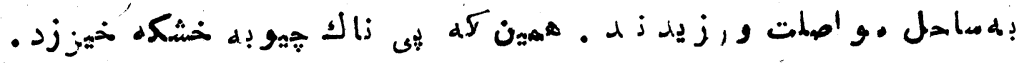

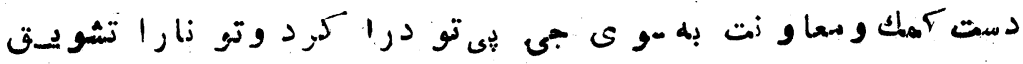

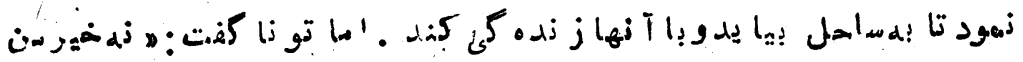

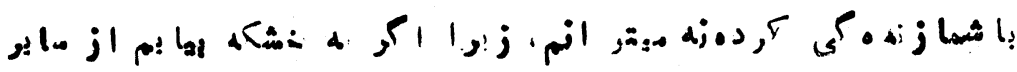

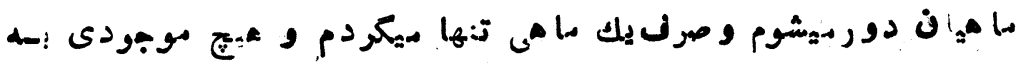

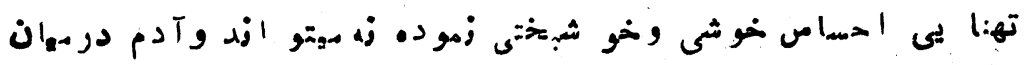

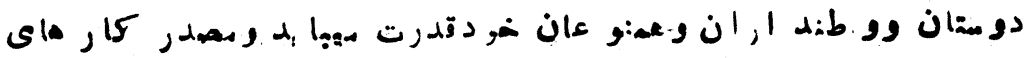

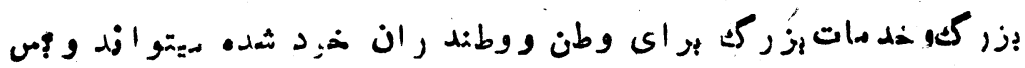

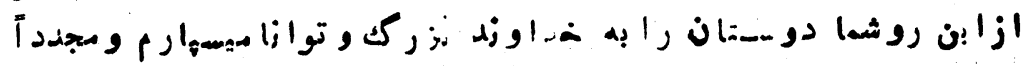

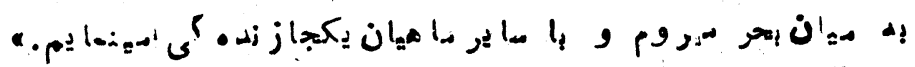

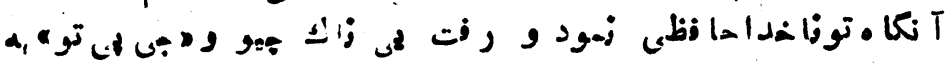

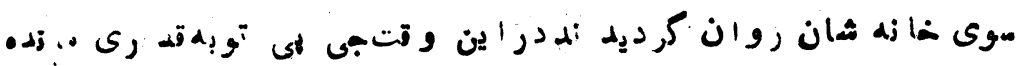

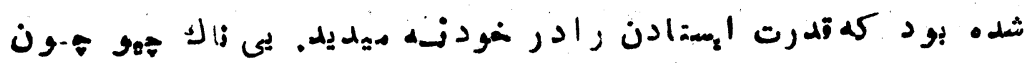

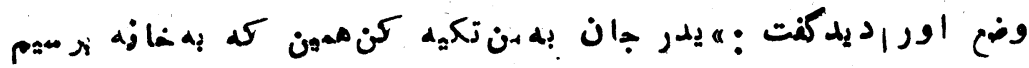

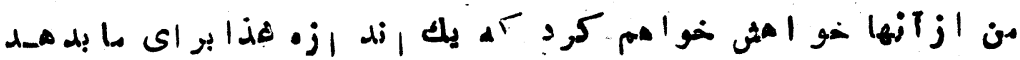

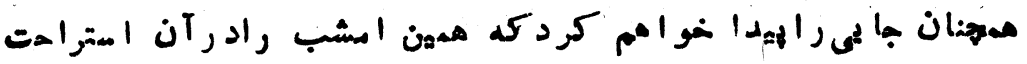

a.pela

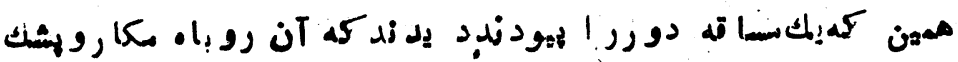

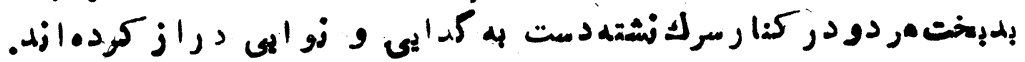

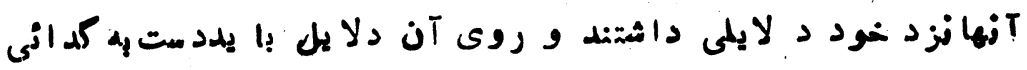

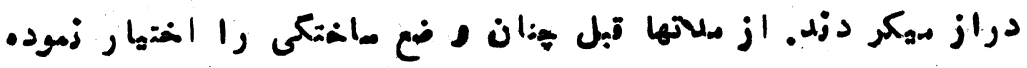

- I vo- 


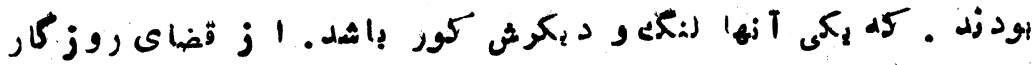

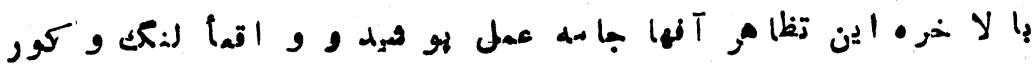
هد. بود زمد .

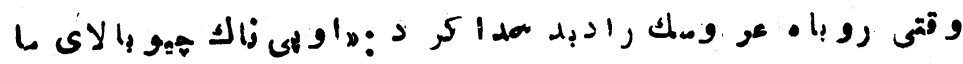

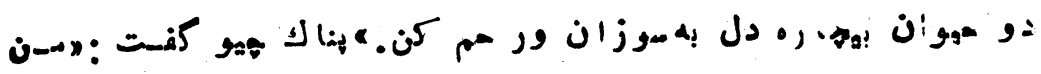

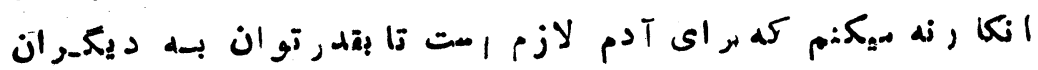

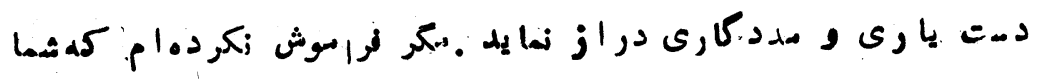

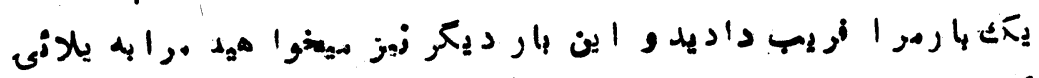

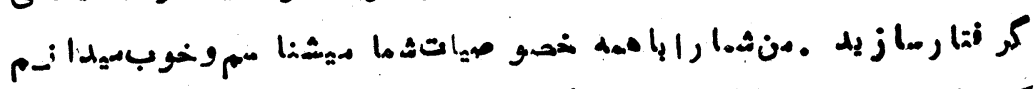

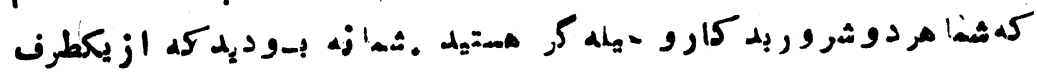

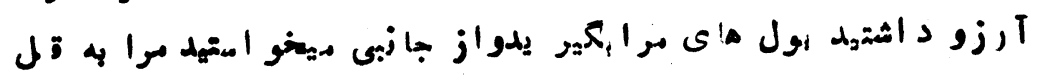

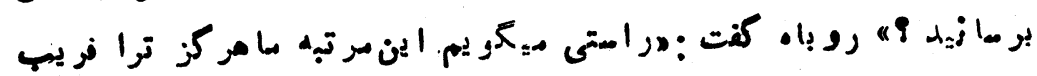

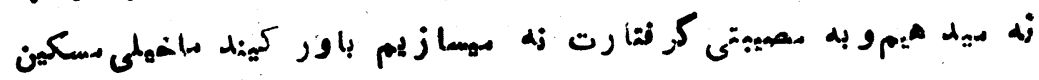

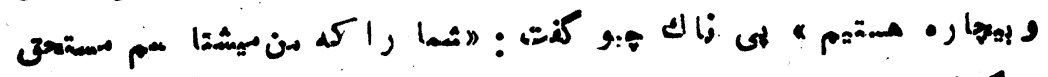

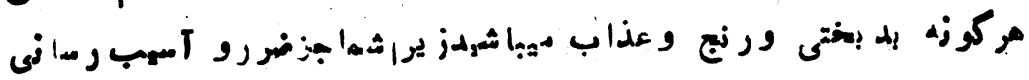

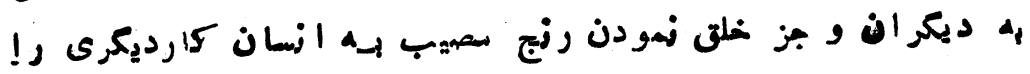

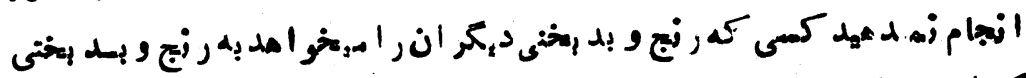

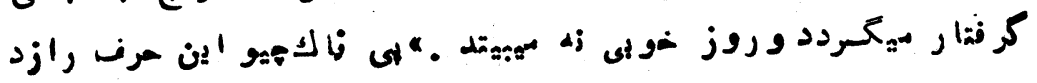

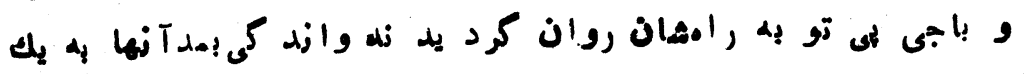

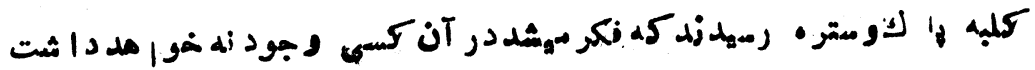

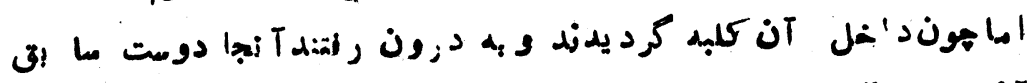

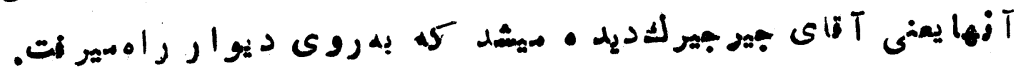

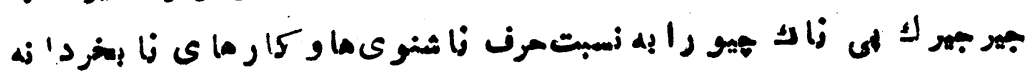




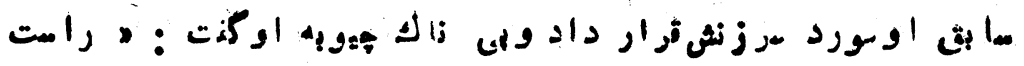

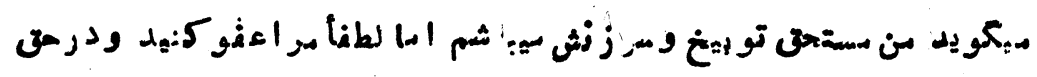

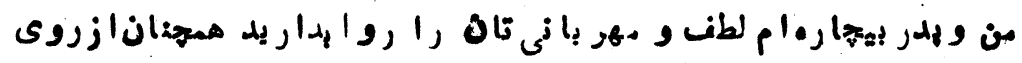

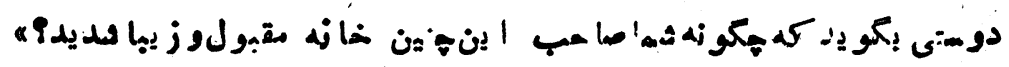

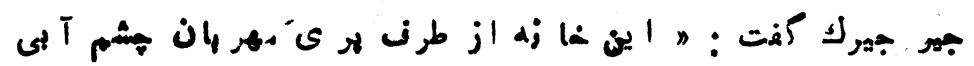

$$
\text { " . }
$$

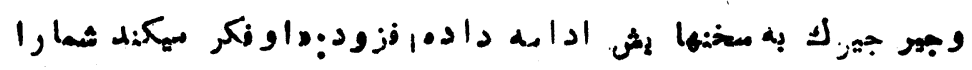

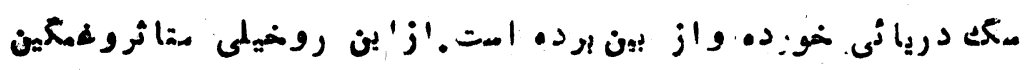

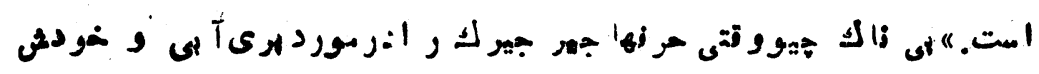

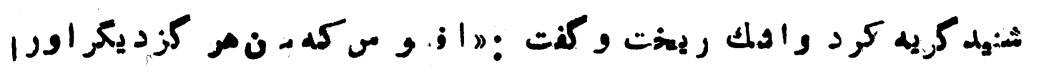

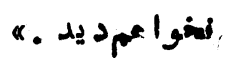

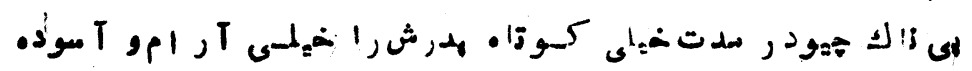

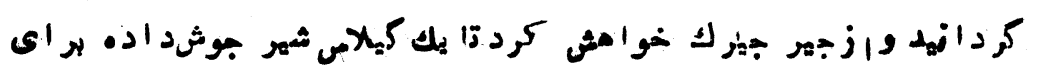

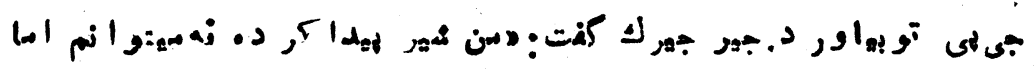

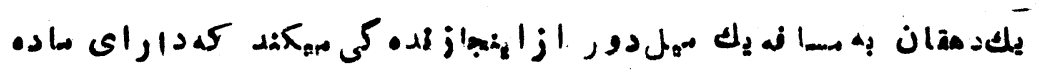

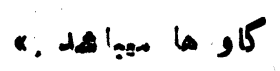

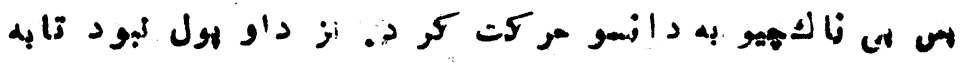

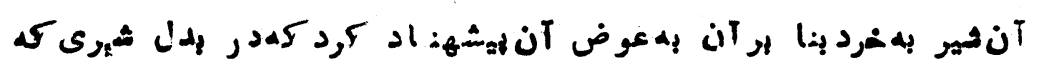

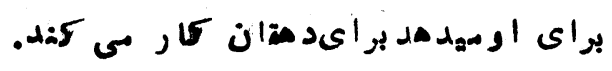

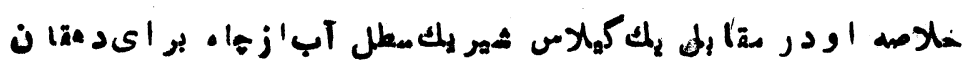

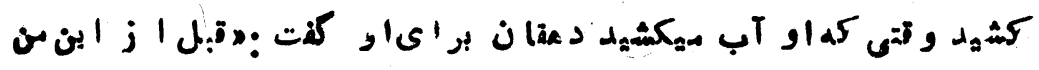

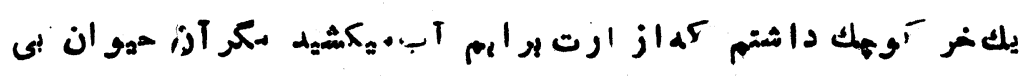

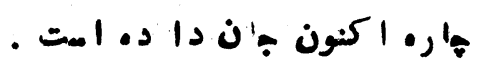




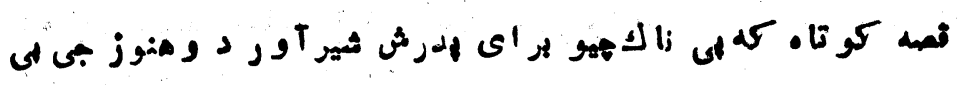

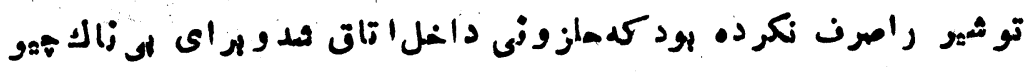

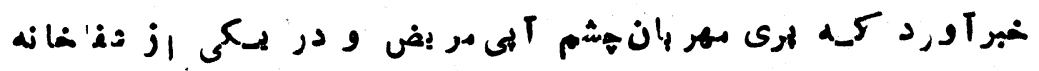

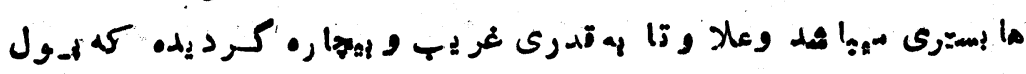

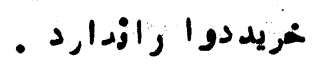

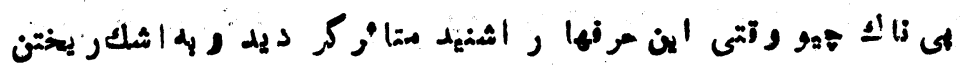

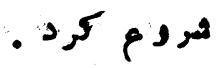

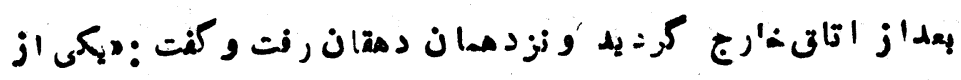

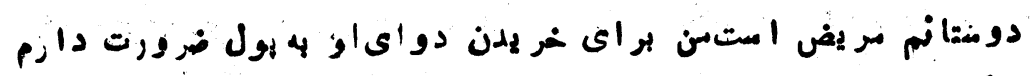

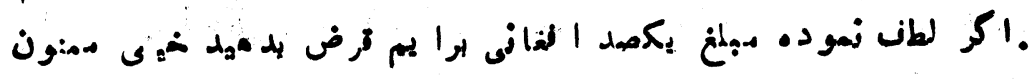

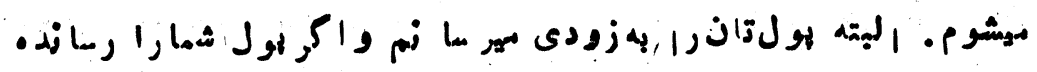

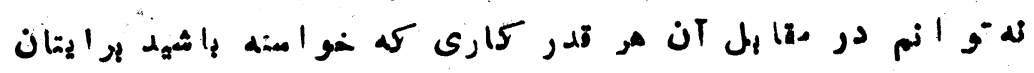

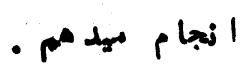

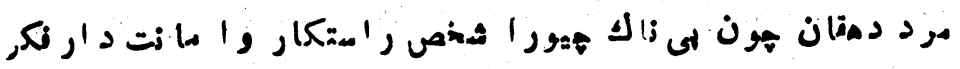

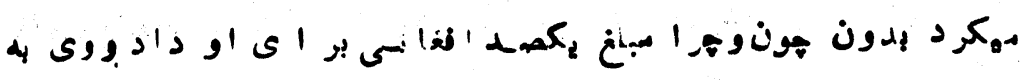

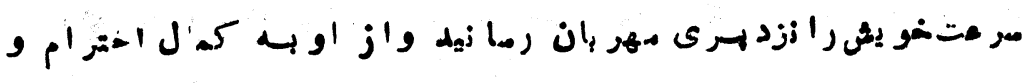

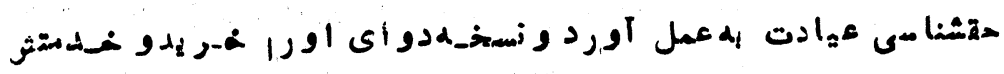

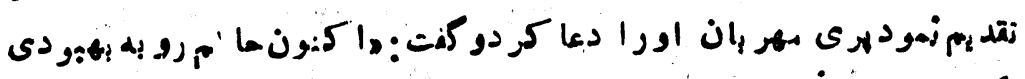

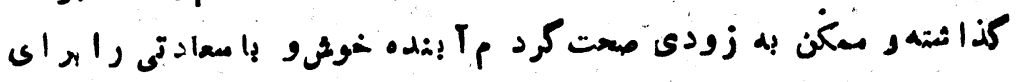

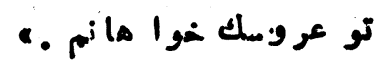

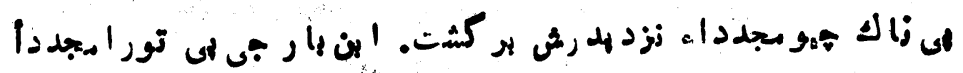

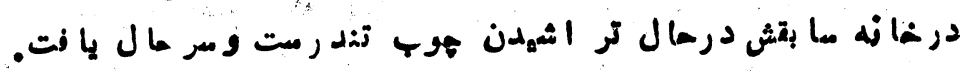

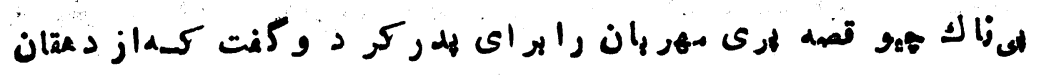

- ivr- 


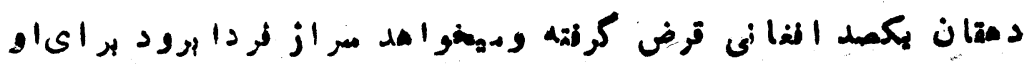

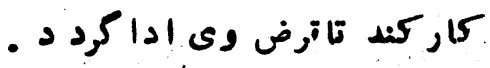

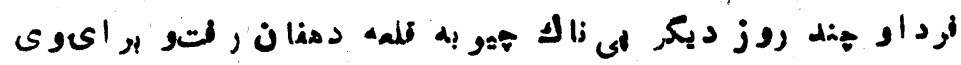

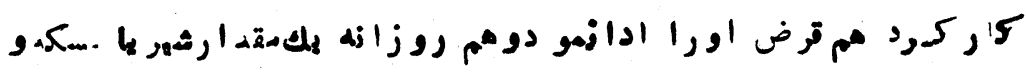

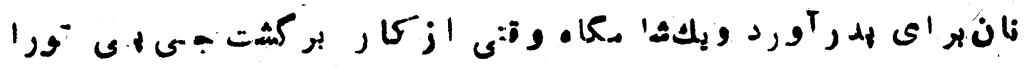

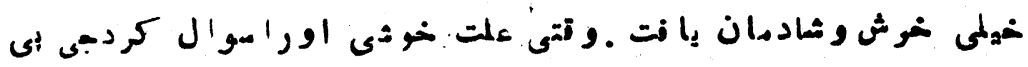

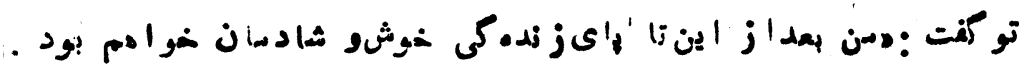

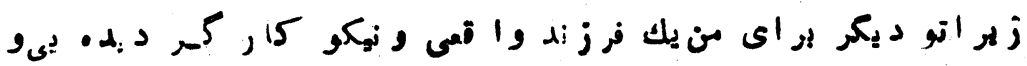

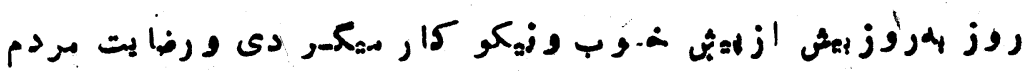

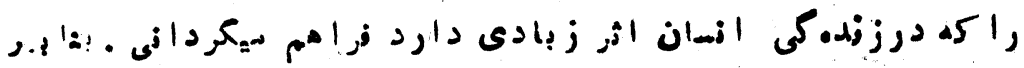

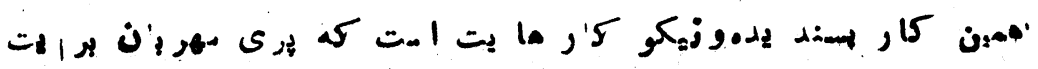

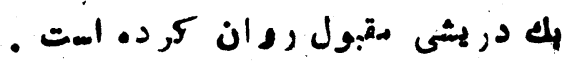

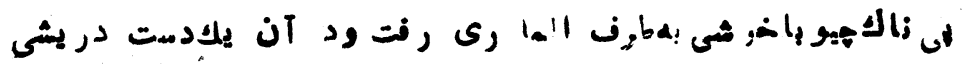

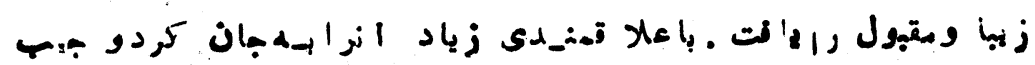

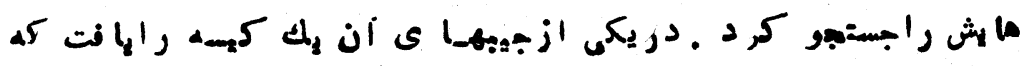

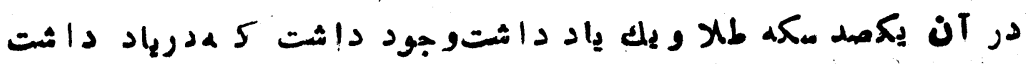

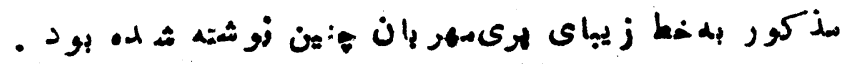

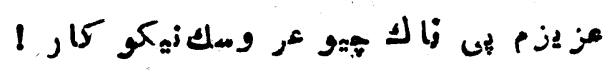

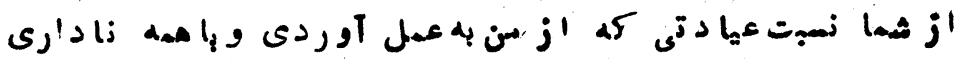

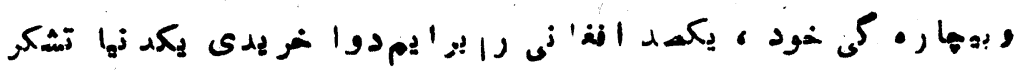

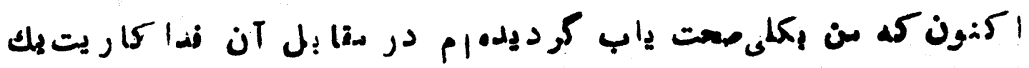

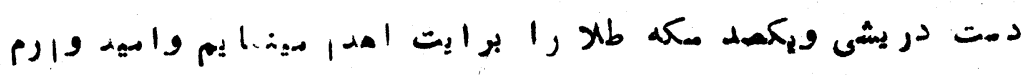

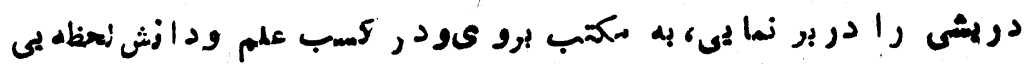




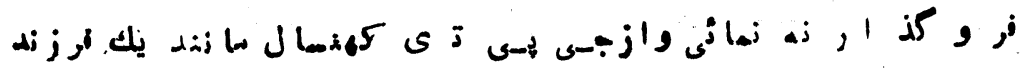

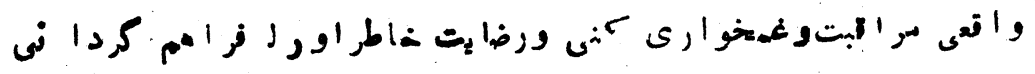

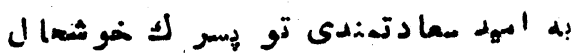

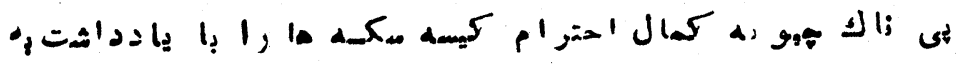

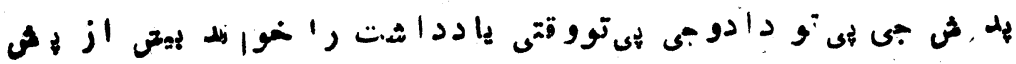

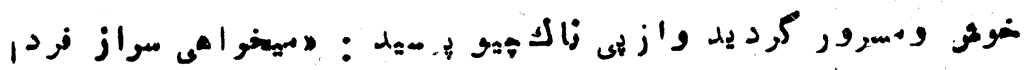

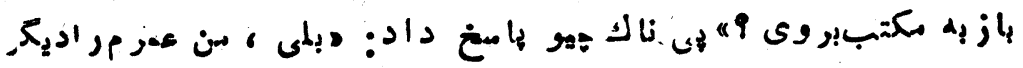

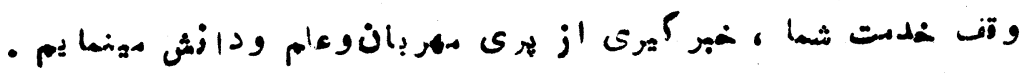

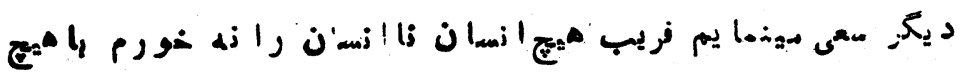

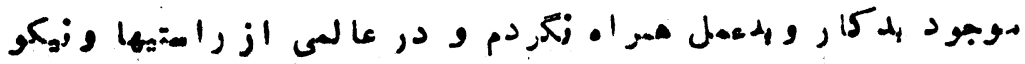

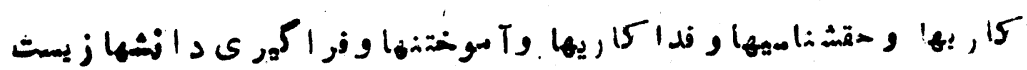

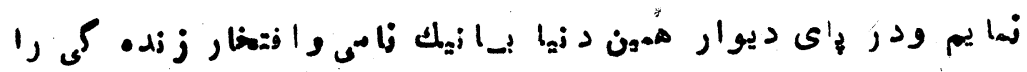
- م

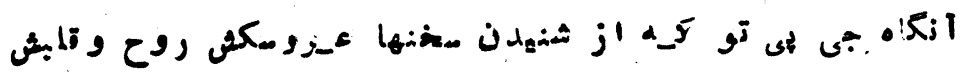

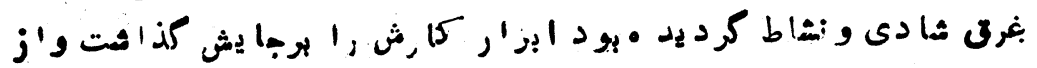

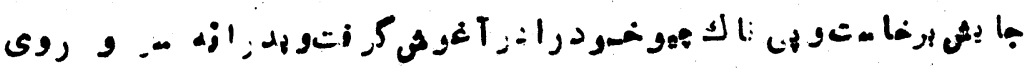

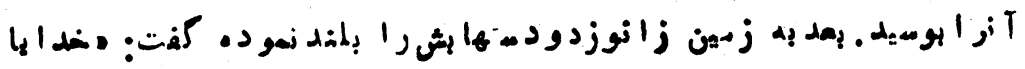

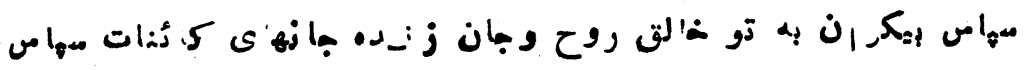

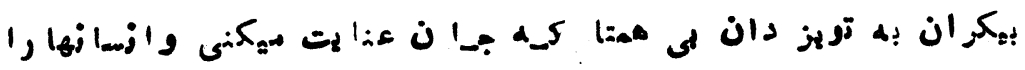

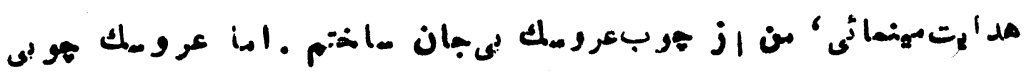

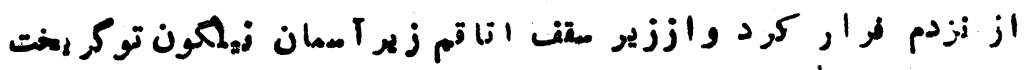

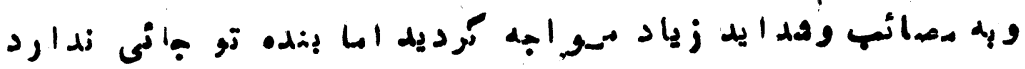

-1 von 


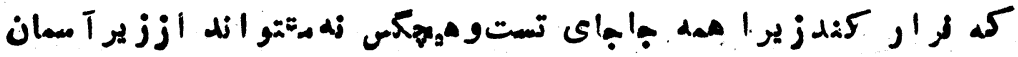

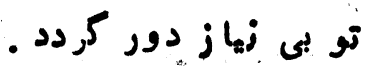

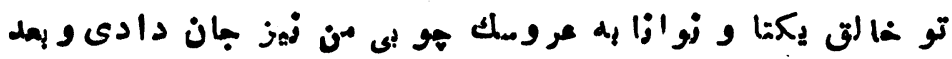

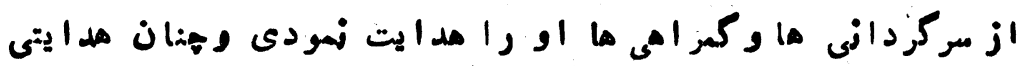

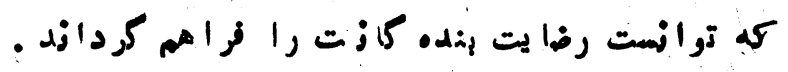

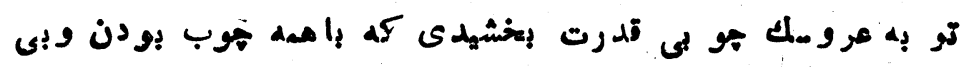

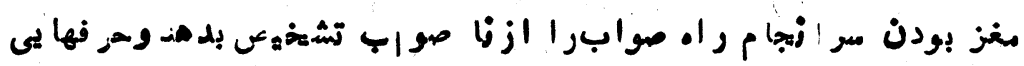

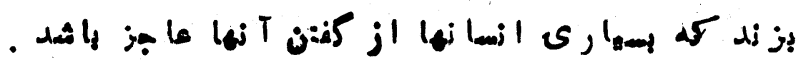

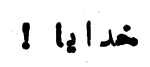

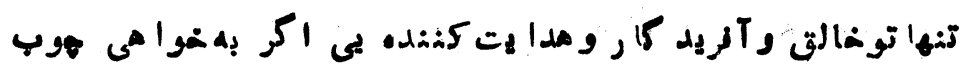

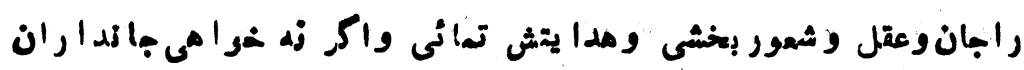

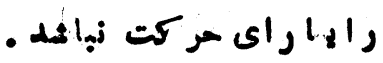

$$
\begin{aligned}
& \mid \text { | }
\end{aligned}
$$

عروسك مرا زيز هدات زما كمه ترا عبادت وم:ا يش زمايله وبراى

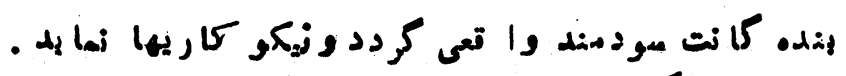

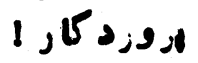

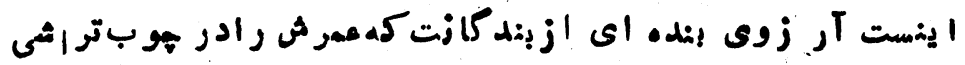

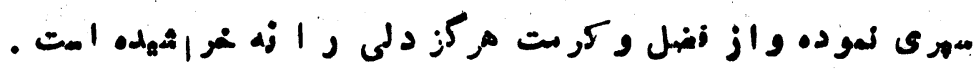


سوداگرو خدمتخار انش

إود نه بود بككمود كر كهنسمال اوذ وثثروت سر شار و خدمتيكار ان

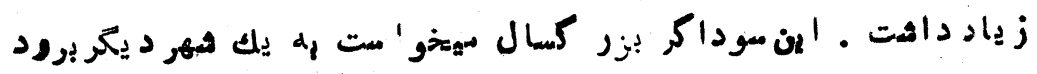

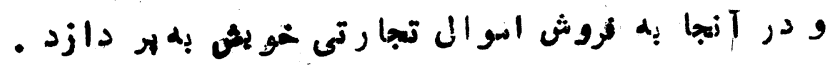

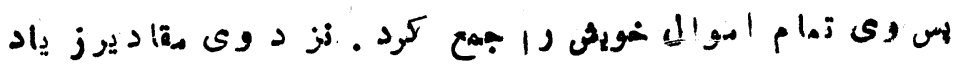

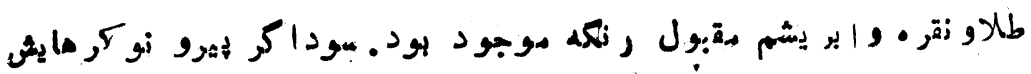

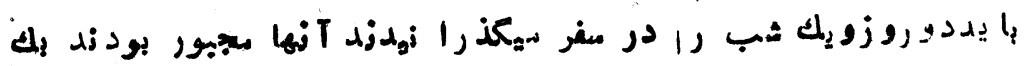

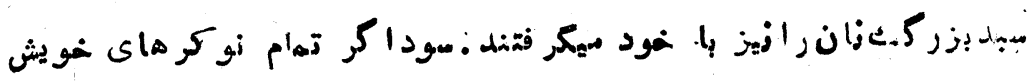

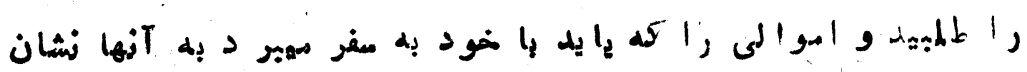

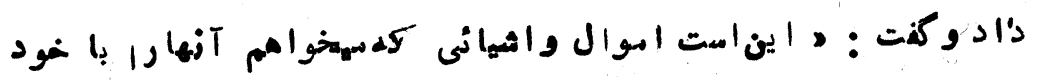

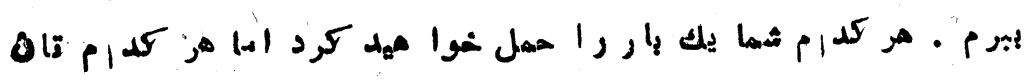

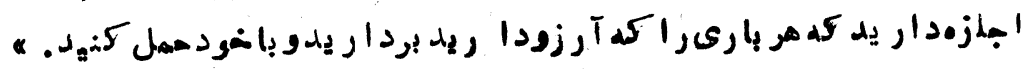

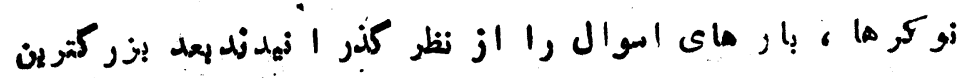

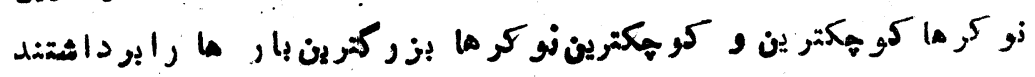

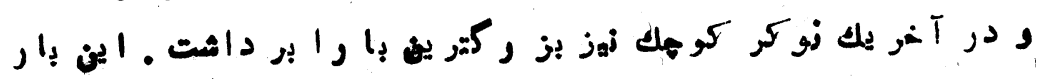

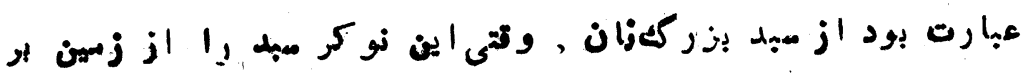

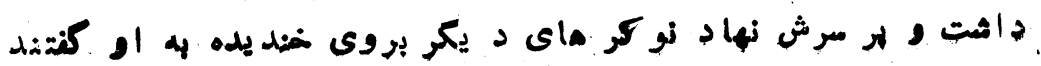

$-10 v-$ 


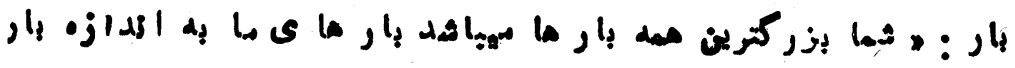

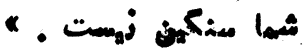

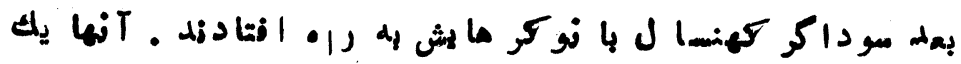

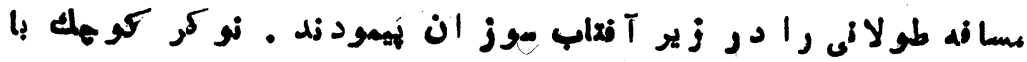

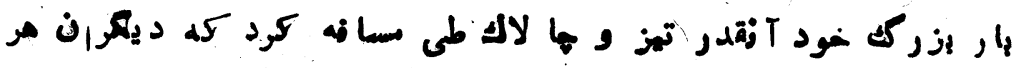

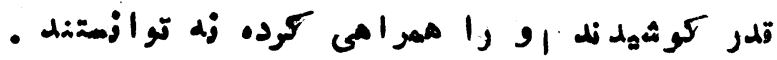

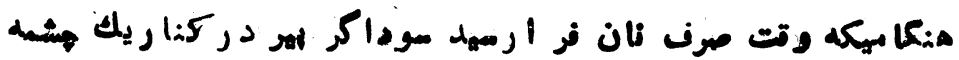

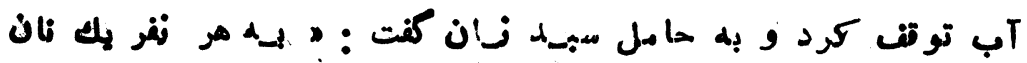

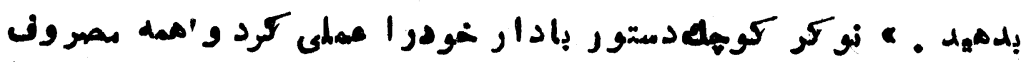

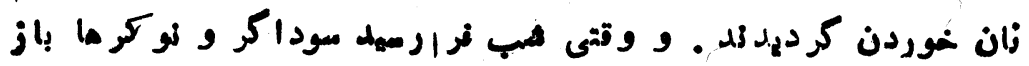

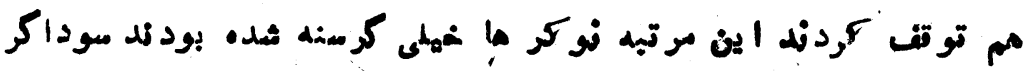

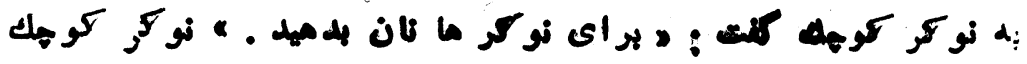

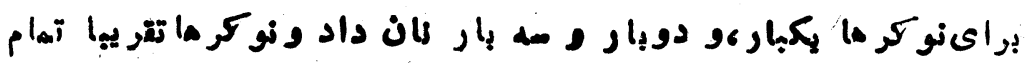

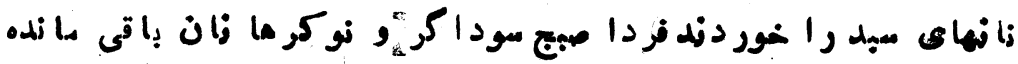

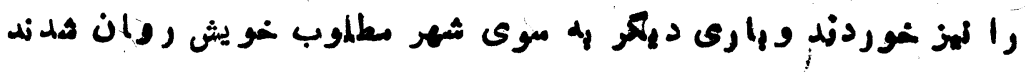

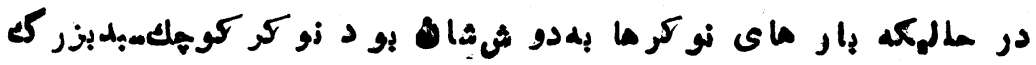

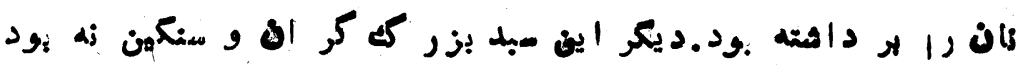

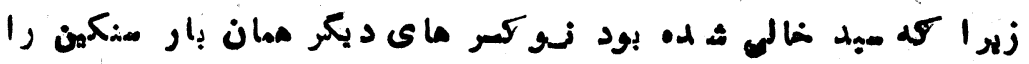

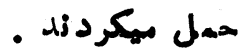

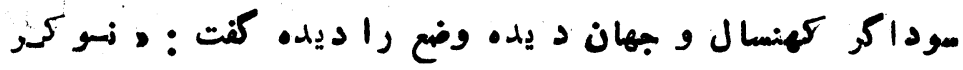
كو هك يك آدم زيرك و ومونهار است در آهاز مغر او بزر كمر ين

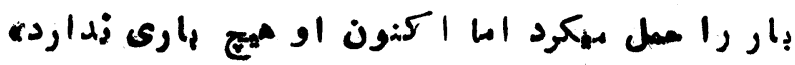

-1 VA- 


\section{مسافرت هاى كليور \\ سفرنتخست بdمسحله ليلى بت}

\section{بيثر اول}

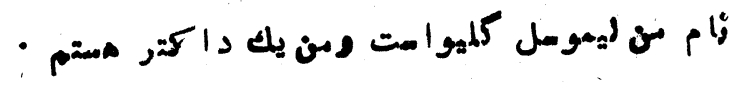

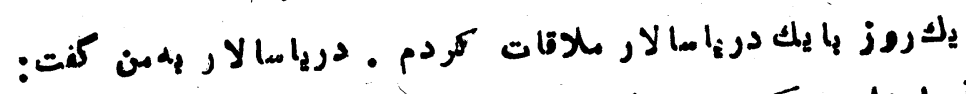

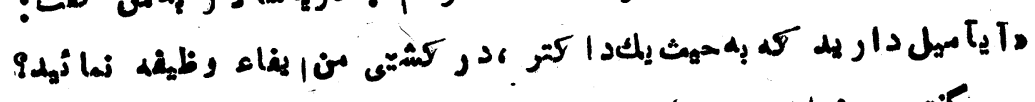

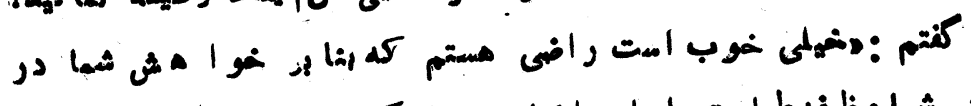

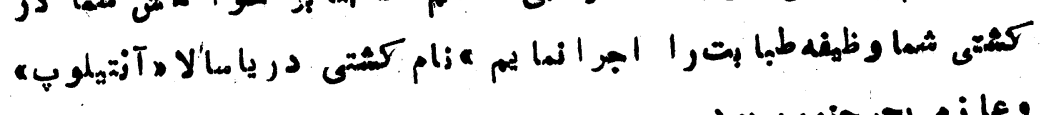

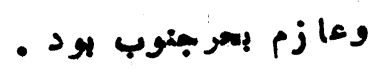

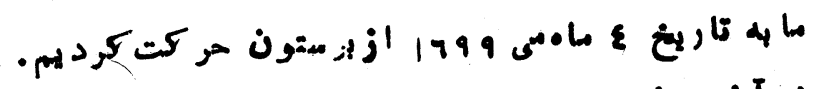

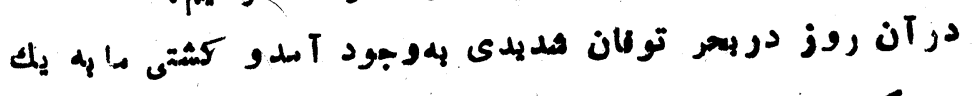

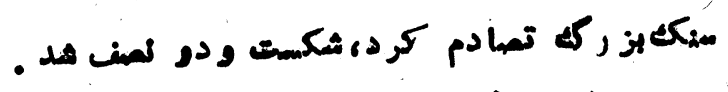

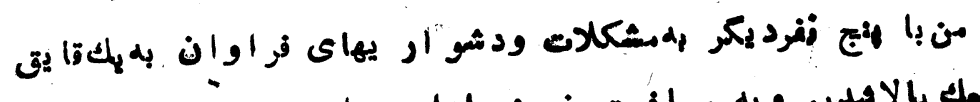

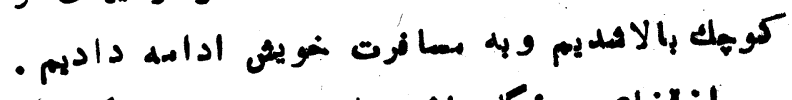

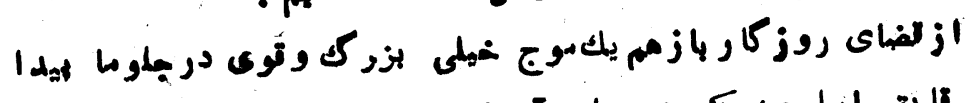

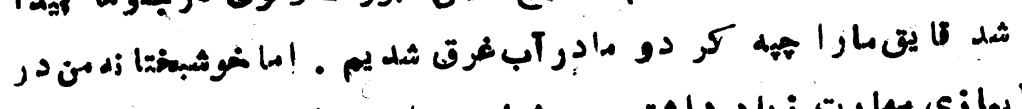

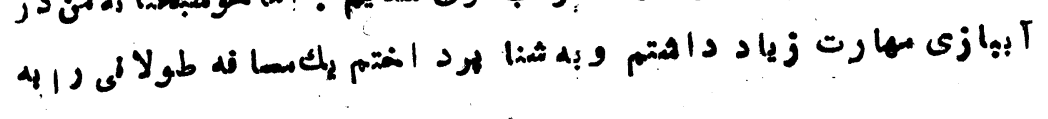

$$
\text { -'vi- }
$$




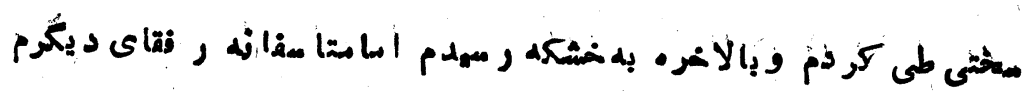

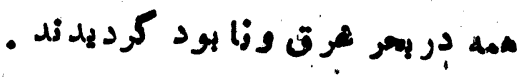

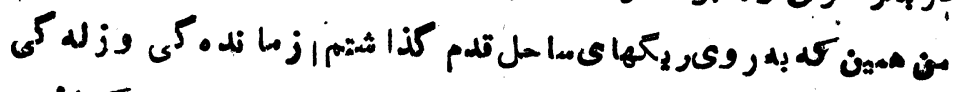

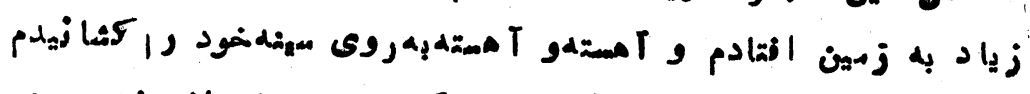

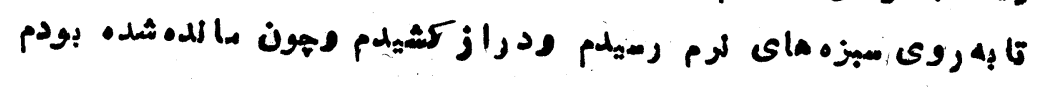

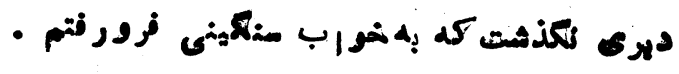

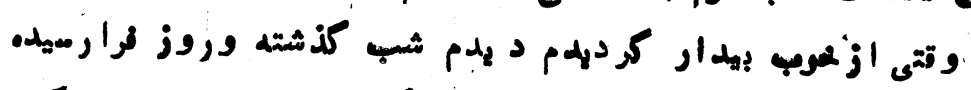

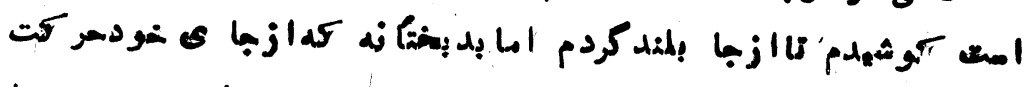

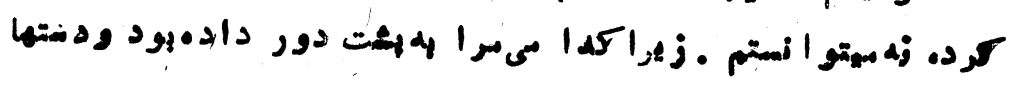

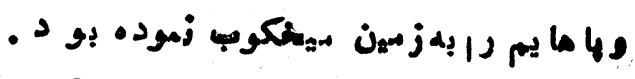

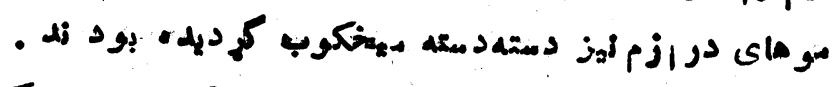

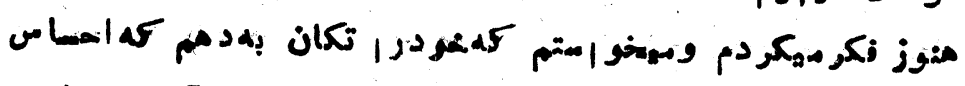

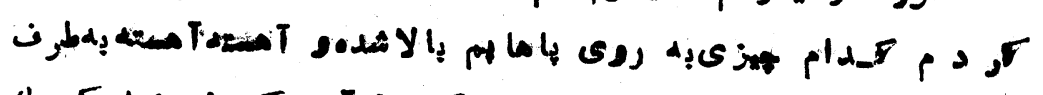

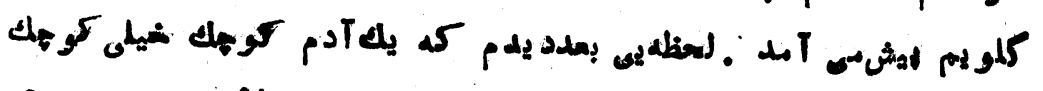

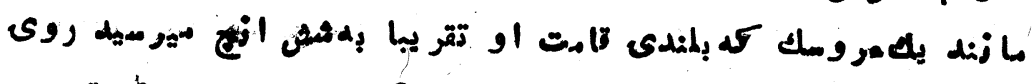

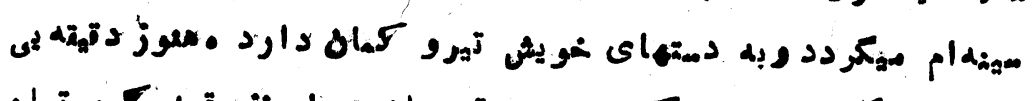

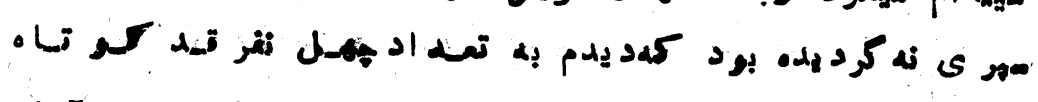

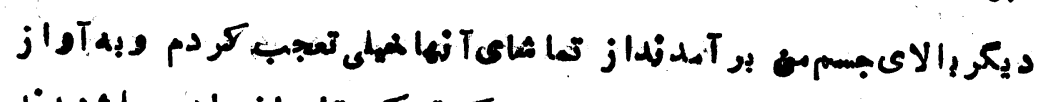

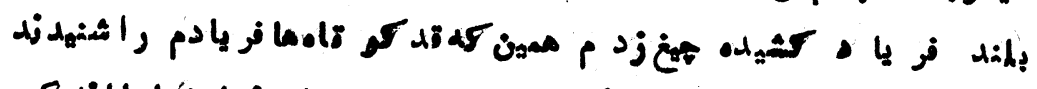

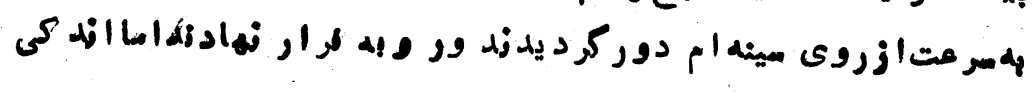

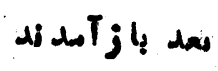

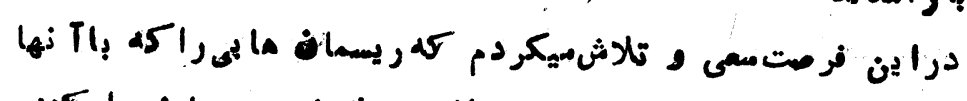

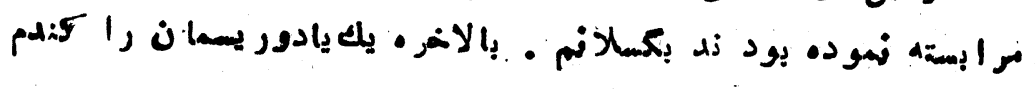

-11.- 


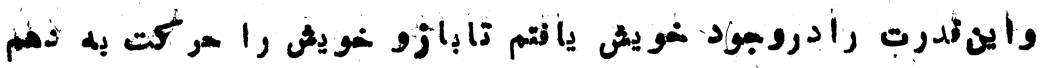

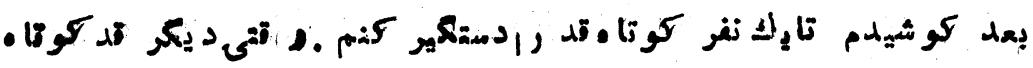

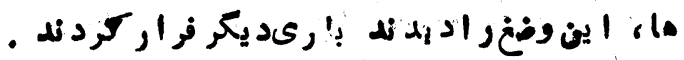

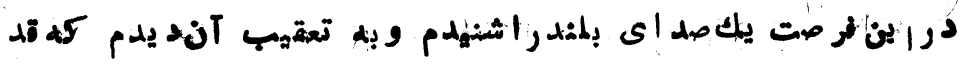

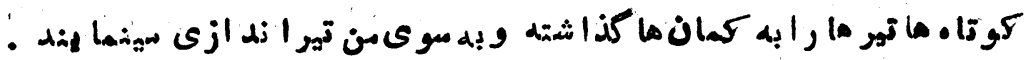

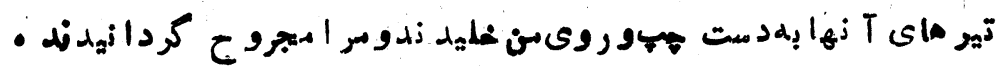

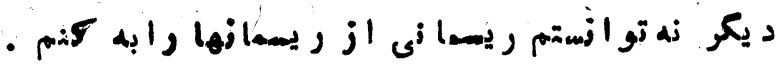

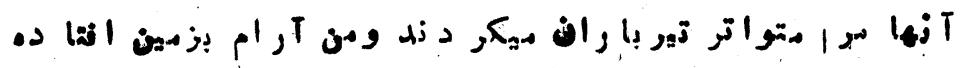

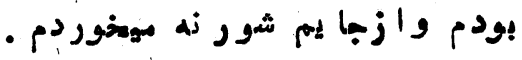

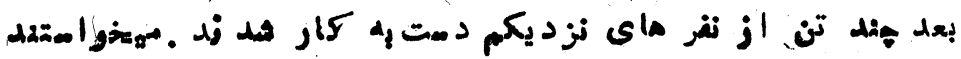

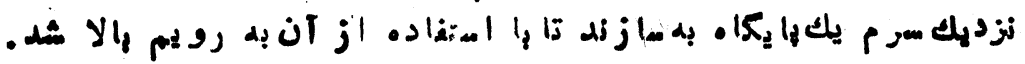

- $d$ dij I

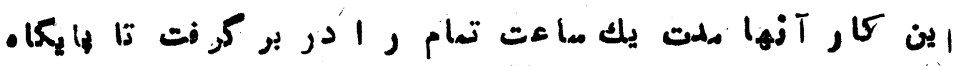

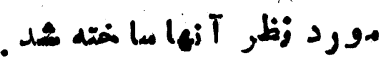

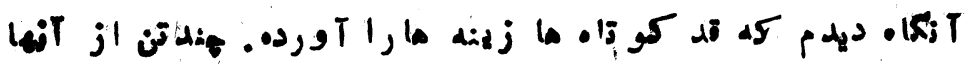

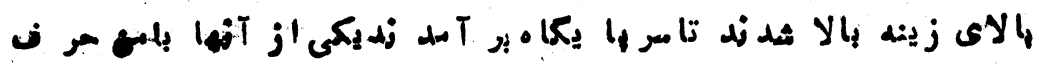

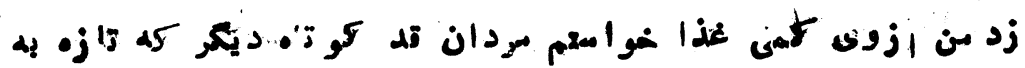

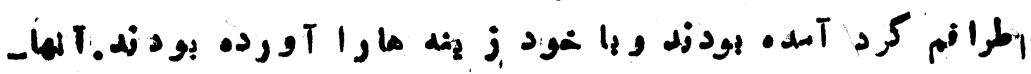

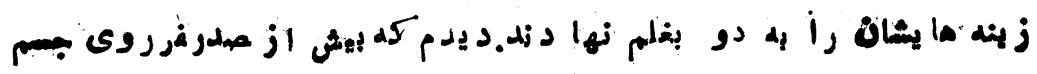

هن بالا مثدند

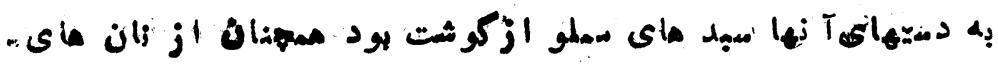

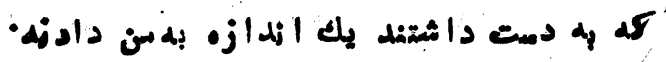

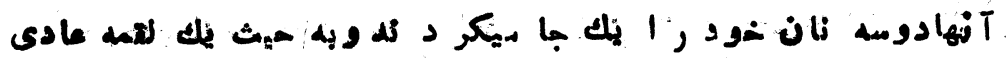

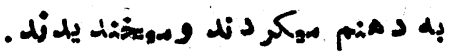

$-|\wedge|-$ 


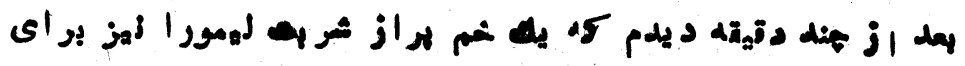

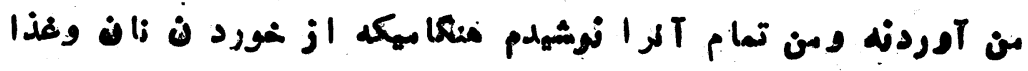

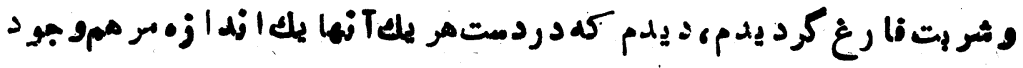

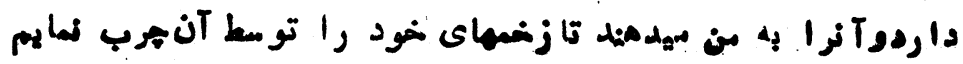

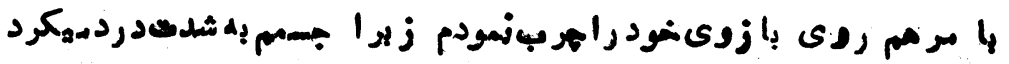

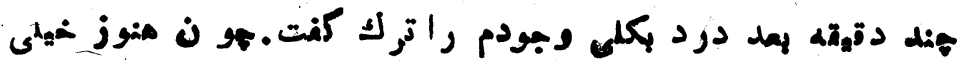

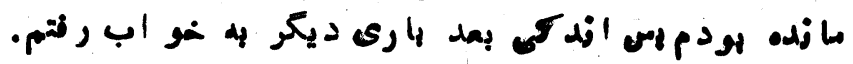
مدن

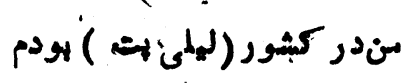

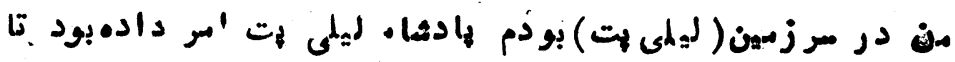

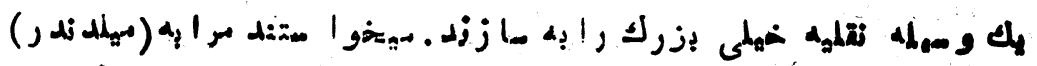

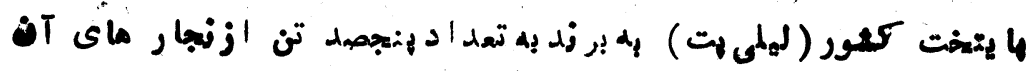

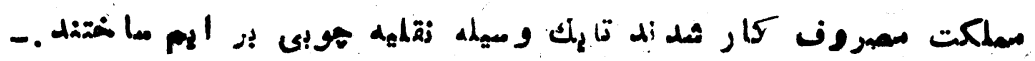

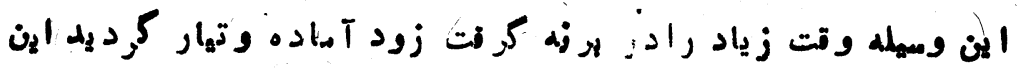

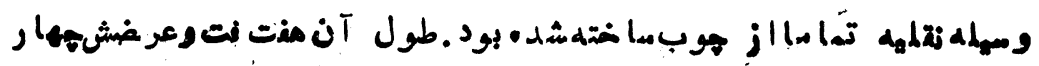

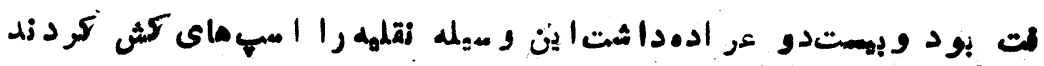

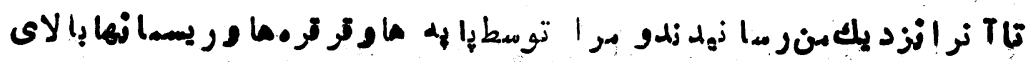

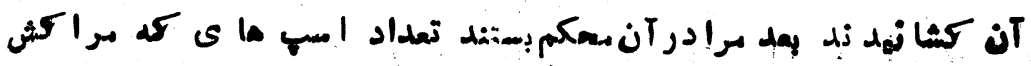

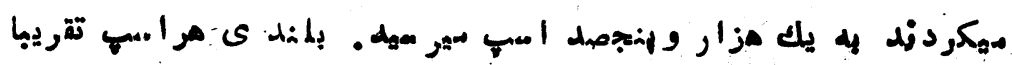

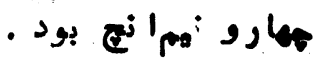

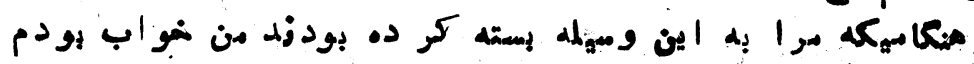

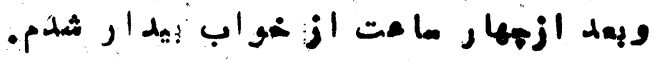

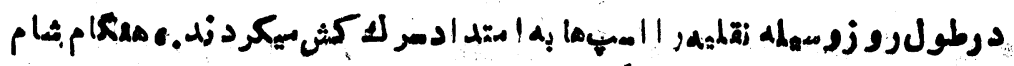

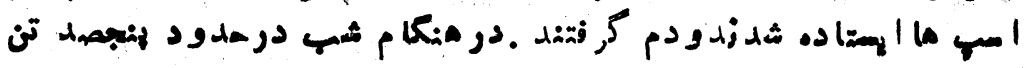

$-1 \wedge \cdots-$ 


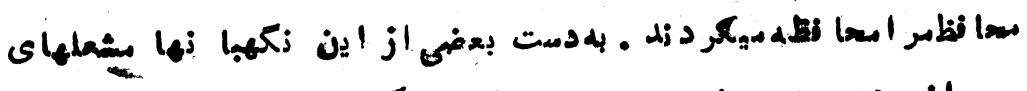

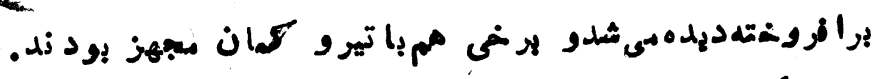

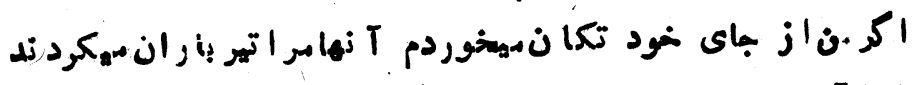

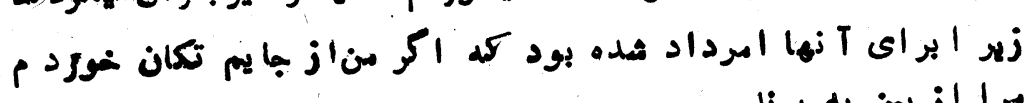

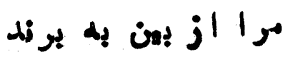

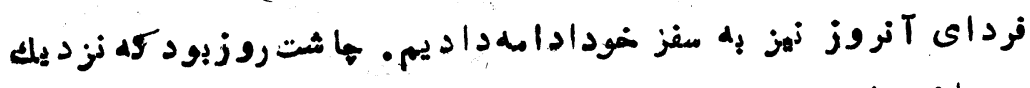

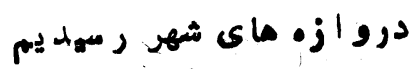

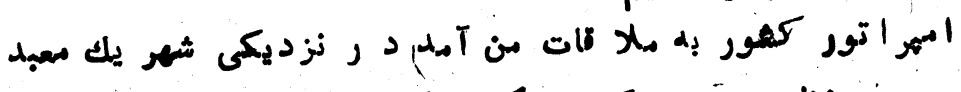

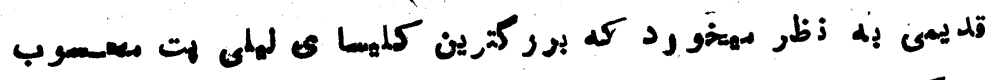

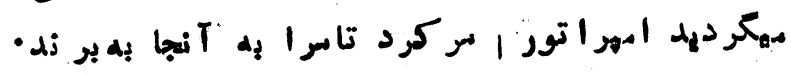

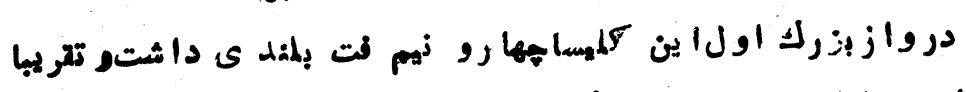

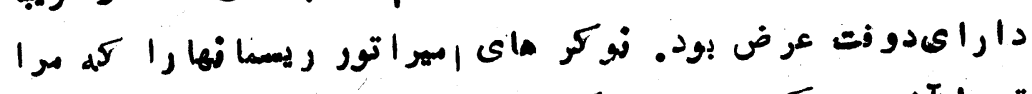

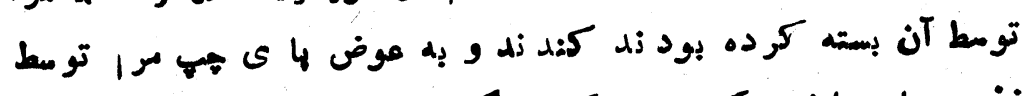

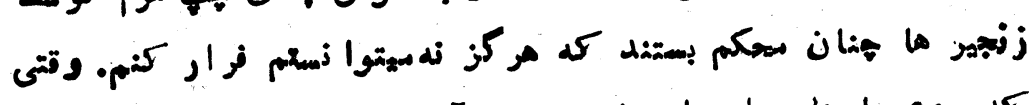

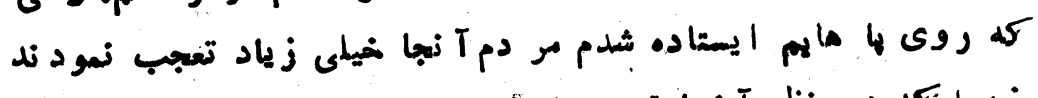

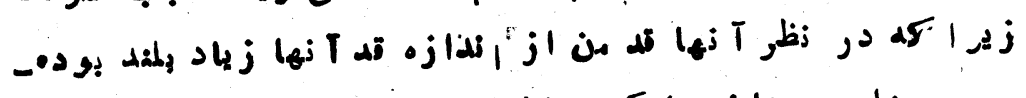

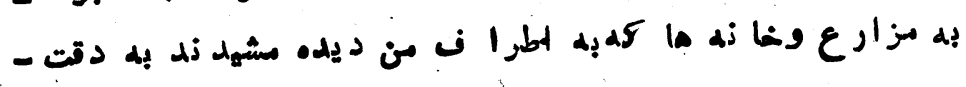

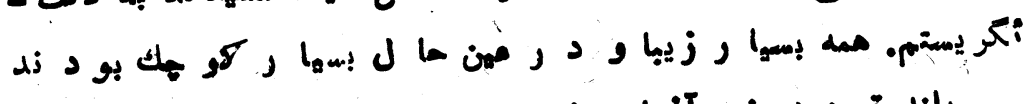

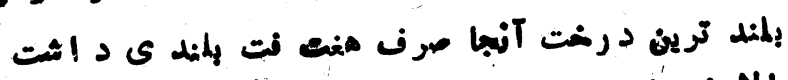

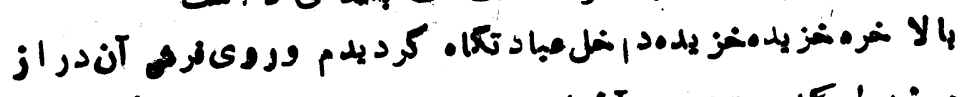

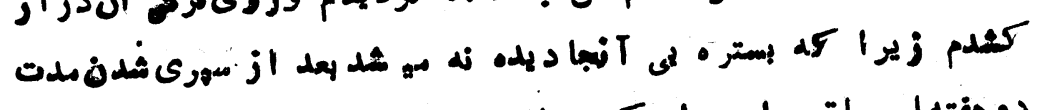

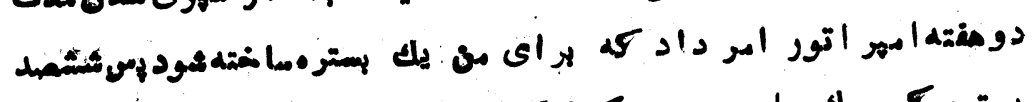

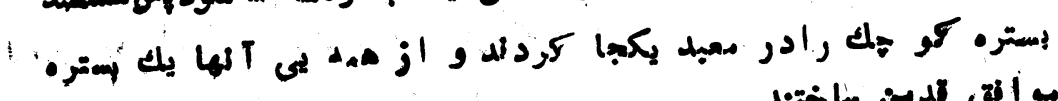

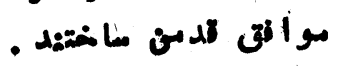
$-1 \wedge r$ 


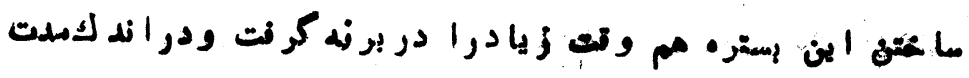

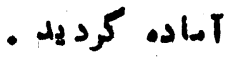

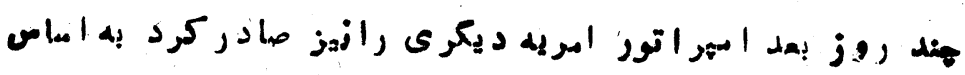

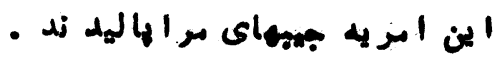

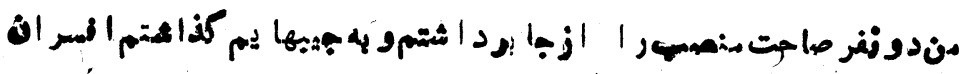

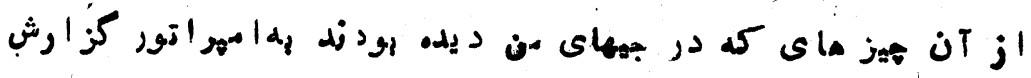

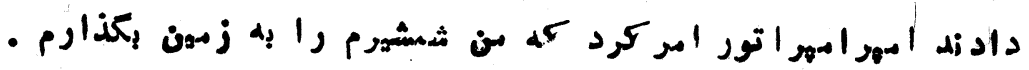

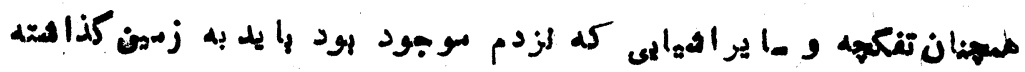

منهڤمد نمي.

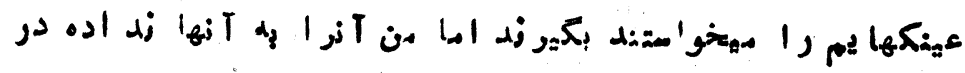

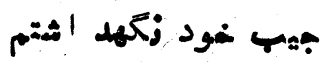

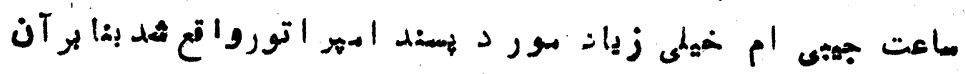

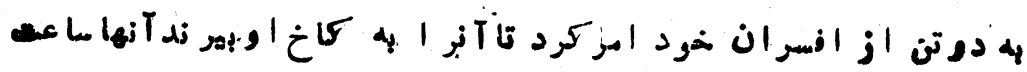

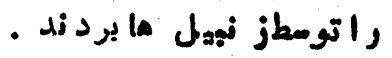

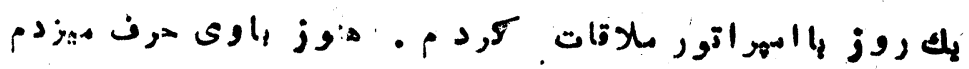

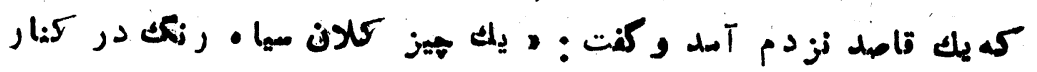

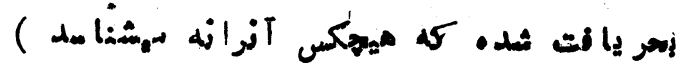

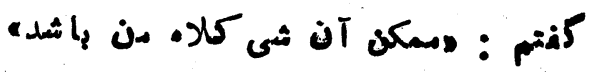

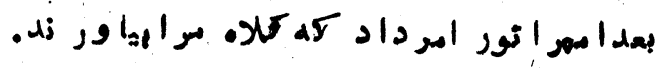

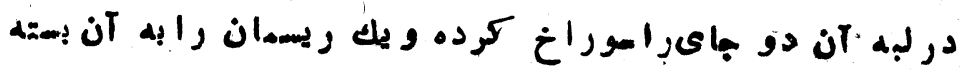

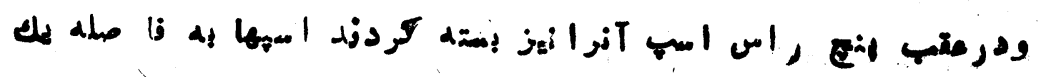

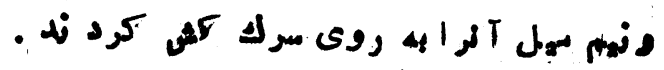

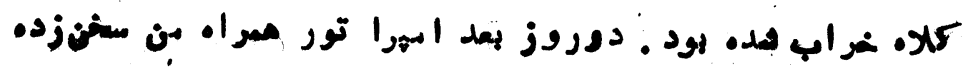

$-1 \wedge \varepsilon-$ 


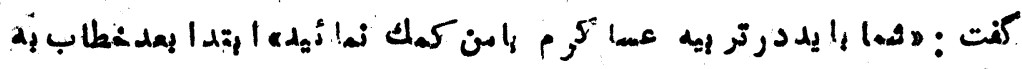

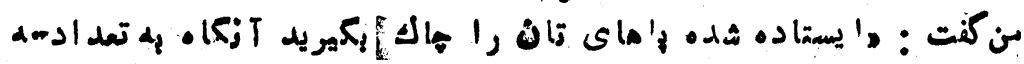

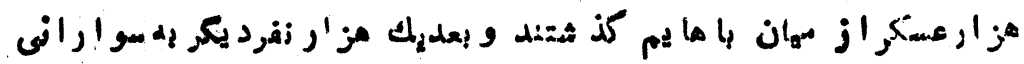

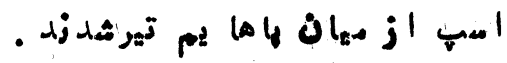

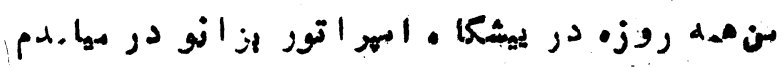

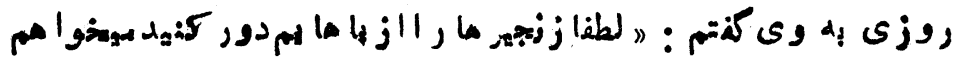

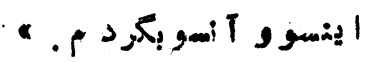

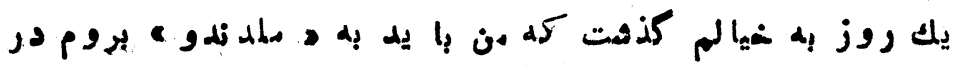

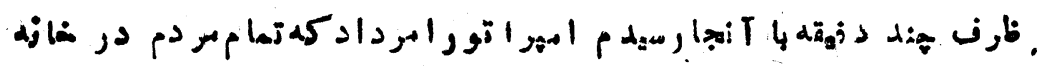

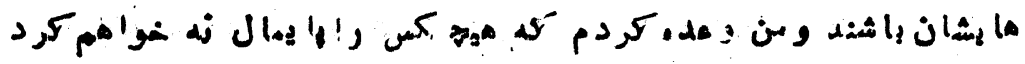

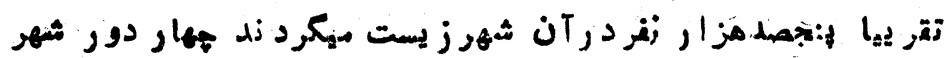

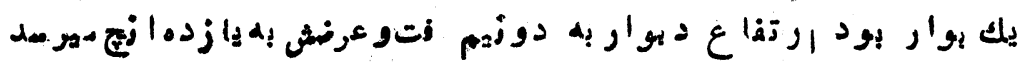

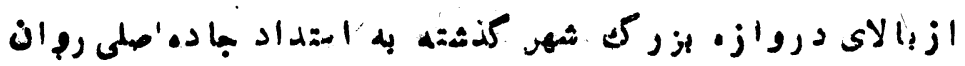

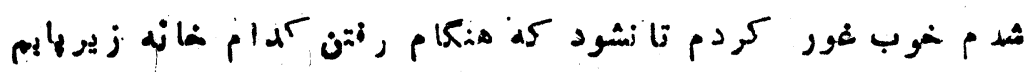
دود

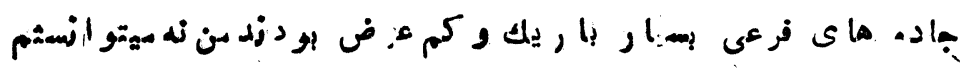

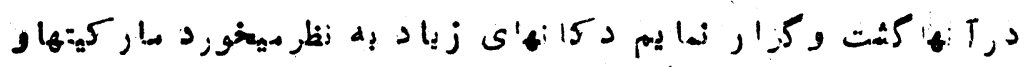

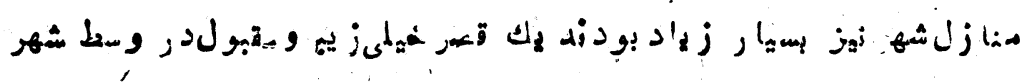

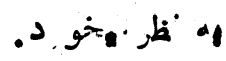

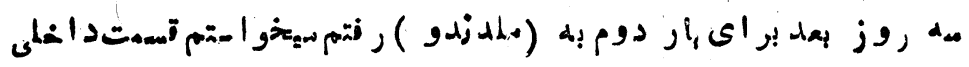

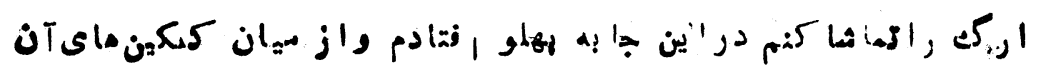

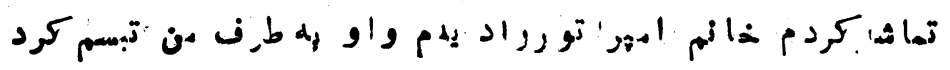

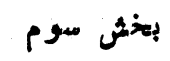

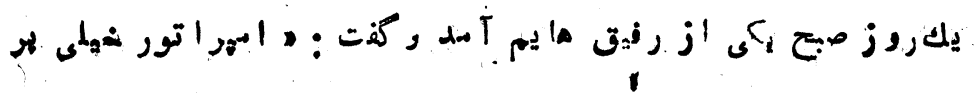
$=11^{\circ}-$ 


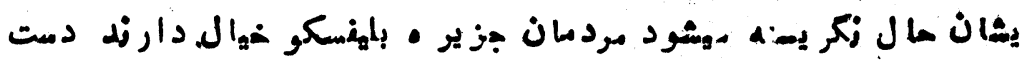

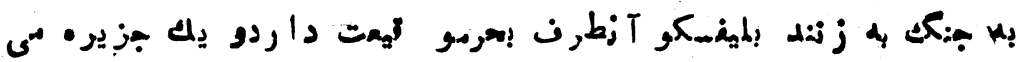

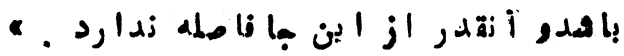

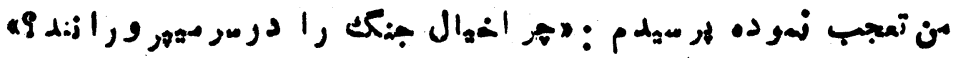

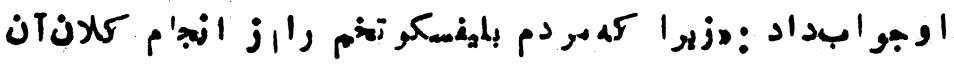

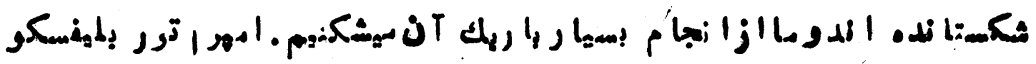

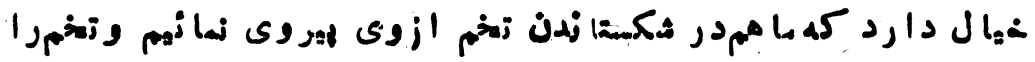

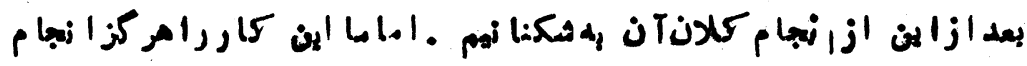
-

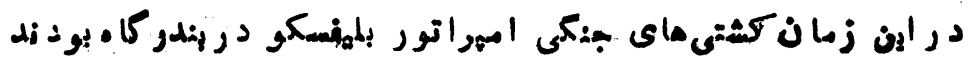

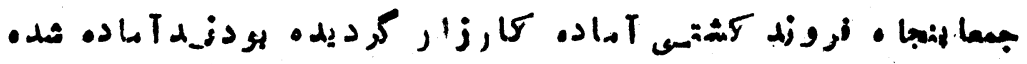

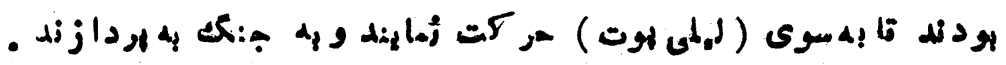

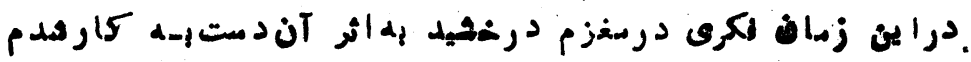

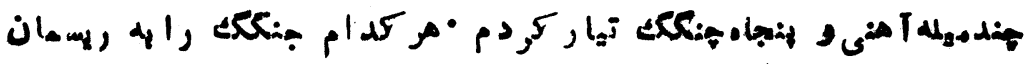

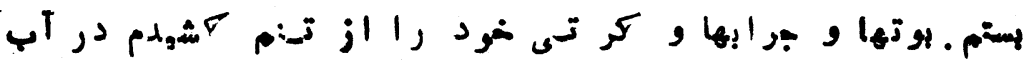

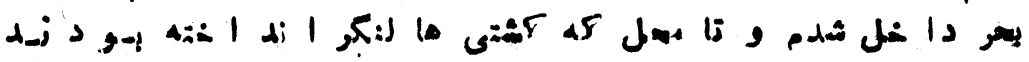

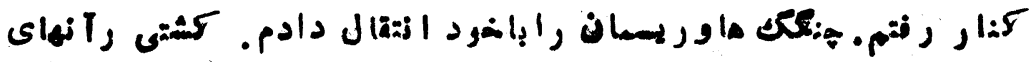

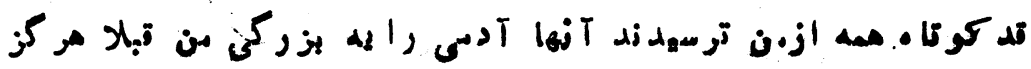

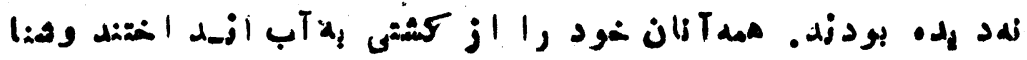

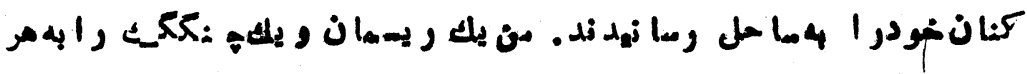

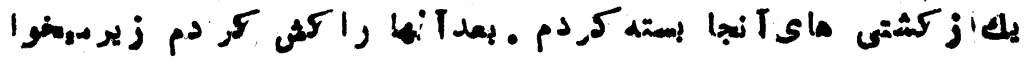

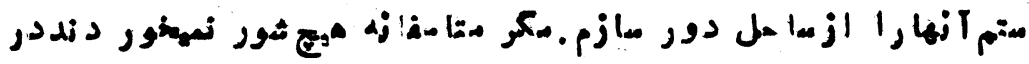

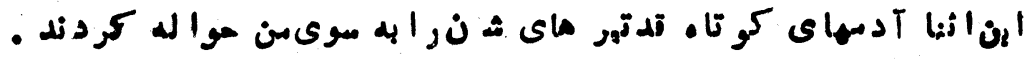

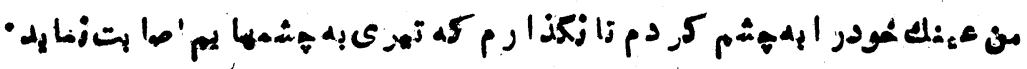
- ATA 


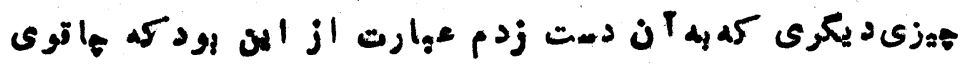

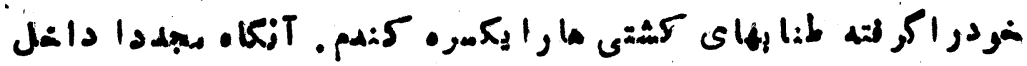

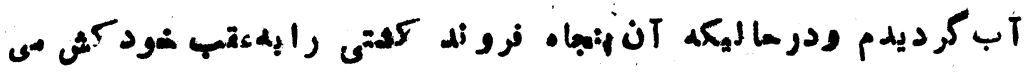

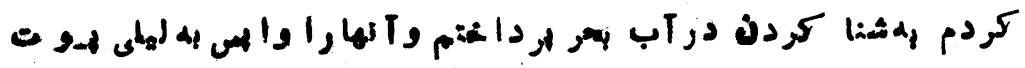

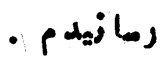

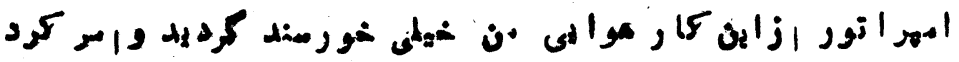

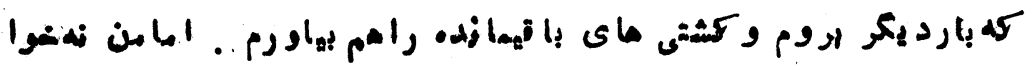

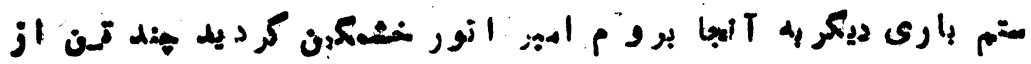

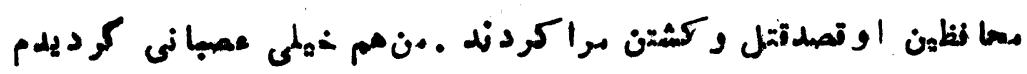

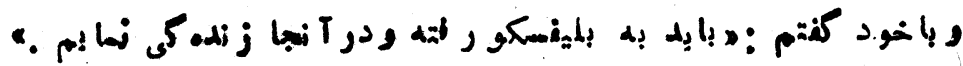

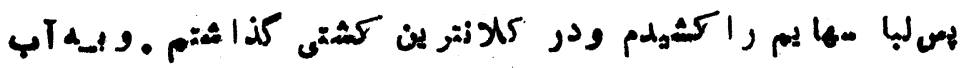

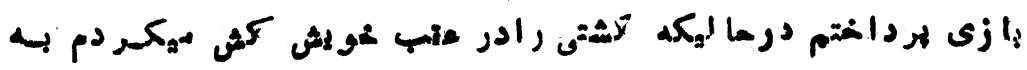

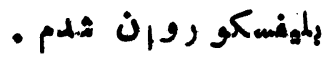

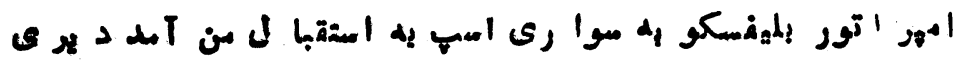

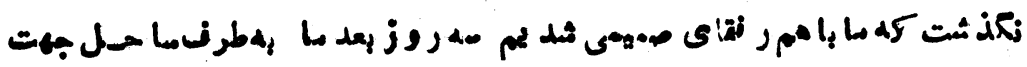

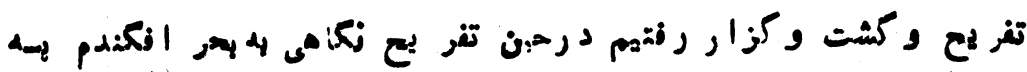

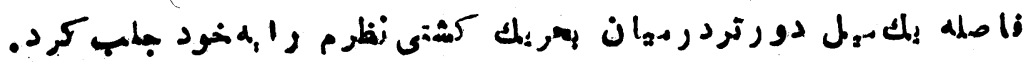

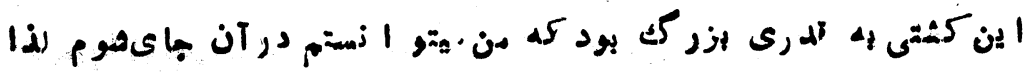

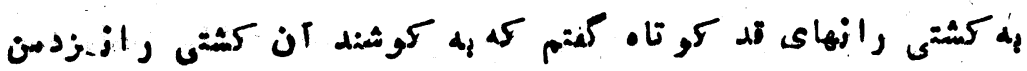

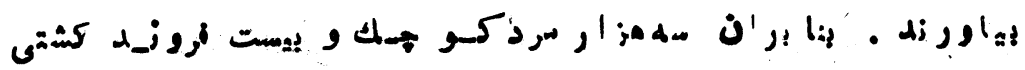

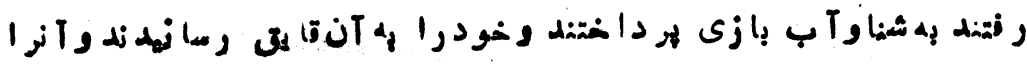

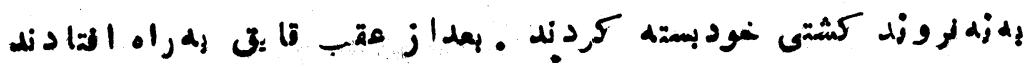

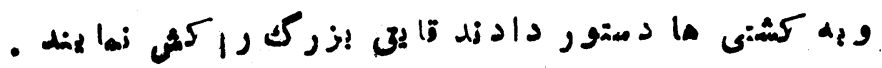
$-\operatorname{Av}-$ 


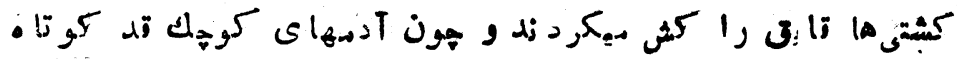

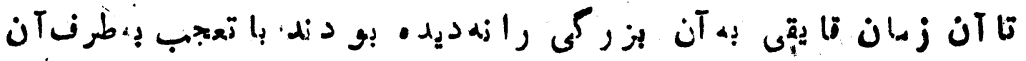

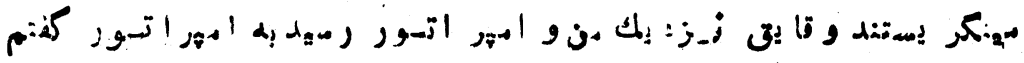

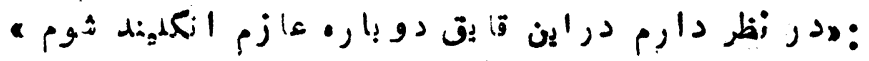

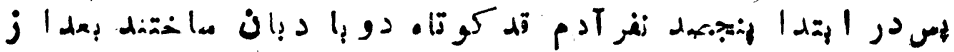

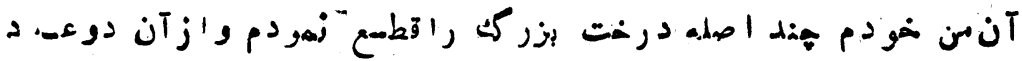

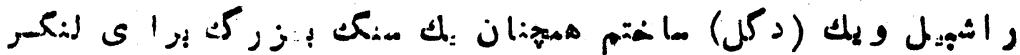

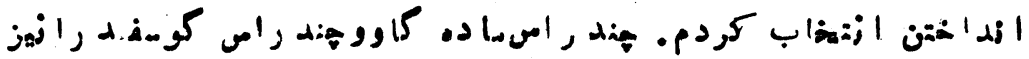

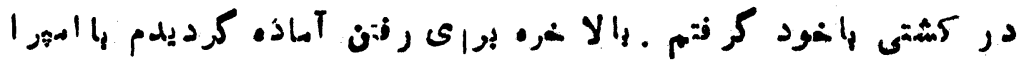

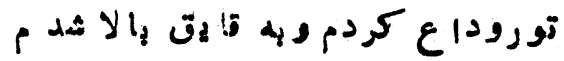

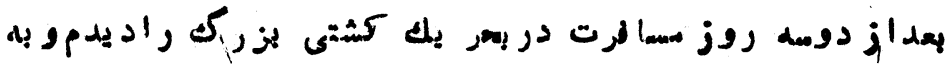

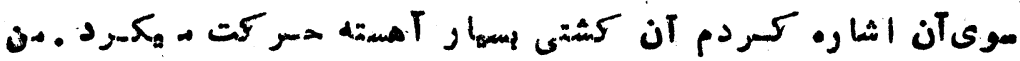

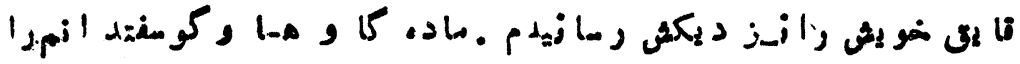

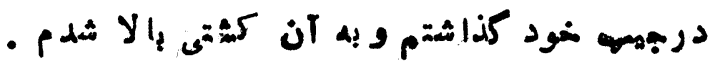

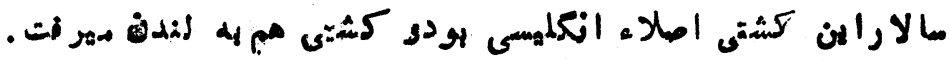

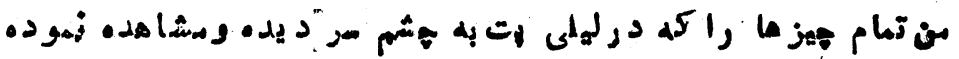

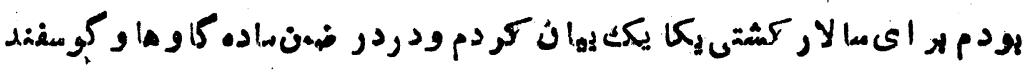

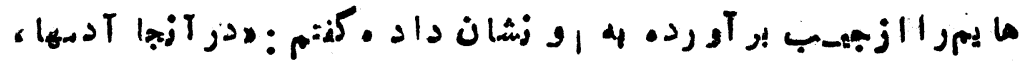

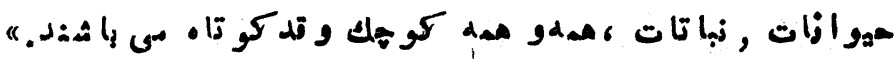

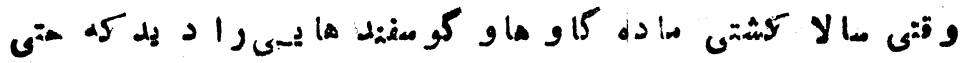

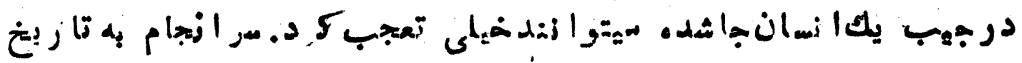

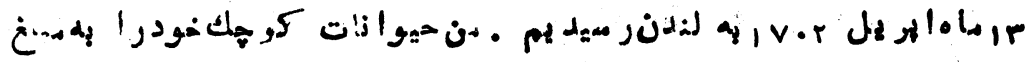

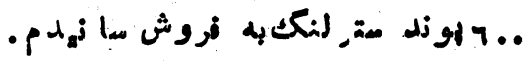




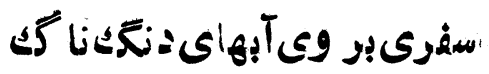

لsk

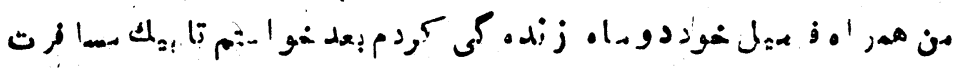

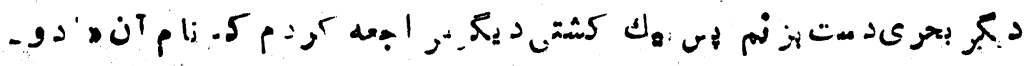

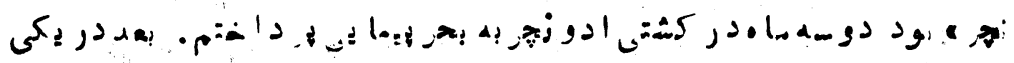

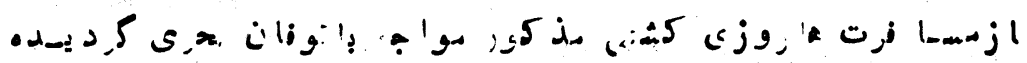

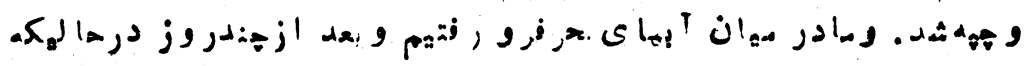

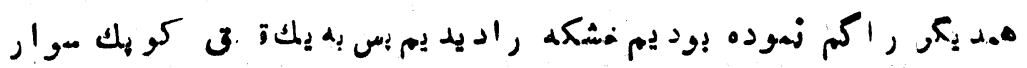

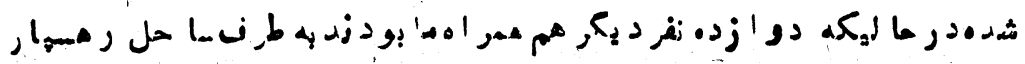

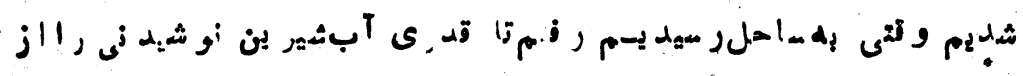

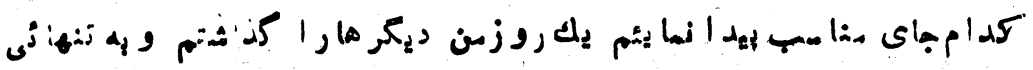

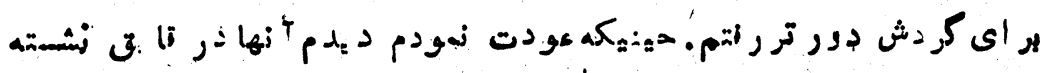

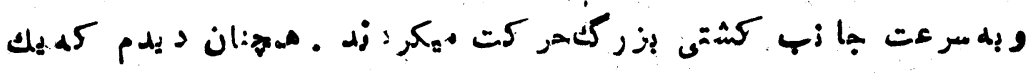

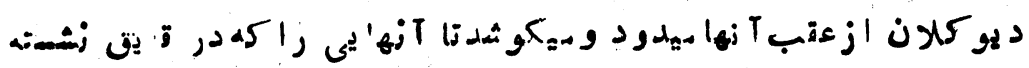

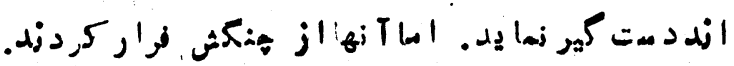

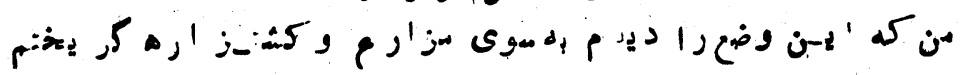

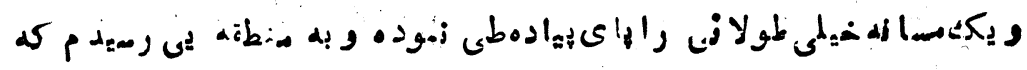

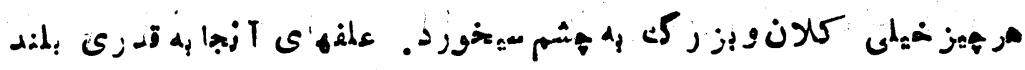

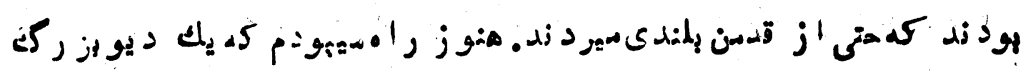

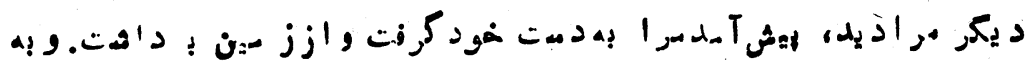

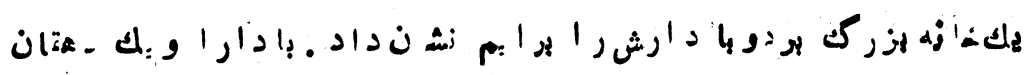

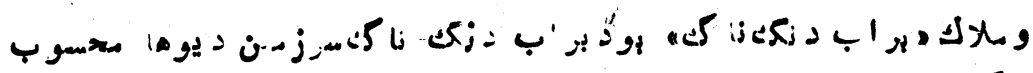

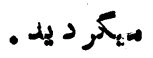

$-119-$ 


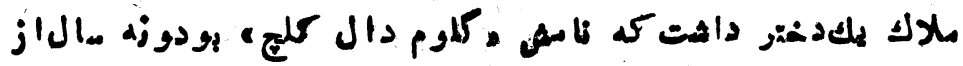

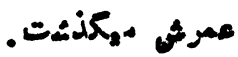

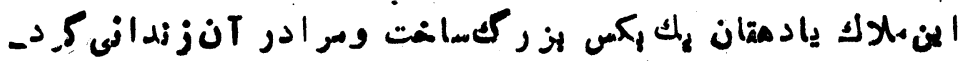

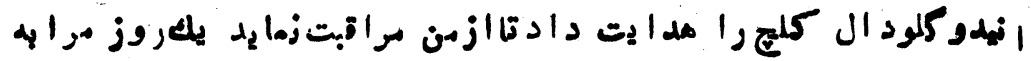

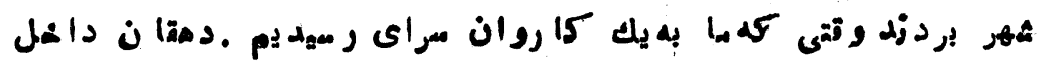

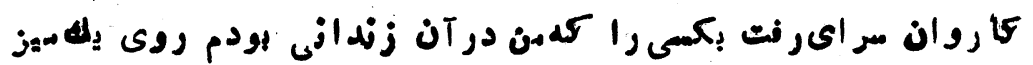

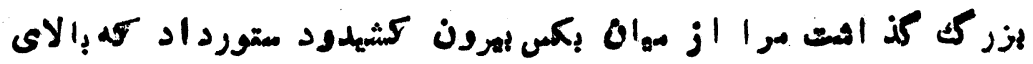

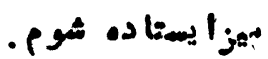

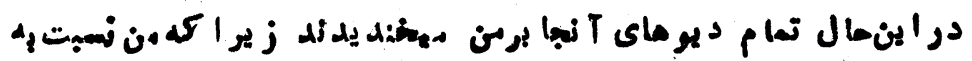

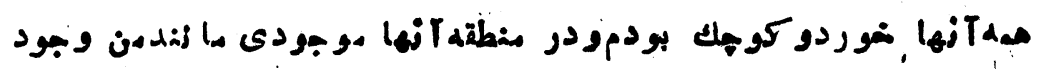
ندا أشت.

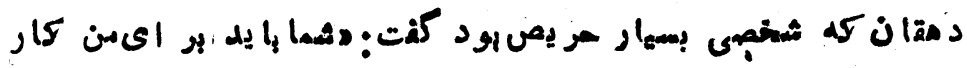

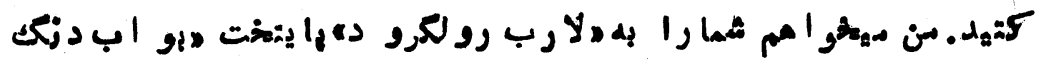

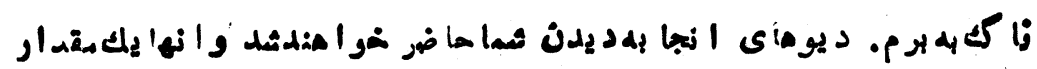

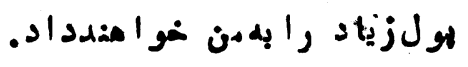

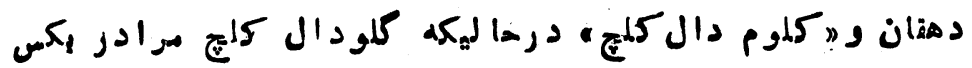

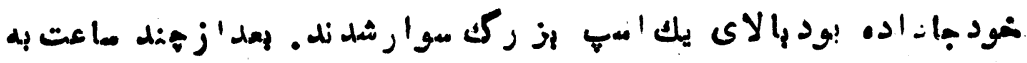

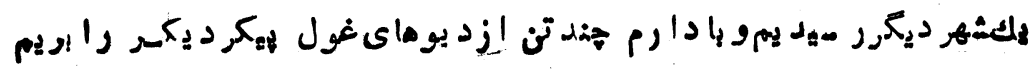

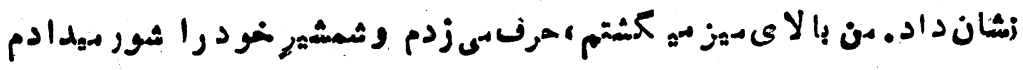

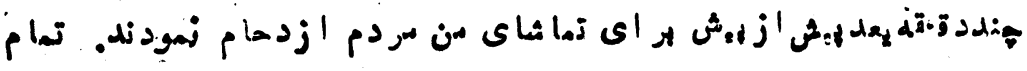

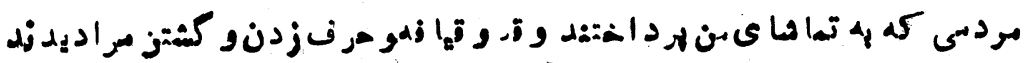

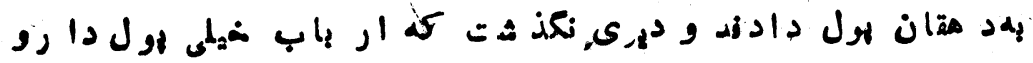

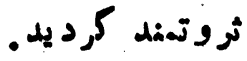


ع عضثندوم

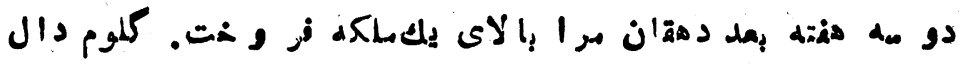

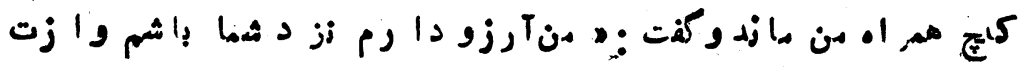

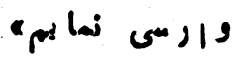

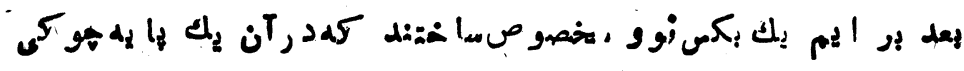

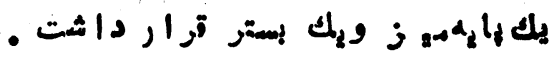

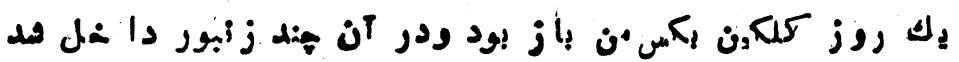

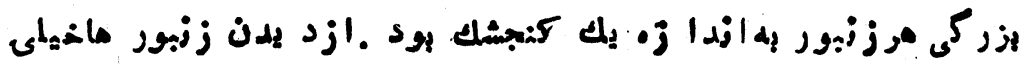

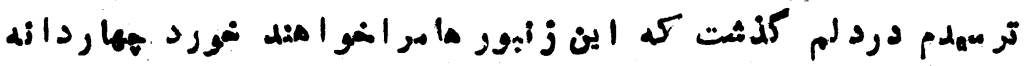

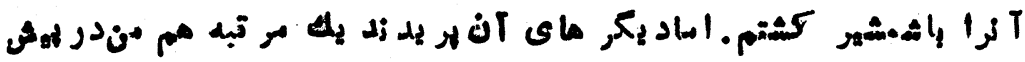

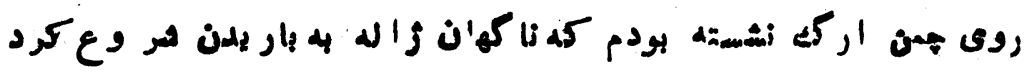

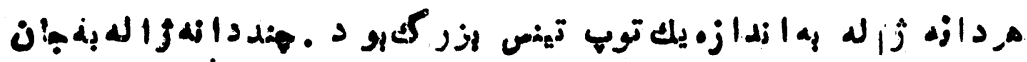

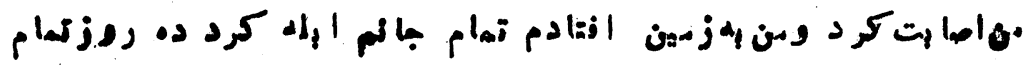

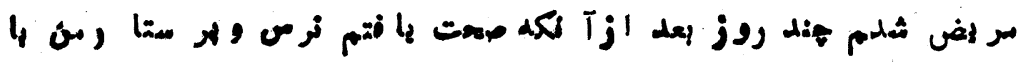

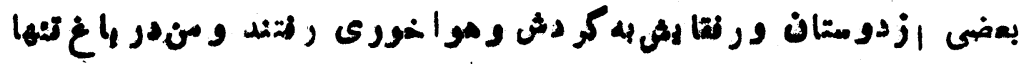

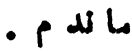

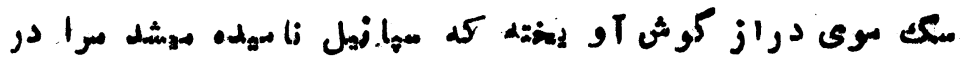

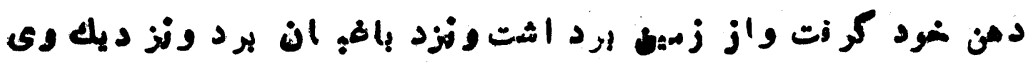

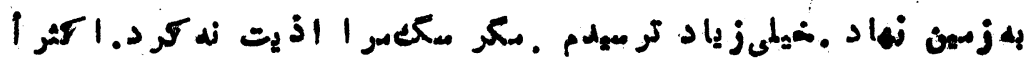

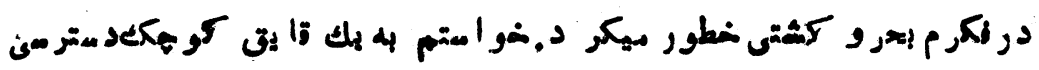

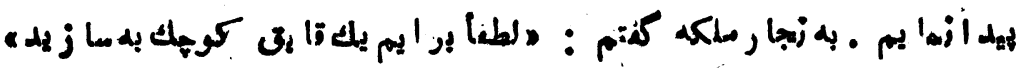

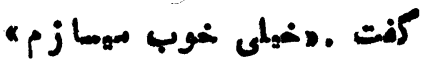

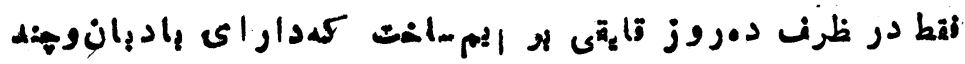
$-191-$ 


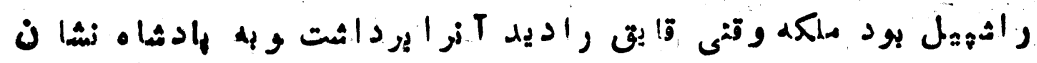

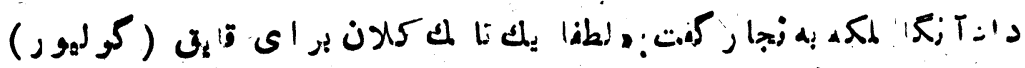

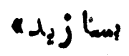

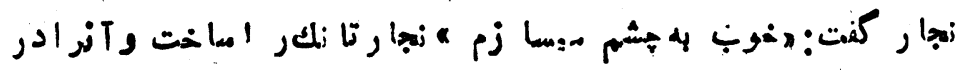

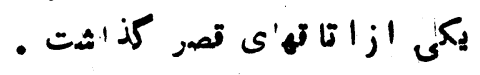

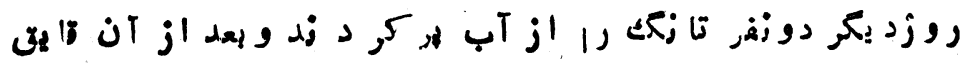

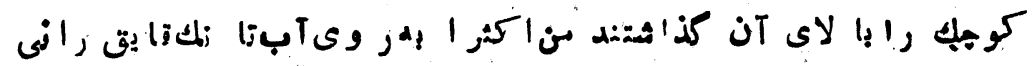

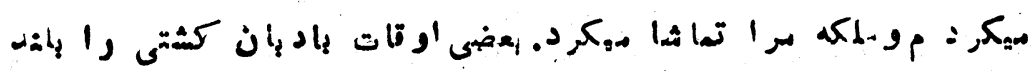

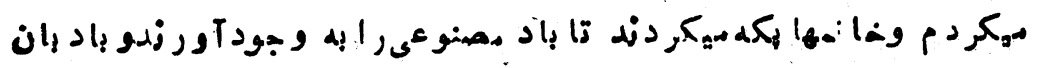

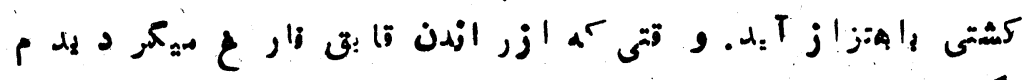

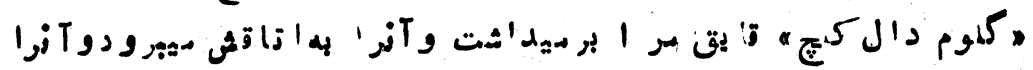

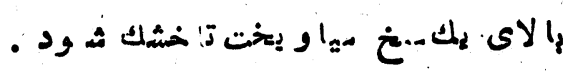

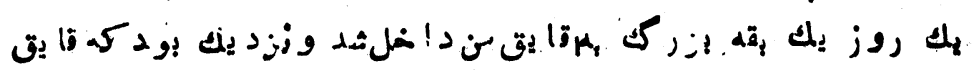
را

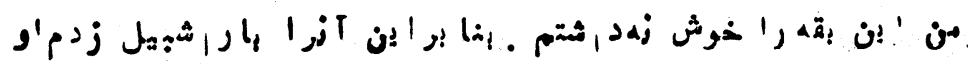

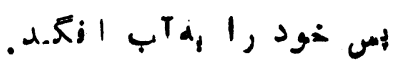

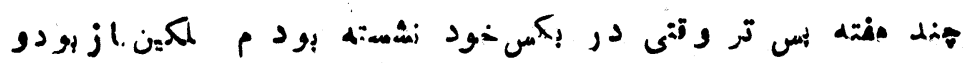

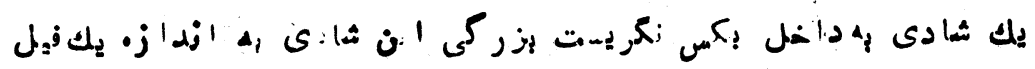

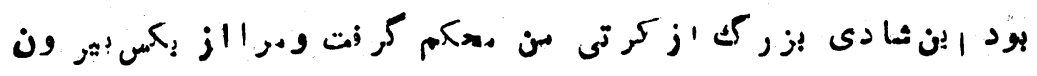

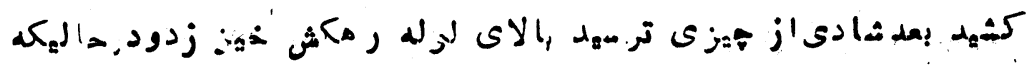

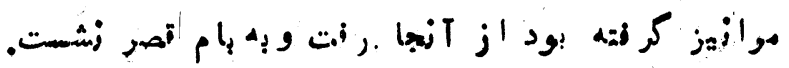

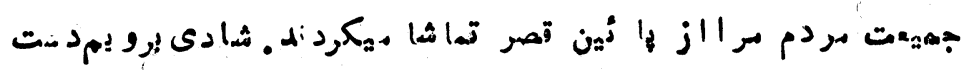

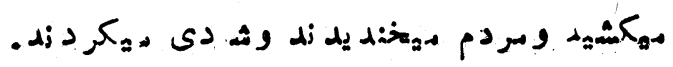


•

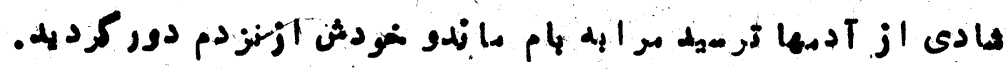

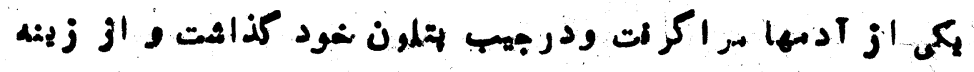

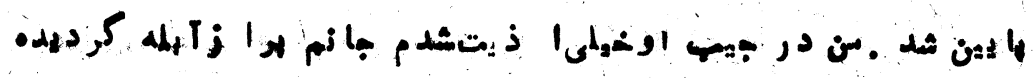

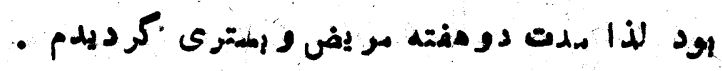

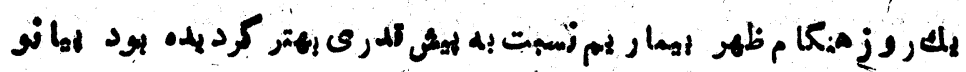

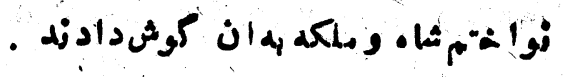

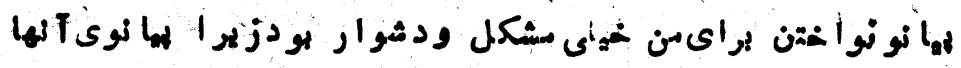

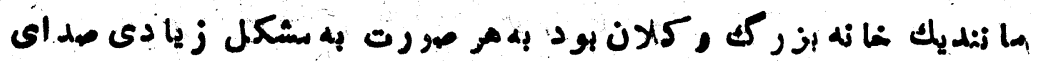

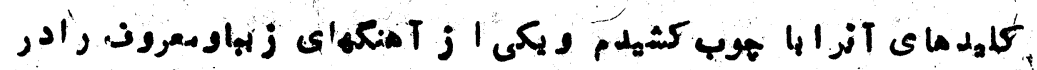

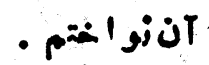

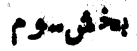

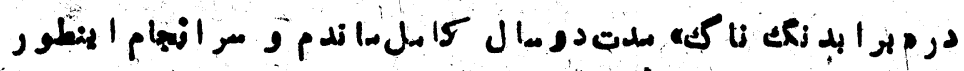

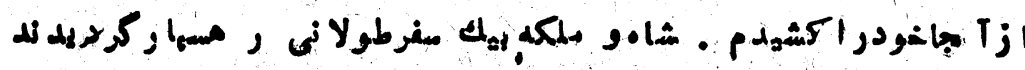

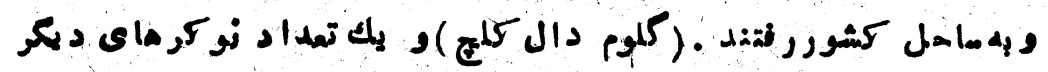

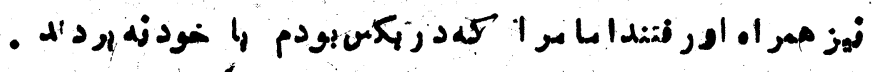

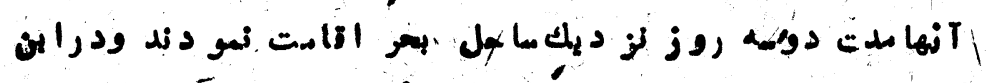

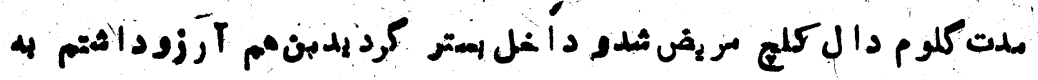

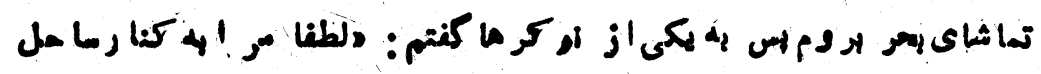
به بر إلده

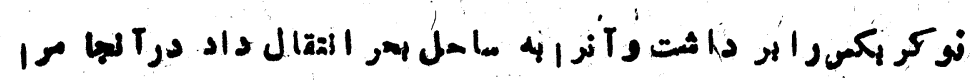

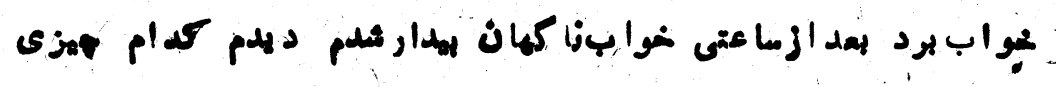
$-19 r-$ 


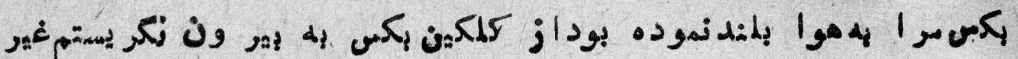

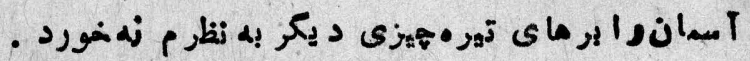

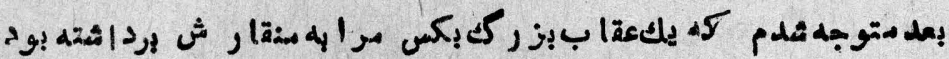

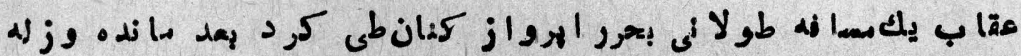

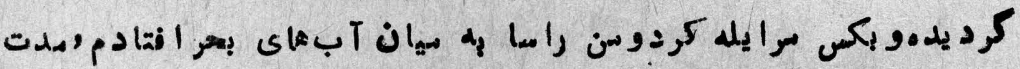

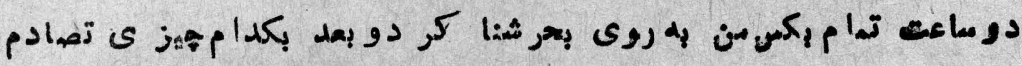

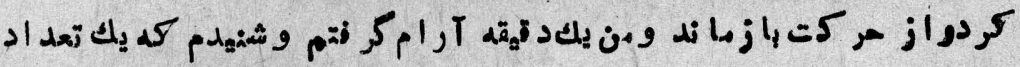

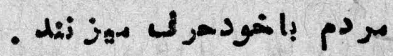

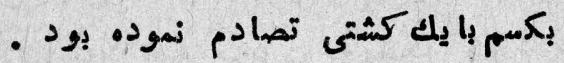

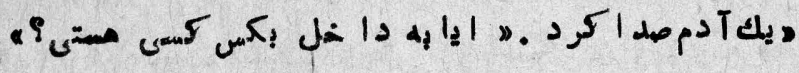

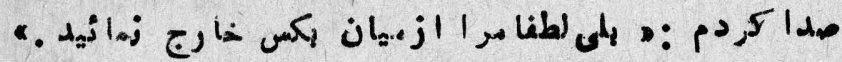

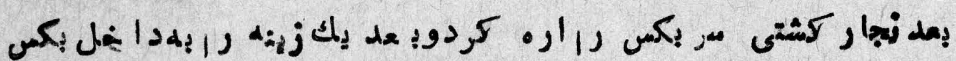

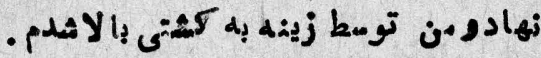

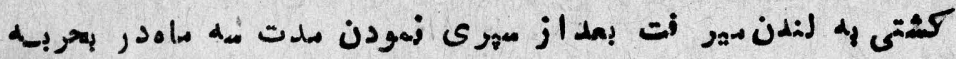

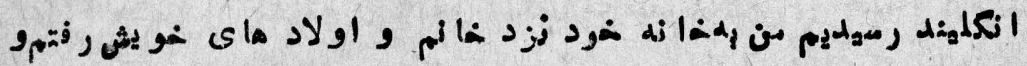

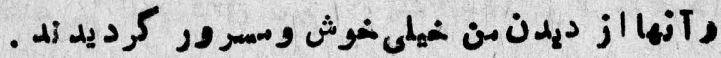




\section{خيال}

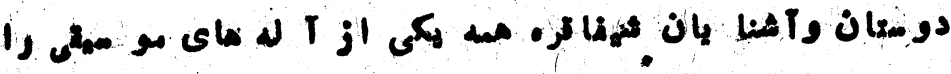

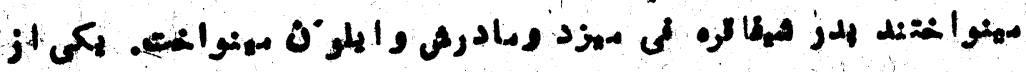

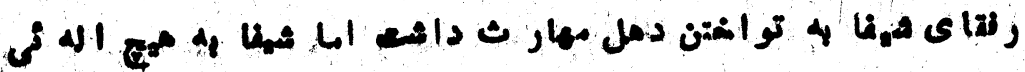

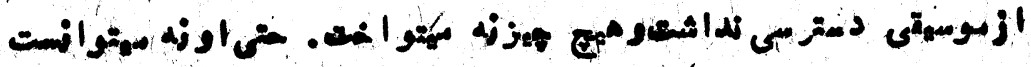

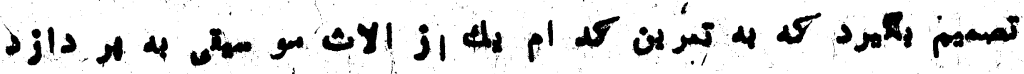

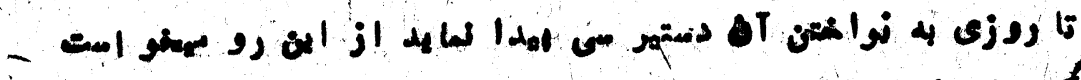

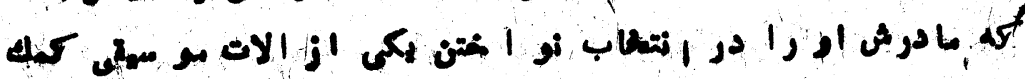

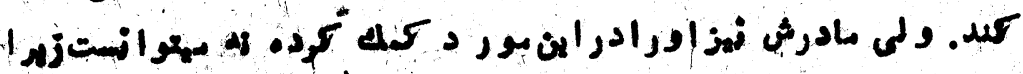

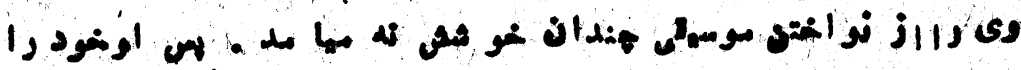

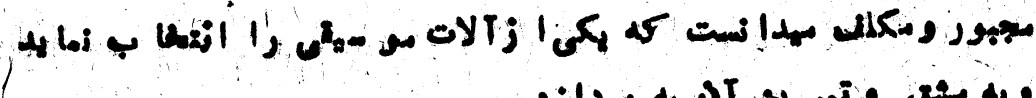
- 20

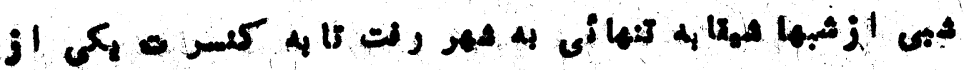

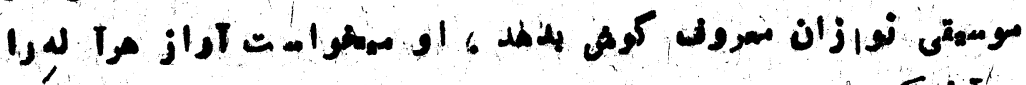

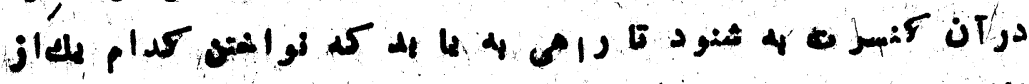

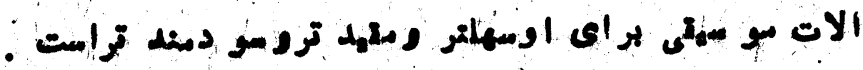

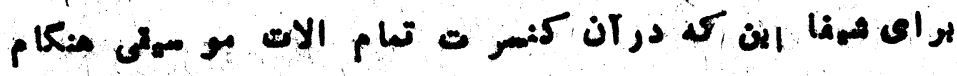

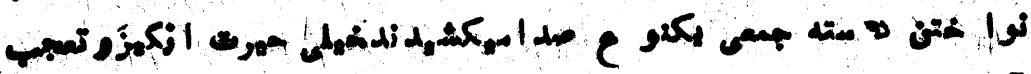




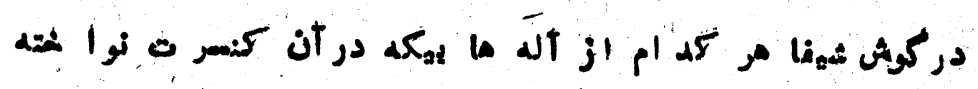

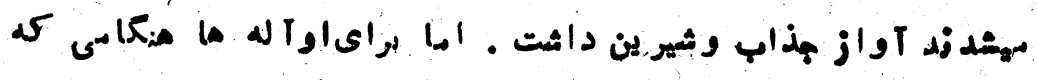

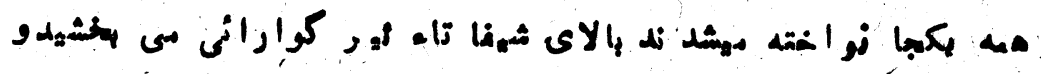

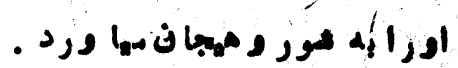

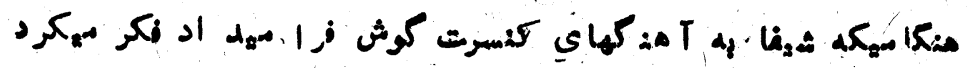

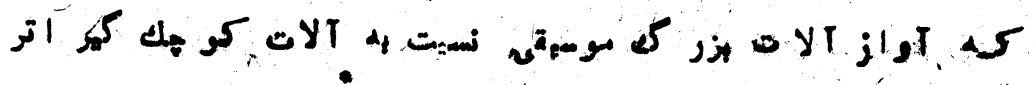

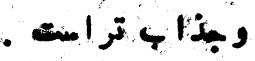

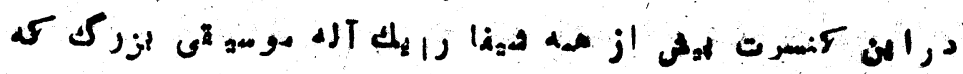

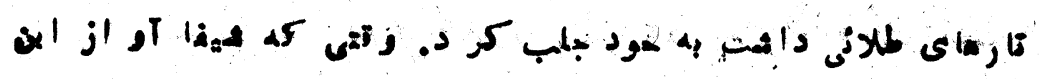

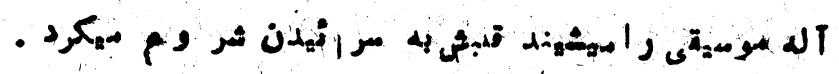
و لتى

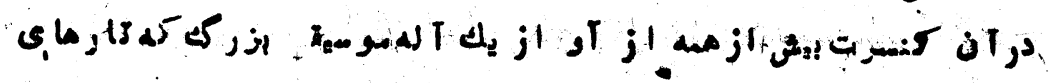

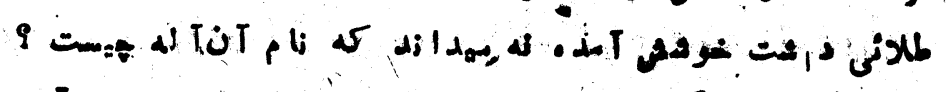

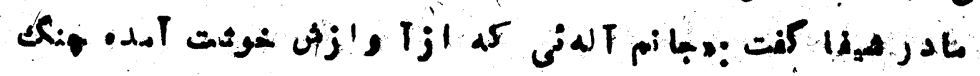

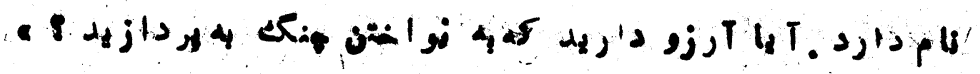

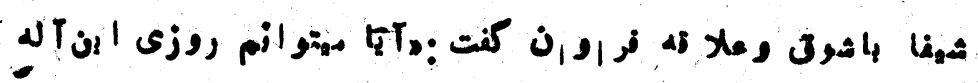

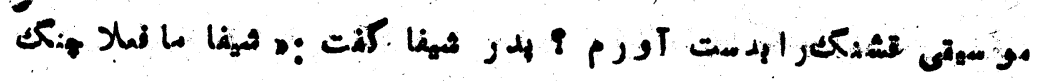

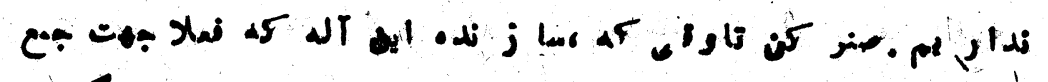

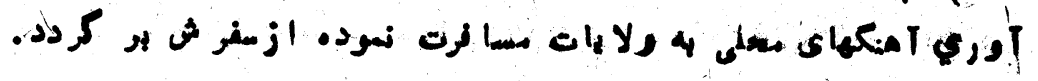

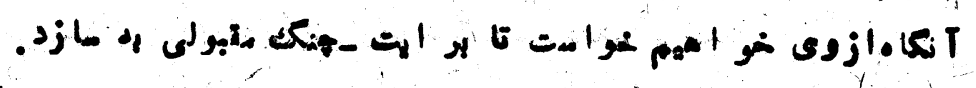

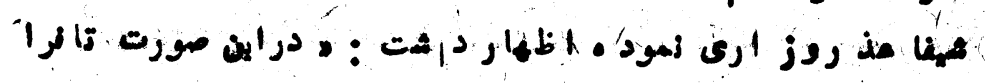

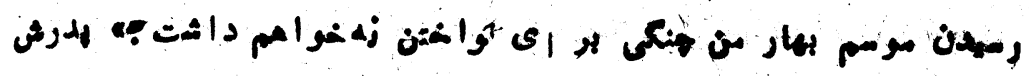

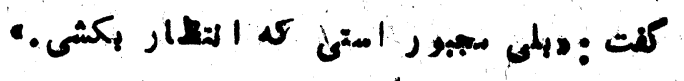




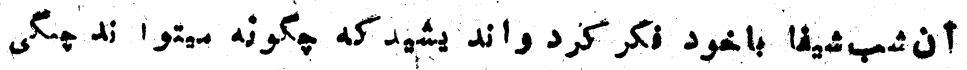

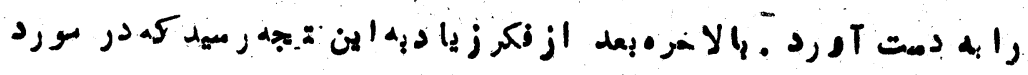

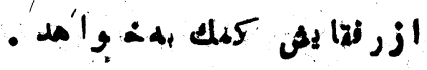

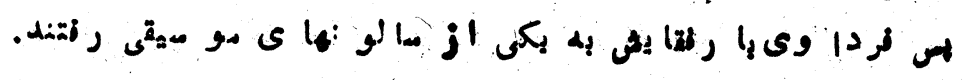

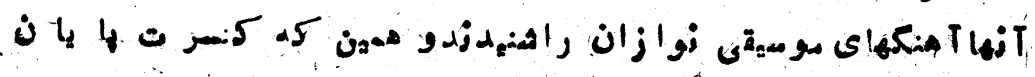

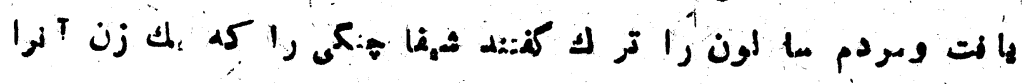

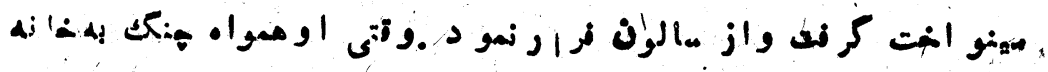

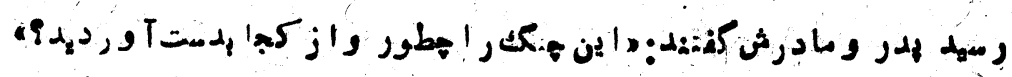

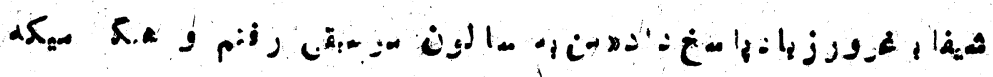

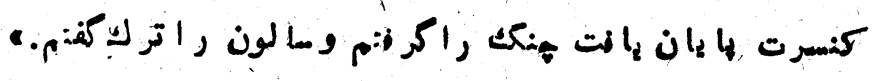

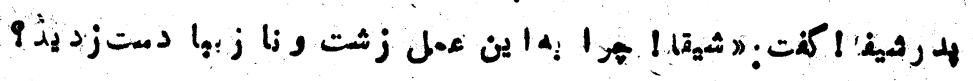

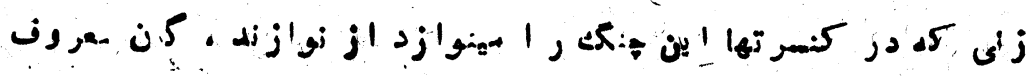

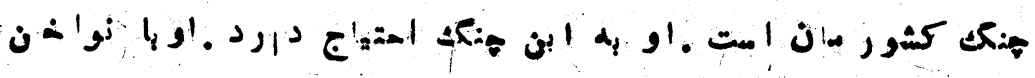

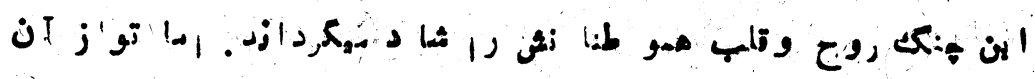

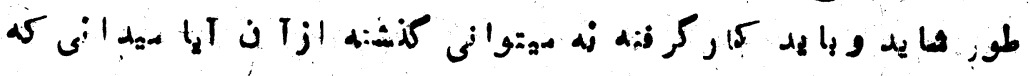

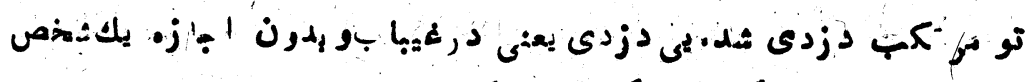

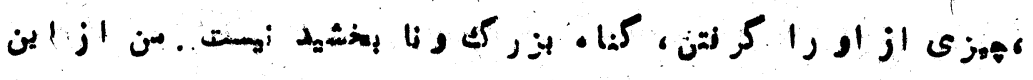

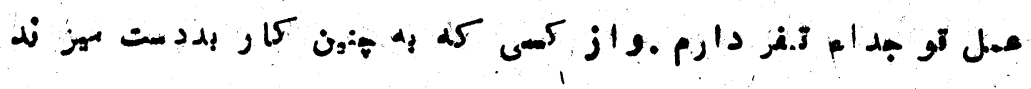

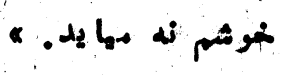

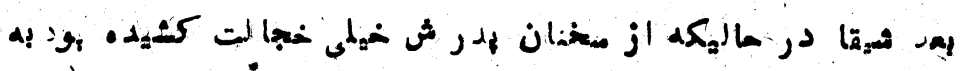

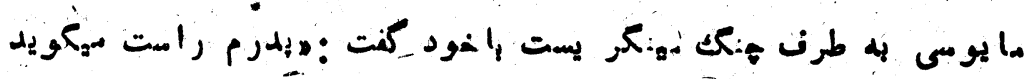

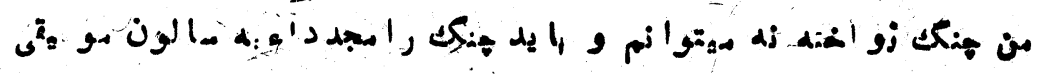

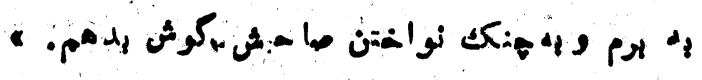
-1 Iŕ $^{-}$ 


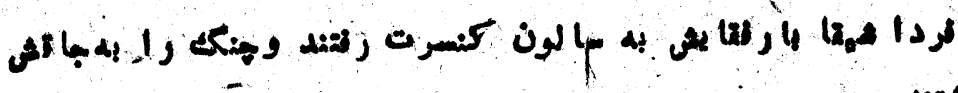
dis 1 is

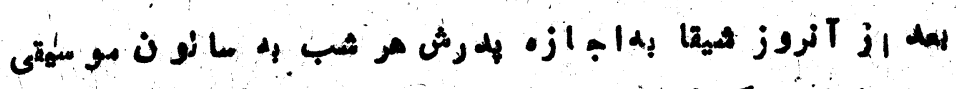

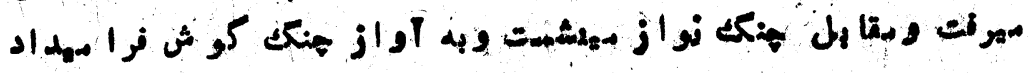

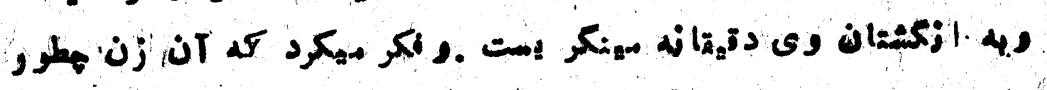

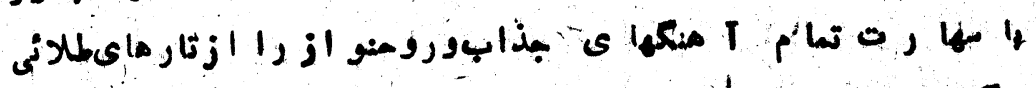

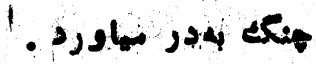

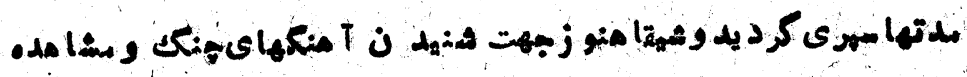

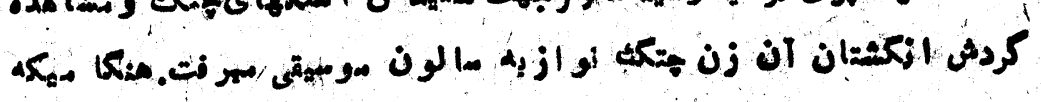

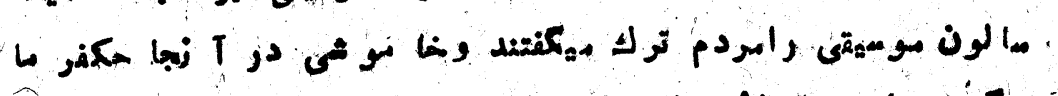

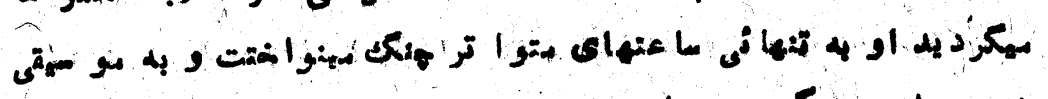

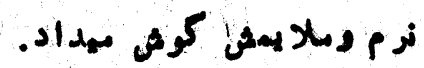

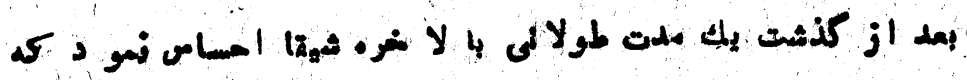

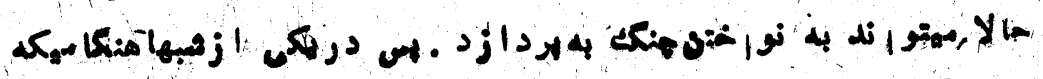

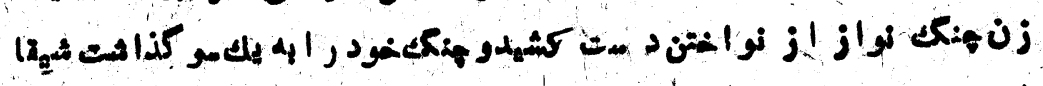

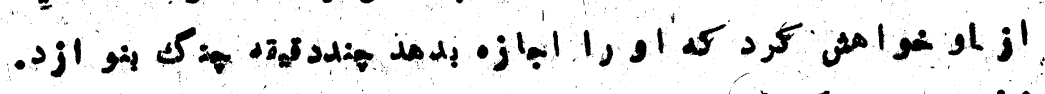

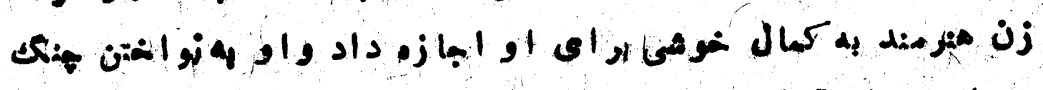

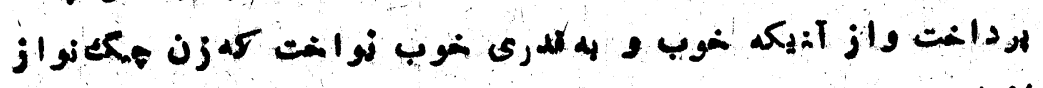

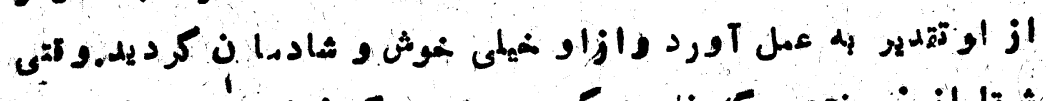

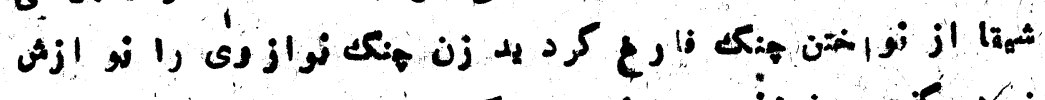

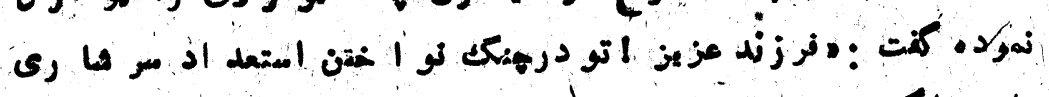

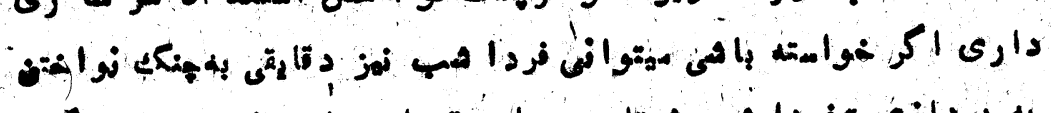

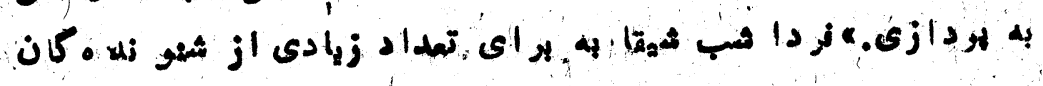
- INA- 


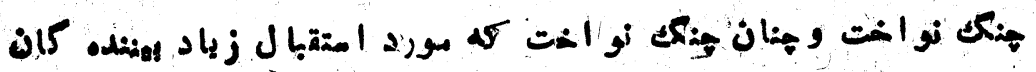

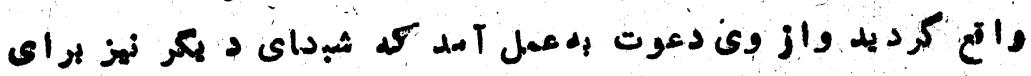

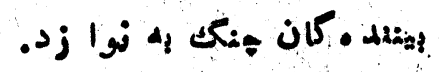

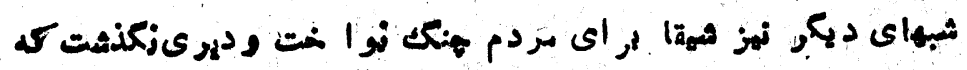

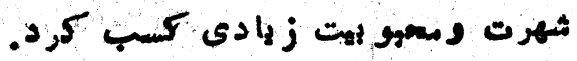

$$
\begin{aligned}
& \text {. }
\end{aligned}
$$

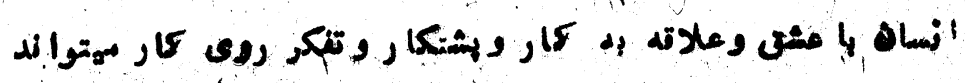

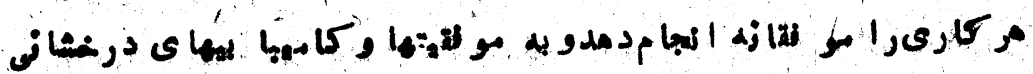

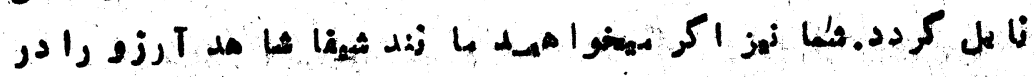

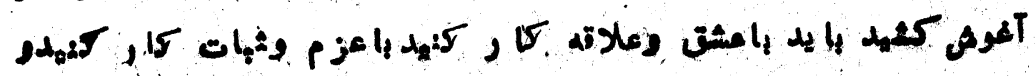
। 


\section{شال زيباونفيس}

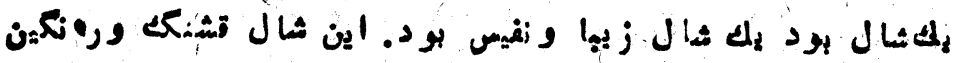

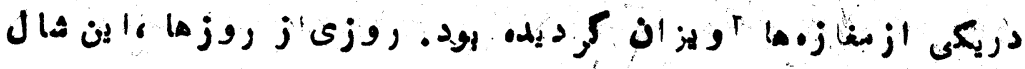

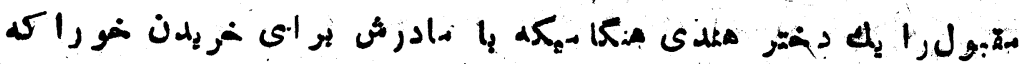

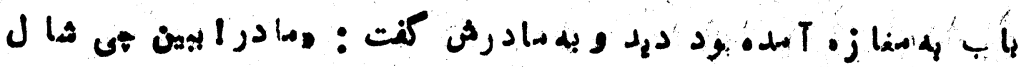

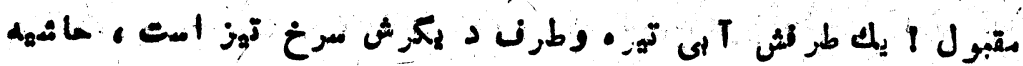

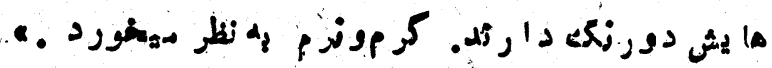

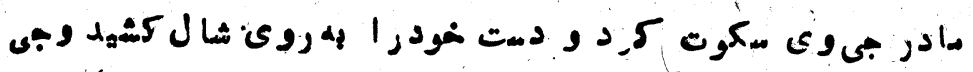

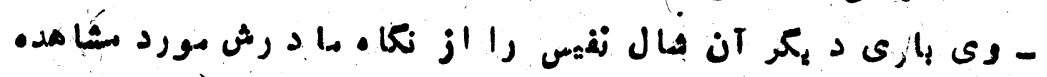

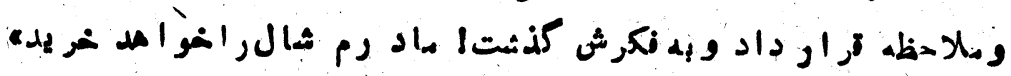

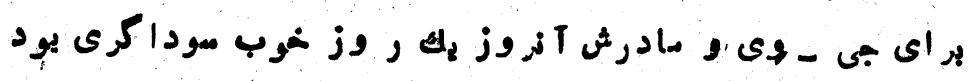

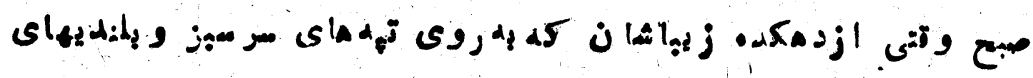

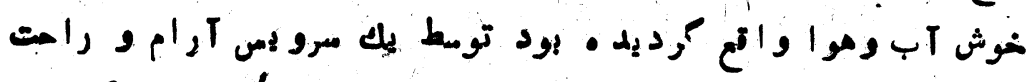

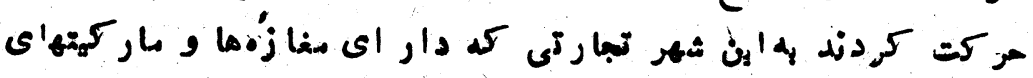

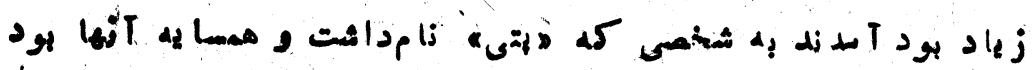

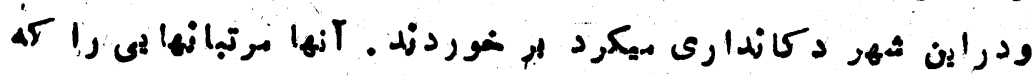

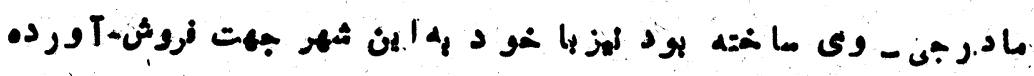

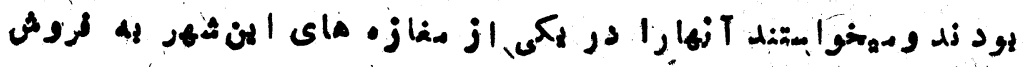

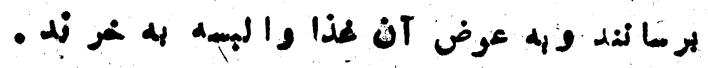




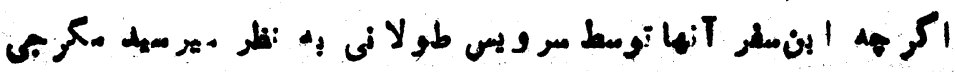

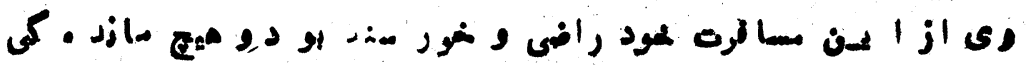

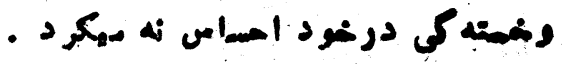

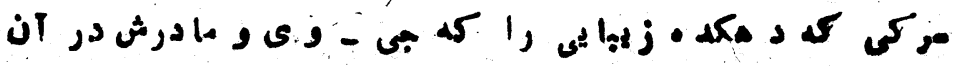

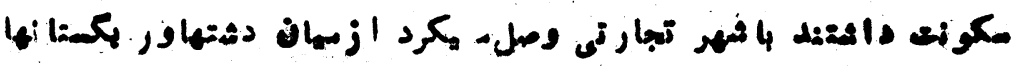

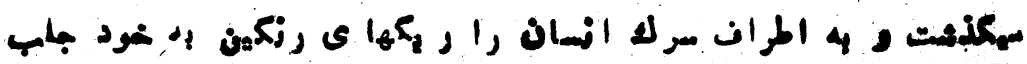

- مa

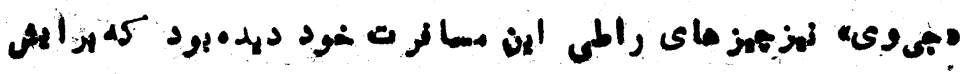

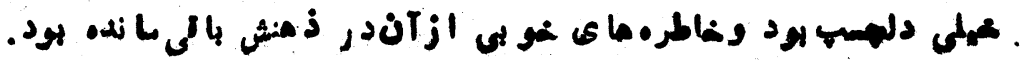

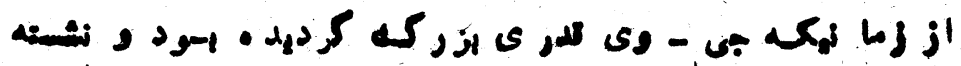

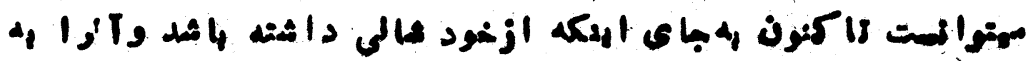

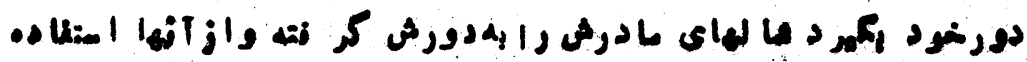

- Dr opar

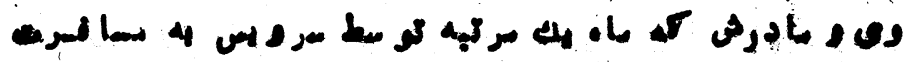

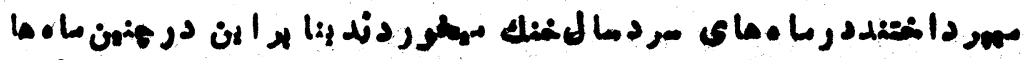

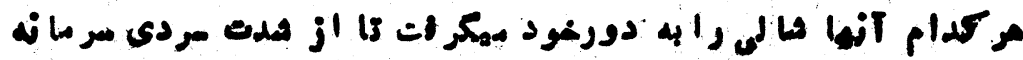

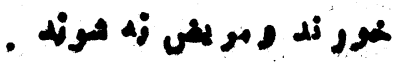

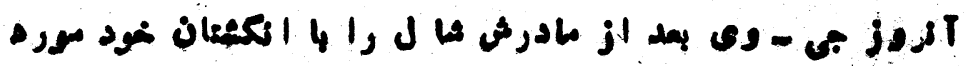

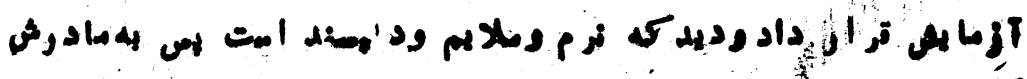

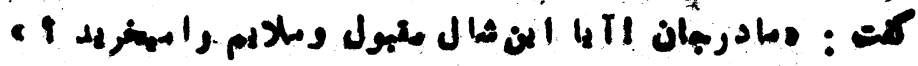

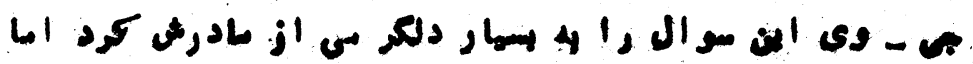

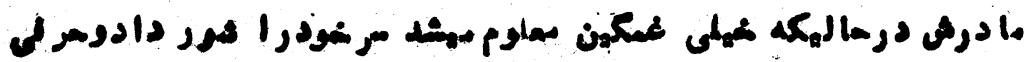

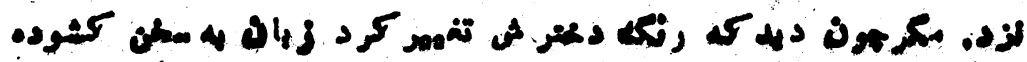
$-1-1$ 


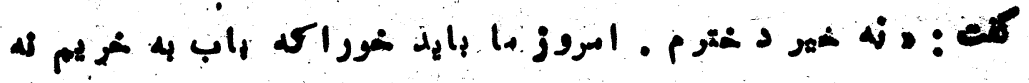

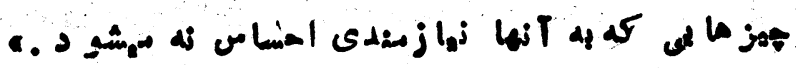

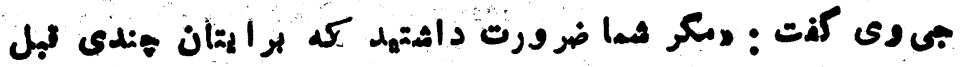

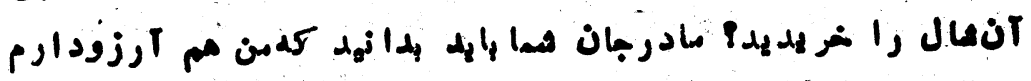

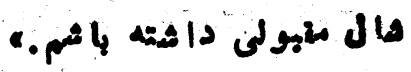

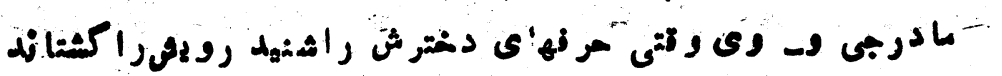

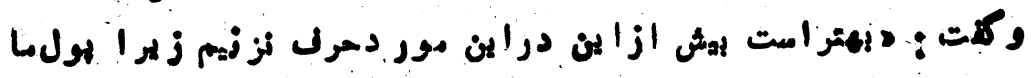

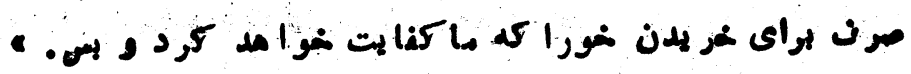

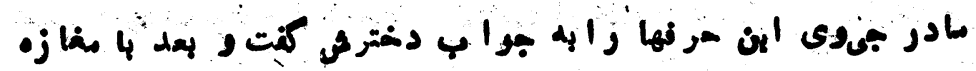

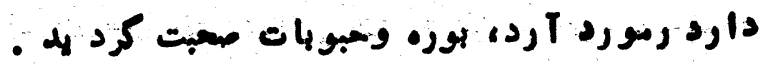

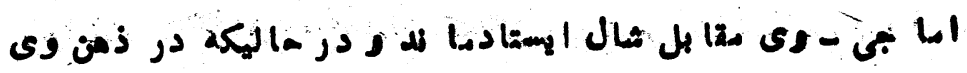

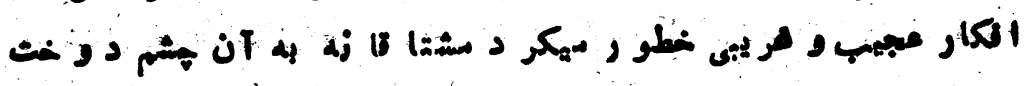

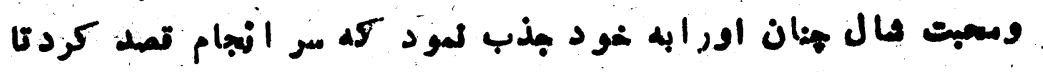

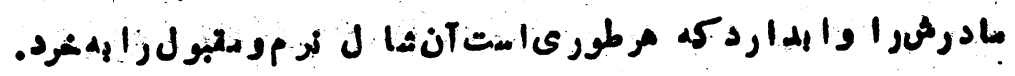

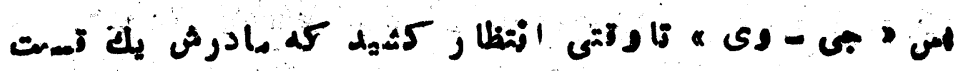

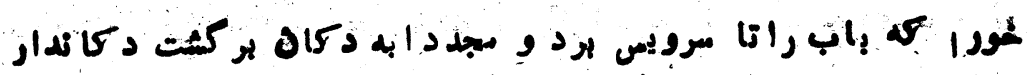

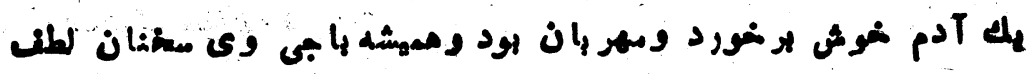

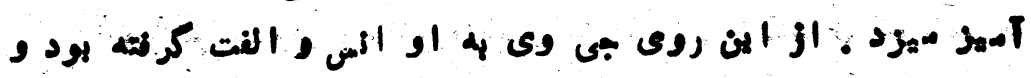
.

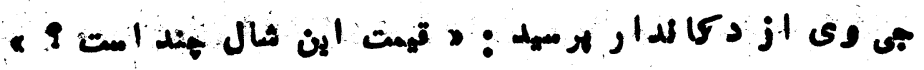

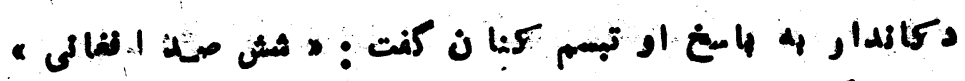
ه

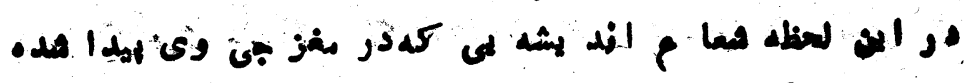
$r \cdot r-$ 


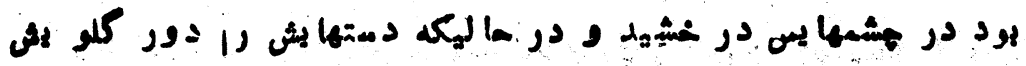

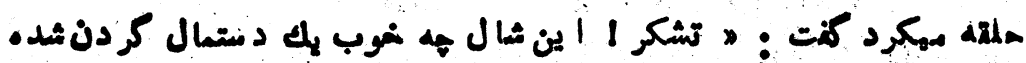

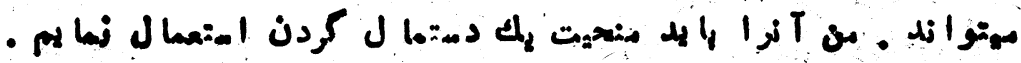

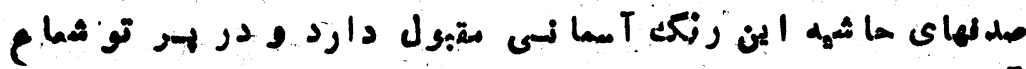

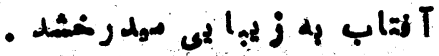

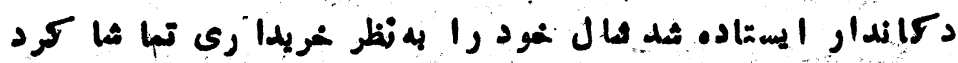

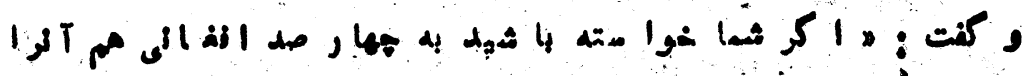

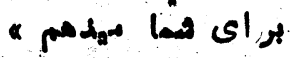

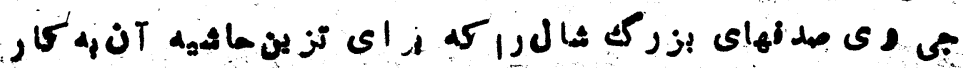

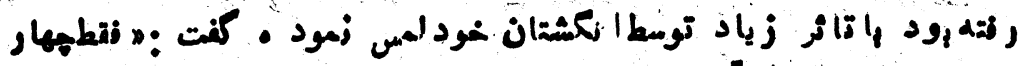

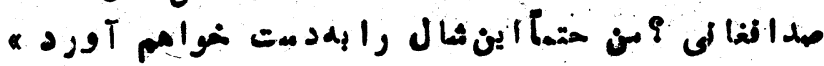

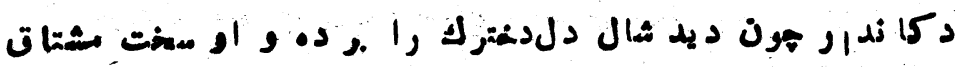

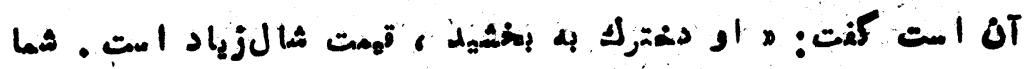

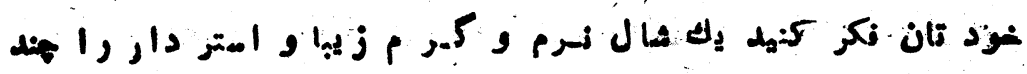

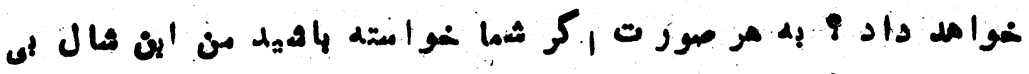

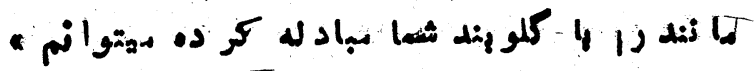

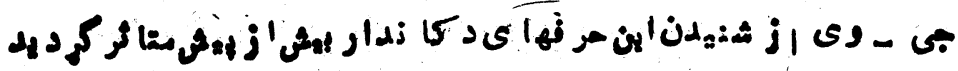

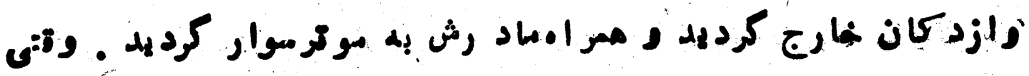

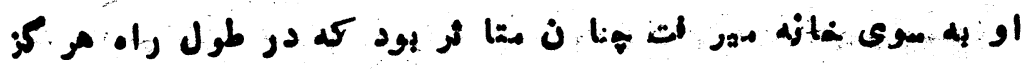

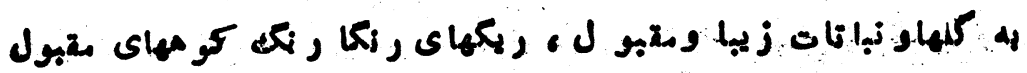

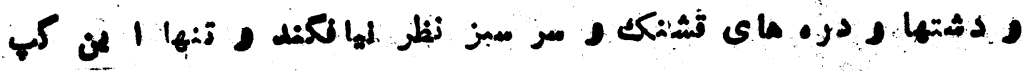

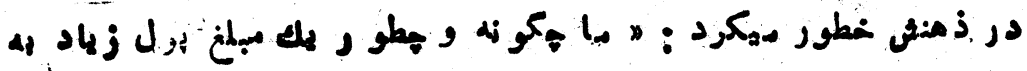

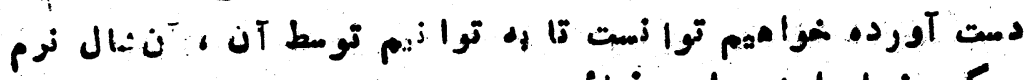

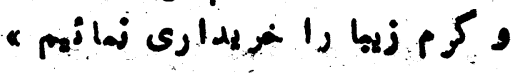
-r.Pr- 


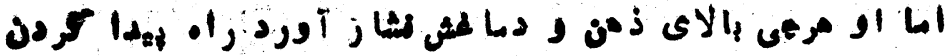

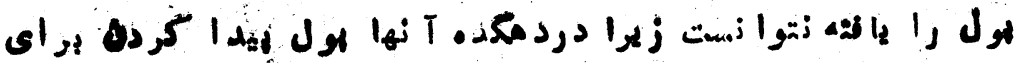

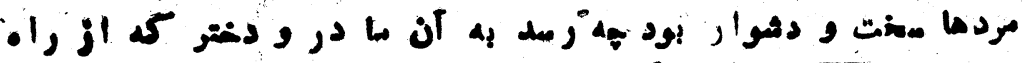

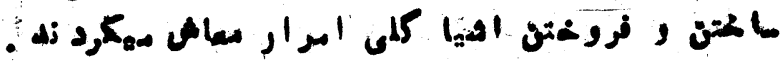

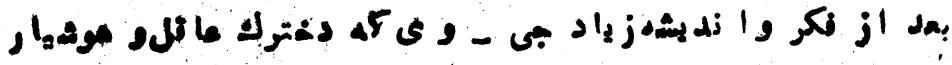

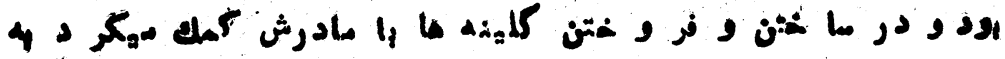

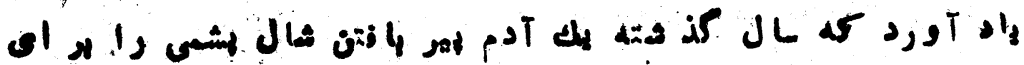

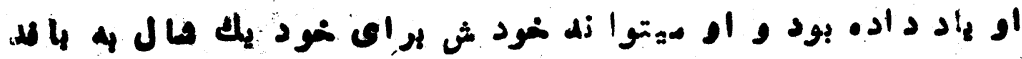

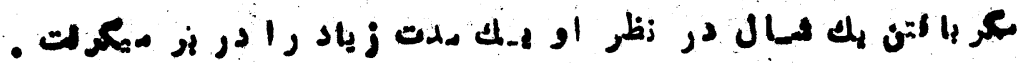

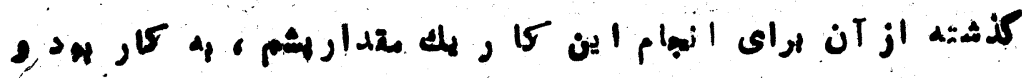

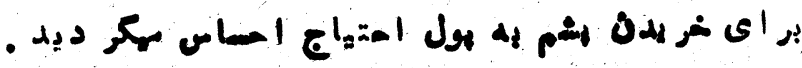

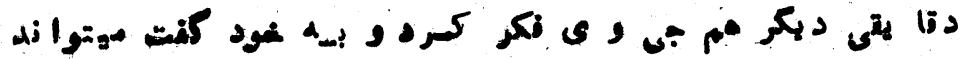

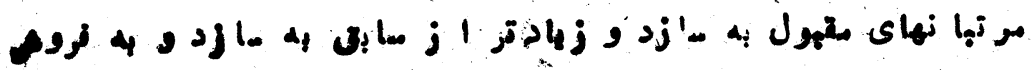

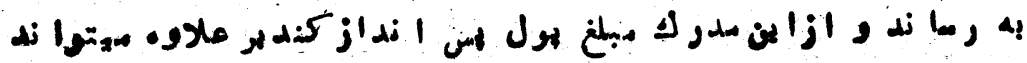

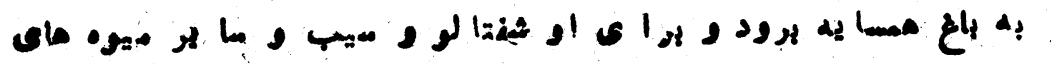

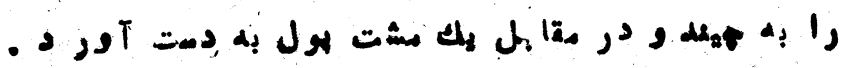

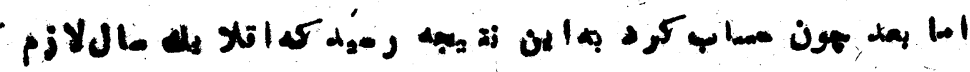

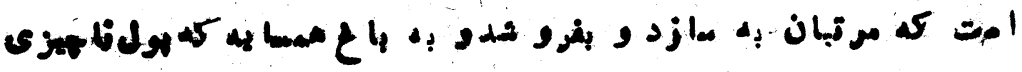

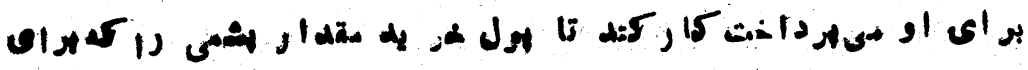

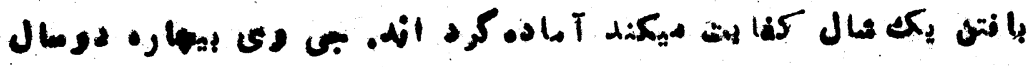

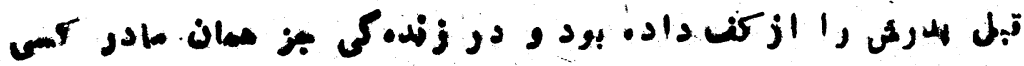

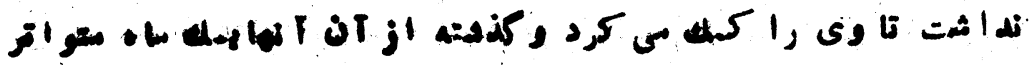

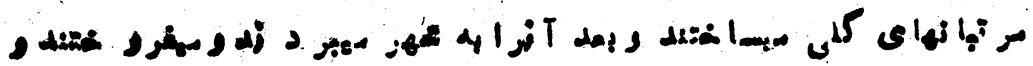




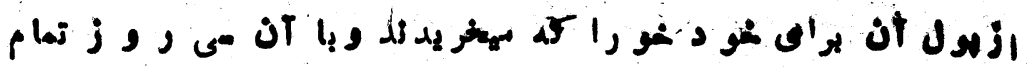

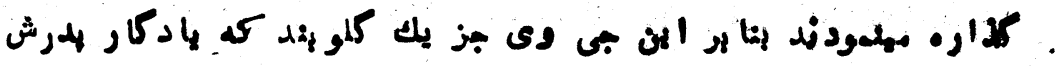

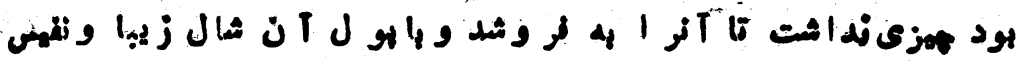
(1,

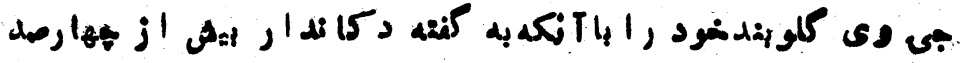

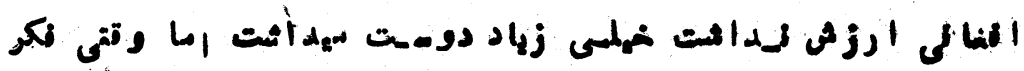

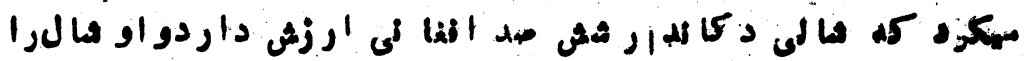

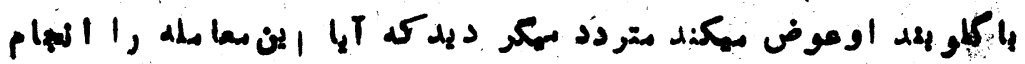

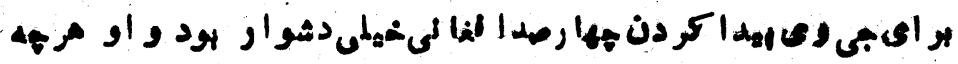

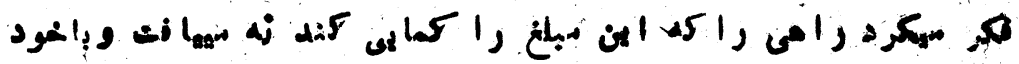

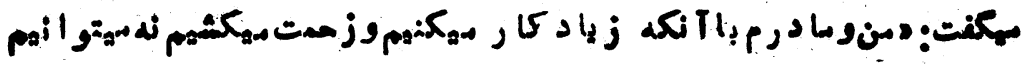

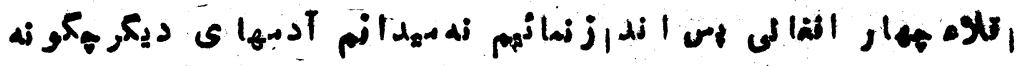

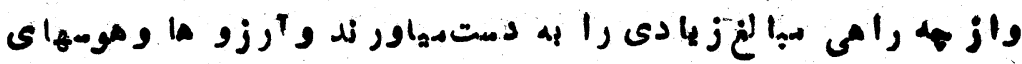

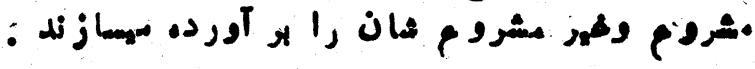

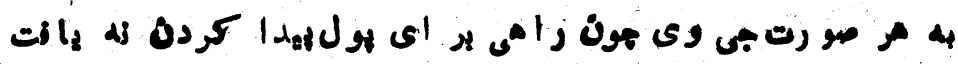

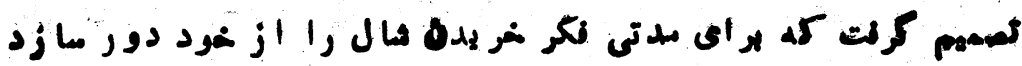

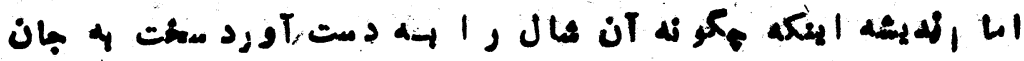

أ

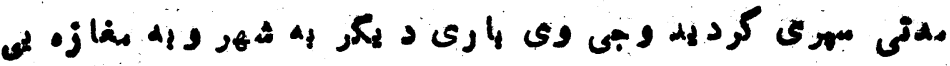

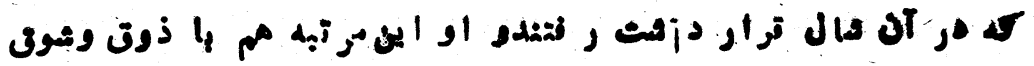

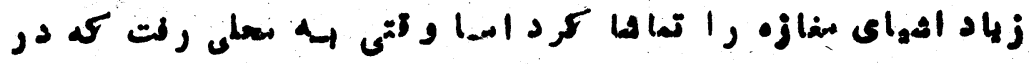

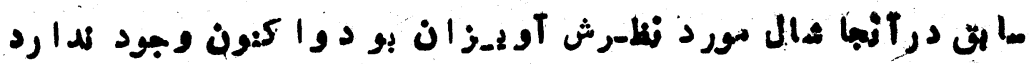

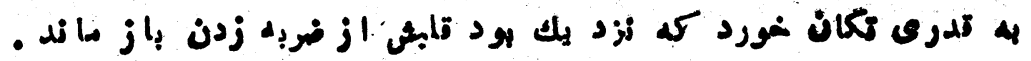




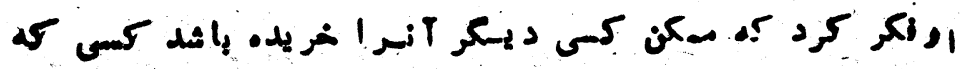

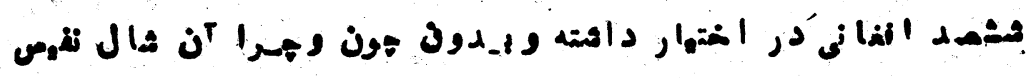

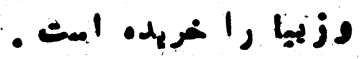

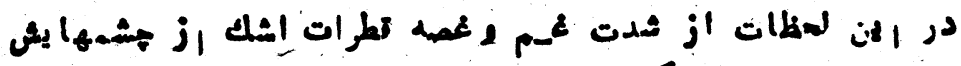
4

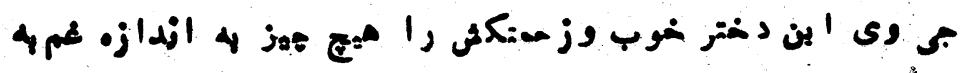

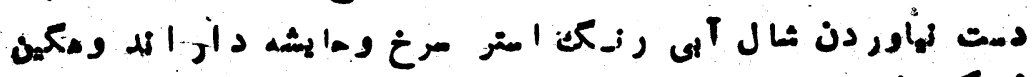
زه كرد' فعده بود . ماورد

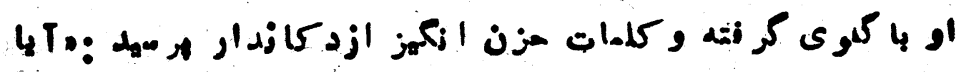

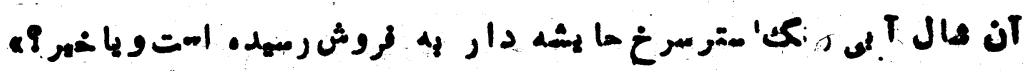

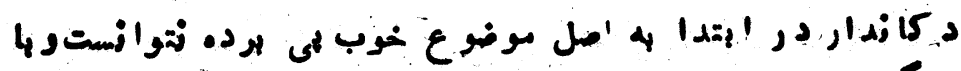

ن

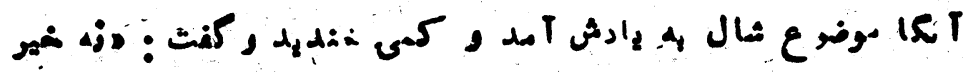

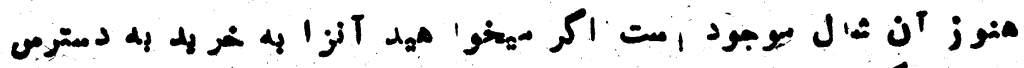

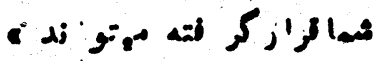

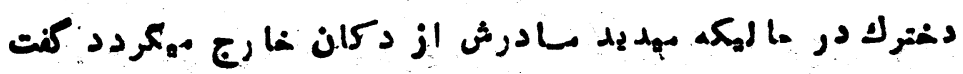

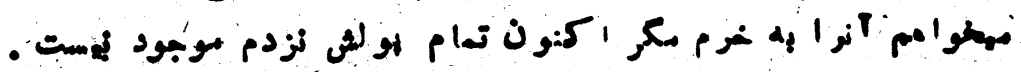

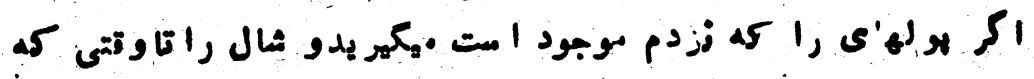

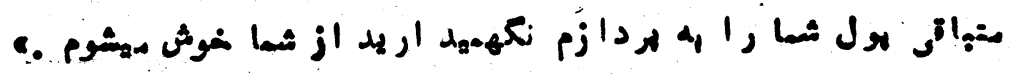

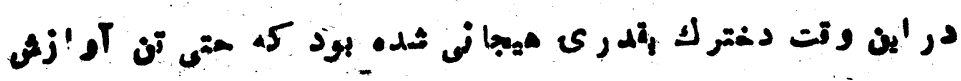

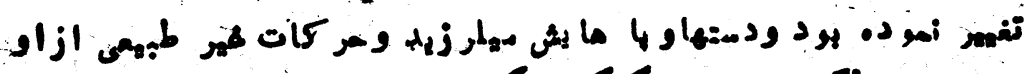

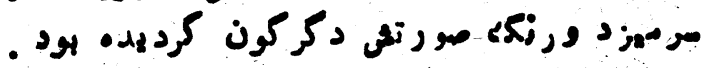

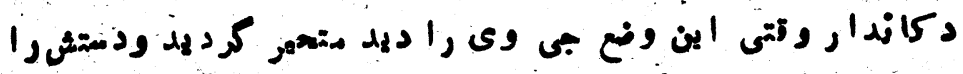

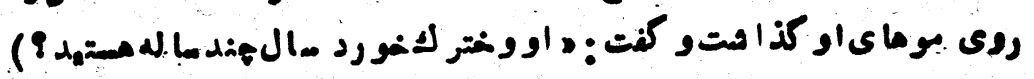
- r - 


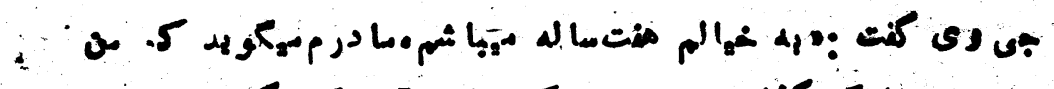

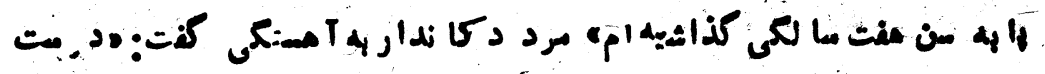

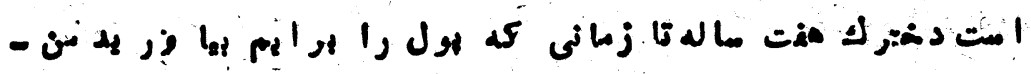

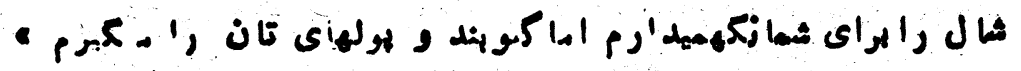

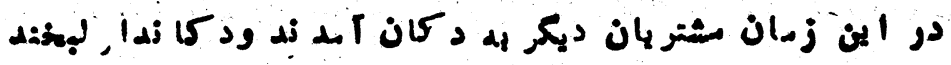
- زلان

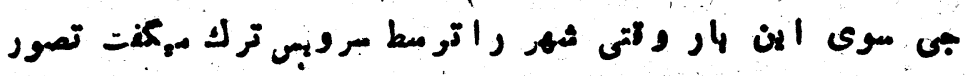

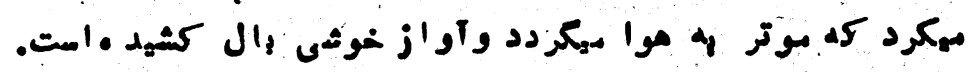

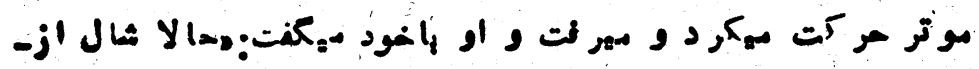

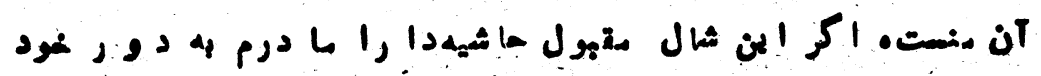

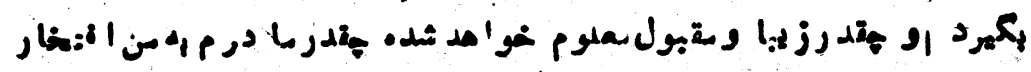

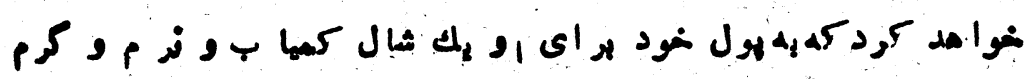

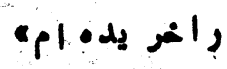

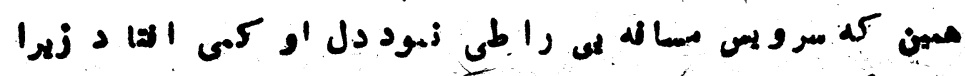

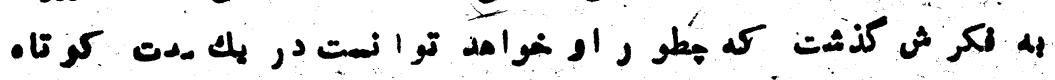

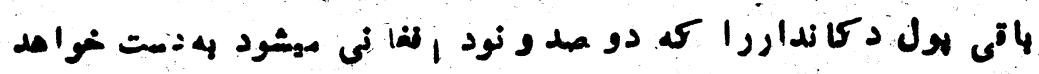

•.

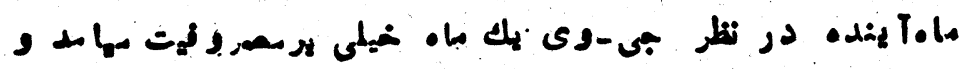

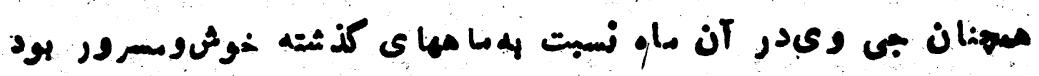

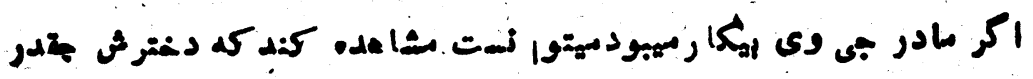
.

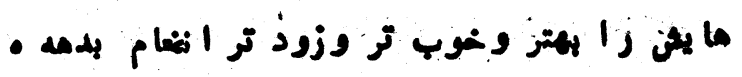
$-r, v-$ 


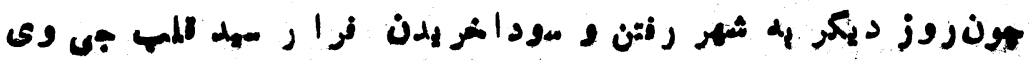

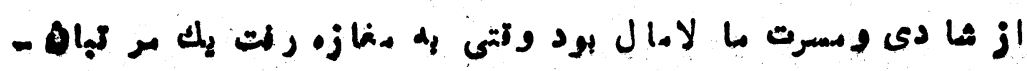

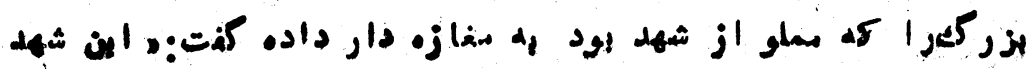

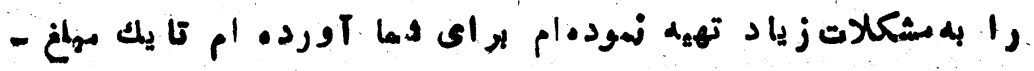

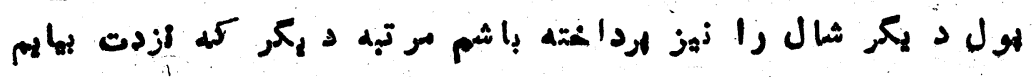

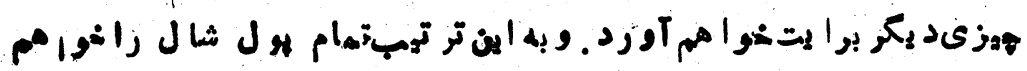

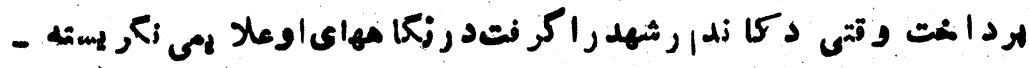

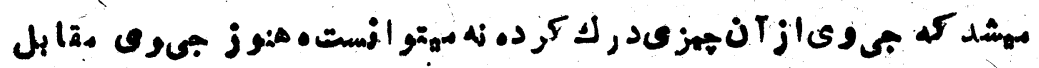

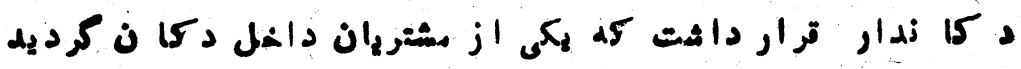

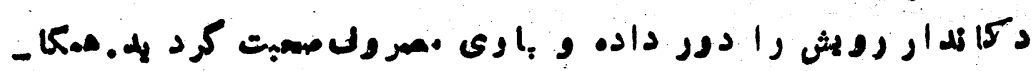

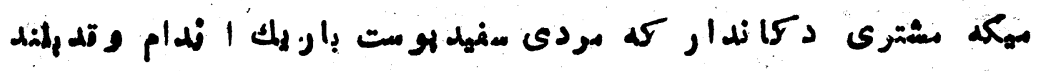

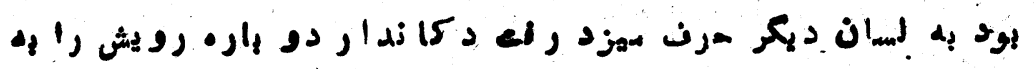

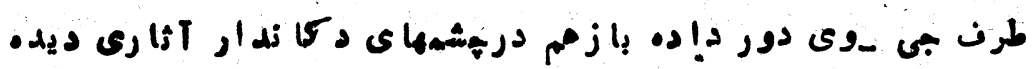

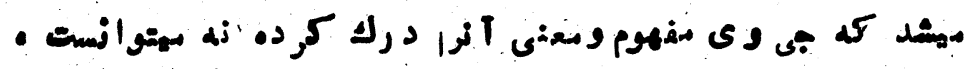

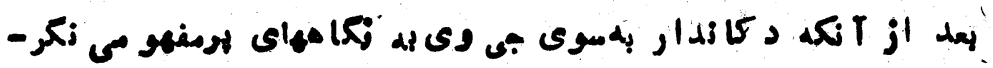

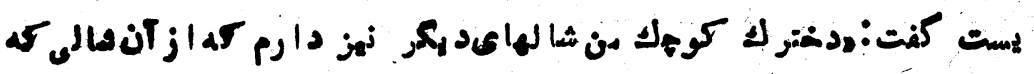

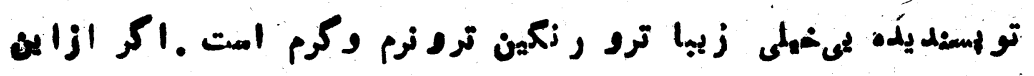

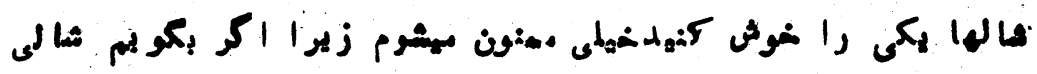

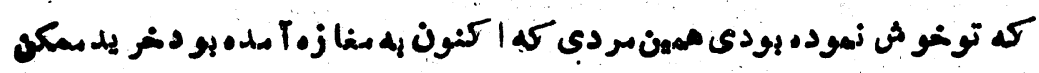

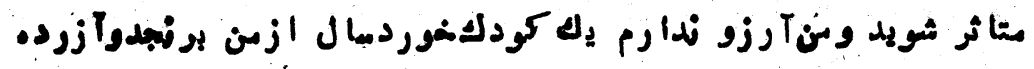

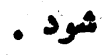

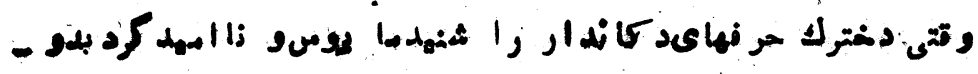

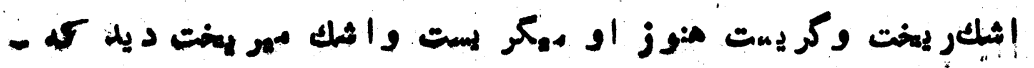

$-r, \wedge=$ 


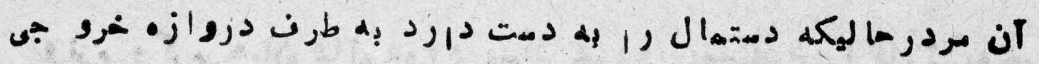

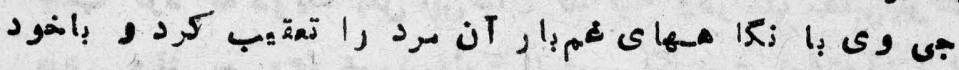

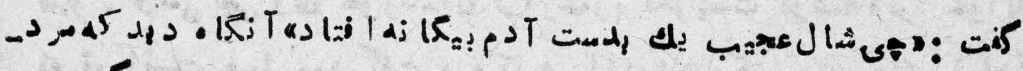

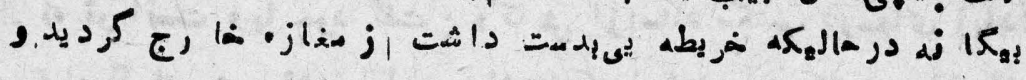

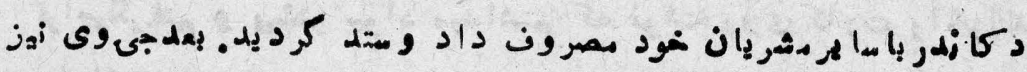

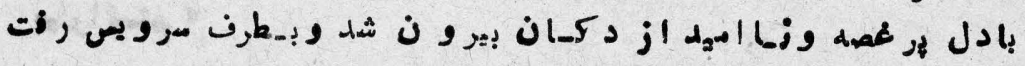

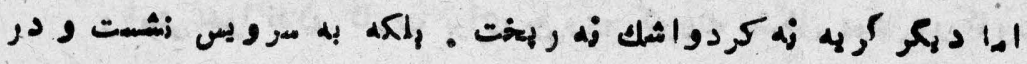

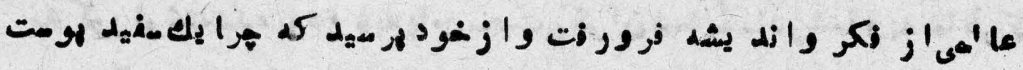

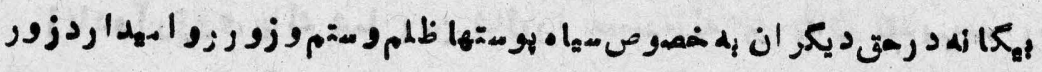

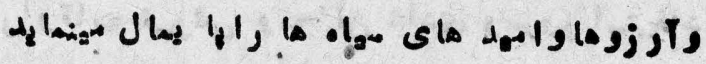

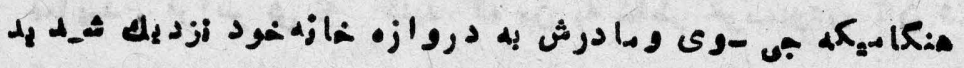

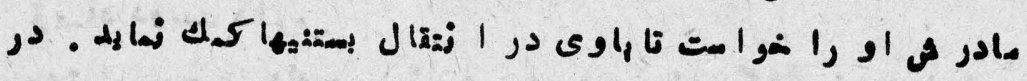

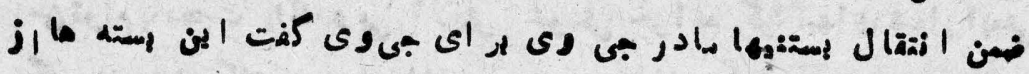

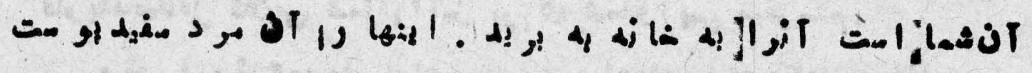

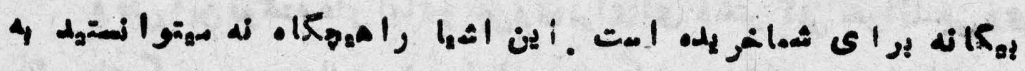
-

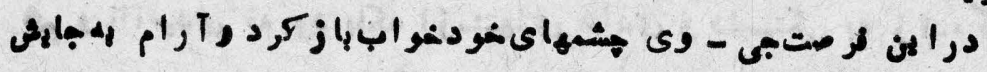

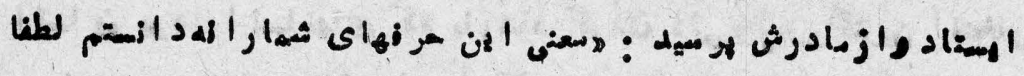

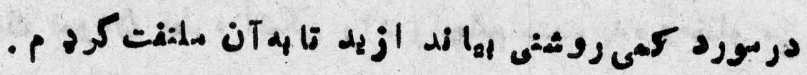

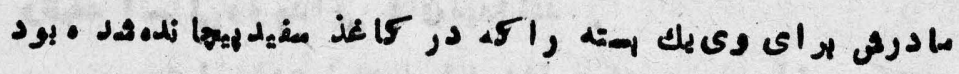

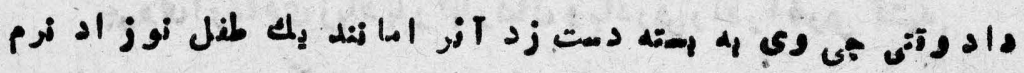
و

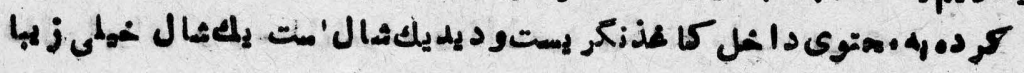


20

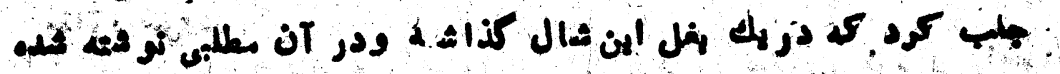

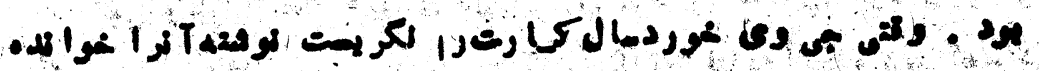

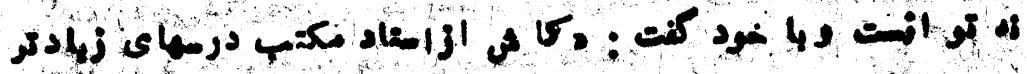

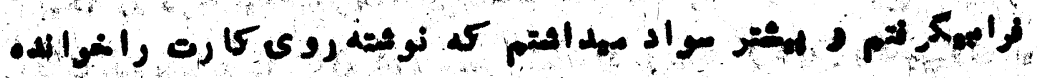
risisis

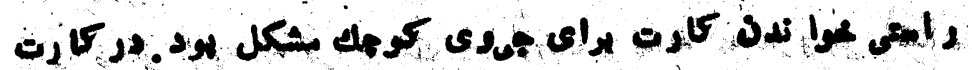

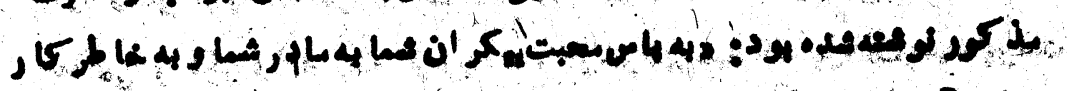

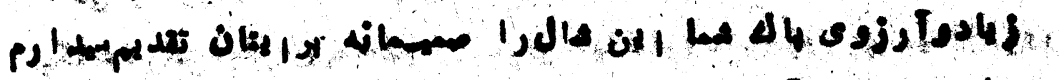

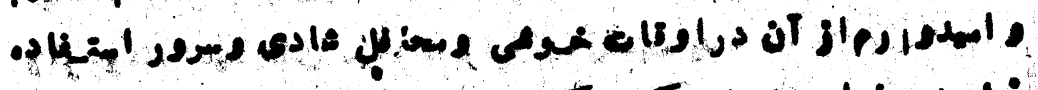

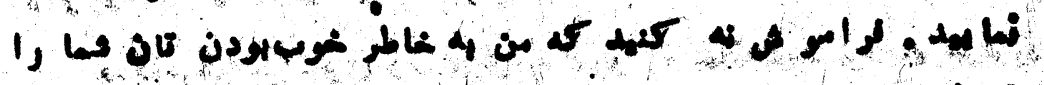
$.012=0203$

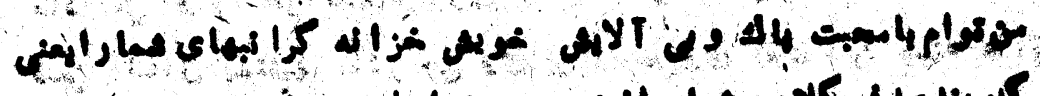

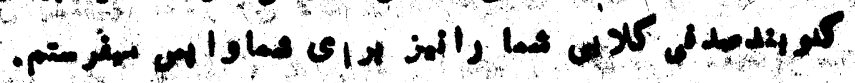

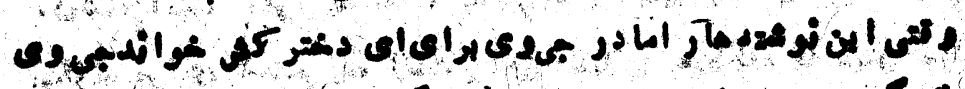

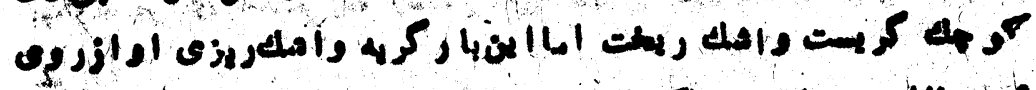

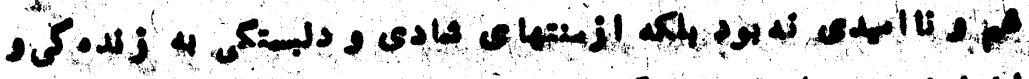

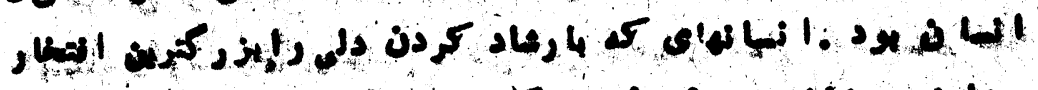

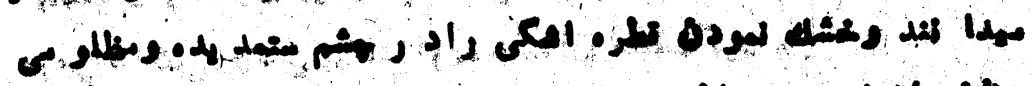

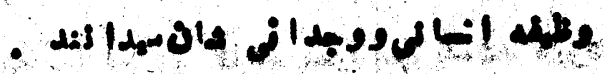

.4

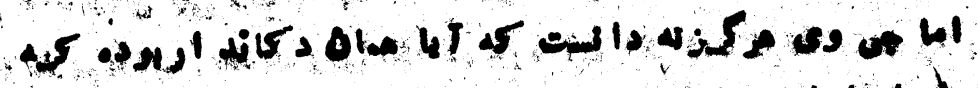

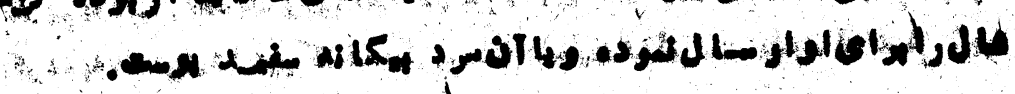
- 11 o- 


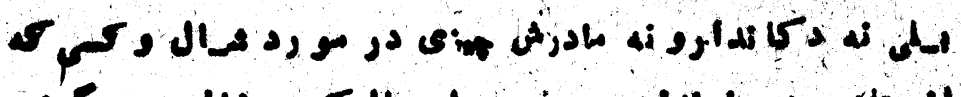

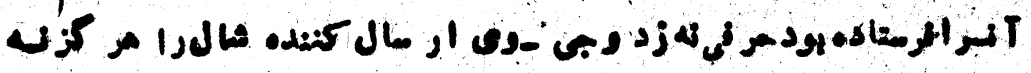

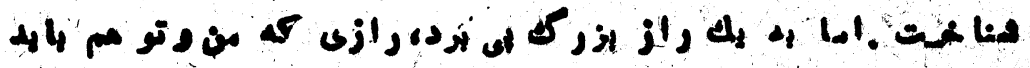

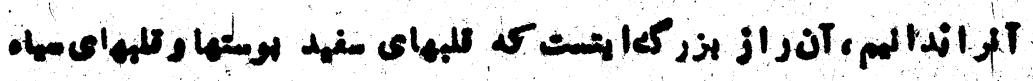

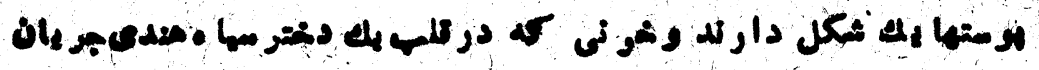

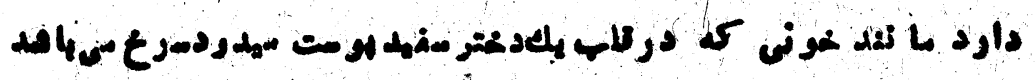

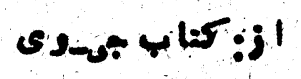

$$
\text { نو }
$$




\section{جسمش}

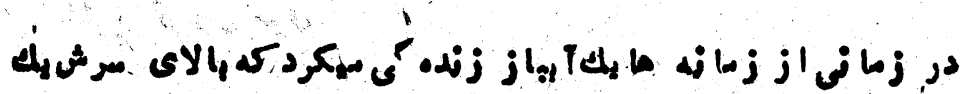

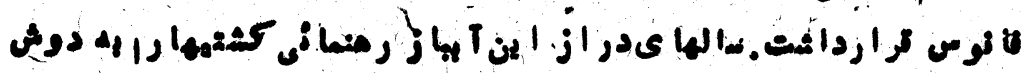

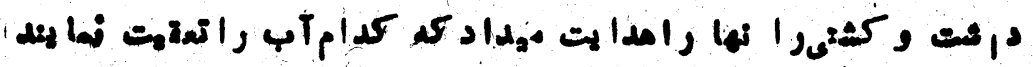

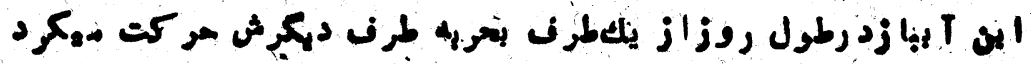

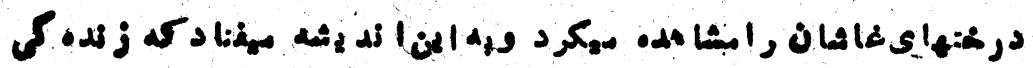

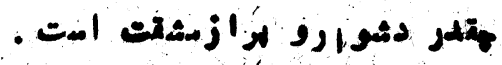

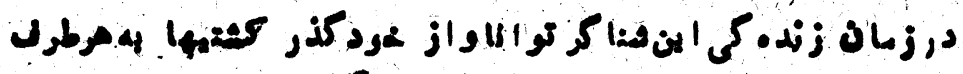

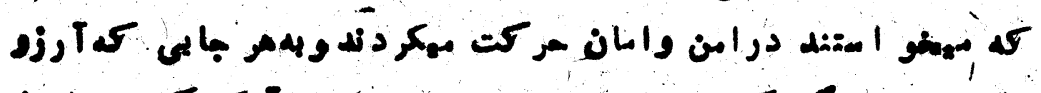

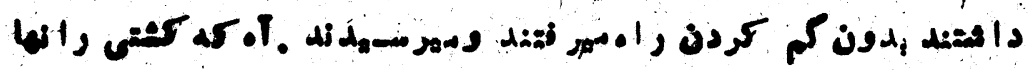

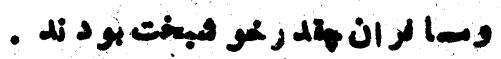

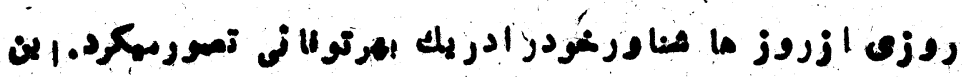

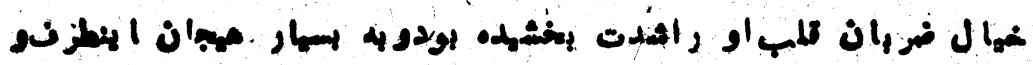

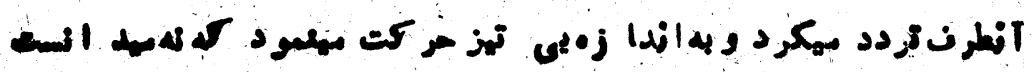

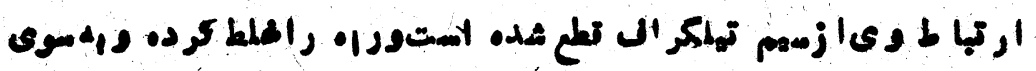

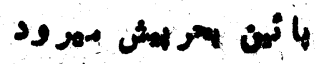




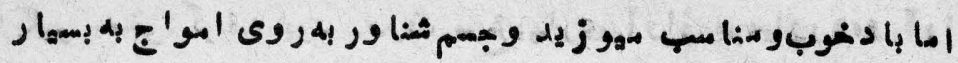

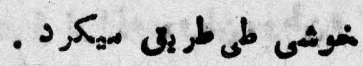

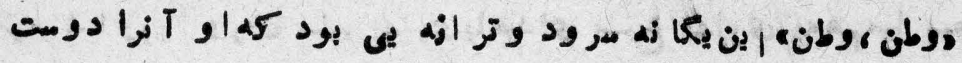

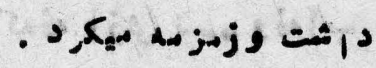

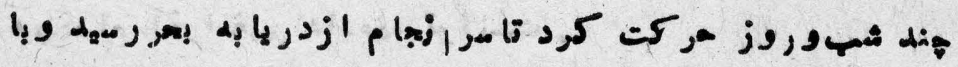

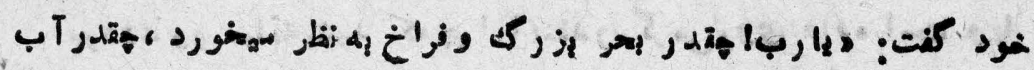

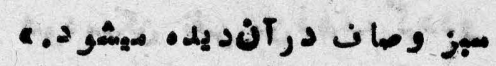

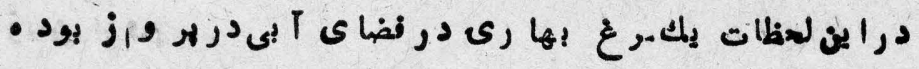

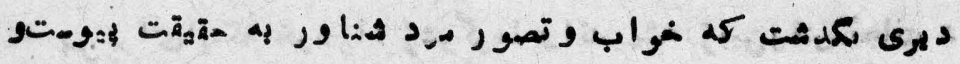

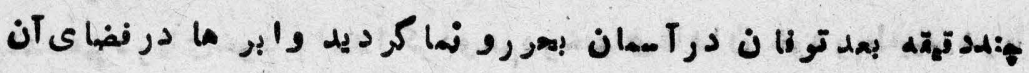
- dis is coi

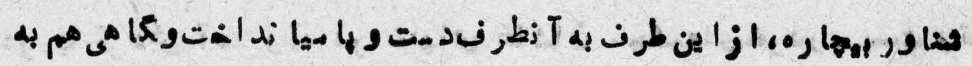

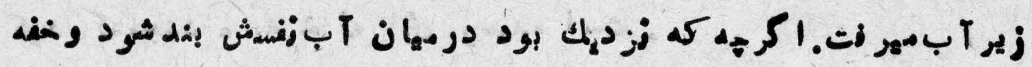

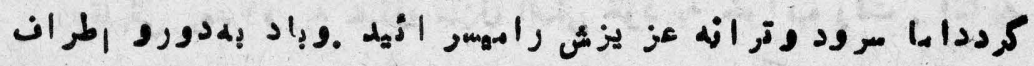

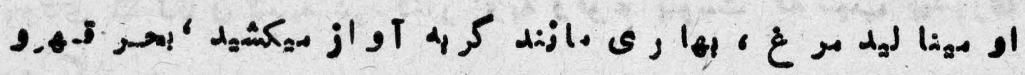

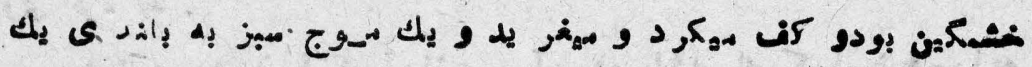

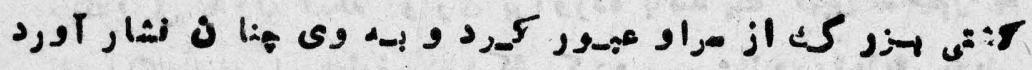
.

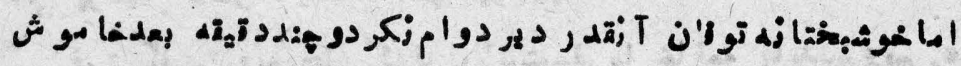

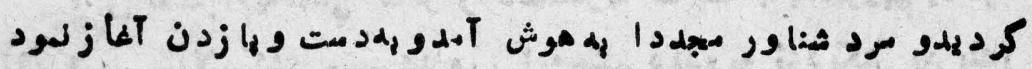

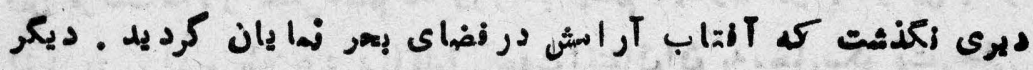

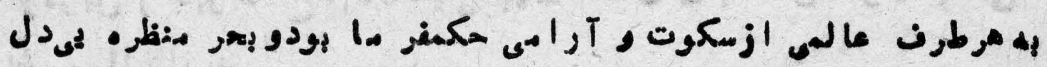




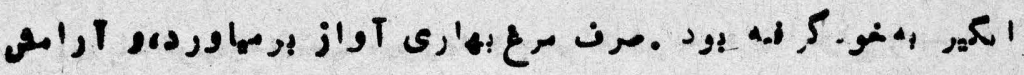

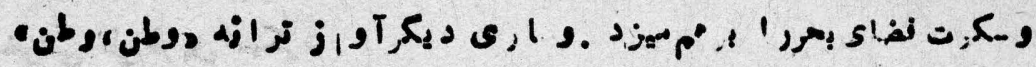

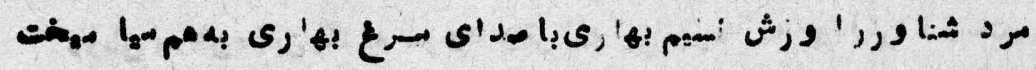

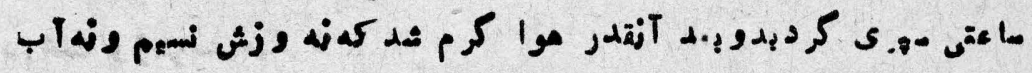

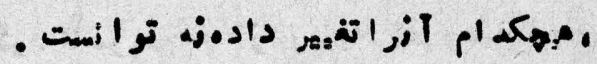

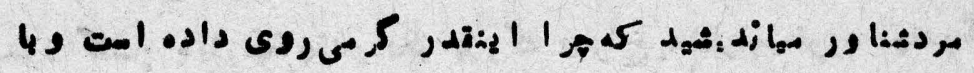

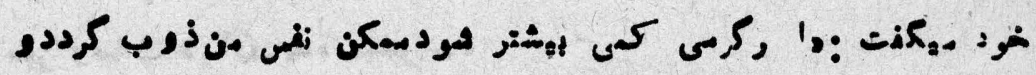
-

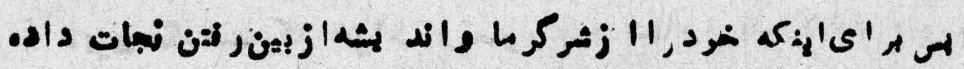

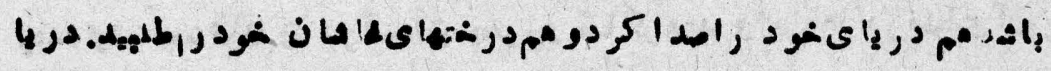

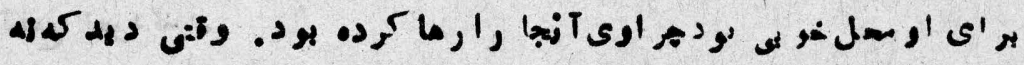

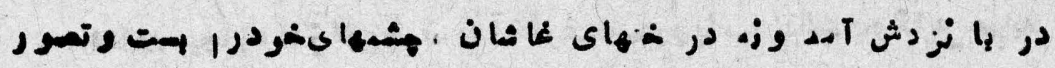

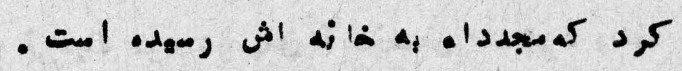
با

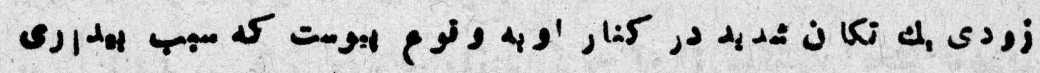
- A 28

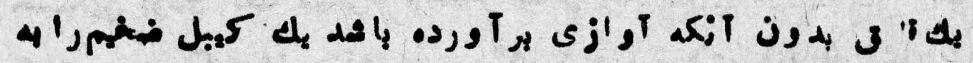

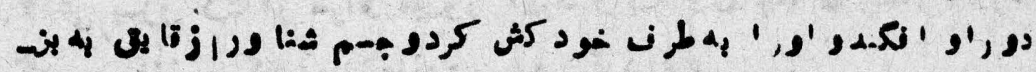

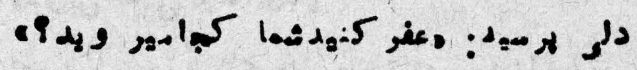

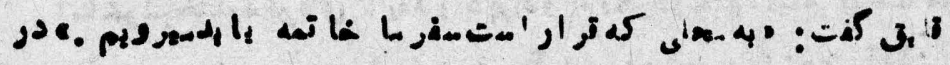

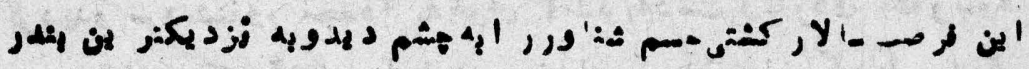

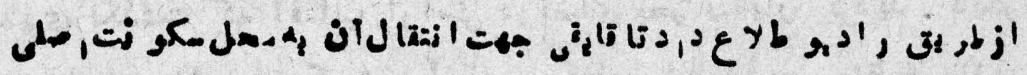

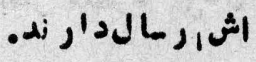




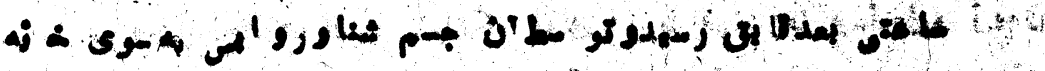

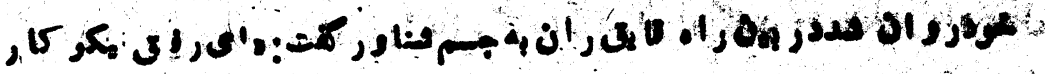

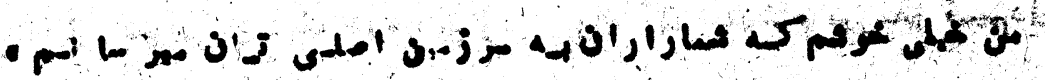

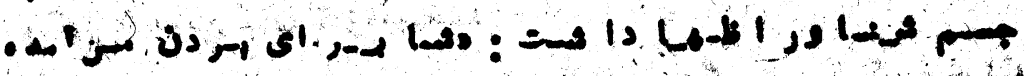

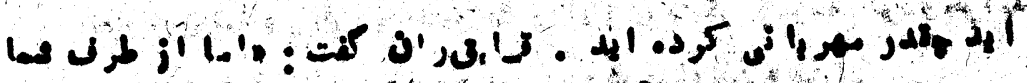

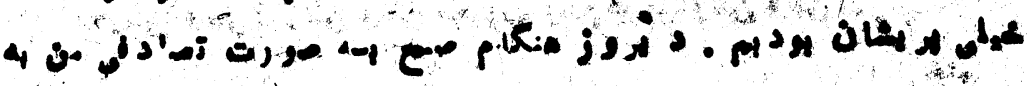

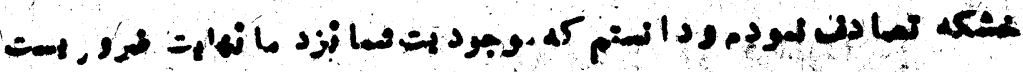

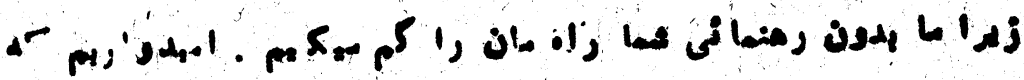

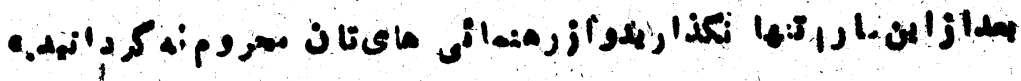
ه c.en pos

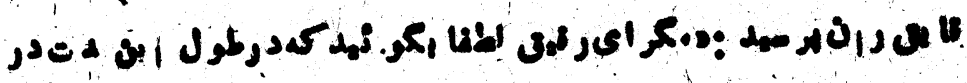

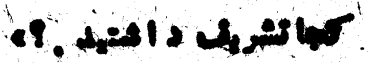

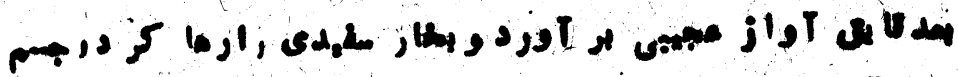
.

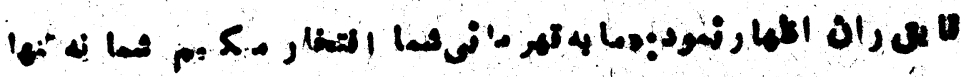

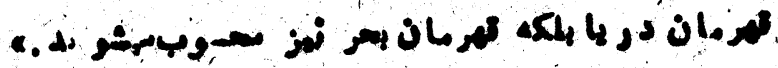

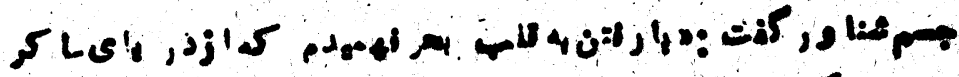

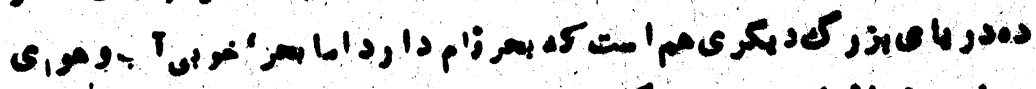

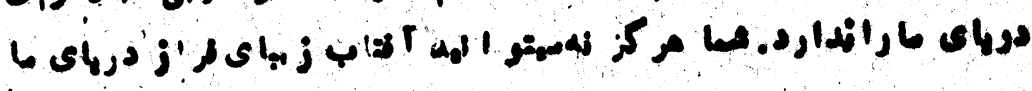

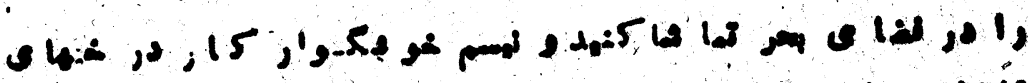

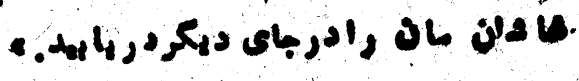




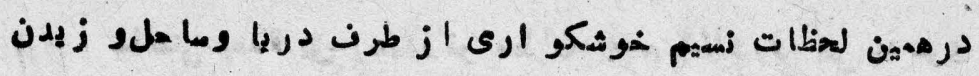

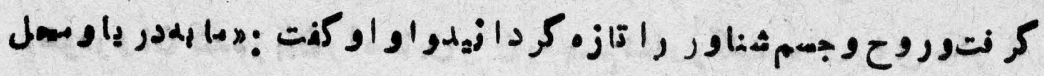

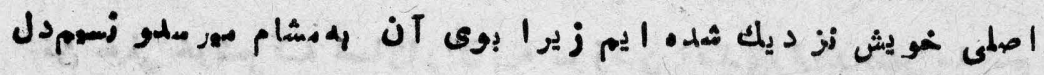

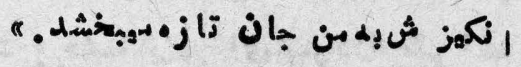

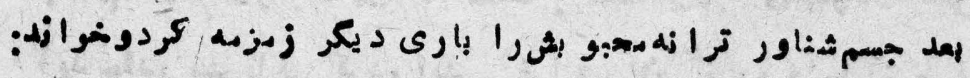

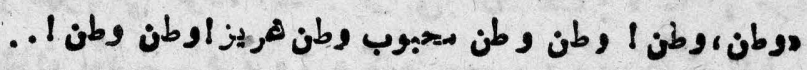

$$
\text { از كر انودارد: }
$$

PIT 



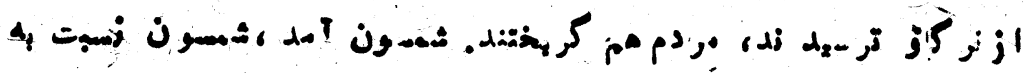

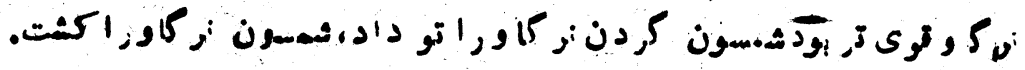

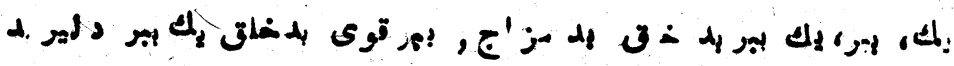

-

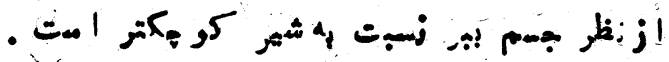

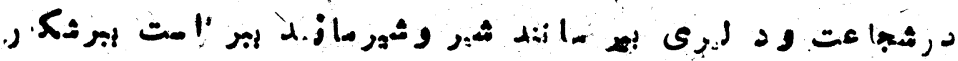

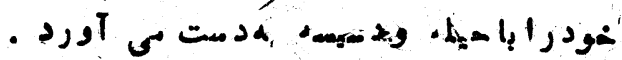

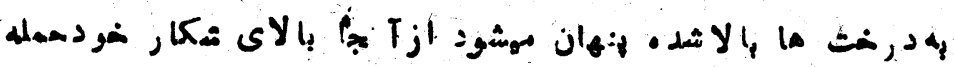

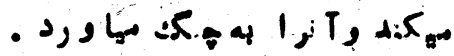

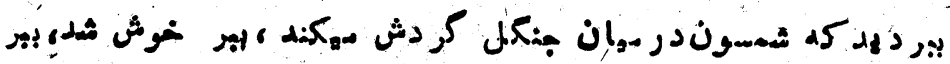

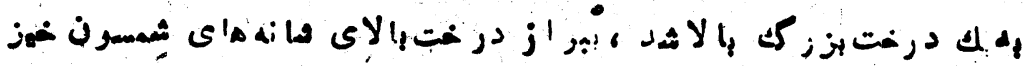

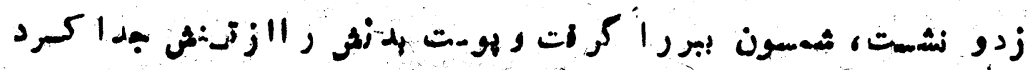

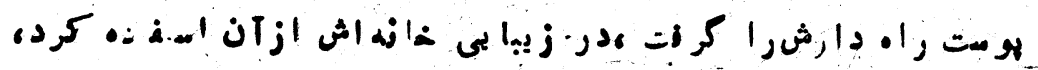

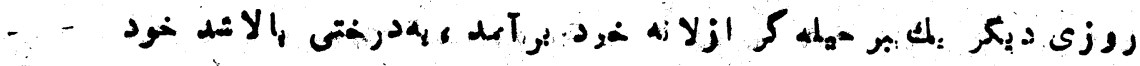

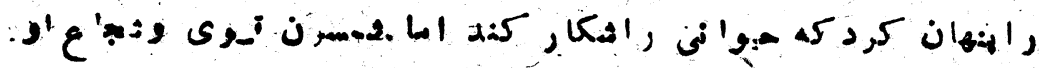

.

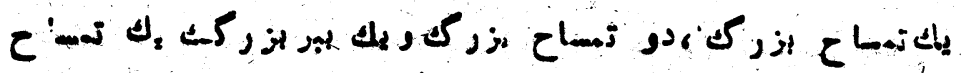

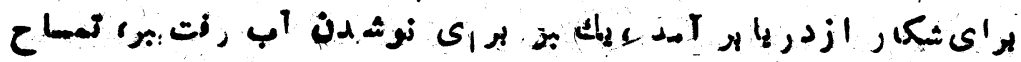

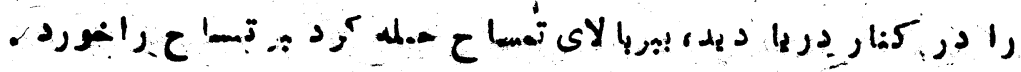

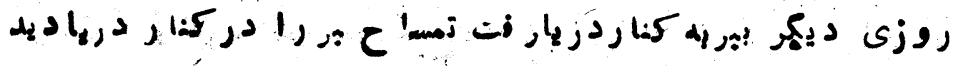

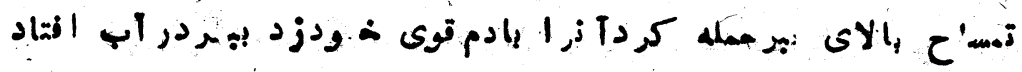

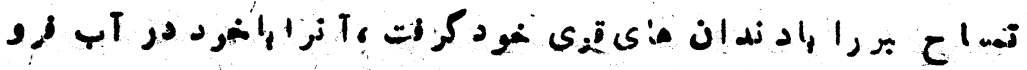

-

- rIA- 


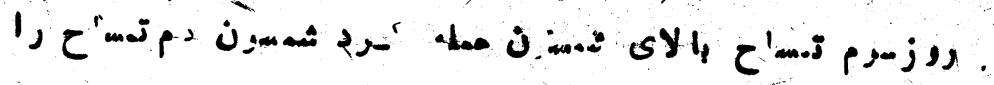

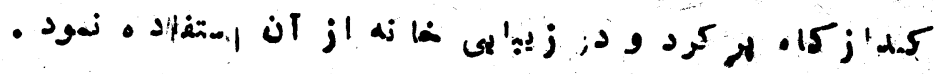

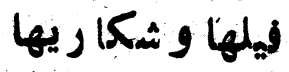

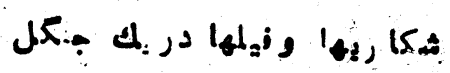

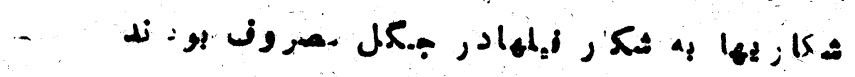

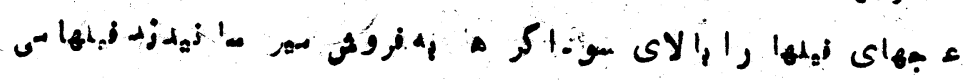

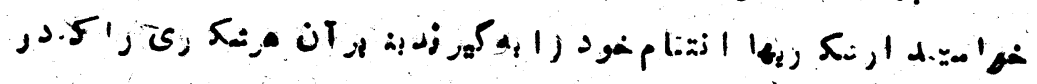

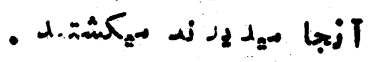

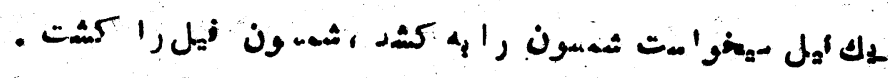

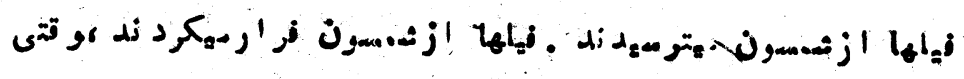

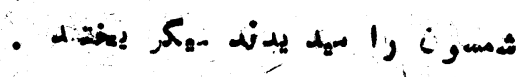

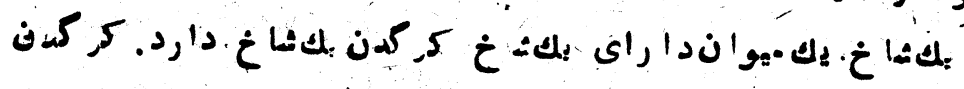

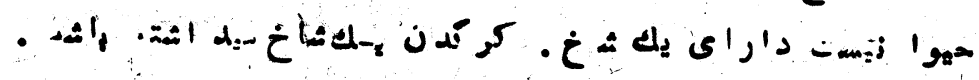

كر كa نها.

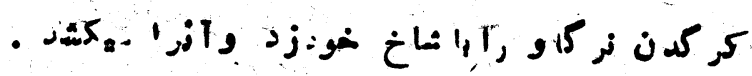

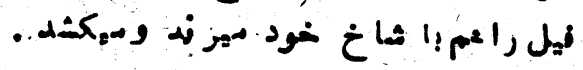

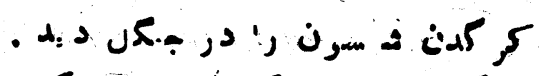

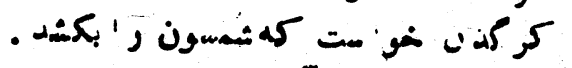

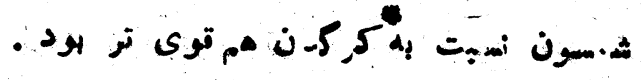

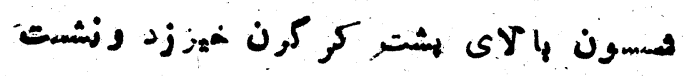

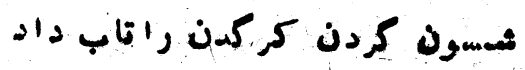

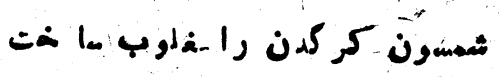

$-r 19-$ 


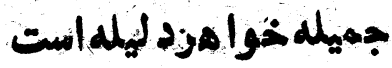

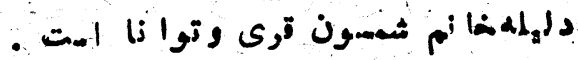

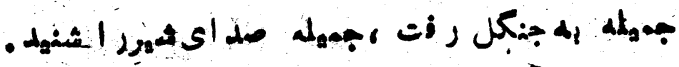

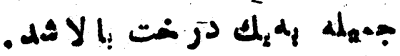

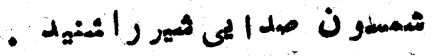

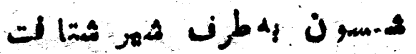

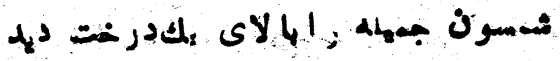

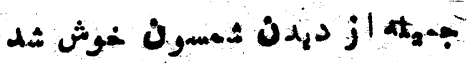

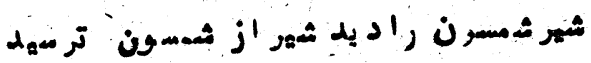

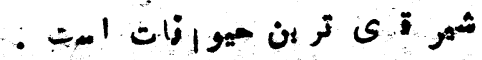

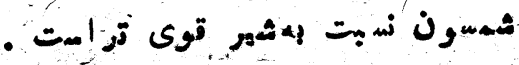

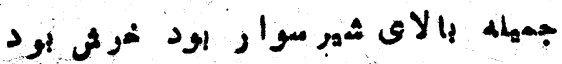

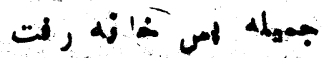

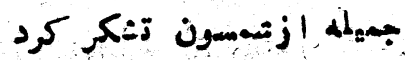

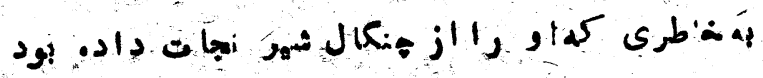

.

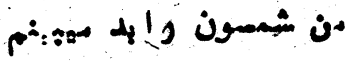

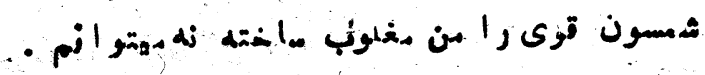

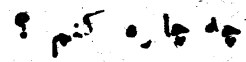

وز

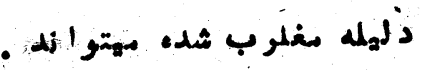

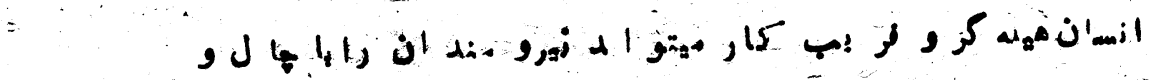

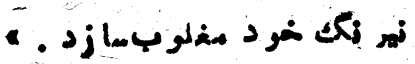




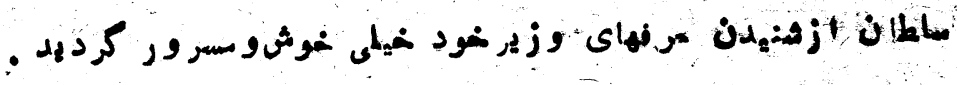

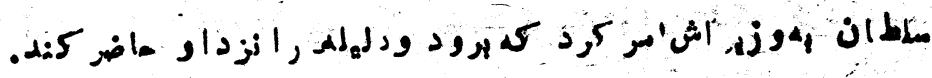

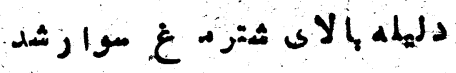

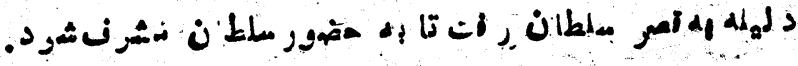

وز

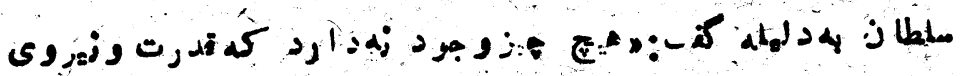

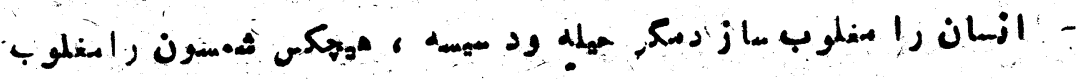

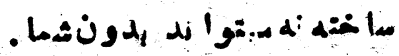

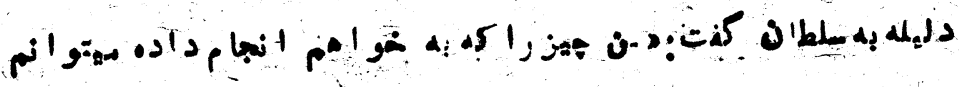

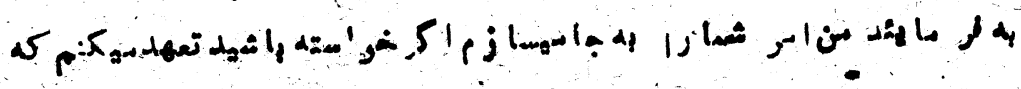

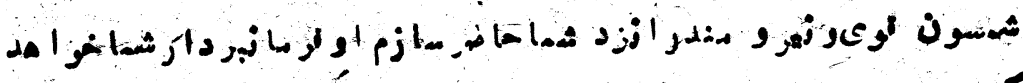

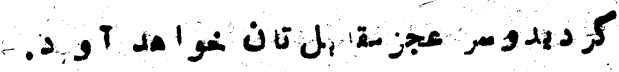

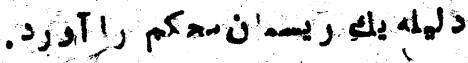

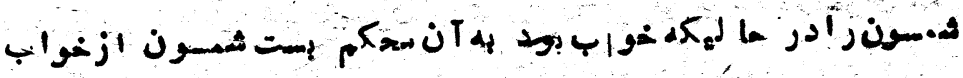

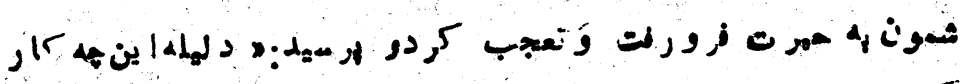

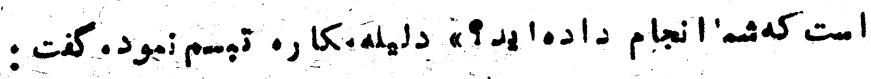

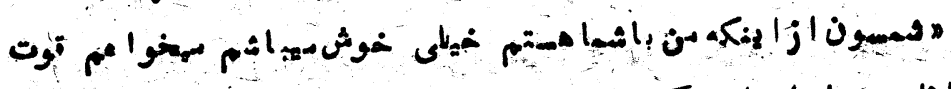

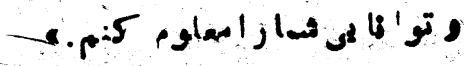

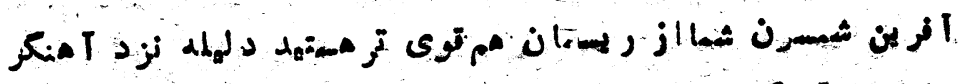

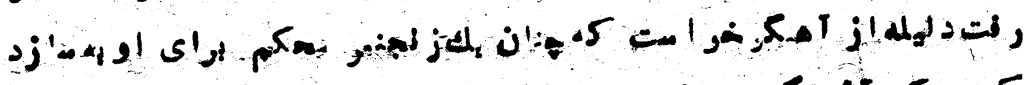

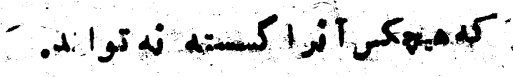




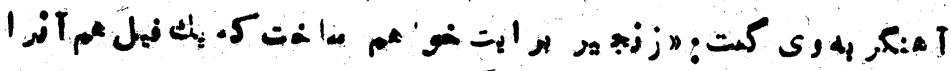

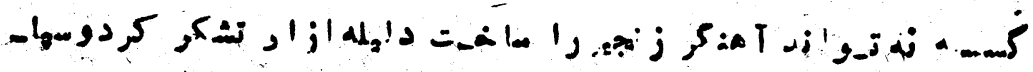

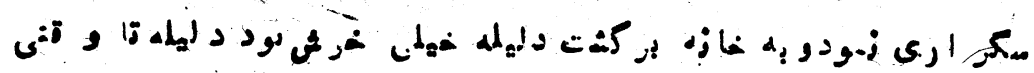

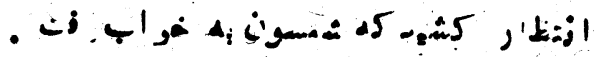

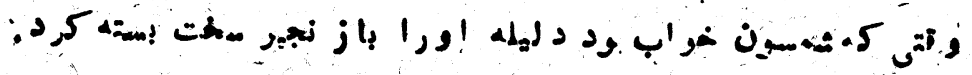

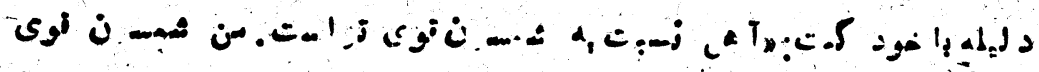

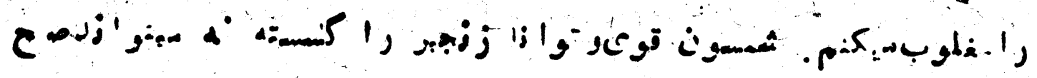

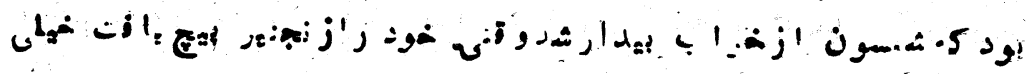

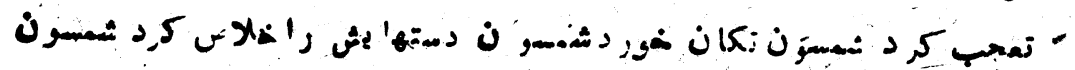

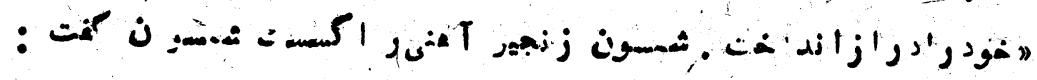

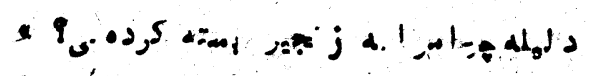

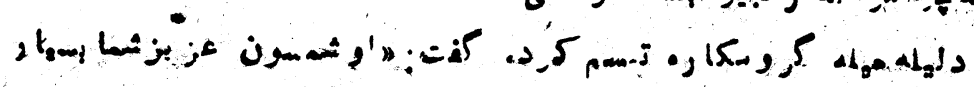

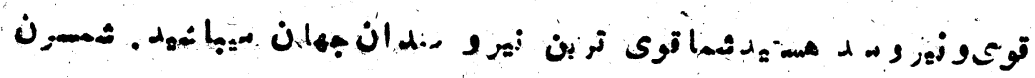

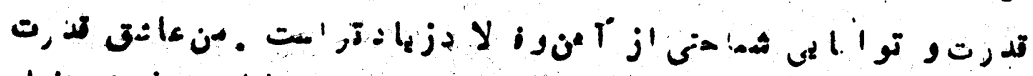

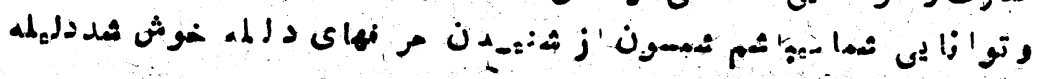

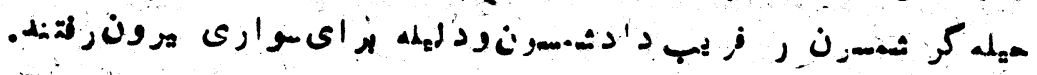

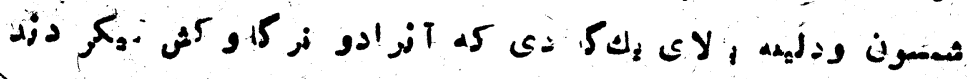

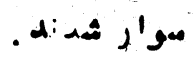

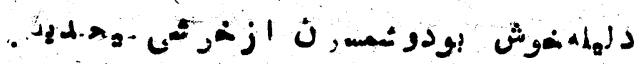

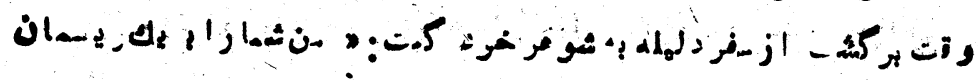

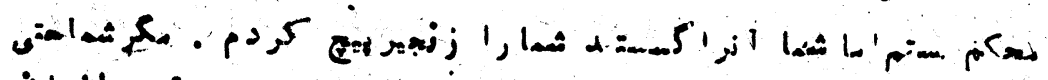

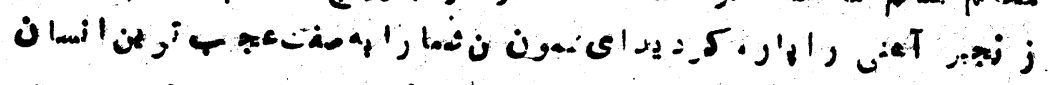

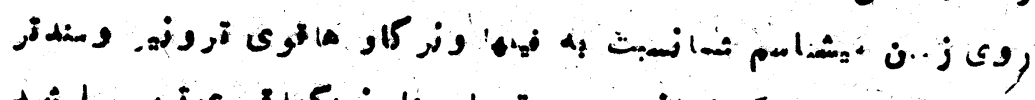

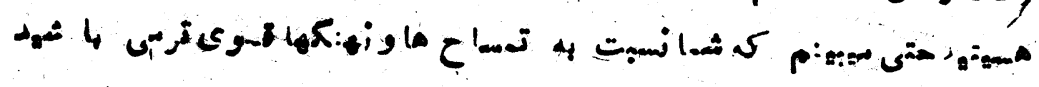




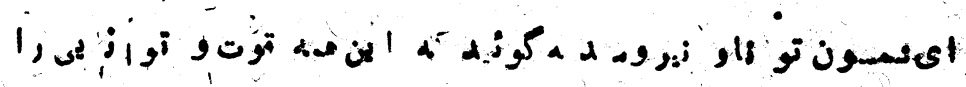

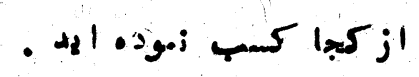

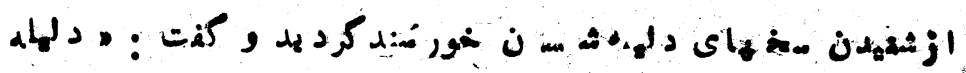

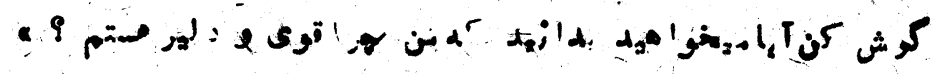

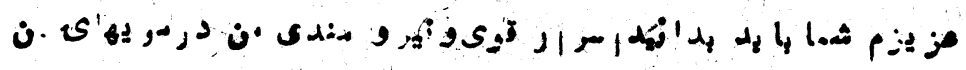

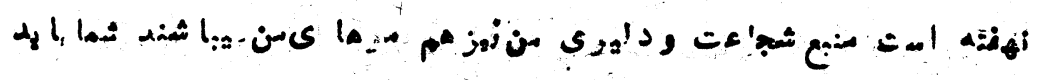

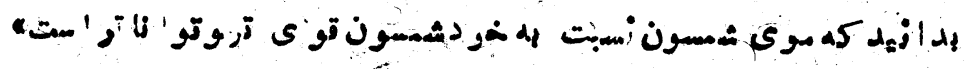

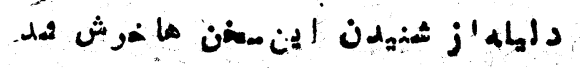

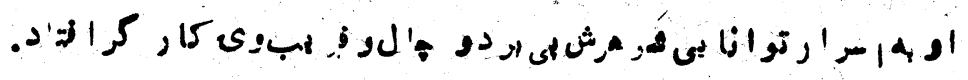

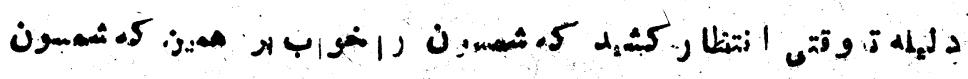

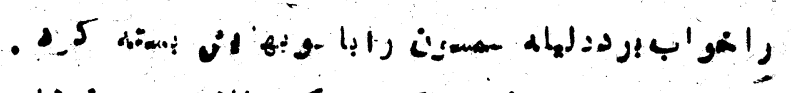

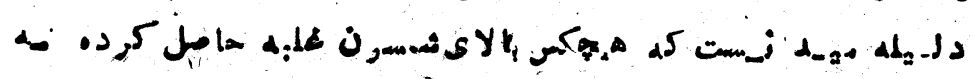
.

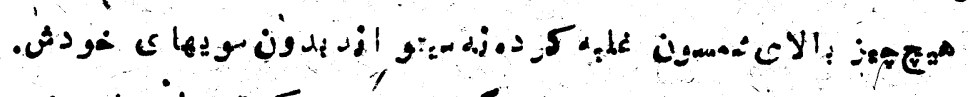

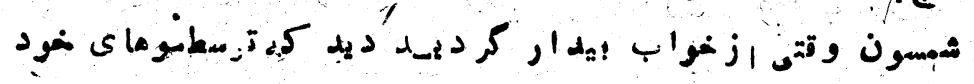

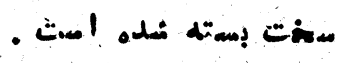

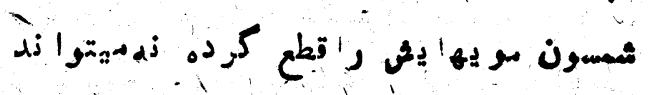

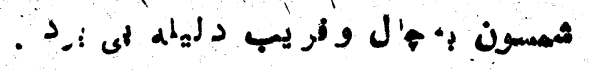

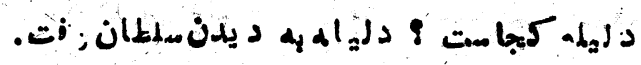

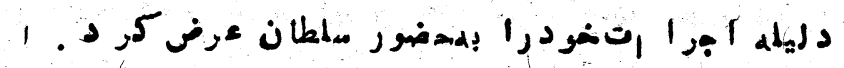

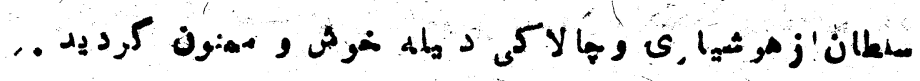

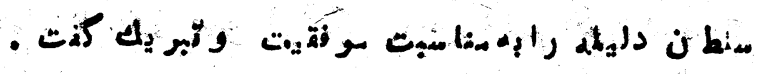

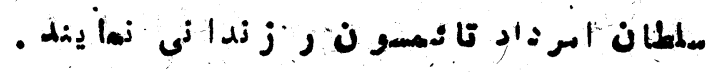




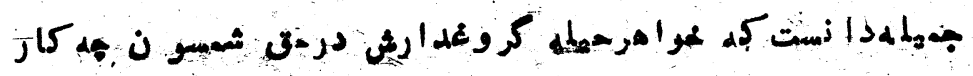

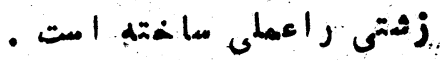

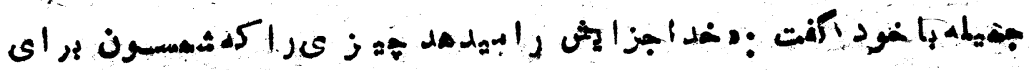

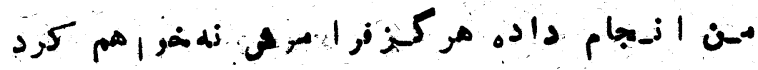

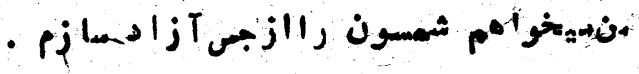

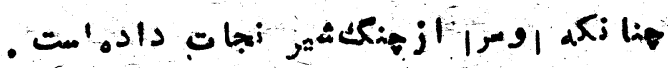

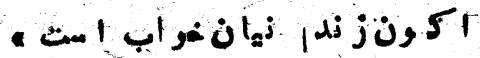

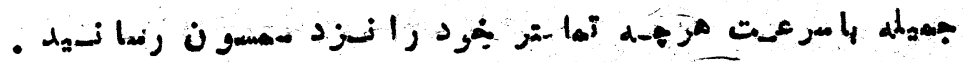

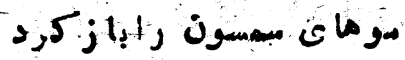

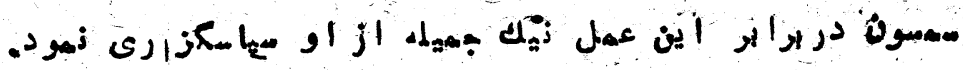

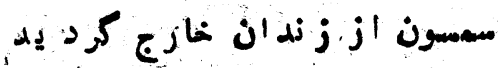

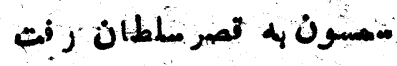

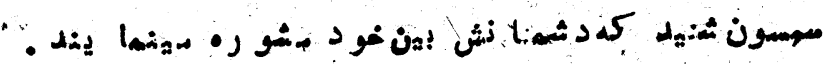

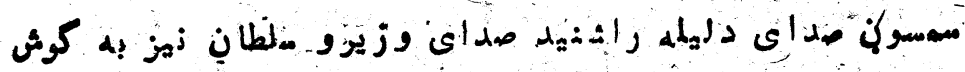

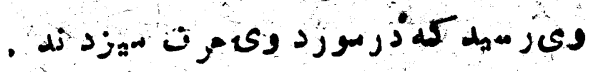

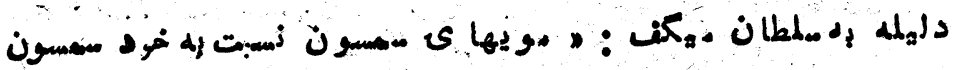

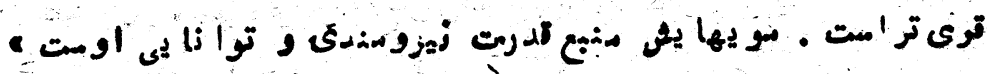

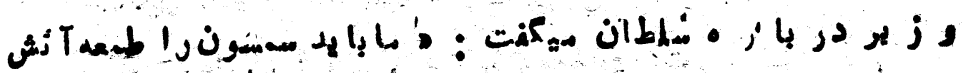

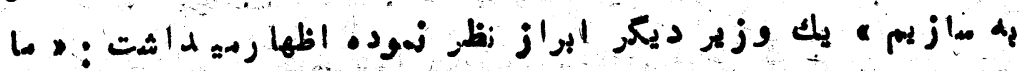

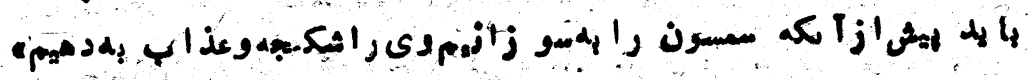

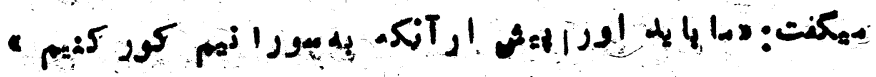

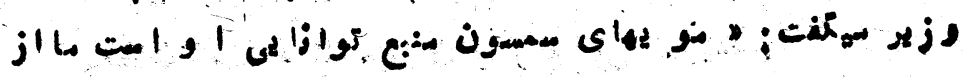
orrmo 


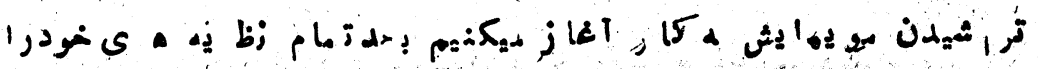

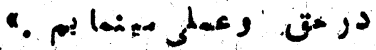

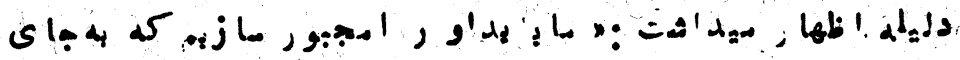
- ز

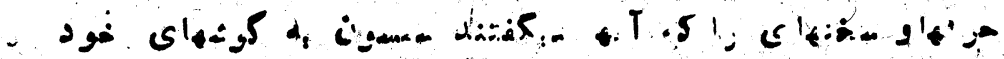
- د

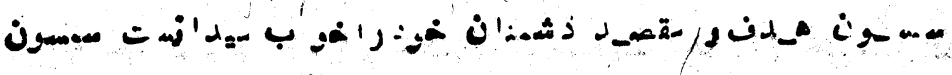

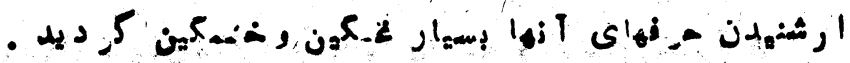

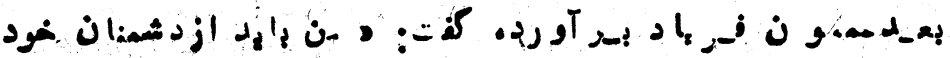

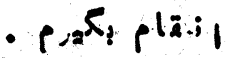

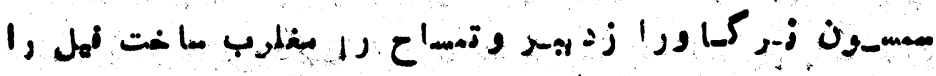

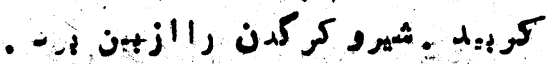

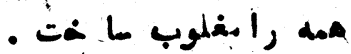

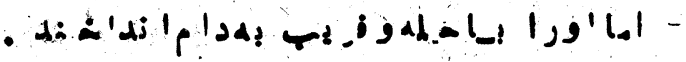

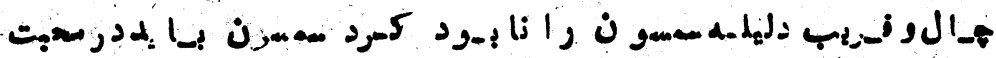

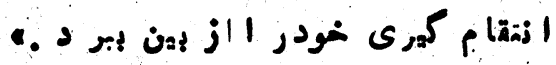

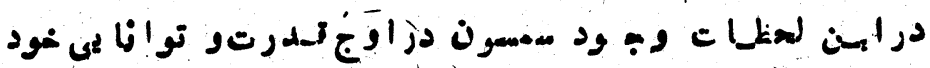

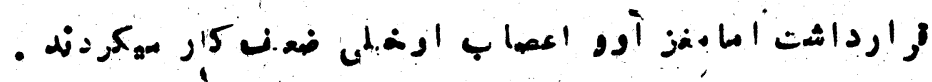

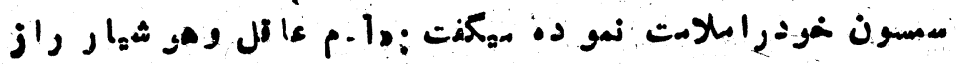

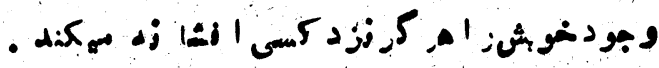

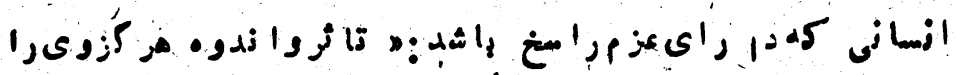

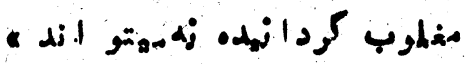
-rre- 


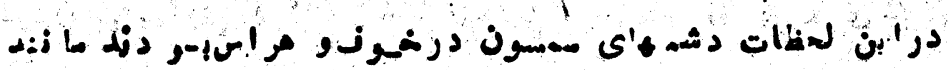

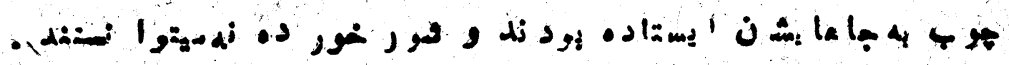

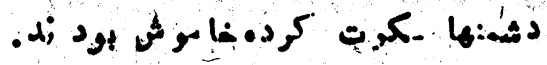

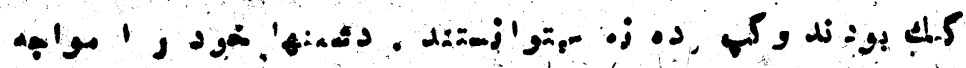

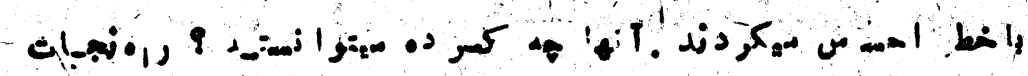

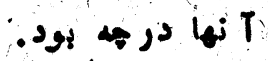

S)

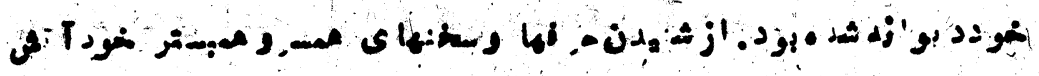

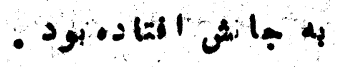

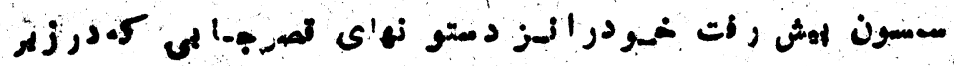

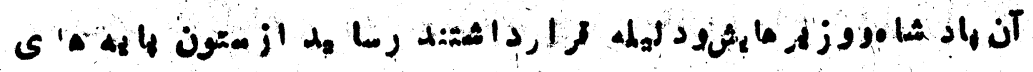

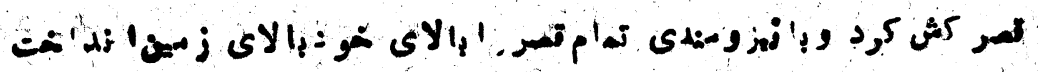

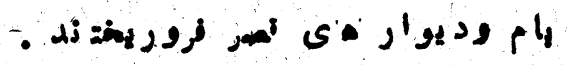

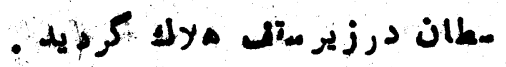

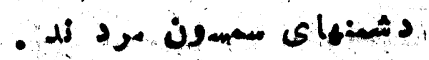

$$
\text { - }
$$


زشترنفرت انغير

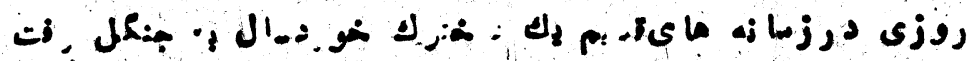

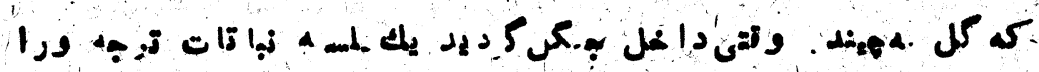

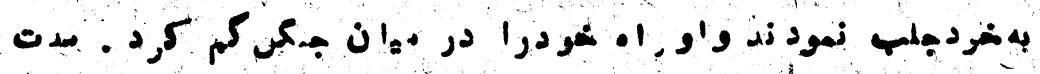

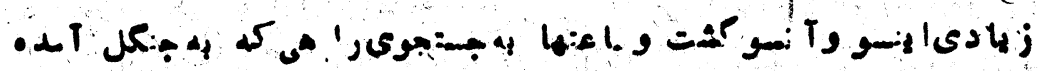

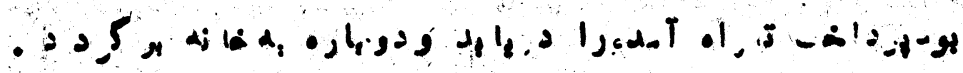

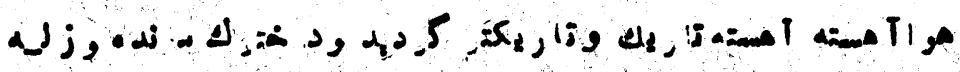

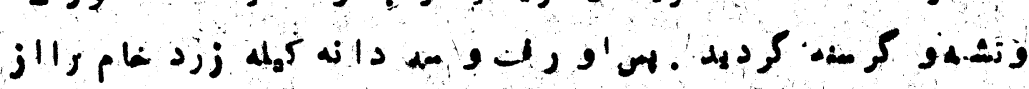

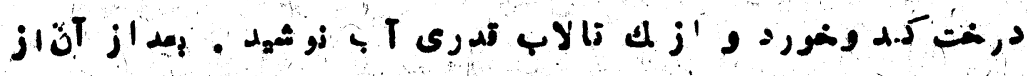

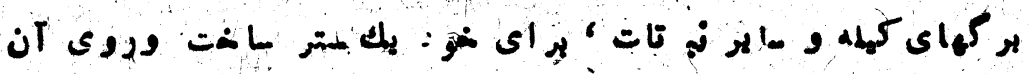

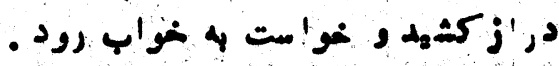

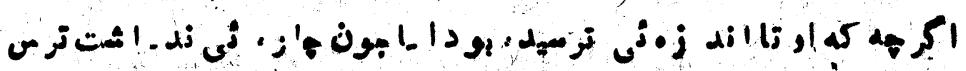

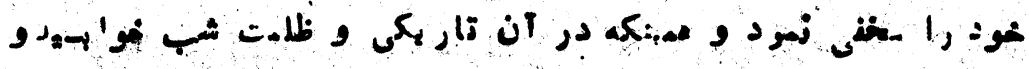

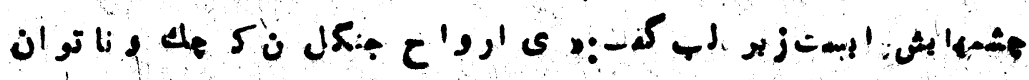

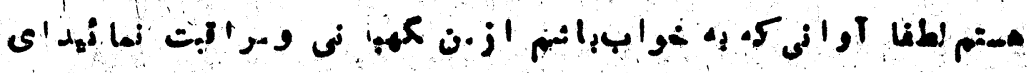

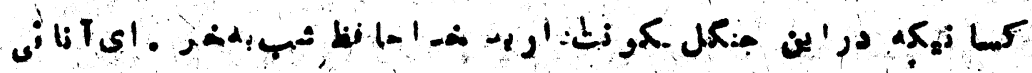

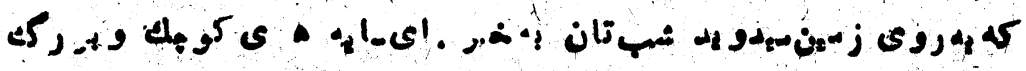
-rrv- 


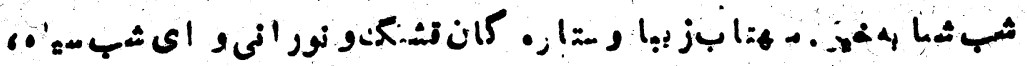

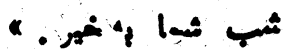

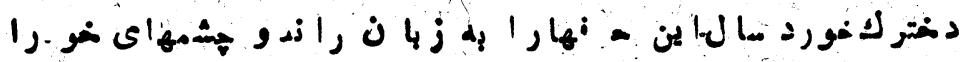

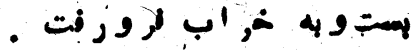

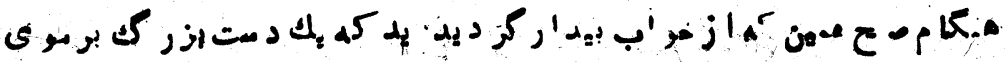

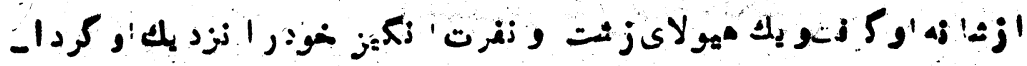

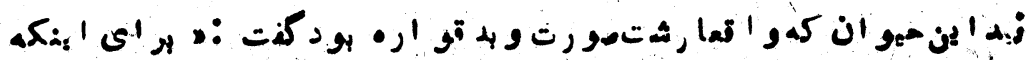

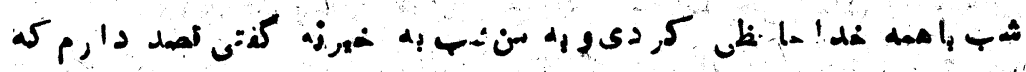

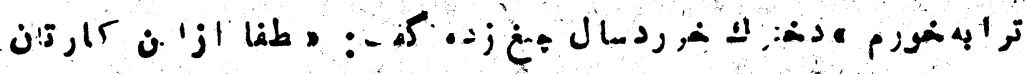

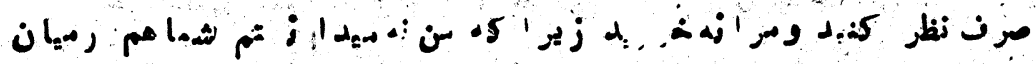

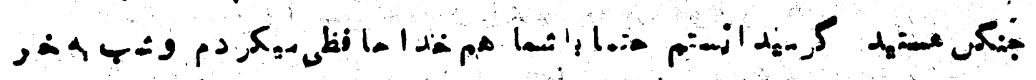
a co

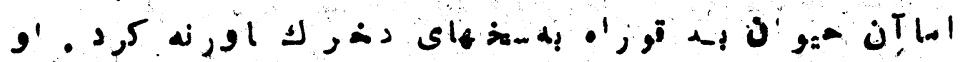

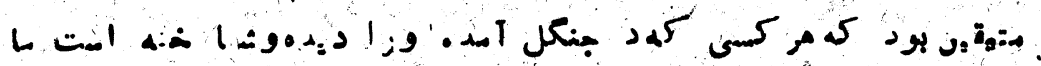

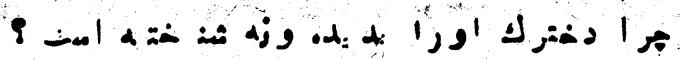

1 !

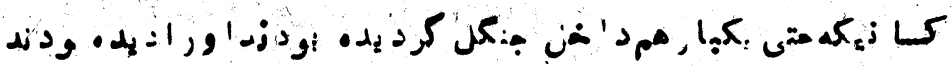

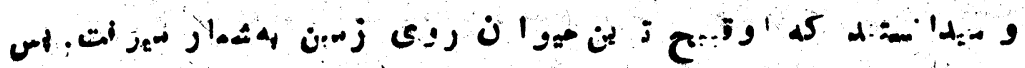

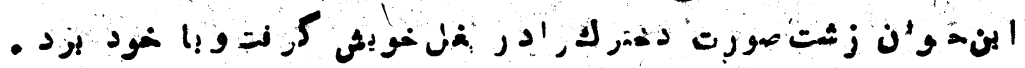

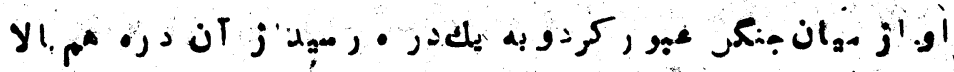

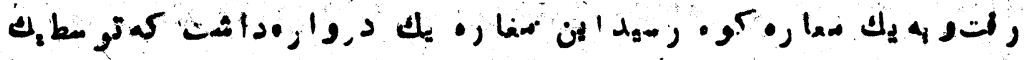

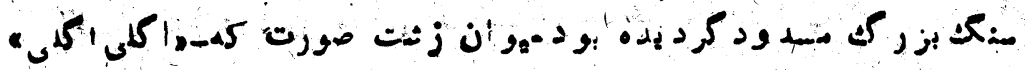

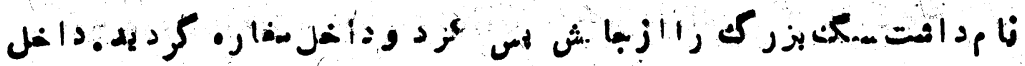

-rPA- 


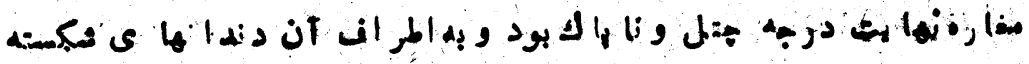

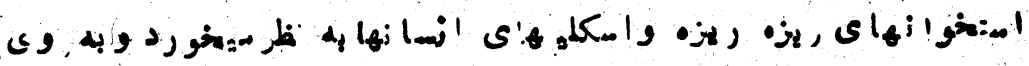

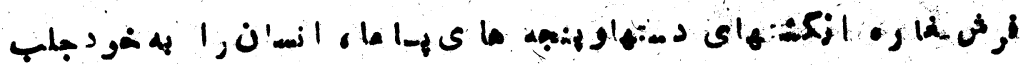

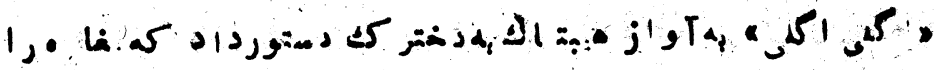

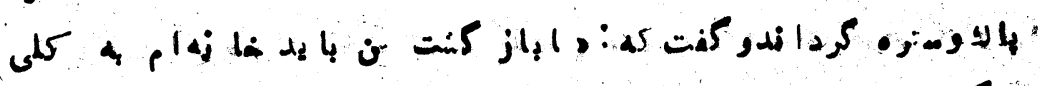

$$
\text { - . }
$$

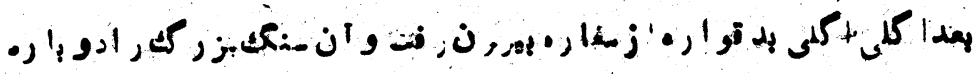

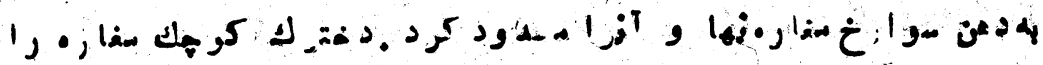

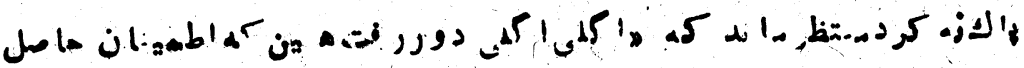
和

$$
\text { F }
$$

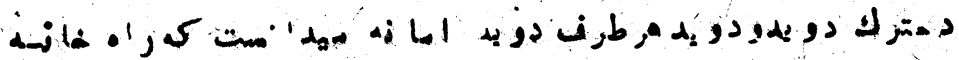

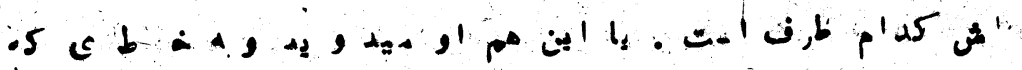

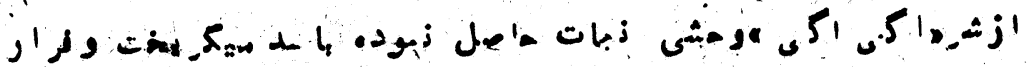

$$
\text { ग, }
$$

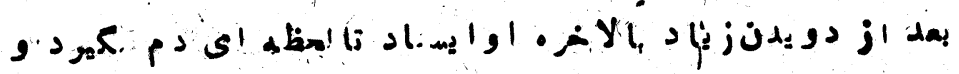
S. A د'

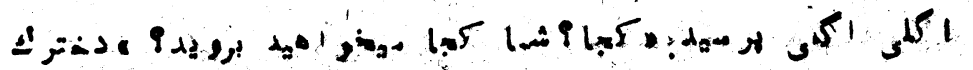

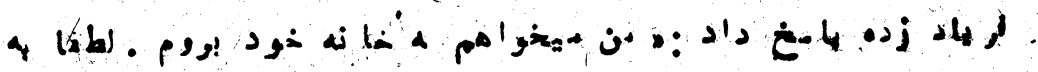

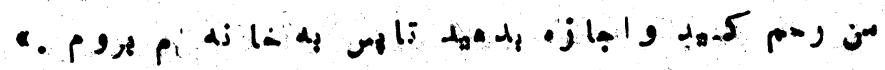

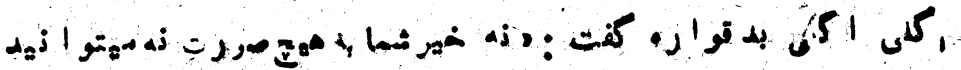




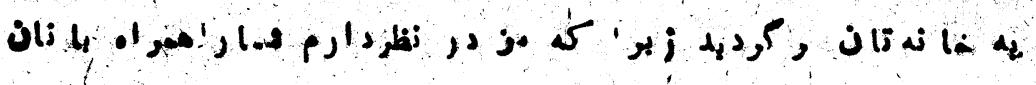

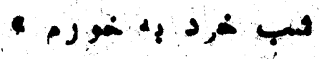

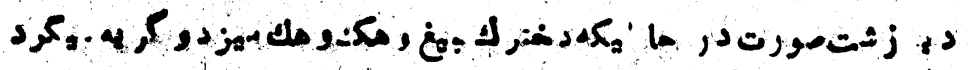

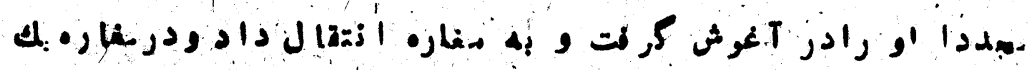

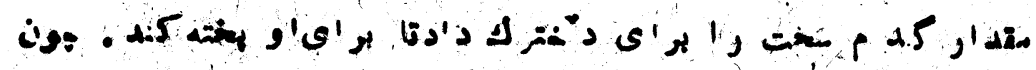

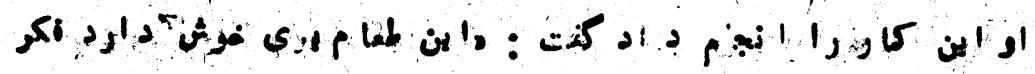

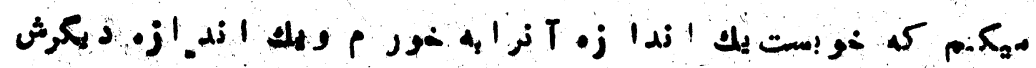

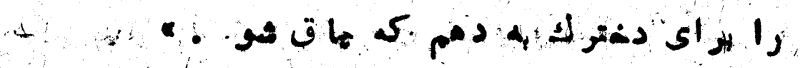

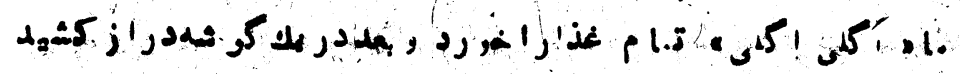

$$
\text { - }
$$

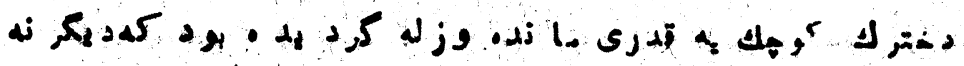

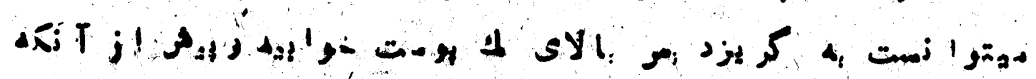

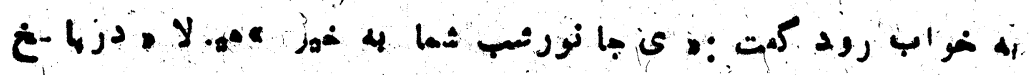

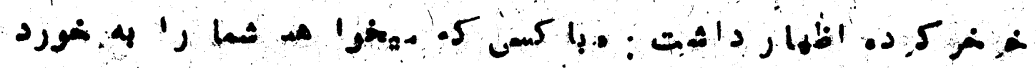

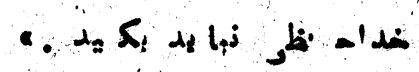

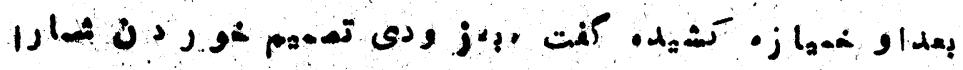

$$
\text { - }=5 \text { م مa }
$$

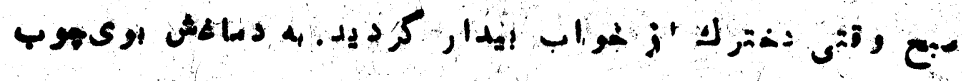

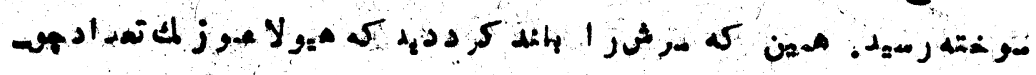

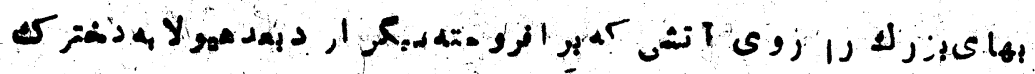

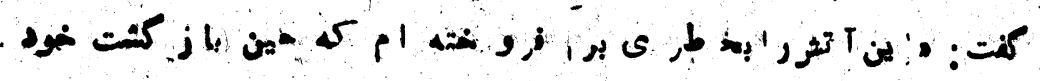

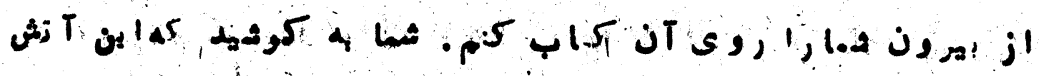

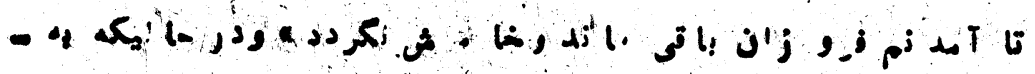

$$
\text { -rr.- }
$$




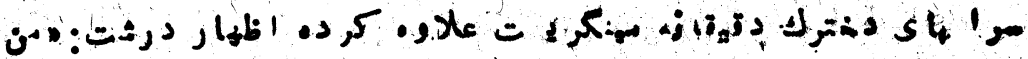

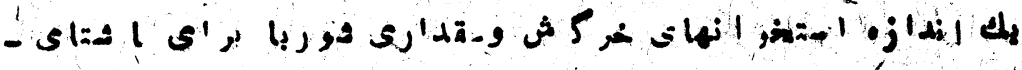

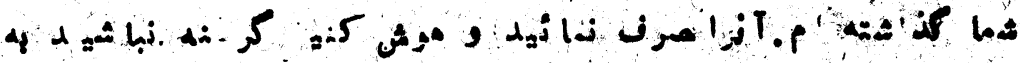

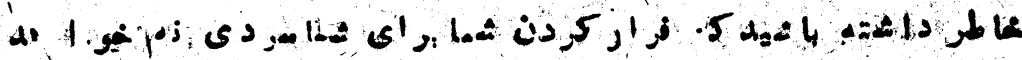

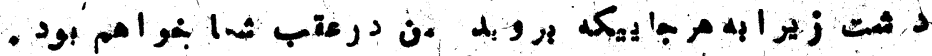

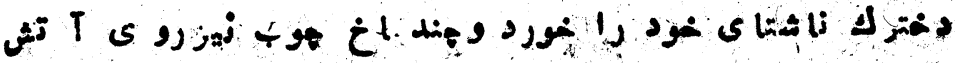
ا أله 'ا

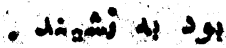

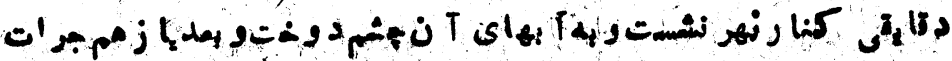

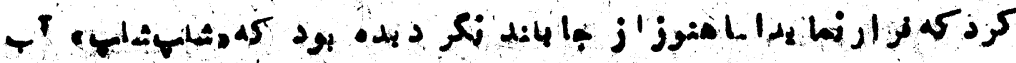

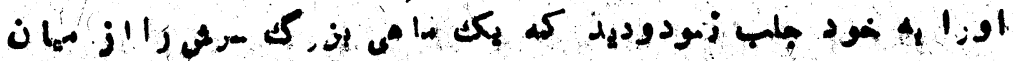

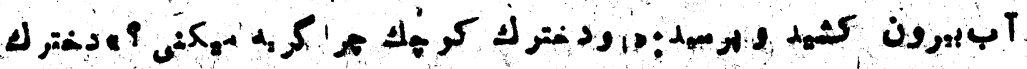

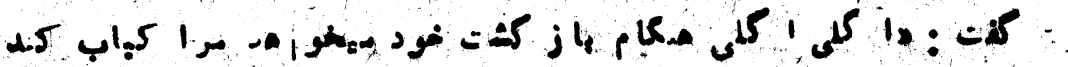
. os a

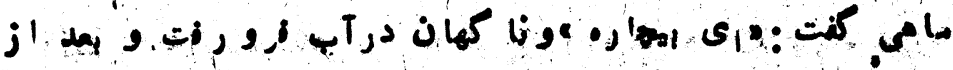

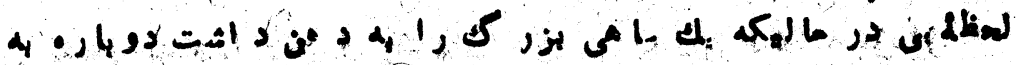

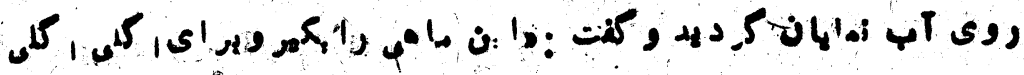

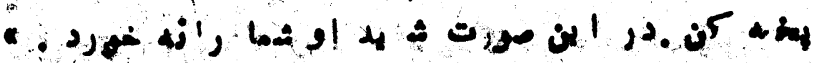

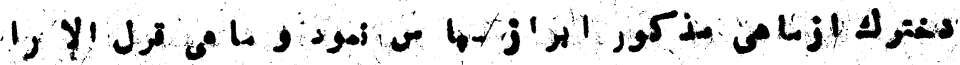

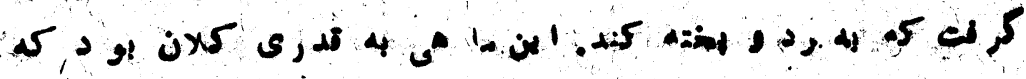

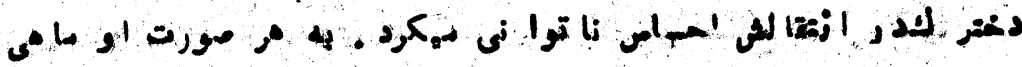

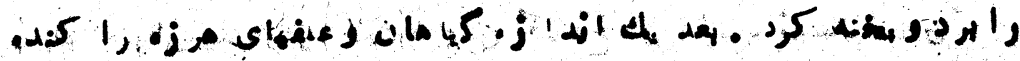

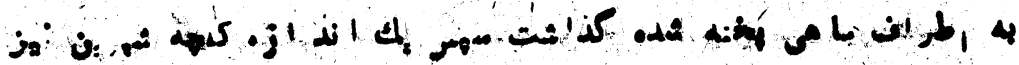




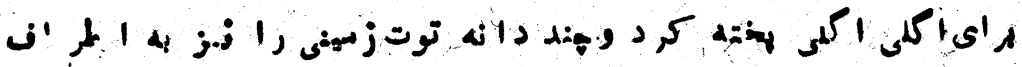

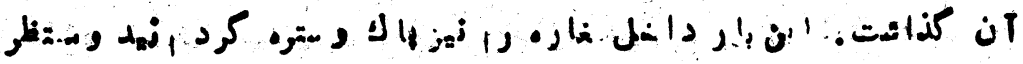

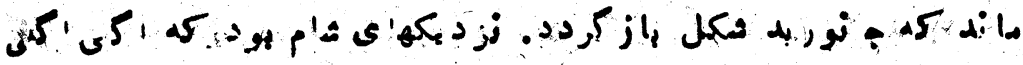

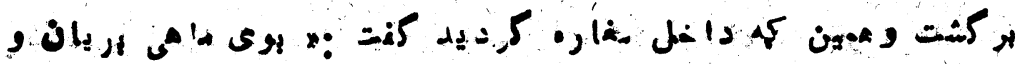

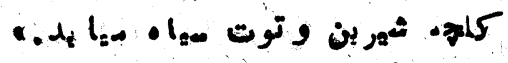

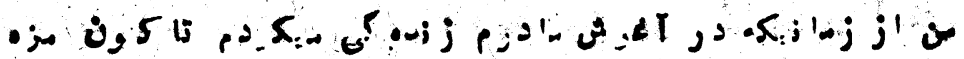

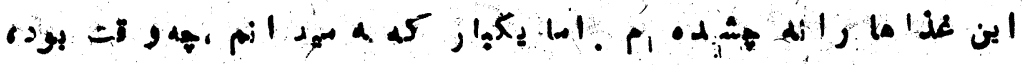

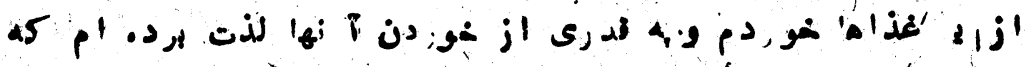

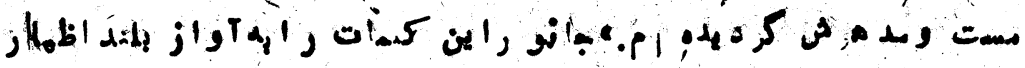

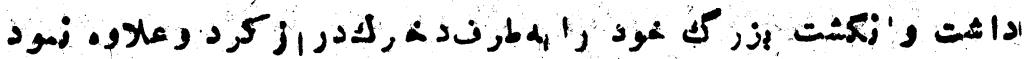

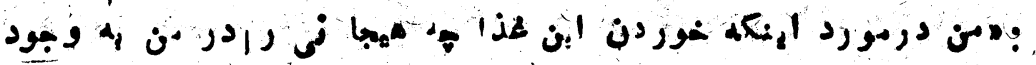

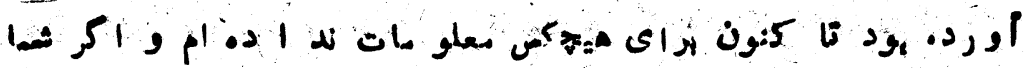

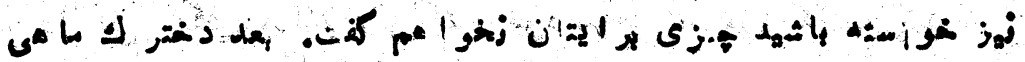

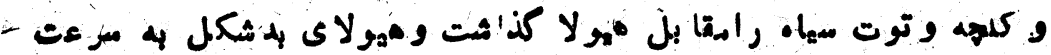

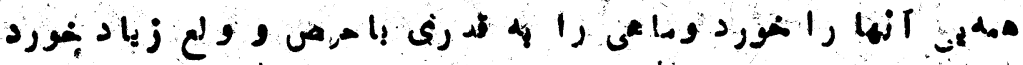

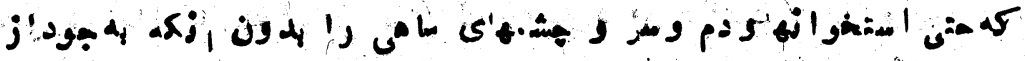

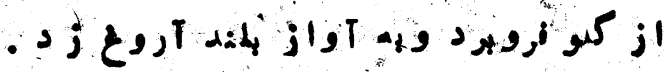

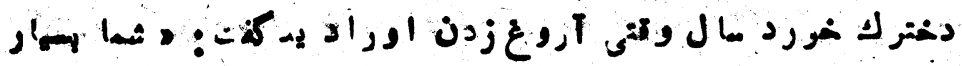

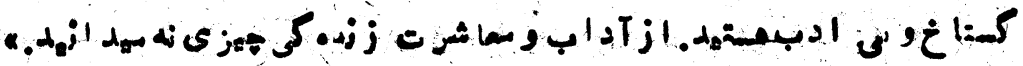

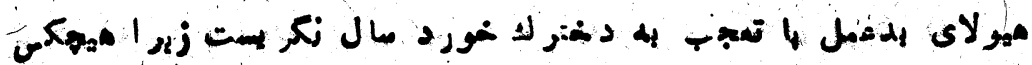

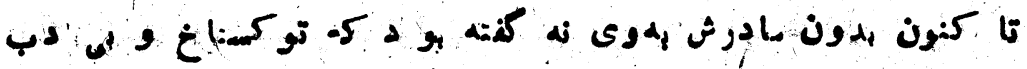

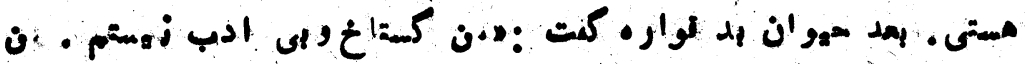

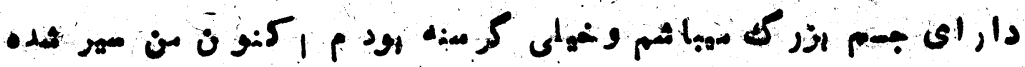




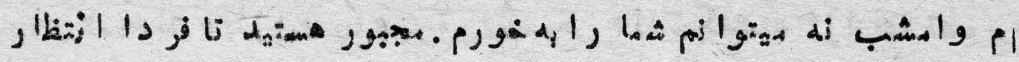
a. $d_{\mathrm{a}}$

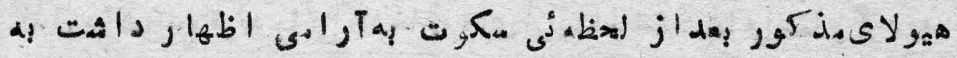

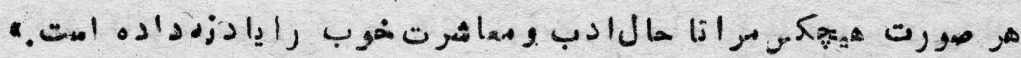

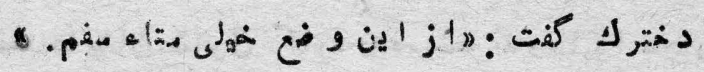

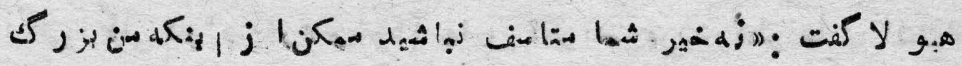

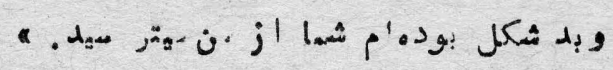

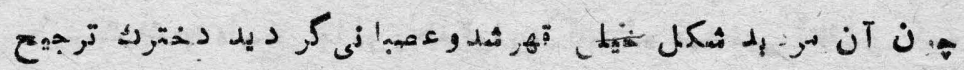

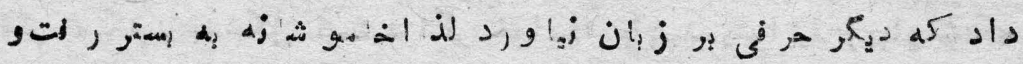

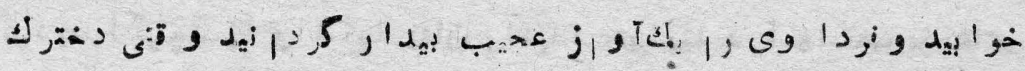

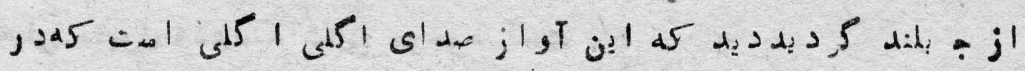

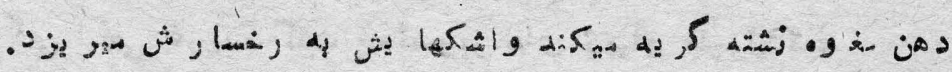

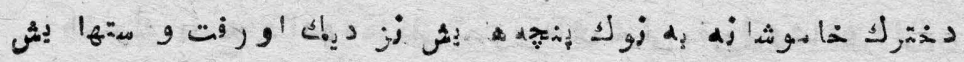

$$
\begin{aligned}
& \text { ? }
\end{aligned}
$$

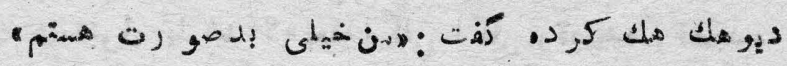

.

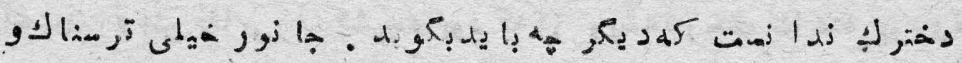

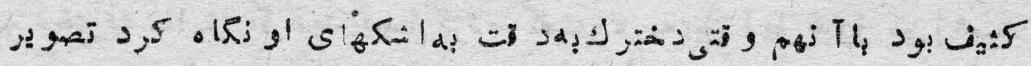

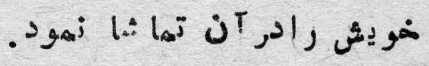

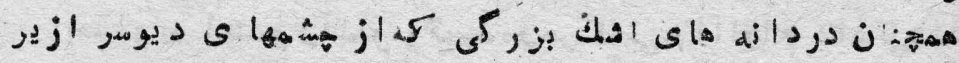

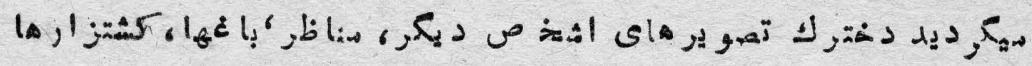

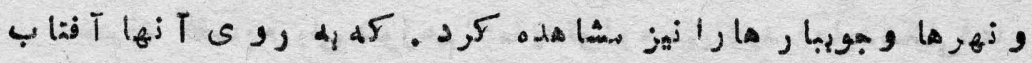

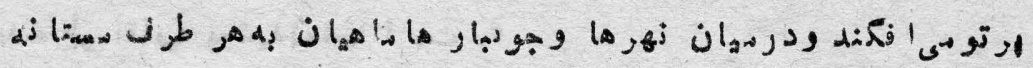




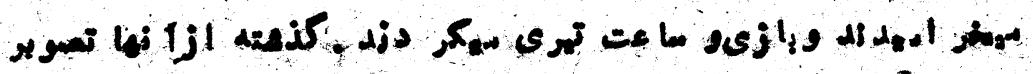

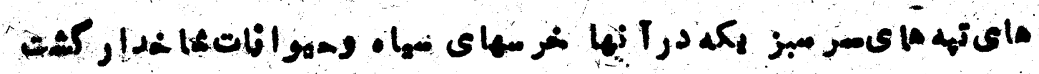

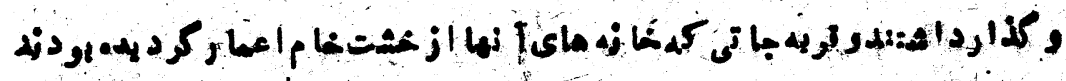

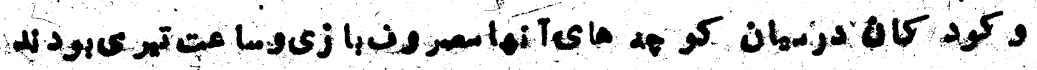
واروبا نواندرونا

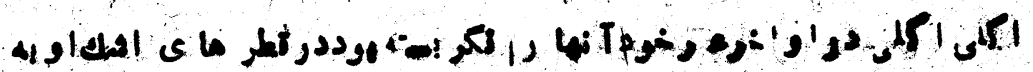

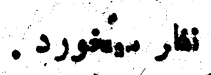

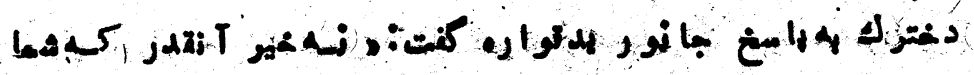

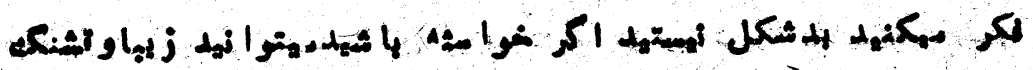

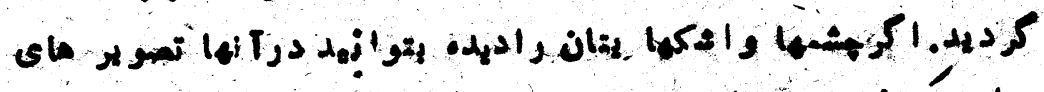

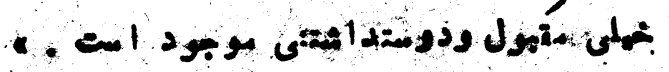

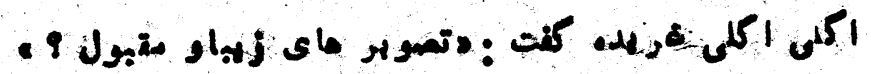

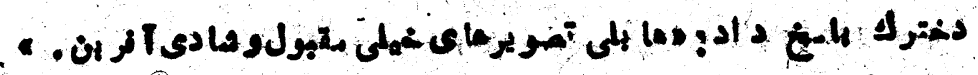

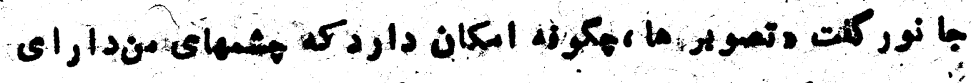

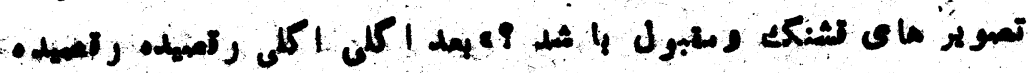

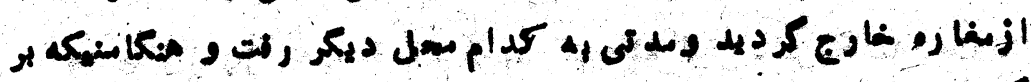

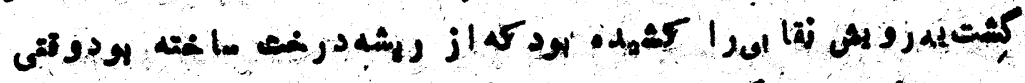
ب صور ت

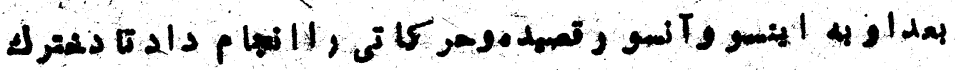

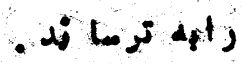

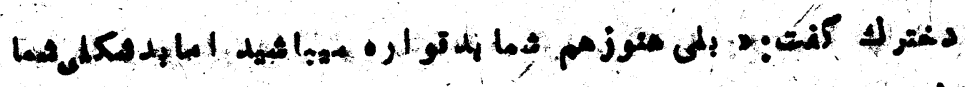

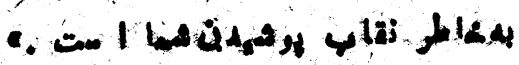




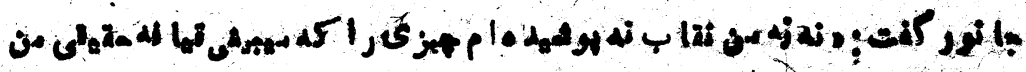

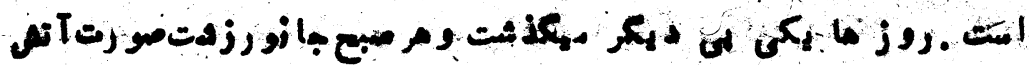

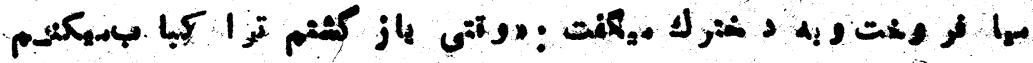

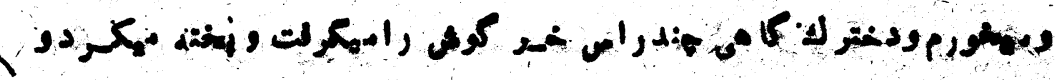

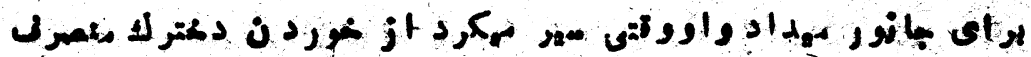

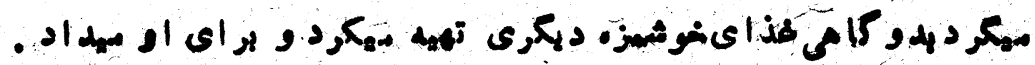

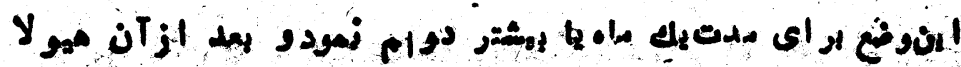

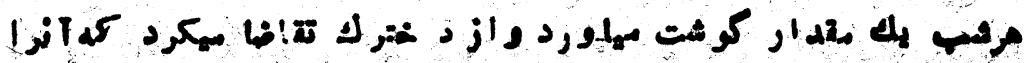

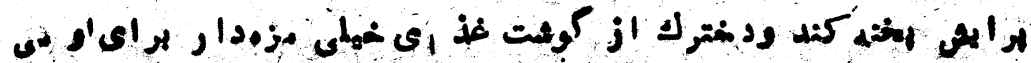

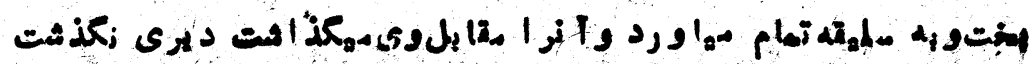

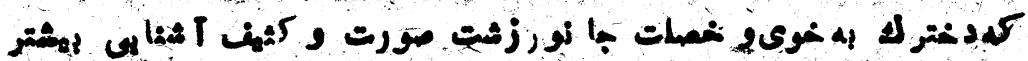

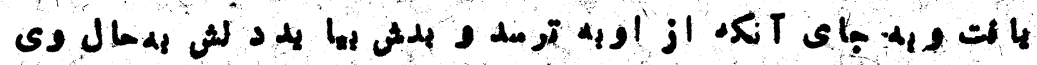
مونسومت.

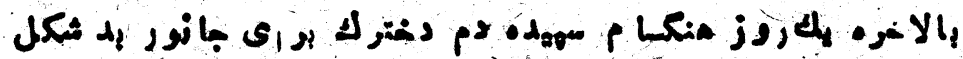

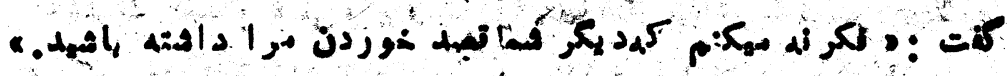

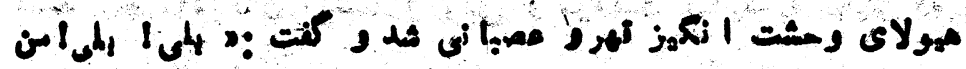

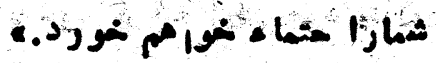

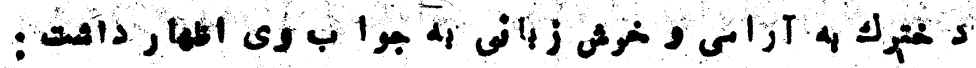

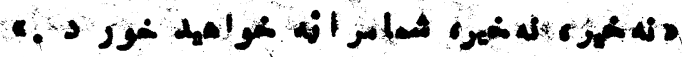

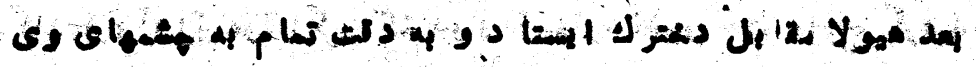

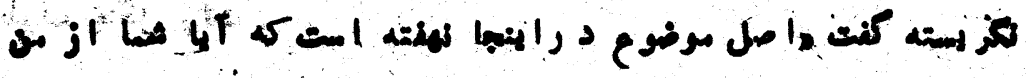

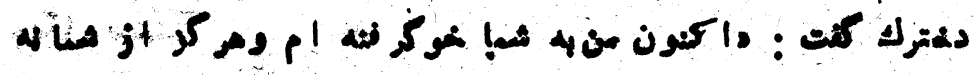




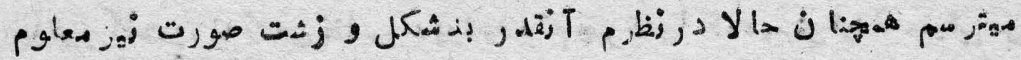

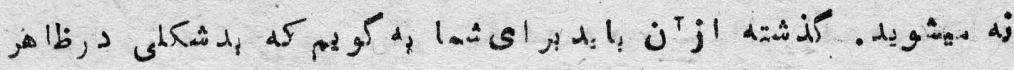

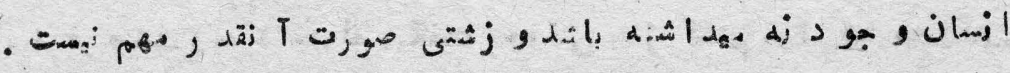

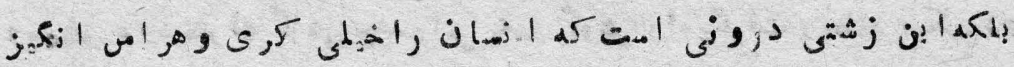

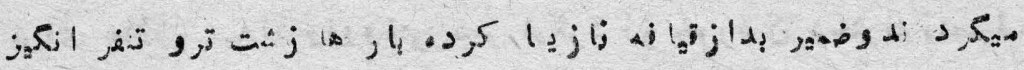
- $1+4$

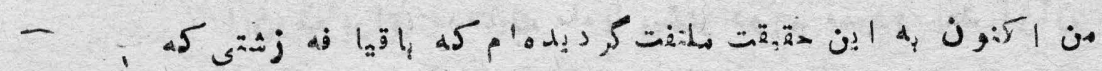

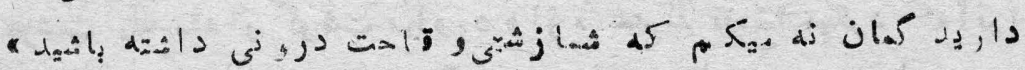
:

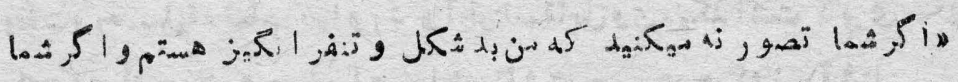

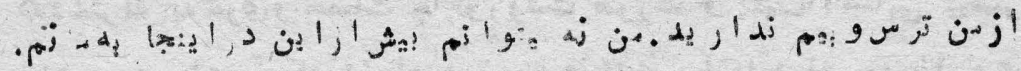

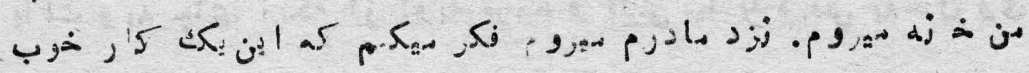

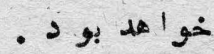

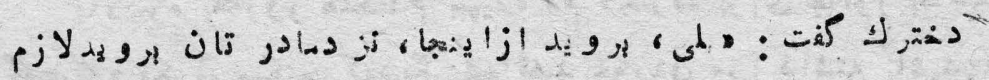

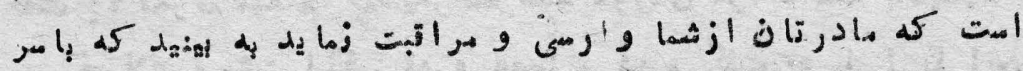

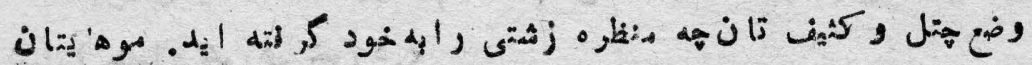

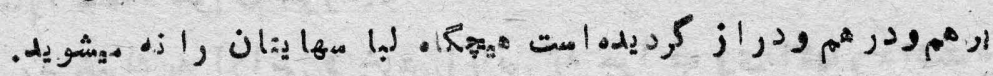

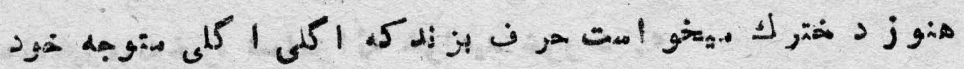
كرد .

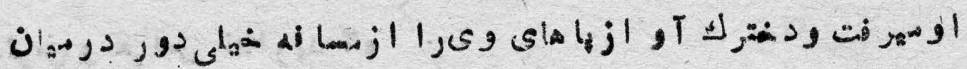

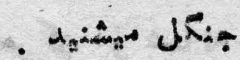




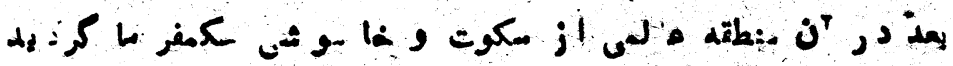

ا

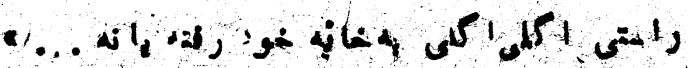

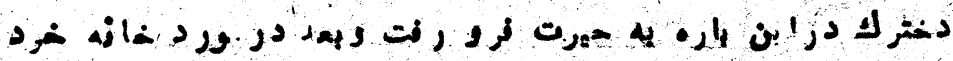

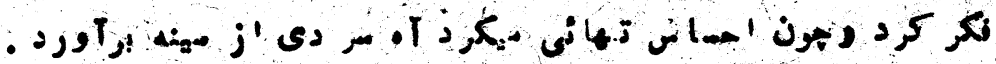

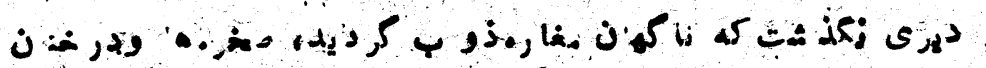

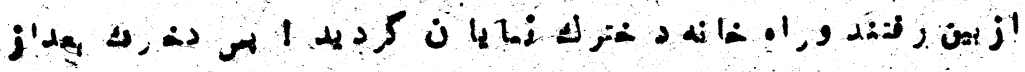

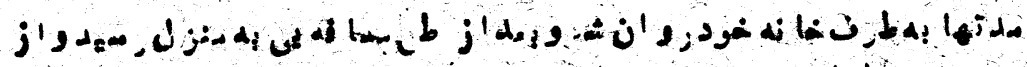

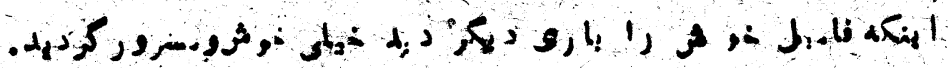

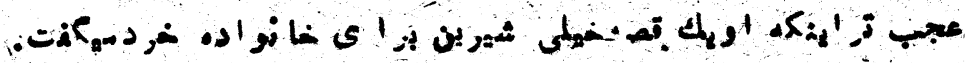

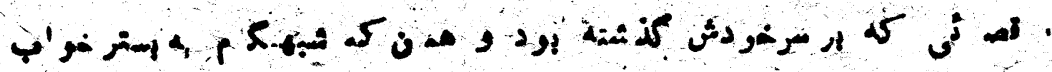

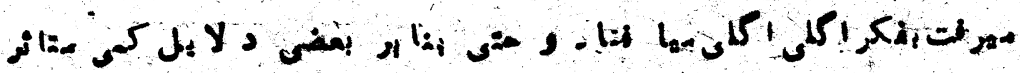

- 430.3

$\left(\begin{array}{l}\text { QERP } \\ \text { ACKU } \\ 6829\end{array}\right)$

orde 
